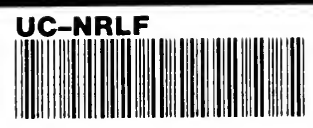

$\begin{array}{lll}5 B & 36 & 8\end{array} 33$

A GUIDE TO
INCOME-TAX PRACTICE

BY

ADAM MURRAY

AND

Roger N. Carter,

Charierco Accountanis,

MANCHESTER 


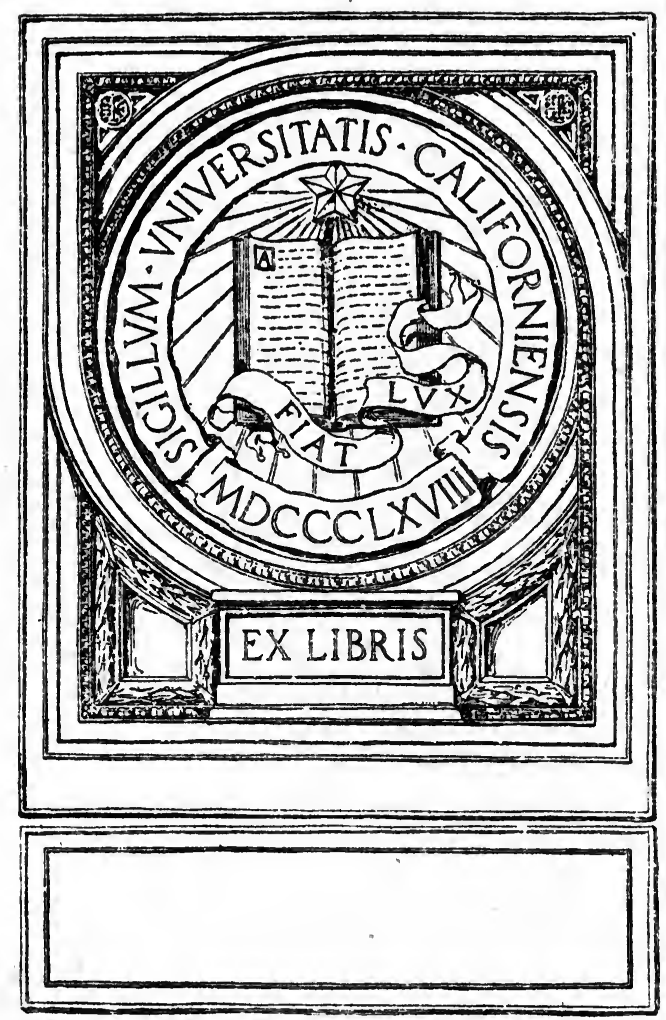


Digitized by the Internet Archive in 2007 with funding from Microsoft Corporation 


\section{A Guide TO}

\section{INCOME-TAX PRACTICE}

BY

\section{ADAM MURRAY \& ROGER N. CARTER. Chartered Accountants, Manchester.}

\section{CONTAINING}

A SUMMARY OF THE VARIOUS ENACTMENTS RELATING TO INCOME-TAX ; INSTRUCTIONS AS TO THE PREPARATION OF RETORNS FOR ASSESSMENT AND ACCOUNTS IN SUPPORT OF APPEALS ON THE GROCND OF OVER-ASSESSMENT; ALSO FOR CLAIMING EXEMPTION AND ABATEMENT:

\section{A.N}

A CONCISE POPCLAR DIGEST OF THE PRINCIPAL LEGAL DECISIONS ON THE CONSTRUCTION OF THE ACTS :

FOR THE USE OF TAXPAYERS.

SIXTH EDITION.

$\mathrm{BY}$

ROGER N. ÇARTER, M.Com., F.C.A.

LONDON

GeE \& CO. (Publishers) Ltd., 34 Moorgate Street, E.C. 



\section{PREFACE TO THE FIRST EDITION.}

' HIS work has been undertaken in response to frequent inquiries for a Guide to Income Tax Practice, and in the expectation that it may serve to direct the public upon a difficult and complicated subject.

The endeavour has been to produce a book which, while being useful to the general public, may also be instructive to those desirous of closely examining particular points of practice. With this object in view it has been thought better to incur the risk of erring on the side of fulness rather than to omit anything which might be useful. This idea has also been before us in the preparation of the copious index, which, it is hoped, will add to the value of the work as a book of reference.

The cases quoted have been collected from the reports of the Commissioners of Inland Revenue and from the public Press, as well as from the recognised Accountant and other Law Reports. In every case the facts and the judgment have been cited in such detail that the reader may see the reasons for each decision.

The aim has been to deal with the subject as the law stands rather than to criticise the state of the law, and it has not been thought advisable to enter into controversial matters, such as the incidence of the tax and anomalies in the administration of the Acts. 
We wish to acknowledge the valuable assistance derived from a perusal of Mr. Stephen Dowell's work upon "The Acts relating to Income Tax." In considering the legal construction of the Acts that work has been invaluable.

On points of practice we have made use of correspondence in The Accountant, and with this assistance, added to practical experience extending over a lengthened period, we trust that we have produced a work which will be found to combine accuracy with completeness.

We are, perhaps, justified in thinking that, the principal Act having now been in force for upwards of 50 years, there can be but few points which remain to be decided as regards the construction of the Acts.

It is worthy of notice that the tendency of recent legislation has been to grant further relief to the taxpayer, e.g., the Act of 1890 and that of last year. We have also found that there is a willingness on the part of the Inland Revenue officials to meet exceptional cases in a liberal spirit.

We have also the satisfaction of testifying to the courteous treatment accorded to us on all occasions by Surveyors and other officials. In our experience they have ever been ready and willing to accept accounts when properly prepared and to discuss fairly any points of difficulty arising thereon, there being a desire on all occasions to assist with the fullest information for our guidance. 
We believe that many people have the impression that the Surveyors derive a pecuniary advantage through increased assessments, but we are able to state emphatically that such is not the case. The Surveyors are paid by fixed salary, which is not influenced in the slightest degree by the rise or fall of the Income Tax assessments in their districts. This is also the case now with regard to all officials connected with the administration of the Income Tax. Up to I89o, Assessors, Collectors, and Clerks to Commissioners were paid by a poundage rate on the duty assessed or collected, but, by the Taxes (Regulation of Remuneration) Act, r89r, payment by poundage was abolished, and fixed allowances were substituted in lieu thereof. It is, therefore, plain that no person has a pecuniary interest in the increase of the assessments beyond the amount of profits properly chargeable.

In venturing to introduce the work to the favour of the public we do so in the hope that it will be found, in some measure, to fulfil the object with which it has been written.

\section{A. MURRAY.}

ROGER N. CARTER.

Manchester, February 1895. 



\section{PREFACE TO THE SIXTH EDITION.}

THE principal alteration noted in our Fifth Edition was the first attempt at differentiation-by " relief " to " earned" incomes. We think it will be generally admitted that this relief has worked well and without undue friction.

The present Edition deals with the Super-tax as the outstanding feature of legislative change. The chief difficulty of this is the obtaining of exact particulars in the absence (in most cases) of books of record.

The text of this Edition runs to considerably greater length than that of the former one. This is due largely to the full treatment which we have thought well to accord to the important cases of the Lion Brewery (p. $25 \mathrm{I}$ ) and A.-G. v. Till (p. I 35).

Whilst confirming our previous view as to the courtesy and fairness of the officials, we cannot refrain from protesting against some of the points raised and which are pressed against taxpayers-sometimes sucessfully, at other times the reverse.

Amongst these we may mention :-

(I) The London County Council case, where it has been established that occupation value cannot be set off against tax on interest payable. (p. 355.)

(2) The Lion Brewery case, where the Crown has been unsuccessful in their attempt to disallow a necessary expense of business. (p. $25 \mathrm{I}$.) 
viii.

(3) The General Accident Insurance, Ecc., case, where they have succeeded in establishing that all premiums received are profits, notwithstanding that they are in respect of a risk running in a future period. (p. 204.)

(4) The new "rule" as to abatement to infants. (p. 448.)

(5) The attempt to exact Super-tax for a year in which the taxpayer is dead. (p. 492.)

In all these cases the point (whether legally established in favour of the Crown or not) involves such obvious injustice that it would seem to justify the assertion that in some cases the authorities are more interested in revenue than in fairness, and have resort to claims which (as one of the Judges has said with respect to an action by a municipality), at the hands of an individual, would never be contemplated.

In this connection one may quote the expression of Fletcher Moulton, L.J. (p. 205), that it was painful to give the stamp of judicial authority to something which could not be supported by the practice of the most intelligent and honourable men of the mercantile community, and to a course of treatment which, if acted upon financially, would be a gross fraud.

The Income Tax as a whole is so fair and so fairly administered that one notes these cases with extreme regret.

ROGER N. CARTER.

16 Kennedy Street, Manchester,

November igir. 


\section{O NTENTS.}

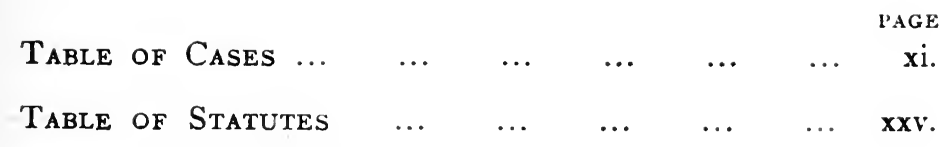

Chap. I. History of the Income Tax and Epitome of the Principal Acts RELATING THERETO $\ldots \quad \ldots \quad \ldots \quad$ I

, II. The Schedules UNder Which INCOME $\begin{array}{llllll}\text { Tax is Charged } & \ldots & \ldots & \ldots & 8\end{array}$

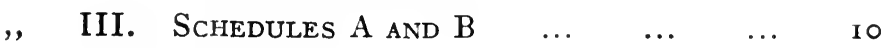

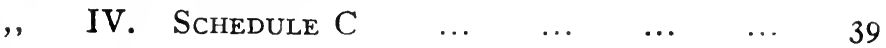

$\begin{array}{lllllllll}\text {, } & \text { V. } & \text {, } & \mathrm{E} & \ldots & \ldots & \ldots & \ldots & 44\end{array}$

,, VI. ,, D :-

Part I. Persons and Property Chargeable $\quad \ldots \quad \ldots \quad 57$

,; II. RETURNS FOR Assessment IIg

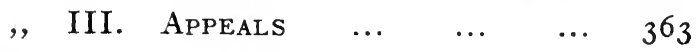

, VII. Rate of Deduction of Tax on Pay-

MENT of Dividends, \&C. $\quad$... $\quad \ldots \quad 392$

,, VIII. Exemptions and Abatements :-

$\begin{array}{lllllll}\text { Part I. General } & \ldots & \ldots & \ldots & 398\end{array}$

, II. Charities and Public Buildings $\quad \ldots \quad \ldots \quad 465$

, III. RELIEF TO " EARNED", INCOMES $\ldots \quad \ldots \quad \ldots \quad 477$

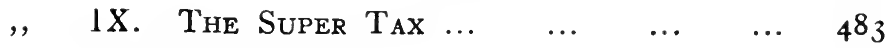

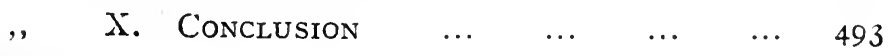

$\begin{array}{lllllllll}\operatorname{INDEX} & \ldots & \ldots & \ldots & \ldots & \ldots & \ldots & \ldots & 507\end{array}$ 



\section{TABLE OF CASES.}

THE following is a list of the various cases cited in this work, with the dates of the decisions and the Courts in which the cases were heard. Where a case is referred to several times the principal reference has been put in prominent type. H.L. denotes House of Lords; C.A., Court of Appeal; Q.B.D. or K.B.D., Queen's or King's Bench Division; C.E., Court of Exchequer, which became, in November 1875, the Exchequer Division of the High Court, but was merged in the Queen's Bench Division in $188 \mathrm{I}$. C.S. denotes Court of Session, Scotland.

Aberdeen (Commissioners of Supply for) $v$.

PAGES

$$
\begin{array}{llllllll}
\text { Russell } & \ldots & \ldots & \ldots & \text { C.S. } & 189 \text { ' } & 302
\end{array}
$$

Town and County Bank v. Russell.

See Russell.

$\begin{array}{lllllll}\text { Adam v. Maughan } & \ldots & \ldots & \ldots & \text { C.S. } & \text { i } 889 & \mathbf{6 8} \mathbf{4 7 0}\end{array}$

Addie \& Sons $v$. Solicitor of Inland Revenue $\quad \ldots \quad$ C.S. $\quad \begin{array}{rrrr}1875 & 314 & 316 & 319\end{array}$

$\begin{array}{lllllll}\text { Aiken } v \text {. Macdonald } & \ldots & \ldots & \ldots & \text { C.S. } & \mathbf{1} 894 & 235\end{array}$

Aikin v. Ferguson. See Ferguson.

Alexander Ferguson. See Ferguson.

Alexandria Water Co., Lim. v. Musgrave $\quad \ldots \quad$ C.A. $\quad 1883296305308$

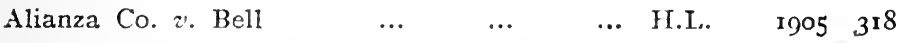

Allan v. Hamilton Waterworks Commissioners C.S. $\quad \begin{array}{rr}1887 & 89\end{array}$

,, v. Scottish Provident Institution. See

Scottish Provident Institution.

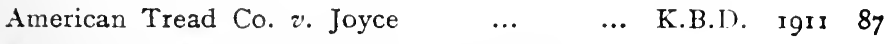

Anderson v. Mary Clark Home. Sce Clark.

Andrew $v$. Hancock

... Court of Common Pleas r8rg $\mathbf{3 0} 273$

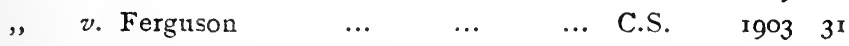

Andrews v. Mayor, \&c., of Bristol $\ldots \quad \ldots \quad \ldots \quad$ Q.B.D. 1892473474

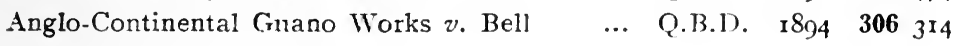





\section{TABLE OF CASES.}

THE following is a list of the various cases cited in this work, with the dates of the decisions and the Courts in which the cases were heard. Where a case is referred to several times the principal reference has been put in prominent type. H.L. denotes House of Lords; C.A., Court of Appeal; Q.B.D. or K.B.D., Queen's or King's Bench Division; C.E., Court of Exchequer, which became, in November 1875, the Exchequer Division of the High Court, but was merged in the Queen's Bench Division in $188 \mathrm{I}$. C.S. denotes Court of Session, Scotland.

Aberdeen (Commissioners of Supply for) $v$.

$$
\begin{array}{llllllll}
\text { Russell } & \ldots & \ldots & \ldots & \text { C.S. } & 189^{\prime} & 302
\end{array}
$$

Town and County Bank v. Russell.

$$
\text { See Russell. }
$$

$\begin{array}{llllllll}\text { Adam } v \text {. Maughan } & \ldots & \ldots & \ldots & \text { C.S. } & \text { i } 889 & \mathbf{6 8} \mathbf{4 7 0}\end{array}$

$\begin{array}{lllllll}\text { Addie \& Sons } v \text {. Solicitor of Inland Revenue } & \ldots & \text { C.S. } & 1875 & 314 & 316 & 319\end{array}$

$\begin{array}{lllllll}\text { Aiken } v \text {. Macdonald } & \ldots & \ldots & \ldots & \text { C.S. } & 1894 & 235\end{array}$

Aikin v. Ferguson. See Ferguson.

Alexander Ferguson. See Ferguson.

Alexandria Water Co., Lim. v. Musgrave $\quad \ldots \quad$ C.A. $\quad \begin{array}{llll}8883 & 296 & 305 & 308\end{array}$

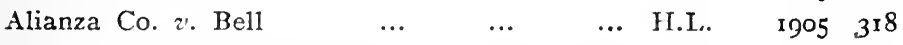

Allan v. Hamilton Waterworks Commissioners C.S. $\begin{array}{rrr}1887 & 89\end{array}$

, $v$. Scottish Provident Institution. See

Scottish Provident Institution.

American Tread Co. $v$. Joyce $\quad \ldots \quad \ldots \quad \ldots$ K.B.1). Igri 87

Anderson v. Mary Clark Home. Sce Clark.

Andrew $v$. Hancock

... Court of C.ommon Pleas r8ig $\quad \mathbf{3 0} 273$

$\begin{array}{llllllll} & \text { v. Ferguson } & \ldots & \ldots & \ldots & \text { C.S. } & 1903 & 3^{1}\end{array}$

Andrews v. Mayor, \&c., of Bristol $\ldots \quad \ldots \quad \ldots \quad$ Q.B.D. $\quad$ I 892473474

Anglo-Continental Guano Works $v$. Bell $\quad \ldots$ Q.B.D. I894 306 3r4 
Apthorpe v. Peter Schoenhofen Brewery Co. ...

Attorney-General $v$. Alexander and others (Im. perial Ottoman Bank) $\ldots . \quad$ C.E. $\quad{ }_{1874} 84$

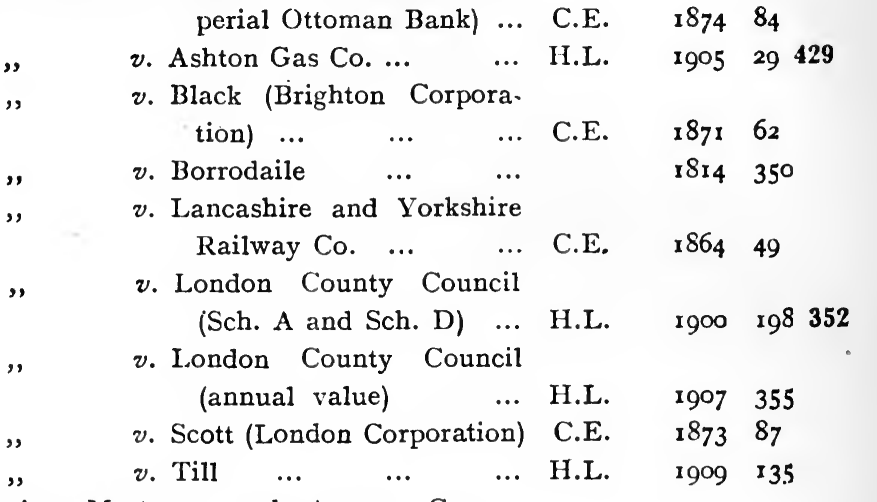

Australasian Mortgage and Agency Co. $v$.

Smiles. See Smiles.

\begin{tabular}{|c|c|c|c|c|c|}
\hline Badham $v$. Williams & $\ldots$ & $\ldots$ & Ch.D. & 1902 & 157 \\
\hline Bain $v$. Free Church of Scotland & $\cdots$ & $\cdots$ & C.S. & 1897 & 474 \\
\hline Baird Trustees $v$. Lord Advocate & $\ldots$ & $\ldots$ & C.S. & 1888 & 469472 \\
\hline Baker $v$. English Crown Spelter & Co. & See & & & \\
\hline $\begin{array}{l}\text { English Crown Spelter Co. } \\
\text { Baptist Psalms and Hymns (Tru }\end{array}$ & tees of) & $v$ & & & \\
\hline Whitwell & $\ldots$ & $\ldots$ & Q.B.D. & 1890 & $47^{I}$ \\
\hline Barry v. Smart & $\ldots$ & $\ldots$ & Ch.D. & 1906 & 284 \\
\hline
\end{tabular}

Bartholomay Brewing Co. (of Rochester), Lim.

$$
\begin{aligned}
& \begin{array}{lllllllll}
v . \text { Wyatt } \ldots & \ldots & \ldots & \ldots & \ldots & \text { Q.B.D. } & \text { I } 893 & 84
\end{array} \\
& \begin{array}{lllllllllll}
\text { Beaumont } ข \text {. Bowers } & \ldots & \ldots & \ldots & \text { Q.B.D. } & \text { 1900 } & 55 & 263 & 265
\end{array}
\end{aligned}
$$

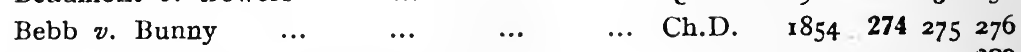

Bell ๘. Alianza Co. See Alianza Co.

„, v. Anglo-Continental Guano Works. See Anglo-Continental Guano Works. 
Bell v. Goerz. See Goerz.

PAGES

$\begin{array}{rlllllll}\text {,y. Gribble } \quad \ldots & \ldots & \ldots & \ldots & \text { C.A. } & 1903 & 55261 \\ \text {, } & \text { \%. National Provincial Bank of England } & \ldots & \text { C.A. } & 1903 & 333 \\ \text { Birmingham Corporation, In re } & \ldots & \ldots & \text { C.E. } & 1875 & 35^{1}\end{array}$

Bishop v. Equitable Life Assurance Society of U.S. See Equitable.

"v. Gresham Life Assurance Society. See Gresham.

," v. Universal Life Assurance Society $\ldots . \quad$ Q.B.D. $\quad$ I899 196

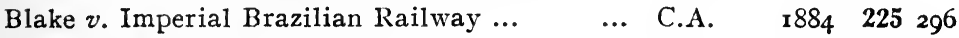

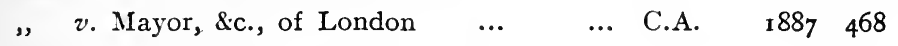

$\begin{array}{lllllll}\text { Bowers } v \text {. Harding } \ldots & \ldots & \ldots & \ldots & \text { Q.B.D. } & 1891 & 452\end{array}$ , v. Beaumont. See Beaumont.

\begin{tabular}{|c|c|c|c|c|c|}
\hline Bray $v$. Brothers & $\cdots$ & $\cdots$ & Q.B.D. & 1897 & 48 \\
\hline ", v. Justices of Lancashire & ... & ... & C.A. & I 889 & 469 \\
\hline Brickwood \& Co. $v$. Reynolds & $\cdots$ & $\ldots$ & C.A. & 1897 & $\begin{array}{lll}250 & 252 & 253 \\
25.5 & 256 & 258\end{array}$ \\
\hline
\end{tabular}

Brighton Corporation. See Attorney-General v. Black.

Brisley v. Walker. See Walker.

Bristol, Mayor, \&c., of, v. Andrews. See Andrews.

British India Navigation Co. v. Leslie. See Leslie.

Broughton and Plas Power Co. v. Kirkpatrick Q.B.D. ${ }_{1} 884 \quad 324$

Brown v. Burt

... C.A. 191162

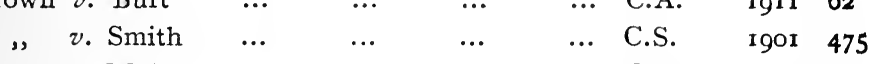

$\begin{array}{lllllllll} & \text { v. Walsh } & \ldots & \ldots & \ldots & \ldots & \text { Q.B.D. } & \text { I } 898 & \text { Ir3 }\end{array}$

$\begin{array}{lllllllll}\text { " } & \text { v. Watt } & \ldots & \ldots & \ldots & \ldots & \text { C.S. } & 1886 & 375\end{array}$

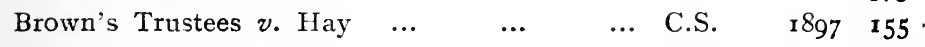

$\begin{array}{llllllll}\text { Bruce } v \text {. Burton } \quad \ldots & \ldots & \ldots & \ldots & \text { K.B.D. } & \text { 1901 } & 38378\end{array}$

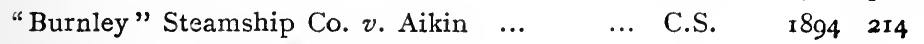

Burton v. Bruce. See Bruce.

Cadwalader, re. See Cooper v. Cadwalader.

Calcutta Jute Mills Co., Lim. v. Nicholson $\quad \ldots \quad$ C.E. $\quad 1876 \quad 84$

Caledonian Railway Company $v$. Banks $\quad \ldots$ C.S. 18802 II

Californian Copper Syndicate $v$. Harris $\quad \ldots$ C.S. $\quad 1904 \quad 74 \quad 75$ II 5

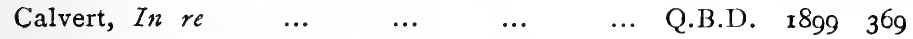

Cape Copper Mining Co., Lim. See Reg. $v$. Commissioners for Special Purposes of Income Tax. 
Cawse v. Committee of Lunatic Asylum,

$$
\begin{array}{lllllllll}
\text { Nottingham } & \ldots & \ldots & \text {... } & \text { (.B.D. } & 1891 & 471
\end{array}
$$

, v. Dunlop. See Dunlop.

Cesena Sulphur Co., Lim. v. Nicholson $\quad \ldots \quad$ C.E. $\quad{ }_{1876} 84$

Chadwick v. Pearl Life Assurance Company $\ldots . \quad$ Ch.I). $\quad$ IgO5 $_{283}$

$\begin{array}{llllllll}\text { Charlton } v \text {. Corke } \ldots & \ldots & \ldots & \ldots & \text { C.S. } & \text { r } 890 & 5^{1}\end{array}$

Chew $v$. Reading. See Reading.

Clark (Mary) Home $v$. Anderson $\quad \ldots \quad \ldots \quad \ldots$ K.B.D. $1904 \quad 475$

„, $v$. Sun Insurance Office $\quad \ldots \quad \ldots$ C.A. 19 rI 191205

Clayton v. Newcastle-under-Lyne Corporation... Q.B.D. $\quad$ r888 229

Clerical, Medical, and General Life Assurance

$\begin{array}{llllllllll}\text { Society } v \text {. Carter } & \ldots & \ldots & \ldots & \ldots & \text { C.A. } & 1889 & 184 & 289\end{array}$

Clerk $v$. Commissioners of Dumfries ... $\quad \ldots \quad$ C.S. $\quad 1880 \quad 468$

$\begin{array}{lllllllll}\text { Colquhoun } v \text {. Brooks } & \ldots & \ldots & \ldots & \ldots & \text { H.L. } & \times 889 & 75 & 114\end{array}$

$\begin{array}{llllllll}\text {, } & v \text {. Heddon } & \ldots & \ldots & \ldots & \text { C.A. } & 1890 & 260\end{array}$

Coltness Iron Co., Lim. v. Black $\quad \ldots \quad \ldots \quad$ H.L. $\quad$ I88I 62277311

Commissioners of Income Tax $v$. Pemsel. See 318 319 322

Reg. v. Commissioners of Income Tax.

$\begin{array}{llllllllll}\text { Cook } & v . & \text { Knott } & \ldots & \ldots & \ldots & \ldots & \text { Q.B.D. } & \text { I } 887 & 55228\end{array}$

$\begin{array}{lllllll}\text { Coomber } v \text {. Justices of Berkshire } \quad \ldots & \ldots & \text { H.L. } & \text { I } 883 & 467\end{array}$

$\begin{array}{lllllllll}\text { Cooper } v \text {. Blakiston ... } & \ldots & \ldots & \ldots & \text { H.L. } & 1908 & 53 & 54\end{array}$

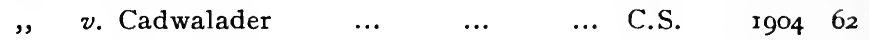

$\begin{array}{llllllll}\text { Corke } v \text {. Fry } & \ldots & \ldots & \ldots & \ldots & \text { C.S. } & 1895 & 455\end{array}$

Coulson $v$. Cunard S.S. Co. See Cunard.

Craigerne, s.s. In re $\quad \ldots \quad \ldots \quad \ldots \quad \ldots \quad$ C.S. $\quad 1902{ }^{\circ} 333$

$\begin{array}{lllllll}\text { Crane } v \text {. Kilpin } \quad \ldots & \ldots & \ldots & \text { Chancery Court } x 868 & 275\end{array}$

Craven's Mortgage, Davies v. Craven $\quad$.. Ch.D. 1907275

Crookston Bros. $v$. Furtado ... $\quad \ldots \quad$... C.S. $\quad$ rgro 93

$\begin{array}{lllllll}\text { Cumming } v \text {. Bedborough } \quad \ldots & \ldots & \ldots & \text { C.E. } & 1846 & 30 & 273\end{array}$

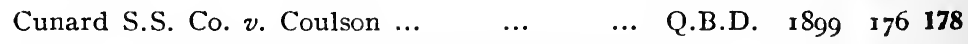

Curtis v. Old Monkland Conservative Association H.L. $\quad 1905 \quad 407408$

Cuxson v. Turner. See Turner $v$. Cuxson.

Cwmorthen Slate Co. $v$. Jones. See Jones.

Davies $v$. Craven. See Craven.

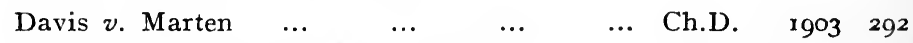

De Beers Consolidated Mines, Lim. v. Howe ... $\quad$ H.L. $\quad$ rgo6 818487

Delage $v$. Nugget Polish Co., Lim. ... $\quad \ldots$ K.B.D. 1905293

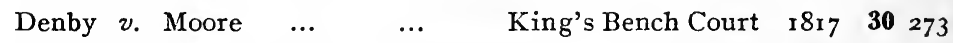

Denver Hotel Co., Lim. v. Andrews ... $\quad$... $\quad$ C.A. $\quad 189584$

$\begin{array}{llllll}\text { De Peyer } v \text {. The King } \quad \ldots & \ldots & \ldots & \text { C.A. } & 1909 & 310492\end{array}$ 
Dick, R. \& J. See Walker, Jas. re

Dillon v. Corporation of Haverfordwest $\quad$ A. Q.B.D. $1891 \quad 233 \quad 256$

$\begin{array}{llllllll}\text { Dinning } v \text {. Henderson } \quad \ldots & \ldots & \ldots & \text { Ch.D. } & 1850 & 273\end{array}$

$\begin{array}{lllll}\text { Dublin Corporation v. McAdam } \quad \ldots & \text { Ireland C.E. } & 1887 & 89\end{array}$

Dumfries, Commissioners of, v. Clerk. See Clerk.

Duncan's Executors v. Farmer

C.S. $\quad 1909 \quad 5054 \quad 116$

Dundee Town Council v. Musgrave. See

Musgrave.

Dunlop Pneumatic Tyre Co., Lim. v. Cawse ...

Durban-Roodeport Gold Mining Co., Lim. v.

Stevens. See Stevens.

East India Railway Co. $v$. Secretary of State for India

Edinburgh and District Water Trust $v$. Maughan. See Maughan.

, Corporation v. Harris. See Harris.

", v. Lord Advocate. See Lord Advocate.

Life Assurance Co. v. Lord Advocate. See Lord Advocate.

Life Assurance Co. v. Revell. See Revell.

(Justices of) $v$. Surveyor of Taxes. See Adam v. Maughan.

Royal College of Surgeons $v$. Sulley. See Sulley.

Southern Cemetery Co. v. Commissioners of Inland Revenue C.S. $\quad 1889 \quad 19232 \quad 319$

Elliott $v$. Grove. See Grove.

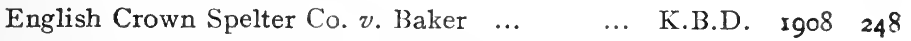

Equitable Life Assurance Society of U.S. v.

$\begin{array}{llllll}\text { Bishop } & \ldots & \ldots & \ldots & \ldots & \ldots\end{array}$

$\begin{array}{cccccc}\text { Co. of Copenhagen) } & \ldots & \ldots & \ldots \\ \text { Essex Hall, re. See Rex } & v & \text { Special } & \text { Com- }\end{array}$

C.A. $1905 \div 81$

Essex Hall, re. See Rex v. Special Commissioners.

Exploration Co., Lim., case. See Rex v. Commissioners of Inland Revenue.

Farrell v. s.s. Sunderland, Lim.

Ferguson v. Andrew. See Andrew.
,
v. Aikin ...
...
$\cdots$
... C.S.
$1898 \quad 332334$ 
Fletcher, Ex parte. See Queen v. Chew.

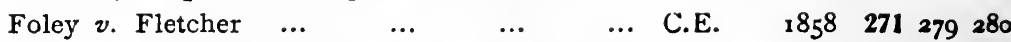

Forbes v. Scottish Provident Institution, \&c.

See Scottish Provident Institution, \&c.

$\begin{array}{llll}\text { Forder } v \text {. Handyside } & \ldots & \ldots & \ldots\end{array}$

C.E. $\quad 1876 \quad 225$

Forth Bridge Railway.

Frank Jones Brewing Co. v. Apthorpe. See Apthorpe.

Galashiels Provident Building Society $v$. Kenneth Newlands $\quad \ldots \quad \ldots . \quad \ldots$

Gateshead Conservative Building Society $v$.

C.S. $\quad 1893 \quad 273 \quad 3^{12}$ Raffles. See Raflles.

General Accident, Fire and Life Assurance Co., Lim. v. McGowan ... $\quad$... $\quad \ldots \quad \ldots$

Gilbertson v. Fergusson (Imperial Ottoman Bank)

Gillespie v. Jardine. See Jardine.

Gilliatt \& Watts $v$. Colquhoun $\quad \ldots$

Glamorgan Quarter Sessions v. Wilson _..

Glasgow Corporation Gas Commissioners, In re

H.L. 1908 191 204

", Waterworks v. Inland $\begin{array}{lll}\text { Revenue } \quad \ldots & \ldots \\ \text { Water Commissioners } & v\end{array}$

C.A. $\quad 188164$

Q.B.D. $\quad 1884 \quad 226$

K.B.D. Igro 185

C.S. $\quad 1876 \quad 63$

C.S. $\quad 1875 \quad 63$

$\begin{array}{llllll}\text { Miller } \quad \ldots & \ldots & \text { C.S. } & \mathbf{1} 886 & 88\end{array}$

$\begin{array}{llllllll}\text { Goerz } & v \text {. Bell } \quad \ldots & \ldots & \ldots & \ldots & \text { K.B.D. } 190485\end{array}$

Goslings \& Sharp $v$. Blake ... $\quad \ldots \quad \ldots \quad \ldots$ C.A. $\quad$ r889 $272 \quad 274275$

$\begin{array}{llllllllllll}312 & \\ \text { Grainger } v \text {. Gough } & . . & \ldots & \ldots & \ldots & \text { H.L. } & 1896 & 91 & 93 & 96 & 98\end{array}$

Gramophone \& Typewriter, Lim. v. Stanley $\ldots$ C.A. $\quad$ rgo8 $85 \mathbf{8 6}$

Granite Supply Association v. Kitton... $\quad$.. $\quad$ C.S. $\quad 1905239$

Great Indian Peninsular Railway. See Scoble.

, Northern Telegraph Co. of Copenhagen.

See Erischen $v$. Last.

Gresham Life Assurance Society $v$. Styles $\quad \ldots \quad$ H.L. $\quad 1892 \quad 233255302$

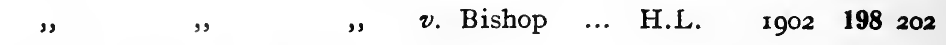

Gribble v. Bell. See Bell.

" v. Hudson. See Hudson.

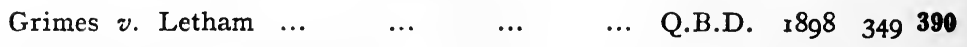

$\begin{array}{llllll}\text { Grove ข. Elliott \& Parkinson } \quad \ldots & \ldots & \text { Q.B.D. } & \text { เ } 896 & 84\end{array}$ 
Grove v. Y.M.C.A. ...

Guest, Keen \& Nettlefolds, Lim. v. Fowler $\quad \ldots$ K.B.D. 1910242

Hall, Jno., Jr. \& Co. v. Rickman $\quad$.. $\quad \ldots$. K.B.D. 1905 I 78219

Hamilton Waterworks Commissioners. See Allan.

Hancock, W. \& Co., Lim. v. Gillard ... $\quad$.. $\quad$ K.B.D. 190627252

Hargreaves, Lim., In re Joseph $\quad \ldots \quad \ldots \quad$ C.A. $\quad 1900155$

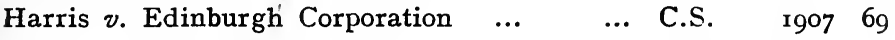

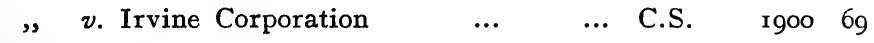

Haverfordwest, Corporation of, v. Dillon. See

Dillon.

Hay v. Brown's Trustees. See Brown.

$\begin{array}{lllllll}\text { Herbert } v \text {. McQuade } & \ldots & \ldots & \ldots & \text { C.A. } & 1902 & 51\end{array}$

$\begin{array}{llllllll}\text { Hesketh } v \text {. Bray } \quad \ldots & \ldots & \ldots & \ldots & \text { C.A. } & \text { I } 888 & 33\end{array}$

Highland Railway Co. v. Special Commissioners of Income Tax (Steamships case) ... ...

Highland Railway Co. v. Balderston (Improvements case) $\quad . . . \quad \ldots . . . .$.

Holborn Viaduct Land Co. $v$. The Queen $\quad \ldots$ Q.B.D. 1887 I 51299

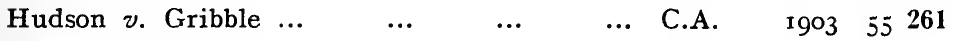

Hudson's Bay Co., Lim. v. Stevens ... $\quad . . . \quad$ C.A. 1909 105

$\begin{array}{llllllll}\text { Hue } v \text {. Miller } & \ldots & \ldots & \ldots & \ldots & \text { Q.B.D. } & \text { I900 } & 50\end{array}$

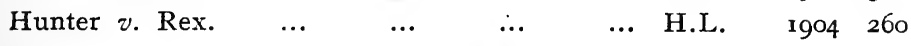

Imperial Continental Gas Association $v$. $\begin{array}{lllllll}\text { Nicholson } \quad \ldots & \ldots & \ldots & \text { C.E. } & 1877 & 17\end{array}$

", Fire Insurance Co. v. Wilson $\quad \ldots$ C.E. $\quad 1876$ I9 203

, Ottoman Bank. See Attorney-General

v. Alexander.

", , See Gilbertson v.

Fergusson.

India (Secretary of State for) $v$. Scoble. See Scoble.

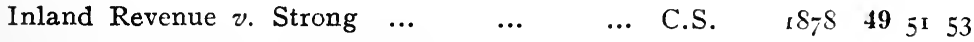

Irvine Corporation. See Harris.

$\begin{array}{llllllll}\text { Jardine } & v \text {. Gillespie } & \ldots & \ldots & \ldots & \text { C.S. } & \text { 1906 } & 54\end{array}$

Jones $v$. Civmorthen Slate Co. $\quad \ldots . \quad \ldots$. C.A. $\quad 1879 \quad 16$

, (Frank) Brewing Co. v. Apthorpe. See Apthorpe. 
King, The. See Rex.

PAGLS

King's Lynn Harbour Mooring Commissioners,

$\begin{array}{lllllllll}\text { In re } & \ldots & \ldots & \ldots & \ldots & \ldots & \text { C.E. } & 18_{75} & 224\end{array}$

King's Lynn Harbour Mooring Commissioners

v. Sowrey. See Sowrey.

Kitton v. O'Gilvie. See O’Gilvie.

\begin{tabular}{|c|c|c|c|c|c|}
\hline$\cdots$ & $\ldots$ & $\ldots$ & C.E. & 1877 & $\begin{array}{r}22314316 \\
317319\end{array}$ \\
\hline & & & C.A. & $9 \circ 3$ & 8586 \\
\hline
\end{tabular}

Kodak, Lim. v. Clark

(n)

Lamb \%. Brewster

Lancashire \& Yorkshire Railway Co. $v$. Attorney-

C.A. $\quad 18_{79} \quad 30$

General. See Attorney-General.

, Justices of, $z^{\prime}$. Bray. See Bray.

l.angston 2 . Glasson ... $\quad \ldots \quad \quad \ldots \quad \quad \ldots \quad$ Q.B.D. $1891 \quad 45^{2}$

Ianston Monotype Corporation, Lim. $v$.

Anderson

Last v. London Assurance Corporation

... C.A. 1911 $15^{\circ}$

Law Guarantee Society $v$. Smith. See Smith.

Leeds Corporation $z^{\prime}$. Sugden... $\quad \ldots \quad \ldots$

, Permanent Benefit Building Society $v$.

$$
\text { Mallandaine } \quad \ldots \quad \ldots \quad \ldots
$$

Leith, Hull \& Hamburg Steam Packet Co. v. Bain

$$
\text { , , } \quad \text {, v. Musgrave }
$$

H.I.

$\mathrm{ISR}_{5} \quad \mathbf{9 8} 100102$

104189200

Leslie $v$. Fritish India Steam Navigation Co. ...

C.A. $1911 \quad 357$

C.A. $\quad{ }^{1} 997 \quad 288$

C.S. $\quad 18_{97} \quad 215$

C.S. $\quad 1899 \quad 216$

Letham $v$. Grimes. See Grimes.

Lion Brewery. See Smith $v$. Lion Brewery.

Liverpool and London and Globe Insurance Co.

$$
\begin{array}{llllll}
v \text {. Bennett } & \ldots & \ldots & \text {.. } & \text { K.B.D. } 191 \mathrm{r} & 199
\end{array}
$$

School for Blind $v$. Lund. See I.und.

$\begin{array}{lllll}\text { Lloyd } v \text {. Sulley } & \ldots & \ldots & \ldots & \ldots \\ \text {.London Assurance Corporation } & v \text {. Last. } & \text { See Last. }\end{array}$

C.S. $\quad{ }_{1} 88_{4} \quad 61$

," Bank of Mexico and South America $v$.

$\begin{array}{lllllll}\text { Apthorpe } & \ldots & \ldots & \ldots & \text { C.A. } & \text { IS } & \varepsilon_{4}\end{array}$

,, (City of) Contract Corporation v. Styles

C.A. $\quad 1887 \quad 226$

„ Corporation. See Attorney-Ceneral $v$.

Scott.

, , , See Blake $v$. Mayor, \&c., of London.

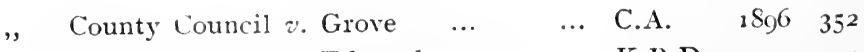

, , , , $\quad$, Edwards ... ,.. $\quad$ K.B.D. 1909212 
Lord Advocate v. Edinburgh Corporation _. $\quad$ C.S. $1903 \& 1905272291$

\begin{tabular}{|c|c|c|c|c|c|c|c|}
\hline ", & , & $v$. Edinburgh Li & fe Assurance & Cọ. & H.I. & 1909 & 207 \\
\hline , & , & $v$. Forth Bridge & Railway & $\cdots$ & C.S. & 1890 & $70 \quad 182$ \\
\hline , & , & v. Hugh Gibb & $\ldots$ & $\ldots$ & C.S. & 1906 & 134 \\
\hline ,, & ,' & v. Maclaren & $\cdots$ & $\cdots$ & C.S. & 1905 & 401 \\
\hline , & ," & z'. Sawers & $\ldots$ & $\ldots$ & C.S. & 1 898 & 135 \\
\hline othian & y. & $\mathrm{rae}$ & $\ldots$ & $\ldots$ & C.S. & 1884 & 4955 \\
\hline
\end{tabular}

, v. Watson Bros. See Craigerne s.s.

Lund $v$. President, \&c., Liverpool School for
Blind
...
...
...
‥ Ch.D. $\quad 1898 \quad 29$

M. v. Lord Advocate. See Lord Advecate.

$\begin{array}{llllllll}\text { McDougall } & v \text {. Sutherland } & \ldots & \ldots & \ldots & \text { C.S. } & 1894 & 454\end{array}$

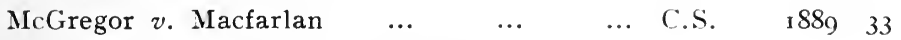

McQuade $v$. Herbert. See Herbert.

Manchester, Mayor, \&c., of, v. McAdam N. H.I. $\quad 1894 \quad 473 \mathbf{4 7 4}$

Market Harborough Advertiser 2'. Mylam. See

Mylam.

Marten $v$. Davis. See Daris.

Mary Clark Home $v$. Anderscn. See Clark.

Maughan v. Edinburgh \& District Water Trust C.S. $\quad 1886 \quad 171$

$\begin{array}{llllll}, & v . \text { Free Church of Scotland... } \quad \ldots & \text { C.S. } & 1893 \quad 473 & 476\end{array}$

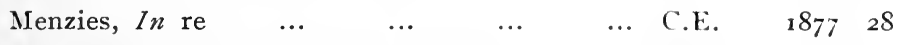

Merchiston S.S. Co., Lim. v. Turner $\quad$.. $\quad$ K.B.D. 1910339

Mersey Docks and Harbour Board v. Lucas ... H.I.. $\quad \begin{array}{rrrr}1883 & 66 & 69 & 232\end{array}$

,, Loan and Discount Co., Lim. v. Wootton Q.B.D. $\quad$ I887 302305

Middlesbrough, \&c., Building Society, ex parte

Wythes

Middleton, In re

Miller $v$. Hue. See Hue.

‥ Q.B.D. $\quad 188_{5} \quad 28_{7}$

Moore $v$. Armitage. See Armitage.

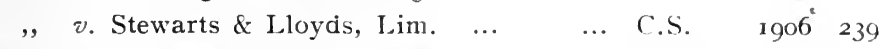

Morant $v$. The Wheal Grenville Mining Co. ... Q.P.D. $1894 \quad 32 \mathrm{I}$

Moravian case. See Reg. $v$. Commissicners of

Income Tax.

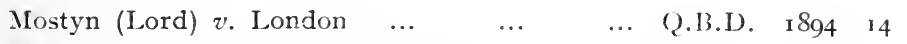

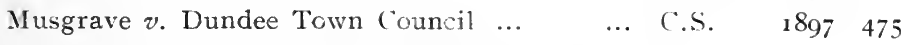

, v. Leith, Hull \& Hamburg Stcam

Packet Co. See Lcith Stcam

Packet Co.

Mylam v. Market Harborough Advertiser $\quad \ldots \quad$ K.B.D. ${ }_{905} 408$ 
National Bank of Wales, In re ... Ch.D. 1899291

, Provincial Bank of England, Lim. $v$. Bell. See Bell.

Needham $v$. Bowers ...

New York Life Insurance Co. $v$. Styles ... Q.B.D. $\quad 1888 \quad 469$

, Zealand Shipping Co., Lim. v. Stephens... Nizam's State Railway Co. $v$. Wyatt ...

... Q.B.D. $\quad 1890 \quad 230296$

Nobel Dynamite 'Trust Co., Lim. v. Wyatt

Norfolk (Duke of) $v$. Lamarque ... Q.B.D. $\quad$ I $893 \quad 84$

North British and Mercantile Insurance Co. $v$.

Surveyor of Taxes ...

.. Q.B.D. $\quad 1890 \quad 34$ ,, of Scotland Bank v. Russell. See Russell.
C.S.
I889 I90

Northampton Hospital (St. Andrew's) v. Shearsmith. See St. Andrew's.

Northern Assurance Co. $v$. Surveyor of Taxes ... , Investment Co. of New Zealand $v$. Smiles. See Smiles.

Norwich Union Fire Insurance Co. $v$. Magee ... Nottingham Lunatic Asylum v. Cawse. See Nottingham.

Nugget Polish Co. See Delage.

Offlow (Commissioners for) $v$. Rex. See Rex.

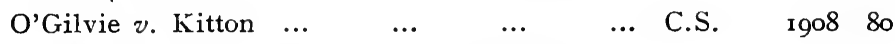
Old Monkland Conservative Association $v$. Curtis. See Curtis.

\section{C.S. $\quad 1889 \quad 190 \quad 192$}

Q.B.D. $\quad{ }_{1} 896 \quad$ I $88 \quad 195 \quad 196$

Paddington Burial Board $v$. Commisioners of Inland Revenue

Q.B.D. ${ }_{1} 884 \quad 67232$

Paisley Cemetery Co. v. Reith $\quad \ldots \quad \ldots$ C.S. $\quad 1898 \quad 73$

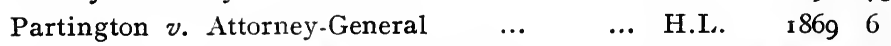

Partridge \& Hancox $v$. Mallandaine ... $\quad$... Q.B.D. $\quad$ Q 88667

Pearl Iife Assurance Co. v. Chadwick. See Chadwick.

Pemsel, re. See Reg. v. Commissioners of Income Tax.

Peninsular \& Oriental Steamship Co. $v$. Leslie Pocock v. Eustace $\ldots \quad \quad \ldots \quad \quad \ldots \quad \quad \ldots$ Pommery $\approx$. Apthorpe $\quad \ldots \quad \quad \ldots \quad \quad \ldots$ Portobello (Magistrates of) $v$. Sulley ... $\quad \ldots$ Poynting $v$. Faulkner

$\begin{array}{lll}\text { C.A. } & 1900 & 216 \quad 218 \\ & 1809 & 23 \\ \text { Q.B.D. } & 1886 & \mathbf{9 0} 93 \\ \text { C.S. } & 1890 & 231 \\ \text { C.A. } & 1905 & 53\end{array}$


xxi.

Pretoria-Pietersburg Railway Co., Lim. $v$.

$\begin{array}{lllllllll}\text { Elwood } & \ldots & \ldots & \ldots & \ldots & \ldots & \text { C.A. } & \text { 190\$ } 294\end{array}$

Psalms (Baptist) and Hymns (Trustees of) $v$.

Whitwell. See Baptist.

Queen, The. See Regina.

Queensland National Bank ... $\quad \ldots \quad \ldots \quad \ldots \quad$ K.B.D. 1909276

Rafles v. Gateshead Conservative Building

$\begin{array}{llllllllll}\text { Society } & \ldots & \ldots & \ldots & \ldots & \text { County Court } & 1889 & 288\end{array}$

Reading $v$. Chew $\quad \ldots \quad \quad \ldots \quad \ldots . \quad \ldots \quad$ Q.B.D. 1898 30

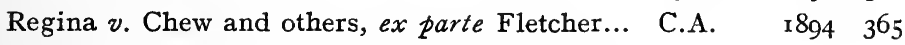

,, v. Commissioners for Special Purposes of Income Tax (Cape Copper $\begin{array}{lllllll}\text { Mining case) } & \ldots & \ldots & \ldots & \text { C.A. } & \text { I } 888 & 370\end{array}$

, v. Commissioners of Income Tax (Pem$\begin{array}{lllllllll}\text { sel's case }) & \ldots & \ldots & \ldots & \text { H.L. } & \text { I } 89 \text { I } & 469 & 472 & 474\end{array}$

, v. Commissioners of Income Tax (Yorkshire Penny Bank case) ... $\quad$... $\quad$ Q.B.D. $\quad \begin{array}{lll}1889 & 470\end{array}$

$\begin{array}{llllll}\text { Reid's Brewery Co. v. Male ... } \quad \text {... } & \text {... } & \text { Q.B.D. } & \text { I } 89 \mathrm{I} & 247\end{array}$

Reith v. Paisley Cemetery Co. See Paisley.

Religious Tract, \&c., Society v. Forbes $\quad$.. $\quad$ C.S. $\quad \begin{array}{llll}\mathbf{1} 896 & \mathbf{7 1} & 74\end{array}$

Revell v. Edinburgh Life Assurance Co. $\quad$.. $\quad$ C.S. $\quad 1906 \quad 184$

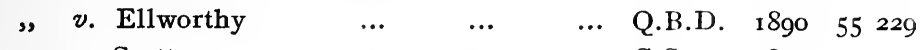

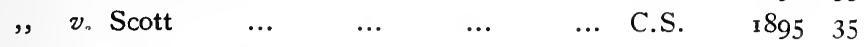

Rex $v$. Hunter. See Hunter.

$\begin{array}{llllll}\text {, v. Cook } & \ldots & \ldots & \ldots & \ldots\end{array}$

,v. Commissioners of Inland Revenue (Ex-

$\begin{array}{llllllll}\text { ploration case) } & \ldots & \ldots & \ldots & \text { K.B.D. } & 1904 & 3^{8} 5\end{array}$

, v. General Income Tax Commissioners for

$\begin{array}{llllllllll}\text { Offlow } & \ldots & \ldots & \ldots & \ldots & \text { K.B.D. } & \text { I9I I } & 28\end{array}$

, v. Special Commissioners (N. Wales $\begin{array}{lllllll}\text { College case }) & \ldots & \ldots & \ldots & \text { C.A. } & 1909 & 476\end{array}$

„v. Special Commissioners (Essex Hall case) C.A. 19 I 476

Rhymney Iron Co. $v$. Fowler

‥ Q.B.D. $\quad 1896 \quad 237239243$

Ricknian v. Turner. See Turner.

$\begin{array}{llllll}\text { Rogers } v \text {. Inland Revenue } \quad \ldots & \ldots & \text { C.S. } & \text { I } 879 & 61\end{array}$

Royal Insurance Co. $v$. Watson. See Watson.

Russell v. North of Scotland Bank, Lim. ... C.S. I 89 I 370

,, v. Town and County Bank, Lim. $\quad$... H.L. $\quad$ I $888 \quad 249$

$\begin{array}{llllll}\text { Ryhope Coal Co., Lim. v. Foyer } \quad \ldots & \text {... } & \text { Q.B.D. } & \text { I88 } & 328 & 343\end{array}$ 
xxir.

Vallambrosa Rubber Co., Lim. v. Farmer

C.S. $1910 \quad 245$

PAGES

$\begin{array}{llllllllll}\text { Walker } & v & \text { Brisley } & \ldots & \ldots & \ldots & \ldots & \text { Q.B.D. } & \text { 190o } & 28\end{array}$

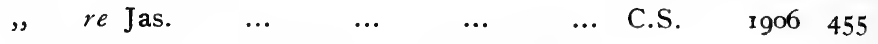

Wallasey U.D.C. v. Stockham. See Stockham.

Walsh v. Brown. See Brown.

IVatchmakers' Alliance v. Ernest Goode's Stores,

Lim.

$\begin{array}{llllll}\ldots & \ldots & \ldots & \text { Ch.D. } & 1905 & 149\end{array}$

$\begin{array}{lllllll}\text { Watney } v \text {. Musgrave } \quad \ldots & \ldots & \ldots & \text { C.E. } & & & \end{array}$

$224 \quad 251252$

Watson Bros. v. Lothian. See Craigerne s.s.

,$\quad v$. Royal Insurance Co.

$\begin{array}{llllll}\ldots & \ldots & \text { H.L. } & 1896 & \mathbf{2 3 6} & 240 \\ \ldots & \ldots & \text { Q.B.D. } & \mathbf{1} 897 & 93 & \\ \ldots & \ldots & \text { C.S. } & \mathbf{1} 893 & 68 & \\ \ldots & \ldots & \text { C.A. } & \mathbf{1} 888 & \mathbf{9 1} 93 & 98\end{array}$

Webber v. Glasgow Corporation

Werle \& Co. v. Colquhoun ...

Westinghouse Brake Co. v. Smith. See Smith.
Wheal Grenville Mining Co. $v$. Morant. See

Morant.

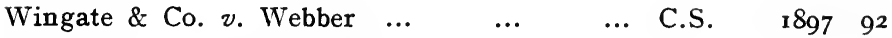

Woodifield v. Strong. See Strong \& Co., Lim.

Yorkshire Penny Bank, In re. See Regina $v$.

Special Commissioners of Income Tax.

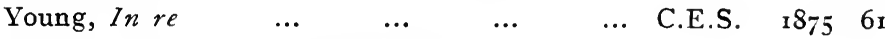

Y.M.C.A. v. Grove. See Grove.

Ystradyfodwg \& Pontypridd Main Sewerage

$\begin{array}{lllllll}\text { Board } v \text {. Bensted } \quad \ldots & \ldots & \ldots & \text { H.L. } & 1907 & 17\end{array}$ 


\section{TABLE OF STATUTES REFERRED TO.}

Where a Section is referred to several times the principal reference has been put in prominent type.

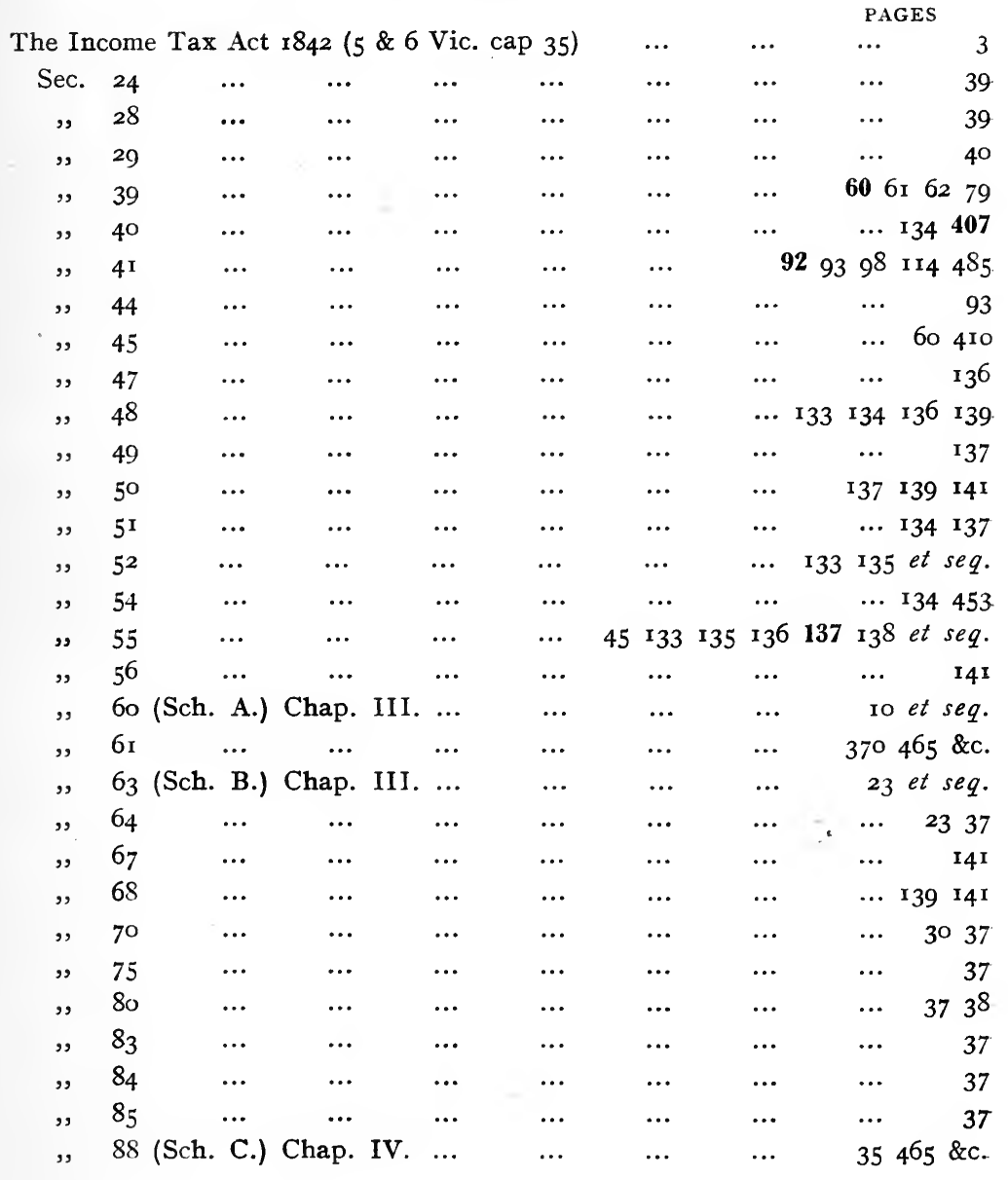


The Income Tax Act 1842 (5 \& 6 Vic. cap 35)-continued.

PAGES

Sec. 89

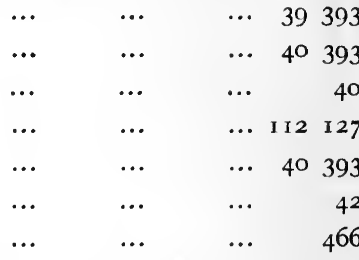

, 98

(Sch. D.) Chap. VI.

$\begin{array}{llllllll}78 & \text { I13 } 114 & \text { 120 } & \text { 126 \&c. } 161327\end{array}$

, ror

$\begin{array}{llllllll}\text {.. } & 74 & \text { I } 26 & 248 & 34 & 349 & 35^{\mathrm{I}}\end{array}$

, $\mathrm{J} 02$

$\begin{array}{lllllll}\ldots & 183 & 193 & 194 & 297 & 303 & 304\end{array}$

, 103

,$\quad 105$

Sec. 106

, I I I

, , I 3

$\begin{array}{llll}\ldots & \ldots & 29 & 31\end{array}$

II6 $370465 \&$ \&. 47 I

, II 8

., 120

, 122

,, 123

, I 124

,, $\quad \mathbf{2} 25$

,, 126

,$\quad 127$

, 129

, 130

, 131

,, 133

, 134

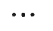

I 46

, 137

, 138

, 139

, 140

$$
\cdots
$$

... $147 \quad 170$

... 139 I 7 I

.. 363 \&c.

$$
\cdots
$$

... 366

... 366 \&c.

.. 366 \&c.

.. 366 \&c.

.. $366 \& c$.

364

.. $\quad 140$

${ }_{13} 8$ et seq.

... $\quad 363$

$147364 \& c$.

r6 $369 \& \mathrm{c}$.

$20434737037245^{\circ} 492$

.. $147 \quad 149$

I 49

I 49

$\begin{array}{lll}\ldots & \ldots & 149\end{array}$

, I4I

,, 142

,, 146 (Sch. E.) Chap. V.

...

...

... $\quad 149$

, 159

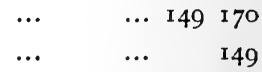

... $\quad \ldots \quad 44262$

I 3323324029739 I

, 160 26

, $16 \mathrm{r}$

, 162

,$\quad 163$

398408

,, 166 
The Income Tax Act ${ }_{1} 8_{42}(5 \& 6$ Vic. cap. 35)-continued.

Sec. 168

PAGES

$\begin{array}{ll},, & \text { I } 7 \mathbf{I} \\ ,, & \text { I } 73 \\ , & \text { I } 77 \\ ,, & \text { I } 7 S \\ , & \text { I } S S \\ ,, & \text { I90 } \\ ,, & \text { I92 }\end{array}$

A further Act of 1842 (5 \& 6 Vic. cap. 80)

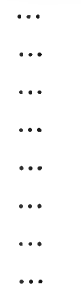

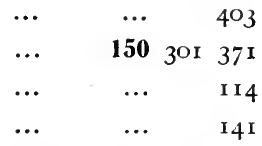

I39 I4O I4I I $44 \mathbf{4 0 2}$

Customs and Inland Revenue Act I 85 I (I4 \& 5 Vic. cap. I2)

The Income Tax Act 1853 (16 \& 17 Vic. cap. 34) ...

$\begin{array}{rrr}\cdots & \cdots & 4 \text { I } 42 \\ \cdots & \cdots & \text { I } 43\end{array}$

Sec. I

$\begin{array}{lllll}\ldots & \ldots & \ldots & 184\end{array}$

$\begin{array}{cccccc}, & 2 & \ldots & \ldots & \ldots & \ldots \\ , & 10 & \ldots & \ldots & \ldots & \ldots \\ , & 18 & \ldots & \ldots & \ldots & \ldots \\ , & 28 & \ldots & \ldots & \ldots & \ldots \\ , & 30 & \ldots & \ldots & \ldots & \ldots \\ , & 35 & \ldots & \ldots & \ldots & \ldots \\ , & 37 & \ldots & \ldots & \ldots & \ldots \\ , & 39 & \ldots & \ldots & \ldots & \ldots \\ , & 40 & \ldots & \ldots & \ldots & 23 \\ , & 48 & \ldots & \ldots & \ldots & \ldots \\ , & 49 & \ldots & \ldots & \ldots & \ldots \\ , & 50 & \ldots & \ldots & \ldots & \ldots \\ , & 51 & \ldots & \ldots & \ldots & \ldots \\ , & 52 & \ldots & \ldots & \ldots & \ldots \\ , & 53 & \ldots & \ldots & \ldots & \ldots \\ , & 54 & \ldots & \ldots & \ldots & \ldots\end{array}$

$\begin{array}{lllllllll}S & \text { Iо } 34 & 39 & 44 & 57 & 76 & \text { I25 } & \text { I } 83\end{array}$

4064393

$37 \mathrm{I}$

401

$45^{\circ}$

30

33

$\begin{array}{llll}\cdots & \cdots & \cdots & 34\end{array}$

An Act of 1853 (16 \& 17 Vic. cap. 9I) ..

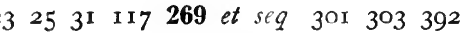

$$
\text { , }
$$

I8 54 (I7 \& I8 Vic. cap. 24)

I $\$ 55$ (18 \& 19 Vic. cap. 35)

$1859(22 \& 23$ Vic. cap. 18) ...

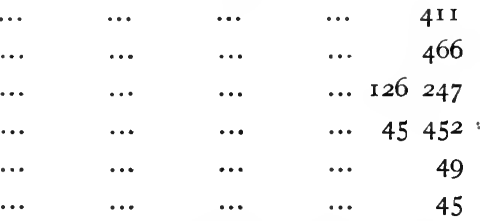

An Act of 1860 (23 \& 24 Vic. cap. 14)

$\begin{array}{llllll}259 & 264 & 370 & 463 & 47 & 48\end{array}$

Sec. 7

7

An Act of 186 r (24 \& 25 Vic. cap. 9I)

Companies Act r 862 (sec. I I 5)

$\begin{array}{lll}\ldots & \ldots & 259\end{array}$

.. $\quad$.. 393

, 


\section{PAGES}

National Debt Act $1870(33 \& 34$ Vic. cap. 71, sec 36 ) $\quad \ldots \quad \ldots \quad 40113$

Customs and Inland Revenue Act 1876 (39 \& 40 Vic. cap. 16) $\quad \ldots \quad 4399$

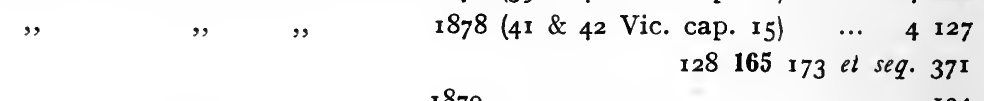

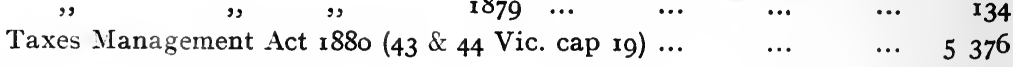

$\begin{array}{lllllllllll}\text { Sec. } & 2 \mathrm{I} & \ldots & \ldots & \ldots & \ldots & \ldots & \ldots & \text { I } 34 & \text { 135 } & \text { I7 }\end{array}$

$\begin{array}{llllllllll}, & 39 & \ldots & \ldots & \ldots & \ldots & \ldots & \ldots & \ldots & 37\end{array}$

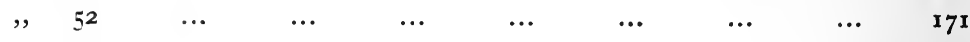

$\begin{array}{lllllllllll}, & 57 & \ldots & \ldots & \ldots & \ldots & \ldots & \ldots & \ldots & 56 & 364\end{array}$

$\begin{array}{llllllllll}, & 59 & \ldots & \ldots & \ldots & \ldots & \ldots & \ldots & \ldots & 364\end{array}$

$\begin{array}{lllllllllll}, & 60 & \ldots & \ldots & \ldots & \ldots & \ldots & \ldots & \ldots & 33 & 301\end{array}$

$\begin{array}{rrrrrrrrrr}, & 6_{3} & \ldots & \ldots & \ldots & \ldots & \ldots & \ldots & \ldots & 171\end{array}$

$\begin{array}{llllllllll}, & \mathrm{S}_{2} & \ldots & \ldots & \ldots & \ldots & \ldots & \ldots & \ldots & \text { 170 }\end{array}$

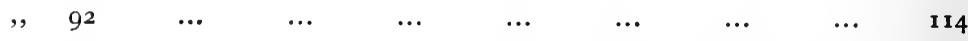

$\begin{array}{llllllllll}, & 95 & \ldots & \ldots & \ldots & \ldots & \ldots & \ldots & \ldots & 170\end{array}$

Inland Revenue Act $x 880(43 \& 44$ Vic. cap. 20$) \quad \ldots \quad \ldots \quad \ldots \quad \ldots \quad 536$

Customs and Inland Rerenue Act 1885 ( 48 \& 49 Vic. cap, 51 ) $\ldots \quad 40$

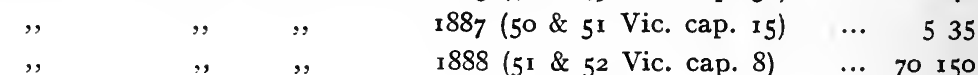

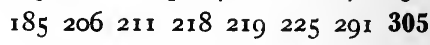

$35^{2}$ et. seq. 393 \&c.

$\begin{array}{lllllllll}\text { Interpretation Act } \mathbf{1} 889 & \ldots & \ldots & \ldots & \ldots & \ldots & \ldots & 408\end{array}$

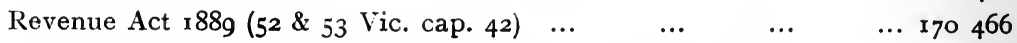

Inland Revenue Regulation Act 1890 (53 \& 54 Vic. cap. 21) ... . . 135 171

Customs and Inland Rerenue Act $1890(53 \&$ 54) Vic. cap. 8) $\quad \ldots \quad 5 \quad 566$

349371375 et seq. 450

$\begin{array}{llllllllllll}\text { Sec. } 23 & \ldots & \ldots & \ldots & \ldots & \ldots & \ldots & \text { I } 84 & 375 \text { et } \text { seq. }\end{array}$

$\begin{array}{lllllllllll}\prime, & 24 & \ldots & \ldots & \ldots & \ldots & \ldots & \ldots & \ldots & 171 & 485\end{array}$

Industrial and Provident Societies Act, 1893 (56 \& 57 Vic. cap. 39) ... 466

Trade Union (Provident Funds) Act 1893 (56 \& 57 Vic. cap. 2) $\quad \ldots \quad 466$

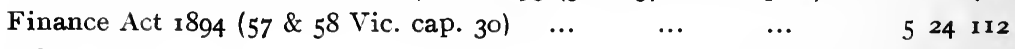

Sec. 34

... $\quad$ ․ 399479

, 35

$\begin{array}{llllll}10 & 12 & 25 & 27 & 162 & 484\end{array}$

, 36

Poor Law Officers' Superannuation Act 1896

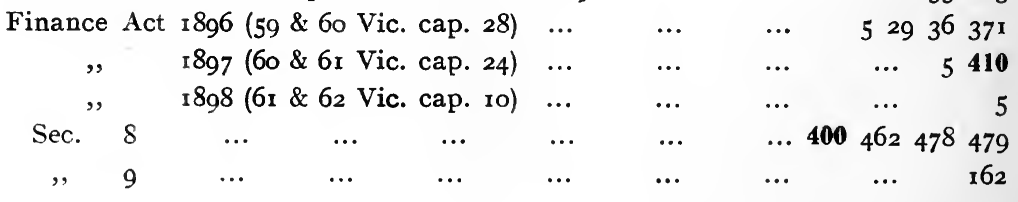

‥ 55263 
xxix.

Finance Act 1898 (6r \& 62 Vic. cap. roj-continued.

PAGES

Sec. ro

,, 16

Revenue Act r903 (3 Edw. VII. cap. 46)

Finance Act 1904 (4 Edw. VII. cap. 7)

Revenue Act 1906 (6 Edw. VII. cap. 8) ...

Finance Act r9o7 (7 Edw. VII. cap. I3)

Sec. 19

, 20

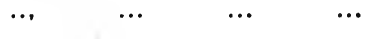

$\begin{array}{lll}\cdots & \cdots \\ \cdots & \cdots\end{array}$

.. $\quad \cdots \quad 233^{2}$

2 I

, 22

,, 23

,, 24

,, 25

,, 26

,, 27

$\cdots$

$\cdots$

$\cdots$

$\cdots \quad \ldots$

...

... 364

,, 28

Finance (rgog-ro) Act rgro (ro Edw. VII., cap. 8) ...

Sec. 66

, 67

,, 68

, 69

, 70

,, $7 \mathbf{I}$

, 72

$\cdots \quad \cdots$

$\cdots$

$\cdots$

$\cdots$

... 267365

... 267409

... 267

$\begin{array}{llllll}6 & \text { I35 } 37 \text { r } & 477 \quad \& c .\end{array}$

462477479

... 403 \&c.

45493 \&c.

... I 33

... II4 I7I

‥ 369373

149 \&c. 2 10

... 177219

... 375

... 268

$\begin{array}{lll}682 & 477\end{array}$

... $483 \& \mathrm{c}$.

... 479

... 462

... I I

‥ 467

42459460

Revenue Act rgr I (r Geo. V., cap. 2)--

Sec. II

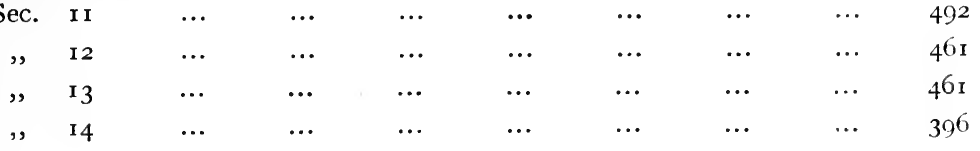



A Guide to Income Tax Practice. 



\title{
A GUIDE TO INCOME TAX PRACTICE.
}

\author{
CHAPTER I. \\ HISTORY OF THE INCOME TAX AND EPITOME OF THE \\ PRINCIPAL ACTS RELATING THERETO.
}

$\mathrm{H}^{-1}$

AVING regard to the object of this work, namely, to provide a practical guide to the preparation of accounts Object and scope of the Work. in support of income tax returns and appeals, it has been thought desirable to go somewhat fully into many of the very numerous decisions on the construction of the Income Tax Acts; it has not, however, been considered needful to do more than glance at the origin and history of the income tax, which are, briefly, as follows :-

In I798 an Act was introduced by Mr. Pitt, entitled "An "Act for granting to His Majesty an aid and contribution "for the prosecution of the war." 'The effect of the Act was

History of Income tax 1798. Pitt's war tax. 
History of Income Tax.
1803.

Charging income at

the source.

not to impose a duty upon property, but to impose additional duties of assessed taxes, regulated by the amount of income which the person already charged with assessed taxes possessed. It did not, howerer. affect persons whose incomes were less than $£ 60$ per annum, and it only applied to such persons as were already charged with assessed taxes.

In 1799 these duties were repealed, and a duty was imposed on incomes at the rate of ro per cent. The Act required returns of income from every source. Reduced rates were charged on incomes between $£^{60}$ and $\mathcal{E}_{200}$ per annum, and, as previously, those under $£ 60$ were exempt.

In 1803 the practice of charging incomes at the source was introduced, and the previous method was abandoned. The

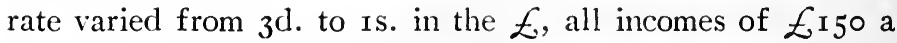
year, or upwards, paying the latter rate. At the same time the various descriptions of income chargeable with duty were distributed under schedules as at present. The same limit of exemption $\left(£^{60}\right)$ remained in force. It is worthy of notice that, when income thus came to be taxed at the source, the produce of the tax at the reduced rate of 5 per cent. was almost equal to that of 1799 , when the rate was 10 per cent. on the assessment of income as returned by the taxpayer.

1803 to 1806 . Several Acts were passed between 1803 and 1806 carrying out the same principle, but in 1806 the duty was again raised to 10 per cent., the limit of exemption was reduced from $£ 60$ to $£ 50$, and a graduated scale was imposed on incomes from $£ 5^{\circ}$ to $£^{150}$, but limited to incomes arising from trades, 
professions, and offices. Where the income was derived History of Income tax. wholly or in part from land and houses, the tax on the whole or on such part was to be paid in full. In the guide-book published by the Tax Office at that period it is stated that many persons fraudulently brought their incomes below the $£ 60$, and the Legislature found the necessity of confining the exemption to $£ 5^{\circ}$, that the former returns of such persons might be made use of. By this same Act of 1806 the dividends of the public funds, which had previously been returned by the recipients as part of their income, were for the first time brought within the principle of charging income at the source. An allowance for repairs of buildings, which before existed, was at the same time taken away, and abatements previously allowed to persons with a certain number of children were likewise discontinued, but see post. The allowance for life assurance premiums was confined to persons whose incomes were less than $\mathcal{E}^{\mathrm{r}} 5^{\circ}$ a year.

In 18 I6 the tax ceased, but it was revived-not as a war tax, but for the general purposes of the country, and to Income Tax ceased. facilitate certain reforms in aid of commerce-under Sir Robert Peel's Government, by the Act of 1842 ; and it is by this and subsequent Acts that the income tax is still governed.

The principal Acts relating to income tax are :-

Acts relating to Income Tax.

The Income Tax Act I842 (5 \& 6 Vic. cap. 35), containing :-

Re-imposed in 1842 .

Act of 1842 5 \& 6 Yic. cap. 35 .

The schedules under which income was charged, since repealed and provided for in the Act of 1853 .

The rules of assessment. 
Acts relating to Income Tax.

Act of 1853 , 16 \& 17 Yic. cap. 34

Act of 1876, $39 \& 40$ Yic. cap. 16.

Act of 1878 , 41 \& 42 Yic. cap. 15.
Provisions for various exemptions, such as charitable institutions, \&c.

Provision for exemption in respect of incomes under $E^{5} 5^{\circ}$ (limited by the Act of $\mathrm{r} 853$ to $\mathcal{E r o o}$, but restored to $\mathcal{E}_{5} 5^{\circ}$ in 1876 , and raised to $\mathcal{E}_{\mathrm{I}} 60$ in I894).

The Income Tax Act I853 (I6 \& I7 Vic. cap. 34), containing :-

The schedules under which income is charged--somewhat similar schedules under the Act of $\mathrm{I}_{42}$ being repealed.

Provisions relating to the extension of the income tax to Ireland.

Provision for abatement of duty to persons who have insured their lives, on the amount of the premium paid, up to one-sixth of the income.

The Customs and Inland Revenue Act 1876 (39 \& 40 Vic. cap 16 ), restoring the limit of exemption (which had been reduced to $£$ roo by the Act of $\left.18_{53}\right)$ to $£^{150}$; and granting an abatement of $£ \mathrm{r} 20$ to persons whose incomes were not less than $£ \mathrm{I}_{5} \mathrm{o}$ but were less than $£ 400$, in lieu of that previously in force under the Customs and Inland Revenue Act 1872, viz.:- to persons whose incomes were between $£$ roo and $£ 300$. Further abatement is granted by the Acts of 1894,1897 , and 1898 .

The Customs and Inland Revenue Act 1878 (4I \& 42 Vic. cap I5), directing the Commissioners to allow deduction for diminished value of machinery and plant by reason of wear and tear. 
The Taxes Management Act I880 (43 \& 44 Vic. cap I9), dealing principally with the management of the tax.

The Customs and Inland Rerenue Act 1887 (50 \& 5 I Vic. cap I 5), allowing farmers to elect to be assessed under Schedule D instead of under Schedule B.

The Customs and Inland Revenue Act 1890 (53 \& 54 Vic. cap. 8), granting relief to trading or professional persons Act of 1890 , 53 \& 54 Yic. cap. 8. and farmers in case of losses.

The Finance Act 1894 ( 57 \& 58 Vic. cap. 30 ), raising the limit of exemption (as mentioned above) to incomes not Act of 1894, cap. 30. exceeding $£ \mathrm{r} 60$, and granting further concessions of a like nature to those granted by the Act of ${ }_{1} 876$ (further extended in 1897 and 1898 ), and in respect of joint income of husband and wife; also granting an allowance under Schedule $\mathbf{A}$ in respect of repairs.

The Finance Act 1896 (59 \& 60 Vic. cap. 28), repealing the Acts of $\mathrm{I} 85 \mathrm{I}$ and $\mathrm{I} 880$ as to the assessment of farmAct of 1896, $59 \& 60$ Yic. cap. 28. ing profits, and enacting similar provisions.

The Finance Act 1897 (60 \& 6r Vic. cap. 24), granting a further concession in respect of joint income of husband Act of 1897, 60 \& 61 Yic. cap. 24. and wife.

The Finance Act 1898 (6r \& 62 Vic. cap. Io), granting further concessions of a like nature to those granted by Act of 1898 , $61 \& 62$ Yic. cap. 10. the Acts of 1876 and 1894 . 
Acts relating to Income Tax.

Act of 1907, 7 Ed. YII. cap. 13.

The Finance Act 1907 (7 Ed. VII. cap. I3), granting relief to " earned" incomes and repealing a section (I33) of the Act of $18_{42}$, which had given a certain right of appeal where the profit had fallen short of the amount previously returned for assessment, also extending the time for recovery of duty and penalties by the Crown.

Act of 1910, 10 Ed. YII. cap. 8.
Construction of Taxing Acts. Partington $v$. The Attorney. General.
The Finance (rgo9-ro) Act rgro (ro Ed. VII. cap. 8), introducing the super-tax, granting relief in respect of children, and restricting abatement, \&c., formerly granted to persons resident outside the United Kingdom.

It may not be out of place to quote here the rule as to the construction of Taxing Acts. In the case of Partington $v$. The Attorney-General (decided in 1869), Earl Cairns, in giving judgment in the House of Lords, said :-

"As I understand the principle of all fiscal legislation it is this: If the person sought to be taxed comes within the letter of the law he must be taxed, however great the hardship may appear to the judicial mind to be. On the other hand, if the Crown, seeking to recover the tax, cannot bring the subject within the letter of the law, the subject is free, however apparently within the spirit of the law the case might otherwise appear to be. In other words, if there be admissible in any statute what is called an equitable construction, certainly such a construction is not admissible in a taxing statute, where you can simply adhere to the words of the statute."

Coltness Iron Co. v. Black.
In Coltness Iron Company v. Black (decided in $\mathrm{x} 88 \mathrm{I}$ ) L.ord Blackburn, in the same tribunal, said :- 
"No tax can be imposed on the subject without words in an Act of Parliament clearly showing an intention to lay a burden on him. But when an intention is sufficiently shown, it is, I think, vain to speculate on what would be the fairest and most

Construction of Taxing Acts.

Coltness Iron Co. v. Elack. equitable mode of lerying that tax. The object of those framing a Taxing Act is to grant to Her Majesty a revenue. No doubt they would prefer, if it were possible, to raise that revenue equally from all, and, as that cannot be done, to raise it from those on whom the tax falls with as little trouble and annoyance and as equally as can be contrived; and when any enactments for the purpose can bear two interpretations, it is reasonable to put that construction on them which will produce these effects. But the object is to grant a revenue at all events, even though a possible nearer approximation to equality may be sacrificed in order more easily and certainly to raise that revenue; and I think the only safe rule is to look at the words of the enactments and see what is the intention expressed by those words." 
CHAPTER II.

THE SCHEDULES UNDER WIIICH INCOME TAX IS CHARGED.

THE section of the Act of $\mathrm{r}_{4} \mathbf{H}_{2}$ containing the schedules of charge has been superseded by sec. 2 of the Act of I853, which contains similar provisions. The properties and profits are divided and charged under five heads-Schedules $\mathrm{A}, \mathrm{B}, \mathrm{C}, \mathrm{D}$, and $\mathrm{E}$.

Schedule A.

Schedule A relates to the property in lands and buildings. (Chapter III.)

Schedule B.

Schedule B is in respect of the occupation of such lands. (Chapter III.)

Schedule C.

Schedule C comprises interest and dividends payable out of the public funds of the United Kingdom, the Colonies, or any foreign State. (Chapter IV.)

Schedule D.
Schedule D is in respect of

Profits accruing to a person in the United Kingdom from a trade, \&c., carried on in the United Kingdom or elsewhere; 
Profits accruing to any person-although residing out Schedule $\mathbf{D}$. of the United Kingdom-from any property in the United Kingdom or any trade carried on in the United Kingdom;

And interest of money and other annual profits not charged under any other schedule. (Chapter VI.)

Schedule E relates to annuities, salaries, \&c., payable schedule E out of the public revenue, and salaries paid by public companies, and corporations. (Chapter V.) 


\section{CHAPTER III.}

\section{SCHEDULES A AND B.}

Schedule A. General rule for assessment of lands and houses.

\section{Finance Act} 1894, sec. 35 .

Allowance for repairs.
THE tax under schedule $A$ is levied on the annual value of lands, tenements, \&c. (1853, sec. 2). Previous to the $5^{\text {th }}$ April 1894 the assessment was the rack-rent, if such rent had been fixed by agreement commencing within seven years preceding the $5^{\text {th }}$ April before the making of the assessment, but if not so let at rack-rent, then at the rack-rent at which the lands, \&c., were worth to be let by the year $(1842, \mathrm{sec} .60$, Sch. A, No. I). Now, however, the assessment, still made in this way, is governed by sec. 35 of the Finance Act 1894 , which is as follows :-

"In respect of the income-tax hereby imposed under Schedule $A$, where the tax is charged upon annual value estimated otherwise than by relation to profits, the following provisions shall have effect:---

(a) In the case of an assessment on lands inclusive of the farmhouse and other buildings (if any) the amount of the assessment shall, for the purposes of collection, be reduced by a sum equal to one-eighth part thereof; and

(b) In the case of an assessment upon any house or building (except a farmhouse or building included with lands in assessment), the amount of the assessment shall, for the purposes of collection be reduced- 
(I) Where the owner is occupier or assessable as landlord, or where a tenant is occupier and the landlord undertook to bear the cost of repairs, by a sum equal to one-sixth part of that amount; and

(II) Where a tenant is occupier and undertook to bear the cost of repairs, by such a sum, not exceeding one-sixth of that amount, as may be necessary to reduce it to the amount of rent payable by him.

(c) As between the owner and a mortgagee of his property, or any person having a charge thereon or entitled to any ground rent, rent charge, annuity, or other annual sum payable thereout, the owner's right of deduction under the Income Tax Acts in respect of income-tax shall be in no wise prejudiced or affected by the relief afforded by this section.

(d) Where the amount of the assessment in the case of lands (inclusive of the farmhouse and other buildings) is more than one-eighth, and in the case of any house or building jexcept a farmhouse or building included with lands in assessment) is more than one-sixth below the rent, after deducting from such rent any outgoing which should by law be deducted in making the assessment, this section shall not apply."

It will be obserred that the effect of this section is that, in the case of an assessment of lands (including farmhouses, \&c.), tax is to be paid on only seren-eighths of the annual value; and in the case of houses, Sc. (exclusive of farmhouses), on five-sixths.

Some further relief is granted by the Finance Act rgro, sec. 69, to owners of land or of small houses, viz. :-

"(I) If the owner of any land or houses to which this section applies shows that the cost to him of maintenance, repairs, insurance, and management, according to the average of the preceding five years, has exceeded, in the case of land, one-eighth part of the annual value of the land as adopted for 
Schedule A.

Finance Act 1910 , sec. 69 .

the purpose of income-tax under Schedule $A$, and in the case of houses one-sixth part of that value, he shall be entitled, in addition to any reduction of the assessment under sec. 35 of the Finance Act 1894 , on making a claim for the purpose, to repayment of the amount of the duty on the excess, not exceeding in the case of land one-eighth part, and in the case of houses one-twelfth part, of the duty on an amount equal to the annual value.

For the purposes of this section the term 'maintenance' shall include the replacement of farm-houses, farm buildings, cottages, fences, and other works where the replacement is necessary to maintain the existing rent.

(2) This section shall apply to any land (inclusive of farmrouses and other buildings, if any) the assessment on which is, for the purpose of collection, reduced under sec. 35 of the Finance Act 1894 , and to any houses the annual value of which, as adopted for the purpose of income-tax under Schedule A, does not exceed eight pounds, the assessment on which is so reduced.

(3) In comparing the cost of maintenance, repairs, insurance, and management of any land or houses for the purpose of this section with the annual value of the land or houses, the total cost of the maintenance, repairs, insurance, and management on any land managed as one estate, or of any houses on any such land, shall be compared with the total annual value of the land or houses as the case may be.

(4) All the provisions of the Income Tax Acts which relate to claims for exemption, relief, or abatement, or the proof to be given with respect to those claims, shall apply to claims for repayment under this section and the proof to be given with respect to those claims :

Provided that if the owner of any land or house makes and delivers to the Surveyor of Taxes of any district in which the land or house is wholly or partly situate a declaration as to the cost to him of maintenance, repairs, insurance, and management, and the Surveyor is satisfied as to the correctness of the declaration, the amount of the allowance to which the owner is entitled under this section shall be certified by the Surveyor, and repayment shall thereupon be made in accordance with his certificate. 
(5) In computing the five-year average for the purposes of this section, the year shall be taken to be the year ending on the thirty-first day of $\mathrm{March}$, or such other date as may be adopted by the.owner of the land or houses with the consent of the Surveyor of Taxes of the district, and the five preceding years shall be taken to be those preceding the commencement of the year for which the duty in respect of which a claim for repayment is made is charged."

Tithes, profits of manors, fines on renewals of leases, \&c., are likewise chargeable under this schedule. The annual values of these respective properties are deemed to be as follows :-

Tithes, if taken in kind, and dues and money payments in right of the Church. The average amount of the profits received during the three preceding years.

Tithes, if compounded for. The profits received during the preceding year.

Tithes taken in kind.

Tithes compounded for.

\section{Profits of} manors. during the seven preceding years.

Fines for the renewal of leases. The amount received in Fines. the preceding year. (1842, sec. 6o, Schedule A, No. Ir.)

In the case of fines, however, it is provided by the same section that where the party chargeable shall prove, to the satisfaction of the Commissioners, that such fines, or any part thereof, have been applied as productive capital on which a profit has arisen or will arise otherwise chargeable under the Act, for the year in which the assessment has been made, the Commissioners may discharge the amount so applied as pro- 
Schedule A.

ductive capital from the profits which would otherwise have been liable to assessment. One case has been decided as to the interpretation of the term "productive capital" (Lord Mostyn v. London, Surveyor of Taxes, Queen's Bench

Lord Mostyn $v$. London (Surveyor of Taxes.) Productive capital.
Division, 22nd November 1894). Under the will of Lord Mostyn's father, all fines were, after payment of debts, to be invested as capital in the purchase of property, and the tenant-for-life had not any power to appropriate them for his own use. In 1890 fines amounting to $£ \mathrm{r}, 795$ were received, and of this sum $£ 906$ had been placed on deposit with the London and Westminster Bank at interest, and had yielded E44. The money was placed in the bank temporarily on deposit, as received, and it remained there until required for permanent investment. The Surveyor contended that the money, having been placed on deposit temporarily, had not been applied as "productive capital" and he accordingly included the sum in his assessment. This was confirmed by the Commissioners, and Lord Mostyn appealed to the Queen's Bench Division, it being argued on his behalf that the money had been applied as " productive capital," and had produced $£ 44$ interest. On behalf of the Crown it was urged that if this were held to have been applied as " productive capital," the deposit of money for a day or two would be so also, and would fall within the exemption. The Court dismissed the appeal, holding that the amount was liable to assessment. They did not consider that a mere temporary deposit while a permanent investment was determined upon, was an application as "productive capital." The word "capital " itself rather pointed to a source of income otherwise than a mere 
loan. Even if the Commissioners were wrong, they were not bound to allow the sum, as their power was discretionary.

The manner in which the annual value of, or profit arising from, certain other properties is to be estimated, is laid down in the same section. In the case of quarries of

Stone,

Slate,

Limestone, or

Chalk,

it is deemed to be the amount of profit in the preceding year. (1842, sec. 60, Sch. A. No. III., Rule r.) In the case of mines of

$$
\begin{aligned}
& \text { Coal, } \\
& \text { Tin, } \\
& \text { Lead, } \\
& \text { Copper, } \\
& \text { Mundic, } \\
& \text { Iron, } \\
& \text { and other mines, }
\end{aligned}
$$

it is deemed to be the average profit of the five preceding years. ( 1842 , sec. 60 , Sch. A, No. III., Rule 2.) If, however, the yield or output of any such mine has, from any unavoidable cause, been decreasing, so that such arerage will not give a fair and just estimate of the annual value thereof, the General Commissioners may compute the annual value on the amount of the profits in the preceding year; and, if the mine has wholly failed, they may discharge any assess- 
CHAP.

Schedule A.

ment made. (I842, sec. 60. Sch. A, No. IV., Rule 5.) See also post "Succession." In view of the repeal of sec. I33 this may become an important clause.

Jones $v$.

Cwmorthen

Slate Co.

Quarry or mine?
Ironworks, gasworks, \&c.
In Jones v. Cwmorthen Slate Co. (Court of Appeal, rgth December 1879) it was held that where slate is obtained from the side of a hill by underground workings carried on through levels, the concern is to be assessed as a quarry (on the profits of the preceding year) and not as a mine (on the five years' average).

In the case of

Ironworks,

Gasworks,

Salt springs or works,

Alum mines or works,

Waterworks,

Streams of water,

Canals,

Inland navigations,

Docks,

Drains and levels,

Fishings,

Rights of markets and fairs,

Tolls,

Railways and other ways,

Bridges,

Ferries,

and other concerns of a like nature,

the annual value is to be computed on the profits of the year preceding. (1 842 , sec. 60 , Sch. A, No. III., Rule 3.) 
In Imperial Continental Gas Association v. Nicholson (Court of Exchequer, r2th June 1877) it was held that this section does not apply to a gasworks abroad belonging to a company registered in England, but that such is assessable under Schedule D.

Schedule A.

Imperial Continental Gas

Association v. Nicholson.

Gasworks abroad.

Ystradyfodwg, \&c. Sewerage Board $v$. Bensted. June 1907) were as follows:-

There is a sewer $17 \frac{1}{4}$ miles long, two and a-half of sewer. which passes through or over land in the parish of Rumney, which land is rated for the relief of the poor. Of the two and a-half miles 182 yards is on arches above ground, r,02I yards below, I,890 above the surface but corered by an artificial embankment, and r, 246 (called "outfall") is partly over and partly under the foreshore of the Bristol Channel. Works have been erected in connection with the outfall. $£ \mathrm{I}_{5} 6,000$ was borrrowed from the Public Works Loan Commissioners, repayable over thirty years. The proportion for Rumney was $\mathcal{E}, 210$, raised by a rate. Agreements had been made with several authorities for carrying off their sewage. But for these payments the rate for Rumney would presumably have been higher, but no calculation of the cost incurred to earn the money from outside had been made.

The seat of management is at Pontypridd, which is not in the parish of Rumney for income tax purposes. 
Schedule A.

\section{Ystrady:}

fodwg, \&c.

Sewerago

Board v.

Bensted.

Sewer.

The assessment appealed against was in respect of the property in the parish of Rumney. No other part of the undertaking was assessed to Schedule A:

The Sewerage Board contended that their interests were " easements" only.

If all the superficial area occupied by the carrier were on the surface it would be one and a-half acres.

The sewer runs orer agricultural land, which is not interfered with by the carrier eren in the case of the embankment, which varies from 18 in. to $6 \mathrm{ft}$., and is overgrown with grass.

The value of the adjoining land is $£^{2}$ per acre per annum, and this sewer is assessed to the relief of the poor at $£ 700$ net.

The appellants contended that it fell under No. 3, Rule 3, and was assessable upon the whole concern (Rule 3, Sch. A) in accordance with the rules of Sch. D (1866, sec. 8), and at Pontypridd (1842, sec. 60, No. 4, Rule I); that they were neither owners nor occupiers, the land being already assessed on other persons. Further, that if assessable at all it should be on one and a-half acres at $\mathcal{E}^{2}$.

The Surveyor contended-

That it was a "hereditament" (No. I, Sch. A)-not only an "easement" - and was capable of actual occupation. That 
a poor rate case against the Sewerage Board had decided that it was a rateable hereditament. That they were not a trading concern (No. 3, Sch. A). He referred to the Edinburgh Southern Cemetery case (post), where Lord Maclaren had said that an unnamed business carried on by the use of land would not come under Rule 3, if it were possible to put it under Rule I or 2.

He further argued that "levels" were such as Bedford Level. That the annual value did not depend on use, and this case was thus distinct from that of a concern under No. 3 , Sch. A.

It was held that the sewer was a hereditament capable of actual occupation, and was occupied by the Sewerage Board, and that they were chargeable with income tax on the annual value thereof under sec. 60 , Sch. A, Rule I.

In Turner v. Carlton the facts were that "The Ealing Theatre and Lyric Hall and Restaurant" were held on a lease for three years, at $£_{525}$ for the first half-year, and $£_{\mathrm{I}, 600}$ Turner v.
Carlton.

Deduction of Insurance
Premium. per annum for the remainder of the term (an average of $£ \mathrm{r}, 509)$. The lease recited that the rent included $£ 2$ ro for rent of certain furniture. The lessors paid a fire insurance premium of $£ 429$ per annum ( $£ 397$ Ios. od. on the fabric and $£ 3^{I}$ Ios. od. on the furniture). 
Schedule A.

Turner $v$. Carlton.

Deduction of Insurance Premium.

The lessee contended that the assessment should be :-

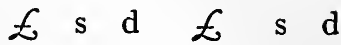

Amount as above $\quad \ldots \quad \ldots \quad \ldots \quad$ r, 509 ○ 0

Less other premises in lease as above (agreed) $\ldots . \quad \ldots \quad$ I30 0 ○

Rent of furniture (agreed) 2 10 $\circ \circ$

Insurance $\ldots \quad \ldots \quad \ldots \quad 397$ 10

$73710 \quad 0$

Net $\ldots \quad \ldots \quad 77$ I 10 o

Add for internal repairs ... $\quad \ldots \quad \ldots \quad$ II 6 ○

$£ 887$ 10 $\circ$

The Surveyor objected to the item of $£ 397$ ros. od.

Channell, J., decided against the company (K.B.D., Ioth February 1909), on a technical point on the Quinquennial Valuation List, viz., that the value was to be "taken" as the annual value in the previous year-and this was conclusive and did not mean "provisionally taken," and it was therefore not necessary to decide as to the insurance. He stated, however, that he had been brought to the opinion that the amount should not be allowed, but had it been necessary for the decision of the case to decide it, he would have taken a little further time to consider the case and go into it more in detail. 
By an Act of ${ }_{1788}$ the predecessors of the Conservators of the River Thames were exempted in respect of certain property from Parliamentary taxes (the income tax not having been then imposed), and under a consolidating Act of 1894 the Conservators were exempted in respect of the same property from all Parliamentary rates, taxes, assessments, and payments whatsoever. It was held in Stewart v. Conservators of the River Thames (K.B.D., Irth and I th February r908) that the exemption included income tax.

By the Act of 1860 it is provided that railways are to be assessed by the Commissioners for Special Purposes, and that Rallways to by speclal Commisthey shall also assess the duties payable under Schedule E in respect of all offices and employments of profit held in or under any railway company, and an assessment shall be made on the company in respect of them. The company are also empowered to deduct the duty on payment of the salaries.

By the Act of 1866 ( $29 \& 30$ Vic. cap. 36), sec. 8, all these concerns described in sec. 60, No. III. (1842), viz., quarries, mines, ironworks, \&c., are to be assessed according to the rules prescribed under Schedule $\mathrm{D}$, so far as such rules are consistent with No. III., and they are therefore dealt with under that head in this work, both as to assessments and appeals. (Chapter VI.).

In " Dowell's Income Tax Laws," 5th Ed., it was stated :- 
Schedule A.

Effect of Act of 1866 .

Knowles $v$.

McAdam.

Coltness Iron Co. v. Black.
"In Knowles $v$. McAdam it was held that the effect of this section is to transfer the concerns described in No. III from Schedule A to Schedule D. This decision has since been overruled in Coltness Iron Company v. Black, where Lord Blackburn observed :-

'If the effect of sec. 8 was to transfer cases in Schedule A, No. III, to Schedule D, it would change the respective times on an average for which the profits were to be assessed. Mines would be reduced from a five-year period to a threeyear period. Quarries and things of that sort would be raised from a single year to three. I cannot think this was either intended or expressed. But on the assumption that it had this effect, the Exchequer Division came, in Knowles ข. McAdam, to a very startling decision.'

"As a fact," "Dowell" continues, " the section was introduced at the instance of the mine owners, to enable them, if they desired, to return their profits for assessment in one sum by the Special Commissioners instead of returning them for assessment by the Local Commissioners. There was no intention to alter the incidence of the tax or the average (of years) on which returns were required to be made by mine owners. See Twenty-fourth Report, Inland Revenue, p. $78 . "$
Business, \&c. commenced within period prescribed.
If the accounts required by Rule II., Sch. A, cannot be made out in consequence of the possession or interest having commenced within the periods prescribed, viz., within three years, one year, or seven years (No. II., p. I3), within the one year in the case of quarries, \&c., and ironworks, \&c., or within the five years in the case of coal mines, \&c. (No. III., p. $\mathrm{I}_{5}$ it seq.), the profits are to be estimated in proportion to the profits received since the commencement of such possession or interest. (1842, sec. 60 , Schedule A, No. IV., Rule 6.) 
In the case of dwelling-houses of a less annual value than $£$ ro, and of lands (which term includes buildings) let for a less period than one year, the assessment under Schedule A is to be made on the landlord (sec. 60, No. IV., Rule 3). In other cases the assessment was, until the Finance Act 1898 (below), always on the occupier (sec. 63, No. IX., Rule I), but he was (and is) entitled to deduct the tax from his landlord when he makes the next payment of rent (No. IV., Rule 9) on production of the collector's receipt (Pocock v. Eustace, 2 Camp., I $8 \mathrm{r}, 1809)$. The Finance Act 1898 , sec. 10 , provides that the Commissioners, on a request in writing from the landlord (which, howerer, is rerocable) on or before the 3 ist July in any year, may from year to year charge him instead of the occupier, but there is still the usual remedy against the occupier in case of default in parment by the landlord. If, in such a case, the occupier still has to pay the tax he may deduct it from " the next or any subsequent payment of rent." (I898, sec. Iо.)

By the Act of 1853 sec. 40 , it was provided that the occupier should only be entitled to deduct tax on the rent; and if he is assessed at more than this it is for him to see that the assessment is reduced, otherwise he must himself bear the difference between the amount he pays and the tax on such amount. The assessment for income tax being usually based on the poor rate raluation where that assessment is the full annual value $\left(18_{+2}\right.$, sec. 64$)$, his first step will be to get that reduced. As a rule there will not be any must appeal. difficulty in this; where, however, he has paid a premium

If occupler charged, he duty on payment of rent.

\section{Obtaining} reduction of assessment. 
for a lease of premises they will be assessed at the annual value, not at the rent, and in this case he will not be able to get the assessment reduced to the rent. If he is a trader carrying on business in such premises, he will be recouped by charging the annual value (in lieu of rent) against his trading for income tax purposes; but, if the lease for which he has paid a premium is in respect of a dwelling-house, he has not any means of recouping himself the tax on the difference between the rent pairl and the annual value.

Deduction of tax on payment of rent by tenant.
Prior to 1894 there was not any difficulty as between landlord and tenant as to the amount of tax which the latter (having paid) could deduct from his landlord on payment of his rent. It was clearly either an amount equal to tax on the rent or the amount actually paid, whicherer was the lesser of the two.

Since the Act of 1894 some doubt has arisen as to whether the position is not different now.

In ordinary cases the position is simple. Premises of the annual value of $f .60$ let from year to year for that sum are assessed at $£ 5 \circ$ ( $£ 60$ less one-sixth), tax on which is paid by the occupier, and he is entitled to deduct the same on payment of his rent-the landlord thus bearing tax on $£ 50$ in respect of his gross income of $£ 60$, the balance of $£$ ro being the statutory amount allowed for repairs. 
In many cases, however, the rent does not correspond with the annual value, and premises of the annual value of $£ 60$ may be let at (say) $£ 50$ for various reasons, e.g. :-

Schedule A.

Deduction of tax on payment of rent by tenant.

(I) Where the tenant has undertaken to bear the landlord's repairs, or holds the premises under a repairing lease, as in London.

(2) Where the tenant has paid a premium for a lease.

In the first case the position is clear. The assessment is $£ 50$ net (1894, sec. $35(b)(2))$, the tenant deducts tax on the full $\AA_{5} 5^{\circ}$ on payment of rent to the landlord ( 1853 , sec. 40 ), and he has the allowance of Ero annual value as against repairs: The landlord bears tax on $£ 5^{\circ}$, his absolute income from the property. If the gross annual value were $£ 57$, only $\mathcal{E}_{7}$ could be deducted for repairs (1894, sec. $\left.35(b)(2)\right)$; if the gross annual value be $£_{72}$ the net would be $£_{60}$. In both these cases the tenant would deduct tax on $£ .50$ from his rent.

The second case presents a slight difficulty. The assessment is $£ 60$ gross, $£_{5 \circ}^{\circ}$ net, and the rent is $\mathcal{E}_{5 \circ}^{\circ}$. Previous to 1894 (when the assessment was $\mathcal{E}_{60}$ ) it is clear that. though the landlord had to bear repairs, he had to suffer deduction of $\operatorname{tax}$ on the whole $£ 5^{\circ}$ (1853, sec. 40) just as he would have had to suffer then on the whole $\mathcal{E}_{60}$ in an ordinary case. On the other hand, the tenant had no means of recouping himself for the whole tax, his right of deduction being limited as above to tax on $£ .50$; and this is still so. 
Schedule A. Deduction of
? It is clear that the intention of the Act of 1894 was to give relief to landlords who had previously to pay tax on their gross income. We would submit that the effect of sec. 6o, No. IV., 9th Rule, providing that-

"the occupier . . . paying the said duties . . . shall deduct so much thereof in respect of the rent payable to the landlord for the time being (all sums allowed by the ${ }^{\circ}$ Commissioners being first deducied) as a rate of (rs.) for every 20 s. thereof, would by a just proportion amount unto. . . ."

is to entitle the landilord to demand that the tenant shall allow " all sums allowed by the Commissioners" before deducting tax, and that in the case in question the amount of tax which the tenant is entitled to deduct is on $£ 40-v i z ., £ 50$ rent, less firo" allowed by the Commissioners."

As mentioned above, a trader may recoup himself by setting off the difference against his profits assessable under Schedule D.

To take an exaggerated case, we submit that where the gross annual value is $£_{60}$ (net $E_{5 \circ}$ ), and the tenant has paid such a premium that the rent is only $£$ ro, the landlord is entitled to ask that he shall have his rent in full, the $£$ ro "allowed" being deducted off the $£_{10}$ of rent, thus not leaving anything from which the tenant may deduct tax.

By sec. 160 of the Act of $184^{2}$ the matter is one for settlement by the Commissioners.

The above view is supported by officials of experience, and we submit that the intimation on the demand note that- 
The landlord is bound, under a penalty of $£ 50$, to allow out of the next payment of rent after the date of the collector's receipt the amount of duty paid under Schedule $A$ up to an amount not exceeding $1 \mathrm{~s}$. $2 \mathrm{~d}$. in the $f$ on the rent payable for the year,

can only be read as applying to ordinary cases, and must not be considered to be applicable universally.

It should, however, be mentioned, that in a case submitted to the Board in I905 they expressed the view that the right to deduct tax up to the amount of rent paid " was not in any way interfered with by the Act of 1894 "' (sec. 35), though they admitted that in such a case where the gross Schedule A assessment is in excess of the rent " some portion of the relief granted by the section mentioned accrues to the tenant."

In W. Hancock or Co., Lim. v. Gillard (King's Bench Division, 26th October I906) a tenant of a tied house let at froo per annum had paid $\mathcal{E}_{20}$ to the Compensation Fund, and of this amount $\mathrm{EI}_{4}$ was the sum which he was entitled to deduct on payment of his rent (uncier sec. 3, subsec. (3), of the Licensing Act r904). The premises were assessed at f29I I4s. od. The landlords claimed that he could only deduct tax on $£ 86$ when paying his rent to them, and sued him for $14 \mathrm{~s}$.

Bigham, J., held that he was entitled to deduct on the full froo.

Hancock $v$. Gillard.

\section{Licensing Act} 1904.

\section{Deduction of tax on payment of rent by tenant.}


Schedule A.

Walker $v$. Brisley.

Poor Rate valuation not binding.

In re Menzies.

\section{$\operatorname{Rex} v$.}

Commis.

sioners of

Offlow.

\section{Expert}

exidence.
It must be understood, however, that the poor rate valuation is not binding for income tax purposes (Walker $v$. Brisley, Queen's Bench Division, 26th June 1900). If the valuation is made throughout on the full annual value, then the Commissioners usually adopt the poor rate figures, and will not reduce an assessment till the poor rate valuation is reduced; but in many cases, especially in the country, the valuation is not on the full annual value, and there is also great inequality in the rating of different properties.

In the case of In re Menzies (Court of Exchequer, Scotland, 23 rd August 1877) it was held that where the Surveyor of Taxes is not appointed assessor under the Lands Valuation (Scotland) Acts, the valuation under those Acts is not binding for the purposes of the Income Tax Acts.

A like decision was given in Stocks v. Sulley (Court of Session, Scotland, 27 th and 28 th June 1899).

In Rex v. General Income Tax Commissioners for Offlow the Commissioners refused to hear an expert valuer whose evidence the owner of an inn sought to put forward on an appeal under Schedule $A$, and the owner applied for a mandamus. The Court discharged the rule (K.B.D. $23^{\text {rd }}$ March I9II), holding that, as the Commissioners had been told the nature of the evidence and had come to the conclusion that it would be of no assistance to them, it was not such a "refusal to hear the case" as would justify a mandamus.

By the Act of $184^{2}$, the assessment being upon the occupier, it was he who had to appeal if the assessment was 
considered excessive, but, by the Finance Act 1896 , sec. 28 , Schedule A it is provided that any owner, \&c., although not the occupier, shall have the same right of appeal as if the assessment were made upon him.

It will thus be seen that the tax falls on the owner, and any contract for payment of rent or any other annual sum in full and without deduction is absolutely void ( 1842 , sec. I03).* The tax is, however, a charge on the property, and ultimately falls on the landlord. It is only as a matter of convenience that the assessment is usually made on the tenant. In the case of dwelling-houses, it is included on the same demand note as Inhabited House Duty. In the case of warehouses and shops, where, of course, there is not any Inhabited Tax collected from landlord for wareHouse Duty payable, the tax is in some districts collected from the landlord.

*Very specific language is required to render an annuity, \&c., under a will or settlement payable in full without deduction of tax. Speaking generally, a direction to pay "free of all deductions" would not make it payable in full. It was held in Lund $v$. President, Ecc., of the Liverpool School for the Blind (Ch.D. Ist July 1898), that the chaplain of the school, which was incorporated by a private Act of Parliament of 1829 , was not entitled to have his salary in full, though the Act provided for the payment of it "without any deduction or abatement for taxes howsoever." See also AttorneyGeneral v. Ashton Gas Co. (post.)

Similarly in Shrewsbury v. Shrewsbury (King's Bench Division, 29th May 1906) it was held that $£ 4,000$ a year " clear of all deductions" did not entitle the recipient to receive the amount without deduction of income-tax. 
Schedule A.

Reading $v$. Chew.

Distress for Arrears.
Omission of tenant to deduct tax paid on pay ment of rent.

Cumming v.

Denby $v$. Moore.

Andrew $v$ Hancock. Bedborough.

In Reading v. Cherw (Queen's Bench Division, r4th and I 5 th June 1898 ) it was held that a distraint on the goods of the occupier for the time being for income tax (Schedule A) for the previous year when the premises were unoccupied was lawful under sec. 70 of the Act of $184^{2}$, and that sec. 35 of the Act of 1853 only qualifies the right of distress where the duty ought to have been paid and borne by a former occupier.

Probably in this case there may have been some difficulty, such as that the Commissioners had not been furnished with proof of the premises being unoccupied, for, by sec. 70 , duties are not to be levied on any house in respect of a period during which it is proved to have been unoccupied.

Until 1898 where a tenant had paid property tax and omitted to deduct it from his next payment of rent, he could not afterwards recorer the amount as money paid to the use of the landlord (Cumming $v$ Bedborough, decided in 1846 ; see also Denby v. Moore, decided in I8I7; and Andrew v. Hancock, decided in $18 \mathrm{rg}$ ). Now, however, in certain cases, he can deduct it from any subsequent payment (see p. 32).

Lamb $v$. Brewster.
The case of Denby v. Moore was relied on in Lamb v. Brewster and another (Queen's Bench Division, 25th February 1879), where Mr. Lamb sued the executors of his late landlord for income tax (Schedule A) paid by him for several past years. It appeared that he had made application for the amount after each payment, and the landlord had agreed with him that if he would continue to pay the rent in 
full, he (the landlord) would refund him what he had paid in past years, or should pay in the future. The Court gave Schedule A. judgment for Mr. I.amb, distinguishing the case of Denby $v$. Moore, on the ground that in that case the tenant had not made application to his landlord for the tax. They further held that sec. I०3 of the Act of 1842 (rendering void all contracts for the payment of rent, \&c., in full) did not apply, as the effect of the present agreement was, not to throw the burden of the tax on the tenant, but rather to create a contract of loan between the tenant and the landlord. This decision was subsequently confirmed by the Court of Appeal.

We understand that in the case of Thomson $v$. Adcock, Thomson $v$. Adcock. heard in the Liverpool County Court, 3rd February I893, where the tenant had deducted two years' tax from his rent and was sued for it by the landlord, judgment was given in farour of the tenant.

The case is not fully reported, but there must have been some special circumstances to have led to the decision.

Further, it was held in the Court of Session, Scotland,

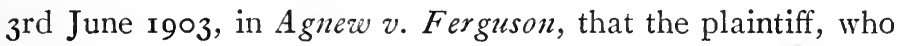
had paid certain royalties to the defendant without deduction of tax, was entitled to recover the amount of the tax by action. The defence was that the Act of 1853 only gave the right to deduct on payment, and not a right to recover after payment.

The Court held that, as the statute said that a person was entitled to deduct or retain the amount, it conferred the 
Schedule A.

privilege of reimbursement, the statute giving, in short, the

Agnew $v$. Ferguson. tenant a lien over the royalties for payment of the duty and entitling him to repayment of money paid to the landlord, which the landlord had no title, moral or legal, to retain.

As to deduction of $\operatorname{tax}$ on payment of arrears of annuity, see post.

Tenant may sometimes deduct

from any subsequent payment of rent.

Deductions.

Stevens $v$. Bishop.

Expenses of collection of tithe allowed.
Now, however, by sec. Io of the Act of 1898 , if the landlord has elected to be assessed himself and the tenant has been compelled to pay the tax, he may deduct it from "the next or any subsequent payment on account of rent" (ante, p. 23 et seq.).

Deduction from the gross annual value is allowed for the purpose of assessment under Schedule A, in respect of tithes returned for income tax purposes by the tithe owner, and for land tax paid by the owner. Since $5^{\text {th }}$ April 1894 deduction is also allowed in respect of repairs, but only to the extent before mentioned ( $\mathrm{pp}$. Io and II).

In the case of Stevens $v$. Bishop, heard in the Court of Appeal (1 $5^{\text {th }}$ February 1888 ), it was held that a clergyman, being assessed to income tax in respect of tithe commutation rent charge, was entitled to a deduction for the actual expense of collection. It was so held on the ground that the annual value was, by the Acts, to be the rent at which the tithe rent charge would let, and it was said that any tenant would have to incur such expense. 
In Hesketh v. Bray it was held by the Court of Appeal (7th August I888) that the allowance under Schedule A for repairing sea-walls or other embankments " necessary for the "preservation or protection of such lands against the " encroachment or orerflowing of the sea or any tidal river" (1853, sec. 37), does not apply to embankments made for the improvement of the land by altering its condition, but only to embankments made for its protection or preservation in its existing state.

In McGregor v. Macfarlan (Court of Session, Scotland, 9th February I889) Mr. McGregor appealed against an assessment upon him under Schedule A on the ground of haring been called upon to pay, and having paid, to his Grace the Duke of Argyll, as superior of the lands, a casualty of superiority amounting to a full year's rental of the lands. $\mathrm{He}$ had had to pay the casualty in full without deduction of tax, and, moreover, his Grace was required by the Commissioners to make a special return of, and to pay income tax direct upon, all casualties received by him. He contended that this was a double assessment, and should be racated in the manner provided by the 'Taxes Management Act i 880, sec. 60 .

In support of the assessment it was maintained that the payment was one of capital.

The Court gave judgment for the Crown. They said the appellant's view was founded on the idea that a composition paid to a superior for his entry made the superior the proprietor in right of the rents for the year in which the entry

Schedule A. Deductions.

Hesketh $v$. Bray.

Cost of

embankment for improye-

ment of land

disallowed.

\section{Mcaregor $v$}

Casualty of superiority disallowed. 
Schedule A. was obtained. This was a fallacious view. The composition Deductions. was exigible, not as a rent, but as the price for entry, and it was a mere accident that in some cases that price was measured by a year's rent.

Duke of Norfolk $v$. Lamarque.

Expenses of collecting manorial rates disallowed.
The decision in Stevens v. Bishop was relied on by the appellant in the case of The Duke of Norfolk $v$. Lamarque, where he claimed to be entitled to deduct from the amount of the manorial rights due to him the expense of collecting the same. Baron Pollock, in giving judgment for the Crown in the Queen's Bench Division, 2oth January I890, said there was a marked distinction between the two cases. In Stevens v. Bishop it was admitted that the sum there claimed to be deducted was necessarily expended; but there was not any such admission in this case.

Schedule B. General rules for assessment.

\section{In re Middleton.}

Schedule A assessment Is basls for Schedule B.
The tax under Schedule B is levied on agricultural lands, hop gardens, \&c. (1853, secs. 2 and 39). The estimate of profit is based on the rent or annual value, and (subject to the right to elect to be assessed under Schedule D as mentioned below) the occupier pays tax for the current year I 9 II-I 2 at Is. $2 \mathrm{~d}$. in the $£$ on one-third thereof, subject to the right to relief to "earned" incomes (post).

In the case of In re Middleton (Court of Exchequer, Scotland, x6th March 1876 ) it was held that the basis of assessment for Schedule $B$ was to be the value charged under Schedule A. The case arose in connection with the occupation of a deer forest, which the appellant had claimed was not "capable of actual occupation" (Rule 7), and that though 
it was assessed at a considerable sum under Schedule A, it schedule B. should not be charged under Schedule $\mathrm{B}$ beyond the ordinary grazing value of the land.

The tax under Schedule B, unlike that under Schedule A, is borne by the occupier. It is, in fact, analogous to that Tax to be borne by occupier. under Schedule D, and is in respect of the occupier's estimated profits arising from his farming business.

The profits arising from lands occupied as nurseries or gardens for the sale of produce are to be estimated accordNurseries, \&c. to be assessed under

Schedule D. ing to the rules contained in Schedule D ( 1842 , sec. 63 , Schedule B, No. VIII.).

In Revell v. Scott (Court of Session, Scotland, 26th June I895) Mr. Scott, who is a tenant of the same farm under two leases - one of the farm as a sheep farm, and the other of the landlord's shooting rights over it-sought to establish that he was not liable to assessment under Schedule B in respect of the latter. The Court held, however, that he was clearly liable.

$\mathrm{By}$ the Act of 1887 , any farmer may, before assessment, elect to be assessed under Schedule D, instead of Schędule B. Farmer may elect to be assessed under The election is to be signified by notice in writing to the surveror, delivered within two months after the commencement of the year of assessment. If the notice is sent by post the letter must be registered.

The notice is to be given annually within the stipulated time, and in the absence of such notice the assessment will

Revell v. Scott.

Farm assessable under Schedule B, both in respect of value as a farm and for shooting rights. 
Schedule B. be made under Schedule B in the ordinary course. In introducing his Budget in the House of Commons, 26th March 1888, the Chancellor of the Exchequer stated that, during the year $1887-8,160$ farmers availed themselves of the Act, the result being that they paid tax on $£_{2,500}$ instead of on $£ 22,000$.

Finance Act 1896.

Relief to Parmers.
By the Finance Act 1896 , sec. 27 , it is provided that, for the purposes of any claim to exemption, \&c., the income chargeable under Schedule $\mathrm{B}$ shall be taken to be one-third of the annual value thereof under Schedule A; except that, if it be shown at the end of any year that the profits and gains fell short of that amount, the income shall be taken to be the actual amount of such profits and gains, and the tax on any difference shall be repaid. No objection is taken to such appeals if notice be given within twelve months following the year to which such appeal relates.

This Act repeals the former provisions contained in the Acts of 1851 and 1880 .

Schedules $A$ and $B$.

Assessment where tenant's rates paid by landlord, \&c.
Where the tenant's rates or taxes are paid by the landlord, the annual value, for the purpose of Schedules $A$ and $B$, is to be estimated after deduction of such rates, \&c., and, conversely, where the landlord's taxes are paid by the tenant, the amount is to be added to the rent $\left(18_{42}\right.$, sec. 63 , Schedules $\mathrm{A}$ and B, No. X., Rules $\mathrm{I}$ and 2). Information on this point is furnished to the Revenue by the tenant in the return which he has to make every five years. 
Where the assessor is not satisfied with the return made, or if there has not been any return made, he is himself to estimate the annual value of the property and make an assessment, according to the full annual value (1842, sec. 64 ; see Schedules Where return not made, assessor to estimate annual value. also ante, p. 23).

Due allowance is to be made, if claimed, in respect of buildings unoccupied for the year or any part thereof $\left(184^{2}\right.$, sec. 70$)$.

The original assessments in 1842 were based on the poor rate assessment (1842, sec. 64), see, however, p. 23 , and the Poor rate to be basis. overseers of the poor are to produce the Rate Books to the Commissioners when required (I $84_{2}$, sec. $75 ;$ I 880 , sec. 39 ).

So soon as the assessments are allowed, the Commissioners are to cause notice to be given in such manner as they shall judge expedient.

Any person aggriered may appeal to the Commissioners against the assessment (I 842 , sec. 80 ).

Where, by reason of flood or tempest, loss shall be sustained to crops, or any lands shall be rendered incapable Abatement by by flood, \&c. of cultivation, the Commissioners, on proof that the owner has abated any portion of the rent, may abate the assessment under Schedules A and B to a like extent. Similar relief is granted where the owner is himself the occupier ( $18_{42}$, secs. 83,84 , and 85 ).

Notices to be given of assessments. 
Schedules $\mathbf{A}$ and $\mathbf{B}$.

Claims for repayment.

Appeals.

Bruce $v$. Burton.

Houses of Wesleyan Ministers.

'Although the assessments under Schedule $\mathrm{A}$ are only revised as a whole every five years, adjustment will be made in respect of increased rents due to structural alterations, or reduced rents, during the last four years.

Claims for repayment under Schedules $\mathrm{A}$ and $\mathrm{B}$ are dealt with in Chapter VIII. (Exemptions and Abatements).

Appeals against assessments under Schedules A and B are to be heard by the General Commissioners (I 842 , sec. 80), except in the case of quarries, mines, ironworks, \&c., in which cases the appeal may be either to the Special Commissioners or to the General Commissioners (Act of 1860, 23 \& 24 Vic. cap. I4, sec. 7).

In connection with Schedule B, see the case of Bruce $v$. Burton (post).

We understand that since 1902 the furnished houses provided for Wesleyan ministers are not assessed to Schedule A (except as to interest, \&c.), if the stipend of the minister does not exceed £r6o. A circular issued from Somerset House gives authority for the-

"Schedule A assessment to be discharged in those cases where a dwelling-house belonging to the trustees of a Nonconformist religious body, or of a public elementary school, is occupied rent free, and without power of letting, by a minister or teacher whose total income, exclusive of the annual value of the house, does not exceed £iro per annum." 


\section{CHAPTER IV.}

SCHEDULE C.

THE tax under this Schedule is levied on all profits arising from interest, annuities, dividends, and shares of annuities payable out of any public revenue (1 853, sec. 2).

The Governor and Directors of the Company of the Bank of England are Commissioners for the purpose of charging the duties on their own profits, and in respect of all annuities, dividends, \&c., payable out of the revenue of the United Kingdom, and of all other dividends, \&c., entrusted to them for payment, and of all pensions and salaries payable by them (1842, sec. 24).

The Commissioners for the Reduction of the National Debt are Commissioners for the purpose of charging the duties on the annuities and pensions paid by them (1 842 , sec. 28 ).

Such respective Commissioners are required to keep an account of the dividends, annuities, \&c., and from time to time to make an assessment of the duty chargeable thereon, and to deliver the books of assessment to the Commissioners for Special Purposes, who are to make an assessment upon them accordingly ( $184^{2}$, sec. 89 ).
Tax leyied on interest payable out of public revenue.
Commissioners for charging duties under Schedule C. 
Schedule C.

Tax to be deducted on payment of interest, \&c.

Tax on Dividends, \&c. out of reyenue of colony.
Tax on

National Debt certificate coupons.

They are then required to retain the tax before payment of the dividend, \&c., and from time to time to pay the same into the account of the Accountant and Comptroller-General of Inland Revenue with the Bank of England (1842, secs. 93 and 94).

Similarly, persons entrusted with the payment of dividends, $\& c$, payable out of the public revenue of any colony or settlement belonging to the United Kingdom are to retain the tax, and to pay it to the same account (1842, sec. 96 ; Act of I 885, 48 \& 49 Vic. cap. 5 I, sec. 26).

The National Debt Act 1870 (33\& 34 Vic. cap 7 I, sec. 36) makes similar provisions as to tax on coupons attached to National Debt certificates.

Tax on interest from foreign state.

Interest and dividends from foreign, Indian and colonial companies to be charged under Schedule D.
The $\operatorname{tax}$ on interest and annuities payable out of the revenue of foreign States which are entrusted for payment to anyone resident in the United Kingdom is, by the Income Tax Act I842 (sec. 29), and a subsequent Act of the same year (5 \& 6 Vic. cap 80), chargeable under this schedule.

In 1853 these provisions were extended to include the duties on all interest, \&c., payable in respect of the stocks, funds, or shares of any foreign company when so entrusted for payment, which interest, \&c., was made chargeable under Schedule D (1853, sec. 10).

By an Act of I86I (24 \& 25 Vic. cap. 9I) the provisions were further extended to include colonial companies, and by the Act of 1866 (as to which see also p. 2 I) to include cases 
where the title of the person to whom the sums may be Schedule C. payable is shown by the registration of his name in any book or list ordinarily kept in the United Kingdom, and by the Revenue Act I868 (3I \& 32 Vic. cap. 28) to annuities, \&c., payable out of the funds of any institution in India.

In reply to an inquiry in the House of Commons in December 1906 as to the justification for refusing to refund income tax to British subjects resident abroad upon interest of colonial and foreign government serurities, on the ground British abroad not exempt in respect of colonial interest paid here. that these are assessed under Schedule $C$ and not under Schedule D, as are dividends of other foreign securities, Mr. Asquith stated that under Schedule D liability in respect of income arising out of the United Kingdom was only incurred by residents within the United Kingdom, and therefore the interest on foreign and colonial securities chargeable under that schedule was not liable to duty when received by any person resident outside the United Kingdom, although the payment may be actually made within the United Kingdom. Under Schedule C income tax was chargeable in respect of all colonial and foreign Government securities the interest of which was payable in the United Kingdom. By Administrative Treasury concessions of very long standing, exceptions from the charge under Schedule $\mathrm{C}$ were made in favour of : (a) Foreign Government and colonial securities owned by foreigners resident abroad; (b) colonial Government stock owned by inhabitants of the colony contracting the loan. Section 188 of the Act of 1842 had no application to the point raised by the question. 
Schedule C.

\section{British}

subjects abroad not exempt in respect of colonial interest paid here.
Exchequer Bills.

"Every provision in this Act contained, and applied to the duties. in any particular schedule, which shall also be applicable to the duties in any other schedule, and not repugnant to the provisions for charging, ascertaining, or levying the duties in such other schedule, shall, in charging, ascertaining, and levying the same, be applied as fully and effectually as if the application thereof had been so expressly and particularly directed: anything herein contained to the contrary notwithstanding.",

The concession referred to is that interest and dividends arising from foreign and colonial Government securities payable through agents in the United Kingdom are exempted from income tax where the owners of the securities are foreigners and reside out of the United Kingdom, unless they live in the colony contracting the loan. But this concession has not been extended to British subjects, and hence those to whom the concession has not been granted are required to include all such dividends and interest in any statement of income rendered by them for the purposes of a claim to exemption or abatement.

Now see also sec. 7 I of the r 9 io Act.

The interest on Exchequer bills, \&c., is likewise chargeable under Schedule C, and any person purchasing any such security with current interest thereon is entitled to deduct the proportion of tax thereon (1842, sec. 97).

Rate of deduction.

As to the rate at which tax should be deducted, see Chapter VII.

Exemptions. As to claims for exemption, \&c., see Chapter VIII. 
SCHEDULE D.

As this work is intended to deal mainly with this schedule, $\begin{gathered}\text { Schedule } \mathbf{D} \\ \text { considered }\end{gathered}$ it may be convenient now to take Schedule $\mathrm{E}$, and then to proceed in detail with Schedule $\mathbf{D}$. 


\title{
CHAPTER V.
}

\author{
SCHEDULE E.
}

Tax lexied on salaries, \&c., of public offices.
$T^{H E}$ tax under this schedule is charged in respect of every public office or employment of profit, and upon every annuity, pension, or stipend, payable by His Majesty or out of the public revenue of the United Kingdom, except annuities charged under Schedule C (1853, sec. 2). The schedule includes the salaries of Gorernment officials and directors, managers, \&c., of public companies, auditors' fees, \&c. In the case of the salaries of Government officials and of other salaries payable at Government offices, the tax is paid by way of deduction ( $184^{2}$, sec. 146 , Rules $5 \& 6$ ). In other cases the assessment is usually made upon the person holding the office ( $188_{4} 2$, sec. $\mathrm{r}_{4} 6$, Rule $\left.\mathrm{I}\right)$, and he pays the tax on demand, as in the case of a salary chargeable under Schedule D.

In the case of public companies it used to be customary to assess in one sum the remuneration roted to directors, and, the tax being paid by the company, to deduct it from the payment to the directors, but, since the question of relief to " earned" incomes (Chapter VIII., Part III.) will invariably arise now, each one is usually charged separately. 
In some cases the remuneration is paid to the directors in full, without deduction of tax. This is irregular, and not justified by the usual resolution of shareholders; if it is desired to have the payment made in full, the resolution should be worded accordingly.

Where the person to be charged is necessarily obliged to incur expense, such as travelling or keeping and maintaining a horse, to enable him to perform his duties, the amount of such expense is allowed as a deduction ( 1853 , sec. $5 \mathrm{r}$ ), but not the expenses of travelling to his business.

The amount of the assessment is to be the salary, \&c., for the year current ( 1842 , sec. I46); and any person assessable Assessment to be on salary of year. under Schedule $\mathrm{E}$ who shall, at any time during the year of assessment, become entitled to any additional salary or fees, is to be charged by additional or supplemental assessment (1853, sec. 53).

It is provided by sec. $2 \mathrm{I}$ of the Finance Act 1907 that :-

(1) Every employer, when required to do so by notice from an assessor, shall, within the time limited by the notice, prepare and deliver to the assessor a return of the names and places of residence of any persons employed by him, to whom this provision applies, and of the payments made to those persons in respect of that employment, and section fifty-five* of the Income Tax Act 1842 shall apply with respect to any such return as it applies with respect to the lists, declarations, or statements mentioned in that section.

*The penalty section. (See post.) 
Schedule E.

Employer to return

salaries of

servants.
Memorial by civil servants.
This provision applies to all persons employed by an employer, except persons who are not employed in any other employment, and whose remuneration in the employment for the year does not exceed the sum for the time being fixed as the limit for total exemption from income tax.

(2) Where the employer is a body of persons, corporate or unincorporate (including a company), the secretary of the body, or other officer (by whatever name called) performing the duties of secretary, shall be deemed to be the employer for the purposes of this provision, and any director of a company, or person engaged in the management of a company, shall be deemed to be a person employed.

It will be observed that the proviso is designed to cover all persons who can possibly be liable, as the name is to be included if the person is in any other employment, notwithstanding that he does not receire $\mathcal{E}_{\mathrm{r}} 6 \mathrm{0}$ in the employment in question.

In 1897 a memorial was addressed to the Chancellor of the Exchequer by certain civil servants, asking that legislation should be proposed with a view to secure that their salaries should be assessed under Schedule D instead of under Schedule E, thus giving them the benefit of the average. The Chancellor, however, signified his inability to comply with the memorial, pointing out that the principle of average under Schedule D was specially devised to meet the cases of profits and earnings necessarily of a more uncertain and precarious character than incomes derived from fixed and regular salaries. With respect to salaries of civil servants, he said : 
"Those salaries, in the great majority of cases, rise by regular increments; where they do not so rise, they are stationary. The system of averaging, therefore, would either be Schedule E. inoperative, or would inevitably work against the Revenue by enabling the civil servant to pay income tax on something less than his annual income. This would be equivalent to a special system of abatement for official incomes."

The argument of the Chancellor, which was urged as to the average under Schedule D, is easily answered. For instance, in the case of an individual or firm in trade, the salaries and commissions of managers and others are all assessed under Schedule D. When such a business is formed into a limited company, the salaries of the secretary and others and commission to managers are chargeable under Schedule E. If there be any excuse for transferring salaries to Schedule $\mathrm{E}$ the same does not appear to be applicable to fluctuating commissions to managers. Indeed, the argument is rather in favour of continuing the assessment as before under Schedule D ; the mere nominal change in a business not appearing to be sufficient to justify the transfer to Schedule E, and, further, a distinction is made even in such a transfer in assessing subordinates on the average (see below) and only the higher officials on the income of the year.

Complaints are made that there is much inconvenience and trouble caused by widening the scope of Schedule $\mathrm{E}$ beyond what is thought to have been the intention of the Act of 1842 , seeing that the present Limited Liability Act relating to general businesses was only passed twenty years later. 
Schedule E.

Clerks, \&c. allowed to ayerage.
Commissions and bonuses.

Bray v. Brothers.

Claim to set off past losses in business against salary under Schedule E disallowed.
It will be noticed that the fact of the assessment being on the salary of the year of assessment, instead of on the average, places persons employed by public companies at a disadvantage as compared with those employed by private firms. We find, howerer, that it is the practice to allow such persons, other than secretaries, managers, \&c., if in a subordinate position, to take a three years' average, as if they were assessable under Schedule D.

In reply to an inquiry in 1906 as to whether managers of departments, secretary, cashier, chief clerks (or heads of departments), or foremen could have the benefit of the average, the Board replied that the foremen were the only persons so eligible.

It is also usual (though not universal) to assess commissions and bonuses of fluctuating amount on the average of past years, except in case of beginning of such bonus, \&c., when the same is treated as in the case of a new business (post).

In Bray v. Brothers (Queen's Bench Division, 2nd April 1897) it was held that, where a person who had carried on a business at a loss subsequently converted it into a limited company, being himself appointed managing director, he was assessable on his salary for the year under Schedule E, and could not bring the losses on past years into average with his salary.

It may be noticed that, had an average been permitted, the losses would have been allowed twice, as the company 
would pay on past results, the change being a "succession" schedule E. (post, Chapter VI., Part II.).

In the case of The Attorney-General v. The Lancashire and A. = G. V. L. \& Y. Ry. Co. Yorkshire Railway Company (Court of Exchequer, Ist February 1864), a case had been stated for the opinion of the Court by order of a Judge. The question was whether the Salaries of workmen, \&c. chargeable under Schedule D. company were liable to assessment under Schedule $\mathrm{E}$ in respect of their officers, clerks, or servants engaged at weekly wages, as well as in respect of those engaged at annual salaries. The Court held that such wages were assessable under Schedule D, and not under Schedule E, and that Schedule E extended only to offices or employments of a public nature, and not to wages of workmen or artisans, like engine drivers, porters, and labourers.

As already mentioned (p. $2 \mathrm{I}$ ), offices of a public nature held under railway companies are assessed by the Special Commissioners.

Offices under railways assessed by Special Commissioners.

A clergyman may deduct any sum paid by him wholly, exclusively, and necessarily in the performance of his duty (1853, sec. 52). This does not include sums paid to another person to perform part of his duty for him (Lothian $v$. Macrae, Court of Session, Scotland, I3th December 1884).

Clergyman may deduct necessary expenses, but not payments to another to perform his duty.

(Lothian $v$. Macrae.)

I.R. v. Strong.

Contribution by parishioners chargeable. Ifth June 1878). The Rev. Mr. Strong did not appear, and the Lord Ordinary made the following note :- 
Schedule E.

I.R. v. Strong.
"Although this case has been heard ex partc, the appellant not having appeared, I have not disposed of it as in absence, but only after carefully considering the argument for the appellant stated in the case. It is with some reluctance that I have formed the opinion that the Commissioners are wrong, and that the appellant is liable for income tax on the $f$ roo mentioned in the case. It is true that it is a voluntary contribution by the parishioners, one which they are under no obligation to make, and which they may withdraw at any time. But still it is a payment made to the appellant as their clergyman, and it is received by the appellant in respect of the discharge of his duties of that office, which is one of public employment in the sense of the statutes. This being so, it follows that the payment must be regarded as either 'emolument' under Schedule E, or 'gain' under Schedule D, and that it is chargeable with duty."
Turner $v$. Cuxson.

Grant from Curates Augmentation Fund not assessable.
Hue v. Miller case not argued.
An allowance from the Curates Augmentation Fund is not assessable. Such an allowance is given as a donation for faithful service for fifteen years or upwards, and on condition that the party obtains donations to the fund for half the amount of the grant, and it does not accrue to a person by reason of his office (Turner, Surveyor of Taxes v. Rev. G. A. Cuxson, decided in the Queen's Bench Division, IIth December 1888). (See also Duncan v. Farmer, post.)

In Hue v. Miller (King's Bench Division, 29th November 1900) the Crown (on appeal from the decision of the Commissioners) sought to assess the Rev. Mr. Miller in respect of a grant of $£$ I5 made to him from the Sustentation Fund of the St. Alban's Diocesan Poor Benefices Fund as a "perquisite." On the case coming into Court, the SolicitorGeneral asked leave to withdraw it, as he had come to the conclusion that he could not, on the facts stated in the case, 
argue the points on which it was desired to obtain the opinion Schedule E. of the Court. The appeal of the Crown was therefore dismissed.

In Charlton v. Corke (Court of Session, Scotland, a nd May r890), a minister of the Church of Scotland was allowed to deduct-

(i.) Expenses incurred in visiting the members of the congregation beyond the limits of his parish;

Deduction of Trayelling Expenses allowed.

(ii.) Travelling expenses involved in the discharge of duties laid upon him by his ecclesiastical superiors;

but his claim for allowance for a room in his manse used as a study, and for books, was refused.

Annual value of study disallowed.

Inland Revenue v. Strong was approved, and Turner v. Cuxson was distinguished-reversing the decision of the King's Bench Division-in Herbert v. McQuade (Court of Appeal, roth July I902), where a grant made by the Queen Victoria Clergy Sustentation Fund was held to be assessable. Towards the end of his judgment in the King's Bench Division Phillimore, J., said :

"This is an unsavoury case. One cannot help seeing that there has been an attempt to wrest a tax out of this public benevolence. It is pressed against a poor and particularly helpless man, and it is only the fortunate accident that there is a numerous class of men equally poor and helpless which has enabled him to resist what we have found to be an unfounded claim put forward by the officers of the Crown."

The case first came before the Court of Appeal in Norember I9oI, when the Attorney-General stated that he

Herbert $v$. McQuade.

Grant from Q.V.C. Sustentation Fund is assessable. 
Schedule E.

Herbert $v$. McQuade.

Grant from Q.Y.C. Sustentation Fund

is assessable.

considered it his duty to state, in consequence of the above remarks, that the Commissioners of Inland Revenue, deeming the point raised in the case to be one of great and widereaching importance, and, at the same time, feeling that the litigation of the point might involve some hardship upon the individual clergyman whose case was taken as a test case, had arranged with him, before the case was stated, that the Crown would pay all his costs in any event in all the Courts. The observations of the learned Judge were therefore without foundation.

The case eventually stood over (till July 1902) that the special facts as to the precise form of the application and of the resolution authorising the grant in each year might be brought before the Court. The Master of the Rolls considered this might be a most important factor in determining the case. In giving judgment for the Crown, the Master of the Rolls said the case raised a very nice question of law, as it was very near the line. If it was a personal gift it would not be liable to income tax. He pointed out that no inquiry was made as to the personal income of an incumbent (the only inquiry was as to the income of the benefice); also that, if the benefice fell vacant, the grant was divided. He thought it was therefore very difficult to contend that it was not in terms, and in fact and in result a grant to the benefice, and not to the person. It came to the incumbent only because he was the incumbent for the time being of an inadequately provided-for parish, therefore it fell, he considered, directly within the words " accruing by reason of such 
office," and was assessable. Reviewing Turner v. Cuxson, he distinguished it, as in that case it was a personal eleemosynary gift-not by virtue of the office of the curate of that particular parish. Dealing with $R e$ Strong, he said that though upon the particular facts the decision might be open to discussion -though he did not give any opinion upon that-the principle upon which it was decided was right, as the Judge had held that the gift was made by virtue of the office of the recipient.

In Turton v. Cooper (King's Bench Division, Igth and 2oth April and 23rd May 1905) a portion of a collection made in church was given by way of "Easter offerings" to an incumbent by reason of his office, but the gift would not have been made if the recipient had not been poorly off. It was held that the offerings were not given as additional remuneration for services, but on account of personal poverty, and that they were not assessable (but see Cooper v. Blakiston later).

In Poynting v. Faulkner it was held by the Court of Appeal (26th, 27 th, and 30 th May I905), reversing the decision of the lower Court, that grants made from a Ministers' Stipend Augmentation Fund in augmentation of the stipend of ministers were assessable. In making grants regard was had to the following facts :-

(a) Ability of a congregation to make adequate provision for their minister.

(b) The fact that the minister had been regularly educated for a minister.

(c) The amount of his income.

Schedule E.

Herbert $v$. McQuade.

Turton v. Cooper.

Easter offerings not assessable.

Poynting v. Faulkner.

Grants from Stipend Augmentation Fund assessable. 
Schedule E.

Cooper v.

Blakiston.

Easter

offerings

chargeable.

Turton $v$.

Cooper

discussed.
Jardine $v$. Gillespie.

Yarious Allowances.
In Cooper v. Blakiston (House of Lords, I2th and 16 th Norember and roth December 1908) it was held, affirming the decision of the Court of Appeal, that Easter offerings (consisting partly of collections in church and partly of gifts by parishioners) were assessable.

In the Court of Appeal, Lord Alverstone, C.J., said he doubted whether he would have decided Turton v. Cooper in exactly the same way as Channell, J., decided it, "but " still he seemed to have taken it as the basis of his decision " that the money would not have been paid to the incumbent " of the church if he had not been poor. There are findings " in the report (he continued) which, as I have said, would " have made me doubt whether the decision was exactly a "strict application of the principle, because there is a state" ment that the money was given to the appellant by reason "of his office as incumbent, but, looking at the case, I think "it was a decision upon the particular facts of that case."

Their Lordships were unanimous in affirming the decision. See also Duncan $i$. Farmer (post).

In Jardine v. Gillespie (Court of Session, Scotland, 6th and I6th November I906) a minister was allowed to deduct-

(I) A sum representing part of the cost of keeping a horse and carriage used partly for pleasure and partly in the performance of his duty ;

(2) Cost of Communion elements; 
but deductions were disallowed in respect of-

(3) Expenses of Process of augmentation of stipend;

(4) Pulpit supply during holidays (following Lothian $\because$ Macrae).

The Commissioners also allowed-

(5) Expenses attending meetings of Presbytery and Synod ;

(6) Stationery $\left(\mathcal{E}^{2}\right)$.

See also in Schedule D (Clergyman).

In Beaumont v. Bowers (Queen's Bench Division, roth May I900) the appellant sought to deduct from his salary for the purpose of assessment a compulsory deduction suffered by him

Beaumont v. Bowers.

Deduction under Superannuation Act under the provisions of the Poor Law Officers' Superannuation Act I896. He claimed that such deduction fell under the description "duties or other sums payable or chargeable on " the same (i.e., the salary) by virtue of any Act of Parlia" ment," and "bonâ fude paid and borne by the party to be " charged." The Surveyor contended that the payment was not "borne" by him, since it might eventually be returned to him.

The Court gave judgment against the Crown, holding that the deduction was clearly allowed in the terms of sec. 146. This was, however, overruled in Bell v. Gribble and Hudson i. Gribble (post).

Other cases are those of Cook v. Knott and Revell v. Ellworthy (Chapter VI., Part II.). 
schedule E. By sec. 57 of the Taxes Management Act 1880 a general Appeal. right of appeal is given against any assessment. This includes assessments under Schedule E.

The question of Exemption and Abatements is fully considered in Chapter VIII. 


\section{CHAPTER VI.}

SCHEDULE D.

\section{PART I.-Persons and Profits Chargeable.}

$\mathrm{B}^{\mathrm{E}}$

EFORE considering the mode of preparation of accounts

Schedule o?

for income tax assessment it will be well to go some-

what fully into the question of the persons chargeable, and the description of income liable to duty. The duties under this schedule are deemed to be granted-

"For and in respect of the annual profits or gains arising or accruing to any person residing in the United Kingdom from any kind of property whatever, whether situate in the United Kingdom or elsewhere, and for and in respect of the annual profits or gains arising or accruing to any person residing in the United Kingdom from any profession, trade, employment, or vocation, whether the same shall be respectively carried on in the United Kingdom or elsewhere.

"And for and in respect of the annual profits or gains arising or accruing to any person whatever, whether a subject of His Majesty or not, although not resident within the United King. dom, from any property whatever in the United Kingdom, or any profession, trade, employment, or vocation, exercised within the United Kingdom. . . .

"And for and in respect of all interest of money, annuities, and other annual profits and gains, not charged by virtue of any of the other Schedules. . . ." $\left(\mathrm{I}_{53}\right.$, sec. 2.) 
The profits chargeable under Schedule D are divided into six cases, viz. :-

Case 1.

Case I.-In respect of any trade, manufacture, adventure, or concern in the nature of trade, not contained in any other schedule of the Act, unless the trade, \&c., has been set up and commenced within the year of assessment, in which case it falls under Case VI.

Case 11.

Case II.-In respect of professions, employments, or rocations rot contained in any other schedule of the Act, unless the profession, \&c., was entered upon within the year of assessment, in which case it falls under Case VI.

In Cases I. and II. the profits are to be estimated on an arerage of the three preceding years. See post as to a business, \&c., set up within that period.

Case III.

Case III.-In respect of profits of an uncertain annual value not charged under Schedule A.

In this case the assessment is on the amount arising in the preceding year. 
Case IV.-In respect of interest arising from securities in the British plantations of America, or in any other of His Majesty's dominions out of the United Kingdom, and foreign securities, except such annuities, dividends, and shares as are directed to be charged under Schedule C.

Here the assessment is on the amount which has been or will be received in the United Kingdom in the current year.

Case V.--In respect of possessions in the British plantaCase $\mathbf{Y}$. tions of America, or in any other of His Majesty's dominions out of the United Kingdom, and foreign possessions.

In this case the assessment is on the average amount actually received in the United Kingdom during the three preceding years.

Case VI.- In respect of any annual profits or gains not Case VI. falling under any of the foregoing rules, and not charged by virtue of any other of the schedules. In this case are included profits, \&c., derived from a trade, \&c., set up, or profession, \&c., entered upon within the year of assessment.

Here the assessment is to be either on an arerage or otherwise, as the Commissioners may direct. 
British subject temporarily abroad

chargeable.

Foreigner in

United

Kingdom

temporarily

not

chargeable.

Residence.

Employee permanently abroad.
A British subject temporarily residing abroad is liable to tax on the whole of his profits; and, conversely, a person residing in the United Kingdom temporarily is not chargeable except as to any business, \&c., carried on in the United Kingdom. A person residing here, even at different times, for a total period of six months in any year is chargeable; so also is any person who shall leave the country after claiming exemption and return on or before the $5^{\text {th }}$ April following (x 842 , sec. 39). A person keeping an establishment in any place may be said to reside there, though he may not go there for years.

We believe endeavours have sometimes been made to charge an employee permanently residing abroad.

So far as we can see, such a claim could only be substantiated by a contention that the expression profits, \&c., accruing from any trade, \&c., " exercised within the United Kingdom" (see Schedule of Charge, p. 57) means profit accruing to one person from a trade carried on by another person. It is fairly clear, however, that the expression means a trade carried on by the person sought to be charged. Any other construction is straining the words of the Act.

Remittances from abroad.
Where a wife receives remittances from her husband abroad the question of her liability is governed by Instruction $3^{6} 3$ to Surveyors of Taxes, viz. :-

"A wife receiving an allowance or remittance from her husband abroad is to be charged for the same as his agent (under the second proviso to sec. 45 of the Act of 1842 ) when 
the remittances are derived from any kind of property out of the United Kingdom, whether real or personal, movable or immovable. Remittances derived from trade profits, salary, \&c., are not taxable."

In the case of In re Young (Court of Exchequer, Scotland, roth July 1875) the appellant, who was master of the s.s.

Re Young.

"Residence." " Olympia," trading to New York, \&c., was consequently only in England eighty-eight days in the year. He had, however, a house for his wife and family in Glasgow. It was held that he was "resident" in Great Britain and only temporarily absent, and thus assessable.

In Rogers v. Inland Revenue (Court of Session, Scotland, 28th June 1879) Mr. David Rogers, who was in command of the ship "Saint Magnus," of Glasgow, which traded to the East Indies, had been absent from July I877 up to April I 879. He had a dwelling-house in Fifeshire, where his wife and family had resided during that time. He sought to be exempt from income tax on his salary on the ground that his absence from Great Britain was not of the temporary character contemplated by sec. 39 of the Act of 1842 . The Court held, however, that he had a residence in Great Britain, and that the fact of his having been absent during the entire year was a mere accident, and he was liable to be assessed as a "resident" in Great Britain, following the above case.

In Lloyd v. Sulley (Court of Session, Scotland, I 2 th March ${ }_{188}$ ) it was held that a merchant carrying on business in Italy, and ordinarily residing there, but also having a place of residence in the United Kingdom, where he dwelt with his family for several months in the year, was "resident" in the United Kingdom.

Rogers v. I.R. Captain of ship "resides" here though absent for the whole year.
Lloyd $v$. Sulley.

Merchant ordinarily in Italy, but having place of residence in United Kingdom "resides" here. 
These cases were followed in Cooper v. Cadwalader (Court of Session, Scotland, 22nd November I $_{904}$ ). Mr. Cadwalader is an American citizen ordinarily residing in New York, but he rented certain shootings and Millden Lodge, Forfarshire, for three years from ist February r9o0, afterwards extended two further years. Mr. Cadwalader resided at Millden for two months in each year, and a caterer from London supplied him with food and servants. He had not any place of business in the United Kingdom, and during his stay at Millden his establishment in New York was kept up so that he could return to it at any time. The Lord President, in holding Mr. Cadwalader liable to assessment, on remittances from abroad, pointed out that a person may have residences in more countries than one. He undoubtedly "resided" at Millden, and could not have the benefit of sec. 39 to a person residing in the United Kingdom " for some temporary purpose only, " and not with any view or intent of his establishing his "residence there. . . ."

Brown $v$. Burt.

Residence on Yacht.

In Brown v. Burt (Court of Appeal, 26th July I9II) it was held that a person who habitually lived on a yacht, which was moored at a place in the river Colne, within the port of Colchester, was "resident" in the United Kingdom.

A.:G. $v$.

In the case of Attorney-General v. Black, heard in the Duty on coal is a "profit."

Court of Exchequer, 24th and 26 th January and $I 7$ th June $187 \mathrm{I}$, the facts were as follows :- 
A " rate or duty" on coal landed on the beach, or otherwise brought into the town of Brighton, and originally directed to the maintenance of sea-walls, was granted by a A.:G. v. Black. Duty on coal, is a "profit." local Act to the Corporation of Brighton. Coals which were sent beyond the limits of the town were exempt from the rate. By another Act the rate was increased, and it was enacted that any surplus from it should be deroted to aid the rate for paring, watching, lighting, \&c., the town. A subsequent Act, repealing the former Acts, empowered the corporation to buy lands, widen streets, build a town hall, raise a general district rate, and continue to impose the "rate or duty" on coal, and enacted that all other rates, duties, assessments, and impositions authorised by the Act should be consolidated into one fund, and be applied to the general purposes thereof.

It was held that this "rate or duty" was a "profit" within Schedule D, and was consequently liable to duty under the Income Tax Acts.

In Glasgow Corporation Water Works v. Inland Revenue (Court of Session, Scotland, 26th May i875) the corporation were held to be liahle to assessment only in respect of interest, \&c., from which they retained tax. The water rate was a compulsory one, levied on all persons, whether consumers or not, and the corporation could not make a "profit."

But In re The Glasgow Corporation Gas Commissioners (Court of Session, Scotland, zoth June 18;6) it was held that there were profits of the Gas Department. There was not any power to levy a rate or to compel anyone to buy gas. It was 
quite optional whether a person took the gas or not, and any surplus was " profit," and was liable to taxation.

OIIbertson $v$. Fergusson.

English branch of foreign bank entrusted with payment of dixidends out of their own earnings,

haying paid tax on profit, not to be further assessed under Schedule D.
The case of Gilbertson (on behalf of the Tondon Agency of the Imperial Ottoman Bank) v. Fergusson was heard in the Exchequer Division of the High Court of Justice on the

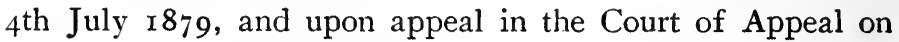
the roth May i88I. The facts of the case were shortly as follows :-

A foreign company carrying on business and earning profits abroad had an agency in London, which conducted a branch and earned profits. The dividends of the company were payable, at the option of the shareholders, either abroad or by the agency. In a particular year the agency earned an amount of profits which enabled them to pay all the dividends payable by them in that year without requiring or obtaining any remittance from the company abroad. The agency were assessed to income tax under Schedule $\mathrm{D}$ on the profits earned in the United Kingdom on an average of the three preceding years, the amount on which they were so assessed being less than the amount of those profits in that year. Section ro of the Act of 1853 provides that all persons entrusted with the payment in the United Kingdom of dividends of any foreign company, \&c., are to deduct tax on payment thereof, and to furnish particulars to the Board of Inland Revenue, and an assessment is to be made upon them by the Commissioners for Special Purposes. In lieu of a further return under this section the agency handed in a 
statement to the effect that no interest, dividends, or other annual payments payable out of or in respect of the stock, funds, or shares of the company had been entrusted to them for payment in the United Kingdom, and they appealed against an assessment of the Commissioners, whereby they were charged also in respect of the whole of the dividends paid by them, leaving them to prove upon appeal what Gilbertson $v$ Fergusson.

English branch of foreign bank entrusted with payment of dixidends out of their own earnings, haxing paid tax on profit, not to be amount should be deducted as having been included in the assessment on the profits earned in the United Kingdom.

The Judges of the Exchequer Division differed in opinion, the judgments of Mr. Baron Huddleston and Mr. Baron Pollock being in favour of, and the judgment of Chief Baron Kelly being against, the Crown.

It was held by the Court of Appeal (Lords Justices Bramwell, Brett, and Cotton), affirming the judgment of the Exchequer Division, that the agency were entrusted with the payment of dividends in the United Kingdom within the meaning of the section, and that they were liable to be assessed on the full amount of the dividends they so paid in the year, but that since the dividends were payable out of the general earnings of the company, consisting of profits made partly in the United Kingdom and partly elsewhere, and the agency had already been assessed to income tax on the former under Schedule D, an allowance should be granted in assessing the dividends in respect of that portion of the dividends which arose out of the business carried on in the United Kingdom. 
Mersey Docks and Harbour Board $v$

Lucas.

\section{Profit}

assessable irrespective of Its application.

The case of The $\dot{M}$ ersey Docks and Harbour Board $v$. Lucas was heard in the Queen's Bench Division on the r6th March $188 \mathrm{I}$; on appeal in the Court of Appeal on the 6th and 7th December I88I; and subsequently in the House of Lords, 26th and 28th June 1883 . The facts were shortly as follows :-The Mersey Docks and Harbour Board were constituted by Act of Parliament a corporation for the management of the Mersey Dock Estate. Under the Act the surplus revenue of the Board, which was derived from dock dues, \&c., after payment of interest on moneys borrowed, was to be applied towards a sinking fund for the extinguishment of the principal moneys spent in the construction of the dock, and for no other purpose whatsoever.

The Dock Board contended that their liability to income tax did not extend beyond the sum paid for interest on the debt. The Surveyor contended that they were liable for tax on profits, and not in respect of interest only.

The judgment of the Queen's Bench Division was against the Crown, but it was held by the Court of Appeal, and subsequently by the House of Lords, that the surplus moneys which remained after payment of the expenses of earning the same, and which, under the statute, could only be applied in a particular manner for the purpose of reducing the past debt, were available as "profits," and were assessable to income tax. 
In Paddington Burial Board v. Commissioners of Inland Revenue (Queen's Bench Division, $13^{\text {th }}$ and 14 th March 1884) the Board claimed that they were not liable to be assessed to income tax on their gains, on the ground that such gains could not be "profits" because they were applied in aid of the poor rate. The Court held that the Board clearly made a profit, and the destination of it was immaterial. They therefore gave judgment for the Crown.

In Sulley v. The Attorney-General (Court of Exchequer, I th May I860) one partner in a United States house resided at Nottingham, and purchased and shipped goods abroad, the other partners residing in the United States. The profits were made by the resale of goods in America; no money was received here except from New York; a large part of the profits of the firm was made by the resale of goods purchased in America, France, and Germany. It was held that the only profit assessable was so much of the share of the partner resident here as came to this country.

In the case of Partridge and Hancox v. Mallandaine

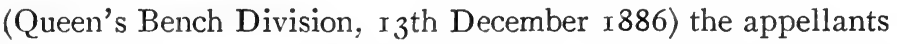
sought to escape payment of income tax on income from betting transactions. It was admitted that they made a

Partridge and Hancox $v$. Mallandaine.

Profits of betting transactions liable. practice of attending racecourses as bookmakers or bettors, but they argued that they were not carrying on any " profession, trade, vocation, or employment" within the meaning of the Act, that their gains were illegal, and could not be recovered by law, and that they were not the gains and profits 
of any trade contemplated by the Legislature, and that there was not any income tax payable. The Court held that the word "vocation" was a very large and wide one, and covered such a case. They therefore gave judgment for the Crown.

Sowrey $v$. Harbour Mooring Com. missioners of King's Lyan.

Corporation liable to tax on tolls.
In Sowrey v. Harbour Mooring Commissioners of King's Lynn (Queen's Bench Division, 23rd and 24th March 1887) the Commissioners were held liable to tax on tolls raised by them, and payable to the corporation, in respect of a contribution by the corporation of $£ 60,000$ towards the cost of making a cut from the Wash to King's Lynn.

Adam v. Maughan. Baths liable (Schedule A) though no profit.

In Adam v. Maughan (Court of Session, Scotland, r5th November 1889 ) the question was raised whether the excesses of revenue over expenditure in connection with the Edinburgh
Webber v. Glasgow Corporation.

Liability in respect of certain dues. Markets and Slaughter Houses (which were applied for public purposes), were "profit" (under Schedule A, No. III.), and they were held to be so; it was also held that the baths were assessable under Schedule $A$ though not yielding any profit.

The question of the assessment of certain dues payable to a corporation was raised in Webber v. Glasgow Corporation (Court of Session, Scotland, rgth January 1893), on appeal by the corporation. The case, however, was not argued, and the Court gave judgment for the Crown (following Adam v. Maughan) without expressing any opinion on the merits of the case. 
In Harris v. Corporation and Burgh of Irvine (Court of Session, Scotland, I2th and 22nd June 1900) the corporation supplied water to neighbouring parishes, which parishes paid in respect thereof an annual sum based on the gross rental of the parishes, and raised by compulsory rate. It was held that the profit thereon was assessable, since the compulsory rate was not levied by the corporation but by the parishes; it was further held that the portion contributed to the sinking fund was equally liable (following the Mersey Dock case, p. 66).

In Harris v. Edinburgh Corporation (Court of Session, Scotland, I8th June and Igth July I907) the question arose as to the assessment of certain slaughter-houses owned by the corporation. The revenue is (by an Act of $185^{\circ}$ ) to be employed--

(I) In payment of expenses.

(2) In parment of an annuity of $£ \mathrm{I}, 000$, for interest on capital adranced by the corporation.

And, so far as possible, the revenue is to be kept down to a sum corering these two items.

The corporation contended for either ( $\mathrm{I}$ ) an assessment according to the rules of Scherlule D, under No. III., Rule 3 of Schedule A (on profits); or (2) an assessment of £I,००० under Schedule A. 
Harris v.

Edinburgh Corporation.

Lord

Advocete $v$

Forth Bridge

Railway Co.

Company not having made

profit equal to

interest must

pay tax on

interest.
The Surveyor contended that the houses were capable of being let at an annual rent, and should be assessed accordingly, and any surplus profit was assessable under Schedule D, Case I.

The Court held that the concern was assessable under Schedule A on annual value, the provisions as to assessment of property under Schdule A on profits not being applicable where the concern was expressly prohibited from making a profit.

The case of Lord Advocate v. The Forth Bridge Railway Company was decided by the Court of Session, Scotland, I 7 th October I89o. The company were not making any profit, but were paying interest on capital during construction, and they returned the amount so paid in the year previous to the year of assessment, and were assessed thereon. The amount paid in the year of assessment being greater than the amount in the previous year, the Revenue claimed tax on the difference. It was held that the company were liable (under the Act of I888, sec. 24 post).

It should be noted that this decision relates only to cases where there have not been any profits made out of which to pay interest, or where the profits made (or net assessment after abatement and insurance have been allowed) are less than the interest payable on borrowed money-the interest in such cases being therefore wholly or partially payable out of capital. The tax is, indeed, deducted by persons or companies as collectors for the Revenue, and where it has not been paid 
over to the Crown by the person or company returning their profits for assessment without deduction of interest, it has to be specificaily paid.

In The Religious Tract and Book Society of Scotland $v$. Forbes (Court of Session, Scotland, 2nd January 1896) it appeared that the Society sold Bibles, \&c., at a shop in Edinburgh, and sent out travelling vendors (colporteurs), who sold Bibles and acted as cottage missionaries. The sales at the shop resulted in a profit, but the other transactions in a loss. The net result was an annual loss, met by subscriptions. It was held that the colportage was not a trade, nor an appurtenance of a trade, and that the loss on it could not, for the purposes of income tax, be set against the profits from the shop business.

In the case of Assets Company, Lim. v. Forbes (Court of Session, Scotland, 23rd February 1897 ), the facts were as follows :-A company, formed of solvent contributories of the City of Glasgow Bank, acquired from the liquidators the outAssets Co.
Lim. $v$. Forbes. No liability in respect of profit on a single transaction. standing assets of the bank, including sums expected to be recovered from estates of contributories, paying therefor a sum sufficient to enable the liquidators to discharge the liabilities of the bank. From time to time the company sold portions of these assets at prices exceeding the values at which they were estimated in the books of the liquidators.

The Court held that the case, as stated, did not contain materials for a decision whether profits liable to assessment 
Assets Co., Lim. $v$. Forbes.

No llability in respect of profit on a single transaction.

had been made or not, but some of the statements in the judgment of Lord Young are of interest. He said :-

“. . . Now, what about recoveries from debtors? The company took them over. I should say that I have really no doubt that any person, or any company, making a trade of purchasing and selling investments, will be liable to income tax upon any profit which is made by that trade. It is quite an intelligible business. . . . But it is another proposition altogether that, where there is not a trade, a gain or loss upon the purchase and re-sale of property comes within the meaning of the Income Tax Acts. Take even proper traders : if proper traders sell their old premises and buy new ones, and sell the old premises at a higher price than they paid for them. . . I should say it was a totally untenable proposition that anything in excess of what they had paid for the old premises . . . is income within the meaning of the Act. I do not think it is at all. It is no more so in the case of a trader's income than in the case of a private individual selling his house at more than he had paid for it. . . They were not making a trade of buying and selling debts. . . . The proposition that where anybody purchases a doubtful debt, and makes more than he paid for it-one purchase, he not being a trader in that kind of thing-that that is income, is, I think, a proposition which cannot be sustained. . . ."

This is certainly a liberal construction of the Acts from the public point of view. It might readily be said that there is a distinction between this case and that of a private individual. The company was formed for the express object of making a profit in the manner described, and it would seem that that profit should just as much be taxed as the profit of, say, a building company. 
In Paisley Cemetery Co. v. Reith (Court of Session, Scotland, ${ }^{5}$ th June and $5^{\text {th }}$ July 1898 ) the facts were as follows :-'The company make a charge of is. 6d. for the keeping and dressing of a lair for one year, or a slump sum of $\mathcal{E}^{2}$ for doing it in perpetuity. Where the amount of $\mathcal{E}^{2}$ was paid it was credited direct to Capital Account, and formed part of the funds accumulated and invested. There was, however, no contract to so set the amount aside. The company claimed that such sums were not assessable, being properly treated as capital.

The Court held that the amount was clearly assessable, following the principle laid down in previous cases.

In Armitage v. Moore (Queen's Bench Division, 9th May 1900) the trustee of Craven \& Craven had realised a great portion of the estate, and paid dividends amounting to $8 \mathrm{~s}$. $6 \mathrm{~d}$. in the $\mathcal{E}$. He continued, however, to supply steam-power at a profit. He contended that this was not an actual profit, but only the liquidation of a loss already incurred. It was held that, the rest of the business having ceased, this was an assessable profit.

In the case of Grove (Surveyor of Taxes) v. Young Men's Christian Association (King's Bench Division, I5th May 1903) it was sought to escape liability from taxation in respect of the profits of a restaurant carried on by the London Young Men's Christian Association. The Young Men's Christian

Armitage v. Moore.

Bankrupt business-one portion carried onprofit.
Grove $v$.
Y.M.C.A. Profits of restaurant. 
Association contended that as the restaurant was carried on in conjunction with, and formed part of, their scheme and work they were entitled to consider it as a department only of their work, and that they were entitled to deduct the losses on other branches of their work-viz., Educational Classes, Gymnasium, and Publication Departments-from such profit, and that the accounts as a whole showed a loss.

The Court gave judgment for the Crown, considering the case was indistinguishable from The Religious Tract Society case (p. $7 \mathrm{r}$ ), the restaurant being carried on on commercial principles, but the other departments of the Young Men's Christian Association work not being so carried on, and consequently the loss on them could not be set off (under sec. IOI).

Callfornian

Sale for Shares.
The case of the Californian Copper Syndicate v. Harris was heard in the Court of Session, Scotland, 2 Ist and 2 nd June and ist July I904. The company acquired copperbearing land in Fresno, California, for $£^{24,000}$. They sold the same to the Fresno Copper Company, Lim., for $£ 300,000$, payable in fully-paid shares. The profit, if any, was agreed

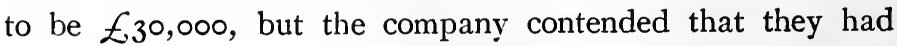
simply substituted capitai in shares for capital in land, and that any benefit was a growth of capital and not of income, and that in any case tax was not payable till the shares had been realised. The Commissioners held that the property was acquired with the object of re-sales, and that by such re-sales they carried on a concern in the nature of trade. 
Part i. Sch. D.-Sale of Concern-litability of Person

The Court held that the company was in its inception formed with the object of making profit from the sale of its property. The transaction was essential, being the appointed means of making gains, and the company was liable.

Lord Justice Clerk stated it to be a well settled principle that where the owner of an ordinary investment realised it at an enhanced price the difference was not assessable unless carrying on or carrying out a business (as in the case of a person or association of persons buying or selling lands, \&c., speculatively, in order to make a gain).

In Tebraii (Johore) Rubber Syndicate, Lim., in Liquidation, ข. Farmer (Court of Session, I6th July 1910) it was held that the syndicate was formed for the purpose of growing and trading in rubber, and that the surplus on sale of their assets to a new company was a realisation of their capital, and was therefore not liable to income tax.

The case was distinguished from that of The Californian Copper Syndicate (p. 74) on the ground that in that case the object of the company was to sell the property at a profit; it was not so in this case.

One of the most important cases as to the liability to assessment of profits abroad is that of Colquhoun v. Brooks. Mr. Brooks resided solely in England, and was a partner in the firm of $\mathrm{Hy}$. Brooks \& Co., of London, and of Brooks, Robinson \& Co., of Melbourne. The two businesses were distinct. Mr. Brooks returned for assessment the profit

Tebraii Rubber Syndicate $v$. Farmer.

Sale of concern.
Colquhoun $v$. Brooks.

Liability of person residing in United Kingdom in respect of profits of business carried on abroad. 
Colquhoun v. received in England in respect of his interest in the Melbourne
Brooks. firm. There was, however, a further sum placed to his credit with the Melbourne firm, in respect of profit not remitted to England; and he was assessed not only upon the amount received in England, but upon this further sum. The Income Tax Commissioners seduced the assessment to the amount of Mr. Brooks's return, but stated a case for the opinion of the Court. The Divisional Court were divided in opinion, but the junior Judge withdrew his judgment, and judgment was entered for the Crown. This decision was overruled in the Court of Appeal, and on being carried to the Hotise of Lords they affirmed the decision of that Court. The claim was based on Schedule D of the Act of 1853 , sec. 2, whereby duties are imposed-

"for and in respect of the annual profits or gains arising or accruing to any person residing in the United Kingdom from any kind of property whatever, whether situate in the United Kingdom or elsewhere; and for and in respect of the annual profits or gains arising or accruing to any person residing in the United Kingdom from any profession, trade, employment, or vocation, whether the same shall be respectively carried on in the United Kingdom or elsewhere," \&c.

Prima facie liable on total profit.
In giving judgment (9th August I 889) Lord Herschell said he thought it must be admitted that the words of the statute did prima facie support the contention of the Crown. The respondent did reside in the United Kingdom, and profits did arise or accrue to him from a business carried on elsewhere than in the United Kingdom. Reliance had been placed upon decisions under the Legacy and Succession Duty Acts which had imposed a limit upon the broad language of 
these enactments, which without such limitation would apply, although neither the testator, nor the legatee, nor the property, was within or had relation to the British dominions. A construction leading to such a result was obviously inadmissible. But the Income Tax Acts also imposed a limit, and if the person whose income was sought to be taxed was resident in the United Kingdom, he thought it was competent to the Legislature to determine the measure of taxation to be applied to him. At the same time, he was far from denying that if it could be shown that a particular interpretation of a taxing statute would operate unreasonably in the case of a foreigner sojourning in this country, it would afford a reason for adopting some other interpretation if it were possible consistently with the ordinary canons of construction. It was clear from the Act that, as regards income from investments, or from possessions outside the United Kingdom, the tax was only payable on so much of the income as was received in this country. If the contention of the Crown were correct, there was no such limit in the case of a foreign income arising from a trade, \&c., carried on abroad, and the whole would be subject to taxation, though no part of it ever reached this country. This would be a glaring anomaly, but would not avail the respondent if the taxation were imposed by the clear language of the statute. But as was said by Lord Blackburn in The Coltness Iron Company v. Black, if any taxing enactment would bear two interpretations, it was only reasonable to apply that construction which would raise the tax as equally as possible.

If a particular construction of Act would operate unreasonably some other. interpretation to be acted on if possible. 
Colquhoun $v$. Brooks.

Not any

machineryl for assessing duty on profits remaining abroad.
Not sought to tax profit of other partners abroad.

By what authority could a separate assessment be claimed by Crown?
" It is beyond doubt, too," continued Lord Herschell, " that we are entitled, and, indeed, bound, when construing the terms of any provision found in a statute, to consider any other parts of the Act which throw light upon the intention of the Legislature, and which may serve to show that the particular provision ought not to be construed as it would be if considered alone and apart from the rest of the Act."

The respondent had contended that by thus seeking the aid to be derived from other provisions of the Acts it would be seen that the Surveyor's view was erroneous. His Lordship then considered the machinery provided for carrying out the taxing purposes of the Act, and he was of opinion that the respondent had shown that the Act had not provided the requisite machinery for assessing the duty on trade profits arising to a sleeping partner and remaining abroad. This he considered a strong point towards showing that it was not intended to tax them. Again, the rules provided that in case of any partnership the assessment was to be made jointly in all cases except for the partners claiming exemption, \&c. (1842, sec. roo, third rule, applying to first and second cases). Now it was not contended that the whole of the profits of the Australian firm were assessable; the shares of the Australian partners clearly could not be taxed. By what authority, then, did the Crown contend for such a separate statement and assessment as was here claimed? He did not think that a rejection of the argument on behalf of the Crown would lead to the conclusion that profits received here from a business carried on abroad were not subject to tax. Such a conclusion would be a formidable obstacle to yielding to 
in Respect of Profits of Business Abroad.

the argument of the respondent. He thought the word "possessions" in the fifth rule-charging duty in respect of possessions in the Colonies, \&c., on the sum actually received in the United Kingdom-was meant to include more than "property," if not, he could not think but that the word " property" would have been used. "Possessions" was a wide expression, and he did not think any violence would be done to the language if it were held to include the interest which a person in this country possessed in a business carried on elsewhere. Such a construction would remove the glaring anomaly above referred to. The conclusion he had come to was strengthened by the 39 th section of the Act of 1842 , which exempts persons temporarily residing in England from tax in respects of profits received from foreign possessions. If the contention of the Crown were upheld such a person would still be liable to taxation in respect of the entire profits arising from a business carried on abroad, though not received here. He considered that the whole section pointed strongly to the conclusion that money received in this country arising from possessions or securities outside its limits was supposed to be the only portion of foreign income which was taxable. Some anomalies might possibly result from his decision, but it appeared to him the one least open to objection and most in accordance with the intention of the Legislature, so far as he gathered it from the provisions of the Acts taken as a whole.

A question has been raised as to the liability to income tax of a firm consisting of two partners, and having a house here

Colquhoun $v$. Brooks.

"Possessions" different from "property."
Amount received in United Kingdom is the only amount taxable in respect of foreign possessions or securities.
Liability of firm haying house abroad managed by partner resident there. 
Liability of house abroad managed by partner

resident there. firm haying

managed by one permanently residing here and another abroad (a separate business) managed by the other who permanently resides abroad. The point is not entirely free from doubt, but it is submitted, on the authority of Colquhoun $v$. Brooks, that in respect of the profits of the foreign house, they are only liable in respect of such portion of the profits as are remitted to the United Kingdom.

In any case, the position as to a firm in Scotland might be different, it being a separate persona under Scotch law and domiciled there.

Ogilvie v. Kitton.

Owner of Canadian business.

Businesses abroad.
In Ogilvie, Senr. v. Kitton (Court of Session, Scotland, I 7 th June I908), it was held that the sole proprietor of a business in Canada who resided here was liable to tax on the whole profit, whether remitted here or not.

With respect to the question of the taxation of companies carrying on business abroad, these may be divided into three classes :-

(I) Those registered here but whose operations take place abroad.

(2) Those registered here and carrying on business abroad by means of a subsidiary company.

(3) Those registered abroad but controlled from here.

The decision in the House of Lords in the San Paulo case establishes the principle to be applied in cases falling into Class I; the decision in the Schoenhofen Brewery case 
establishes the principle for cases in Class 2 ; and that in the De Beers case establishes the principle for Class 3 .

The facts and decisions in these cases were as follows :-

The San Paulo (Brazilian) Railway is registered under the Companies Acts, and has its office in London. The control and direction of it are in London, and the business of the San Paulo Railwoy v. Carter.

Railway in Brazil. compary is carried on under the direction of the direstors here. Purchases of rails, engines, \&c., are made by the directors here; the acrounts are kept in London, and meetings are held and dividends declared and paid in London.

The House of Lords held (San Paulo (Brazilian) Railway Company v. Carter, i 7 th December r895) that the company was liable to tax on the whole of its profits, whether remitted tc the United Kingdom or not. The profit was $£ 375,000$, of

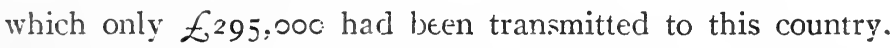
It did not appear why the difference had been retained, or how it had been appiied.

Lord Watson, in the course of his judgment, said :-

"When it has been ascertained that a person interested in the profits of a trade has his residence in the United Kingdom in such sense as to bring him within the incidence of the Income Tax Acts, the only question remaining for determination is whether the measure of his liability is to be found in the first or in the fifth case of Schedule D. In the one case he is liable to pay duty in respect of the net profits accruing to him from such trade, in the other in respect only of such part of those profits as shall have been actually received by him in this country. But he cannot, according to the rule established in Colquhoun v. Brooks, escape from liability under the first case unless he is able to show that no part of the trade is 
Businesses abroad.
Schoenhofen Brewing Co., Lim.

Company worked by subsidiary company. carried on within the United Kingdom, or, what comes to precisely the same thing, that it is exclusively carried on in a country or countries outside the United Kingdom, whether subject to Her Majesty or not. If he succeeds in proving that fact, his liability will be under the fifth case. . . . To my mind it is perfectly clear that in point of fact part of (the company's) trade is carried on (in England)."

The Peter Schoenhofen Brewing Co., Lim., is registered under the Companies Acts and has its registered office in London. It was formed to acquire a brewery in the United States.

As, by the American law, a foreign company cannot hold American properties, an American company was formed. All the shares of this company except three are held by the English company. The shares of the English company are held partly here and partly in America. The amount required for payment of dividend to the American' shareholders is retained in America. The Surveyor sought to assess the whole of the profits to income tax, but the company contended that they were only liable in respect of the profit remitted to England.

The affairs of the brewery can be, if necessary, directed from and administered at, the registered office by the board, who have the entire right of control and the entire directing power over the affairs of the American company. As a fact, however, the directors delegated their power to the managers of the brewery at Chicago, who were the directors of the American company, and who were appointed as a committee of management in America. During the year the chief husi- 
ness personally transacted by the board in England was the passing of transfers, the payment of dividend in England, the consideration of reports received from America, and the issuing of the Balance Sheets, \&c.

The Court of Appeal held (Apthorpe v. Peter Schoenhofen Brewing Co., Lim.) (Court of Appeal, 6th March 1899), that the whole of the profits were chargeable, considering that the observations in the judgment of the San Paulo case applied.

The De Beers Consolidated Mines, Lim., is a company registered in the Cape Colony. It owns or is interested in extensive diamond mines, \&c., in South Africa, and investDe Beers
Mines, Lim. Directing power in ments in English Gorernment Securities. By its articles of association its head office is to be at Kimberley, or at such other place as the directors shall deem fit. The company has offices in London and Kimberley. Under the articles of association "four at least of the directors shall reside in England."

The profits are derived chiefly by the sale of diamonds to a syndicate of six or seren firms under contract. The said contracts are negotiated and executed in London, and the firms composing the syndicate are all described as of London.

The Commissioners found (I) that the business was one business carried on at the London office, and (2) that the head and seat and directing power were at the office in London. 
Businesses abroad.

Do Beers Mines, Lim.

Directing power in

London.
The House of Lords held (De Beers Consolidated Mines, Lim. v. Howe, i8th and rgth June and 3 oth July 1906) that these conclusions of fact could not be impugned, and that the company was resident within the United Kingdom and assessable on the whole of its profit.

In consequence of the decision the company have altered their articles of association.

Older cases.
The following cases, which were dealt with at greater or less length in the previous Editions of this work, may be referred to on special facts, though they seem to be covered by the above:-The Attorney-General v. Alexander and others (Court of Exchequer, 2oth November 1874); Cesana Sulphur Co., Lim. v. Nicholson, and Calcutta Jute Mills Co., Lim. v. Nicholson (Court of Exchequer, 31st January and ist and 2nd February 1876 ); Erischen (Representative of the London Agency of the Great Northern Telegraph Company of Copenhagen) v. Last (Court of Appeal, 6th December 188I); London Bank of Mexico and South America v. Apthorpe (Court of Appeal, 3rd June r891) ; Bartholomay Brewing Co. (of Rochester) Lim. v. Wyatt (Queen's Bench Division, I 2th August 1893); Nobel Dynamite Trust, Lim.v. Wyatt (on the same day); Denver Hotel Co., Lim. v. Andrews (Court of Appeal, I4th February 1895); Grove v. Elliotts \& Parkinson, and Elliotts \& Parkinson v. Grove (Queen's Bench Division, I $3^{\text {th }}$ May 1896); Frank Jones Brewing Co. v. Apthorpe, United States Brewing Co. v. Apthorpe, and St. Louis Breweries v. Apthorpe (Queen's Bench Division, I $3^{\text {th }}$ 
December 1898); Goerz \& Co., Lim. v. Bell (King's Bench Division, 9th March 1904).

Two cases on the border line are those of the Kodak Co. and the Gramophone Co.

In Kodak, Lim. v. Clark (Surveyor of Taxes) (King's Bench Division, rgth June I902, Court of Appeal, I $3^{\text {th }}$ February 1903), the question was again raised as to the liability of a company registered in England and holding 98 per cent. of the shares of another company abroad (the Eastman Kodak Company). Phillimore, J., in reviewing the various cases previously decided, called attention to the difference between "controlling" and "carrying on" a business. A company might control another, but it did not necessarily follow that it carried it on. In this case the English company neither carried on nor controlled the American company. The American company were manufacturers and the English company were buyers. He gave judgment for the appellants, and directed that there was no evidence upon which the Commissioners could have come to the conclusion as stated in the case (viz., that the business and profits of the American company were the business and profits of Kodak, Lim.). There remained, however, he said, a serious question-whether 98 per cent. of the profits of the Eastman Kodak Company ought not to be returned (that question had not been argued before him) or whether the Crown could not compel Kodak, Lim., to make the Eastman Kodak Company return their profits. Those questions, he Kodak, Lim.,
v. Clark.

\section{Distinction} between "controlled" and "carried on." 
Businesses abroad.

Gramophone, Ac., Lim.

Shares in independent company. said, were matters upon which he was not asked to give a decision.

In The Gramophone and Typewriter, Lim. v. Stanley (Court of Appeal, 27 th March 1908) the company held all the shares of the Deutsche Grammophon Aktiengesellschaft. Under the deed of association of the German company accounts were made up to $3^{\text {Ist }}$ August each year, and onethird of the working profit was to be devoted to writing down patents. The official bodies of the company are a board of supervision and a board of management. The members of the board of management are also directors of the English company, and the members of the board of supervision are nominees of the English company. In the year in question the amount deroted as above was £5,000. The Commissioners held (I) that the English company controlled the German company, and (2) that the entire business of the German company was carried on by the English company, and that therefore the whole profits (including the $\left.\mathcal{E}^{\mathrm{I} 5}, \infty 00\right)$ were assessable.

Walton, J., gave judgment for the company. He said there were dicta in Kodak v. Clark which appeared to be sometimes in favour of one side and sometimes of the other; but he did not think Kodak v. Clark bound him on this question. $\mathrm{He}$ thought that the German company was not the business of the English company ; the fact of all its shares being held by the English company did not make it so. The English company had an interest in the German company, and that interest had been taxed. The appeal was therefore allowed. 
The Court of Appeal approved this, pointing out that the German company was a genuine company and an independent entity.

Following these cases it would appear perfectly clear, by analogy, that where a company here works its business in foreign countries by means of subsidiary companies, of which it owns the whole share capital, it is quite in order to set off losses made by one company against profits made by another or others.

The decision in the De Beers case was followed in New Zealand Shipping Co., Lim. v. Stephens (Court of Appeal, $5^{\text {th }}$ December 1907), and also in American Thread Co. v. Joyce (King's Bench Dirision, i5th February igir).

One of the earliest corporation cases is that of The Attorney-General v. Scott (Chamberlain of the City of London), heard in the Exchequer Division, I6th January 1873. The facts were:-

The Corporation of the (ity of London derive a large annual income from renewal fines, profits of markets, corn and fruit metages, brokers' rents, and Mayor's Court and other fees. The receipts from these sereral sources, after deducting the cost of collection, were carried to a general account from which was deducted the whole expenditure of the corporation for the ciril government of the city, including the maintenance of the police, \&c., and the balance was returned by the City Chamberlain (the proper officer of the corporation) as the profits of the corporation chargeable under Schedule D. 
A.-G. v.

Scott.

Olasgow

Water Com -

missloners $v$. Miller.

Profit on water supplied beyond municipal boundary liable to tax.
It was admitted at the trial that the renewal fines were chargeable in the ordinary manner under Schedule A, No. II., Rule 5, of the Act of 1842 , but with this exception it was contended that the defendant's return was correct.

It was held by the Court :-

That the profits of the corporation derived from market tolls, corn and fruit metages, brokers' rents, Mayor's Court fees, \&c., were liable to income tax under Schedule D, without reference to the purposes to which they were applied; and that the proper principle upon which the assessment should be made was to take each item or head of income separately, and to assess the income tax upon the net produce of such item, after deducting from the gross receipts the expenses incurred in earning and collecting the same.

The facts in the case of The Glasgow Water Commissioners v. Miller (Court of Session, Scotland, 8th January 1886) were as follows :-

The Commissioners, by a local Act, were empowered (I) to levy a compulsory rate on all dwelling-houses within the municipal boundaries; (2) to fix a rate for persons who chose to take water beyond the boundaries; and (3) to sell water to manufacturers and others. The Act required the Commissioners in each year to fix a rate within the compulsory area, sufficient, with the other income, to defray the interest on the debt and the annual expenses, and to provide a sum to form a sinking fund for the redemption of the debt, and 
it directed that any surplus in any one year should be applied to reduce the rate within the compulsory area in the following year.

It was held that, while the rates levied within the compulsory area were to be regarded as sums levied to defray the cost of water supplied within the district, so that any surplus remaining over could not be regarded as profit, any surplus of rates-over outlay-collected beyond the compulsory area, or from sales to manufacturers and others, was profit which went to reduce the cost of the water supply to those within the compulsory area, and was liable to assessment to income tax under Schedule D.

In Allan v. Hamilton Waterworks Commissioners (Court of Session, Scotland, 2and January r887) the Commissioners were held liable, following the Glasgow case (above), for tax on profits derived from selling water by meter to barracks within the area of compulsory supply.

The facts in the case of Corporation of Dublin v. McAdam were as follows:--By their Act the corporation were empowered to supply water to Dublin and certain extramunicipal districts, and to borrow money on the rates. By

Corporation of Dublln $v$. McAdam.

Profit on water supplied beyond municipal boundary liable to tax.

a further Act it was provided that the income derived from the extra-municipal districts was to form, with the city rates, a consolidated fund, available for payment of principal and interest on loans, \&c. It was held by the Exchequer Division of the High Court of Justice in Ireland ( $13^{\text {th, }}$ i 4 th, and 16 th June 1887 ) that the excess of receipts orer expenditure in 
respect of extra municipal districts was liable to income tax. There was not, of course, any profit in respect of water supplied within the city.

There have been a number of cases on the question of agency.

Tischler $v$. Apthorpe.

\section{English} agency of foreign firm. Crown may assess agents or principals.
In Tischler and another $v$. Apthorpe the appellants were wine merchants residing at Bordeaux, and carrying on business there. Messrs. Feuerheerd \& Co., of London, acted as general agents for them, and were paid by commission. Mr. Geo. Tischler spent some months in England every year, but had no residence here, and always stayed at an hotel. Messrs. Feuerheerd \& Co. reserved a room in their offices for the use of Mr. 'Tischler, and Messrs. Tischler's name was painted on their premises. The plaintiffs appealed against an assessment upon them in respect of the portion of their profits made in England, contending that they were not British subjects nor domiciled in England, and had no exclusive place of business in England. The Queen's Bench Division held (I 2th and $13^{\text {th }}$ March 1885 ) that although the Crown had power to assess the agents in London if they chose to do so, yet that power was in aid of the Revenue, and did not prevent the Commissioners from assessing the foreign principals in respect of the profits made by them on that portion of their business which was carried on in this country, and the appeal was therefore dismissed.

Pommery v. Apthorpe, following the aboye.
This case was followed in Pommery v. Apthorpe (Queen's Bench Division, I 7 th December I886), where the facts were very similar. 
In the case of Werle ''. Colquhoun (Court of Appeal, i ath and $13^{\text {th }}$ March 1888 ) a firm at Rheims employed a London firm to obtain orders in England, and had their name up on the business premises of the London firm. The Rheims firm had not any stock in England, and all orders were executed

Werle $v$. Colquhoun.

Liability of Poreigners for tax on profit on orders obtained by agents in United Kingdom. direct from Rheims. Any payments made to the London firm were remitted immediately to Rheims, and not carried to a current account. The London firm were paid by a commission, and had not any share of the profit on the sales. It was held that there was a trade exercised in the Lnited Kingdom (the contracts being made here) from which profits accrued to the Rheims firm, and that ther were assessable in respect of profits made in the United Kingdom.

In the case of Grainger \& Son v. Gough, in which judgment was giren by the House of Lords, Ist May 1896, the facts were as follows:-Messrs. Grainger \& Son, wine merchants, of London, are agents for Mr. Louis Roederer, of Rheims. All wine sold by them on his account is despatched to purchasers direct from Rheims, and all invoices are made out and sent from there by Mr. Roederer. Remittances are made either to Messrs. Grainger \& Son, or direct to Mr. Roederer. Messrs. Grainger \& Son are paid by means of a commission, and had paid income tax thereon. The assessments were made for I $88_{4}$, I 885 , and I 886 upon "Louis Roederer, of Rheims, champagne shipper. in the name of Grainger \& Son, agents, 108 Fenchurch Street." The appellants contended that Louis Roederer was not a person exercising a trade within the United Kingdom, nat the

Grainger v. Gough.

Question as to person exercising a trade within the United Kingdom or not. 
appellants were not agents within the terms of sec. $4 \mathrm{I}$ of the Act of $\mathbf{I 8 4 2}_{4}$ (charging any person resident in the United Kingdom in the name of his " agent" or receiver " having the receipt of any profits " on his account), and that the assessment should be discharged, or that their names should be erased therefrom. The House of Lords held (reversing the decision of the Court of Appeal) that Mr. Roederer did not exercise a trade in this country (contracts not being made here nor delivery effected here), and that Messrs. Grainger \& Son were not answerable to the Crown, as his agents, to pay income tax on the assessment made in respect of the business of their principal.

It was sought to establish that the words in sec. $4 \mathbf{I}$, "having the receipt of any profits or gains," applied only to "receivers," but the Court expressed a unanimous opinion that this was not so.

In James Wingate \& Company v. Webber (Court of

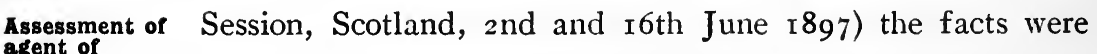
afent of
foreign firm. as follows:-A steamship company which was registered abroad owned one vessel, the chartering, \&c., of which was dealt with by a firm resident in Glasgow.

It was held that the company was not resident in the United Kingdom, but exercised a trade within the United Kingdom, and that the Glasgow firm were assessable as agents. 
In Watson $v$. Sandie \& Hull the facts were as follows:Messrs. Sandie \& Hull are commission agents in Liverpool, Messrs. J. P. Squire \& Co., of Boston, U.S.A., being one of the firms who make consignments to them. Messrs. Sandie \& Hull are paid solely by way of commission. All goods are, however, invoiced in their own name, and they receive payment in the first instance. An assessment was made upon them (under secs. 41 and 44 ), in respect of the profits realised from a trade exercised within the United Kingdom by Messrs. J. P. Squire \& Co. There were cited the cases of Erischen v. Last (p. 84), Tischler v. Apthorpe (p. 90), Ponmery v. Apthorpe (p. 90), Werle v. Colquhoun (p. 91), and Grainger v. Gough (p. 9I). The Queen's Bench Division gave judgment ( 1 3th December 1897) for the Crown. They considered the case stronger than the cases cited. Here the goods were all actually in England before the contract of sale was entered into. In other cases, some of them, at any rate, were in foreign countries.

In a similar case, Turner $v$. Rickman, a like judgment was giren (Queen's Bench Division, I 3th December 1898).

In Crookston Bros. v. Furtardo (Court of Session, Scotland, 29th September I9.0) the Crown sought to assess Messrs. Crookston Bros. as agents of the Compagnie des

Phosphates du Dyr, a company owning phosphate mines in Algeria, on the ground (I) that the company carried on a trade here, and (2) that Messrs. Crookston Bros. were " agents in receipt of the profits" (sec. 4I). The facts were

Crookston v. Furiardo.

"Agent in receipt" or not. 
Crookston $v$. Furtardo.

"Agent in receipt" or not.
(I) the head office of the company is in Paris, where all its board and other meetings are held, its books kept, and its general business transacted; (2) Messrs. Crookston Bros., of Glasgow, are the sole principal agents for sale in the United Kingdom; their senior partner is administrateur delegué of the company, an honorary position and not carrying any salary; sub-agents are appointed by Messrs. Crookston, subject to approval by the company ; (3) sales are made at or over minimum prices, fixed by the company but without reference to the company, but the agents are not liable for bad debts, and they hold no stock; (4) contracts are sent from Glasgow, and signed "The Compagnie . . . . per Crookston Bros." ; (5) bills of lading are sent to the agents by post, and when endorsed by them are handed to purchasers, before the arrival of the goods, in exchange for three-fourths of the invoice price; (6) invoices are rendered by the agents, and the price includes cost, freight, and insurance, but the freight is deducted from the invoice price and paid by the purchasers direct to the shipowners; (7) cheques are made payable by the purchasers in some cases to the company and in other cases to the agents. The agents invariably send on the cheques to the company in Paris, and do not in any case pay them into a bank here. There has never been a case where payment has been made in cash, or where a cheque has been realised before the handing over of the shipping documents. Receipts are signed in the same way as the contracts. (8) The agents are paid by commission by remittance from the company in Paris. 
The Court (Clerk, Ardwall, Salvesen, and Dundas, L.JJ.) gave judgment against the Crown. Lord Dundas differed from all the others on the question of "carrying on a trade" Crookston' $v$. Furtardo. here, but the Court were unanimous in holding that Messrs. Crookston were not "agents in receipt." Clerk, L.J., said the goods were not delivered in the United Kingdom, for the Court were all of opinion that delivery took place either at Bona, the port of despatch, or where the bill of lading was endorsed, which took place before the goods reached here. $\mathrm{He}$ thought the facts brought the case under Grainger v. Gough; it was not the same as where the foreigner came here himself to solicit; or where there was a sole agent with their name up and holding a stock (Pommery v. Greno). Grainger's case laid down that the question of the contract being made here was not conclusive; the place of delivery and mode of payment were important elements. Also, inasmuch as Messrs. Crookston had to hand over any cheques received, and had no right to take possession of them, it could not be said that they were " agents in receipt."

\section{Lord Ardwall agreed. He said :-}

"Were it to be affirmed that in this case the company were liable as exercising a trade within the United Kingdom, it appears to me that on similar grounds every foreign manufacturer, mine owner, or merchant who consigns goods to a commission agent in this country might be held liable."

In every other decided case there was some element not present in this case. Messrs. Crookston Bros. were not "representatives" in the sense that Erischen was in Erischen v. Last. On the second point he considered that it was not 
Crookston Furtardo.

"Agent in receipt" or not. a "receipt" where the agreement was that there was no power for the agents to make the price of the goods payable to themselves.

Lord Salvesen likewise agreed. He said that any business man would have no hesitation in saying that the French company did not carry on a trade here. He did not suppose anyone would dream of saying that a merchant or manufacturer " exercised a trade" in every country where he sold his goods. A difficulty was occasioned by certain judicial dicta which might be construed as meaning that if contracts for the sale of merchandise were habitually made here and delivery took place here, then the foreign merchant " exercised a trade" here. But in none of the cases was this the only element; in all of them payment was regularly received here. " There is therefore," he said, " no case in " which a foreign firm has been held to exercise a trade in " this country, where it did not receive direct or through its "agents payment in this country" -and the importance of this fact appeared in Sully's case (p. 67). He thought undue importance had been attached by some of the English Judges to the place where, in the legal sense, the contract was made. He said this because the foreign firm could always reserve the right of suspending any sale until its sanction had been obtained, and if so (under Grainger v. Gough) the contract would be made abroad, and yet there would be no substantial difference. "I am fully aware," he continued, "that my " opinion runs counter to some dicta of the English Judges, " and especially to the dictum of L.J. Brett, in Erischen v. 
" Last, which was quoted without disapproval in Grainger's "case, and from which it might be inferred" that the making of the contract in England was conclusive to prove Crookston v. Furtardo.

"Agent in receipt" or not. the "exercising of a trade" here. Such a view would be destructive of agency business altogether. Again, if a foreign merchant had various agents in the country, which of them would be exercising the trade on his behalf, or would they all be doing it? "An obiter dicta which involves " so many difficulties, none of which it was necessary to con" sider in the case in which it was delivered, humbly appears " to me," he said, " not to be one which affords any useful "guidance in applying the simple words of the Acts to any "given set of circumstances of an entirely different nature." As to the question of receipt, the words must mean "lawfully in receipt." The intention of the statute was only to make the agent liable where he had an opportunity of recouping himself. Here he would have no such opportunitypurchasers would no doubt hereafter be notified that documents would not be delivered except against cheques in favour of the company, and the agents would never have any opportunity of so recouping themselves.

Lord Dundas said that the fact of his agreeing as to there being no "receipt" here rendered it unnecessary to decide the other point, but, as it had been argued, and he disagreed with the other Judges, he stated his opinion upon it. $\mathrm{He}$ thought the company did exercise a trade here. Firstly, on the facts, he considered payment was made in Glasgow, receipts being signed "Compagnie des Phosphates du Dyr, 
Crookston $v$. Furtardo.

"Agent in receipt" or not.

per Crookston Bros.,' and delivered here. Also, he thought the contracts were made here. Crookston Bros. were not mere canvassers for orders which were to be approved or rejected by their principals-they had full authority to sell within limits. He thought that the principle to be deduced from the decided cases was that there was a "trade exercised " here, even if only the contract was concluded here (Grainger's case). Lord Watson had stated (apparently with approval) that in Werle's case the decision proceeded on that ground, and Cotton, L.J., had expressed a similar view in Erischen v. Last. Lord Herschell had also (in Grainger's case) quoted a similar expression of Esher, M.R. He (Lord Dundas) thought all this went to the question of the contract being the conclusive test. Also, in Werle's case, the argument which was expressly rejected was that only the contract was made here.

The "receipt" here was not the receipt of the agent. As Lord Esher had said in Werle's case, "if the Crown can "find such an agent as is described in sec. 4r, they can "assess him, but, supposing they cannot, they must take " such means as they are able to get at the person who should "be assessed."

Last $v$.

London

Assurance Corporation.

Mode of computing profits of proprietary life office.
The question how far the surplus of a proprietary insurance company is assessable has been largely settled in principle by the decision of the House of Lords in Last $v$. London Assurance Corporation (14th July I885). The London Assurance Corporation is a proprietary office carrying on fire, 
life, and marine insurance. Two-thirds of the life "profits" Last v. are appropriated to participating policy-holders as bonus.

Four questions arose upon the case, viz. :-

(a) Whether bonuses paid to policy-holders participating in "profits" were "profits" for the purpose of assessment.

(b) If so, whether the whole expenses were a deduction.

(c) Whether the life profits were to be arrived at by a deduction of payments from premiums received.

(d) Whether the business was to be assessed as a whole.

The Commissioners were of opinion-

(a) That the bonuses were not "profits."

(b) That the whole expenses were deductible.

(c) That the life profits were to be ascertained actuarially ; and,

(d) That the business was to be assessed as a whole.

The Crown appealed. In the Queen's Bench Division, Day, J., accepted the view of the Commissioners on all points. $\mathrm{He}$ considered that the setting aside of the fund for bonus distribution was a necessary expense of making the income; the fund constituted the sole consideration for the policy-holders paying an increased premium.

Smith, J., agreed with Day, J., on all points, except that as to bonuses. He considered these as part of the "profit." Smith, J. (as junior), withdrew his judgment on this point, 
Last $v$. London Assurance Corporation.

Mode of computing profits of proprietary life office.!

and judgment was given accordingly. This was accepted, except so far as it related to the bonuses, and the Crown went to the Court of Appeal on that point. There Brett, M.R., and Cotton, L. J., being of the same opinion as Day, J., the appeal was dismissed, Lindley, L. J., dissenting. The Crown appealed to the House of Lords, where the decision of the other Courts was reversed, Lord Blackburn and Lord Fitzgerald being in favour of the Crown, and Lord Bramwell dissenting very strongly. Lord Blackburn drew a distinction between such a case as this, and one which might arise if a company asked, say, £I I3s. 2d. per cent. from a non-participating policyholder and $\mathcal{E}^{\mathrm{I}}$ Igs. Iod. from a participating policy-holder, on the understanding that if the latter paid premiums for five years the difference (of 6s. 8d.) per cent. per annum, or any part of it, should be returned to him in any event. Here the participating policy-holders received a share of the profit.

We thus get :-

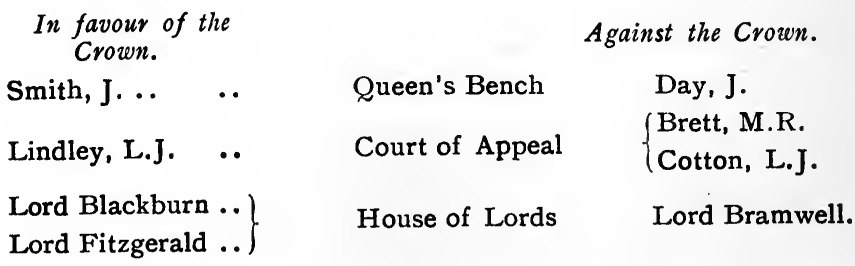

Equitable Life Assurance Society of U.S. $v$. Bishop.

Last's case. Form agreed upon.
This case was followed in Equitable Life Assurance Society of United States v. Bishop (Court of Appeal, 8th December I 899).

The following is the form of return agreed upon between the Board of Inland Revenue and the London Assurance Company after the decision in 1885 . For convenience of 
reference we have inserted hypothetical figures. The words in italics are also ours :-

Last's case. Form agreed upon.

\section{YEAR 1905-6.}

YEAR 1902.

Marine Profits, viz., Premiums, less Losses, Commission,

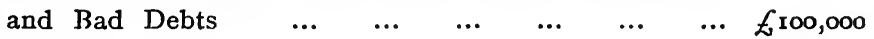
Fire, do., do. $\quad \ldots \quad$... $\quad \ldots \quad$... Life,* do., viz. :

Surplus at quinquennial valuation on 31st December 1899-including an average of $£ 200,000$ taxed and $£ 50,000$ untaxed Interest $\quad \ldots \quad \ldots \quad £ 280,000$

Less Balance undivided at previous quinquennium $(1894) \quad \ldots \quad \ldots \quad 5,000$

One-fifth $\stackrel{275,000}{=} 55,000$

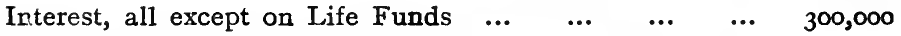
Profits on realisation of Securities (except on Life Account included in surplus)

Net Profit

$$
\begin{array}{ccccccr}
\cdots & \cdots & \cdots & \cdots & \cdots & 5, \infty 00 \\
\text { Deduct expenses of the year } & \ldots & \ldots & { }_{110, \infty} \\
\end{array}
$$

Taxed Interest-Life Account $\quad \ldots \quad \ldots \quad £ 200,000$ , , Other than Life Account ... $\quad$ I50,000

Amount remaining to be assessed, or amount on which the $\operatorname{tax}$ has been overpaid, as the case may be $\quad \cdots \quad £ 50,000$ * All Life Profits.

350,000

\begin{tabular}{|c|c|c|c|c|c|c|c|}
\hline \multirow{2}{*}{ " } & \multirow{2}{*}{ ", } & \multicolumn{3}{|c|}{1903 (arrived at as above) } & $\cdots$ & $\ldots$ & \multirow{2}{*}{$\begin{array}{l}29,000 \\
71,000\end{array}$} \\
\hline & & 1904 & , & & $\cdots$ & $\cdots$ & \\
\hline & & & & & & & 3) 150,000 \\
\hline & & Ave & for $1905-6$ & $\cdots$ & ... & ... & $£ 50,000$ \\
\hline
\end{tabular}

$£ 50,000$

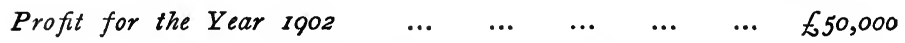

The practice as to the assessment of Insurance Companies is discussed later. 
New York Insurance Co. v. Styles.

Mode of computing profits of mutual life offlce.
Last v. Assurance Corporation contrasted.
The case of The New York Life Insurance Company v. Styles (Surveyor of Taxes) is one of the utmost importance to life insurance companies. The facts, according to the case, are as follows :-

The company is a mutual one, not having any shareholders. The members are policy-holders, and the rate of premiums contributed is such as to leave, at the end of the year, a surplus after payment of expenses. This surplus is partly returned as bonus or in reduction of premiums, and partly carried forward as funds in hand to the credit of the members. The Surveyor contended that this surplus was liable to be assessed as "profits or gains." The Commissioners decided to the contrary, but stated a case for the opinion of the Court. The Queen's Bench Division (Stephens and Wills, JJ.) and the Court of Appeal (Esher, M.R., Fry, and Lopes, L.JJ.) considered the case could not be distinguished from The London Assurance case, and they gave judgment for the Crown. The case was ultimately heard in the House of Lords before the Lord Chancellor, Lord Watson, Lord Bramwell, Lord Fitzgerald, Lord Herschell, and Lord Macnaghten. Judgment was delivered on the rst July r 889, and their Lord. ships-reversing the decision of the Court below-decided in favour of the appellants. The Lord Chancellor (Lord Halsbury) and Lord Fitzgerald were unable to distinguish the case from that of Last $v$. London Assurance Corporation (p. 98), and considered that the judgment should be affirmed. But the other Judges said that the cases were quite different. The distinction drawn was that the London Assurance 
Corporation was a proprietary office, consisting of members and shareholders quite distinct from the insured. Two-thirds of any surplus funds were to be returned to the holders of participating policies who paid a higher premium than those holding non-participating policies. The one-third was admittedly business profit, but it was held that the other two-thirds were none the less profits from the fact of their being returned to the policy-holders. There were two bodiesshareholders and assured. The former had for their object the making of profits in dealing with the latter, and the whole profit so made. whether returned or not, was liable to be assessed. The New York case, however, was held by the majority of the Judges to be entirely different, and each one gave a long and exhaustive judgment.

The judgment of I.ord Bramwell perhaps draws the distinction as clearly as possible. After stating the above facts as to the London Assurance Corporation, he proceeded to deal with the position of the members of the New York Company in the following terms:-

" They are a corporation, but the case may be, as is admitted, dealt with as though they were an unincorporated association of individuals. Take it that they were; take it that half-adozen persons so associated themselves together at the beginning of the year; they each put into a common purse $£$ io, to be given to the executors of anyone who dies, or divided, if more than one dies, among the executors of those having died. In fact, no one dies, and the money is returned, or carried on for the next year. Is it possible to say that this is an association for the purpose of profit, or that it has made any profit?" 

contrasted.

- He then went on to say that the business of the New York company was precisely a similar combination on a much larger and more complex scale. He continued :-

"I am of opinion, then, that as a matter of reasoning, the judgment is wrong. But it is said that we are bound by the authority of Last $v$. London Assurance Corporation to hold otherwise. If I thought that that case decided otherwise, I would abide by it; it would be my duty to do so, and, 1 may say, my inclination, for it is much better that a wrong decision should be set right by legislation than that idle distinctions should be made between it and other cases, and the law thrown into confusion."

We thus get Lord Halsbury, Lord Watson, Lord Herschell, and Lord Macnaghten approving the London Assurance case, in addition to the others already stated, which should be sufficient evidence of the case being rightly decided. As to whether the two cases are the same or not, we have-

Considering the cases the same.
Considering the cases different.

\begin{tabular}{lll|} 
Stephens, J. & $\ldots$ & $\ldots$ \\
Wills, J & $\ldots$ & $\ldots$
\end{tabular} Queen's Bench.

Esher, M.R. $\quad$. $\quad$.. Court of Appeal.

Lopes, L.J. $\quad$.. $\quad$..

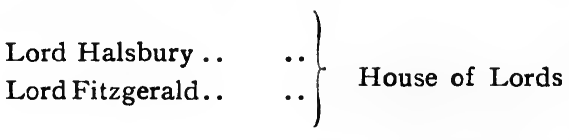

Lord Watson Lord Bramwell Lord Herschell Lord Macnaghten

It must thus be taken as fully established that-

(a) A proprietary office is liable to be assessed on all its surplus, whether distributed to policy-holders or not.

(b) A mutual office is not liable to assessment on its surplus, except so much as arises from transactions with persons who are not members of the society.

For the application of these principles in practice see post. 
The principle of this decision would appear to apply to all strictly mutual societies, \&c., whether registered under the Limited Liability Acts or not. For example, in the case of a club where the revenue exceeds the expenditure, the difference is not assessable. The members have simply subscribed more than is required to pay the expenses and the balance is not "profit."

In Hudson's Bay Co., Lim. v. Stevens (Court of Appeal, r6th and rgth February rgog) the question was as to the liability of the company to assessment in respect of the proceeds of land sold. The gross proceeds of sales in the year were $£ \mathbf{1 7 7 , 8 5 7}$, and it was impossible to say the cost of such land.

'The company was incorporated by Royal Charter in 1670 . In 1869 they surrendered their rights within Rupert's Land in consideration of $£ 300,000$ cash and certain rights to claim grants of land, which rights they have exercised from time to time. It is their regular practice to sell the land, and in I903 they paid $£^{2}$ per share out of such proceeds in reduction of capital. No land had ever been bought except under the original Charter, and modifications thereof.

The Crown claimed tax on the full amount.

The Court were unanimously in favour of the company.

The Master of the Rolls said :-

"A chartered company is essentially different from a statutory company, and, speaking generally, it occupies a position similar to that of an individual; it can do anything that it is not prohibited from doing. The charter contains no provision as to profits, and $I$ think it is clear that the familiar doctrines as

Hudson's Bay Co., Lim. v. Stevens.

Land sales.
The principle applies universally in the case of mutual concerns. 
Land Sales. to the distinction between capital and income, and the powers of the directors in paying dividends, had no application to the company." . . . "The real question is whether this money can be regarded as profits or gains derived by the company from carrying on a trade or business. In my opinion it cannot. The company are doing no more than an ordinary landowner does who is minded to sell from time to time, as purchasers offer, portions suitable for building, of an estate which has devolved upon him from his ancestors. I am unable to attach any weight to the circumstance that large sales are made every year. This is not a case where land is from time to time purchased with a view to resale; the company are only getting rid by sale, as fast as they reasonably can, of land which they acquired as part of a consideration for the surrender of their charter."

He did not think the conıpany was carrying on the trade of selling land.

Farwell, L.J., said :-

"It is clear that a man who sells his land, or pictures, or jewels, is not chargeable with income-tax on the purchasemoney or on the difference between the amount that he gave and the amount that he received for them. But if instead of dealing with his property as owner he embarks on a trade in which he uses that froperty for the purposes of his trade, then he becomes liable to pay, not on the excess of sale prices over purchase prices, but on the annual profits or gains arising from such trade, in ascertaining which those prices will no doubt come into consideration.". . . "A landowner in England may establish a game farm on part of his estate, and make profits thereby which would be liable to incometax, and he may also sell parts of his estate for building purposes, but his trade as a game farmer does not bring his sales as a land owner within the Income Tax Acts; and I see no difference in this respect between his position and that of the company. Again, a landowner rriay lay out part of his estate with roads and sewers, and sell it in lots for building, but he does this as owner, not as a land speculator. . . . Landowning is not a trade. . . . The actual claim by the Crown is extravagant. . . . If the company were to be treated as trading they must at least be allowed the price paid for the land."

Kennedy, L.J., gave judgment to the same effect. 
A difficult question arises as to the liability to tax of a land development company. It is submitted that such a company must at least be bound by their own accounts, and if they allocate a portion of the proceeds of sales to "Profit and Loss Account" it must be paid upon, even though not distributed. We believe that in some cases nothing is taken to Profit and Loss Account until as much is realised as the entire cost of the land. It is uncertain whether the Crown would consider themselves bound by such an account, but apparently there need not be any objection from their point of view, for, even if they allowed it, they would get tax on all proceeds after that time.

The mode of assessment under the fifth case (i.e., on the amount received in the United Kingdom) sometimes leads to Difficulties in mode of anomalous results, as an amount received here is not necessarily profit. This is emphasised by the statement of a correspondent to the London Times, that he has been called on to pay income tax on his share of a sum of $£ 35^{\circ}, 000$, received from abroad in respect of the proceeds of the sale of the Odessa Waterworks, which company was formed aboút 1870 with a capital of $£ \mathrm{I}, 100,000$, and has never paid any dividend.

The pensions of retired Indian officers when remitted to this country are chargeable with duty, although they have been charged with the income tax of India. 

in UNited Kingdom as well as in Colonies.

Reply of

Chancellor of Exchequer to memorial as to profits taxed in Unlted Kingdom as well as in Colonies.
In June 1896 the Chancellor of the Exchequer sent the following reply to a memorial of the Royal Colonial Institute, respecting the payment of income tax in the United Kingdom on income earned and taxed as such in other parts of the British Empire :-

Treasury Chambers, May 271896.

Sir,--The Chancellor of the Exchequer has laid before the Board of Treasury the memorial which you forwarded to him on the $15^{\text {th }}$ ultimo from the Royal Colonial Institute praying for such an amendment of the law as will exempt from ircome tax in this country any income which has been remitted from other parts of the British Empire, and which has already paid income tax where it was earned; and their Lordships, after giving the matter their careful consideration, direct me to submit the following observations in reply :-

(I) My Lords are unable to reconcile the proposal before them with the leading principle of the income tax legislation in this country.

The income tax here is, as its name implies, a tax upon income received in the United Kingdom.

In this respect it appears (according to the statements in the memorial) to differ from the income tax established in the Colonies, which extends only to incomes earned in the country where the $\operatorname{tax}$ is in force.

In the United Kingdom, however, it is levied without regard to distinctions based upon either the nature or the locality of the property from which the income arises; though it has often been urged that such distinctions might reasonably be held to justify a different treatment.

For example, a person receiving income from realised property is taxed in the same way and at the same rate as a person receiving income from the exercise of a profession.

Similarly, a person receiving income from an industrial business in the Colonies or abroad is taxed in the same way and at the same rate as one receiving income fronı a similar business in this country. 
In short it is the income which is taxed, and not the property or other source from which the income is derived.

As the incomes to which the memorialists refer are received (and, in most cases, spent) in this country, my Lords see no injustice in taxing them in the same way and to the same extent as other

Reply of Chancellor of Exchequer to memorial as to proflts taxed in United Kingdom as well as in Colonies. incomes subject to the same conditions.

(2) Nor does it appear to them inequitable that a person who possesses property in one country and spends the income derived from it in another should be subject to taxation in both.

Owing to the circumstances of his position he is, fro tanto, a citizen of two countries, and requires the protection of two Governments.

My Lords cannot admit that such a person should be exempted from taxation in the country where he spends his income because he has already been taxed in the country whence he derives it.

(3) The contention of the memorialists is limited to incomes derived from the Colonies; but the arguments advanced apply with equal force to incomes derived from foreign countries under similar circumstances.

If it is "oppressive and unjust" to tax income in the country where it is spent, when it has already been taxed in the country whence it is derived, the oppression and the injustice are the same, whether it is derived from a foreign country or a Colony.

(4) My Lords do not wish it to be supposed that in their opinion the Colonies are on the same footing as foreign countries. They recognise with satisfaction the many ties which bind together the different portions of the Empire; but they inust remind the memorialists that those ties are not fiscal ties.

The system of taxation, both in this country and in the self-governing Colonies, has always been based on the principle of treating each area as distinct and independent for fiscal purposes; and Parliament has made no concession to the Colonies in such matters which is not equally applicable to foreign countries.

Concessions of this kind have usually been based upon the grant of reciprocal advantages; and it is from this point of view alone that any such measure as that now in question could be justified. 

in United Kingdom as well as in Colonies.

Reply of Chancellor of Exchequer to memorial as to profits taxed in United Kingdom as well as in Colonies.
But for this purpose it would be necessary to consider as a whole the fiscal relations and the burdens of the different parts of the Empire.

The point now raised relates only to the income tax; and the memorialists suggest that the principle of reciprocal exemption should be introduc 2 d in respect of that source of revenue alone.

But my Juords must point out that the concession is practically all on one side.

The amount of income enjoyed in the United Kingdom from property in the Colonies is far larger than the income enjoyed in the Colonies from property in the United Kingdom; and the loss to the Imperial Exchequer would be much greater than the aggregate gain to the individual taxpayers in this country.

(5) The concession made under sec. 20 of the Finance Act of 1894 , to which reference is made in the memorial, does not, in their Lordships' opinion, present a true analogy to the proposal under discussion.

The relief from taxation accorded by that section extended only to the amount of duty which had already been paid under the colonial law, whereas the memorialists claim that the payment of income tax in the Colonies, at however low a rate, should exempt from payment here, at however high a rate the tax may for the time being be fixed.

A further distinction may also be noted. The income which it is desired to relieve from taxation is received and spent in this country.

The colonial property which (except for sec. 20) might be taxed under the Finance Act is actually situated in the Colonies, though it is constructively in this country through the operation of a rule of law.

(6) The proposed exemption could not be limited to colonists resident in this country, but must be extended to all persons drawing any part of their incomes from property in the Colonies.

The loss to the Imperial revenue which the proposal would involve is estimated at not less than $£ 500,000$. A loss of so large an amount to the Imperial revenue raises very serious practical ccnsiderations, which applied hardly at all to the case of the con- 
cession made in the Finance Act of 1894 . The loss would have to be made good, and it could only be made good by the imposition of other taxes. But my Lords would feel great difficulty in asking Parliament to increase the burden on the general body of the taxpayers in this country merely because some of their number draw their incomes from property situated in the Colonies.

(7) Finally, I am to point out that the benefits which would accrue from the proposed exemption would be very unequally distributed.

It would apply only to incomes coming from Colonies in which an income tax was levied.

It must, however, be assumed that, in Colonies where there is no income tax, the burden of taxation, both on property and on individuals, is substantially the same as in Colonies where there is such a tax.

But under the proposal it is the latter class alone which would benefit.

In the other Colonies the income remitted to this country, though not liable to colonial income tax, would nevertheless have paid its due share of colonial taxation in some other form, but would obtain no relief here. The injustice, if any, of the present system would only be replaced by another.

For the reasons above set forth my Lords regret that they are urable to accept the suggestion made by the memorialists.

I am, Sir, your obedient servant,

Francis Mówatt.

The Secretary, Royal Colonial Institute, Northumberland Avenue.

In June 1898 this subject was again brought before the Chancellor of the Exchequer by the Royal Colonial Institute, hut the Chancellor replied that "he had nothing to add to the views expressed in his letter of 27 th May 1896 ." 

Dividends.

Premiums on shares issued.

Premiums received by a company on an issue of shares, \&c., are not profits liable to tax within the meaning of the Acts.

A case has come under our notice where the Surveyor made a claim for tax on such premiums, which was, however, ultimately withdrawn. It is difficult to see how such a claim can be seriously entertained, and we have not heard of such a one before. If such sums were held to be liable, a railway company would have to pay heavily on the issue of their stock. It is almost sufficient answer to such a case to point out that a company who wish to raise $£ \mathrm{I}, 000,000$, and who issued $£ \mathrm{r}, 000,0003$ per cent. stock at par would not have to pay any tax, but if they decided to issue $£ 666,6664 \frac{1}{2}$ per cent. stock at I50-precisely the same thing to them-they would have to pay tax on $£ 333,333$.

Yoluntary gifts.

A voluntary gift, e.g., an allowance by a father to his son, would not be assessable (see also cases quoted in Chapter V.).

Diyidends on Goyernment securities under 50s. per half-year.

Though dividends on Government securities, \&c., are chargeable under Schedule $C$, yet where the amount of the dividend, \&c., is less than $£^{2}$ ros. per half-year, they are not so chargeable, but are paid to the stockholder in full, and are to be returned, if he or she be liable to tax, under Schedule D ( 1842 , sec. 95). (A similar provision is contained in the Finance Act $\mathrm{r} 894$, in respect of interest on Savings Bank deposits, whatever be the amount of the interest.) In 
the case, however, of National Debt Certificate Coupons, tax will have been deducted, though the amount of the coupon is less than $\mathcal{L}^{2}$ ros. per half-year (National Debt Act r870), and therefore this will not have to be returned for assessment.

Where lands, occupied by a cattle dealer or dairyman, have been assessed or charged on the rent or annual value, and it is found that the lands are not sufficient for the keep and sustenance of the cattle brought on the said lands, so that the annual value does not afford a just estimate of the profits of such person, he is to be charged on his actual profits on a three years' arerage (or as the case may be) as in the case of a trader (1842, sec. 100, Schedule D, Case III., Rule 3). The case of Broi'n $v$. Walsh, which arose on a question of fact as to whether Mr. Brown was or was not a "dealer," and which was taken up by the National Sheep-breeders' Association, is fully stated in an appendix to the fourth edition.

The duty on interest arising from such foreign and colonial securities as are not includer under Schedule C-e.g., interest Foreign and Colonial
securities. received from abroad without deduction of tax-is to be computed on the full amount received, or to be received, in the United Kingdom in the current year, without any deduction (1842, sec. roo, Schedule D, Case IV.).

The duty in respect of toreign and colonial possessions is payable on the amount received in the United Kingdom, calculated on the arerage of the three preceding years, and, generally, in the same manner as in the case of a trader (1842, 
sec. 100, Schedule D, Case V.). As to the interpretation put upon the word "possessions," see the case of Colquhoun $v$. Brooks (p. 75).

Sweeping

clause in

Schedule D.

The intention of the Legislature being to tax all income received in the United Kingdom, there is a sweeping clause in the Act of $184^{2}$ (sec. roo, Schedule D, Case VI.), providing for charging any annual profits or gains not falling under any of the previous rules or under any other schedule. The nature of the profits and the manner in which they have been computed are to be stated to the Commissioners, who may direct in what manner the annual value is to be arrived at.

Infants.

The parents or guardians of an infant are chargeable in respect of profits accruing to him during his minority ( 1842 , secs. $4 \mathrm{I}$ and $\mathrm{I} 73$; I880, sec. 92).

Deceased persons.

The executors or administrator of a deceased person are chargeable in respect of profits accruing to such person (1842, sec. I73; I880, sec. 92).

An assessment in respect of unreturned profits may be made upon the representatives within three years of the expiration of the year of assessment (1907, sec. 23), but subject to the previous limitation in respect of any year prior to 1907-8.

In the case of a person not residing in the United Kingdom an assessment may be made, in respect of his profits, upon his agent here $\left(184^{2}\right.$, sec. $\left.4 \mathrm{r}\right)$. 
A dealer in stocks and shares is liable to assessment in

Dealer in stocks. respect of profits on his transactions, but a profit or loss on a casual change of investment is an increase or decrease of capital, and should not be taken into account (see Californian Copper Syndicate case, p. 74), and so far as we are able to ascertain it would appear that the result of habitual speculations in stocks and shares must be disregarded for income tax purposes.

As to whether surplus or deficiency on sale of investments, or buildings held by a financial company, is profit or loss for income tax purposes, see post.

Where a manufacturer goes outside his business, and (say) inrents a machine, which he patents and then sells the patent rights, the profit would not be assessable.

Attempts are sometimes made to assess the profit on promotion of a single company, but they are not usually pressed where it appears that the profit is clearly casual and not recurring.

In the case of a syndicate, or of a property, \&c., company, formed to hold shares of subsidiary companies, and whose Property, \&c., company, and Promotion profits.

Sale of patent rights. Profit and Loss Account might be as follows :-

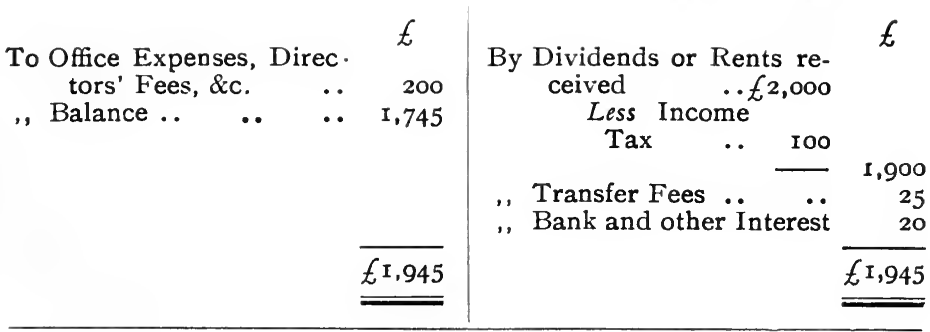


Sch. D.-Property Company-"Paper" Profits. Chap. vi. -Grant from Aged Ministers' Fund.

the directors' fees would be assessable in the hands of the directors, and the company would only be liable for tax on interest (post). It has been suggested that as the fees to directors are paid out of taxed income they should not be again assessed. It is held, however-and rightly so, we would submit-that they are chargeable as income of the directors.

"Paper" profits.

In the case of (say) a financial company having paper profits-i.e., having shares allotted to them instead of being paid in cash-the principle of assessment is as follows :-

(a) If the shares are retained, to assess the estimated value of them. If that is objected to, to onit the shares altogether, and the company to give an undertaking to account for them as and when sold for three years, the remainder (if any) to be valued at the end of the three years.

(b) If the shares have been distributed, to take the average Stock Exchange quotation during the following month.

Duncan v. Farmer.

Grant from Aged Ministers' Fund.
In Duncan's Executors v. Farmer (Court of Session, Scotland, I8th March and I8th June 1909) the executors appealed against an assessment on $£$ roo, a grant made to the deceased by the Committee of the Aged and Infirm Ministers' Fund of the Church of Scotland. The grant had been made to Mr. Duncan on his retiring from his living on account of ill-health. The income of the Fund is exempt from income tax (1842, sec. 105). 
The executors contended that the grant was a voluntary gift; the Surveyor, that it was either (I) a profit under Schedule $\mathrm{E}$ by virtue of his having been a minister, or (2) an annuity.

The Court held that the amount was taxable under Schedule $D$ as an annuity. It clearly could not be in respect of his office (under Schedule E), when the whole reason for his receiving it was that he was no longer in office. But, equally clearly, it could not escape either as a charity (section 105 applying only to the funds when in the hands of the institution) or as being paid out of taxed income (1853, sec. 40), the interest not being taxed. The Lord President said that the distinction between the case and Turner $v$. Cuxson (p. 50) was that in that case the payment was a mere donation, here it was a regularly constituted annuity.

It is sometimes felt to be an unfair advantage to co-operative societies that they are not assessed to income tax, but this is not so. The reason is very clearly stated by the assessed.

Chancellor of the Exchequer in a Parliamentary paper in August 1904 as follows :-

"There is no exemption from income tax granted, as is popularly supposed, to co-operative societies or their members. In only one respect does the position with regard to the tax differ from that of the ordinary society or company. The ordinary society or company deducts income tax from the member's or shareholder's dividend before it is paid over to him, leaving it to him either to bear the tax or to re-claim the amount deducted from the Inland Revenue authorities, if his income falls within the limit of exemption. In the case of cooperative societies most of the members are working men whose incomes fall within the limit. Accordingly, to deduct income 
Co-operatixe Societies. Why not assessed. tax in their cases from the dividend before paying it over would involve nearly all the members claiming repayment. Nothing would be gained to the revenue, and infinite annoyance and trouble would be given both to those who had to make the claim and to the Revenue officials in dealing with the enormous number of claims so made. It is therefore provided that if certain conditions are satisfied income tax need not be deducted from the profits of co-operative societies before their distribution as dividends to individual members. No exemption, however, is given, as every individual member whose income is above the exemption line is liable to the tax on his share of those profits when received by him. The Army and Navy Co-operative Society, Lim., and Civil Service Cooperative Society, Lim., do not fulfil the necessary conditions, and are therefore directly assessed to the income tax."

This statement was confirmed and elaborated in the Report of the Committee which sat in 1904, who were instructed inter alia "To inquire and report whether co-operative societies enjoy under the present law any undue exemption from liability to income-tax." 


\title{
CHAPTER VI.-(continued).
}

\author{
SCHEDULE D (continued).
}

PART II.-Returns for Assessment.

T'HE Form of Return (No. II), issued by the assessors, $\underset{\text { return No. } 11 .}{ }$ contains a list of the various descriptions of income to be returned for assessment under Schedule D. The following is from the form and instructions issued for the year I9II-I2, and for convenience of reference we have noted the sections of the Act in exch paragraph. 
Form of

return No. 11.

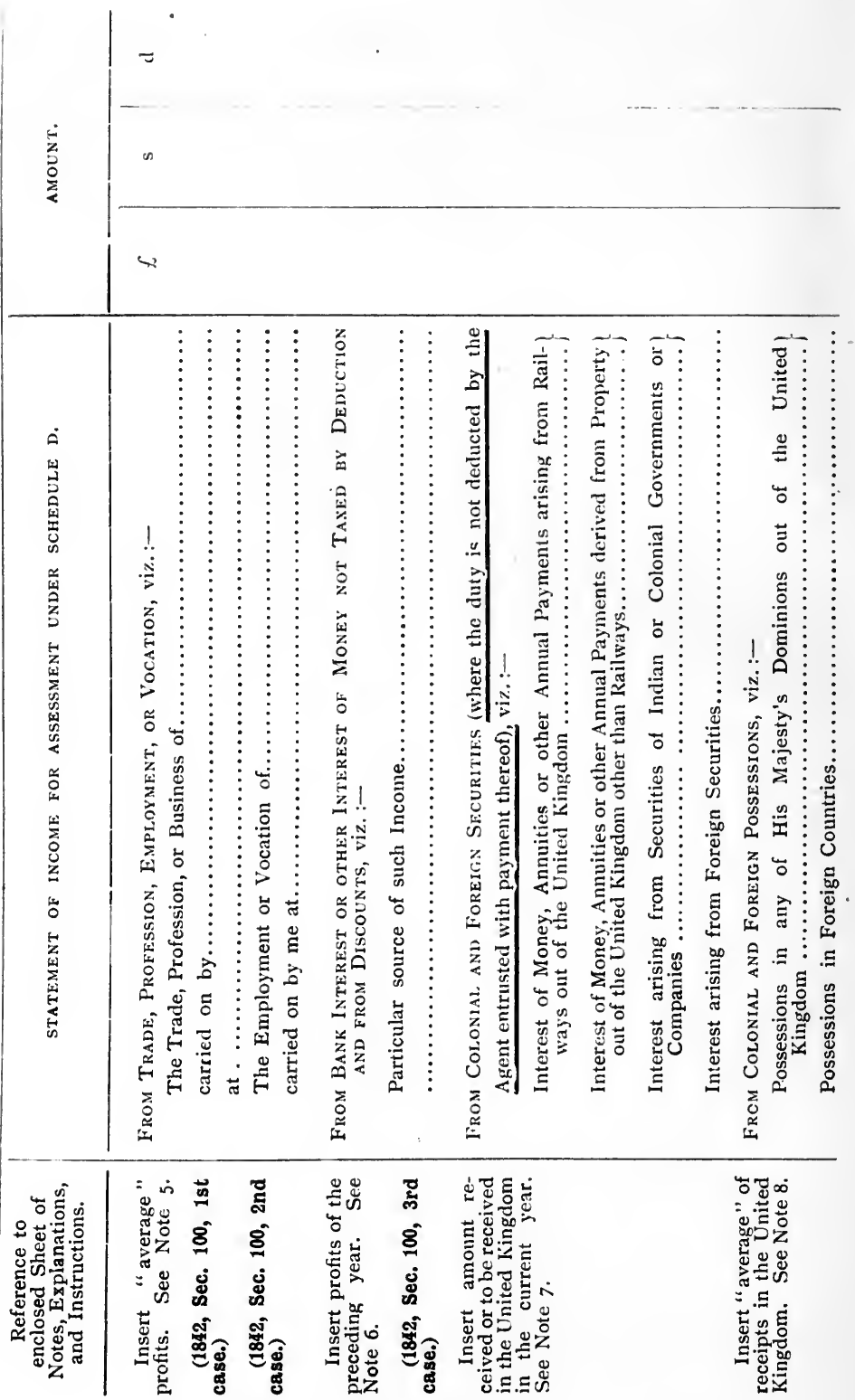




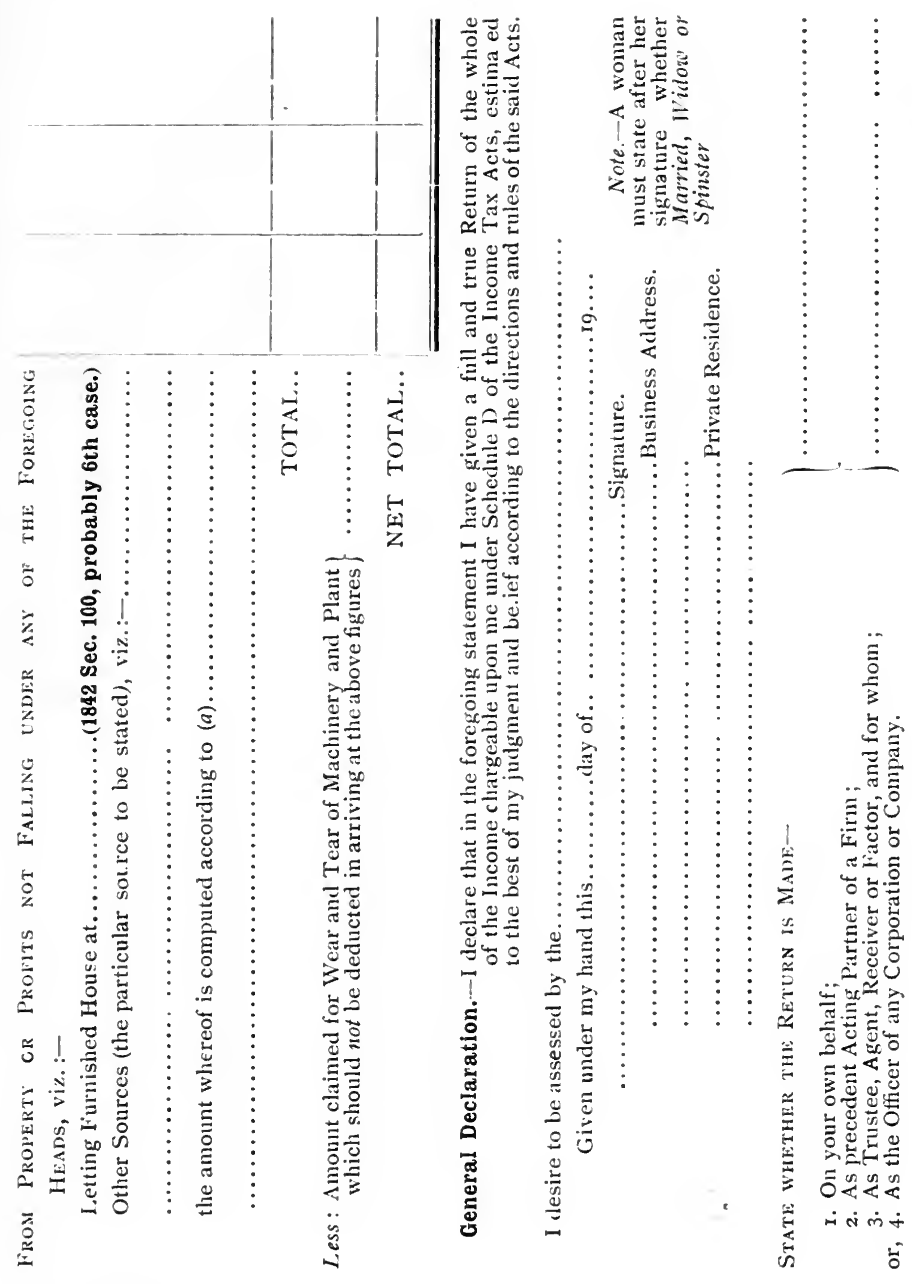

Form of

return No. 11.
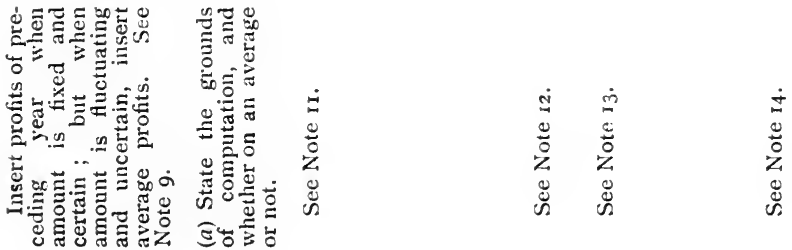


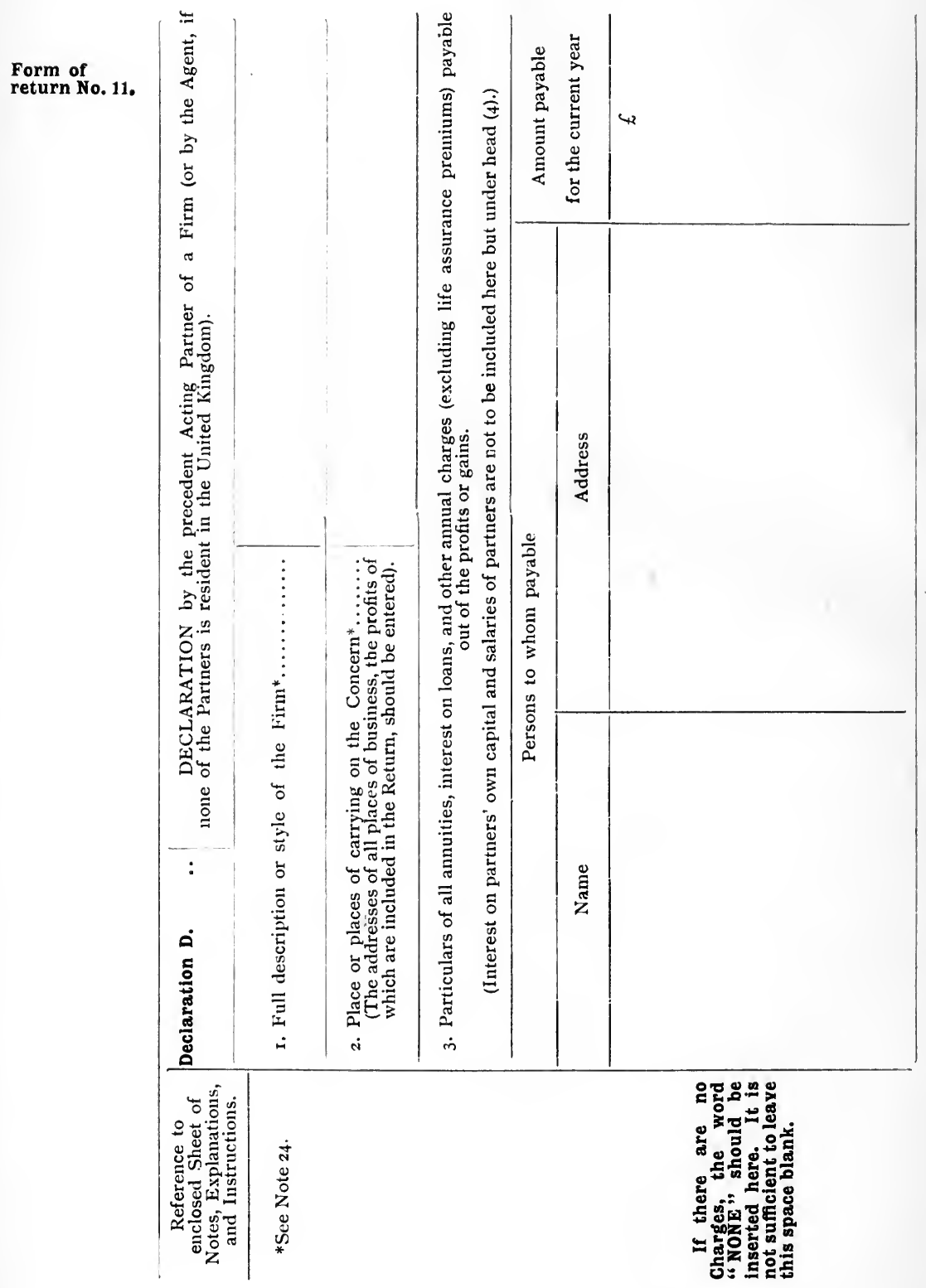




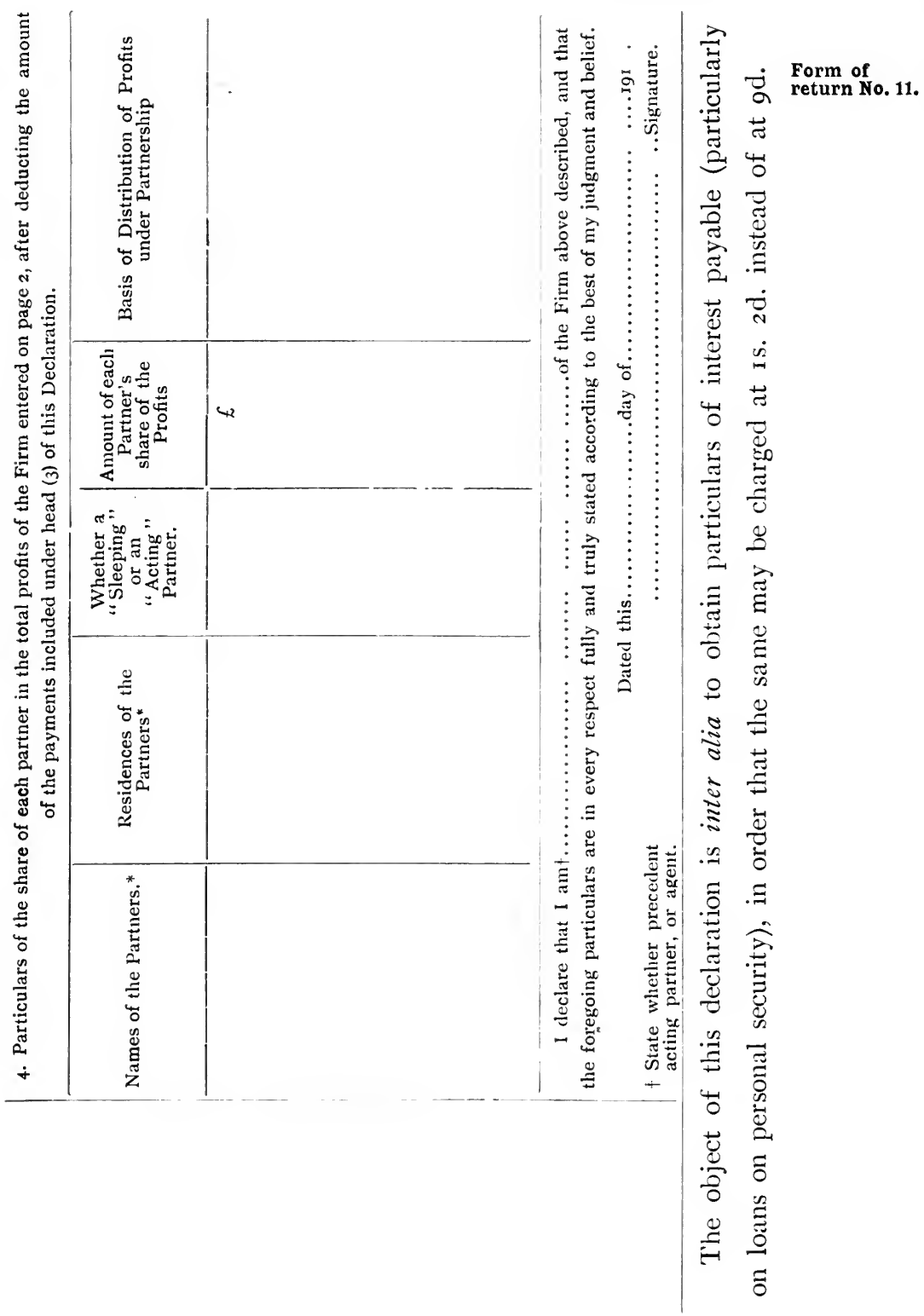


Notes, Explanations, and Ixstrections in Regard to the

Income Tax Fory of Return, No. II.

(1). Persons liable to Assessment to Income Tax.

All persons resident in the United Kingdom, whether subjects of His Majesty or not, are liable to Assessment; and also all persons not resident within the United Kingdom (whether subjects of His Majesty or not) in so far as they derive Income from property, trade, or employment in the United Kingdom.

\section{(2). Income to be entered on Form No. II.}

The Income to be entered in the Statement on page 2 of Form No. II is specified below, and is confined to Income not already taxed by deduction; but when Exemption, Abatement, or Relief in respect of Farned Income is claimed, the total Income from all sources (whether taxed or not) must be entered on page 3 of the form, according to the instructions given below.

(3). Income to be entered on page 2 of Form No. II.

The Income to be entered on page 2 of Form No. II is all such Income as is assessable under Schedule $\mathrm{N}$, that is:--

(i.) Profits of Trade, Profession, Employment, or Vocation.

(ii.) Profits from Discounts and Interest of Money not taxed by deduction.

(iii.) Profits from Colonial and Foreign Securities, where the duty is not deducted by the agent entrusted with the payment thereof.

(iv.) Profits from Colonial and Foreign Possessions.

(v.) Property or Profits not coming under any of the foregoing heads, or of those enumerated below.

(4). Income not to be entered on page 2 of Form No. II.

Income falling under any of the following heads should not be entered on page 2 of Form No. II, viz.:-

(i.) Income arising within the United Kingdom from the ownership of Land, Houses, or Buildings, or from the occupation of Land. 
(ii.) Income derived from the salary or emoluments of any office or employment in the public service, or under any public body (corporate or not corporate), or from any annuity, pension, or stipend payable out of public revenues of the United Kingdom.*

(iii.) Income arising within the United Kingdom from the profits, rents, or annual value of Quarries, Mines, Iron Works, Gas Works, Salt Springs or Works, Alum Mines or Works, Water Works, Streams of Water, Canals, Inland Navigations, Docks, Jrains and Levels, Fishings, Rights of Markets and Fairs, Tolls, Bridges, Ferries, Cemeteries, and other concerns of the like nature.*

[*Special forms are provided for the return of Income falling under these heads, and will be supplied on application to the Assessor or Surveyor of Taxes.]

(iv.) Income from which Tax has been deducted upon payment to the recipient.

The following are the classes of Income upon which Tax is commonly deducted before the Income reaches the recipient, viz.: Income from the Public Funds, from Loans to Corporations or to Colonial and Foreign Governments, from Interest on Mortgage of property in the United Kingdom, and from Dividends paid out of the profits of Companies carrying on business in the United Kingdom.

\section{(5). Profits of Trade, Profession, Employment, or Vocation.}

Where Income is derived from the exercise of any business, profession or employment, attention is particularly directed to the fact that the amount of Income to be returned for assessment in any given year is neither the actual Incorne of that year, nor the Income which a person expects to make in that year, but is a "statutory" Income, of which the amount is to he computed from actual ascertained figures. These are the figures shown by the accounts of the business or profession for the three years immediately preceding the year for which a return has to be made, and the computation from them is to be made according to prescribed rules, of which the following is an abstract:-

\section{RLLES ANi) REGLLATIONS FOR CALCULATING PROFITS.}

The Tax extends to the Profits of all Trades, \&c., carried on or exercised in the United Kingdom by any Person whatsoever, whether a subject of His Majesty or not, and wheresoever residing; and also to the Profits of Trades carried on or exercised elsewhere than in the United Kingdom, if carried on or exercised by Persons residing in the United Kingdom. (1 $8_{53}$, sec. 2.) 
Form of return No. 11.

Average.-The amount of Profits is to be computed on an Average of the Three preceding years, ending either on the date, prior to the $5^{\text {th }}$ day of April 191 I, to which the Annual Accounts have been usually made up, or on the $5^{\text {th }}$ day of April I9II;

Or, if the Trade, \&c., has been set up or commenced within three years, on an average from the period of commencing the same;

Or, if commenced within the year of Assessment, the Profits are to be estimated according to the best of your knowledge and belief, and the grounds on which the amount shall have been estimated should be stated for the information of the Commissioners. (1842, sec. roo.)

In computing the Profits upon which tho average is to be takenDeductions are allowed-

For Repairs of Premises occupied for the purpose of the Trade, \&c., and for the Supply or Repair of Implements, Utensils, or Articles employed, not exceeding the sum usually expended for such purposes according to the average of the three years preceding. (r842, sec. roo.)

Debts proved to be bad ( 1842 , sec. 100); also for Doubtful Debts according to their Estimated Value. (1853, sec. 5o.)

the Rent of Premises used solily for the purposes of business, and not as a place of residence. (1842, sec. 100.)

, a proportion, not exceeding two-thirds, of the Rent of any dwelling-house partly used for the purposes of business. (1842, secs. roo and ror.)

the Annual Value of any premises occupied by the Owner solely for the purposes of business, and not as a place of residence, according to the amount on which duty has been paid under Schedule A (1842, sec. 100); less ground rent, if any.

,, a proportion, not exceeding two-thirds, of the Annual Value (according to the amount on which Duty has been paid under Schedule A-less ground rent, if any) of any dwelling-house occupied by the Owner and partly used for the purposes of business. (1842, sec. ror.)

,, any other disbursements or expenses wholly and exclusively laid out for the purposes of the Trade, \&c. (1842, sec. Ioo.) 
No Deductic ns are allowed-

For any Iriterest on Capital, for any Annual Interest, Annuity,

or other Annual Payment, payable out of the Profits or Gains, or for any Royalty or other sum paid in respect of the user of a Patent. (The duty on such Interest, Patent Royalty, or other Annual Payment should be deducted from the person to whom the payment is made.) (1842, sec. 100.)

,

any Sums paid as Salaries to Partners, or for Drawings by Partners.

" any Sums invested or employed as Capital in the Trade or Business, or on account of Capital withdrawn therefrom. (1842, sec. roo.)

,

any Sums expended in Improvement of Premises or written off for Depreciation of Land, Buildings, or Leases.

„, any Loss not connected with, or arising out of the Trade, \&c. (1842, sec. 100.)

,, any Expenses of Maintenance of the Persons assessable, their Families, or Private Establishments. ( $18_{42}$, sec. IOO.)

, any Loss recoverable under an Insurance or Contract of Indemnity. (1842, sec. 1оo.)

, any Sum paid as Income Tax on Profits or Gains, or on the Annual Value of Trade Premises.

, any Premium for Life Assurance, or for Wear and Tear of Machinery or Plant; but Allowances may be Claimed in respect of these items, see page 2 of the Form No. Ir, and Notes (II) and (15) below. (Acts of 1853 and $18_{78}$.)

\section{6j. Profit: from Discounts, and Interest of Money not taxed by} deduction.

Under this head fall all Discounts and untaxed Interest received or credited, including Interest on Banking Account or Deposits, and also Dividends in the Public Funds of which the half-yearly amount is less than fifty shillings, where such Dividends are not payable upon Coupons annexed to Stock Certificates payable to bearer. (1 842 , sec. 95.) 
Form of return No. 11 .

\section{(7). Profits from Colonial and Foreign Securities.}

If received through an Agent who deducts British Income Tax on payment of the Income, these profits should not be entered on page 2 of the Form No. 11. But if British Income Tax is not so deducted the amount received in the United Kingdom must be returned for assessment. (1842, sec. 100, $4^{\text {th }}$ case.)

\section{(8). Profits from Colonial and Foreign Possessions.}

Average.-The amount to be returned is the full annual amount received in the United Kingdom on the average of the three preceding years, without any deduction. (1842, sec. $100,5^{\text {th }}$ case.)

\section{(9). Income from Property or Profits not falling under any of the foregoing heads.}

Under this head fall all annual profits or gains not included under ary of the foregoing heads and not charged under any other schedule. (1842, sec. 1oo, 6th case.)

\section{(1o). Date to which Profts are to be computed.}

In the cases mentioned on page 2 of Form No. II where the profits of " the preceding year" are to be taken as determining the amount of the income to be assessed, the year to be taken is strictly speaking the year ended on the preceding $5^{\text {th }} A$ pril : but in practice it is usually the last calendar year, or the last year to the date at which it is the custom of the taxpayer to make up his accounts. Similarly, where "the current year" is to be taken, this should in strictness be the current Income Tax year to $5^{\text {th }}$ April following: but in practice it is usual to take the current calendar year.

\section{(II). Wear and Tear of Machinery and Plant.}

An allowance for diminished value of Machinery and Plant by reason of Wear and Tear may be claimed where the Machinery or plant belongs to the trader, or is so let to him that he is bound to maintain and deliver it over in good condition.

Where rent is paid for the use of Machinery or Plant, and the surden of maintaining and restoring it falls upon the Lessor, no deduction for Wear and Tear is allowable to the Lessee. (Act of 1878.) 
(12). Mode of Assessment.

Persons assessable to Income Tax under Schedule D may elect to be assessed either by the Commissioners of their District under a number or letter, or by the Special Commissioners of Income Tax. In the absence of election, they will be assessed in the usual course by the Commissioners of their District.

Persons who desire to select one of the two alternatives named above should give notice to that effect in the manner provided for on page 2 of the Form No. 11 .

Returns for Assessment by the District Commissioners under a number or letter should be sent to the Clerk to the Commissioners, whose address will be furnished by the Assessor or Surveyor of Taxes on application. Returns for Assessment by the Special Commissioners should be sent to the Surveyor of Taxes under cover, marked "For Special Assessment." In other cases the form should be returned to the Assessor or Surveyor by whom it was issued. The form should be filled up before transmission in all cases."

\section{(13). Inione of Married IV omen.}

The income of a married woman living with her husband is, by the Income Tax Acts, deemed to be the husband's Income, and should be returned by the husband on Form No. II. The only exception to this rule is where a wife earns an income independently of her husband by the exercise of her own personal labour, and the joint income of husband and wife does not exceed f500. In such a case the profit so earned by the wife may be treated as a separate income, for the purpose of claiming exemption or akatement (see Note (16) below).

\section{(14). On whose behalf Return made.}

If the Return is made on behalf of a Firm, Declaration (D) on page 4 of Form No. II should always be filled up as far as it is applicable (see Note 24), and if any of the individual partners desire to claim Exemption, Abatement, or the Relief allowed in respect of Earned Income (see Note (i6) below), application should be made to the Assessor or Surveyor of Taxes for any additional forms required. 
Form of return No. 11.

(15). Allowance in respect of Life Assurance Premiums.

The Allowance is authorised only in respect of Premiums paid on the Claimant's own Life or on that of his Wife; it is limited to an expenditure on Annual Premiums not exceeding one-sixth of the Claimant's net personal Income from all sources, and is not admissible as a deduction in arriving at the total Income for the purpose of a claim for Exemption, Abatement, Allowance for Children, or Relief in respect of "Earned Income." In order that the Allowance may be granted in respect of such Premiums it is necessary that the particulars indicated on page 2 of Form No. 1 I should be stated, and that the Receipts for the Premiums should, if required, be transmitted to the Surveyor of Taxes.

(16). Exemption, Abatement, and Relief in respect of Earned Income.

Total Exemption may be claimed when the Income from all sources does not exceed $\&$ i 60 per annum.

Abatement of $f$ r6o may be claimed when the Income from all sources exceeds $£ \mathrm{I} 60$, but does not exceed $£ 400$.

Abatement of $£$ iso may be claimed when the Income from all sources exceeds $£ 400$, but does not exceed $£ 5^{\circ}$.

Abatement of $£_{120}$ may be claimed when the Income from all sources exceeds $£ 5^{\circ}$, but does not exceed $£ 600$.

Abatement of $£$;o may be claimed when the Income from all sources exceeds $£ 600$, but does not exceed $£ 700$.

When the Income from all sources does not exceed $£ 3,000$, and any part of that Income is Earned Income, a Claim may be made for reduction of the Income Tax on the Eanned Income to the lower rate applicable thereto. In order to obtain this relief a Claim must be preferred at the time the Return is made, and must in any case be preferred before 3oth September in the year for which the $\operatorname{tax}$ is charged.

Note.-No Exenuption, Abatement, or Relief in respect of Earned Income is given unless the individual is resident in the United Kingdom, except in the case of persons who are or have been employed in the service of the Crown or of any missionary society abroad or of any of the Native States under the protectorate of the British Crown, or who are resident in the Isle of Man or Channel Islands, or who satisfy the Commissioners of Inland Revenue that they are resident abroad for the sake of health. 
(1;). Income to be sntered on page 3 of Form No. II.

.In order to obtain Exemption, Abatement, or Relief in respect of Earned Income, the Claimant must fill up page 3 (as well as page 2) of Form No. II, setting forth every source of his Income, including, if married, that of his wife (see Note (1 3 ) above), with the amount derived from each source, whether returned for assessment elsewhere or not, and whether tax has already been paid on the Income or not.

The object of this requirement is to ascertain whether the total Income falls within the prescribed limits of Fxemption, Abatement, or other Relief. Taxed Income included in a statement of total Income will not be assessed a second time by reason of its being entered on page 3 of Form No. II.

(18). Income from Trade, Protession, Employment, or Vocation.

(a) An individual who has made a Return on page 2 of Form No. I I on his own behalf should carry to page 3 the Income from this source as entered on page 2, less the deduction (if any) for Wear and Tear.

(b) A partner in a firm should enter on page 3 his individual share of the partnership profits, calculated as follows:--From the average profits of the Firm returned for Assessment, the amount of any Annuities, Interest, and other annual charges payable for the current year, other than Interest on partner's capital, should be deducted. The balance then remaining should be divided according to the terms of the partnership agreement, and the individual partner's share of that balance, for the current year, is the amount to be entered on page 3 of Form No. II.

When several partners desire to make claims, a separate form must be used by each.

(I9). Income from any Public Office or Employment.

Income from any Public Office or Employment is taxable under Schedule $\mathrm{E}$ of the Income Tax Acts, but should be included in the statement of total Income entered on page 3 of Form No. II.

(20). Income from Property.

If any of the total Income arıses from the ownership of Land, Tenements, or Hereditaments, state the precise situation of each Property, with the name of the occupier, and the rent or annual value, including in the statement particulars of any house, land, 
or other property in the claimant's own occupation, whether belonging to himself or his wife. If ground rent, mortgage interest, or other annual charge is payable on any of the property, particulars thereof must be stated in space No. 2 on page 3 of Form No. 11.

\section{(21). Income from the Occupation of Land.}

Profits from the occupation of Land are to be taken at one-third of the full annual value inclusive of Tithe.

(22). Income from Interest, Annuities, Dividends, and Miscellaneous Sources.

In the case of Income from Annuities, Interest of Money, or other sources not coming under any of the foregoing heads, state fully the particulars. State also in regard to each item under this head whether it has been subjected to Income Tax before receipt. The amount to be entered is the gross amount, and not the net amount received after deduction of the tax.

\section{(23). Charges on Income.}

Particulars must be given in space No. 2 on page 3 of Form No. 11 of all deductions from the income, such as Ground Rent, Interest on Mortgage or Loan (whether secured on Property, Life Assurance Policy, Reversion, or otherwise), Annuities, Patent Royalties, or other Annual Payments from which the taxpayer is entitled to deduct tax, but excluding Life Assurance Premiums, which should be entered in Claim (B) on page 2. If there are no such deductions the word "None" should be inserted. It is not sufficient to leave the space blank.

\section{(24). Declarations on page 4 of Form No. II.}

Declaration (D).-The Precedent Acting Partner of every Firm is required to fill up the spaces marked $\left({ }^{*}\right)$ and to sign the Declaration. It is unnecessary to fill up the remaining spaces unless individual partners claim Exemption, Abatement, or Relief in respect of Earned Income.

Declaration (E) should be filled up when applicable (i.e., when there is more than one place of business). The object of this Declaration is to obtain information which will prevent the making of two assessments upon the same source of Income. 
There is not any express provision in the Acts as to depreciation of land, buildings, or leases ; these, however, would be looked upon as a loss of capital; partners' salaries are obviously payments out of profit after the profit has been ascertained.

The disallowance of income tax itself is not so obvious. It appears to be an ordinary business charge, and, as such, deductible. An allowance of it, however, to a business man would naturally involve a like allowance to a salaried individual, and would produce the rather curious result that a person in a situation at about an abatement limit (say) $£ 720$ per annum, would have to make a mathematical calculation to ascertain whether or not he was entitled to a certain abatement. There is also an express provision in sec. 159 of the Act of 1842 that it shall not be lawful " to make any other deductions therefrom (i.e., from the profit) than such as are expressly enumerated in this Act."

It is the practice to allow deduction in respect of fire insurance and local rates on business premises.

The form is sent out by the assessor at the commencement of the income tax year (5th April) to all persons whom he considers liable to pay income tax ( $1842, \sec .48)$. It is to be filled up and forwarded to the surveyor or assessor (1 842 , sec. 52 ) within twenty-one days from the date it bears, under a penalty of twenty pounds, and treble duty if the person making default is sued before the Commissioners for the district, or fifty pounds if sued in any of His Majesty's Courts ( $184_{2}$, sec. 55).

The form is to be filled up and returned whether the person is or is not liable to tax, and the penalty is exigible in either, Penalty for non-return. case ; but if such person proves that he is not chargeable, the penalty is not to exceed $£ 5$ for any one offence (Finance Act 1907, sec. 22). 
Penalty for non-return.

Lord Advocate $v$. Gibb.

\section{Underwriters}

to return profits paid to clients.
This section is as follows :-

(I) Every person upon whom notice is served in manner prescribed by section $4^{8}$ of the Income Tax Act 1842 (which relates to the delivery of notices by assessors), requiring him to make a return of any profits, gains, or income in respect of which he is chargeable with duty under Schedule D or Schedule $\mathrm{E}$ in the Income Tax Act 1853, shall make a return in the form required by the notice, whether he is or is not chargeable with duty, and in default shall be liable to a penalty under section 55 of the Income Tax Act 1842 accordingly:

Provided that a penalty inflicted in the case of a person proceeded against for not complying with this provision, who proves that he was not chargeable to duties, shall not exceed five pounds for any one offence.

(2) The duties imposed on officers of any corporation, company, fraternity, fellowship, or society by sections 40 and 54 of The Income Tax Act 1842 , and by section 18 of the Customs and Inland Revenue Act 1879 , shall, in the case of any company, be performed by the secretary of the company or other officer (by whatever name called) performing the duties of secretary.

In Lord Advocate v. Hugh Gibb (Court of Session, Scotland, 7 th June 1906 ) it was held that underwriters transacting business on behalf of clients were bound to deliver a list (under sec. 5I) of the names and addresses of the clients, and also of the profits paid to each of them.

Taxes Management Act 1880, Sec. 21.

Penalties.
By sec. $2 \mathrm{I}$ of the Taxes Management Act 1880 , it is provided :-

Sub-sec. (3) All penalties exceeding $£ 20$ imposed by virtue of this Act, the Tax Acts, or Land Tax Acts, excepting such as are directed to be added to the assessments, shall be recoverable in the High Court. 
Sub-sec. (4) In default of prosecution within the space of Penalties. twelve months from the time of any penalty being incurred under the provisions of this Act, or of the said Acts, no penalty or forfeiture shall afterwards be recoverable in any other manner.

In Lord Advocate v'. Sawers (Court of Session, Scotland,

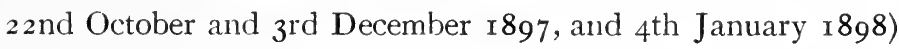
it was held that the words in sub-sec. 4 of sec. $2 \mathrm{I}$ of the Taxes Management Act 1880 (above) mean that in default of prosecution within twelve months no penalty or forfeiture shall be recoverable in any other manner than before the High Court. It was further held that the Inland Revenue Regulation Act I 890 applies to income tax, and consequently, under sec. 22, sub-sec. (2), of that Act, proceedings for fines or penalties may be commenced within two years after such fine or penalty is incurred; that sec. 55 of the 1842 Act means that the penalty is incurred if there is a failure to deliver the kind of statement required by sec. 52, either by not delivering any statement or by delivering one which is untrue or incorrect

Now, howerer, see Finance Act 1907.

In Attorney-General v. Till the facts were that by a deed of June 1899 Mrs. Coombs assigned to Mr. Till, in consideration of $£ 200$ per annum for I5 years, the goodwill of return. her late husband's practice as a solicitor. In rgor Mr. Till married Mrs. Coombs. Before his marriage Mr. Till deducted the annuity from his profits for income tax purposes, but Mrs. 
Penaltles. Coombs herself paid the tax, so there was no loss sustained A.-G. v. Till. by the Revenue. For 1901-2 and 1902-3 he again deducted the annuity, but it was added by the Commissioners. For 1903-4, 1904-5, and 1905-6 he again deducted it. On inquiry by the local Surveyor Mr. Till replied that he had made a deduction "for interest on capital. An annuity of " $£ 200$ to Mrs. Till, my wife, on which income tax is assessed and paid by her." This was incorrect. In April 1907 proceedings were instituted for penalties under sec. 55, the return having been made 2oth May 1905. On trial of the action before a special jury, they found that the mistake was made by the defendant's negligence. No fraud was suggested. The question, therefore, was whether a person who had delivered a statement of his income chargeable with income tax which, through negligence or carelessness but without fraud, was incorrect, was liable to the penalty.

Following Lord Advocate v. Sazvers, and expressing his own concurrence with the views expressed, Lord Chief Justice Alverstone gave judgment for the Crown for $£ 50$ and costs.

In the Court of Appeal this judgment was reversed.

Cozens:
Hardy, M.R.

Cozens-Hardy, M.R., s.id the Act was so framed that it was difficult, if not inpossible, to arrive at a clear and satisfactory conclusion, but he thought the arguments of the appellant should prevail. Sec. 47 , he said, provided for a general notice; sec. 48 provided for a personal notice, and, in default of a return, the Commissioners were to issue a 
summons in order that the penalty might be duly levied. These words clearly referred to sec. 55. Sec. 49 prescribed the place and time of delivery; sec. 50 required a list of Penalties. A.-G. V. TIII. Inaccurate employees ; sec. $5 \mathrm{I}$ required trustees to deliver statements on behalf of their beneficiaries; and sec. 52 dealt with a person himself liable. Sec. 55, he said, was ungrammatical and almost unintelligible. It is as follows :-

"If any person who ought by this Act to deliver any list, declaration, or statement as aforesaid shall refuse or neglect so to do within the time limited in such notice, or shall under any pretence wilfully delay the delivery thereof, and if information thereof shall be given, and the proceedings thereupon shall be had before the Commissioners acting in the execution of this Act, every such person shall forfeit any sum not exceeding twenty pounds and treble the duty at which such person ought to be charged by virtue of this Act, such penalty to be recovered as any penalty contained in this Act is by law recoverable, and the increased duty to be added to the assessment, but, nevertheless, subject to such stay of prosecution or other proceedings by a subsequent delivery of such list, declaration, or statement, in the case following (that is to say), if 'any trustee, agent, or receiver, or other person hereby required to deliver such list, declaration, or statement on behalf of any other person, shall deliver an imperfect list, declaration, or statement, declaring hinself unable to give a more perfect list, declaration, or statement, with the reasons for such inability, and the said Commissioners shall be satisfied therewith, the said trustee, agent, or receiver, or other person as aforesaid, shall not be liable to such penalty in case the Commissioners shall grant further time for the delivery thereof; and such trustee, agent, receiver, or other person shall, within the time so granted, deliver a list, declaration, or schedule as perfect as the nature of the case will enable him to prepare and deliver; and any person who shall be prosecuted for any such offence by action or information in any of His Majesty's Courts, and who shall not have been assessed in treble the duty as aforesaid, shall forfeit the sum of fifty pounds." 


\section{Penalties.}

A..G. v. Till. Inaccurate return.

\section{Cozens.} Hardy, M.R.
Sec. 129 provides :-

"Provided always, that if any person who shall have delivered a statement or schedule shall discover any omission or wrong statement therein, it shall be lawful for him to deliver an additional statement or schedule rectifying such omission or wrong statement, and such person shall not afterwards be subject to any proceeding by reason of such omission or wrong statement; and if any person shall not have delivered a statement or schedule within the time limited by the Commissioners for that purpose, it shall be lawful for him to deliver a statement or schedule, in manner herein directed (section 120), at any time before a proceeding shall be had to recover the penalty herein mentioned (section 128), and no proceeding shall be afterwards had for recovering such penalty; and if any proceeding shall have been actually had before the Conmissioners for recovering such penalty, it shall be lawful for the same Commissioners, on due proof to their satisfaction that no fraud or evasion whatever was intended, to stay such proceedings, either on the terms of paying or without paying the costs then incurred, as the Commissioners shall think fit; and if any proceedings shall have been commenced in any Court, it shall be lawful for the Commissioners to certify that, in their judgment, no fraud or evasion was intended by the party making such omission, and it shall be lawful for any Judge of such Court, on a summary application, to stay such proceedings on such terms as he shall think fit; or if such person shall have delivered an imperfect statement or schedule, and shall give to the Commissioners a sufficient reason why a perfect statement or schedule cannot be delivered, the said Commissioners, being satisfied therewith, shall give further time, and so from time to time, for the delivery of such statement or schedule; and such perscn shall not be liable to any penalty for not having delivered such statement or schedule within the time before limited, in case such person shall have delivered as perfect a statement or schedule as from the nature of the case he was enabled to give, and so from time to time as long as the Commissioners shall grant further time as aforesaid."

It was contended, he said, on the one hand, that the words

" as aforesaid" (sec. 55) referred to the previous sections. 
If so, the result would be that any error or omission, however slight or however innocent, involved the penalty. On the other hand, it was contended that the section applied only to Penalties. A.-G. v. Tili. Inaccurate non-delivery, as distinct from an imperfect or inaccurate statement. He thought the latter the preferable view, because-

(1) Other sections (68 and $\mathrm{I}_{7} 8$ ) spoke of a person having delivered "such account as aforesaid," although it was false.

(2) The words "as aforesaid" naturally referred to sec. 48. He suggested that a document might be so illusory that a tribunal would be justified in holding there had been no delivery.

(3) The Act contained provisions not of a penal character for rectifying errors, \&c. (sec. 129).

(4) The Act imposed a penalty on a person for making a false or fraudulent statement, which was less severe than that which, on the other hypothesis, was imposed upon an honest mistake (sec. I78).

(5) The proviso in the middle of sec. 55 presupposed non-delivery, and then authorised delivery of an imperfect list.

(6) The Revenue had power to assess (sec. I13) and to surcharge (secs. $16 \mathrm{r}, \mathrm{r} 62$ ).

On the other hand, sec. 50 supported the opposite view. Sec. I29 did not apply, nor did sec. I13, nor sec. I6 r. 
Penalties.

A.-G. v. TIII.

Inaccurate return.
Moulton, L.J.
On the whole, he was not satisfied that the arguments addressed in this case had been so fully presented to the Scotch Court, in Lord Advocate v. Sazers, and he felt unable to decide this case in accordance with the view adopted in the Scotch Courts.

Moulton, L.J., said that the view expressed in the Scotch Courts, that the slightest inaccuracy in a statement should make its delivery a nullity, was a very startling proposition. He thought very different language would have been used if that had been intended. Moreover, the nature of the penatty suggested that only non-delivery was aimed at. The penalty was treble the duty on the whole assessment. This might be necessary and proper where there was a total failure, but there was no justification for it if there was only an inaccuracy. 'The contention of the Crown could not logically stop even at requiring every detail to be absolutely accurate and strictly in accordance with the Acts ; it must extend, whether the mistake was for or against the person delivering the statement, or even had no effect either way. The presumption in favour of the section dealing with non-delivery only was strengthened by sec. ${ }_{7} 78$. 'There the penalty depended on the magnitude of the error. It seemed to him incredible that the Legislature shouid have inflicted a less penalty for a fraudulent return than for an honest mistake. Sec. 127 was also in the same direction, where the penalty was three times the surcharge only. The decision of the Court below rested, he said, entirely on the interpretation of the words " as aforesaid." But, in his opinion, the Act countenanced no such interpre- 
tation. He alluded to secs. $178,68,67$, and 177 , which all supported the view that non-delivery was dealt with. $\mathrm{He}$ thought Lord Advocate v. Sawers had not been fully argued. Penalties. A. .G. v. Till. Inaccurate return. The decision seemed to have turned on an interpretation of the latter portion of sec. 55 , but he thought the latter part of that section was in farour of the defendant. Both sec. 55 and sec. I 29 pointed to non-delivery. The Crown had argued that there was no hardship in the penalties because the Commissioners had power to relieve against them. The argument, he said, had very little effect in reconciling him to an interpretation which made the penalties of an unnecessary and almost barbarous severity. There was a temptation to use powers of this kind for an indirect purpose, an example of which was given in the present case. If the Crown's contention were correct, he thought the Court had no jurisdiction to lessen the amount. It was practically admitted that this action was brought to indirectly recover sums otherwise irrecoverable. If penalties were to be used for indirect purposes, the taxpayer was practically at the mercy of the Commissioners. The existence of an error, however sniall, would put them in the position of being able to insist that almost any view they might entertain should be accepted, and he did not think that His Majesty's subjects should be left so defenceless unless it could be shown that it was the clear meaning of the Act.

Buckley, L.J., was of the same opinion. He thought Buckley, L.J. sec. $5^{6}$ bore out the view that sec. 55 applied only to nondelivery. Sec. 50 certainly presented a difficulty, and he 
Penalties.

A.-G. v. TIII.

Inaccurate return.

\section{Lord}

Chancellor.

thought it was inconsistent with other provisions of the Act. He also differed from the decision in Lord Advocate $v$. Sawers, thinking it had not been fully argued.

The case was subsequently heard in the House of Lords on November ${ }_{15} 5^{\text {th }}$ and 16 th 1909 , and judgment was unanimously given for the Crown on December 8th.

The Lord Chancellor said the penalty attached if the person failed to deliver any statement or delivered one which was incorrect. It had been argued that if this were so, a hard penalty might fall on a person who made an innocent mistake, and it had been urged that it was no answer to say that the Crown would never use such a power. He agreed that such an answer could not prevail, but he did not think it was true that an innocent mistake exposed a man to those penalties. Full relief was given by sec. I 29.

Lord Atkinson agreed that judgment should be given for the Crown, but he did not think that their contention, as he understood it, was well founded-riz., that any taxpayer who sent in a statement of the gains and profits earned by him in his trade or business, which statement was erroneous in fact, necessarily became liable to the penalties. $\mathrm{He}$ continued :--

"With all due respect to the Court of Appeal, it would appear to me that, finding themselves confronted with this contention, they allowed themselves to be too much influenced by the quite natural repugnance which one must necessarily feel against adopting a construction of these enactments which would render the subject liable to these very heavy penalties if, while honestly endeavouring to furnish a correct statement according to his light, he made some mistake, or was guilty of some error in estimating what his gains and profits amounted to." 
Rule XV. of sec. 190 provided that the declaration was that the profits were truly stated, "estimated to the best of his judgment and belief according to the directions and rules

Penalties.

A. G. G. Till. $=-x-1$ Inaccurate return. of the Act." No doubt the words in sec. I 29, "and such person shall not afterwards be subject to any proceedings by reason of such omission or wrong statement," would seem to suggest that he would be liable if he had made a statement not true in fact, though true and accurate according to his belief, but he did not think that was enough to override the express words of sec. I9o and the rules. He thought the jury should have been asked to find whether the respondent applied the rules according to the best of his judgment and belief. Their finding of "negligence" must, he thought, be taken as a finding that he did not so apply them.

Lord Gorell reviewed the various sections, including sec. Lord Gorell. $\mathrm{I} 90(\mathrm{XV}$.$) , and stated that the finding of the jury disposed of$ any suggestion that the estimate had been made to the best of Mr. Till's judgment and belief. Sec. 55, he stated, was illexpressed, and so much so as to trustees, \&c., as to render it almost unintelligible. He understood the judgment of the Court of Appeal to proceed on three main grounds :-

(I) That the wording of the section was not such as to impose in plain terms a penalty for an incorrect return.

(2) That if it did the penalty was exigible, however slight or innocent the error.

(3) That other sections showed only non-delivery was aimed at (because less penalties were stated for fraudulent returns). 
Penalties,

A.oG. v. Til .

Inaccurate return.

Lord Gorell.
He thought-

(I) That sec. 55 clearly related to both non-delivery and inaccurate delivery. The first line of the section was meant to have read, "Any such list__ " and the section should read as if " such" were inserted. The proviso in favour of trustees pointed to that reading.

(2) He was not satisfied, without further argument on the point, that the penalty would be incurred in such a case; but that was not the case here, where the return had been made negligently. Further, it was not disputed that the penalty arose on failure to deliver within the time, so that the delay of a single day would bring the person within the penalty. "I should expect," he said, " that common experience would show that these hardships do not occur in practice."

(3) Lesser penalties for a greater offence (sec. I 78) could not prevent the reading of sec. 55 according to its terms.

There was a further important section (129). This was also badly drafted. It might be doubted whether it applied only to the sections immediately preceding, but he thought it covered sec. $5^{2}$, \&c. It seemed a necessary implication that in the absence of that section a person would be liable under sec. 55 for having delivered an incorrect statement, and he thought the word "omission" in the latter half covered both 
omission to deliver at all and omission to deliver a proper statement.

Penalties.

A.-G. v. Till.

Inaccurate return.

Lord Shaw.

Lord Shaw agreed. He also reviewed the various sections. As to any relief under sec. I29, it was admitted that the respondent did not deliver any rectifying statement, that the Commissioners had not made any certificate, and that, in short, sec. I 29 had not been, and could not now be, invoked. $\mathrm{He}$ answered seriatim the six points in the judgment of the Master of the Rolls as follows :-

(I) There was no inconsistency in the language of the sections. The real meaning was to make operative both a duty and a penalty; the penalty was for the falsehood of that which was bound to be returned as true. It purported to be true, and turned out to be false.

(2) He thought the sounder view was that "as aforesaid " referred to all the previous sections, including very particularly sec. $5^{2}$.

(3) He differed strongly as to the inference to be drawn from sec. 'I29. The provision of a means of escape from penal consequences seemed to him to point conclisively to the initial duty having been to make a true and accurate statement. It would appear an extraordinary thing to say to the taxpayer that he could deliver anjthing and afterwards correct it, perhaps on the eve of proceedings. 
Penalties.

A.-G. v. TIII.

Inaccurate return.

(4) 'This was well worthy of consideration. But it was unsafe to deduce from the various penal sections any view that penalties were graduated upon any scale of moral delinquency. As a matter of administration, defects in returns, unless heavily punished, might become widespread and habitual, and so cause great interruption to the efficiency of departmental work.

(5) He thought the view expressed was inconsistent with the terms of sec. 55. Accuracy was expected all round, but as trustees might not have such access to information as would be in the possession of an ordinary taxpayer, special provisions dealing with salary, \&c., not unnaturally occurred.

(6) The powers of surcharge, \&c., were because, in addition to penalties, the Inland Revenue must gather in the taxation.

Where return
is to be made.

Where return
is to be made.

Trayellers.

Form No. 11b for quarries, mines, \&c.
The returns for assessment on persons engaged in trade, \&c., are to be made in the parish or place where the trade, profession, or concern is carried on, or the employment or vocation exercised (1842, sec. 106).

Travellers of a firm would be assessed at the place where the business of the firm is carried on if travelling for only one firm, but at their residences if for more than one.

A separate form (No. IIB) is provided for the return of profits or annual value of quarries, mines, iron works, gas works, salt springs or works, alum mines or works, water 
works, streams of water, canals, inland navigations, docks, drains and levels, fishings, rights of markets and fairs, tolls, ways (except railways, for which a special form, No. гов, is provided), bridges, ferries, and other concerns of a like nature.

The taxpayer in England or Scotland may elect to be assessed either-

(I) By the Commissioners of the district in the ordinary course (I842, sec. III).

(2) By the Commissioners of the district under a number or letter (x842, sec. I37).

(3) By the Commissioners for Special Purposes appointed by the Crown (1842, sec. I3I).

In Ireland all assessments are under the Special Commissioners.

If the second or third method be selected, the desire of the taxpayer is to be added to the general declaration on page 2 of the form, and, on the completion thereof, the form is to be directed to the Clerk to the Commissioners in case (2), or to the Surveyor of Taxes for the district (instead of to the assessor) in case (3), and endorsed "Number or Letter," or "For Special Assessment," as the case may be.

If there is not any such wish expressed, the assessment will be made by the General Commissioners in the ordinary course. 
Assessment by Special Commissioners.
The advantage of being assessed by the Special Commissioners is that they are Government officials, whereas the General Commissioners are local gentlemen, and possibly competitors in trade, neighbours, or bankers, to whom it may be considered very undesirable to disclose the amount of profit made. In the case of a desire being expressed for the assessment to be made by the Special Commissioners, the return only passes under the notice of the Surveyor and themselves, and it is not seen by the General Commissioners. Where an assessment is made by the Special Commissioners, the tax is to be paid to the Accountant and Comptroller-General of Inland Revenue, or the proper officer for receipt, according as these Commissioners direct. In Scotland, tax in respect of all special assessments is to be paid to the Collector of Inland Revenue, Edinburgh.

Assessment under number or letter.
In the case of a person electing to be assessed by the General Commissioners under a number or letter, the return of profits made is submitted to the General Commissioners, and if they are satisfied with the declaration made, they issue a certificate of assessment to the party (who must pay the duty on or before the ist January), and they exclude his name and assessment altogether from the duplicate of assessments delivered to the local collector. They then send a duplicate of assessment, containing only the number or letter under which the party is assessed, together with the amount of duty payable, to the officer of receipt (i.e., the collector of Inland Revenue for the district), and the party must make payment on or before ist January to this officer, as already stated, and 
not to the local collector of taxes. If, however, he fails to pay the duty before the Ist January, the Commissioners may authorise the local collector to recover the same as in the case of assessments by name ( 1842 , secs. 137 to 142 ).

It may be noticed from the form No. I I that the instructions given are very clear and concise, and if carefully followed out they should be of material assistance in arriving at the amount to return.

In Re The Watchmakers' Alliance and Ernest Goode's Stores, Lim. (Chancery Division, 28th March and I 4 th Norember 1905) it was held that where liquidators had paid away all the assets to contributors and others, without making provision for a claim of the Crown for income tax, they must pay the amount to the Crown; and that, in default of payment, a writ of attachment was issuable as a matter of right, the Court having no discretion in the matter.

Prior to 1907 royalties payable in respect of patents were taxed in the hands of the recipient, and not by way of deduction; now, however, by the Finance Act 1907, sec. 25, it is provided :-

(I) In estimating, under any schedule of the Income Tax Acts, the amount of the profits and gains arising from any trade, manufacture, adventure, concern, profession, or vocation, no deduction shall be made on account of any royalty, or other sum, paid in respect of the user of a patent, but the person paying the royalty or sum shall be authorised, on making the payment, to deduct and retain thereout the amount of the rate of income tax chargeable during the period through which the royalty or sum was accruing due.

Royalties not to be deducted.
Assessment under numbes or letter.

\section{Watch. makers'} Alliance.

Liability of liquidator. 
(2) Subsection (3) of section 24 of the Customs and Inland Revenue Act 1888 (post), shall apply to any such royalties or st:ms as it applies to interest of money or annuities charged with income tax under Schedule D in the Income Tax Act r853.

\section{Lanston Monotype Corporation, Lim. $v$. Anderson.}

Royalty not payable in current year.

Omission to deduct annual yalue of trade premises.

Double assessment.
In the case of Lanston Monotype Corporation, Lim. $v$. Anderson judgment was delivered in the King's Bench Division on the $I_{5}$ th February I9I, and, on appeal, in the Court of Appeal, 26th July igr. The question was whether a royalty which had been payable up to $3^{\text {Ist }}$ December 1906, and which then ceased, was to be added to the profits of the years 1904,1905 , and 1906, in computing the amount for assessment for 1907-8 (Finance Act, 1907, sec. $25(\mathrm{I}))$.

In the High Court, Hamilton, J., held (with doubt and regret) that the words of the section clearly made the royalty an addition to the profit, and the decision of the Commissioners (in favour of the Corporation) was therefore reversed, but this was overruled by the Court of Appeal.

The deduction which may be claimed for annual value of premises used for the purpose of business is frequently overlooked in the case of a firm or company occupying their own works, and many cases have come under our notice where there has not been any such deduction made. The result is, that such persons have paid tax twice on the annual value of their premises-viz., under both Scheclule A. and Schedule D. It is submitted that this would be a "double assessment" within the meaning of sec. $17 \mathrm{I}$ of the Act of $18_{42}$, which provides that- 
"Whenever any person shall have been assessed to any of the duties granted by this Act . . . and shall by any error or Assessment. mistake be again assessed for the same cause, and on the same account, and for the same year . . the Commissioners - . shall cause such assessment . . to be vacated - . and whenever it shall be proved to the satisfaction of the Commissioners of Inland Revenue that such double assessment hath been made, and hath not been vacated, and that payment hath been made of both assessments, it shall be lawful for the said Commissioners of Inland Revenue to order and direct the Receiver-General of Inland Revenue, or any officer for receipt, to repay to the party the sum so erroneously and doubly assessed upon him, and paid as aforesaid."

The section does not express any limit as to the time within which a claim must be made, and there would not appear to be any objection to a claim for three years (the general limit prescribed by the Act of 1860, sec. I0); but, so far as we are aware, there has not been any case decided by the Courts on this point. As a strict matter of law, the point is not by any means certain, as it might well be said in such a case that the assessment had not been made "by any error or mistake," but that it had followed upon the return in the ordinary course, and that the "error" had been in the double return. In a somewhat similar case, The Holborn Viaduct Land Company, Lim. v. The Queen (post), Mr. Justice Stephen said :-

"The conclusion, therefore, is that this claim is not to be allowed unless it is made within three years. Then this claim was certainly not made within two or three years, and I think therefore, on that view, that the utmost amount which can in any case be claimed is the amount for the last three years." 
It will be seen that this does not admit a right to repayment for three years, but the department will always allow such a claim.

To arriye at amount of profit to return.

Acounts

applicable generally.
Before considering in detail the various regulations as to making returns of profits, we will take as an illustration, applicable to almost any trade, the case of a firm carrying on the business of cotton spinning. There are, broadly, two methods of preparing accounts for income tax purposes, viz. :-

(I) To prepare a Profit and Loss Account as for ordinary purposes, and then to make the necessary adjustments.

(2) To prepare a Profit and Loss Account, excluding items not allowed as deductions.

Both these accounts would give the same result, but the latter would not show the balance of profit for ordinary purposes.

The following accounts illustrate the difference between the two methods :- 
PART II. SCH. D.-Pro ForMa ACCOUNT FOR REtUrN.

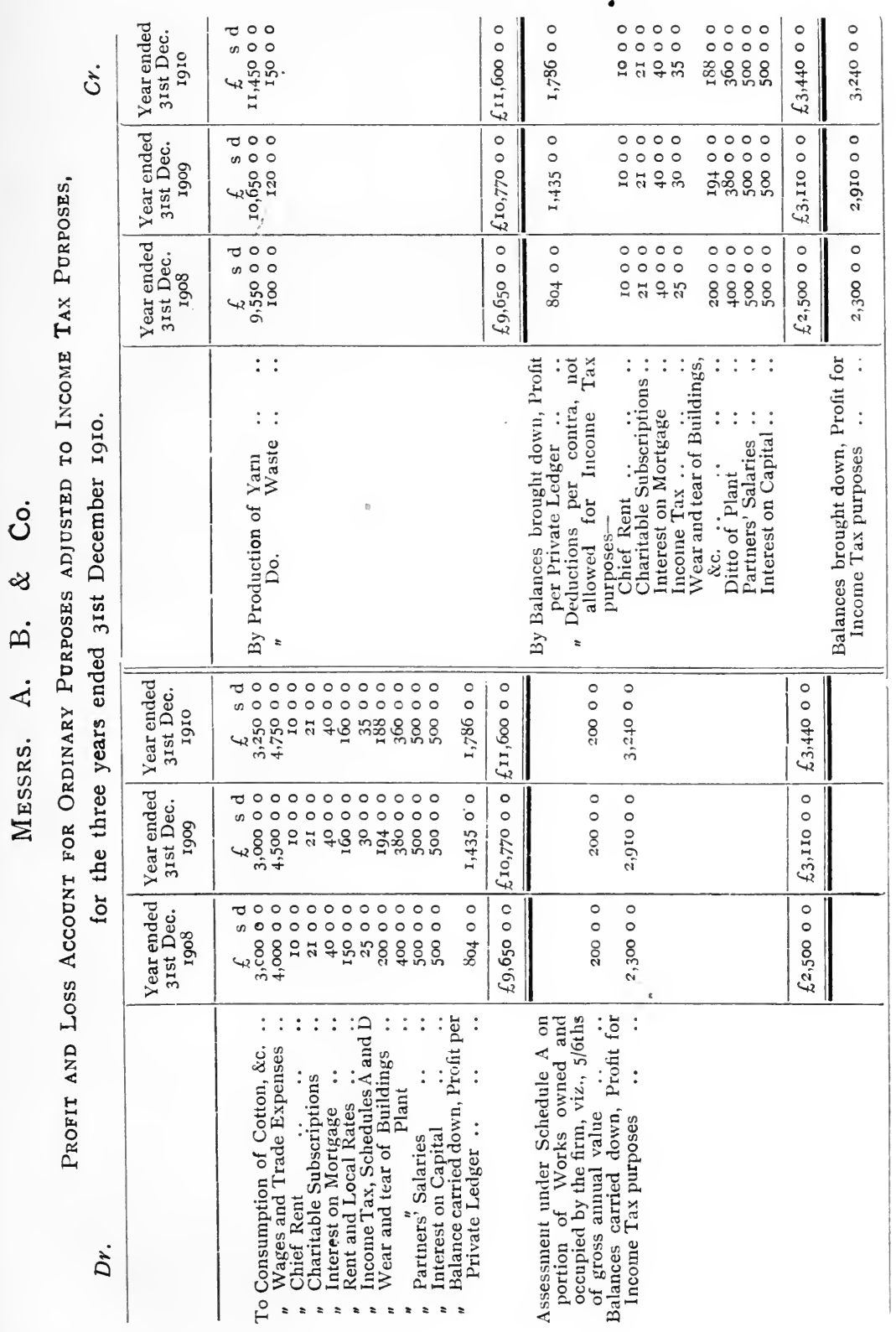




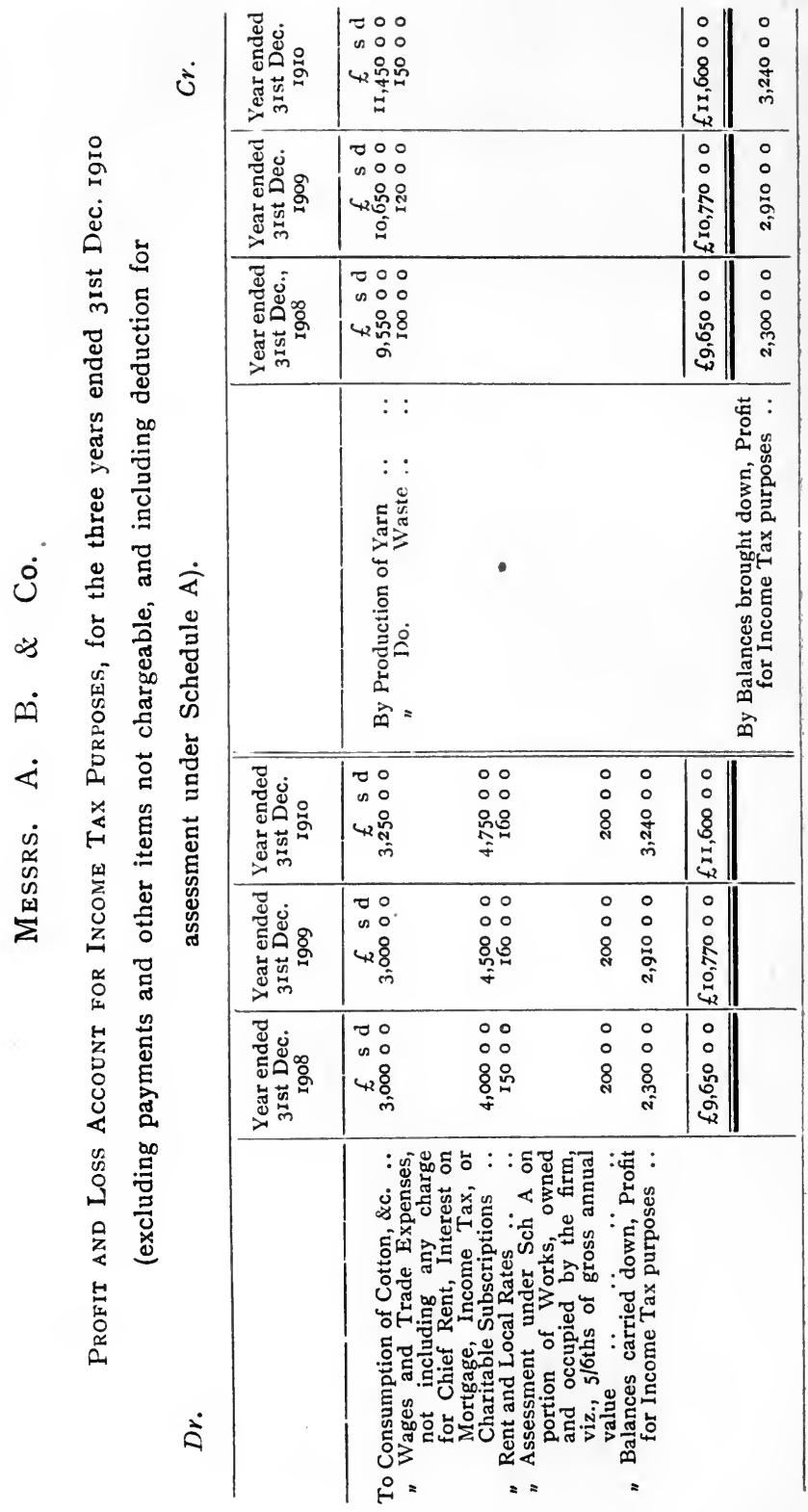


It is submitted that the former is the better one, as it at once discloses what deductions have been written back.

There is always absolute secrecy as to accounts furnished.

In Brown's Trustees v. Hay (Court of Session, Scotland, 26th October 1897) it was held that a public department cannot be compelled by a Court of law to produce confidential documents in its possession coming from third parties; if so to compel it would be to discourage similar communications being made in future. The case arose in connection with an action against an auditor for having inter alia made statements to the Inland Revenue authorities regarding the income tax which ought to have been paid by the trader, and production was sought of certain documents passing between the auditor and the Inland Revenue authorities.

In Re Joseph Hargreaves, Lim., the liquidator called on the Surveyor at Bradford to produce under sec. II 5 of the Companies Act 1862 copies of certain Balance Sheets which had been furnished to him for the purpose of an assessment. The Court, in their discretion, refused to compel production, having before them the opinion of the Board of Inland Revenue that the public service would suffer by such production of confidential documents (Chancery Division, r $4^{\text {th }}$ December 1899). The liquidator appealed, but the Court of Appeal, without calling on the Crown, dismissed the appeal (24th January I900), stating that usually the Court of Appeal would not interfere with the discretion of the Court exercised under this section. 
Shaw v. Kay. Similarly, in Shaw v. Kay (Court of Session, Scotland, I9th October and 3 rd December 1904), where application was made for the production by the Surveyor of Taxes of income tax returns with a view of proving that a defendant was in a position to repay a loan, leave was refused by the Court on the ground of confidentiality and public interest. The plaintiff had obtained an order for production by the defendant of his income tax receipts, and the defendant had sworn that he had, and had had no such receipts. Lord Pearson said he recognised the hardship in the plaintiff being deprived of that aid, and it might be that possibly he could not prove his case in any other way; but private convenience must give way to public interest. It was difficult, he said, to imagine so exceptional a case as would justify the Court in compelling discovery in the exercise of their discretion.

It may be observed that the account is drawn to show (as it would do in a complete system of bookkeeping) the production of yarn, thus-

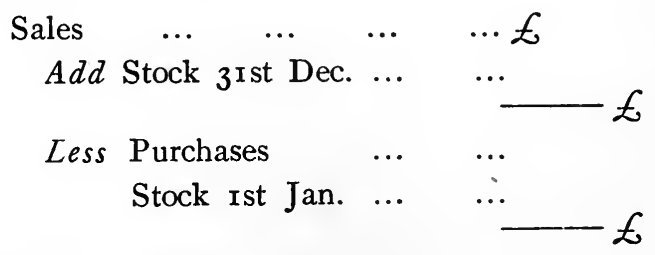

and consumption of cotton, \&c., thusPurchases $\ldots £$

Add Stock Ist Jan. ... ...

Less Sales

Stock 3 ist Dec. ...

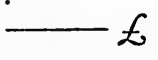


i.e., the stock has been analysed, and the amount of it appertaining to each item at the beginning and end of each year has been taken into account. This is instead of entering the stock at the beginning and end of each year in one sum on the debit and credit sides of the account respectively, and dealing with sales of yarn and purchases of cotton. The result is, of course, the same; and, in the case of accounts being produced, either will do equally well, according to the method in which the books may have been kept.

If the books have not been kept on the system of double entry the trader may, by means of an account arrived at by drawing statements of affairs at the commencement and end of the period under review, arrive at what he may consider to be a sufficiently accurate estimate of profits. If, however, his return is not accepted, and he wishes to appeal (see Part III. of this chapter), he will usually be required to produce such an account as is here given.

The difference between a Cash Account and a Profit and Loss Account is one affecting bookkeeping as such rather than income tax. It may not, however, be out of place to mention it. It may be assumed that no one in ordinary commercial business would for a moment regard a Cash Account as a Profit and Loss Account, but a Cash Account is frequently used by solicitors as a basis of settlement, and indeed in Badham v. Williams (1902) it has been held that this is the proper basis for division of profit. The point also arises in practice in the case of retail traders, who keep their books

Difference between Cash Account and Profit and Loss Account.

\section{Bookkeeping by Single Entry. How profit may be ascertained.}


Difference

between Cash Account and

Profit and
Loss Account. Ledger.

The result produced over a series of years will be the same in each case, subject to adjustment in the last year; but this is not sufficiently accurate for income tax purposes, where the profit is required year by year. It will usually happen that a great deal of work has been done one year, the payment for which comes into a subsequent year, and the difference is even more accentuated in the first year of a business. Assume a Cash Account for such first year as follows (omitting drawings, \&c.) :-

\begin{tabular}{|c|c|c|c|c|c|c|c|c|}
\hline \multirow[t]{2}{*}{ Costs received } & $\cdots$ & $\cdots$ & f.I,500 & $\begin{array}{l}\text { Expenses } \\
\text { Balance }\end{array}$ & $\ddot{x}$ & $\ddot{x}$ & $\ddot{m}$ & $£_{30}^{\mathrm{I}, 20}$ \\
\hline & & & $£^{\mathrm{I}, 500}$ & & & & & 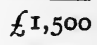 \\
\hline
\end{tabular}

There may be $£ 300$ of outstanding costs, and rent, \&c., due $£$ ioo. The Profit and Loss Account should, of course, be-

Expenses paid ... $£^{1,200}$

Expenses accrued 100

Balance, Profit .. $\quad £^{\mathrm{r}, 300}$

$\underline{5 \mathrm{I}, 800}$

Costs received $\quad \ldots £^{\mathrm{I}, 500}$

Costs accrued due 300

$£^{\mathrm{I}, 800}$

$£^{1}, 800$

To follow it on another year, assume the Cash Account to be-

\begin{tabular}{|c|c|c|c|c|c|c|c|c|}
\hline \multirow[t]{2}{*}{ Costs received } & .. & .. & $£ 3,000$ & $\begin{array}{l}\text { Expenses } \\
\text { Balance }\end{array}$ & .. & .. & .. & $\begin{array}{r}£_{1}, 700 \\
I, 300\end{array}$ \\
\hline & & & $£ 3,000$ & & & & & $\overline{£ 3.000}$ \\
\hline
\end{tabular}


And now let us suppose the costs outstanding are $£ 500$, and rent, \&c., due £150. The Profit and Loss Account becomes-

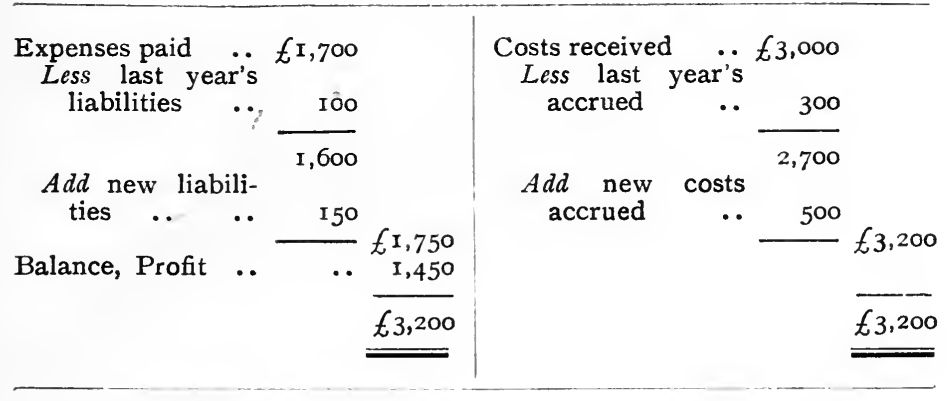

The question arising (as suggested) in the accounts of retail traders requires exactly similar treatment.

The account must not run into the current year; thus, if the books are only made up annually to, say, 3oth April, the return for I9II-I 2 ending 5 th April I9I2 would have to be on the three years encled-

$$
\begin{gathered}
\text { 3oth April r908, } \\
,, \quad,, \quad \text { I909, and } \\
,, \quad,, \quad \text { I910. }
\end{gathered}
$$

If the trade expenses are entered in one item, instead of being particularised, and the second form is used, it is rather Trade expenses. important that the item should read :-

"Wages and trade expenses, not including any charge for chief rent, interest on mortgage, income tax, or charitable subscriptions,"

otherwise the surveyor usually asks whether any such items are included. However much they are particularised there

Years to be brought into a yerage.

(1)


160 Schedule D.-Income Tax Paid for Employees. chap. vi.

Charitable
subscriptions. will almost invariably be an item "Sundry Expenses," or " Miscellaneous Expenses." To avoid a similar query as to this, it is desirable to add " not including any charge for charitable subscriptions "- -as these are looked upon not as. a trade charge, but as a disposal of profit. Where, however, subscriptions are paid by a manufacturer to an infirmarywhere any of his workpeople might be sent if injured-such subscriptions are allowed as a deduction, the payment being looked upon as a trade expense.

Income Tax

paid on

salaries of

employees.
Some companies pay the income tax chargeable on the salaries of the officials, and it has been argued that this, being (so to speak) an addition to the salary, should be allowed as: such. This is sound, but it is at once apparent that being so allowed it must be added to such salary, and paid upon in that manner, and it might affect the amount allowed for abatement or life insurance.

Thus, if $\mathrm{A}$. receive a salary of $£ 590$ per annum, and the company pay the tax thereon, that is equivalent (assuming. him to be entitled to the relief to "earned" incomes) to $£ 6$ i3. less $£ 23$ tax thereon, and there would only be an abatement of $E_{\text {To }}$ allowed thereon; further, he would be entitled to an allowance for life insurance up to one-sixth of f6r 3 .

A bonus paid to an employee would be allowed as a deduc. tion from the business profits, and would be income in the hands of the recipient. 
Proceeding now to prepare the return for assessment to tax for the year Igri-I2, ending April rgi 2. We take

$$
\text { E s d }
$$

Profit for the year ending 3 Ist Dec. 1908 ... 2,300 $\circ \quad \circ$

Ayerage profit.

\begin{tabular}{|c|c|c|c|c|c|}
\hline , &,$_{i}$ & , & 3ist Dec. I909 ... & 2,910 & $\circ$ \\
\hline \multirow[t]{3}{*}{,', } &, & , & 3 ist Dec. Igio... & 3,240 & $\circ$ \\
\hline & & & & 3) $8,45^{\circ}$ & 0 \\
\hline & & Ave & e annual profit & $\mathcal{E}^{2,8}, 6$ & I 3 \\
\hline
\end{tabular}

In the example given the firm are supposed to rent part of the premises, and to own part. This will be at once apparent from the fact that Income Tax Schedule A is charged against the profit, for, as previously pointed out, it is a landlord's tax, and would not be borne by a firm who did not own premises. The annual value of the premises owned is charged as an expense, just as the rent is, and tax will be paid on it under

Deduction of annual yalue under Sch. A since Finance Act 1894. Schedule A.

The provisions of the Acts as to deduction from profits under Schedule D of annual value under Schedule $\mathrm{A}$ are as follows :-

"The computation of the duty to be charged in respect of any profession, trade, manufacture, adventure, or concern, whether carried on by any person singly, or by any one or more persons jointly, or by any corporation, company, fraternity, or society, shall be made exclusive of the profits or gains arising from lands, tenements, or hereditaments occupied for the purpose of such profession, trade, manufacture, adventure, or concern." (2nd rule applying to the first and second cases of Schedule 1), r $\$_{42}$, sec. Ioo.) 
Deduction of annual yalue under Sch. A. since Finance Ict 1894.

Rent or annual yalue in cases of change in assessment, ac.
“. . In the case of an assessment upon any house or building . . . the amount of the assessment shall, for the purposes of collection, be reduced . . . by a sum equal to one-sixth part of that amount. . ." (1894, sec. 35.)

"Where in estimating the amount of annual profits or gains arising or accruing from any profession, trade, employment, or vocation, and chargeable to income tax under Schedule D of the Income $\operatorname{Tax}$ Act 185.3 , any sum is deducted on account of the annual value of the premises used for the purpose of such profession, trade, employment, or vocation, the sum so deducted shall not exceed the amount of the assessment of the premises for the purpose of income tax under Schedule $A$ to the said Act, as reduced for the purpose of collection under sec. 35 of the Finance Act 1894." (1898, sec. 9.)

A question sometimes arises as to how the rent or annual value of premises is to be dealt with in cases where it is not uniform in the three years. Suppose a trader rents his premises for two years and then purchases them. His profits for the first two years after charging rent of, say, $£ 400$, are

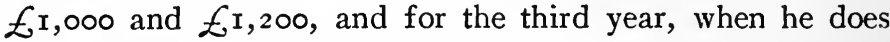
not pay rent, his profits are $£ \mathrm{r}, 800$. The proper course is to charge the amount of assessment to Schedule $A$, in respect of annual value, to his trading in the third year, not to take the average and then deduct it. He must, in fact, make an adjustment between himself as tenant and as landlord. The result would be-

First year's profit after charging rent $\quad \ldots £ £$ r, , Second do. do. $\quad \ldots \quad \mathbf{I}, 200$

Third do. after deducting annual value assessed under Schedule A, $£ 400 \ldots \quad \mathrm{r}, 400$ 
Our view is that the Schedule A assessment would be dealt with in precisely the same manner if it had varied in any way from year to year. Thus, reverting to the accounts given

(pp. $\mathrm{r}_{53}$ and $\mathrm{r}_{54}$ ), if the assessments had been :-

$\begin{array}{rrr}\text { I908 } & \ldots & £ 200 \\ \text { I909 } & \ldots & 250 \\ \text { I910 } & \ldots & 300\end{array}$

the profits would have been :-

$$
\begin{array}{lllr}
\text { r908 } & \ldots & \ldots & £ 2,300 \\
\text { r909 } & \ldots & \ldots & 2,860 \\
\text { r910 } & \ldots & \ldots & 3,140 \\
& & & \frac{3 \longdiv { 8 , 3 0 0 }}{£ 2,766} \text { r3s. } 4 d \text { d. }
\end{array}
$$

The authorities approve this method, and apply it, subject to variation in exceptional cases.

An apparent injustice arises where a person has rented his business premises for two years and then buys them. Assume :-

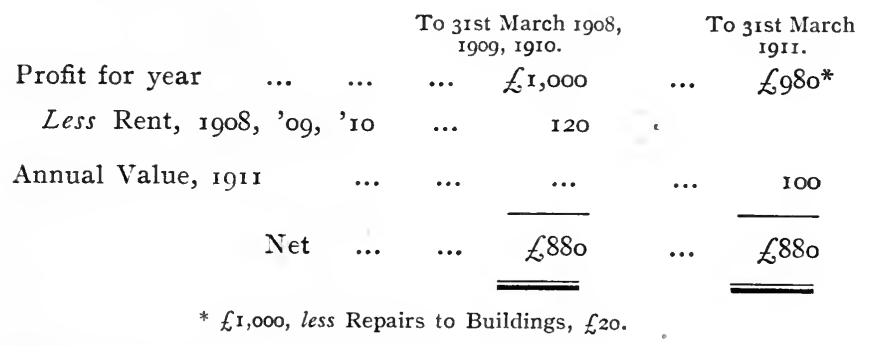

The original return for I9 10-1 I would be $£ 880$. Tax would be paid under Schedule $\mathrm{A}$ on $£ \mathrm{I}$ (oo, and it is frequently suggested that this should then be deducted from the $£ 88 \circ$ 
under Schedule D. Those who so argue overlook the fact that the $£^{880}$ is arrived at after a charge for rent, though at first sight their argument appears sound. Another reason against their contention is that, if it were correct, the change of ownership would diminish the amount receivable by the Crown by the amount of the Schedule A assessment.

Average when there is a loss in one year.
Should any year result in a loss instead of a profit (say, for example, the third year), the average would be-

Profit for the year ending 3ist Dec. I908 ... $£^{2,300} \circ$ o

,

$$
\text { , }
$$$$
\text { , }
$$$$
\text { I } 909 \ldots
$$$$
f 5,2 \text { I0 } 0 \text { o }
$$

Less loss for the year ending 3rst Dec. I9ro, (say)

$$
\text { ‥ } 3,240 \quad \circ \quad \circ
$$

3) $1,970 \circ \circ$

Average annual profit ...

$$
\cdots \quad \cdots \quad £^{6} 5^{6} \quad \text { I3 } 4
$$

The amount brought out by the average $\left(£^{2,8}, 8\right.$ I3s. $4 \mathrm{~d}$., return. be filled in on the second page of the form. It then only remains to fill in the amount claimed for wear and tear of machinery, the amount of which allowance is (by the Act of I878) in the discretion of the Commissioners, prior to which time there had not been any such allowance. 
The text of the Act is as follows :-

Wear and

tear.

Act of 1878.

"Notwithstanding any provision to the contrary contained in any Act relating to income tax, the Commissioners for general or special purposes shall, in assessing the profits or gains of any trade, manufacture, adventure, or concern in the nature of trade, chargeable under Schedule $\mathrm{D}$, or the profits of any concern chargeable by reference to the rules of that scheaule, allow such deduction as they may think just and reasonable as representing the diminished value by reason of wear and tear during the year of any machinery or plant used for the purposes of the concern, and belonging to the person or company by whom the concern is carried on; and for the purpose of this provision, where machinery or plant is let to the person or company by whom the concern is carried on upon such terms that the person or company is bound to maintain the machinery or plant, and deliver over the same in good condition at the end of the term of the lease, such machinery or plant shall be deemed to belong to such person or company.

"And where any machinery or plant is let upon such terms that the burden of maintaining and restoring the same falls upon the lessor, he shall be entitled, on claim made to the Commissioners for general or special purposes, in the manner prescribed by section sixty-one of the Act of the fifth and sixth years of Her Majesty's reign, chapter thirty-five, to have repaid to him such a portion of the sum which may have been assessed and charged in respect of the machinery or plant, and deducted by the lessee on payment of the rent, as shall represent the income tax upon such an amount as the said Commissioners may think just and reasonable, as representing the diminished value by reason of wear and, tear of such machinery or plant during the year: Provided that no such claim shall be allowed unless it shall be made within twelve calendar months after the expiration of the year of assessment."

As illustrating the circumstances under which this Act came to be passed, we gave in the Appendix to the Fourth Edition extracts from the Inland Revenue Reports for the years ended 3 ist March 1877 and 1878 . 
Schedule D.-Partiers aNd Reture after chap. vi. Claim under ACt of 1890 .

Return by partner after claim under Ict of 1890.

An interesting case in practice arose in respect of a return after a claim had been made by one of two partners (A. and B.) under the Act of 1890 . Assume the following figures :-

\begin{tabular}{|c|c|c|c|c|c|c|}
\hline Year & I903 & $\cdots$ & $\cdots$ & $\ldots$ & $\ldots$ & Profit $£$ ro,ooo \\
\hline , & 1904 & $\ldots$ & $\ldots$ & $\ldots$ & $\ldots$ & 5,000 \\
\hline & 1905 & $\ldots$ & $\ldots$ & $\ldots$ & $\ldots$ & 40,000 \\
\hline
\end{tabular}

A., having private taxed income and a private business, recovered tax on his share of the $£ 40,000$. For the year 1906-7 it was sought to make out the return as follows :-

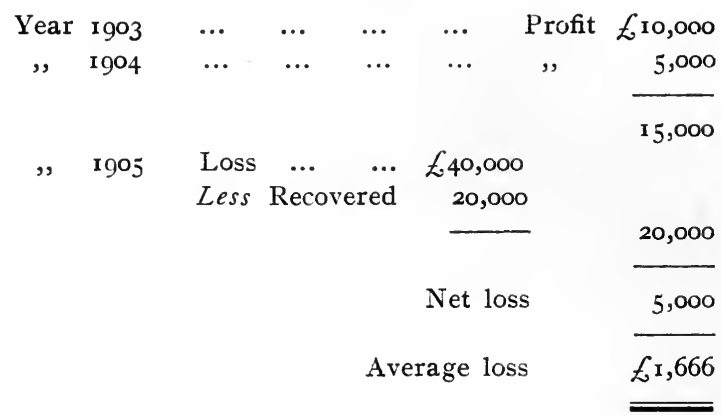

and it was sought to set off A.'s share, $£ 833$, against the profit of his private business (under Section ror). The matter went to the Board, who ruled that this was an attempt to set off B.'s share of loss against A.'s profits, and that the return must be divided as follows :-

A. B.

$$
\begin{aligned}
& \begin{array}{llllllllll}
\text { Year } 1903 & \ldots & \frac{1}{2} & \text { Profit } & \ldots & \ldots & \ldots & £ 5,000 & \ldots & £ 5,000
\end{array} \\
& \text { ד,500 } \\
& \text { been repaid) ... } \mathrm{Nil} \\
& \text { Profit } \quad \ldots \quad \ldots \quad \ldots \quad £ 7,500 \text { Loss } £ 12,500 \\
& \begin{array}{lllllllll}
\text { Average } & \ldots & \frac{1}{3} \mathrm{rd} \ldots & \ldots & \ldots & \ldots & £ 2,500^{\circ} & \mathrm{Nil}
\end{array}
\end{aligned}
$$


In the case actually submitted a loss in the earliest year created a small average loss to A., which was allowed as a Return by claim under set-off, but it naturally follows that, if the mode adopted by the Board is correct, an average profit (as above) should result in an assessment upon A. It is difficult, however, to see how this would be justified in the face of the rule that a partnership is to be assessed jointly, except for the purposes of abatement, \&c. (post).

Where a partner of a firm claims relief in respect of " earned income" (see post), Form $3^{8}$ is to be filled up (see Chapter IX).

If the business has been commenced within the three years, the amount to return should be arrived at as follows :-

(Say) Profit for the 8 months ended $5^{\text {th }}$ April r9ro $\ldots \quad \ldots \quad \ldots \quad \ldots \quad \ldots \mathrm{I}, 600$ Profit for the 12 months ended $5^{\text {th }}$ $\begin{array}{llllll}\text { April rgri } & \ldots & \ldots & \ldots & \ldots & 3,000\end{array}$

Profit for 20 months ... $\quad \ldots \quad \ldots \quad £ 4,600$

Average annual profit for I9II-I2 ... £2,760

Or (say) Profit for the 8 months ended $5^{\text {th }}$ $\begin{array}{lllll}\text { April, } 1909 & \ldots & \ldots & \ddots & £ \mathrm{r}, 600\end{array}$

Profit for the 12 months ended $5^{\text {th }}$ $\begin{array}{lllll}\text { April I9ro } \ldots & \ldots & \ldots & \ldots & 3,000\end{array}$

Profit for the 12 months ended $5^{\text {th }}$ $\begin{array}{llllll}\text { April IgI I ... } & \ldots & \ldots & \ldots & 2,600\end{array}$ Profit for 32 months $\quad \ldots \quad \ldots \overline{£ 7,200}$ . Average annual profit for rgrris ... 
New business commenced within year of assessment.
The assessment of a new business is sometimes a matter of difficulty. Assume a business to be commenced $5^{\text {th }}$ October I9I0, and the accounts to be made up in the first case to 3 Ist March rgrr, and so on half-yearly. In the ordinary course the assessment for I9ro-I I would be on the profit of the period from October igro to March I9I I and the assessment for I9II-I 2 would be on the same basis-viz., double that amount. It may, however, be the case that the business is one doing a season's trade, in which case, if that period happened to be the season, the proprietor might argue that he should not be assessed on double the amount for the next year, and per contra the Surveyor might take up similar ground if the season were March to October. There is not anything definite in the Acts to guide us, and the Commissioners differ in their views.

The first rule of the first case reads :-

"The duty to be charged in respect thereof shall be computed on a sum not less than the full amount of the balance of the profits or gains of such trade, manufacture, adventure, or concern, upon a fair and just average of three years, ending on such day of the year immediately preceding the year of assessment on which the accounts of the said trade, manufacture, adventure, or concern shall have been usually made up, or on the fifth day of April preceding the year of assessment.

"Provided always that in cases where the trade, manufacture, adventure, or concern shall have been set up and commenced within the said period of three years, the computation shall be made for one year on the average of the balance of the profits and gains from the period of first setting up the same. . . ." 
It has been argued that the second paragraph does not limit the assessment to an average based on the results of the period

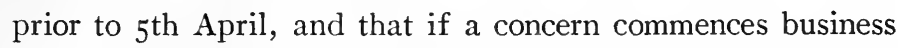
3oth June I9ro, and makes up annually, the assessment for I9I2-I 3 should be on the average annual profit of the two years up to 3 oth June 1912. Again, we are informed that the Commissioners in London in dealing with a new business assess each year on the profits of that year until a three years' Practice of Commissioners in London. average can be obtained. However equitable this latter method may be, it is clearly not in conformity with the Act (above). The other point is not so clear, but we think that the first part of the rule should be read into the second part, and that the period should not over-lap into the year of assessment, and that in the case suggested the assessment for I9I2-I 3 should be on the profits of the year up to 3 oth June IgII.

As to a right of appeal at the end of any of the first three years, see post.

Where the trading of a company results in an average annual loss, or a profit not equal to debenture interest and chief rent paid, the amount of such interest and chief rent (less the amount of the assessment to Schedule A) must be returned for assessment to Schedule $\mathrm{D}$, the tax thereon having been deducted by the company simply as collectors for the Revenue.

Similarly, a person trading with borrowed money, and who makes a loss or a profit not equal to the interest thereon, must

Amount to return where accounts show an ayerage loss.

\section{New Business.}


return the interest for assessment, unless he has private taxed income equal to such interest or the balance thereof.

Set off against interest.
In a case in practice, a company (lessees), who paid $£ 3,000$ for rent and were assessed under Schedule $A$ at $\mathcal{E} 3,500$, made a loss, and therefore became liable to pay on debenture interest as above. The question arose whether they could set off the difference of $\mathcal{E}_{500}$ against such interest. The authorities took a liberal view, and allowed the set-off, not drawing any distinction between a company as lessees and owneroccupiers.

How assessment is made.

When tax payable.

Making the assessment.
The form having been returned to the surveyor or assessor, an assessment is made by the Commissioners, of which due notice is given, and if, for any reason, the person charged is not satisfied with the assessment made upon him, he can appeal (see Part III. of this chapter). The tax is payable in one sum on the Ist January (1880, sec. 82), except in the case of tax under Schedule D charged on English and Irish railways, when it is to be paid by four quarterly payments, on the 2oth June, 2oth September, 2oth December, and 2oth March, during the year of assessment (1880, sec. 95).

Discount at the rate of $2 \frac{1}{2}$ per cent. per annum is allowed on tax paid in advance, viz., before rst January ( 1842 , sec.' I 4 I ; 1889 , sec. 10).

All returns of profits (Form No. I I) under this schedule (except returns to be assessed by the Special Commissioners) are to be laid before the Additional Commissioners, or the Commissioners for General Purposes acting as Additional Commissioners, who make the assessments (I842, sec. III). 
If they are not satisfied with any return made, or in case there has not been any return made, they make an assessment of such sum as, to the best of their knowledge, represents the profits chargeable ( $184_{2}$, sec. II3).

The case of Maughan v. Edinburgh and District Water Trust (Court of Session, Scotland, 2nd July r886) is superseded by the provisions of the Finance Act, r907, sec. 23. This section is as follows :--

(I) Notwithstanding anything in an Acte concerninge Informers, being chapter five of the Acts of the thirty-first year of the reign of Queen Flizabeth, or in subsection (4) of section twenty-one of the Taxes Management Act 1880, or in subsection (2) of section twenty-two of the Inland Revenue Regulation Act 1890 (p. 135), or in any other enactment, proceedings for the recovery of any fine or penalty incurred under the Income Tax Acts may be commenced within three years next after the fine or penalty is incurred.

(2) The time during which an assessment may be amended or an additional first assessment made under section fifty-two of the Taxes Management Act 1880 (which relates to the amendment of assessments), or during which an assessment may be made on the estate of a deceased person under section twenty-four of the Customs and Inland Revenue Act 1890 (which relates to the power to make such assessments), shall be any time within the year of assessment or within three years after the expiration thereof, and the time during which in cases of omission to charge any person a charge may be made and allowed or signed under section sixty-three of the Taxes Management Act 1880 (which relates to the powers of surveyors to make such charges), shall be a period of three years after the expiration of the year for which the person ought to have been charged.

*(3) Nothing in this section shall affect proceedings for the recovery of fines or penalties incurred before the commencement of this Act, or extend the time during which any assessment may be made or amended, or a charge may be made on any person in respect of income tax charged under any Act passed before the commencement of this Act. 
Put briefly, the right to make further assessments under the Act of 1880 , secs. $5^{2}$ and 63 , was limited as follows :-

Profits not assessed at all might be assessed within twelve months of the end of the year.

An additional assessment on profits only partially assessed had to be made within four months of the end of the year.

Wear and

tear.

Rate allowed. where renewals are provided out of revenue and the amount is charged against the trading for income tax purposes, there will not be any wear and tear allowed; but, where renewals are provided out of capital, wear and tear will be allowed.

The practice as to allowance for wear and tear is that, It frequently happens, on an existing business being floated as a company, that the machinery is valued at a greater price than that at which it has previously stood in the books. In such a case, the purchaser, of course, desires to have an allowance for depreciation on the new figure. The almost invariable practice of the authorities is only to allow wear and tear upon the figure at which the machinery last stood for income tax purposes. Presumably, the view taken is that, consciously or unconsciously, the valuation includes goodwill, and there is considerable weight in the argument.

In an appeal in this connection the appellant is bound to admit that the rise in value is due either :-

(a) To a rise in the market value of the machinery;

(b) To an over-allowance for wear and tear in the past; or

(c) To the machinery having been improved in value by material used and work done to it by workmen, all charge for which has been debited to Revenue. 
But against this it may be urged that the fact of the seller having paid less tax than he should have done is no reason why the purchaser should have to pay more than his due.

The following memorial as to depreciation of machinery was addressed to the Chancellor of the Exchequer in 1897 :-

Wear and tear.

Memorial to Chancellor of Exchequer.

\section{INCOME TAX ALLOWANCES.}

To the Right Hon. Sir Michael Hicks Beach, Bart., M.P., Chancellor of the Exchequer.

The Memorial of the Association of Chambers of Commerce of the United Kingdom.

Sheweth :-

That the present system of allowances for depreciation of machinery for Income Tax Assessments, and the absence of any allowance for obsolete machinery, is a great hardship to the manufacturing industries of this country, inasmuch as it amounts to an additional tax.

That owing to the present spirit of invention, machines become obsolete much more quickly than formerly, and even when not obsolete their value diminishes very rapidly. Those who are amongst the first to purchase new machines pay a very heavy premium upon them as compared with those who purchase them later, and it not infrequently happens that after using them for a year or two, they would be able to buy superior machinery of the same class for half the original price. In such a case, unless the old machines have been heavily depreciated, the anomaly would remain that the manufacturer had old machinery taken in stock at a higher price than superior new machinery of the same class would cost.

That machinery is now worked at such a high speed that it wears out much sooner than formerly, and consequently must be more rapidly depreciated.

That these conditions, whilst applying to all users of machinery, are especially applicable to the two principal industries of Leicester -namely, the boot and shoe and hosiery trades, where machines are rapidly superseded by new inventions, and are frequently obsolete in a very few years. 
That, according to the law, Income Tax Assessors have no power to make any allowances for obsolete machinery, and in justice to manufacturers it is highly desirable the law should be altered so as to pernit such allowances.

That the deduction as at present admitted-namely, a small percentage upon the value of machinery at each stocktaking, is not on a proper basis, inasmuch as with a depreciation of 5 per cent. per annum on this basis, $f \mathrm{I}, \infty \mathrm{o}$ worth of machinery stands at E. 128 ros. 3 d. after 40 years, and at a depreciation of $7 \frac{1}{2}$ per cent. stands at $£ 444$ S. 7 d. after the same period.

That the allowance of a small percentage for depreciation only benefits the departments in the early years, as after the eleventh year the amount upon which it is allowed is so much greater at the $7 \frac{1}{2}$ than the ro per cent. scale that from that time forward the amount allowed on the $7 \frac{1}{2}$ per cent. scale is the largest, and the same occurs between the $7 \frac{1}{2}$ and 5 per cent. scales after the sixteenth year.

That the allowance for depreciation on the annual stocktaking value instead of upon the original value of machinery practically speaking never extinguishes this from the nominal assets of the firm.

That no prudent manufacturer would take stock of his machinery on the principle adopted by Income Tax Assessors, and is he therefore obliged to take stock twice, once for his own information, and again specially for the assessors.

That the amount expended in repairing machinery so as to keep it in workable condition should be allowed to be deducted in full for Ir.come Tax Assessments. These repairs are absolutely necessary to keep the machinery of any value at all, and if it is disposed of as second-hand does not prevent a serious depreciation, equalling or even exceeding anything likely to be deducted for stocktaking, whilst when the machines become obsolete they are, of course, totally lost.

That the result of the present system of depreciating machinery for income tax assessments is calculated to foster commercial immorality by inducing manufacturers to show a fictitious capital in their books in the Machinery Account. Instances are numerous where manufacturers, apparently solvent from this cause, have continued to carry on business for years after being insolvent with disastrous results. The absence of an allowance for obsolete machinery also fosters the spirit of false declarations which it is most important should be avoided. 
That, as the income tax purports to be an impost levied upon the actual income received, Her Majesty's Government be urged in the interests of the commercial community who already pay their fair share of all taxes, to take the necessary steps to remedy the anomalies

Wear and tear.

Memorial to ChanceIlor of Exchequer. above mentioned.

Given under the Common Seal of this Association, the Ist day of April i 897 .

And his reply was as follows :-

\section{Treasury Chambers, Whitehall, S.W.}

DEAR Sir, May 28th 1897 .

The Chancellor of the Exchequer has had under his consideration the Memorial of the Association of the Chambers of Commerce of the United Kingdom, which you sent him at the beginning of April.

The chief points raised in the memorial are as follows :-

(I) That the allowances in respect of repairs and depreciation of machinery are insufficient, and the methods of calculating such depreciation are unsatisfactory.

(2) That no allowance is made for the cost of replacing machinery which has become obsolete.

As to the first point, I am to say that, as the law now stands, deductions are allowed both in respect of expenditure incurred in repairs or alterations of machinery according to an average of the three years preceding the year of assessment, and also in respect of the diminished value of machinery by reason of wear and tear during the year. The allowance of these deductions is in the hands of the District or Special Commissioners, as the case may be, and they have to decide in each case as it arises the adequacy of the deductions allowed.

As to the second point, I am to say that the Board of Inland Revenue have given instructions to their surveyor at Leicester, which is particularly referred to in the memorial, that, where a claim is made in respect of the introduction of more modern machinery in a factory, no objection is to be taken to the allowance, as a deduction from the assessable profits of the year, of so much of the cost of replacement as is represented by the existing value of the machinery 
CHAP. VI.

Wear and tear.

Reply of Chancellor.

Concession.

Method of arriving at same. replaced. Any excess in the cost of the new machinery over the actual present value of the old is an addition to the capital of the business, and cannot properly be regarded as a charge upon revenue for the purposes of income tax assessment.

I am to add that similar instructions will be given to surveyors in other districts when this question arises there.

$$
\text { I am, Sir, }
$$

Your obedient servant,

\section{The Secretary,}

W. A. Mount.

This would appear to be a distinct concession to the taxpayer, as the Ac̣t of 1878 only provided for an allowance in respect of diminished value by reason of wear and tear; whereas this sanctions an allowance for the supersession of obsolete machinery by reason of improvements, \&c. This is equivalent to charging all renewals to revenue and not having any depreciation allowance, which method is supported by surveyors of experience, both in respect of machinery and of wagons.

The allowance for wear and tear is made off the average profits after that arerage has been ascertained. The amount charged in the accounts should always be written back to credit, and the deduction claimed off the average. (Cunard S.S. v. Coulson (post).) This is so even if the rate allowed is the same as that charged in the accounts, for the allowance is for wear and tear for the year succeeding those on which the profit is based, and is on the machinery figure standing as at the commencement of the year. Thus, if the Machinery Account be :- 


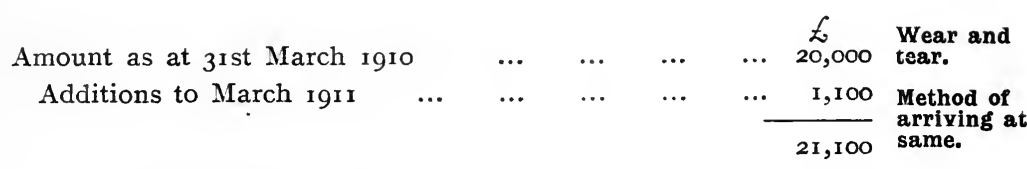

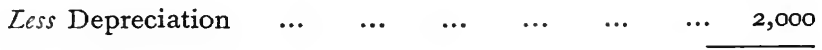

The amount on which depreciation is allowed is-

Amount at $3^{\text {rst March }}$ igro for Income Tax purposes ... $\underbrace{£}_{25}, 000$

This will usually be greater than the book figure, as there will probably not have been so much allowed as has been written off.

Less Depreciation allowed for $1910-11$.

23,125

$\begin{array}{lllllllll}\text { Additions } & \ldots & \ldots & \ldots & \ldots & \ldots & \ldots & \ldots & \mathrm{I}, \mathrm{1}, 0\end{array}$

Amount on which Depreciation will be allowed for I91 I-12 $£^{24,225}$

The following important provision is contained in the Act of 1907 , sec. 26 :-

(1) For the purpose of enabling deductions for wear and tear to be allowed by the additional Commissioners, claims in respect of those deductions shall be included in the annual statement required to be delivered under the Income Tax Acts of the profits or gains of the concern for the purpose of which the machinery or plant is used, and the additional Commissioners in assessing those profits and gains shall make such allowances in respect of those claims as they think just and reasonable.

(2) No deduction for wear and tear or repayment on account of any such deduction shall be allowed in any year if the deduction when added to the deductions allowed on that account in any previous years to the person by whom the concern is carried on will make the aggregate amount of the deductions exceed the actual cost to that person of the machinery or plant, including in that actual cost any expenditure in the nature of capital expenditure on the machinery or plant by way of renewal, improvement, or reinstatement.

Cumulative wear and tear. 
Wear and

tear.

Cumulative

wear and tear.
(3) Where as respects any trade, manufacture, adventure, or concern full effect cannot be given to the deduction for wear and tear in any year owing to there being no profits or gains chargeable with income tax in that year, or owing to the profits or gains so chargeable being less than the deduction, the deduction or part of the deduction to which effect has not been given, as the case may be, shall, for the purpose of making the assessment for the following year be added to the amount of the deduction for wear and tear for that year and deemed to be part of that deduction, or if there is no such deduction for that year, be deemed to be the deduction for that year, and so on for succeeding years.

(4) In this section the expression "deduction for wear and tear" means the deduction allowed, or which would be allowed, under section twelve of the Customs and Inland Revenue Act 1878, as representing the diminished value, by reason of wear and tear during the year, of machinery or plant used for the purposes of any trade, manufacture, adventure, or concern.

Though subsec. (2) would prevent an allowance such as was upheld in Hall v. Rickman (post), it would obviously not prevent a new owner having depreciation, in view of the words " allowed . . . to the person by whom the concern is carried on."

Subsec. (3) would not appear to give any right to use unexhausted depreciation for any year prior to 1907-8-the expression " cannot be given . . . " would not apparently cover past years.

Cunard S.S. Co. $v$. Coulson.

Wear and tear is to be for the year.
In Cunard S.S. Co., Lim. v. Coulson (Queen's Bench Division, 2oth March 1899) the Court held that it was quite clear under the Act that the depreciation to be allowed was for the year, and that it was first necessary to ascertain the average profit before deduction for depreciation, and then to 
deduct the amount allowed; and the company's claim to be assessed on the average of three years' net profits (after deduction of depreciation) was disallowed.

Where machinery or plant is let to a person, and such Machinery, \&c., let. person has undertaken to maintain it and deliver it over in good condition, he is entitled to deduction for wear and tear as if he were the owner. Where, however, the burden of maintaining and restoring it falls on the owner, he is entitled to repayment of tax on such an amount as the Commissioners consider just and reasonable as representing the diminished value of the machinery, \&c., by reason of wear and tear. The claim is to be made within twelve months after the expiration of the year of assessment (Act of 1878 , ante).

An important question arises in such a case as that of a financial company, where the tax-paid income received, and debenture interest paid, vary from year to year. On what principle is the assessment to be made? Several methods have been suggested :-

Ist.-To take one-third of the profit for the three years as per the Profit and Loss Accounts (after elimination of deductions not allowed, other than interest, e.g., income $\operatorname{tax}$, then add the estimated debenture interest paid, and deduct the estimated tax-paid income received for the year of assessment.

2nd.- To take one-third of the profit for the three years, Second eliminating debenture interest paid and tax-paid income received.

First method suggested.
Financial

How amount to return arriyed at. 
Third method.

3 rd.- To take one-third of the total of the net profit and debenture interest for the three years, including tax-paid income received, and then to deduct tax-paid income for the year of assessment.

It is obvious that if the debenture interest paid, and taxpaid income received, are respectively about the same in each of the three years brought into average, the difference in result by each of the three methods will be only slight. But where they vary considerably, as would probably be the case during the earlier years of a company's existence, it becomes important to determine on which basis the accounts are to be prepared. Annexed is a summary Profit and Loss Account of a financial company for the three years ended 3 rst December 1910. During the year Igo8 the profits are derived in such a manner that a comparatively small amount is taxed at its source, and they have very little debenture interest to pay, but in subsequent years they raise more money by way of debentures, and, that money being invested, more of the income is taxed by way of deduction. This causes a striking difference in the amount for return to assessment as prepared in the three modes, viz. :-

Difference in result of yarious methods.

\begin{tabular}{|c|c|c|c|c|c|}
\hline Year ending & $\begin{array}{l}\text { Profit per the } \\
\text { Profit and } \\
\text { Loss Account } \\
\text { after adjust- } \\
\text { ment, except } \\
\text { in respect of } \\
\text { Interest }\end{array}$ & $\begin{array}{l}\text { Add } \\
\text { Interest paid } \\
\text { on } \\
\text { Debentures }\end{array}$ & $\begin{array}{l}\text { Total of } \\
\text { Profit and } \\
\text { Interest }\end{array}$ & $\begin{array}{l}\text { Deduct } \\
\text { Tax-paid } \\
\text { Income } \\
\text { received }\end{array}$ & $\begin{array}{l}\text { Balance of } \\
\text { Profit after } \\
\text { eliminating } \\
\text { tax-paid } \\
\text { Income } \\
\text { received and } \\
\text { Interest on } \\
\text { Debentures } \\
\text { paid }\end{array}$ \\
\hline \multirow[t]{2}{*}{$\begin{array}{l}\text { 3Ist Dec. } 1908 \\
\text { 3Ist Dec. I909 } \\
\text { 3Ist Dec. I9IO }\end{array}$} & $\begin{array}{ccc}£ & \text { s } & d \\
36,000 & 0 & 0 \\
30,000 & 0 & 0 \\
24,000 & 0 & 0\end{array}$ & $\begin{array}{rrr}f_{600} & s & d \\
12,000 & 0 & 0 \\
24,000 & 0 & 0\end{array}$ & $\begin{array}{ccc}f & s & d \\
36,600 & 0 & 0 \\
42,000 & 0 & 0 \\
48,000 & 0 & 0\end{array}$ & $\begin{array}{ccc}£ & \text { s } & d \\
3,000 & 0 & 0 \\
18,000 & 0 & 0 \\
45,000 & 0 & 0\end{array}$ & $\begin{array}{rrr}f & s & d \\
33,600 & 0 & 0 \\
24,000 & 0 & 0 \\
3,000 & 0 & 0\end{array}$ \\
\hline & $£ 90,000 \circ 0$ & $£_{36,600 \circ \circ}$ & $f_{126,600 \circ 0}$ & $£ 66,000 \circ 0$ & $£ 60,600 \circ 0$ \\
\hline
\end{tabular}




\section{Ist Method.}

Profit for three years as per the Profit and Loss Account $\quad \ldots \quad \ldots \quad \ldots \quad \ldots \quad £ 90,000$ Average $£ 30,000$

$A d d$ estimated debenture interest for year of assessment (say, as in rgro)

24,000

$£ 54,000$

Deduct tax-paid income for year of assessment (say, as in 19ro) ...

45,000

Amount for return to assessment $£ 9,000$

2nd Method.

Profit for three years, omitting debenture interest and tax-paid income $\ldots \quad \ldots \quad £ 60,600$

Amount for return to assessment, $\frac{1}{3}$ rd thereof

\section{$3^{\text {rd Method. }}$}

Profit and debenture interest for the three years, including tax-paid income $\quad \ldots \quad £ \mathrm{I} 26,600$ Average $E_{42,200}$

Deduct tax-paid income for the year of assessment
Result if first method adopted.
Result if second method 
At first glance frst method seems the correct one.

Arguments in fayour of it.

At the first glance the first method seems the correct one. The fact of some of its income having been received after deduction of tax, and of the company itself having retained tax on some of the interest paid by it, should not make any difference in the amount of their profits for income tax purposes.

The company made $\ldots \quad \ldots \quad \ldots \quad \ldots \quad £ 30,000$ on which they should pay tax.

They estimate that they will, during the year, collect tax on

$$
\begin{array}{ccc}
\cdots \quad \cdots \quad \cdots & 24,000 \\
\text { Making a total of } & \ldots 54,000
\end{array}
$$

On the other hand, they expect to pay, by way of deduction, $\operatorname{tax}$ on $\quad \ldots \quad \ldots \quad 45,000$

and it seems a good argument to say they should now pay on $\quad \ldots \quad \ldots \quad \ldots \quad \ldots 9,000$

This view is supported if we consider that the debenture interest is really assessed upon the debenture-holders separately, the Revenue being merely assisted in the collection of the tax by the company deducting it from the debenture-holders; and that the tax-paid income received is assessed at the source for the same reason. Such tax-paid income is, nevertheless, income of the company in the course of their business, the company being formed for the special purpose of making a profit consisting of the difference between what the capital and borrowed money of the company can be employed at, and the amount of interest, \&c., payable for such capital and borrowed money. In further support of this view it was held in the Forth Bridge case (p. 70), that the 
interest upon which the tax had to be paid was not the interest for the year prior to the year of assessment, but was the interest for the year of assessment.

But the Surveyors and the authorities at Somerset House contend that the return must be made up in the second method. They resist a claim to arrive at the amount for assessment on any other principle than that of excluding debenture interest paid and tax-paid income received, as in the ordinary case of excluding interest payable by a trading company. The principle must be considered apart from its effect in individual cases. In the instance given it operates in favour of the Revenue, but in other cases it might be the reverse. The reasons given in support of this view of the authorities are :-

(I) That interest of money is chargeable separately as a distinct head of income, quite apart from all other income (1853, sec. 2, Schedule D, $3^{\text {rd clause) }}$

(2) That where interest is payable out of profits the person receiving the interest is not to be taxed, but the assessment is to be made on the whole profits without distinguishing such interest ( 1842 , sec. 102).

It seems a good reply to the second contention to say that the interest is not payable out of profits, but that the profits are not ascertained until such interest has been provided for. The first contention, however, seems to follow the ruling in

Second method shouid be adopted.

Reasons for adopting second

examined. 
Clerical, General, \&c. Assurance Society $v$. Carter.

Assessment of Iife assurance company.

Must pay on interest received, irrespective of amount of profit.
Edinburgh

Life Insurance case. the case of Clerical, Medical, and General Life Assurance Society v. Carter (Surveyor of Taxes), heard before the Court of Appeal on the r6th February 1889, and which decided an important question as to the returns of life assurance companies. The society had paid tax by way of deduction on $£ 107,000$, interest on investments. They received a further sum of interest, amounting to $£_{1} 6_{5}$, from which tax had not been deducted. The profit of the society only amounted to $£ 74,600$. The Crown claimed to assess the sum of $£_{165}$, and the society resisted on the ground that they had already paid tax on more than their total profit. The Court decided in favour of the Crown. Lord Esher said that in the Act of 1842 there was not any such section as section I of the Act of 1853, which dealt with interest as a distinct subject of taxation. This seemed to point to an intention to alter the law. Then in Schedule D came the words that the duties were made payable " for and in respect of all interest of money." Looking at these plain words he could not see his way to limiting them to interest made in a trade or business. The words must be read in their ordinary sense, and duty would be chargeable.

Following the result of their application under sec. 23 of the Act of 1890 (post Chapter VI.), the Edinburgh Life Insurance Co. claimed (Revell v. Edinburgh Life Insurance Co., Court of Session, Scotland, 28th June 1906) that, as it had been held in a prior application under the Act of $189^{\circ}$ that taxed interest must be included, they should not now be called upon to pay on untaxed interest, the former having (as in the Clerical case), largely exceeded their profit. 
The Court gave judgment for the Crown, holding that the claim under the Act of 1890 could not affect the question.

In Glamorgan Quarter Sessions v. Wilson (K.B.D., 8th March I9IO) the question was raised as to the liability to tax in respect of bank interest on moneys in the hands of the licensing authority.

The Court held that the amount was assessable; that the Act of 1888 gave an additional remedy to the Crown, and that even if the bankers should have deducted the tax that did not prevent the Crown recorering it from the recipient.

The question has been raised in practice whether a company which issues debentures for interest in lieu of payment thereof in cash should pay tax on the full amount of the interest, though the debentures may not be negotiable at par. In such cases we believe that tax has been required to be paid in full. This seems the most convenient method to adopt, as all such debentures will, no doubt, become repayable at par at some future date, and if tax were not paid on the par value it would involve an adjustment at a distant date, and, in many cases, from a person not the original holder of the debenture.

But where preference shares were so issued to the Manchester Corporation in respect of debenture interest due by the Manchester Ship Canal, the Corporation were successful before the Commissioners (1907) in their contention that they should only pay on the market value of such shares ( $55^{\frac{3}{4}}$ per cent.).

Debentures issued for interest.

Deduction of tax on nominal amount. 
Paper issued In.lieu of preference ilvidend.

Scottish Mortgage, sc. Co. $v$. McKelvie.

Financial company recelving interest abroad may be assessed under either first or

Pourth case.
The position in respect of paper issued in lieu of arrears of preference dividend is even stronger than that in respect of paper issued in lieu of debenture interest. In the one case the claim of the Crown arises under the Act of 1888 in respect of interest and annuities (practically) paid, but not paid out of profits. In the case of preference dividend, however, the right of the Crown can only be for tax on profits (the Act not applying to diviajends), and where there have not been any profits surely a claim could not be established. This view is supported by the fact that the Crown abandoned such a claim (without any legal action) which they had preferred against the Entre Rios Railways Co., Lim., in 1905 .

In The Scottish Mortgage and Land Investment Company of New Mexico, Lim. v. McKelvie (Court of Session, Scotland, I 9 th November I886) the facts were that the company was formed for the purpose of borrowing money here and lending it abroad. The Profit and Loss Account was as follows :-

$$
\mathrm{Cr} \text {. }
$$

Interest of money, received in the United States $\ldots £ 6,926 \quad 5 \quad 2$

Transfer fees $\quad \ldots \quad \ldots \quad$ 2 12

$$
\text { Dr. }
$$

Management expenses in the States

$$
\ldots \quad \cdots £ \text { I } 193 \quad 5 \text { ro }
$$

Management expenses at

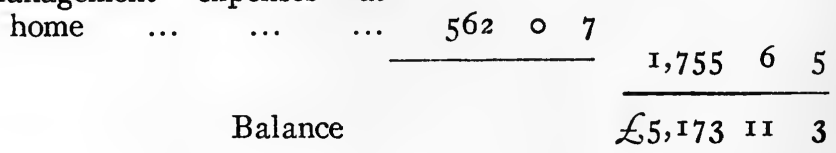


This was applied as follows :-

Interest on debentures ... £.3,094 i 8 I

Dividend to Shareholders... $700 \circ \circ$

To extinguish debit balance, I 883

$$
\begin{array}{cccccc}
1883 \quad \ldots & \ldots & \ldots & 499 & \text { 10 } & 7 \\
\text { Preliminary expenses } & \ldots & 508 & 5 & 5 \\
\text { Carried to next year } & \ldots & 370 & \text { I } 7 & 2
\end{array}
$$

Scottish

Mortgage,

\&c., Co. $v$.

McKelvie.

Financial

company

receiving

interest

abroad may

be assessed

under either

first or

fourth case.

The interest received in the States was not actually remitted to this country, but it was entered in the books, and when money was raised here for the purpose of lending there, a corresponding amount was retained, and the dividend, \&c., paid out of it.

The Surveyor contended that the interest was, in effect, received here, and he sought to assess the company under the fourth case of Schedule D (charging interest arising from foreign securities upon the full amount receired in the United Kingdom-without any deduction).

The company claimed that they should be assessed under the first case of Schedule D (charging the profits of trades, \&c.) in respect of their trade of bankers, \&c.; or, alternatively, that if they were assessable under the fourth case it could only be on interest actually received in the United Kingdom, and that there had not been any received.

The Court held that, with the exception of the balance carried forward, the interest was in effect received here. If, in the process of bookkeeping, it had not been converted into 
Scottish Mortgage, dc., Co. $v$. McKefvie.

Financial company receiving interest abroad may be assessed under either first or fourth case.

\section{Smilles $v$.}

Northern

Investment

Company of

New Zealand,

Lim.,

following

Scottish

Mortgage

and Land

Investment

Co. $v$.

McKelvie. income, then the payments made out of that money were payments out of capital, and illegal. They had entered it in their books as interest, and paid it away as such. The company might fall either under the first or the fourth case, and, that being so, the Commissioners might choose the more favourable to themselves. See, however, Norwich Union Fire. Insurance Company v. Magee (p. 195). They did not see why the expenses at home had been allowed as a deduction, but the Inland Revenue had allowed them, and the company would therefore have the benefit

In Smiles (Surve yor of Taxes) v. The Northern Investment Company of New Zealand, Lim., it was held by the Court of Session, Scotland (31st May 1887), following The Scottish Mortgage and Land Investment Company of New Mexico, Lim., v. McKelvie, that a company carrying on the business of borrowing money in this country and investing it abroad, could be assessed either under the first or fourth case of Schedule D. In this case the company had been assessed under the first case from 1880 (the year of incorporation) up to and including the year $1885-86$; and it was for this last year that the Commissioners surcharged them on the difference between the profit as originally assessed under the first case, and what it amounted to under the fourth case. This was upheld by the Court.

\section{Lord Mure said :-}

"I see no other course. The case is specifically mentioned as the fourth case in Schedule D of section roo of the Act; and that is what we decided substantially in the case of the Mexican Company. It is desirable that uniformity of decision should be 
kept up in these sort of cases, even if it was possible that there was alternative power to take it under the rules in the first case; but here it has been actually decided in a case substantially the same that it should be under the fourth case, and I think there should be uniformity, and that the Commissioners are wrong in departing from that rule."

In Smiles (Surveyor of Taxes) v. The Australasian Mortgage and Agency Company, Lim., a Scottish limited company carried on business as wool-brokers in Australia, and made advances of money, the interest accruing being of fluctuating amounts. It was held by the Court of Session, Scotland, I2th July I888 (distinguishing Scottish Mortgage and Land Investment Company of New Mexico, Lim., and Northern Investment Company of New Zealand, Lim.), that the company should be assessed under the first case in respect of its whole profits, including interest received from its investments in foreign and colonial securities; and that it was not separately chargeable for interest under one rule and profits under another.

The Court were very strong in their judgment that the cases were absolutely distinct. The fourth case was, they considered, to meet the case of an investment abroad.

In Last v. London Assurance Corporation (Queen's Bench Division, I4th March, I884) it was held :-

(I) That the profits of the three branches of the company's business (fire, life, and marine) were to be treated as

Last $v$. Assurance Corporation.

Mode of ascertaining profit. a whole, and not dealt with as three separate businesses; and 
(2) That the profits of the life department for income tax purposes were to be arrived at by the usual quinquennial valuation, as, since each year's premium had relation to the whole duration of the life or risk, it could not be said that the profit or loss in any one year was the difference between the premiums received and the claims paid.

In this case a further point was raised (and ultimately carried to the House of Lords) as to whether bonuses paid or credited to participating policy-holders were liable to assessment. (See Part I. of this chapter, p. 98.)

\section{Insurance} Companies $v$. Surveyor of Taxes.

Fire and Life Insurance Co. profit.

In the

Scottish Union and National Insurance Company,

North British and Mercantile Insurance Company,

Northern Assurance Company, and Scottish Provincial Assurance Company,

$v$. Surveyor of Taxes,

heard before the Court of Session, Scotland, 8th February I889, the following rules were laid down with respect to the mode of ascertaining the profit chargeable in the case of an insurance company carrying on both fire and life business :-

(I) The net profits from both branches to be massed together, and the company to be assessed under the first rule of Schedule D (charging duty in respect of any trade, manufacture, adventure, or concern in the 
nature of trade). This followed Smiles $v$. The Australasian Mortgage and Agency Company, Lim., as contrasted with The Scottish Mortgage and Land Investment Company of New Mexico., Lim. v. McKelvie.

Insurance Companies
Surveyor of Taxes.

Fire and Life Insurance Co.

Mode of ascertaining profit.

(2) Interest on investments received without deduction of tax to be taken into account.

(3) As fire policy contracts are usually for one year only, the premiums received for the year, or average of three years after deduction of losses and expenses during the period, may fairly be taken as the profit of the fire department, without any allowance for risks unexpired. (See The Imperial Fire Insurance Company v. Wilson, the General Accident case, and the Sun case, post.)

(4) The profit of the life department, on the other hand, to be obtained by actuarial calculation.

(5) Profit on investments realised to be brought into account.

In the case of Scottish Investment Trust Company, Lim. v. Forbes, the company claimed that they should not be assessed to income tax on "profits on sales of securities during the year." In the books of the company these profits were written off against depreciation in the book value of other investments. They maintained that varying their investments was incidental to, but not one of, the real objects of the com-

Scottish Investment Trust Co. $v$. Inland Revenue, following Northern Assurance Co. $v$. Surveyor of Taxes.

Profit on sale of securities. 
Scottish

Investment Trust Co. $v$. Inland

Revenue,

following

Northern

Assurance

Co. v.

Surveyor of

Taxes.

Profit on saie of securities.

Depreciation in value of securities. pany, and that any profit derived therefrom was not divisible among the shareholders, but went to equalise any loss on the capital, which was to be treated as a whole.

The Court of Session, Scotland, held (I 2 th December I893), following Northern Assurance Company v. Surveyor of Taxes (p. 1.90), that the sum in question was truly profits, and was subject to income tax, and that its application by the company was immaterial.

It will be noticed that these two decisions recognise the principle that profits and losses on the realisation of investments made as part of the business of a concern are to be brought into account.

In the Scottish Investment Trust case it was shown that the depreciation in the value of the investments was permanent, and the decision, in effect, therefore, lays down the rule that, in the case of a pure investment trust-as this company wasa permanent depreciation in market value is to be disregarded for income tax purposes. It is not absolutely clear that a permanent depreciation in the value of an investment could never be taken into account, but the weight of authority supports such a view, and, in any case, it would be exceedingly complicated to allow one class of depreciation and not another; also the question of appreciation would have to enter into account if depreciation were seriously asked for. It also seems fairly clear that a surplus or deficiency on sale of premises (even in the case of a bank or insurance company) is not a profit or loss for income tax purposes. 
In Forbes v. Scottish Provident Institution, and Forbes v. Scottish Widows' Fund and Life Assurance Society, the facts were as follows. These societies (which are both mutual) lend out sums of money in Australia at interest. The interest accruing is not remitted to the United Kingdom specifically, but is retained abroad and invested. (In the latter-named case, part of the interest was applied to cover the expenses of the office in Sydney.) The interest is, howerer, entered in the Revenue Account of the society. The insurance business is entirely a home one, and the agencies outside the United Kingdom are purely for the purposes of inrestment of its funds. The companies contended that the interest had not been received in the United Kingdom, and that, as they fell to be assessed under the fourth case of Schedule D (charging interest arising from foreign securities upon the full amount received in the United Kingdom), there was not any tax payable thereon. The Surveyor desired to assess the interest under the first case (charging profits), or as "yearly interest" under sec. 102, and argued that, even if the claim came under the fourth case, there was a constructive remittance and the amount was chargeable. The claim under the first case was ultimately abandoned by the Crown, but only on the ground of it being considered that the facts stated in the cases were not sufficient. Judgment was giren in the Court of Session, Scotland, I 7 th December 1895 . 'The Court said the claim of the Crown rested alternatively on sec. 102 of the Act of 1842 and the fourth case of Schedule D. The argument under sec. ro2 
Forbes $v$. Scottish Provident Institution, ac.

Interest received and retained abroad.

Sec. 102 not a charging section.

was admittedly novel, and involved surprising consequences. It amounted to contending that the section subjected to duty all interest, disregarding the distinction drawn in Case IV. (the only case dealing with income from foreign securities) between what is received here and what is only received abroad; in other words, that it subjected to tax a class of profits, \&c. (i.e., foreign income not remitted here), not included in Schedules A, B, C, D, or E. The answer to that argument was twofold. First, the actual statute under which duty was charged was the Customs and Inland Revenue Act 1893 , which charged the profits, \&c., charged under Schedules A, B, C, D, and E of the Act of 1853 . If, then, sec. 102 charged profits, \&c., not covered by the lettered schedules, it was not in force during I893-4. It appeared, however, that sec. 102 never had that effect. It was so expressed as, in terms, to charge with duty, but the general words used were, in truth, introductory to the provisoes, and they were general because they were introductory, and, therefore, did not rehearse the limitations which had been already expressed.

The Court was, therefore, against the Crown on sec. Ioz.

They were likewise against them on Case IV. of Schedule D. The colonial interest, they said, was left where it was. There was not a constructive remittance. The fact of recording the amounts would never make interest " received in the United Kingdom." The Scottish Mortgage Company of New Mexico v. McKelvie (p. I86) was totally different. The 
money there could only be said not to have been received if money sent home by bill is not received in this country, or if no colonial interests are received in the United Kingdom which do not reach it in specific form. This being the decision, it became unnecessary to decide whether the expenses of the Sydney office (in the Scottish Widows' Fund case) were legitimate deductions.

\section{In Norwich Union Fire Insurance Company v. Magee} (Queen's Bench Division, I3th and I4th January I896) it was held that interest on American securities brought to account in the books of the company, but invested in America in American securities (in order to build up a reserve, as required by the laws of the United States), forms part of the profit of the company assessable under Case I. of Schedule $\mathrm{D}$, and that the interest is in effect received in this country. Wright, J., said :-

"If there is a trade which cannot be carried on without making investments abroad, the interest arising on the investments necessarily made for the purposes of the trade is, as it seems to me, part of the gains of that trade."

With respect to the case of Scottish Mortgage Company v. McKelvie, he said :-

"The Scotch case of McKelvie has been referred to as an authority for saying that the Crown may elect under which case it will tax the subject. I doubt if it is an authority for that proposition to its full extent. It is, no doubt, an authority for the proposition that, if a particular company is clearly within Case IV., the Crown may tax it under Case IV., even though it may also be under Case I.; but I doubt whether it is an authority for the converse proposition altogether. I doubt 
whether the Crown could always elect to tax under Case I., if the company were clearly under Case IV. I do not say whether it is so or not. I only say it seems to me doubtful whether the Scotch case decided the proposition which the Attorney-General has stated in its full entirety."

Universal

Life

Assurance Society $v$. Bishop, following New Mexico case.
Standard Life Assurance Co. v. Allan, following Scottish Provident case.

In Universal Life Assurance Society v. Bishop (Queen's Bench Division, 23rd and 24th March, and Irth August r899) the Court held that interest received in India and used inter alia for the payment of its obligations there was constructively remitted to England, and was therefore chargeable. The Court considered the facts fell within the Scottish Mortgage Company of New Mexico v. McKelvie and Norwich Union Fire Insurance Company v. Magee. That Forbes v. Scottish Widow' Fund and Life Assurance Society and Forbes v. The Scottish Provident Institution were distinguishable on the facts, as in neither of the latter cases was the interest received abroad treated in any division of profits (as was done in this case) as forming part of the divisible profits ; it was simply retained and used abroad for purposes of loans and investment. See, however, the Gresham case, decided in the House of Lords (post).

In the case of the Standard Life Assurance Co. v. Allan (7th and 8th March and 3oth May 1901) the Court of Session, Scotland, considered the facts fell within Forbes v. The Scottish Provident Institution, where the Court, rightly, they considered, had held that there was not a constructive remittance to this country. 
Scottish Provident Institution v. Allan (House of Lords, Scottish 3 oth April 1903) was another case where money was remitted Institution to Australia for investment, and certain sums remitted to Scotland. The Court of Session had held (distinguishing Scottish Provident Institution v. Forbes, p. I93) that the interest was assessable.

\section{The Lord President said :-}

"It appears to me that, under the circumstances, indefinite remittances to this country must be presumed to consist of interest, not of capital, so long as the amount of capital remitted to Australia for investment still remains invested there."

The House of Lords affirmed the decision, approving of the above view.

So far as one can judge from the report of the case, it must have been a weak one to contest. For example, it was sought to allocate one sum of $\mathcal{E}_{25}$,000 as capital under the following circumstances. The amount was remitted to Australia for investment 2 Ist May I886; it was repaid Ist June I89I; on rst February I898 three sums of $£ 25,000$, $\mathcal{E} \mathrm{10}, 000$, and $£ 9,000$ were remitted home. Accompanying the draft for $\AA^{25}, 000$ was the following statement :-

"For your guidance in dealing with the Inland Revenue Department, the above amount represents proceeds of the draft of $£ 25,000$ drawn by the attorneys of the institution on 2 Ist May ı $886 . "$ 
Gresham Life Assurance Soclety $v$. Bishop.

Interest must be actually recelved.
The only item upon which the institution succeeded was a sum of $£ 5,000$ cabled direct to England in 1898 by one who had borrowed $£ 70,000$ in 1886 . It was, perhaps, straining the law a little to decide against the institution that a sum of $\mathcal{E}^{28,000}$ remitted home on 16 th November was not the same $\mathcal{E}^{28,000}$ as a similar amount which had been repaid on the 14 th November.

The words of Lord Davey in the London County Council case seem to be particularly applicable to this case. "It is difficult to see how any account-keeping by the debtor could alter the rights of the Crown."

The question of "constructive remittance" has been largely cleared up by the decision of the House of Lords in the case of Gresham Life Assurance Society v. Bishop (I 7 th February, 3rd and 6th March, and 16th May 1902). Their Lordships were unanimously in favour of the Society, and held that the amount must be actually received here to render it liable to tax. The Lord Chancellor said :-

"The difficulty of identifying the actual sum is no limit on the enactment. . . . If the Legislature had intended that bringing it into account was to be equivalent to its being received, it would have been easy to say so."

Lord Macnaghten and Lord Shand both considered that the New Mexico case (ante p. I86) was rightly decided. Lord Brampton was not satisfied that this was so, but in any case considered it distinguishable. He said he did not like the expression " constructive" remittance; if a "constructive" receipt was the same as an actual receipt, there was no reason to use the word "constructive" at all ; and if it meant 
something different from, or short of, actual receipt, then it was not recognised by the statute, which, in using the word " received" alone, must be taken to have used it in its ordinary acceptation.

Lord Lindley considered that the cases of Forbes $v$. Scottish Provident Institution (ante p. 193) and Standard Iife Assurance Co. (p. I96) were both right.

He considered the New Mexico case was distinguishable, but, assuming it not to be so, he thought it would be more correct to overrule it than to decide this appeal in favour of the Crown.

In the case of The Scottish Widow' Fund and Life Assurance Society (Court of Session, Scotland, I8th June I909) it was held that where coupons were sent to America, Scottish Widows'case.

Interest "received" here? cashed there, and the proceeds invested in bonds which were then transmitted here, the interest was not "received" here.

\section{In Liverpool and London and Globe Insurance Co.v.} Bennett it was sought to establish that dividends received and retained abroad were not part of their profits for income tax purposes.

The Court held (K.B.D., 3oth March rgrI) that the investments were clearly made as part of the business of the company, and that their contention was untenable.

In view of the Gresham decision, the remarks of the Lord President (in the Court of Session) in the case of Scottish Principle to apply. 
Principle to apply.
Insurance companies.

\section{Application}

of legal

decisions to

cases in

practice.
It may be noticed that the Scottish Provident Institution is purely a home business, and there are not any premiums received abroad. The actual application of the principle, particularly in the case of a company also carrying on a foreign business, may yet involve complication and difficulty. For example, see the case of the Odessa Waterworks (ante, p. I07).

The application of these cases in practice is as follows :-

In recent years it has been found that the form settled in the London Assurance case (p. IOI) is open to improvement, and the following is generally used :-

$$
\text { YEAR I9II-I2: }
$$

\section{YEAR 1908.}

Marine Account Profits, less Expenses $\quad \ldots \quad \ldots \quad \ldots \quad \ldots \quad £$ roo,, 00

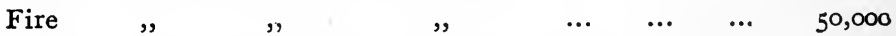
Profits on Realisation of Securities (except on Life $\begin{array}{lllllllll}\text { Account) } & \ldots & \ldots & \ldots & \ldots & \ldots & \ldots & \ldots & 5,000\end{array}$

Deduct Life Account Deficiency, viz.:I 55,000 Surplus at Quinquennial Valuation, $3^{\text {rst }}$

$\begin{array}{llllllll}\text { Dec. } & 1907 & \ldots & \ldots & \ldots & \ldots & \ldots & £ 3^{10,000}\end{array}$

Less Balance undivided at previous

$\begin{array}{llllll}\text { Quinquennium } & \ldots & \ldots & \ldots & \ldots & \text { го, } 0 \text { o }\end{array}$

The Taxed Interest received on Life

$$
300,000
$$

Account during the five years being

$$
\begin{array}{lllllll} 
& \cdots & \cdots & \cdots & \cdots & & 950,000 \\
\text { Deduct } \text { one-fifth of Deficiency } & & & 650,000
\end{array}
$$


Untaxed Interest for the year (foreign interest), whether received in the United Kingdom or not (other than on Life Account) and not included in above profits ...

It will be noticed that in the first form one-fifth of the quinquennial surplus is taken, and taxed interest for each of the three years is deducted. The net result of this is, firstly, to include one year's taxed interest on an average of a certain five years, and then to deduct one year's taxed interest on an average of certain other three years. For this reason it is felt that the second form is the more appropriate, as it has the effect of simply eliminating the exact amount of taxed interest which has been originally included.

The authorities claim, under the Scottish Mortgage case, that they have a right to assess a company either under Case I. or Case IV., and they act, naturally, upon the principle of adopting the case most advantageous to themselves, and also of changing from year to year. Doubt has, however, been expressed in the Norwich Union case whether the case does really go so far as this. Of course, mutual societies or companies do not come under Case I., and it is very arguable that that is one of the reasons why Case IV. was inserted in the Act-viz., to provide the extent of the liability of a person receiving interest from abroad but not trading. 
Insurance companies.

Application of legal decisioas to cases in practice.

Interest taxable as such.
"Receipt" in United Kingdom.
Where interest has been taxed at the source, or annual value has been paid upon, both are, of course, allowed as a deduction from the surplus before charging the profit for assessment to Schedule D.

It remains clearly laid down by the Court of Appeal that interest is taxable as such, and irrespective of whether there is any profit or not, and it must be paid upon, even though there either be a loss (subject to an exception, which we will deal with later), or if tax has already been paid by way of deduction on an amount in excess of the total net profit.

The construction of the Gresham case is likely to be the most troublesome thing which insurance companies will have to face in the future. We have seen that the Crown, firstly, require a return under Case I. They claim that this must include all foreign interest, whether received in the United Kingdom or not.

It would appear impossible to controvert this after the test applied by the House of Lords in the San Paulo case (p. 8r), and see Liverpool and London and Globe case (p. 199).

Referring to the pro form $\hat{a}$ account it will be noticed that all untaxed interest is included, whether received here or not, and we get an average of $£ 50,000$. Assume the same result year by year, and the whole of the $£ 60,000$ remains abroad.

Ten years later $£ 600,000$ comes home. The average under Case I. is still $£ 50,000$, so the Revenue turn round and charge under Case IV., but they are faced with the difficulty 
that the foreign interest now received has already been taxed year by year as profit.

Again, assume in the case before us that the whole untaxed interest in 1910 is $£ 60,000$, and that it is received here, though the average profit is $£ 50,000$. Then we are (as mentioned) called on to pay on $£ 60,000$. For future averages $£ 10,000$ of that interest (viz., the excess of interest over profit) is to be regarded (naturally) as taxed, and on the figures given the profit of the year would be $\mathcal{E} 50,000$, but this causes a departure from the usual practice of the authorities-viz., not to disturb past accounts.

Again, if in a given period a company receive $£$ roo,000 from abroad and remit $£ 60,000$ back, have they " received" $£ 100,000$ of interest (see the Scottish Provident case), or have they only received $\mathcal{E} 40,000$ ? The Lord Chancellor evidently realised the position to some extent when he spoke in the Gresham case of the diffculty of identifying the actual sum.

In The Imperial Fire Insurance Co. v. Wilson (Exchequer Division, 28th and 29th January 1876 ) the company sought deduction in respect of unearned premiums. They contended Imperial Fire Insurance Co. v. Wilson. that, on an average, 33 per cent. of the year's premiums was in respect of risks which had not run off. It appeared that they were not in the habit of so treating the premiums in the books, and this was the first occasion on which they had endeavoured to do so for income tax purposes; and judgment was given for the Crown. The Court said that they gave 
Imperial Fire Insurance Co. v. Wilson.

Unearned premiums disallowed.
Car, dc., Insurance Corporation.

Unearned premiums allowed.
General Accident Corporation v. McGowan.

Unearned premiums disallowed. that decision with some reluctance, but there was not any power in the Act to make up the assessment in the manner desired ; and, taking one year with another, the only injustice that could be done would be in the first year. If ever the company discontinued business they would have a remedy in respect of the last year under sec. I34 of the Act of 1842 .

It is submitted that the decision is unsound. The headnote speaks of a deduction from "profits" for unearned premiums. The deduction is from receipts before arriving at profits, and is no more from profits than a deduction of any ordinary liability from gross trading receipts is.

In connection with a claim by the Car and General Insurance Corporation, Lim., in 1905 , for deduction for unearned premiums, the Surveyor (after considerable correspondence) allowed the same, because it was provided for in the accounts of the company, and, as the premium income was rapidly increasing, the receipts obviously referred to the succeeding year. The authorities, however, are rejecting (at least) all such claims where the amount is not provided for in the accounts.

In General Accident, Fire and Life Assurance Corporation, Lim. v. McGowan, Surveyor of Taxes (House of Lords, 8th April 1908), a claim for unearned premiums was disallowed.

The case, however, seems to have been decided on particular facts. The Lord Chancellor pointed out that it was 


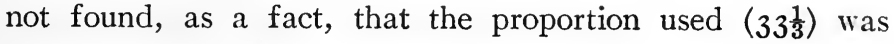
correct, and that the accounts, so adjusted, showed any more accurate result than was shown without such adjustment. $\mathrm{He}$ thought such adjustment should be granted in any case where it was shown that the real profits and gains would not be shown without it.

In Clark v. Sun Insurance Office the King's Bench Division held (on the finding of the Commissioners that 40 per cent. Clark v. Sun Insurance Office. of the premiums was a reasonable amount to carry forward) that the case was distinguishable from the General Assurance case, and they therefore allowed the deduction-but this was overruled by the Court of Appeal (roth April I9II), who considered themselves bound by the General Assurance case.

Cozens-Hardy, M.R., said that, apart from authority, he would have agreed without hesitation that a properly ascertained percentage would have been a legitimate deduction, but, in his view, the House of Lords had decided on the general principle that it was not so; and he did not feel justified in distinguishing this case from the General Accident case, because the deduction had actually been made by the Sun Company and had not been made by the General Accident Company.

Fletcher Moulton, L. J., expressed the same view absolutely, saying it was "painful to give the stamp of judicial authority" to something which could not be supported by 
Clark v. Sun Insurance Office.

the practice of the most intelligent and honourable members of the mercantile community. The decision of the Court must be in favour of a course of treatment for income tax purposes which, if acted upon financially, would probably be a gross fraud, and had, as a fact, been held at least to be a grave fault, and one which involved directors in damages. The history of the decisions on the point had been unfortunate, as in erery case the companies had contended for an income tax treatment different from what they themselves adopted. He hoped that, if this case went to the House of Lords, they would feel themselves capable of putting the matter on a more satisfactory footing.

Buckley, L.J., was of the same view. He could give reasons for "distinguishing" this case from the General Accident case, but, as he did not agree with that decision, he was suspicious of himself. On the whole he thought it better for this case to go to the House of Lords, for them to say whether their decision was on the whole principle or whether the cases were distinguishable the one from the other.

Insurance companies.

Application of legal decisions to cases in practice.

Annuities payable by
A life office is bound (under the Act of r888) to deduct tax from the annuities payable by them, and to account for the same to the Crown; they may, however, be considered to be payable pro tanto out of the taxed income of the Annuity Fund, and the amount of tax to be accounted for will be regulated accordingly. 
In Edinburgh Life Assurance Company v. Lord Advocate (House of Lords, 9th, 2oth and 2 Ist July and 9th December I909) the question arose as to whether or not the company were to account to the Crown for tax deducted from annuities. Edinburgh Life Assurance Co. V. Lord Advocate. The receipts for the quinquennium to 3 Ist December I907 were :-

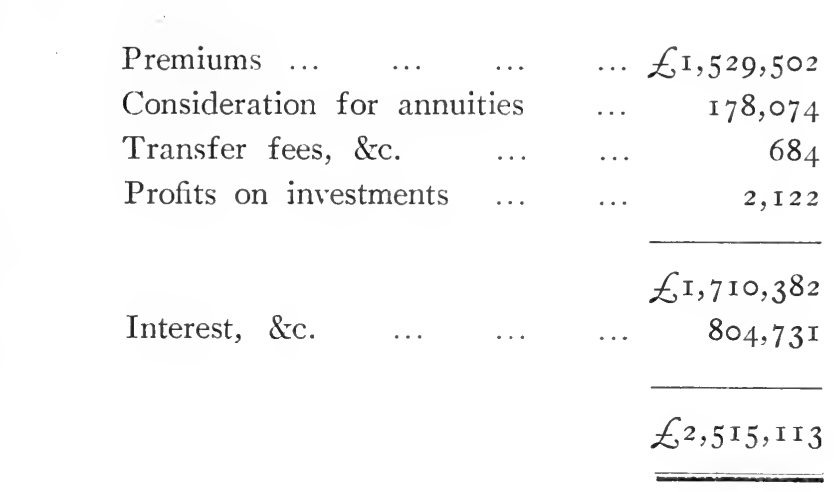

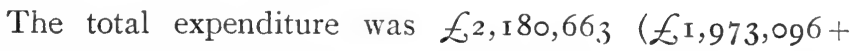
increased liability $£_{207,567)}$, of which $£_{1} 68,204$ was management and $£^{218,463}$ payment of annuities. The surplus was therefore $£ 334,45^{\circ}$, after crediting the taxed interest of $£ 804,731$.

The decision of the First Division was that the annuities were to be treated as payable pro ratâ out of taxed income and out of other receipts, and that tax on the latter proportion must be accounted for.

The House of Lords reversed the decision and decided in favour of the company. 
Edinburgh

Life

Assurance

Co. v. Lord

Advocate.

Tax on

Annuities.

\section{Lord Atkinson said :-}

"In my opinion, where annuities such as these are charged upon a tax-bearing fund amply sufficient to pay them in full, though not set apart for that purpose, they cannot be held to be 'not payable' or 'not wholly payable' out of gains and profits brought into charge within the meaning of the 24th section (Act of 1888 ). For the purposes of that section I think that the interest on annuities charged upon the tax-bearing fund must under such circumstances be treated as payable out of that fund, so far as it will reach."

Lord Gorell said that the question appeared to be whether the fact that the annuities were not payable exclusively out of profits charged prevented the company from having the right of deduction and retention. There did not seem to be any authority for the proposition of the learned Judges of the First Division that, because there were two funds, the liability must be apportioned rateably. They might pay out of whatever of the funds they pleased. The argument that it had not been shown that the annuities had been paid out of taxed income would, he said, seem to make the rights of the Crown depend upon the bookkeeping of the company; but this could not be, "nor do I think," he said, "the liabilities of the company can be made to depend upon their system of accounts.'"

Arrangements have been made with some offices for annuities to be paid in full in certain cases where the annuitant is in receipt of not more than $£$ r6o per annum. In order to obtain the benefit of this concession, the following form has to be filled up annually by the annuitant and 
an account of income later on, if called upon, and a list of all such annuities has to be forwarded by the company to the authorities together with the forms.

Edinburgh

D. ANNUITIES-INCOME TAX.

YEAR I- -

Name of Life Insurance Company

Address

I declare that the total amount of my Income from all sources does not exceed $\ell^{160}$ per annum for the current year $I \ldots$, and $I$ request that my Annuity of $\ell-$ may be paid to me in full, without deduction of Income Tax, with the understanding that, when called upon to do so by the Surveyor of Taxes, I am prepared to furnish on the usual official form proof of my title to the exemption hereby claimed.

*This form is not applicable to annuities payable to married women who can only obtain exemption on Form No. 38 through theSurveyor of Taxes. Lady annuitants who sign this form must therefore state distinctly that they are either widows or spinsters.
Signature of Annuitant*

Address

Occupation

For exemption and abatements generally, and the reason for the note as to married women, see Chapter VIII. 
(I) Annual payments of fixed amount, or being a fixed share of profits, are assessed on the person making the payment in the same way as interest.

(2) An author, playwriter, or artist selling copyrights, \&c., to publishers is chargeable on the amount received less his expenses; if sold on royalty, the whole amount of the royalty is chargeable.

(3) No charge is made upon a person who has an isolated transaction of such a nature; it is looked upon as capital.

(See also Finance Act 1907 as to Royalties for use of Patents, p. r49.)

Mr. E. E. Nott Bower (Commissioner of Inland Revenue) stated before the Income Tax Committee which sat in 1904 that the aim was to tax the whole profit, and it was for vendor and purchaser to arrange together how it should fall upon each of them. They tax the whole of the copyright in the hands of the author, and that being the case, to avoid taxing it twice they allow the amount as a deduction in some shape from the publisher's profits.

Mr. Nott Bower's words may be of use to us on other matters :- "The District Commissioners are very unwilling, as Mr. Gayler has said, to tax the same profits twice, and so is the Board of Inland Revenue." Probably this 
coincides with the experience of most of us, but the expression is worth emphasising. If we have grievances it is more in the nature of taxing once something which, we think, should not be taxed at all.

As an illustration take the case of Strong $v$. Woodifield (post).

With respect to diminished value by reason of wear and tear, in the case of Caledonian Railway v. Banks (Surveyor of Taxes) the Commissioners had refused to grant an allowance under the Act of 1878 , on the ground that there was not any diminution of value within the meaning of the Act, the sums allowed in respect of repairs and renewals having been sufficient to meet the loss by wear and tear. They had also refused to grant any allowance under the Act for wear and tear of new plant which had not been in need of repair. It was stated that, during the first five years of the life of locomotives or carriages, they did not require any repairs. At the expiration of this time they were considered to be worth 75 per cent. of the original cost, and allowance was claimed in respect of this assumed depreciation of 25 per cent. The decision of the Commissioners was upheld by the Court of Session, Scotland (6th July and $4^{\text {th }}$ and I8th November ז880). Lord Justice Clerk said :-

". . . The ground on which the Special Commissioners seem to have proceeded is the alleged and assumed fact that, during the first five years of the life of a railway locomotive or carriage, it requires no repairs, and is, therefore, of the same value-that is, capable of earning the same amount of income-as when it was new. That manifestly is a principle quite capable of being maintained, and, in my apprehension,

Wear and tear.

Caledonlan Railway v. Banks.

Allowance to be wear and tear of the year on which profits ascertained. 
Wear and tear.

Caledonian Railway $v$. Banks.

Allowance to be wear and tear of the year on which profits ascertained.
London

County

Council v.

Edwards.

Tramway. it is sound. The view seems to be this. The whole expenditure in repairs and renewals of old plant has been allowed for, and there is no diminution by wear and tear in the value of new additional plant for the first five years, in the sense of producing profit-that is to say, the plant requires no repairs. to enable it to produce the same amount of profit that it did at first; then it is clear that from first to last the plant has been in the position that it was at starting, and is capable therefore, of producing the same amount of profit by the same outlay, and ro more. If the Commissioners assumed that the expression 'diminished value,' in the rath section of the Act of 1878 , signifies value for the purpose for which it was intended in a going concern, I cannot say they were wrong in so holding. I do not think that the words had any reference to the value of the plant as merchantable or marketable articles, because its capacity to earn income constitutes its. sole value to the railway company, and is the only quality contemplated under the statutes relating to the taxation of income."

\section{Lord Gifford said :-}

- The company cannot get deduction for deterioration twice over, first by deducting the actual expense of repair and renewal, and then by deducting an additional estimate for the same thing. Nor will it do, as the railway company urge, to make a distinction between old and new plant, and to deal with the old plant in one way and with the new in another. I think the same principle must be applied to both. . . It is the diminished value by reason of wear and tear for the year to which section 12 of the Customs and Inland Revenue Act r878 relates."

The case of The London County Council v. Edwards was. heard in the King's Bench Division on the Ioth February Ig09.

The London County Council bought certain tramways, and in 1902 they commenced reconstructing them. Electric trams were first running in May 1903, and by March 1904 $3^{8}$ miles of single track were in work. 
Before acquisition it had been the custom to allow actual renewals in lieu of depreciation, and this method was continued by the London County Council up to and including the year $1903-4$.

On reconstruction heavier rails were laid. The London County Council did not ask for all cost of renewal, but only for so much as it would have cost to relay as before.

Of the 38 miles 5 were quite worn out;

I 5 had an unexhausted life of 6 years;

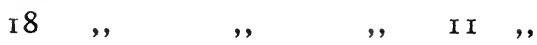

(equal to eight years all round), giving i 2 years exhausted on a computation of a 20-year life. It was proved that the cost of relaying as before would have been $£ 3,725$ per mile, and that the original cost had been more. They claimed r2-2oths of $£ 3,725$ per mile for 38 miles, or alternatively $£_{3,725}$ for five miles ( $\mathcal{I}_{18,625}$ ).

The Surveyor was prepared to allow $£ \mathrm{I} 8,625$, but no more.

Also 322 cars had been discarded. These had been bought in 1899 for $£ \mathrm{x} 60$ each. The present cost would have been $\mathcal{E}_{200}$ each. The electric cars cost $£_{5} 5^{\circ}$ to $£ 850$ each.

The London County Council claimed so much of $£^{6} 5^{\circ}$ or $£ 850$ as could be regarded as renewals on the basis of the cars not being quite worn out (say, $\mathcal{E}_{5}$ o each). 
London

County

Councll $v$

Edwards.

Tramway.

The Surveyor refused any allowance, on the ground that the cars were not thrown out on the ground of wear and tear, but of unsuitability.

The Commissioners gave judgment in favour of the views of the Surveyor.

Channell, J., gave judgment for the Crown. He said there was no question of law, but he did not wish to base his judgment on that. The difficulty arose from the change; had there been no change, " renewals" or "wear and tear" would have been about the same. The London County Council might have objected to the old method and asked for depreciation instead of renewals, but they had not done so. Clearly, there was no "wear and tear," and the London County Council, as a fact, had probably had more than they were strictly entitled to under the statute.

Depreciation of horses.
Depreciation of ships.

Burnley S.S.
In the case of (say) a carrying, or tramway, or omnibus company owning a great number of horses, of which a proper inventory is kept, it is suggested that the most convenient method is to write off the dead horses as such, and to depreciate the living ones, thus showing how much of the charge against profits is for actual loss and how much for depreciation, but no allowance will be made for horses not renerved.

The first reported case on the question of depreciation of ships is that of Burnley Steamship Company v. Aikin (roth July r894). The company are owners of the vessel 
"Burnley," which is a steel ship; they had been allowed a deduction for wear and tear of 5 per cent. on the diminished Depreciation of ships.

Burnley S.S. value. They appealed to the Commissioners, claiming a deduction of $7 \frac{1}{2}$ per cent., and asking that in deciding upon their claim the Commissioners should consider :-

(I) That ships frequently become obsolete and of less earning power before they are physically worn out.

(2) That their market or sale value might, and frequently did, fall below their value as fixed by the depreciation rate allowed in making the assessment, or even that proposed by themselves ( $7 \frac{1}{2}$ per cent.).

The Commissioners considered that the words of the Act of 1878 did not cover either of these cases, and they disallowed the claim of the company, and on appeal to the Court of Session the decision of the Commissioners was confirmed.

A similar question arose in Leith, Hull, and Hamburg Steam Packet Company v. Bain (Court of Session, Scotland, rst, and and r6th June I897). The Commissioners had allowed depreciation at $5 \frac{1}{2}$ per cent., being 5 per cent. on cargo steamers and 6 per cent. on passenger steamers (on diminished value), and the company appealed, claiming $7 \frac{1}{2}$ per cent.-viz., 7 and 8 per cent. respectively. The Court dismissed the appeal, holding that no question of law had 
Leith, \&c., Steam Packet Co. v. Bain.
Peninsular and Oriental S.S. Co.

v. Leslie.
Reviewing decision of Commissioners.

In conflict with Leith, ac., case.

British Indla, \&c., Co. v. Leslie.

Leith, \&c. Steam Packet Co. v. Musgrave.

Reyiewing decision of Commissioners. been raised. 'The Lord President said :-

"I am far from saying that it is the duty of this Court to accept an estimate of diminished value through wear and tear which can be shown either to have been made without rhyme or reason, or to have proceeded upon some demonstrably erroneous method of estimation. But where, as here, there is a whole fleet of steamers; where, as here, both parties argued for an estimate of the depreciation of the whole fleet instead of an appraisement of the depreciation of individual steamers; and where, as here, the choice is between $5 \frac{1}{2}$ per cent. and $7 \frac{1}{2}$ per cent., it is necessary that the appellants should be able to put their finger on the difference which makes the one right and the other wrong."

In the Peninsular and Oriental S.S. Co.v. Leslie the same question was again raised and a like decision was given (Queen's Bench Division, xst February 1898 , and Court of Appeal, 5th February 1900).

In the Court of first instance Wright, J., said that the Court had nothing to do with whether or not the Commissioners had based their allowance on the supposition that the amount allowed should be considered as invested at interest and fixed it accordingly. This view differs from that expressed in the Leith, $\mathcal{E}^{\circ} \mathrm{c}$. , case (post).

This decision was followed in the case of British India Steam Navigation Co., Lim. v. Leslie (Queen's Bench Division, 29th and 3oth November r9o0).

This principle (of reviewing the allowance) was well demonstrated in Leith, Hull, and Hamburg Steam Packet Co. v. Musgrave (Court of Session, Scotland). The Commissioners had allowed $5 \frac{1}{2}$ per cent. on the diminished value, and the company appealed. The case was argued before the 
Second Division of the Court on 2oth December 1898, and on the 27 th January 1899 was sent back for the Commissioners to amend it by stating-

(I) What period of years they assumed as the average Leith, \&c.,
Steam Packet Steam Packet Musgrave.

Reviewing decision of Commisduration' of the profit-producing life of the ships, having regard to their annual depreciation in value solely by wear and tear;

(2) Whether an allowance of $5 \frac{1}{2}$ per cent. on the value of the steamer (year by year) would of itself be sufficient to produce a sum at the end of the steamer's arerage life equal to the steamer's cost; and

(3) Whether in fixing the sum allowed for depreciation they took into account the probable return obtainable by the due investment of the sum so allowed.

The reply of the Conımissioners was :-

(I) That they had assumed 22 years as the average;

(2) That $5 \frac{1}{2}$ per cent. on the diminished value will itself amount, in 22 years, to $E_{7 \mathrm{I}} 3 \mathrm{~s}$. Iod. per cent. ; and if the money so allowed were used in trade to produce 5 per cent., the amount would be increased to $\mathcal{E I}^{\mathrm{I}}{ }^{8}$ 2s. 8d., also, if invested in Consols, say at $2 \frac{1}{2}$ per cent., it would amount to $\oint_{98}^{8}$ is. 2 d. That this left out of view the breaking-up value of the ship ; and

(3) That in fixing the deduction they had taken into account that the sum annually allowed might be 
Leith, \&c.,

Steam Packet

Co. $v$.

Musgrave.

Reviewing

decision of

Commis-

sioners. so invested as to produce a return of 3 per cent. per annum.

Judgment was delivered on the I6th June I899. Lord Trayner said that it had been said the Commissioners were not bound to state the grounds on which they arrived at their determination, and perhaps they could not be compelled to do so. But he thought it only consistent with their public duty - a duty as much to the taxpayer as the Crown-that they should do so if asked. In this case they had done so, and the Court was in a position to judge whether that determination was within their statutory powers or not-in other words, whether it was a valid exercise of their statutory powers. $\mathrm{He}$ agreed with the Commissioners in thinking that the purpose of the Act of 1878 was

"to allow the taxpayer such a deduction from the amount of profits annually realised as will fairly and reasonably represent the diminished value by wear and tear, during the year, of the plant used to produce these profits, so that when the plant is worn out he may be in a position to replace it by new plant or machinery of a like description."

But the Commissioners had not done this. The statute, he said, ciid not limit the deduction to such a sum as if invested at 3 per cent. would indemnify the person; it entitled him to the full amount of the depreciation, without condition as to how he disposed of it. The Commissioners were, therefore, wrong in taking the interest into account.

Judgment was given accordingly (see, however, Peninsular and Oriental S.S. case, p. 216$)$. 
In John Hall, Junr. \& Co. v. Rickman (King's Bench Division, 8th Decembe: 1905) the questions were raised (I) whether depreciation could be claimed where an owner Hall v.
Rickman. had already had the whole value of the ships allowed in past years; and (2), the same point with respect to a hulk, formerly a sailing ship, but which had been dismantled and was used as a floating warehouse. In the latter case it was contended that the hulk was not "plant."

Walton, J., said that the contention of the Crown was not unreasonable in' itself, but he had only to decide on the effect of the Act of 1878 . No agreement had been set up as between the owners and the Commissioners, and, that being the case, they must make a just and reasonable allowance for wear and tear. Nothing had been said by the AttorneyGeneral on the second point, and he himself held that it was "plant" within the meaning of the Act.

Now, howerer, see sec. 26 (2) of the Finance Act ${ }_{1907}$, ante p. 177 .

At the meeting of the Peninsular and Oriental Steamship Company in December I896, Sir Thomas Sutherland, speakExperience of P. \& 0. ing on the question of wear and tear, stated that between I870 and $1894-$ a period of 25 years-the company had sold for $£ 5 x 6,60 \mathrm{x}$ steamers of which the original cost was $£ 4,33^{6,362}$, and, further, that during the time in which these steamers had been in the company's service the amount of depreciation written off at 5 per cent. on the original cost, added to the amount realised by the sales, aggregated only E.4.267.621. as compared with the original cost as above. 
CHAP. VI.

After the decision in the case of the Pcninsular and Oriental S.S. Co. the Board issued another circular in lieu of that of September r895 (as per our Second Edition). The terms they are prepared to agree to are as follows, and have been, at least for the present, accepted by many shipowners :-

That for the year 1901-2, and in future, allowances for wear and tear be made on the basis of prime cost (in substitution for written-down value), without regard to the price paid on a change of owner.

That the revised rates of allowances on such prime cost be 4 per cent. in the case of passenger and ordinary cargo steamers, 3 per cent. in the case of sailing ships; the net expenditure, if any, incurred in the renewal of engines or boilers, as well as the cost of any structural improvements, to be added to the prime cost of steamers; the cost of ordinary repairs to be also allowed as a deduction.

Allowances at the revised rates to be made year by year until the cost of the ressel, less, of course, the breaking-up value -which for facility of computation may be taken at the rate of 4 per cent. in the case of steamers and 3 per cent. in the case of sailing vessels-has been recouped; and if in any year there be no profit, or not sufficient to exhaust the depreciation, the allowance will be correspondingly continued beyond the 24 or 33 years.

Should the total allowance be exhausted before the termination of the ship's life, and the ship subsequently change 
hands, the question of any future allowance which may be claimed for wear and tear should be specially dealt with by Circular by Board of the Commissioners, as also should any case in which, from exceptional circumstances, the revised normal rates may be insufficient to meet the requirements.

The allowance for refrigerators or refrigerating machinery is $6 \frac{1}{2}$ per cent. on the prime cost ; for oil tank steamers 5 per cent. on prime cost.

The Board consider that these rates leave an ample margin to provide for any deficiency which may occur in any particular year, or years, by reason of the absence or insufficiency of profits to cover the depreciation allowance.

The following is a summary of the Board's circular as to the arrangement they are prepared to enter into with gas concerns :-

I. No depreciation.

2. All renewals allowed, but not extensions.

3. Exceptional expenditure may go forward like unexhausted depreciation.

4. This to apply for $1908-9$ and old years which are awaiting settlement.

5. Computations to be recorded, whether any profit or not.

6. Depreciation which has been allowed and unexhausted (i.e., standing to credit) to be taken into account.

7. Disputes to go to the Board. 
222 SCh. D.-IVEAR AND TEAR-EI.eCTRIC UNDERTAKINGS. Chap. Vi.

As to electric undertakings they are prepared to agree as follows :-

Trams-

1. Life of permanent way.

If 50,000 car miles p.a. to be considered 16 years.

\begin{tabular}{|c|c|c|c|c|c|}
\hline 75,000 & , & , & , & , & 14 \\
\hline 125,000 &, & ," & , & g & 12 \\
\hline
\end{tabular}

2. Special circumstances (gradients, \&c.). Special consideration.

3. Renewals-

$£ 4,400$ per mile of single track until general renewal of track takes place.

4. No allowance for repairs or maintenance of permanent way, but an amount to be allowed, based as follows:-

$\begin{array}{llllllll}\text { Renewal } & \ldots & \ldots & \ldots & \ldots & \ldots & \ldots & £ 4,400\end{array}$

Estimated cost of repairs (£ 100 per annum) $\ldots \quad$ I,600

$$
\text { 1-16th } £ 6,000=£ 375
$$

5. Repairs to be arrived at on average of the last three years (or less if trams not running three years).

6. Repairs include renewals at junctions, \&c., which occur at frequent intervals.

7. Repairs allowance to be reviewed every five years.

8. An account to be kept, and in 10 or 15 years, or on general renewal, to be reconsidered, but no re-opening of past allowances.

9. No extensions and improvements allowed.

1o. These regulations apply to overhead trolley systems. Other systems to be specially considered.

Cables-

II. Repairs and 3 per cent. (diminished value) depreciation.

\section{Overhead Equipment-}

12. No depreciation. All expenditure on maintenance and renewals allowed. 
Cars-

13. Usually all expenditure on maintenance and renewals allowed.

14. But depreciation in lieu if circumstances justify it.

15. If so, 7 per cent. (diminished value).

16. Repairs allowed anyway.

General Plant-

17. Repairs and,5 per cent. depreciation (diminished value).

Gas and Water-

18, 19, and 20 as 1,2 , and 3 in case of gas concerns.

Electric Light.

Cables-

21. As II above.

\section{Plant-}

22. As 17 above.

\section{Conduits}

23. No depreciation, but all renewals.

Meters, Loose I'ools, and Office Furniture-

24. No depreciation, but all renewals.

\section{General-}

25. As 6 in case of gas concerns.

26. An account to be kept for special depreciation allowed. Renewals to be written back.

27. Defines "written downward" value.

28. As 4 in case of gas concerns.

29. As 5

30. As 6

3r. As 7

In agreeing to such arrangements it is obvious that concerns should take steps to guard themselves against changes, and to obriate the disadvantage at which the London County Council were placed with respect to their tramways (p. 2 I2).

Coming now to consider in some detail other claims for Deductions. deduction which have been the subject of decisions in the 
Deductions.

King's Lynn HarbourCommissioners.

Repayment of money raised to renew mooring chains allowed.

'In King's Lynn Harbour Mooring Commissioners (in the Exchequer Division, 9th June 1875) the facts were as follows:-The Commissioners had some years previous to I875 renewed 16 or 17 mooring chains at a cost of $£^{1}, 000$ or $£ \mathrm{I}, 500$. Money had been raised by bonds under their Act of Parliament to pay the cost, and the bonds were repayable, say, at $£ 400$ per annum. The question arose on the assessment for $1874-75$ whether $£ 400$ paid in discharge of bonds in that year could be deducted. The Commissioners regarded the $£ 400$, although not strictly belonging to the annual Revenue Account, as a proper deduction, inasmuch as it had been applied in the repayment of money expended in the renewal of works necessary for raising the income of the Commissioners, and this opinion was upheld by the Court.

It is clear that the $£^{\mathrm{I}, 000}$ or $£ \mathrm{I}, 500$ (being paid for renewals) would have been a proper deduction from profits in the year in which it was expended, and the allowance of the $£ 400$ annually simply spread the amount over three or four years.

Watney $v$. Musgrave.

In Watney v. Musgrave (Exchequer Division, IIth March r880) a claim for deduction in respect of premiums paid for leases of public-houses was disallowed. The contention was that the profits were increased by reason of the sale of liquor at the houses leased. The expenditure was, however, held to be an expense unconnected with the production of the article.

In the course of his judgment, Kelly, C.B., said that no doubt advertising increased the profits of a business, but he 
was not aware that any attempt had ever been made to deduct the cost of advertisements.

In practice, ordinary trade advertisements are allowed as Advertisements. a deduction, but where large sums are expended to push a particular thing the whole cost would not be allowed. It would be a matter of arrangement with the Surveyor or Commissioners, and we believe a liberal view is taken in such cases.

In Blake v. Imperial Brazilian Railway (Court of Appeal, ${ }^{1} 5^{\text {th }}$ and 17 th Norember 1884 ) the company had issued $5 \frac{1}{2}$ per cent. debentures, the interest thereon, and redemption, being secured by the Brazilian Government guarantee of 7 per cent. per annum for 30 years on the preference shares and debentures, the difference between the interest payable by the company and that receivable from the Government being applied as a sinking fund for the purpose of redemption of the debentures.

It was sought to establish that this difference was not a profit or gain, but was a contribution towards the making of the line, but the Court held (affirming the decision of the Queen's Bench Division) that the amount was clearly interest, and was assessable.

In Forder v. Handyside (in the Exchequer Division, 29th January 1876 , i.e., previous to the Act of 1878 ) a claim for allowance in respect of wear and tear of fixed plant and machinery was disallowed. 
Deductions.

Gillatt \&

Watts $v$. Colquhoun.

Depreciation of lease disallowed.

City of

London

Contract

Corporation v. Styles.

Portion of purchase money and interest paid disallowed.
In Gilliatt \& Watts v. Colquhoun (Queen's Bench Division, 17 th and r8th December I884) a claim for depreciation in value of a lease of premises year by year was disallowed.

An interesting question was decided by the Court of Appeal, roth November 1887 , in The City of London Contract Corporation, Lim. v. Styles. The company had, on the 5 th June 1882 , purchased a business consisting of partly executed and wholly unexecuted contracts. They claimed to be assessed on $\mathcal{E}_{4 \mathrm{I}}, 894$, being twelve months' proportion of $£ 45,386$, the profit for thirteen months from 5 th June 1882 to 3 oth June 1883 .

They submitted the following Revenue Account for the period :-

Dr. Revenue Account from 5 th June 1882 to 30 th June 1883 . Cr.

\begin{tabular}{|c|c|c|c|c|c|c|c|}
\hline \multirow{3}{*}{\multicolumn{2}{|c|}{$\begin{array}{l}\text { Sundry Expenses, Ad- } \\
\text { vertising, Stamps } \\
\text { and Covers, Stationery, } \\
\text { Printing, Law Charges, } \\
\text { Brokerage, Commission, } \\
\text { Discount, Interest, Office } \\
\text { Rent, Salaries, Direc- } \\
\text { tors' Fees, and General } \\
\text { Charges } \\
\text { " Balance of this Account, } \\
\text { Profit .. .. .. }\end{array}$}} & & & \multirow{3}{*}{\multicolumn{2}{|c|}{$\begin{array}{l}\text { By Profit on Sundry } \\
\text { Contracts .. } \\
\text { Profit on Sundry In- } \\
\text { vestments .. } \\
\text { Less Amount deducted } \\
\text { from Purchase Ac- } \\
\text { count for surplus } \\
\text { assets realised and } \\
\text { amount written off } \\
\text { Goodwill .. }\end{array}$}} & $\begin{array}{c}£ \\
128,747 \\
35,774 \\
\end{array}$ & $\begin{array}{l}\mathrm{s} \\
9 \\
3\end{array}$ \\
\hline & & $\begin{array}{l}39,135 \\
45,386\end{array}$ & & & & 164,521 & \\
\hline & & $£ 84,521$ & & & & $£ 84,521$ & 13 \\
\hline
\end{tabular}

The Commissioners assessed them on $f_{1} 34,202$, being twelve months' proportion of $£ \mathrm{r} 45,386$-viz., the profit before deduction of two sums of $\mathcal{E}_{20,000}$ and $\mathcal{E}^{20,000 \text {. It }}$ was admitted that the item of $\mathcal{E}^{\mathrm{r} 28,747}$ 9s. $7 \mathrm{~d}$. was a net 
sum after deducting $£ 20,000$ paid away in respect of interest guaranteed by the company during the construction of works undertaken by them, and that the company had not deducted income tax on payment of the interest. The sum of $£ 80,000$ substantially represented a portion of the money paid for the purchase of partially executed or wholly unexecuted contracts. The company contended that the $£^{20,000}$ was not chargeable with income tax in their hands, inasmuch as it was not money paid to the shareholders of the company; also, that the $£ 80,000$, being expended in the purchase of the rights and title to, and the benefit of, the identical contracts from the execution of which the net profits of the company arose, such profits could only be fairly estimated after deducting that expenditure.

The Court gave judgment for the Crown. They considered it perfectly plain that the $£ 80,000$ was part of the capital employed for the purchase of the business, and no part of it

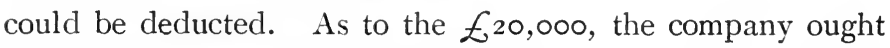
to have deducted tax on payment of it, and they must pay the tax to the Commissioners.

A somewhat analogous case came under our notice, where the A. company, which had been trading at a loss, was paid a Profits for dis continuance of trade. lump sum (spread over several years) by B., in consideration of its discontinuing business during those years. These payments were duly made, but before the expiration of the period the entire assets of the A. company were bought by B. for a further sum. The Surveyor assessed the company, year by

Deductions.

City of London Corporation v. Styles.

Portion of purchase money and interest paid disallowed. 
Deductions.

Profits for discontinuance of trade.

year, on the instalments under the first-named agreement, and the company appealed to the Special Commissioners, claiming :-

(I) That the sum was in effect a purchase of the goodwill, and was a capital item, and not assessable at all ; or

(2) Alternatively, that it was in lieu of any profits which they might have made, and should be averaged with past results.

The Surveyor contended that the sums received were profits " for discontinuance of trade," and fell to be assessed under the sixth case. That the assessment of the company as a going concern was under the first case, and profits assessable under one case could not be averaged with those assessable under another.

The Commissioners accepted the Surveyor's view and decided accordingly.

Cook v. Knott.

Trayelling to residence disallowed.
In Cook (Surveyor of Taxes) v. Knott the Queen's Bench Division held ( $\mathrm{r} 3^{\text {th }}$ December $\mathrm{I}^{887}$ ) that there could not be any deduction allowed a solicitor for expenses of travelling from Bromyard, where he held a public appointment, to Worcester, where he resided and carried on business. This case arose in connection with a claim under Schedule E, but there seems no reason why it should not be equally applicable to Schedule D. 
This case was followed in Revell v. Directors of Ellworthy Bros. \& Co., Lim. (Queen's Bench Division, r6th December I890), where the directors sought to deduct their travelling expenses from their places of residence to the office of the company.

In Smith (Surveyor of Taxes) v. Westinghouse Brake Co. an English company had opened a manufactory at Paris, and fitted machinery there. They subsequently closed it, removed a portion of the machinery, and re-opened the manufactory on a smaller scale, thereby losing a portion of the original expenditure. The Queen's Bench Division held (29th June r888) that this was a loss of capital, and that there could not be any deduction allowed.

In Clayton v. Newcastle-under-Lyme Corporation (Queen's Bench Division, 29th June I888) the corporation sought to deduct a sum of $£ 500$, an annual instalment set aside towards providing a fund for necessary expenditure on plant Clayton $v$.
Newcastle. under-Lyme Corporation. and apparatus in consequence of their having purchased the gas undertaking when the structural condition of the works was imperfect and defective. In making the assessment, deduction had been allowed in respect of the actual cost of all ordinary renewals, repairs, and maintenance of works, such as new retorts, annual repairs to the plant and apparatus, \&c. The Court gave judgment for the Crown. The case is not reported, but the reason of the decision was doubtless that the expenditure of the accumulated sums of $£ 500$ would be an outlay of capital, as it might fairly be considered for an ordinary Profit and Loss Account.

Cost of structural alterations disallowed.

\section{Smith $v$. Westinghouse} Loss on removal of machinery disallowed.
Revell v.
Ellworthy.

Travelling to residence
disallowed. 
Sch. D.-Deductions-Cost of Improvements. Chap. VI. Ixcome Appropriated to Sinking Fund.

Deductions.

Highland Railway Co. v. Speclal Commis. sioners.

Cost of improvements disallowed.
In Highland Railway Company v. Balderston it was held (Court of Session, Scotland, Ioth July r 889) that there could not be any deduction allowed for-

(I) A sum expended on the permanent way of a line acquired by a company, to bring it up to the standard of their main line.

(2) A sum representing cost of extra weight in relaying part of their main line with steel rails in place of iron, and with heavier chairs.

As a matter of fact, the payments had been taken as capital outlay for the purpose of the annual accounts. The company contended that this had been done for convenience only, and that as they did not derive any additional revenue in respect of the outlay it was a proper deduction from the revenue of the year. The Court, howerer, did not think this view could be upheld.

Nizam's

Railway Co. v. Wyatt.

Income appropriated to sinking fund disallowed.
In Nizam's State Railway Company v. IVyatt (Surveyor of Taxes) the Government of the Nizam had agreed to pay the company for twenty years an annuity, equal to 5 per cent. per annum, on the share capital and debentures of the company; the same to be applied in payment of 5 per cent. upon the share capital, and 4 per cent. upon the debentures. The difference of I per cent. upon the debentures was to be set aside as a sinking fund for the redemption of the debentures. The net earnings of the company had not, in any year, amounted to the sum paid by the Nizam; and, under the 
agreement, such net earnings were payable to him in part satisfaction of the sums paid by him under the guarantee. An assessment was made upon the company for $\mathcal{E}_{\mathrm{IIO}}, 448$, the amount received from the Nizam. The company appealed against this, contending that the assessment should be reduced by $£_{2}, 4 \mathrm{I} 6$, being I per cent. on $£_{24 \mathrm{I}}, 600$, the amount of debentures issued.

They contended that since they were compelled to apply it to the sinking fund they became mere trustees for the purpose of applying it to such fund; and that it was not "gain, income, or profit," within the meaning of the Income Tax Acts.

The Queen's Bench Division held (2oth and 2 ist January I89o) that the ultimate appropriation of the sum did not affect its liability to tax. It was, in fact, income, and the company were not entitled to the deduction.

The company gave notice of appeal, and obtained a postponement of the case in order to obtain instructions from India. On the $5_{\text {th }}$ June the company applied for a further postponement, but, though there was not any objection offered by the Crown, the Court considered that ample time had already been allowed, and declined to allow further delay.

The case of Magistrates of Portobello $v$. Sulley (Court of Session, Scotland, Ioth July 1890) raised a question as to the assessment of the profits of a cemetery owned by a town council. By their Act, the town council were to levy a

Deductions.

Nizam's

Railway Co.

v. Wyatt.

Income

appropriated

to sinking

fund

disallowed.
Magistrates $v$. Sulley.

Interest on borrowed money disallowed. 
Deductions.

Magistrates of Portobello v. Sulley.

Interest on borrowed money

disallowed. cemetery rate, in case where the burial fees, \&c., received were insufficient to provide for the expenses, interest on borrowed money, and sinking fund. The council appealed against an assessment on them of $\mathcal{E}_{185}$, being the difference between burial fees, \&c., received, and wages and taxes paid.

They endeavoured to distinguish their case from the Paddington case, p. 67), on the ground that there the money was borrowed from the Public Works Loan Commissioners, and there was not any income tax imposed until after the loan had been repaid, and further it was held by the Court that the cemetery was carried on for the benefit of the ratepayers. In this case, there was still a necessity to tax the ratepayers, as the receipts were not sufficient to corer expenses, interest, and sinking fund. They also contended that the Edinburgh case (post) did not apply, as in that case they were a commercial trading company.

The Surveyor contended that they had made a profit of $£ 185$, and that the assessment was rightly made, in addition to the assessment separately made upon the interest paid out of the rate. He referred to Mersey Docks and Harbour Board v. Lucas (p 66) as showing that surplus income was assessable as profit, without reference to the manner in which it was applied. Further, there was not any real difference between the present case and the Paddington case.

The Court considered that the Council had made a "profit" of $£_{185}$; that interest on borrowed money could not be deducted, as that would be allowing them to deduct tax 
from the creditor, and not to account for it to the Crown. Deductions. That was a thing which nobody was entitled to do; and, therefore, apart from the express words of the statute, the interest could not possibly be a proper deduction. Taking the cases cited, they found it impossible to escape from the conclusion that the whole of the profit was assessable. See also Gresham case (post).

In Dillon (Surveyor of Taxes) v. The Corporation of Haverfordwest, the Corporation, who, by a private Act of Parliament, were empowered to sell gas, provided they first lighted the public streets, claimed to deduct the cost of such lighting from their profits. But the Queen's Bench Division held (5th February I89I) that there could not be any such deduction made. The public lighting was not an expense necessarily incurred in carrying on their trade, but was only an expense necessary to enable them to enter on that trade.

In Arizona Copper Company v. Smiles the Court of Session, Scotland, held (2oth November I89I) that the company were not entitled to deduct the amount of a bonus which they had undertaken to pay along with the repayment of capital sums borrowed. The company had contended that the sums were not paid " out of profits," but were an expense of carrying on the business, without which there could not be any profit earned. The Surveror had contended that it was either a capital parment, or, more likely, additional interest on borrowed capital. Further, he said such a deduction was contrary to the prohibitions in Schedule D and sec. I59 of the Act of 1842 .

\section{Arizona \\ Copper Co. $v$.} Smiles.

Bonus on repayment of loans disallowed. 
Deductions.

Case in practice.

Texas Land, \&c., Co. $v$. Holtham.

Commission for placing shares disallowed.

Expenses of issuing debentures.

Memorial to Chancellor of Exchequer.
In a somewhat similar case, which arose in practice-viz., where a company issued debentures secured by a trust company, and paid the trust company r per cent. per annum for such insurance-the payment was allowed as a deduction by the General Commissioners, but the Board of Inland Revenue gave notice of appeal, and the company did not press the point.

A somewhat analogous case is that of The Texas Land and Mortgage Company', Lim. v. Holtham (Surveyor of Taxes), heard in the Queen's Bench Division 2nd March I894, where the company sought to deduct a sum of $£ 5,000$, commission paid to brokers for placing an issue of debentures. Judgment was given fo: the Surveyor, the Court laying down that the cost of raising capital ought not to be deducted in ascertaining profits.

In this connection in 1896 a memorial was presented to the Chancellor of the Exchequer to the effect that-

"A large part of the business of the (trust) companies is to receive money from the public on deposit or debenture, for the purpose of investment in the manner above indicated (i.e., of investing in stocks, shares, or other securities in the British Colonies, the United States, and elsewhere abroad, or for the purpose of lending money on mortgage over lands in those countries); and the business is analogous to that of a banker, the funds being, in large part, kept in a floating condition, both by the continual repayment to old depositors and receipt of money from new depositors, and by the continuous realisation and re-investment of the moneys invested. In most cases the companies have, many years ago, reached the limit of their borrowing powers, and any moneys which they re-borrow are for the purpose of repaying to depositors desiring to withdraw. The money received on deposit is, in almost all cases, 
received from persons residing in the United Kingdom.

Deductions.

"The money which is received from depositors is not the capital of the company. It is simply the material by the manipulation of which the profits are earned, and in the great majority of cases the charges incurred are not so much for the purpose of adding to the existing deposits, as of maintaining the gross amount on deposit at the full amount required for the successful prosecution of the company's business."

The reply from the Treasury intimated that-

"No arrangement which the Chancellor of the Exchequer might make can in any way affect the discretion of the District Commissioners, who are by law constituted the sole judges in each particular case, and have full authority to determine what are, as a matter of fact, the proper deductions to be made in arriving at the balance of the profits on which income tax is, in any instance, chargeable. Subject to this consideration, it has been arranged that, in the case of renewal of existing debentures, as distinguished from their original creation, the Surveyors will not object, on behalf of the Revenue authorities, to the deduction of reasonable expenses."

An interesting question arose in Aikin (Surveyor of Taxes) v. The Trustees of the late C. M. Macdonald (Court of Session Scotland, 27th Norember 1894). The trustees are part owners of certain tea estates in India, the average profits therefrom received in this country being $\mathcal{E}^{\mathrm{I}}, 6 \mathrm{6}_{4}$. In making their return to income tax they sought to deduct $£ 200$ as the average annual expense incurred in this country in connection with the management of the trust. It was agreed that the assessment fell to be made under the fifth case. The Court disallowed the deduction. They said that duty was to be charged on the full amount received in this country, on an average of the three preceding years, without any deduction other than those expressly allowed, and the trustees had

\section{Reply of Treasury to memorial as to expenses of issuing debentures.}

\section{Alkin v. Macdonald.}

Foreign estate.

Expenses here disallowed. 
Deductions.

failed to show any section of the Act under which power was given to make such a deduction as this.

Watson $v$. Royal Insurance Co.

\section{Amount} paid for commutation of salary disallowed.
The case of Watson $v$. Roval Insurance Company was heard in the House of Lords I 2 th November 1896. The company claimed deduction from the assessment upon them in respect of a sum of $£ 55,846$ under the following circumstances:--They had acquired the business of the Queen Insurance Company in $189 \mathrm{I}$, and by the agreement they were to retain the services of the manager of the Queen Company at $£ 4,000$ per annum, with liberty to commute the salary for a gross sum. This sum was the amount for which they had commuted the salary. The Commissioners had allowed the deduction, and the Crown appealed.

The Surveyor contended that the sum was really part of the consideration paid for the purchase of the business, and was, therefore, a capital expense. It was admitted that, if the company had continued to pay the $£_{4}, 000$ per annum, that would have been a proper charge against the profits for income tax purposes.

The company contended that the sum was a proper deduction from the profits of the year, in the same manner as the $\mathcal{E} 4,000$ per annum would have been.

In the Queen's Bench Division (23rd May r895), the Court differing in opinion, Wright, J., withdrew his judgment, and judgment was given against the Crown. This decision was 
reversed in the Court of Appeal (19th November r 895), whose judgment was affirmed by the House of Lords, the Court being unanimously of opinion that the payment was an expenditure of capital. Lord Herschell said the case was not the same as if it were a payment made to a person employed by the company to determine his service-a mere part of an arrangement between the company and one of their employees. $\mathrm{He}$ desired to say nothing to prejudice the decision if such a case arose. Lord Shand made a similar statement. He said :

"If this had been a case of a voluntary agreement between the manager of an insurance company and the company, for the payment to him of a salary for so many years, to last for a definite time, but with power to the company at any time they might think fit to terminate the service by making the payment at once of a capital sum, I think there would have been much force in the argument that such a payment might properly form a deduction from gross profits in striking the balance liable to income tax; and I should make the same observation as to a case in which there has been wrongful dismissal of a person having an engagement for a term of years, and who succeeds in obtaining damages on that account. But this case seems to me to be entirely different."

In Rhymney Iron Company, Lim. v. Fowler (Queen's Bench Division, I $3^{\text {th }}$ May I896) a subscription had been paid to a Coal Owners' Association, the object of which was to pay its members an indemnity in the event of a deficiency or stoppage

Rhymney Iron Co. $v$. Fowler.

Subscription to Coal Owners' Association disallowed. of output being caused by strikes, \&c. It was held that this was not money laid out for the purposes of the trade, and was, therefore, not admissible as a deduction. (See, however, post, p. 243.) 
Deductions.

Southwell $v$. Savill Bros., Lim.

Call of licences not allowed.

In Southwell v. Savill Bros.. Lim. (King's Bench Division, I $5^{\text {th }}$ May r9or), the Surveyor appealed against a decision of the Commissioners allowing deduction of sums expended by Messrs. Savill Bros., Lim., in applications made by the company to the licensing justices for the grant of new and additional licences to houses owned and leased by them, and for which the company conduct the applications for the purpose of maintaining and, if possible, increasing their trade. They were made up of law costs, printing, advertising, preparing petitions, serving notices, Court fees, surveyors' fees, and payments for "call of licences." The last-named payments were made to owners of licences for the right to call for a surrender of the licences attached to such houses in the event of the justices requiring them to be surrendered before grant of a new licence for a new house. As the licensing justices (in the Beacontree division of Essex) require an applicant for a new licence to offer surrender of existing licences as a preliminary to granting a new one, it was contended that this was a necessary expense. When such applications were unsuccessful, the expenses were charged against revenue; when successful, they were added to the cost of the houses.

The Surveyor contended that it was an outlay of capital for extension, and the Court upheld this view. It was admitted that if the applications were successful the expense could not be deducted; the Court thought it was difficult to see how it could be otherwise when unsuccessful. 
In the Granite Supply Association, Lim. v. Kitton (Court of Session, Scotland, $7_{\text {th }}$ Norember I905) expenses of removing to a new works were disallowed.

In Moore v. Stewarts \& Lloyds, Lim. (Court of Session, Scotland, I 2 th June I906) :-

By an agreement of 1903 the Wilson's Tube Company agreed with Messrs. Stewarts \& Lloyds, Lim., that the latter might nominate directors to their board. In consideration of this Stewarts \& Lloyds, Lim., agreed (substantially) to guarantee the preference dividend of the Wilson's Company.

In $1904 £^{84} \mathrm{I}$ was paid under this guaranty. The results of the Wilson's Company for assessment came out at an average loss, and consequently there was not any tax parable by them.

The Surveyor resisted the deduction of the $£^{84}$ I from the accounts of Messrs. Stewarts \& Lloyds, on the ground that-

(I) It was not an expense of earning the profits, but was in consideration of nomination.

(2) It was not " wholly laid out," \&c. (Rhymney case.)

(3) It was an application of profit. (Mersey Dock case.)

The Commissioners decided in farour of the company, and the Court of Session upheld this, holding that, apart from whether the transaction resulted farourably or otherwise, the money was clearly laid out wholly and exclusively for the purpose of the trade.

Deductions. Granite Suppiy Association, Lim. Cost of removing disallowed.

Moore $v$. Stewarts \& Lloyds, Lim.

Guaranty of dividend. 
Deductions.

Strong $v$. Woodifield.

Damages

disallowed.
In Strong \& Co., Lim. v. Woodificld the facts were that a guest in one of the licensed houses of Strong \& Co., Lim., was injured by the falling upon him of a chimney, during a gale, whilst in bed in the hotel. The damages and costs in an action brought by him against the company amounted to EI,490. This sum the company sought to deduct from their profits for income tax purposes, and the Crown resisted the claim. The point was whether this amount fell to be excluded under Rule I. of Cases I. and II., that " no sum shall be set " against or deducted from . . . such profits or gains for " any disbursements or expenses whatever, not being money " wholly and exclusively" laid out or expended for the purposes " of such trade, manufacture, adventure, or concern." The Commissioners were in favour of the Crown, and the company appealed. On behalf of the company it was argued that this was the same as damages paid by a railway company for personal injury, or to a passenger whose luggage, by the carelessness of a porter, had been left behind, or the case of a bank paying the damage caused by the payment of a forged cheque, or damages paid to an employee for wrongful dismissal, or (as suggested by Phillimore, J.), where a grocer had to pay a fine in consequence of his scales being incorrect. The Crown argued that the whole question was whether damages recovered from a taxpayer for personal negligence (a tort) could be deducted and that this deduction was prohibited by Section 159, and that Lord Shand's words in the Royal Insurance case were merely obiter dicta. Phillimore, J., considered the company was clearly entitled to the deduction, and that Lord Shand's expression was almost prophetic of this case. 
The Crown appealed. They further contended that damages payable to a person who had been negligently run over by a brewer's dray would not be deductible; that Lord Deductions. Shand's dictum was wrong; that damages payable by a newspaper for libel would not be deductible; nor damages payable by a professional man whose coachman had negligently run over someone.

The company replied that this sum must first be deducted to arrive at the "profits" ; that damages payable by a surgeon. who had been negligent in performing an operation would be deductible.

The Court of Appeal reversed the decision of Phillimore, J. The Master of the Rolls said that a sum must be shown to be an expense incident to the earning of the profits to enable it to be deducted. The line was a fine one, and some cases were on one side and some on the other. He considered this to be a sum paid out of profits after they had been earned, though it was granted the company would not have had to pay it unless they had kept the inn and received guests; and Cozens-Hardy and Mathew, L.JJ., agreed, and the former likened the case (erroneously in our view) to that of a claim made by a passer-by who was injured by a chimney falling on him in the street.

The company appealed to the House of Lords, where the decision of the Court of Appeal was unanimously upheld (i $4^{\text {th }}$ June and 3 oth July I906). 
Deductions.

Stevens $v$.

Durban.

Roodepoort

Gold Mining Co., Lim.

"Profits Tax."

The Lord Chancellor said it did not follow that if a loss was connected with a trade it must always be allowed as a deduction; losses by a railway company in compensating passengers for accidents in travelling might be deducted, but a tradesman could not deduct an amount paid to a foot passenger who was injured by (say) one of the shutters falling upon him. Lord James of Hereford entertained some doubt about the decision. He thought there might be a distinction where the person would not have been injured if the company had not been carrying on the business of innkeepers, but his doubt was not sufficient to cause him to differ from their Lordships.

In Stevens v. Durban-Roodepoort Gold Mining Co., Lim. (King's Bench Division, I Ith February I909), it was held that the "Profits Tax" (imposed in the Transvaal in 1902) was to be allowed as an ordinary outgoing in 1902 , and that the assessment was to be based on the average profits of 1900 , I901, and r902. The company had contended (I) that having paid the "Profits Tax" they were not to be chargeable with income tax a second time, or (2) for an allowance of the whole tax off the average gross profits.

Guest, Keen \& Co., Lim. v. Fowler.

Subscription to association.
In Guest, Keen \& Nettlefolds, Lim. v. Fowler (King's. Bench Dirision, 3rd March 1910) the question arose as to. certain payments to the Steel Hoop Manufacturers' Association, which is an association for the purpose of keeping up prices. The members of the association (three) agree to. adhere to fixed prices, and are entitled to shares of the total. 
orders received by the whole of the members in certain agreed proportions. Any member who has invoiced more than the proper percentage pays a fixed amount of ros. per ton on the excess-such payments being distributed in due proportion amongst those who have inroiced less. There were two items in dispute, one being payments (in excess of receipts) to the pool ; and the other being payments towards the administration expenses of the association.

Judgment was given for the company. Bray, J., said that the payment in Rhymney v. Fowler (p. 237) was in the nature of a premium for an indemnity in case of a strike. In that case Baron Pollock and Bruce, J., had both pointed out that the money was not laid out "for the purposes of the trade" ; it was laid out whilst the trade could not be worked. That clearly distinguished it from the present case.

Many associations have now agreed with the authorities in the terms of the following memorandum :-

Arrangements under which Subscriptions and Levies paid by Members of Associations may be allowed as a Trade Expense in computing their Income Tax Liability.

1. That all subscriptions, entrance fees, and leries paid by members of the Association be allowed as a trade expense in the individual accounts of such members on the following conditions :-

2. That the Association renders copies of its rules and regulations to the Board of Inland Revenue.

3. That the Association renders accounts of its income and expenditure, and pays tax on the balance of income over expenditure, on the basis of three years' average, and that all administrative expenses, all payments to the Association, all payments to members by way of compensation for strikes, and grants or payments of any 
Deductions.

Subscription to association.

other kind (other than loans), and payments for legal charges in defending test cases on behalf of the members (including any contributions or subscriptions which may be made to any other organisation, subject to the conditions in paragraph 7), be treated as ordinary expenditure.

4. That the recipients of compensation in labour disputes and grants or payments of any other kind (other than loans) bring the amounts received to the credit of their individual trading accounts, and that the Association furnishes particulars yearly to 31st December, of the amounts paid in that way and to whom paid. In the event of any member or other person refusing to account for the tax on any such receipts in the ordinary course, the amount is to be included in the assessment upon the Association, i.e., by disallowing the items from the expenditure in computing the liability of the Association.

5. That the Association renders accounts for the last completed year, and is assessed on such accounts for the year ending $5^{\text {th }}$ April 1912; that for the following year it is assessed on the basis of the accounts for the two years preceding the year of assessment; for the third year and subsequent years on the average of the three preceding years.

6. That the payment of subscriptions, entrance fees, and levies be allowed, and receipts by members from the Association be credited in the accounts of the individual members for the three or five preceding years in computing the assessment for the year ending April 1912, and similarly for succeeding years.

7. That contributions or subscriptions to any other organisation be only allowed as expenses on production of the accounts of such organisation, and on evidence that it has entered into similar arrangements with the Board of Inland Revenue, or has no surplus income which ought, on the lines of this scheme, to be subjected to $\operatorname{tax}$.

8. The existing and future accumulated funds of the Association to be regarded as taxed income in the event of the Association being wound up and the funds distributed among the members.

9. No allowance to be made or relief granted in respect of the excess in the expenditure of any year over the contributions, except so far as is necessary for the computation of the three years' average. 
Io. In the event of any dispute as to the admissibility or nonadmissibility of any item of expenditure, both parties to these arrangements undertake to submit the question to the Commissioners of Inland Revenue and to accept their decision as final.

II. Each Association to give an undertaking to abide by these regulations.

12. This arrangement may be terminated either by the Board of Inland Revenue, or by the Association, on twelve months' notice, expiring on the $5^{\text {th }}$ April in any year.

In Re Vallambrosa Rubber Co., Lim. v. Farmer (Court of Session, Scotland, I6th March I910) the company sought deduction for :-

I. Superintendence, allowances, weeding, \&c.... $\mathcal{E}^{2,022}$

2. Cutting out rubber, and tapping $\quad \ldots \quad \ldots \quad$ I 8

3. Clearing and draining, and making roads ... 492

Eventually the Crown conceded (2), and the company agreed that $(3)$ was capital. The Commissioners allowed one-seventh of the $£ 2,022$, on the ground that one-serenth of the trees were in full bearing.

The Lord-President allowed the whole deduction. He said it had been argued ( $\mathrm{I}$ ) that no expense was deductible unless referable to a profit within the year, and (2) there was a question whether this was capital or income. The first proposition had only to be stated to be defeated by its own absurdity, because, if it were true, a person whose business was connected with a fruit could not deduct the expense of raising it unless it was ready precisely within the year of assessment. The real truth was it was just one of those mistakes which were made by fixing one's eyes too tightly 
upon the actual rules and cases of the Act of 1842 (which were, after all, only guides), because the real point was, what were the profits and gains of the business. On the second point the Crown had no materials for their case; and, further, at the Bar it had been explained that these expenditures were necessary every year. In a rough way it was not a bad criterion as between capital and income to say that capital expenditure was a thing that was to be spent once for all, and income expenditure was a thing which was going to recur every year.

Damages for subsidence allowed. expenses and new books of company.

Goodwill, patents, \&c.

Loss by fire of mill and stock.
Preliminary

The damages and costs in connection with a claim for subsidence in the case of a colliery have been allowed by the Special Commissioners.

Though there is not any deduction allowed for the preliminary expenses of the formation of a company, the cost of new books-usually included under this head-is allowed.

Deduction is not allowed in respect of the writing down of goodwill, patent rights, \&c.

The loss arising from the destruction of a mill by fire is a loss of capital, and may not be deducted, but the loss arising from destruction of stock is regarded as a trading loss, and the amount thereof may be deducted in ascertaining profits.

Loss by embezzlement.
A loss by reason of embezzlement used to be looked upon as a loss by stratagem, and not one connected with, or arising out of, trade, and it used to be said that the amount could not be deducted. Such a loss, however, is now allowed as a matter of course. 
A question arose in practice some years ago as to the rights of a trader, who unsuccessfully contested an action for wrongful description of his goods, to deduct the costs of the action and the damages.

The decision of the local Commissioners was in farour of the trader, and, the Surveyor having asked for a case to be stated, he was instructed from Somerset House not to press the point.

There is not any difficulty raised by the authorities as to Bad debts. allowance for loss caused by bad debts. In the case of doubtful debts any amount honestly estimated to be bad will be allowed (under 1853 , sec. 50), and the difference between the estimate and the amount actually found to be irrecorerable, whether more or less, would be an item for adjustment in the next account. The authorities will not, however, allow as a deduction amounts carried to a Reserve Account, as is sometimes done in large concerns for the purpose of equalising the loss in different years, e.g., a percentage on the sales, or an arbitrary amount. Where such a prorision is made in the accounts it should be written back to the credit, and the actual bad debts charged on the debit.

In Reid's Brewery Company v. Male (Queen's Bench Division, 6th and 9th February 189r) the company sought to deduct bad debts sustained on loans advanced to their customers on the security of public-houses. It was shown to allowed. be the custom of brewers to carry on the business of bankers and money-lenders as an adjunct to their brewing business, such business being confined strictly to brewery customers. 
Deductions. The Special Commissioners considered the sums advanced were employed as capital for the purpose of extending their business as brewers, and refused to allow the deduction. The Court held that the money-lending business was an adjunct of the brewery business, and the company were entitled to the deduction claimed.

Spelter Co. v. Baker.

Adyance to associated company not a cobad debt."

In English Crown Spelter Co. v. Baker (King's Bench Division, 2 Ist May 1908) deduction was sought in respect of a sum of $£ 3^{8,299}$ as a bad debt under the following circumstances. In order to secure to the Crown Company a good supply of blende (sulphide of zinc) a new company was formed to take over certain mines, the Crown Company and its directors subscribing for the whole of the shares. The directors and secretary of the Crown Company filled corresponding offices in the new company. From time to time the Crown Company advanced the new company various sums at interest " against blende to be delivered," but not against specific parcels of ore. The new company went into liquidation and the whole $\mathcal{E} 3^{8,299}$ was lost. The Court upheld the view of the Commissioners that the case was not within Reid's Brewery Company v. Male (above); that the amount was not wholly laid out for the purposes of the trade; and, further, that it was an employment of capital in a separate concern; and it could not be allowed as a deduction.

Dwellinghouse used for business.
Where part of a dwelling-house is used for the purposes of trade, the Commissioners may allow as a deduction such sum, not exceeding two-thirds of the rent paid, as they shall think proper (1842, sec. IOI). 
The question has been raised whether an hotel proprietor residing with his family on the premises is "using a dwellinghouse for the purpose of trade," and is thus only entitled to Deductions. deduct two-thirds of the Schedule A assessment from his profits. The point is not free from doubt whether an hotel can be a "dwelling-house" within the meaning of the Act. A fair way of treating such a case would be to deduct the whole of the rent or Schedule A assessment, but to add to the profit an amount equal to the estimated benefit the proprietor has derived from so living and thus not needing a dwellinghouse.

The following case removes any doubt which might otherwise exist as to the position where the manager of an hotel lives on the premises.

In Russell (Surveyor of Taxes) v. The Town and County Bank, Lim., the Income Tax Commissioners sought to prevent the bank from deducting from their profits for assessment under Schedule $\mathrm{D}$, the value of certain portions of the bank

Russellv. Town and County Bank, Lim.

Yalue of premises used by officers allowed. premises which were used as dwelling-houses by some of the officers of the bank, but the House of Lords held (26th April 1888) that, for the purpose of arriving at the amount of the profits of the bank, all expenditure must be taken into account, and that that part of the bank which was used for the residence of the officers was used for the purpose of carrying on the necessary business of the bank. The contention of the Commissioners was, therefore, disallowed. 
Deductions.

Brickwood v. Reynolds.

Repairs to tied houses disallowed.
In Brickwood \& Co. $v$. Reynolds the appellants, a brewery company, claimed to deduct $£ \mathrm{x}, 492$, being the balance of a sum of $\mathcal{E}^{2,496}$ (expended by them on the repair of certain tied houses, of which they were owners) after deducting $£ \mathrm{I}, 004$, being one-sixth of the annual value of the houses under Schedule A. It was contended on their behalf-

(a) That the purchasing and letting of licensed houses was an essential part of their business, and alternatively that it was a separate business;

(b) That but for such purchasing and letting, their profits, as assessed under Schedule D, would not and could not have been earned;

(c) That the repairs in question were a necessary outlay, without which such profits could not have been earned, and formed a legitimate deduction in arriving at the balance of profits in respect of which they were chargeable under Schedule D; and

(d) That the tied houses in question were "occupied" by them for the purpose of their trade, manufacture, adrenture, or concern in the nature of trade within the meaning of the first case, rule 3 (allowing deduction in respect of repairs of premises occupied for the purpose of trade, \&c.), and that in this respect there was not any distinction between such houses and those licensed houses which, being owned by the appellants, were not let to tenants, but were conducted on their behalf by their managers or servants. 
The Queen's Bench Division held (26th July 1897) that Deductions. the case was not distinguishable from Watney v. Musgrave (p. 224) and they gave judgment for the Crown, and this was subsequently confirmed by the Court of Appeal ( $17^{\text {th }}$ November 1897).

Judgment in the case of Smith v. The Lion Brewery was given in the House of Lords on I4th February I9II.

The company had tied houses, and admittedly their profits

\section{Smith $v$. Lion Brewery.}

Licensing Act Leyy. were greater than they would otherwise have been. They did not possess them as investments; if any house lost its licence they disposed of it as soon as possible.

By the Licensing Act, I904, the company were compelled to allow their tenants certain deductions from the rent. The amount at issue was $£_{3}, 600$ in three years-average $\mathcal{E}_{\mathrm{I}, 200}$.

No question was raised as to the compensation levy in respect of premises occupied by the company.

The Crown contended the levy was paid as landlords, and not as traders.

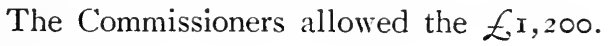

In the King's Bench Division the Crown pleaded that the company had two distinct positions-brewers and landlordsand this payment was not " expenditure wholly, \&c. . . " ; that the brewer's trade ended when he had delivered to the publican; that the trade of the tied house was distinct from the trade of the brewer; that the levy was a charge on the licence, and not on the profits of the brewery; that deduction 
Deductions.

Smith $v$.

Lion

Brewery.

Licensing Act Lexy. by the tenant was from the company quâ landlord, and that the tenant would be equally entitled to deduction whether the landlord was a brewer or not; also that sec. I59 excluded the deduction.

The company argued that this expense was as necessarily incurred as the expense of feeding horses to deliver beer, or fire or burglary insurance. This was in the nature of insurance against loss of capital. That the case found that the houses were necessary to earn the profit; that this was the same as expenses of a traveller, or insurance of a depôt ; that in Strong's case (p. 240) Lord Darey had explained the meaning of "expenditure for the purpose of the trade." He said: "These words . . . appear to me to mean, ' for the purpose of enabling a person to carry on and earn profits in the trade" "; and that Lord James expressed a similar riew. The Commissioners had found the houses were held solely for the purposes of the trade.

Channell, J. Channell, J., gare judgment for the Crown. He said the business was to brew and sell beer. The expenses necessary to sell it and incurred exclusively for the purpose of selling it were deductible. The costs of a depôt were deductible-the payment of an agent, the expenses of tied houses. There were expressions in Watney v. Musgrave (p. 224) which would not bear critical examination, but the decision was right. Then, coming to Brickwood v. Reynolds (p. 250), one point was that the one-sixth was binding, had been dealt with under Schedule $A$, and could not be brought in again. That was absolutely sound. Hancock \& Co. v. Gillard (p. 27) showed 
clearly that the levy was not a charge upon the rent, though there was a statutory right of set-off. It was an insuranceif it was an insurance-of the trade carried on in the house,

Deductions.

Smith v. Lion Brewery.

Licensing Act

Levy. which was the publican's trade, not the landlord's. It looked as if it were a charge-an expense in reference to his trade; but the real thing for which the payment was made was to secure the tenant's trade (though the landlord's, of course, depended upon it). But the difficulty was whether it could be said to be exclusively for the brewer's trade when it was really paid to secure the retail trade. This was one of the grounds of the Brickwood decision, and to that extent it was an authority upon this point. He came to his conclusion with some doubt, and that doubt occasioned to some extent by the arguments of the Crown,
" because I think they may be somewhat afraid-not for the purposes of this case, but for the purposes of other cases-of the consequences of admitting a proposition which seems to me so very clear. It may be that they felt bound to argue propositions which, in my judgment, were not really tenable, and in consequence of their so arguing it seemed to me for a considerable time that their argument necessarily depended upon it. I do not think it does necessarily depend upon it, because $I$ have come to the conclusion that although the annual expense of having these tied houses would be allow- able as a deduction, yet this particular charge cannot be con- sidered as a charge which would be allowable by way of deduction, not because in no sense is it incurred for the pur- poses of the trade, but because, though it goes towards the purposes of the trade in increasing their sales, yet it does so indirectly and not directly, and cannot be said to be exclusively for the purposes of the trade."

In the Court of Appeal it was argued in particular that the case was absolutely concluded by the Brickwood case, and that it was not open to the Court to decide differently. 
Deductions.

Smith v. Lion Brewery.

\section{Licensing Act}

Lexy.

Cozens-

Hardy, M.R.

The Court reversed the decision of the King's Bench Division, and gave judgment for the company.

Cozens-Hardy, M.R., said it was necessary to consider the position both of tenant and landlord. As to the tenant, he was as clearly entitled to deduct the amount in arriving at his profits as an auctioneer or a pawnbroker or solicitor were entitled to deduct their respective payments to the Government. In each case it was a payment which must be made to enable the profits to be earned. The position of the landlord was by no means so clear. If a non-trading landowner, he could not bring it into account. But here the person was a trading landlord. The Commissioners had found that the company, " as part of their business . . ." were owners of tied houses which had been acquired by them " . . . solely for the purposes of their business"; that the houses were employed as "substantially part of their plant or outfit necessary to carry on . . ." and they were thereby " enabled to earn profit . . . which would otherwise be less," and that such possession was " essentially necessary," and they were not held as investments. "Accepting these facts," he said, "it seems to me that every argument which goes to show that the retail seller of beer can deduct what he pays in respect of the compensation levy applies with equal force in farour of the wholesale seller. . ." Further, he thought the authorities were in no way opposed to that view.

Farwell, L.J. Farwell, L. J., considered the findings showed that the money was "wholly and exclusively . . . \&c." $\mathrm{He}$ put it that the company might sell $x$ barrels without the tied 
houses, and $x+y$ with. The lery was a direct expense of selling the $y$ barrels. The Solicitor-General had ignored the brewers' trade as wholesale sellers, and had put the case of a non-trading landlord. But the non-trading landlord made no Deductions.

Smith v. Lion Brewery. profit from a trade of wholesale beer selling, and, therefore, had nothing from which to deduct the levy. It was a false argument that because $\mathrm{A}$. did not trade, therefore B., who did trade, should not be allowed a deduction. Therein arose the distinction between the Brickwood case and the present one. On the findings of fact in that case it was held that the brewers did the repairs as owners. "The facts proved in this case," he said, "render a judgment against the Crown inevitable." $\mathrm{He}$ did not agree with the statement of Channell, J., that the payment was made to insure the tenant's trade-it was made because the Legislature compelled it.

Kennedy, L.J., differed from the other two and approved Kennedy, L.J. the decision of Channell, J. He thought the findings " necessarily incident, \&c.," and " substantially part of their plant, \&c.," rather vague and metaphorical phrases than statements of facts. The scheme of the Licensing Act from the economic standpoint was the creation of a compensation mutual insurance. The argument of the company that tied houses were an essential part of their business, and that their case came within the statement of law made by Lord Herschell in the Gresham case- " The profits of a trade or business is the surplus by which the receipts from the trade or business exceed the expenditure necessary for the purpose of earning 
Deductions. these profits "- appeared at the first blush attractive, but he

Smith v. Lion Brewery.

Licensing Act Leyy.

Kennedy, L.J. his trade was deductible-e.g., see the case of Watney $v$. Musgrave (though some of the language of Kelly, C.B., was open to criticism), and Dillon v. Corporation of Haverfordwest (p. 233), and especially the Brickwood case. Also in Strong's case it was pointed out that it was not enough that an expense should be made in the course of trade, it must be made for the purpose of earning the profits-for the "sole and exclusive" purpose; neither is a loss in connection with the trade necessarily deductible, for it may be only remotely connected with the trade.

He thought the deduction was too remotely connected with the earnings of the trade profit. The rents were not part of the trade profits, and it was the rent receipts which were diminished. The tied houses were necessary, but it was their revenue as rent receivers and not their trade that was affected. Further, he did not consider it "wholly and exclusively laid out." This, he said, was clearly put by Channell, J., in the concluding portion of his judgment. But giving his own views it struck him as a premium for insuring the continuance of the right to carry on the licensed retail trade on the premises.

He could not say, with Channell, J., that the case was fairly clear ; on the contrary, he thought it a difficult case.

In the House of Lords the Lord Chancellor and Lord Shaw were against the company, but Lord Halsbury and 
Lord Atkinson were in their favour, and, accordingly, the judgment was confirmed.

Deductions.

Smith v. Lion Brewery.

Licensing Act

Lexy.

The Lord Chancellor said that the trade of the brewer was the wholesale trade of manufacturing and selling beer, and that the levy, so far as laid out for the purpose of any trade, was laid out for the purpose of insuring the retail trade, which was that of selling wines and spirits, and not beer alone. He could not, therefore, see how the levy could be "wholly and exclusively laid out" for the purpose of the trade of the Lion Brewery, which had nothing to do with wines and spirits. Further, the levy was paid by them in their character of property-owners.

Lord Shaw could not see how an owner's payment could be said to be exclusively for the purpose of a brewer's trade, when the payment would fall upon the owner whether he was a brewer or not.

Lord Atkinson said that, on the findings, it was impossible to contend that the houses were not acquired and let wholly for the purposes of the brewers' trade. The impost differed but little from an auctioneer's, or pawnbroker's, or publican's licence. The payment by the tenant and subsequent deduction from the landlord was mere machinery. No doubt it was paid by the brewers quâ landlords, but they had acquired the houses for the sole and exclusive purpose of setting up the tied-house trade-the same argument would apply if a plot of land were leased to enlarge the brewery. The payment was in effect an insurance premium. If a publican

\section{Lord Shaw.}

\section{Lord
Atkinson.}

Chancellor. 
Deductions. insured licensed premises against fire, his paramount purpose

Smith $v$.

Lion

Brewery.

Licensing Act Levy.

\section{Lord}

Atkinson.
Deductions

allowed in case of railways. was to insure against the loss of his trade, but it was not contended that such a payment should not be deducted. It had been objected that this levy was inadmissible because it was in respect of wines, \&c., as well as beer, but the brewers assumed the responsibility of the house solely to get a market for their beer. Much reliance had been placed on Brickwood $v$. Reynolds. In that case repairs were executed by the lessors on the entire fabric, parts of which were used as dwelling-houses by the tenants, the publicans. Quoting observations of Smith, L. J., and Rigby, L.J., he said it was clear, in his view, that it was not expressly decided in that case that the money expended on the repairs executed on the portions of the houses used for trade purposes could not be deducted. Moreover, the brewery company in that case were not expressly bound to repair, nor did it appear that the repairs were necessary. In any case, that expenditure was not analogous to that incurred in the present case in the obligatory discharge of an incumbrance imposed upon that interest in the premises which the company acquired for the sole and exclusive purpose of increasing the volume of their sales. That case was not binding upon the House, but, even if it were, he considered it distinguishable.

In their eighth report (for the year $1864-5$ ) the Commissioners of Inland Revenue state that railway companies are allowed to deduct :-

(I) Parliamentary and other expenses in opposing new schemes which would be prejudicial to the interest of an established company. 
PREMICMS.

(2) Similar expenses with a view to the extension, or amalgamation, of existing lines, if the company fails to obtain the Act, but not otherwise.

(3) Contributions to funds for the benefit of the servants of the companies called "Benerolent and Servants' Insurance Funds."

The report also contains the following paragraphs:". . We . . drew attention to the peculiar case of leased lines, where the law authorises the lessees to deduct the tax from the rent which they pay. The lessors, however, are obliged to keep up an establishment of directors, secretaries, and clerks, for the purpose of keeping the accounts of the concern, and of distributing the income among the shareholders, as well as of conducting the business relating to transfer of shares and other matters; and for the expenditure on such machinery they have, in law, no right to claim any allowance of the tax.

"Your Lordships concurred in the propriety of recognising the claims of companies so situated to relief."

Where a person has effected an insurance, or contracted for a deferred annuity, on his own life or that of his wife, he is Life Insurance premiums. entitled to deduct the amount of the annual premium paid by him from his profits before paying duty, and if he has paid tax without making such deduction he is entitled to a repayment if claimed within three years. Allowance is not to be made beyond one-sixth of his total income, and the allowance does not entitle him to the greater abatement if his income is thereby reduced below $£ 500$, \&c. (1 853 , sec. 54 , and a further Act of $1_{53}$, I6 \& $1_{7}$ Vict., cap. 9I, sec. I. See, further, Chapter VIII.). Until I906 (see post) this abatement was not allowed when the premium was paid to a foreign 
Colguhoun $v$. Heddon.

company (Colquhoun v. Heddon, Court of Appeal, 6th, 9th, and 1 2 th May 1890). Sec. 54 of the first-named Act provided for the abatement in respect of an insurance with any insurance company which should become registered under any Act to be passed in the then present session of Parliament. By the further Act it was provided that as it might happen that an Act for the registration of insurance companies might not be passed in that session, the provisions were to apply to an insurance, \&c., contracted with any insurance company existing on the 1 st November 1844 , or registered under the Act of $7 \& 8$ Vict., c. I Io (for the regulation of joint stock companies). The Court held (Fry, L.J., doubting) that, unless it clearly appears otherwise, general words used in an Act of our Parliament should be taken to deal only with such things as are within the jurisdiction of our Parliament, and therefore the New York Life Insurance Company, incorporated by special Act of the Legislature of New York in I84 1 , did not fall within the description of a company " existing on the ist November I 844 ."

Where a person insured his life at a premium of $£ 66, £ 33$ only being actually paid by him, and the balance being left as a loan by the insurance company, it was held, affirming the decision of the Court of Appeal (which had reversed that of the King's Bench Division) that he could only deduct the portion of the premium which had been actually paid (Hunter v. Rex, House of Lords, I5th March 1904). 
An endeavour has been made to obtain a similar abatement in respect of contributions to a "Thrift Fund," but the Contribution to "Thrift Fund." answer of the authorities was that, though they were willing to widen the concession, they could not do so against the distinct intention of the Legislature. That intention was to encourage thrift-not generally (or it would have been so expressed), but in a particular manner. The contribution was an investment, though compulsory.

The question came before the Court of Appeal on the I $^{\text {th }}$ and 18th February 1903 in Bell v. Gribble (Surveyor of Taxes) and Hudson v. Gribble.

\section{Bell vi.}

\section{Hudson v.} Gribble.

By a Manchester Corporation Act of 189 I the Corporation were empowered to organise a "Thrift Fund." Persons in the employment of the Corporation in $189 \mathrm{r}$ had the option of joining, and those coming into employment since then were compelled to do so. Mr. Bell belonged to the latter class and Mr. Hudson to the former.

By the Act the scheme was to provide :-

That where a member retired from the Corporation or died, he or his representatives should receive his contributions with interest.

That where a member was dismissed for fraud, \&c., such contributions might be forfeited.

The Corporation fixed $3 \frac{3}{4}$ per cent. of the salary as the contribution. 
Bell v.

Gribble.

Hudson $v$.

Gribble.

"Thrift

Fund."

The deduction from the assessment was claimed under the

first and ninth rules of sec. 146 , viz. :-

"(1) The said duties shall be annually charged on the persons respectively having, using, or exercising the offices or employments of profit mentioned in the said Schedule E, or to whom the annuities, pensions, or stipends mentioned in the same schedule shall be payable for all salaries, fees, wages, perquisites, or profits whatsoever accruing by reason of such offices, employments, or pensions, after deducting the amount of duties or other sums payable or chargeable on the same by virtue of any Act of Parliament where the same have been really and bon $\hat{a}$ fide paid and borne by the party to be charged; and each assessment in respect of such offices or employments shall be in force for one whole year, and shall be levied for such year without any new assessment, notwithstanding a change may have taken place in any such office or employment, on the person for the time having or exercising the same: provided that the person quitting such office or employment, or dying within the year, or his executors or administrators, shall be liable for the arrears due before or at the time of his so quitting such office or employment, or dying, and for such further portion of time as shall then have elapsed, to be settled by the respective Commissioners, and his successor shall be repaid such sums as he shall have paid on account of such portion of the year as aforesaid.

"And each assessment in respect of such annuity, pension, or stipend shall be in force for one whole year, unless the same shall cease or expire within the year, by lapse, death, or otherwise, from which period the assessment thereon shall be discharged.

" (9) In estimating the duty payable for any such office or employment of profit, or any pension, annuity, or stipend, all official deductions and payments made upon the receipt of the salaries, fees, wages, perquisites, and profits thereof, or in passing the accounts belonging to such office, or upon the receipt of such pension, annuity, or stipend, shall be allowed to be deducted, provided a due account thereof be rendered to the said Commissioners, and prored to their satisfaction." 
Reliance was placed on the decision in Beaumont v. Bowers (p. 55), where it had been held that the annual deductions from salaries for contributions under the Poor Law Officers' Superannuation Act 1896 were " duties or other sums payable or chargeable."

The Surveyor argued that the contributions were savings; that under the Poor Law Officers' Superannuation Act poor law officers were only entitled to a life pension, and their representatives derived no benefit after their death, but it was not so in this case. Also that the Poor Law Officers' Superannuation Act I896 was a general Act, and the Manchester Act was a local Act. Further, that the claim did not fall within the provisions of sec. 54 of the Act of 1853 , entitling a person to deduction for life insurance premiums.

In the Queen's Bench Court Hudson's case was decided in favour of the Surveyor, on the ground that the entrance into the scheme was optional. Bell's case was decided the other way, without argument. Appeals were lodged. Judgments were given for the Crown in both cases. The Court said the sums were neither-

(I) "Duties payable by virtue of an Act of Parliament," nor

(2) "bonâ fide paid and borne by the party."

As to the second point, the payment of the sums was simply postponed. 
Bell v.

Gribble.

Hudson $v$. Gribble.

"Thrift

Fund."

As to the first point, the sums were payable not "by virtue of an Act of Parliament," but as part of the contract of service.

\section{Section 54 of the Act of 1853 reads :-}

"Any person who shall have made insurance on his life, or on the life of his wife, or shall have contracted for any deferred annuity on his own life, or on the life of his wife, in or with any insurance company . . . . and any person who shall under any Act of Parliament be liable to the payment of an annual sum, or to have an annual sum deducted from his salary or stipend, in order to secure a deferred annuity to his widow, or a provision to his children after his death, shall be entitled to deduct the amount of the annual premium paid by him for such insurance or contract, or the annual sum paid by him, or deducted from his salary or stipend as aforesaid, from any profits or gains in respect of which he shall be liable to be assessed under either of the Schedules D or E of this Act, or to have any assessment which may be made upon him under either of the said schedules reduced or abated by the deduction of the amount of the said annual premium from the amount of the profits or gains on which such assessment has been made:

"Or if such person shall be assessed to duties under any of the schedules contained in this Act, and shall have paid such assessment, or shall have paid or been charged with any of the said duties by deduction or otherwise, such person, on claim made to the Commissioners for special purposes, and on production to them of the receipt for such annual payment, and on prool of the facts to the satisfaction of the said Commissioners, shall be entitled to have repaid to him such proportion of the said duties paid by such person as the amount of the said annual premium bears to the whole amount of his profits and gains on which he shall be chargeable under all or any of the schedules of this Act:

"Provided always that no such abatement, allowance, or repayment as aforesaid shall be made in respect of any such annual premium beyond one-sixth part of the whole amount of the profits and gains of such person so chargeable as aforesaid : 
"Nor shall any such deduction or abatement entitle any such person to claim total exemption or any relief from duty on the ground of his profits and gains being thereby reduced below one hundred or one hundred and fifty pounds, as the case may be."

As to this, the Court said that if this case was governed by the words of the first rule of Schedule E, nearly all this sec. 54 was unnecessary (i.e., except as to roluntary payments for insurance of wife or child). But this was not the case. The Legislature made no mistake when enacting sec. 54 .

Beaumont v. Bowers was wrong and was overruled.

Beaumont v. Bowers overruled.

The case of Smyth (Surveyor of Taxes) v. Stretton (King's Bench Division, I8th and I9th April 1904), on a similar point, is one of considerable difficulty. Mr. Stretton was an Smyth $v$.
Stretton. Increase of salary not paid in cash. assistant master at Dulwich College, where a Provident Fund for the benefit of assistant masters was established in 1899 . The scheme provided (inter alia) :-

(I) For certain "increases of salaries," viz. :-

(a) 5 per cent. to masters of 5 to 15 years' standing.

(c) A further 5 per cent. to such masters, but such amount was not to be paid to any master retiring (except from ill-health) unless he had completed Io years' service.

(3) That all assistant masters should be required to be members of the fund.

(4) That the increases should be retained and accumulated at interest. 
Beaumont $v$. Bowers oyerruled.

Smyth $v$. Stretton. Increase of salary not paid in cash.
(5, 6, and 7) As to what portions of such increases should be payable to the assistant masters or their representatives in the erent of retirement, death, dismissal, \&c.

Mr. Stretton claimed that $£ 35$ of his salary of $\mathcal{E}_{385}$ (viz., an "increase" of ro per cent. under (I) $(a)$ and (c) above) was not liable to taxation.

Channell, J., decided (with hesitation) in favour of the Crown.

He said the question was whether the true effect of the scheme was to increase the salaries, and at the same time compel the masters to deal with the increase in a certain way; or whether it was to give the masters a gratuity upon.their ceasing to hold their positions.

It was clear, he said, that the first 5 per cent. was a pure addition to the salary, and chargeable as such. The second 5 per cent., if it stood alone, would be very arguable, but though he was not clear about it, he thought that being put, as it was, with the other sum, and distinctly stated as "salary," it did not cease to be chargeable, although on the happening of certain erents it might never become payable to the master.

Any person who has effected such an insurance, \&c., (p. 259), with a British friendly society is entitled to the like privileges. Formerly, in order to obtain the privilege, the premiums parable were not to be for a shorter period than three months (an Act of 1855, I 8 \& i 9 Vict., cap. 35, sec. I), 
but by the Revenue Act 1903, sec. 10, this section is repealed, and it is provided that :--

"Where the premiums payable in respect of any insurance to which that section extends are made for shorter periods than three months, the production of a certificate signed by an officer of the Society to the surveyor of taxes for the district specifying the correct amount of premiums paid during the year shall be a condition of obtaining relief under that section."

In 1859 the privilege was extended in respect of any annuity, \&c., contracted for with the Commissioners for the Reduction of the National Debt (22 \& 23 Vict., cap. 18).

By the Finance Act 1904, sec. 9, the privilege was further extended to apply

"in relation to the life insurances or contracts for deferred annuities effected in or with any insurance company legally established in any British possession.

And it was further extended in 1906 by the Revenue Act I906, sec. II, which provides that :-

"The provisions of sec. 9 of the Finance Act 1904 shall apply in relation to life insurances or contracts for deferred annuities effected in or with any insurance company lawfully carrying on business in Great Britain or Ireland, and accordingly such section shall be read and construed as though the words 'or lawfully carrying on business in Great Britain or Ireland' were inserted therein after the words 'British possessions." ",

The provisions apply to an accident policy if it covers fatal accidents, and claims in respect of such are allowed as a matter of course. They do not, however, apply to a child's endowment policy or to any endowment policy pure and simple, or to a sickness benefit policy. 
Single premium policy

Deferred Annuity

Sickness policy.

Annual yalue of study allowed.

Single premium policies used to be considered to be within the Act, but the Board are now resisting claims.

Also, where a life office issues a deferred annuity, one condition being that if the policy-holder dies or surrenders before the deferred age is reached the premium is to be repaid with compound interest at 3 per cent., the Crown refuses to allow such a premium as a deduction.

Probably this is correct, as it is (or at least may be) simply a deposit at interest.

In the case of a combined life and sickness policy they will allow so much of the premium as the company certify to be due to the life risk.

The Board of Inland Revenue some time ago gave a favourable reply to a Free Church minister, who asked an abatement of $£_{20}$ from his income in the fixing of his income tax, as the rental value of his study and an allowance for books and stationery required in the discharge of his professional duties. "In the opinion of the Board," it was answered,

"a dissenting minister chargeable to income tax under Schedule $\mathrm{D}$, and occupying a house yielding accommodation in excess of that required for private purposes, who devotes a room wholly and exclusively to the purposes of his profession, is entitled to deduction in respect of the annual value thereof, to be settled and ascertained by the Commissioners. Further, that the cost of writing materials is also allowable, but not any expenditure in books, which is regarded as a capital outlay."

Now, the Finance Act, 1907, sec. 28, provides :-

Where a clergyman or minister of any religious denomination pays rent for a dwelling-house, and uses any part 
thereof mainly and substantially for the purposes of his duty or function as such clergyman or minister, such part of the rent of the dwelling-house, not exceeding one-eighth, as the Commissioners by whom any assessment for income tax is made may allow, shall be treated for the purposes of sec. 52 of the Income Tax Act 1853 , as expenses to which the provisions of that section as to deduction and repayment apply.

With respect to the payment of annual interest, it will be noticed that though it cannot be deducted from the profits

Deduction of tax on interest payable. of a trader, yet he gets the same benefit as if he could so deduct it, for he retains the tax before paying the interest (1853, sec. 40). 'This section is as follows:-

"Every person who shall be liable to the payment of any rent, or any yearly interest of money, or any annuity or other annual payment, either as a charge on any property or as a personal debt or obligation by virtue of any contract, whether the same shall be received or payable half-yearly or at any shorter or more distant periods, shall be entitled and is hereby authorised, on making such payment, to deduct and retain thereout the amount of the rate of duty which, at the time when such payment becomes due, shall be payable, for every twenty shillings of such payment; and the person liable to such payment shall be acquitted and discharged of so much money as such deduction shall amount unto, as if the amount thereof had actually been paid unto the person to whom such payment shall have been due and payable; and the person to whom such payment as aforesaid is to be made shall allow such deduction upon the receipt of the residue of such money, under pain of forfeiting the sum of fifty pounds for any refusal so to do.

" Provided always that no tenant or occupier of any property chargeable under Schedule A of this Act shall be entitled to deduct or retain out of the rent thereof any greater sum than the amount of the duty which shall have been assessed and charged upon or in respect of such property, and actually paid by such tenant or occupier." 
Act of 1864,

sec. 15.
Landlord and tenant.

Mortgagor and Mortgagee.
Further, by sec. 15 of the Act of 1864 ( 27 \& 28 Vict., cap. I8) it is enacted that :-

"The persons liable to and making any such payment as aforesaid shall be entitled, and are hereby authorised, to deduct and retain thereout the amount of the rate or a proportionate amount of the several rates of income tax which were chargeable by law upon, or in respect of, such rent, interest, annuity, or other annual payment, or the source thereof, during the period through which the same was accruing due. . . ."

In this way the principle of taxing the income at its source is carried out, and each person pays ultimately on the amount he receives.

For example, A. purchases a house from C., leaving $£ 800$ of the purchase-money on mortgage at 5 per cent. He lets the house at $£ 60$ per annum to B., his tenant. B. pays the income tax under Schedule A on $£ 5^{\circ}$ (since the $5^{\text {th }}$ April I894 there is an allowance of one-sixth off the gross rent for repairs), but deducts it from his landlord when he pays his next rent. He has not any income in respect of the house, and does not bear any tax. A.'s income in respect of it is :-

$\operatorname{Rent}(£ 60$, less one-sixth for repairs) $\quad \cdots \quad £ 50$

$\begin{array}{lllllll}\text { Less interest } & \ldots & \ldots & \ldots & \ldots & \ldots & 40\end{array}$

$$
\frac{40}{£ \mathrm{ro}}
$$

He has paid tax by way of deduction on $£ 5^{\circ}$, but he in his turn deducts tax on the interest when paying it, and thus only bears tax on $£$ ro, the amount of his income. C., of course, pays tax on his $£ 40$ by this deduction. The Revenue thus receives the amount in one sum from $B$. 
In Foley v. Fletcher (Court of Exchequer. I 7 th November 1858 ) the facts were as follows: $-F$. sold certain mines for $£ 49,500$, payable $£ 3: 385$ down, and the residue by halfyearly instalments of $£_{7} 68$ I Is. 8d. during a period of 30 years. The purchaser sought to deduct tax on payment of the $\mathcal{E}_{768}$ ixs. 8d. It was contended on his behalf that $F$. had converted her capital into an anmual payment. By so mixing capital with profits they became inseparable, and the Court should therefore take judicial notice that the annual payments were gains and profits made by allowing the parments to be deferred. This was not equal to a specific debt being paid by instalments.

In giving judgment, Pollock, C.B.. said :- "Duties are to be levied on profits and not on anything else." It had been contended that the estate was worth $£ 23.000$ and the rest was therefore profit, but there was nothing to show this to be so. Possibly the instalments were mere indulgence on the part of the seller. But even if it were granted that part were profit, they would not then come within the Act. " We cannot say capital is liable because found in company with profits." Section I02 must be read:- " Upon all annuities, yearly "interest of money. or other amnual payments ejusdem "generis, \&c. . . ." Section 40 of the Act of 1853 must be read :-

"Every person who shall be liable to the payment of any rent, or any yearly interest of money, or any annuity, or other annual payment ejusdem generis (as profits) either as a charge on any property or as a personal debt or obligation by virtue of any contract ejusdem generis, \&c. . . ." "If," 
Foley v.

Fletcher.

Capital is not liable although found in company with profits. he continued, "the annual payment is the repayment of principal, the return of a debt, and is not profit, it is not at all within the purview of the Act, the very title and all the provisions of which announce that it is for imposing a tax on profits. . ."

"An annuity is made chargeable in express terms."

Bramwell, B., said it had been argued that the payment should be divided into principal and interest. Assuming this, it was admitted, on behalf of defendants, that plaintiff might have been assessed. This being so, it could not be that defendant could deduct tax before paying. Mr. Phipson (for the defendant) said that sec. 40 was positive. Reading the section alone nothing was plainer. Why, then, did it not apply?

"In some way we must hold that it does not apply, because otherwise the plaintiff would be liable to pay income tax twice over. Now, the expression 'liable to payment' (in sec. 40 ) is peculiar. I think it means "where any person is the owner of any property out of which a sum of money is payable, which is an annuity or annual payment, as a personal debt or by virtue of any contract.' It appears absolutely necessary to put a non-natural construction upon the language of this section."

Goslings \& Sharpe $v$. Blake.

Tax on interest other than annual.
In Goslings \& Sharpe v. Blake (Court of Appeal, 24th and $25^{\text {th }}$ June 1889 ) it was held that the provision for deduction of tax only applied to annual interest, and that in the case of loans for short periods the tax must not be deducted by the borrower, but the interest must be returned for assessment by the lender, but this case arose before the Act of I888, and the case of Lord Advocate v. Lord Provost of City of Edinburgh (post) makes it clear that the Crown can ask 
that tax shall be deducted and accounted for on all interest if not paid out of profits brought into charge.

In The Galashiels Provident Building Society v. Kenneth Newlands (Court of Session, Scotland, I $5^{\text {th }}$ June I893) it was held that if a debtor makes a payment of interest without deduction of income tax he loses his right to recover tax in respect of such interest. The Court said he had failed to prove any such right in the strict terms of the statute ( 1853 , sec. 40, p. $22 \mathrm{I}$ ), and he had not produced any other evidence. The case is analogous to those of Cumming v. Bedborough, Denby v. Moore, and Andrew v. Hancock (see p. 30).

One of the oldest decisions as to the deduction of income tax on payment of interest is that of Dinning $v$. Henderson (Ch.D. 9th February 1850). This was a case where the Royal Bank of Scotland had proved under a decree for a sum due, in respect of principal and interest, upon a bill of exchange, accepted by the testator in the cause, and which fell due after his decease. The Master had deducted income tax on the interest, and the petition sought that the Master might review his report in this respect. The bill was drawn 6th March 1839 at six months and accepted by the testator, who died before it became due. It was afterwards dishonoured, and a decree having been made for administering the assets of the testator, the holders of the bill claimed the amount with interest, as creditors of the estate.

The Vice-Chancellor said he would have thought that, according to the true construction of the Act, the interest

Dinning $v$. Henderson.

Tax may be deducted on interest on bill of exchange. 
Dinning $v$. Henderson.

Doubtful Fhether correctly declded.

Bebb v. Bunny.

Annual interest includes all interest calculated at a rate per cent. per annum, but see below.

should have been allowed in full, and the bank left to pay the income tax themselves. But as it appeared that in the offices of three of the Masters the course had been to deduct tax, and there was reason to believe that the same course had bren uniformly pursued in other offices, it would be too much for him to take upon himself to disturb a practice thus adopte:1 for so many years, whatever his own opinion might be, and he declined to do so.

In Goslings \& Sharpe v. Blake (above) some doubt was expressed as to whether this case was correctly decided.

Another old case is that of Bebb v. Bunny (Chancery Division, 22nd December 1854). It was a case for specific performance by a vendor against a purchaser. Before the Judge in Chambers the question was raised as to the right of the purchaser (under sec. 40 of the Act of 1853 ) to deduct the income tax upon interest on the purchase money, payable for the time which had elapsed since the day fixed for completion of the purchase. Vice-Chancellor Sir W. Page Wood said that a mortgage deed rarely reserved a yearly interest. Most deeds contained a covenant to pay the principal, with interest at a certain rate per cent., on a day certain. After that it accrued de die in diem, and the interest, without any particular reservation, was ordinarily paid from year to year. It was difficult to see any difference between interest so reserved and paid and that which, by special agreement, accrued on purchase money, and might run on for a year or stop at any time. He thought the section referred to all interest calculated at a yearly rate per cent. 
This decision was relied on by the appellants in the above case of Goslings \& Sharpe v. Blake, but the Court of Appeal drew a distinction between the two cases, on the ground that in the earlier case the interest might have gone on for a year or more, but in the latter case the loan was for a definite period less than a year, and, therefore, was not " annual interest."

In Crane v. Kilpin (Equity Cases, Vol. VI.), heard rst Crane v. May r868, a debtor had assigned a fund in Court to trustees to pay $£ 300$ a year to his creditors to pay their debts, with interest at 5 per cent. In making the payments there had not been any deduction of tax. It was contended on the one hand that the trustees were entitled to deduct tax, and, on behalf of the creditors, that they should receive interest without deduction. The Court held that, on finally settling with the creditors, the trustees could deduct tax on the payments of interest.

In Re Craven's Mortgage; Davies v. Craven (Chancery Division, 18th July 1907 ) it was held that, where a principal sum secured by mortgage was made payable upon a certain Re Craven's Mortgage.

\section{Interest} payable in lump sum. death with simple interest, the executor was entitled to deduct tax from such interest on payment.

In giving judgment, Warrington, J., reviewed and contrasted Goslings \& Sharpe v. Blake and Bebb v. Bunny. He said that the two cases were not inconsistent ; in the former the Court of Appeal held that the transaction was a commercial transaction wholly apart from an ordinary mortgage transac- 
Re Craven's Mortgage.

Queensland National Bank, Lim.

tion, or a covenant to pay interest for a period which might last for more than a year. Lord Esher had said that the word "other" (sec. 40) must mean something of the same kind as had gone before, and the interest on a short loan was not of the same character at all. Bowen, L.J., had also expressly stated that their decision was not overruling $B e b b$ ข. Bunny.

The case of Re Queensland National Bank (K.B.D. I 7th February I909) is reported as follows in the Financial News of the i8th February igog:--

"Yesterday, in the King's Bench Division, Mr. Justice Channell resumed the hearing of the petition of right of the Queensland National Bank in regard to income tax. The case for the bank was that so far as interest on its interminable stock payable in the United Kingdom was in fact paid out of the profits which were made in the United Kingdom, the bank was entitled to deduct the income tax due from the persons who held the stock, because it was paid out of profits in the United Kingdom. The case for the Crown was that the bank were only entitled to keep so much of the income-tax as was proportionate to the amount actually paid in this country as English profit, compared with the whole profit of the company.

" His Lordship, in giving judgment, said the question at issue did not depend upon any doubt about the law, but upon the application of the law in this particular case. The Queensland Bank had a branch in this country, and the 
question he had to decide was how far the Queensland Bank was bound to account to the Crown for the interest which it had to pay to its stockholders upon interminable stock. Here they had to deal with an entire concern which paid interest out of the profits derived from that concern, and in his opinion he must make a declaration that the bank was not entitled to make the deduction claimed."

In Scoble v. Secretary of State for India the facts were as follows :-The old East India Company (whose powers are now rested in the Secretary of State for India) leased land in 1849 for 99 years for the construction of the Great Indian Peninsular Railway, reserving power under the contract to purchase the undertaking in 50 years either for a lump sum down or by annuities payable in half-yearly instalments.

The material clause (No. 26) in the contract was as follows :-

“. . . it shall be lawful for the East India Company, instead of paying a gross sum of money in respect of the premises, to declare by notice to the said railway company in London their option to pay an annuity from the time when the gross amount would be payable, and to continue during the residue of the said term of 99 years, and in that case such annuity shall be payable in London . . . the rate of interest which shall be used in calculating such annuity being determined by the average rate of interest during the preceding two years received in London upon the public obligations of the East India Company. . . .",

In August 1899 the Secretary of State gave notice that he would purchase. The price was fixed at $£ 34,859,2$ I 7 , pay- 
Scoble v.

Secretary of State for India.

Terms of

agreement

able on June 3 oth 1900, but the Secretary of State declared his option to pay an annuity for the residue of the term of 99 years.

The rate of interest under Clause 26 was ascertained to be $\mathcal{E}^{2}$ r 7 s. per cent., and the annuity was, therefore, fixed at $\mathcal{E}^{\mathrm{r}, 335,563}$ i $8 \mathrm{~s}$. $4 \mathrm{~d}$. (subsequently reduced by agreement

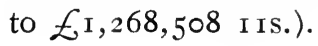

It was held (King's Bench Division, r6th June 1902) that the half-yearly instalments were plainly an annuity, and were therefore subject to income tax; but this decision was overruled by the Court of Appeal, whose decision was ultimately affirmed by the House of Lords (I $3^{\text {th }}$ June 1903).

The case is of such importance that it will be convenient to deal with the facts and judgments at some length.

Argument for company.
On the rst January I90I and Ist July I90I instalments of $\mathcal{E}^{6} 34,2545 \mathrm{~s}$. $6 \mathrm{~d}$. became due. The former instalment was-as argued by the company-as to the sum of $£$ r62,450 r4s. Id., a payment on account, and as part of the capital sum of $£ 34,859,217$ i7s. $6 \mathrm{~d}$., and as to $£ 47$ r,803 iाs. 5 d. was a payment of interest upon $£ 34,859,217$ for the six months. The second instalment, it was contended, was $£$ I 64,765 12s. $6 \mathrm{~d}$. on account of capital, and $£ 469,488$ I3s. on account of interest on the balance outstanding. They admitted that such portion of the instalment as represented interest was liable to income tax. 
It was contended on behalf of the Crown that for the purpose of income tax the sums of $\mathcal{E}^{634,254}$ could not be broken up into principal and interest, but were chargeable as annuities with income tax on the whole of the amount thereof.

In the King's Bench Division, Phillimore, J., said that What is an Baron Watson, in the case of Foley $v$. Fletcher, had given an excellent definition of an annuity, viz. :-

"An annuity means where an income is purchased with a sum of money and the capital has gone and has ceased to exist, the principal having been converted into an annuity."

This was exactly what had happened in this case. One way of testing whether this was an annuity was to see whether the periodical payments were equal. This, he said, was not a certain guide, but it gave some indication as to whether this was a case of an annuity or a mere payment of purchase money by instalments with interest. This case was different from Foley $v$. Fletcher. No doubt, in fixing the price payable in that case, the vendor had had regard to the fact that he must increase his price by capitalised interest, but the instalments were none the less instalments of purchase money. They differed from an annuity.

In the Court of Appeal ( $13^{\text {th }}$ February I903), where the decision of the King's Bench Division was reversed, Vaughan Williams, L.J., said the Attorney-General had granted that an annual sum payable by contract was not necessarily an annuity. It had been admitted that where it appeared on the face of the contract that there was a debt 
Scoble $v$. Secretary of State for Iadia.

Judgment of Court of Appeal. existing, income tax would be payable only on so much of the instalment as represented interest. "The whole question " in this case was (he said): Is income tax payable upon that " portion of the annual payment which you can discover from " the very terms of the contract is a mere payment of an " instalment necessary to complete the payment of an existing " debt? In my judgment no income tax is payable in such " a case." It seemed to him obvious that a debt having come into existence the Indian Government elected to pay it by instalments, plus interest.

Stirling, L.J., said Foley v. Fletcher had been relied on by both sides. The principle laid down in that case with reference to the construction of the word " annuity" had never been departed from. Chief Baron Pollock had said :

"These instalments arê payments of money due as capital; the Act has made no provision for such a case. It professes to charge profits only, and we cannot say that capital is liable to income tax because found in company with profits."

Mr. Baron Bramwell had alluded to the Act charging " profits." The principle established in Foley $v$. Fletcher appeared to him to be that the word " annuity" was not to be read so as to make capital taxable. In the present case the Attorney-General had said that if that be so in the case of every terminable annuity purchased for value the annuity should be split up. He felt the force of that remark, but it seemed to him that the cases were not the same. "Those are " cases of purchase of annuities where investment has been " made in that form of property, and the Legislature in so 
" many words has said that that is to be taxed; and it is " recognised in this very case throughout that an annuity of

" that kind is taxable. And I in no way depart from that."

In the House of Lords (where the judgment of the Court of Appeal was unanimously upheld) the Lord Chancellor said that the loose use of the word "annuity" undoubtedly rendered a great many of the observations of the AttorneyGeneral and of the Solicitor-General very relevant. Still, looking at the nature of the transaction, he could not doubt that in this contract what was called an "annuity" was a mode of paying a debt. In his opinion the Income 'Tax Acts never intended to tax capital. In one sense, no doubt, the Legislature had taxed capital (e.g., in the case of a rent derived from coal). All he could say upon that was that, perhaps from the nature of things, the income tax could not be cast upon absolutely logical lines.

Lord Lindley likewise said that the difficulty arose entirely from the ambiguity of the word "annuity." To his mind it was prored to demonstration that this "annuity" was nothing more than the payment by equal instalments of the purchase money for the railway.

In East India Railway Company v. The Secretary of State for India (King's Bench Division, 22nd June and 25th October 1904) the facts were somewhat similar, but the Crown endearoured to distinguish the case from that of Scoble $v$. Secretary of State for India, on the ground that in this case there was not any capital sum arrived at at all, but the pur- 
East India Railway case.

chase price was, in the first instance, fixed as an " annuity." The Court, howerer, considered that there was not any substantial difference between the two cases; that in both cases there was, practically, the ascertainment of a lump sum and then the provision for its payment by means of an annuity, and they gave judgment for the company.

The Purchase Act recited that the annuity of $£ 5$ i $2 \mathrm{~s} .6 \mathrm{~d}$., into which every $£$ roo stock of the company was to be conrerted at the price of $£_{125}$, was calculated on the basis of $£ 5$ 7s. 6d. as interest at $£ 4$ 6s. per cent. on $£_{125}$, and 5 s. as the amount required to be set aside and invested halfyearly, in order to produce $£ 125$ at the date when the annuity ceased. The Crown contended that the interest payable each half-year was a constant unvarying amount, treated as though the payment of the whole capital was postponed for 73 years, the remaining part of the annuity representing capital repaid only in the sense that it was a constant unvarying amount calculated to produce a sinking fund, which, invested at compound interest, would replace the whole capital in the 73 years. The company contended that of the half-yearly payments the proportion representing capital constantly increased and the amount representing interest constantly decreased.

It was held by Jelf, J. (King's Bench Division, Ist March r905), that the recital to the Purchase Act left it without doubt that the contention of the Crown was correct, and that of each instalment of $£ 424,545$ I Is. I Id. $£ 405,676$ I8s. IId. 
was to be regarded as interest (and taxable as such) and $\mathcal{E}^{18,868}$ I $^{\text {s. }}$ rod. was to be regarded as sinking fund.

Both the company and the Crown appealed. The former contended that the recital was merely for the purpose of showing that the sum allowed was a proper one, and it could not have the effect of altering the character of the payments and turning that which was the liquidation of a debt by instalments into that which it had been held not to be-a mere annuity. The Crown argued that the logical outcome of the decision was to treat the whole sum as income only and taxable as such.

The Court reversed the decision of Mr. Justice Jelf (8th June 1905) accepting the contentions of the company that the statement and the arithmetical calculation by which the amount was fixed were made merely to justify the amount, and did not alter the fundamental character of the transaction. The instalments were therefore held to be-

\begin{tabular}{|c|c|c|c|}
\hline 1903 & Capital & Interest & Total \\
\hline Mar. ... & $£ 49,672$ I 5 & $£ 374,873$ 10 6 & $£ 424,545$ I I II \\
\hline Sep. .. & $50,740 \circ 5$ & 373,805 II 6 & 424,545 II II \\
\hline
\end{tabular}

In Chadwick v. The Pearl Life Assurance Company, Lim. (Chancery Division, I5th April 1905), where the residue of a lease (to December 1912) was sold for $\mathcal{E}_{\mathrm{I}, 000}$ down and $£$ I,625 per annum till December 19r2, it was held that the purchaser was entitled to deduct tax on the sums of $\mathcal{E}_{\mathrm{r}, 625}$ on payment thereof. 
Re Sharp.

Annuities paid in full.

Shrewsbury v.Shrewsbury

Arrears of Annuity.
Bankruptcy and payment of tax.

It was held in In re Slıarp (deceased); Rickctts $v$. Ricketts (Chancery Division, I 7 th March 1906) that where trustees had paid annuities without deducting tax there had been a breach of trust in so doing. But that it was an innocent breach, and the claim upon them to refund the amount was limited to six years, except where the trustee, being also an annuitant, had not paid, but had retained, the excess.

In Shrewsbury v. Shrewsbury (Chancery Division, 28th November 1906) it was held that tax could be deducted on payment of arrears of an annuity, but not in respect of amounts already paid and from which tax had not been dedicted on payment.

In the event of bankruptcy, tax deducted by the bankrupt (and therefore deemed to be in hand) is payable in full to the Crown by the Trustee.

Barry $v$. Smart. Alimony.

In Barry v. Smart (Chancery Division, 27th March 1906) it was held that a husband paying an annuity to his wife as alimony under contract was entitled to deduct tax.

The Board of Inland Revenue have drawn up the following "Memorandum of Alternative Arrangements with respect to Income Tax in the case of Building Societies " :-

\section{Arrangement A.}

1.-All interest to be exempted where the borrowing member is exempt by reason of his total income from all sources not exceeding $£_{1} 160$, the society undertaking to see that the borrowers make the usual claim to the Surveyor of Taxes for the district in which they reside, and otherwise afford facilities to the Surveyor or Surveyors for the requisite verification of the claims. 
2.-Where the borrowers are not so exempt, the properties on which the interest is secured by mortgage, or otherwise, to be retained in charge according to their respective annual values, and the society to allow the borrower to deduct the tax applicable to the interest.

3.-All property in the society's hands as mortgagees in possession to be exempted, except as to ground or lease rents, if any.

4.-The society to furnish a statement, to be verified by the Board's Surveyor of Taxes once a year, of the interest paid or credited to depositors and members whose incomes exceed $£_{1} 60$ a year, from whom the society would have the right to deduct the tax, whether the society exercised the right or not.

5.-The society to furnish a list of the interest received from the borrowers to whom the society has allowed the tax, with all necessary particulars of the properties assessed, and vouchers, in the shape of certificates of deduction of the tax on the annexed Form No. 185 .

6.-Where the total interest received (par. 5) on which the society has allowed the tax, exceeds the total interest paid or credited (par. 4), and on which the society has the right to retain the tax, the society to be repaid the duty on the difference; and where the converse is the case-that is, where the tax which ought to be retained by the society exceeds the tax allowed by the society, the society to render a return of the difference for assessment under Schedule D of the Income Tax Acts.

Arrangenent $B$.

I.-The society consents to be directly assessed under Schedule D of the Income Tax Acts upon the amount paid or credited in the year preceding the year of assessment for, or in respect of, dividends on shares, bonuses, and deposit interest. One-half of the total amount to be charged with income tax and one-half allowed to cover exemptions.

In consideration of such direct assessment:--

2.-All property in the society's hands, as mortgagees in possession, to be exempted, except as to ground or lease rents, if any.

3.-A borrower, whose total income from all sources does not exceed $£^{160}$ is not to be charged for mortgage interest ; if charged, the duty assessed in respect of the mortgage interest is either to be allowed as a double assessment, or repaid by the Board of Inland Revenue. 
4.-A borrower, not entitled to exemption, to be repaid by the Board of Inland Revenue such portion of the duty charged on his property as is applicable to mortgage interest. Application for repayment to be made to the Board, and supported by a certificate frcm the secretary of the society as to the amount of mortgage interest paid for the year of assessment; or, the amount of interest so certified may be allowed from the assessment.

5.-Investors or depositors not to be charged for the dividends or interest they receive; if charged, on proof thereof, to be entitled to relief.

6.-When required, any society accepting this arrangement to permit any duly appointed officer of the Board to test the accuracy of the amount returned for Schedule $D$ assessment, or to verify the correctness of any certificate given under the arrangement.

N.B.-These arrangements have been sanctioned by the Board for the convenience of building societies and their members. It should be noted that societies registered under the Building Societies Acts are not exempi from income tax.

The following is the form of certificate used under Arrangement B. :-

INCOME TAX.

Building Societies (Arrangement B.).

Name of society

Address

I hereby certify that $M$

has, during the year $19 \mathrm{I}$, paid to this society the sum of $£ \mathrm{~s} d$ for mortgage interest on property known as

in the parish of

I further certify that the income tax chargeable under the terms of Arrangement B. has been, or will be, paid over to the Revenue.

R. N.

Secretary. 


\section{Notice.}

The following relief is afforded to borrowing members under the above arrangement:-

(I) A borrower whose total income from all sources does not exceed $£$ r6o per annum is not to be charged for mortgage interest If charged, he should apply to the local Surveyor of Taxes for relief from the assessment, or, if the duty should have been paid, for a form of claim of repayment.

(2) A borrower not exempt from income tax is to receive an allowance from the property tax assessment in respect of the duty on the amount of the mortgage interest. To obtain this allowance he should, before payment of the duty, forward this certificate, together with the collector's demand note, to the Surveyor of Taxes for the district in which the property is situated.

Or, the duty on the mortgage interest will be repaid by the Board of Inland Revenue, upon a written application to the Secretary at Somerset House, London, W.C., supported by this certificate and the collector's receipt for the duty paid.

In August $188_{5}$ the case of Re The Middlesbrough, ENc., Middlesbro' Building Society; ex parte Wythes, reported only in the Law Times Reports (53 L.T. Rep. N.S. 492), came before Mr. Justice Kay, and his Lordship decided that income tax might be deducted by a mortgagor in a building society, calculated upon so much of the mortgage repayments as represented interest. Commenting on this decision some years later, the Law Times said:-

"Although the opinions of some text writers of great weight were in favour of the conclusion at which the learned Judge then arrived, it did not appear that the point had previously been decided in any case before the Courts. Presumably it is on account of that decision of Mr. Justice Kay that the Inland Revenue authorities have now made the satisfactory announcement to which we allude." (A memorandum similar to Arrangement A.) 
Building

societies.

Gateshead Society.

\section{Leeds Building Society $v$ Mallandaine. \\ Society liable for tax on interest.}

This decision was followed in the Gateshead County Court in Raffles v. Gateshead Conservative Building Society, I th March 1889 , in a similar case.

The case of The Leeds Permanent Benefit Building Society v. Mallandaine was an appeal by the society against the assessment to Schedule D of interest received by them on loans to borrowing members. The business was conducted on the usual lines, the advances to members being repaid by instalments representing partly interest and partly principal. The society refused to allow deduction of income tax by their borrowers in respect of such interest, on the ground that the interest could not be distinguished, and that such interest was not vearly interest. The General Commissioners had assessed the interest for income tax purposes, and the Special Commissioners had confirmed the assessment, having found that the society had not been charged or assessed in any other manner.

'The appellants contended that this was not anmual interest, and that income tax was only chargeable on other than annual interest when it came under the head of trade profit, and that their income was not profit; that the borrowing members, if not otherwise exempt, were chargeable, and not the society, from whom they might deduct the income tax if paid; and they contended alternatively that, assuming the sums paid to be annual interest, they were not chargeable under Schedule D, being charges upon land to be taxed under Schedule A. The Society had refused to allow deduction by the borrowers, on the ground that the interest was not " annual" interest. 
The Court of Appeal held (2rst and 22nd July r897) that the sums received were not annual interest, inasmuch as they consisted of monthly instalments made up partly of interest and partly of principal, but that interest so received was liable to be assessed under Schedule $\mathrm{D}$, and came within the principle of The Clerical, ENc., case (p. 184), and that it was immaterial for the present purpose whether the payers were chargeable or ought to have been chargeable under Schedule A.

In the case of wagons taken on a hire-purchase agreement, a question arises as to whether any (and, if so, what) proportion of the instalment can be taken as a charge against profit

Interest Included in instalments under hirepurchase agreement. in respect of interest. The matter is to some extent one of bookkeeping, and opinions differ considerably. In our view, the transaction should, for bookkeeping purposes, be treated by the hirer as a sale, and by the purchaser as a purchase. The amount should be entered at net cash price, and interest charged periodically at such a rate as will cause the last payment to discharge the account. By this means the account of the hirer in the books of the purchaser, and that of the purchaser in those of the hirer, will always show the same balance, and only the interest will be a debit and credit respectively to Profit and Loss Account, both for ordinary and income tax purposes.

The official view is that no portion of the instalments is interest or payment of simple hire, and consequently the whole payment is to be regarded as capital. 
Sch. D.-Deduction of Tax on Interest, \&C., Chap. vi. Payable.

Interest

included in instalments ander hirepurchase

agreement.

With all respect, we cannot concur in this view, and it seems to be entirely opposed to the Indian Railway cases, where instalments of "annuities" were divided between capital and interest.

As a fact, a company will state two prices-one for cash, the other if on hire.

If it be argued that it is annual interest, and therefore that tax is deductible, then the "hirer" should be able to deduct tax, and the amount should, pro tanto, be excluded from the return of the "owner."

Also, if so technical a view be taken on the one side, why not on the other side, and an argument be raised that it is all hire.

It is understood that the point is being contested by wagonowning associations.

Annuities to trustees.
In a case in practice where a testator had left certain persons annuities for managing his estate, the trustees deducted and retained tax on payment of the annuities, contending that they were paid out of profits and fell under sec. 40 of the Act of 1853 . The Surveyor contended that they were payments for services rendered, and payable in full and taxable on the recipient. On the case being submitted to the Board of Inland Revenue they expressed their concurrence in the view of the trustees, and discharged assessments which had been made on the recipients. 
In a case where a former director of a company was ordered to pay to the liquidator, with interest, the amount of Interest on sum awarded as damages. dividends alleged to have been paid to the shareholders out of capital, it was held that income tax was not deductible from the interest under sec. 40 , it being in the nature of damages (In re National Bank of Wales, Ch.D. I899).

In The Lord Advocate v. Lord Provost, Erc., of the City of

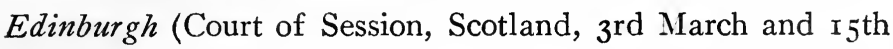
October 1903 and 6th July I905) it was held that the Act of r888, sec. 24 (p. 305), applies to any interest of money, whether yearly interest or not, which is not payable, or not wholly payable, out of profits or gains brought into charge, and that the corporation is bound to retain and render an account of the income tax on the interest on the temporary loans, so far as the interest is not paid out of profits already charged with tax.

In the case of Smith v. The Law Guarantee and Trust Society (Court of Appeal, 9th August 1904) the question was raised whether, when the assets of a company ultimately realised a sum less than the original principal due to debenture-holders, any portion of such sum should be attributed to interest, and be liable to income tax. The Commissioners of Inland Revenue consented to appear and to argue from the point of view that as much as possible ought to be attributed to income. By clause $\mathrm{II}$ in the trust deed it was provided inter alia that the trustees should hold the money to arise from realisation upon trust to pay expenses,

Smith $v$. The Law Guarantee and Trust Soclety.

Deficiency on sale of security. 
Smith $v$.

The Law

Guarantee

and Trust

Society.

Defciency on sale of security.

and the residue first in payment of arrears of interest, and secondly in payment of principal.

The Court held (affirming the decision of the Chancery Division) that the provision (clause II) for payment of interest first was for the benefit of the creditors, and one, therefore, which they could waive, if they so desired. There was no occasion to give them any option to elect, as it was clearly to the interest of every one of them that the payments should be attributed to principal. As suggested by Byrne, J., in the Chancery Division, there might probably be trustee debenture-holders, and part of the amount received by them on account would be distributable as income. The Inland Revenue would, of course, look to them for payment of tax on such amount.

Davis $v$. Marten.

In Davis v. Marten (Chancery Division, 18 th December I903) there was a receiver in possession for debenture-holders, and the rate of interest on the debentures varied. The amount distributable amounted to about 6s. 2 d. in the $£$ on the amount of interest due. The trust deed provided for payment of interest before principal.

Farwell, J., held that, although this provision was inserted for the benefit of the debenture-holders, as their interests differed they could not waive their rights in the absence of agreement of all the debenture-holders. The amount distributed must, therefore, be deemed to be interest, and would be chargeable accordingly. 
In Delage and another v. The Nugget Polish Co., Lim. (King's Bench Division, roth April 1905), the question of the right to deduct tax arose under the following circumstances. By an agreement made in 1898 the plaintiffs sold to Messrs. Lane \& Fitte the exclusive rights to manufacture "Nugget polishes," the consideration being 8 per cent. on the gross receipts for forty years. The rights were assigned in I 900 to the company. The company had deducted tax, and the plaintiff brought this action for the amount thereof.

It was admitted that the profits of the company exceeded the 8 per cent.

On behalf of the company it was argued that this was not a payment out of profits (1853, sec. 40). The 8 per cent. was payable whether there was any profit or not. The recipients were abroad, and if an annuity was payable out of the United Kingdom it could not be taxed. The payments were not income, and, moreover, they fluctuated from year to year.

Phillimore, J., said the defendants were compelled by the Crown, " and rightly so," to pay tax on their profits without deducting the 8 per cent. The amount was clearly an annuity payable out of profits. He continued :-

\section{Delage v.
Nugget Co.}

Deduction of tax on payment of fixed percentage of receipts. 
Pretoria Railway case.

Interest on taking oxer raliway.

"The only point that remains is the question whether it makes any difference that the plaintiffs here are foreigners. I do not think it does; they cannot be directly taxed, but they are receiving a sum of money (not profits) which they only gain because work has been done in this country. It is quite in accordance with the principles of our Legislature that they should receive such money from this country with the deduction of income tax from it. I think, therefore, it makes no difference that they are foreigners."

In Pretoria-Pietersburg Railway Co., Lim. v. Elwood (Court of Appeal, 24th February 1908) the facts were as follows :-

In 1895 a concession was granted by the South African Republic for a railway. The Government were to have power to stop the railway in time of war, \&c., but were only to pay compensation in such a case if they used the railway. The capital of the company was to be $£ 500,000$, and any sum necessary orer and above this was to be raised by debentures. guaranteed by the Republic. The Gorernment had the right to appropriate the railway at any time after completion (on giving two years' notice), in which case they were to pay the full amount of the paid-up capital, with $7 \frac{1}{2}$ per cent. interest, and to take over the debenture liability. The company was duly incorporated in London under the Companies Acts and registered in the Republic.

In 1899 , when war broke out, the Republic seized the railway, which was eventually taken by Lord Roberts.

In 1902 the British Government gave notice to take over the railway from the company under the terms of the concession, which they adopted in its entirety. 
The amount paid was as follows:-

Repayment of Share Capital $£ 500,000$

less an amount previously advanced

to pay a claim on the company

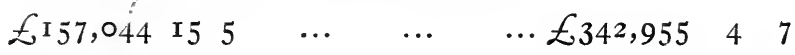

Guaranteed interest thereon from Ist

January I 899 to I 4 th November I903 97,506 I6 II

$7 \frac{1}{2}$ per cent. premium on Share Capital $37,500 \circ \circ$

$\mathrm{I} \frac{1}{2}$ per cent. premium on Share Capital

(for loss on investment to 18 th Feb.

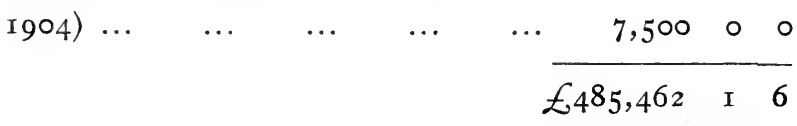

This sum was paid in the United Kingdom by two cheques on the Bank of England, drawn by the Crown agents for the Colonies.

The question was as to $\operatorname{tax}$ on the sum of $£ 97,506$ r6s. Ird. The company contended-

(I) That it was part of a lump (capital) sum and was not either interest or profit ; or

(2) That if it was either they should be assessed as a trading company, this being the assumed gross profit from rst January rgor to I4th November 1903, less expenses in London $\mathcal{E}^{21,624}$ 6s. 3 d., net $£ 75,882$ ros. 8 d. One-third $£^{25,294} 3^{\text {s. } 7 \text { d. }}$ 
The Crown resisted both contentions. The High Court gave judgment for the Crown, considering the point governed by Blake v. Imperial Brazilian Railway and Nizam's Guaranteed State Railway Co. v. Wyatt, but on appeal it was held that the $£ 97,506$ must be treated as profit for the period, and that tax was to be paid only upon one-third of it.

Interest paid in kind.

Deduction of annual

interest.
Where a person borrows money for business purposes and repays it in account, in goods, the question whether or not he should deduct tax in account depends on whether or not the interest is " annual interest." If the goods are taken in account current and the account interested from day to day, it would seem that the interest should be treated like bank interest. If, however, the loan is a fixed one-or repayable by fixed instalments-the interest would seem to be annual, and tax should be deducted when the interest is taken into account.

There have been several important cases before the Courts on the question of the deduction of interest in arriving at profits for assessment.

Alexandria Water Co. v. Musgrave.

Interest payable to foreigners not to be deducted.
In Alexandria Water Company v. Musgrave, heard in the Court of Appeal, 19th April 1883, the company appealed against a judgment confirming an assessment upon them in respect of the whole of their profits. They contended that they should be entitled to deduct a sum of $£ 7,695$, interest payable to debenture bondholders residing in Egypt. Such holders, being foreigners residing out of the United Kingdom, had been paid the full interest without any deduction, and 
the company contended that, as they would be unable to get the tax from anyone, they should not have to pay it. Further, that though there is not to be any deduction made "on " account of any annual interest . . . payable out of "profits" (sec. 100 of the Act of 1842 ), sec. 159 showed that Act of 1842 , the rule was to be limited to cases where the company got back the tax from the recipient of the interest, and that their view was also supported by sec. I02.

These two sections are as follows:-

"Sec. 159. - In the computation of duty to be made under this Act in any of the cases before mentioned (i.e., where the tax has been deducted at the source) either by the party making or delivering any list or statement required as aforesaid, or by the respective assessors or Commissioners, it shall not be lawful-

"To make any other deductions therefrom than such as are expressly enumerated in this Act;

"Nor to make any deduction on account of any annual interest, annuity, or other annual payment to be paid to any person out of any profits or gains chargeable by this Act, in regard that a proportionate part of the duty so to be charged is allowed to be deducted on making such payments;

"Nor to make any deduction from the profits or gains arising from any property herein described, or from any office or employment of profit, on account of diminution of capital employed, or of loss sustained in any trade, manufacture, adventure, or concern, or in any profession, employment, or vocation."

"Sec. 102.- Lipon all annuities, yearly interest of money, or other annual payments, whether such payments shall be payAct of 1842 , sec. 102. able within or out of Great Britain (now the United Kingdom), either as a charge on any property of the person paying the same by virtue of any deed or will or otherwise, or as a reservation thereout, or as a personal debt or obligation by 
Alexandria Water Co. $v$. Musgrave.

Act of 1842, wec. 102. virtue of any contract, or whether the same shall be received and payable half-yearly, or at any shorter or more distant periods, there shall be charged for every twenty shillings of the annual amount thereof the sum of sevenpence (now is. 2d.), without deduction, according to, and under and subject to, the provisions by which the duty in the third case of Schedule D may be charged;

"Provided that in every case where the same shall be payable out of profits or gains brought into charge by virtue of this Act, no assessment shall be made upon the person entitled to such annuity, interest, or other annual payment, but the whole of such profits or gains shall be charged with duty on the person liable to such annual payment, without distinguishing such annual payment; and the person so liable to make such annual payment, whether out of the profits or gains charged with duty, or out of any annual payment liable to deduction, or from which a deduction hath been made, shall be authorised to deduct out of such annual payment at the rate of sevenpence (now is. 2d.) for every twenty shillings of the amount thereof; and the person to whom such payment liable to deduction is to be made shall allow such deduction, at the full rate of duty hereby directed to be charged, upon the receipt of the residue of such money, and under the penalty hereinafter contained; and the person charged to the said duties having made such deduction shall be acquitted and discharged of so much money as such deduction shall amount unto, as if the amount thereof had actually been paid unto the person to whom such payment shall have been due and payable.

"But in every case where any annual payment as aforesaid shall, by reason of the same being charged on any property or security in the British plantations, or in any other of (His) Majesty's dominions, or on any foreign property or foreign security, or otherwise, be received or receivable without any such deduction as aforesaid, and in every case where any such payment shall be made from profits or gains not charged by this Act, or where any interest of money shall not be reserved or charged or payable for the period of one year, then and in every such case there shall be charged upon such interest, annuity, or other annual payment as aforesaid, the duty before mentioned, according to and under and subject to the several 
and respective provisions by which the duty in the third case of Schedule.D may be charged (i.e., on the full amount of Alexandria such interest, \&c., without any deduction):

"Provided always, that where any creditor on any rates or assessments not chargeable by this Act as profits shall be entitled to such interest, it shall be lawful to charge the proper officer having the management of the accounts with the duty payable on such interest, and every such oflicer shall be answerable for doing all acts, matters, and things necessary to a due assessment of the said duties, and parment thereof, as if such rates or assessments were profits chargeable under this Act, and such officer shall be in like manner indemnified for all such acts, as if the said rates and assessments were chargeable."

Brett. I.R., was doubtful whether the company were not entitled to derluct the tax on parment of interest to the foreign Interest payable to
foreigners. debenture-holrlers; but in any case, he said, the contention of the company was in direct contravention to the rule according to its true grammatical reading. It thus became necessary to decide whether there was anything in the statute which would compel the Court to read the rule otherwise than according to its grammatical reading. He considered that sec. I02 did not apply, and that sec. I 59 could not be read into sec. IOO so as to limit its meaning. There certainly was a hardship. but it was one imposed by the plain words of the statute.

Cotton and Bowen, L.JJ., concurred, and the appeal was dismissed, and judgment entered for the Crown.

In The Holborn Viaduct Land Co., Lim. v. The Queen (Queen's Bench Division, I gth, 20th, and 26th May 1887) the facts were as follows: The company had acquired land and built property, having raised for the purpose $\mathcal{E}_{157,800}$

Holborn

Viaduct Land Co., LIm. v. The Queen.

Tax on interest, and under Sch. $A$. Petition of right. 
Holborn Vladuct Land Co., Lim. v. The Queen. by way of mortgage debentures. The income of the property had not been more than sufficient to pay ground rents, rates and taxes, and debenture interest. For the years 1877 to r884 inclusive they had paid tax as follows :-

Under Schedule A, and by way of deduc$£$ s $\mathrm{d}$ tion from ground rents receivable $\quad \ldots \quad$ 2,979 $\quad$ I 9

Under Schedule $D$ in respect of tax deducted from interest paid $\quad \ldots \quad \begin{array}{llllll} & \ldots & \text { r,405 } & 7 & 2\end{array}$

$$
\text { Together } \quad \cdots \quad \cdots \quad 4,384 \quad 8 \text { II }
$$

On the other hand they had deducted from interest and ground rents payable by them tax amounting to $\ldots \quad \ldots \quad \ldots \quad 3,796$ ro

The assessments under Schedule $\mathrm{D}$ had been made in respect of debenture interest, and were based on returns made by them each year. The company sought to recover the said sum of $£$ r,405 7s. 2d., contending that, having been fully assessed under Schedule A, the assessment under Schedule D was a double assessment. The Commissioners, "on the "grounds of fairness, and as a matter of grace but not of " right," offered to repay the above sum of $£ 5^{87}$ i8s. I Id., but the company contended that by petition of right they were entitled to recover the sum of $£ \mathrm{I}, 4057 \mathrm{~s}$. $2 \mathrm{~d}$.

On behalf of the company it was argued that the returns under Schedule D had been made by an oversight; that the company had deducted income tax from the interest under 
sec. 40 of the Act of 1853 , and there was not anything in the Act which entitled the Crown to claim the difference between what a landlord pays and the amount he deducts; that it was a case of double assessment, and the appeal clauses did not relate to double assessments, but there was a clear direction that in such cases the sum was to be returned (I842, sec. I7I ; I880, sec. 60); and that the Act of I860, sec. Io, proriding that-

"No claim for repayment of duty under this Act, or any former Act relating to income tax, shall be allowed unless it shall be made within three years next after the end of the year of assessment to which the claim shall relate,"

did not apply to the case of a double assessment, and if the Commissioners did not comply with their statutory duty of vacating the assessment and repaying the money, the proper remedy was by petition of right.

For the Crown it was urged that the above section did apply, that this was not a case of double assessment, and that there was a complete machinery supplied by the Acts for the correction of any over-assessment-by way of appeal-and where that was applicable it entirely excluded a petition of right; that the company obviously ought to pay over to the Crown the income tax they had retained, as they had, as a matter of fact, simply acted as collectors for the Crown.

The Court decided that the roth section of the Act of 1860 applied, and that the utmost amount which could be claimed 
was the amount for the three past years. This was either a case of double return or of surcharge. If it was a double return the remedy was under sec. I 7 I of the Act of 1842 , or sec. 60 of the Act of 1880 . If this riew was the correct one the Commissioners harl vacated "such part . . . of the assessments as appeared to be an orercharge. . ." (I 880 , sec. 60). The company had, however, refused to accept the offer of the Commissioners. Taking the view of this being a double assessment, they had not taken the appropriate remerly, and they could not have a petition of right. Then, again, if it was a case of overcharge, the remedy was by appeal. The company made a return by mistake, and an assessment was made upon them in respect of it. What they ought to have done when they discovered their mistake was to appeal against the assessment on the ground that it had proceeded on an erroneous return. In either case, they had neglected the proper remedy, and, therefore, could not succeed on a petition of right.

Mersey Loan and Discount Co., Lim. $v$. Wootton (Oyerruled).

Interest payable "out of profits."
In The Mersey Loan and Discount Company, Lim. v. Wootton (Surveyor of Taxes) the facts were as follows: The company received money on deposit and allowed interest calculated from day to day on the balances. The Queen's Bench Division held (I $3^{\text {th }}$ December 1887 ) that the interest was paid "out of profits," and the company was properly assessed upon it. The income tax upon it should have been deducted from the depositors. This decision was, however, overruled by the House of Lords in the case of Gresham Life Assurance Society a. Styles (p. 304). 
In the Commissioners of Supply for Aberdeenshire $v$. Russell the facts were as follows: The Commissioners were assessed to income tax Schedule $A$ on the full annual value of the county buildings. The money borrowed for the erection of the buildings, was secured by mortgage on the rates, not on the buildings. The rents received from part of the buildings were credited, not to the special rate raised to pay the interest, but to the county general assessment. The Commissioners deducted tax on paying the interest, and maintained that they were entitled to retain it, on the ground that they had been assessed under Schedule A for the full annual value.

They urged that the right to make such deduction and retention under sec. 102 of the Act of $\mathrm{r}_{42}$ (ante, p. 297) and sec. 40 of the Act of 1853 (ante, p. 269) was not limited to interest on mortgages of the property assessed, but extended to interest on any personal debt or obligation of the person or corporation whose property is assessed; and, further, that to assess both the interest under Schedule D and the buildings under Schedule A would be a double assessment, as the interest simply represented a portion of the annual value of the buildings. They also urged that the concluding proviso of sec. 102 only applied where the creditor on the rates had no debtor paying income tax deductible from the yearly interest payable to such creditor-i.e., where the interest had not been already paid on in other profits.

The Surveyor contended that as the money borrowed was secured on mortgage over the rate, and the interest on the 
Commis. sioners of Supply for Aberdeenshire $v$. Russell.

Interest payable by corporation.

same was payable out of the assessment levied for that purpose, and not out of the rents of the property, that such interest was assessable in the terms of sec. I02; further, that as the tax under Schedule A was borne by the Commissioners of Supply, and the tax under Schedule D by the creditors on the rates, there was no double assessment.

The Court of Session, Scotland, held (I 4 th June I 890 ) that the tax deducted by the Commissioners was a tax on the lenders, and that there was not any reason why the Commissioners should retain it or receive an abatement from the assessment under Schedule A.

The Lord President said it seemed to him that sec. IO2 was too plain to admit of any double construction. The leading purpose of that section was that all yearly interest not chargeable otherwise under the statute was to be charged in the terms set out in that section, and there was a proviso at the end of the section which specially applied to the case in hand.

\section{See also post, Municipal Corporations.}

Gresham Life Assurance Soclety $v$. Styles.

\section{Annuities} were not payable "out of profits," and could be deducted.
In the case of The Gresham Life Assurance Society v. Styles, in which judgment was delivered in the House of Lords on the 3oth May 1892, the Surveyor of Taxes sought to prevent the company from charging against their profits for income tax purposes the amount of the annuities payable by them. The annuities were granted in consideration of the payment of a lump sum down, which had been brought into the account. 
The Surveyor relied upon the fourth rule of the first case of Scherlule D :-

\section{Gresham Life \\ Assurance \\ Society $*$. \\ Styles.}

"In estimating the amount of the profits and gains arising as aforesaid no deduction shall be made on account of any annual interest, or any annuity or other annual payment, payable out of such profits or gains."

The company contended that the annuities were not payable " out of profits," but that the profits were not ascertained until they had been provided for.

It was held that the annuities were not payable " out of profits," but that they were " money wholly and exclusively "laid out or expended for the purpose of a trade, manu"facture, adventure, or concern," and that they might, therefore, be taken into account. Judgment was accordingly given for the company.

Lord Herschell said this decision was not inconsistent with the decision in The Alexandria Waterworks Company v. Musgrave (p. 296), but it was in conflict with that in The Mersey Loan and Discount Co., Lim. v. Wootton (p. 302).

Now, by the Customs and Inland Revenue Act, I888, sec. 24 , sub-sec. (3), it is provided that-

"Upon payment of any interest of money or annuities charged with income tax under Schedule D, and not payable, or not wholly payable, out of profits or gains brought into charge to such tax, the person by or through whom such interest or annuities shall be paid shall deduct thereout the rate of income tax in force at the time of such payment, and shall forthwith render an account to the Commissioners of Inland Revenue of the amount so deducted, or of the amount deducted out of so much of the interest or annuities as is not paid out of profits or gains brought into charge, as the case may be; and such amount shall be a debt from such person to (His) Majesty and recorerable as such accordingly. . ." 
The Gresham case had been before the Courts previous to the passing of the Act of $\mathrm{x} 888$, and, therefore, the Act (not being retrospective) did not affect the decision.

This Act of 1888 is considered not to create a new liability, but simply to provide machinery. Consequently, in the case of an English company, where foreign agents had paid annual interest to foreigners, the loan being secured on foreign property, the company having made a loss the Revenue surrendered any right to charge the interest, on the ground that such interest would never have been chargeable prior to $\mathrm{I} 888$.

Anglo.

Continental

iuano Works

Bell.

nterest

ayable "out

profits."
In the case of The Anglo-Continental Guano Works v. Bell (Surveyor of Taxes), which was heard in the Queen's Bench Division, Ist March 1894, the facts were as follows: The head office of the company is at Hamburg, and there are branches in London and elsewhere. The London house is carried on as a separate business, and it conducts the whole of the business in the United Kingdom. It is advantageous to the company to buy guano for cash instead of on credit, and in order to do this the London house borrows, from the central office and from bankers abroad, large sums of money of fluctuating amounts, and makes repayments whenever funds are available, paying interest in account current on the fluctuating daily balance. It was contended on behalf of the company that this interest was properly deducted by it in ascertaining the taxable profits of the London house, as it really represented a part of the cost incurred in the purchase of the goods; if the goods had been bought on credit instead 
of for cash a higher price would have been paid, and that higher price would have been properly entered in the books as the cost price of the goods.

The Court gave judgment for the Surveyor. They said that it appeared clear from the Acts that the profits of a business were to be assessed without reference to the consideration as to whether or not the trade was being carried on with borrowed capital. The statement, in rule 3 of the first case of Schedule D, of sums which were not to be deducted, included many charges analogous to the particular one which the company now claimed to deduct. It seemed perfectly clear that such a deduction could not be made. It may be noticed that the interest in this case was payable to a foreign bank, and if allowed as a deduction would have escaped assessment to English income tax, but the decision does not rest on this point, which was not mentioned in either argument or judgment.

In the case of Scottish North American Trust, Lim. (Court of Session, Scotland, I6th July, I9ro), the question was as to the deduction of interest paid on ovedrafts from American bankers. The Trust was formed for the purpose of dealing with American securities, and in the course of their business they borrowed the money on deposit of security and for short periods.

The Crown contended that the money was interest on money "employed or intended to be employed as capital " (p. r27), und, as such, could not be deducted.

Scottish North

American Trust, Lim.

Interest to foreign bank. 
The Court decided in favour of the company. They said

that the dividing line between when the interest on the money was on "capital " and when it was "wholly laid out" for the trade was not easy to define. But that, as Lord Halsbury had said in the Gresham case that "profit" was to be " understood in its natural and proper sense-in a sense which no commercial man could misunderstand," so might " capital " be understood. It might well be said that money borrowed permanently enlarged the "capital," but no commercial man would consider his banking facilities were part of his capital. The natural inference to be drawn from the fact that " annual " interest could not be deducted was that other interest could be deducted.

There does not seem to be any doubt that a company cannot claim to deduct interest from their profits for assess. ment, even though that interest is paid to foreigners permanently residing abroad, and even if the company have not power to deduct tax on payment of the interest (Alexandria Waterworks case, p. 296). The person receiving such interest seems, however, to be clearly within the schedule of charge as receiving it " from any property whatever in the United Kingdom "' (p. 57), and he might be entitled to repayment of the same or part thereof if his total income did not exceed $£ 700$ (see post).

Only one case has come under our notice where the company has been allowed to deduct interest, and that is so exceptional that it is unlikely to form a precedent-viz., the company was originally registered abroad, and issued deben- 
tures to persons abroad charged on land abroad, and which debentures, of course, did not give any right to deduct income tax on payment of the interest. The company being subsequently registered in the United Kingdom, the Crown acknowledged that it was a hardship to include the interest in the profit, and, after considerable delay, they allowed it to be deducted.

It is a little difficult to reconcile some of these decisions with the practice which prevails. For example, it seems to have been held in Bebb v. Bunny (p. 274) that tax could be deducted from the interest because that interest might have gone on for a year or more. Applying the same reasoning to a current account with bankers it might be said that, as such interest might go on for a year or more, tax should be deducted by the banker or customer, as the case might be. It is, however, the universal practice with bankers not to deduct tax before charging or allowing interest. Interest charged by them is brought into their Profit and Loss Account for income tax purposes, and is allowed by the Surveyors as a charge in the customer's account. Interest allowed is, of course, treated in a similar way, viz., is a charge in the bank's books, and a credit on the customer's account for income tax purposes.

Where a loan on mortgage for a fixed amount is made by bankers, tax would be deducted before charging the customer, but where an overdraft on current account is granted on deposit of shares, \&c., the interest would be charged in full; and there is not any provision in the Acts for the recovery of 
the $\operatorname{tax}$ in the case of a person not in business, though the Revenue might obtain it twice, viz., once from the borrower -as he, of course, has it deducted from his dividends (if any) before he receives them-and again partly from the banker in his return of profits.

Diridendenpning thares.

Where, however, the money is specifically borrowed to take up dividend-earning shares, the Board (ex gratia but not ex lege) repay the tax on a certificate from the bank that they have not allowed deduction, and that the interest is included in their return.

De Peyer v. Rex. Interest on overdraft.
In De Peyer v. The King (Court of Appeal, rst February rg09) the facts were as follows:-Mr. E. C. De Peyer had for many years invested money in dividend-paying stocks, and for the purpose of such investment had borrowed from his bankers. Interest had been charged by the bankers at fluctuating rates and for varying periods, and Mr. De Peyer, at the end of each year, had had tax upon the bank interest returned by the Board of Inland Revenue.

The advances by the bankers were sometimes for a longer period than twelve months, and in other cases were paid off in a less period.

In November I905 the plaintiff borrowed from Stuckey's Banking Co., Lim., in order to take up certain debenture stock in a local company. The loan was at bank rate, with a minimum of $4 \frac{1}{2}$ per cent. ; the loan might have remained (at the plaintiff's option) for two years. The debentures of the local company were deposited as security. 
Within twelve months the plaintiff transferred the loan by borrowing the-money from his London bankers, Williams, Deacon \& Co., Lim., from whom he already had an existing loan.

The Board repaid tax on the loan from Williams, Deacon \& Co., Lim., but declined to repay tax on the other loan, on the ground that it had not been outstanding for a period of a year or more. On a prerious occasion tax had been returned on three separate loans, which had not been outstanding for a period of a year or more. On the ist February I907 the Board wrote the plaintiff to the effect that-

"in the case of interest on a fixed sum advanced for a period of a year or more at a fluctuating rate it is doubtful whether the interest is 'annual,' so as to entitle the borrower to deduct tax on payment to the bank (sec. 40), and in view of this doubt if the interest has been paid out of taxed sources and has been taken into account in computing the bank's liability to assessment the Board, as a concession, admit a claim from the borrower if supported by an adequate certificate from the bank. They have extended this concession to cases where interest is paid in full at varying rates on fluctuating advances or overdrafts on current account, although in such cases the interest is clearly not annual. And, strictly speaking, the borrower has no title either to deduct tax on payment or to claim repayment from this department, on the ground that such deduction has been refused by the bankers. But this extension is subject to the proviso that the interest has been paid over one or more years, so as, in fact, to constitute an annual charge on the taxed income of the borrower. It is under this concession that your claims have been admitted for 1906 and past years, but in no case can the Board extend the concession to a case where the advance or overdraft bearing interest has not continued for one year at least." 

De Peyer $v$.
Rex.

Interest on overdraft.

On the case being heard before Lawrence, J., with a common jury, in Middlesex, on $\mathbf{r}^{\text {th }}$ July 1908 , judgment was given for the Crown. The Judge said this was a "short loan," and, under Goslings and Sharpe v. Blake (p. 272), was not subject to deduction of income tax. Even if it had been so subject, the plaintiff, having paid without deduction, had lost his right (Galashiels Provident Building Society v. Newlands, p. 273). If, as a fact, the Commissioners had given him something to which he was not strictly entitled, that gave him no right to a remedy which clearly he was debarred from now seeking.

The plaintiff appealed, contending further that he was entitled to relief under sec. I 7 I (double assessment). $\mathrm{He}$ also contended that this loan was not for less than a year.

The appeal was dismissed.

Cozens-Hardy, M.R., said he assumed, "without in the least deciding it," that the plaintiff had the right to deduct tax on parment of interest to his bankers, but, as a fact, he paicl the interest in full. He also assumed, "without in the least decirling it or expressing any opinion one way or the other." that he might, if so minded. have recovered from the bankers the amount of the income tax which he had failed to deduct. He was unable to see how that could give him any right against the Crown. It had also been said that tax had been paid twice, but that was a fallacy. The bank pay tax on their profits, but it might be they had no assessable profit. It was a fallacy to say they paid tax upon this particular interest. 
'Taking the same assumption, Moulton, L.J., said the De Peyer $v$. provision (deduction on payment) would be meaningless and useless, if everyone could neglect to avail himself of it and then proceed to sue the Crown. The person to whom the interest was paid might be in such a position that he was not paying income tax to the Crown, and the tax would thus be lost. He was not prepared to decide whether, having overpaid the hank. the plaintiff was entitled to recover from them.

Buckler, L.J., said he would assume that the plaintiff was correct in his contention that the decision in Andrew $v$. Ferguson (p. 3I) was right, and the Galashiels case (p. 273) was wrong. If that was so, it was rather against him than in his favour. Clearly there was not a double assessment.

Also, where the money is used for building purposes (in the case, say, of a speculative builder), and the loan secured building purposes. by deposit of the deeds, the Board repay tax on the interest if the borrower supports his application by a certificate from the bank showing the interest charger. They would regard it as an equitable mortgage. On the other hand, it might be contended that the interest should have been debited against trading, and not having been so debited, that there is no redress. It would depend on the exact facts.

The authorities consistently refuse this concession in all cases. except where the loan is from a bank, though there seems no reason why they should not extend it to all cases where they have reasonable security that they are getting the tax from the lender, e.g., in cases of insurance companies. \&c. 
Deduction of bank interest from profits.

Mines.

Addie \& Sons. that of Addie \& Sons, in the Court of Exchequer, Scotland, Cost of plt-sinking disallowed.

Knowles \& Sons, Lim.

Exhaustion of capital allowed, since oyerruled. the Surveyor was instructed " not to press the point." .

In connection with outlay for sinking mining shafts, \&c., in the year 1875 , the cost of pit-sinking was not allowed, being held to be a charge on capital. In the case of $A$. Division, gave judgment in 1877 in favour of the company,
In the case of a trader, which arose in practice, where the Surveyor had refused to allow bank interest as a deduction (relying on the Anglo-Contincntal case), a correspondence was opened up with the Board of Inland Revenue, and ultimately there have been some important cases before the Courts. In Knowles \& Sons, Lim., the High Court of Justice, Exchequer and allowed them to make a deduction for exhaustion of capital by the working of the minerals, the view taken being that the effect of transferring the assessment of mines from Schedule A to Schedule D was, as the Judge thought, to cause the company to be assessed as carrying on the trade of vendors of coal, having bought wholesale a large quantity, not stored in warehouses but in the earth, and which they were going to sell in the course of their trade, and that they ought to be assessed on the principle of valuing the stock-in-trade-that is, the coal thus stored in the earth-at the beginning of the three years (it being considered that mines, \&c., were transferred to Schedule D, it was thought that a three years' average should be taken instead of a five years' average), and again valuing the stock at the end of the three years, taking the difference between them into account in estimating the profits for assessment. This judgment, however, has since been overruled in the case of the Coltness Iron Company. 
The Coltness Company claimed, in the first instance, to have a deduction of $£ 9,027$, being the cost incurred in sinking new pits. This claim was afterwards amended, because it was found to be not the cost of sinking new pits, but the amount of an annual instalment written off an account in the books called "Sunk Capital Account," the instalment being estimated as equal to the exhaustion of capital by the working of the minerals. The claim was disallowed by the Commissioners of the district, and their determination was afterwards affirmed by the Court of Exchequer, Scotland, on the 7 th January r88I. The case was then taken to the House of Lords, and argued very fully, it being maintained, on behalf of the company, that they were entitled to the deduction claimed, under the Inland Revenue Act, 1878, which gave power to allow for depreciation of machinery and plant; that there could not be any profits until the expenditure was repaid; that in the wages expended there was not anything to represent capital ; and that, in fact, the sinking of pits was an expenditure in earning the minerals, and not an investment of capital.

The company also explained that when a mineral field is wrought out the pits become useless, and they do not receive any compensation from the landlord or anyone else in respect of them; and that they have not any means of compensating themselves for the cost of the pits other than out of the gross annual returns derived from the minerals worked from them. They contended that, until these outlays were allowed them, the profits of their business were not ascertained. 
Coltness Iron

Pit-sinking disallowed. Co. V. Black.

The Surveyor contended that the outlay was an investment of capital, and, as such, was specially disallowed by the Act of 1842 . He also referred to several old decisions to the effect that there could not be any deduction allowed for exhaustion of capital by diminution of minerals.

Judgment was given on the 7 th April r88I.

Lord Blackburn said the case was stated in order that the House of Lords might be asked to review the decision of the Court of Session in Addie v. The Solicitor of Inland Revenue, and reliance was placed on the decision of the Exchequer Division in Knowles v. McAdam. Both of these decisions were pronounced at a time when there was not any appeal against either, and, as they were-justly, he thought-considered inconsistent with each other, it was important that both should be brought under review.

Earl Cairns, Lord Penzance, and Lord Blackburn were unanimous in their opinion that the claim of the Coltness Company could not be allowed; that, although the exhaustion of capital would be a proper charge in the Profit and Loss Account, it would not be so for income tax purposes; that the assessment was not on profits but on annual value, and that there was not any distinction between temporary and permanent incomes ; and they instanced the case of terminable annuities. They also held that the decision in the case of
A. Knowles \&o Sons, Lim., was wrong, and one which, in their opinion, was not capable of being supported. 
Lord Blackburn said :

"Whether just or not, there can be no doubt that the same annual charge is imposed upon a terminable annuity and on one in perpetuity, and, what seems harder, that the same annual charge is imposed upon a professional income earned by hard labour, often extending over many years before any return is got, and when earned precariously, as depending on the health of the owner."

The result of the decision in the Coltness case is to overrule that of A. Knowles \& Sons, Lim., and consequently there is not any allowance for exhaustion of capital.

It was also held by the House of Lords that, although mines had been transferred from Schedule $A$ to Schedule D, the assessment of them was still under the rules in Schedule A so far as the five years' arerage was concerned.

\section{Earl Cairns said :}

"I am not prepared to say that a mine owner might not in some cases be entitled to an allowance in respect of the cost of sinking a pit by means of which pit the materials are gotten which are the source of profit for the year in which the pit was sunk. I desire to reserve my opinion on that point until the question arises."

\section{Lord Blackburn said:}

"I do not wish to lay down any general proposition either that money expended in sinking pits can never be in the nature of expenses incurred within the five years in working the coal so as to be properly taken into account in estimating the profits made in that period, or to say what, if any, the circumstances are under which it may be done. That, I think, had better be left to be determined when the case arises." 
Alianza Co. v. Bell:

Nitrate

company.
Principie discussed.
In Alianza Company, Lim. v. Bell (Surveyor of Taxes) (House of Lords, 27th and 28th November 1905), the company, who are owners of nitrate grounds in Chile, claimed a deduction from their profits in respect of the consumption of caliche (the raw material from which nitrate is produced). The caliche is found in deposits about six feet in depth over the grounds, and when the same has been worked out and exhausted the land is of little value. They contended that the caliche should be regarded as stock, and that the fact of that stock being purchased at one operation should make no difference in principle. The Surveyor contended that this was in effect a claim for exhaustion of capital, and the Court upheld this view, and gave judgment for the Crown.

At the time the decision in the Coltness case was given, it was considered to work a hardship, and at first sight this would appear to be so, but on consideration it will be seen that there is not any greater hardship than in the case of those who have purchased life annuities (the tax being deducted from the whole of the annuity, although a portion of it is a return of capital). The view is that when an amount of capital has been invested and formed into an annuity in any shape the whole of the income becomes liable to tax, whether the investment is the purchase of a life annuity or the sinking of capital with the view of getting coal. Another view as regards the ownership of coal may be illustrated thus. Suppose an owner of coal, instead of leasing it, agrees that he will expend the necessary amount in sinking, and that he will then lease the coal under an agreement for a royalty on the coal and a rent equal to the amount expended and interest 
thereon during the term of the lease. It seems clear that in such a case the whole of the rent payable by the lessee would be subject to the tax, and the lessor would pay by way of deduction, or he would be assessed separately for the rent and pay by way of deduction on the royalty. In any case, if such a concession were to be made as that asked for in the cases of Addie \& Sons, Knowles \& Sons, and the Coltness Co., then a distinction would have to be made between the amount of capital and the amount of income included in an annuity created by purchase. Mr. Gladstone, in his Budget speech in 1853 , set up the case of annuities as a great difficulty in the way of dealing with any property of a similar character.

It was held, in Edinburgh Southern Cemetery Company v. The Commissioners of Inland Revenue (Court of Session, Scotland, $13^{\text {th }}$ November 1889 ), that the proceeds of sales of pieces of ground, for burial purposes, were assessable to income tax under Schedule A, No. III., as income derived from a trade carried on by the use of land; and there was not any deduction allowed in respect of part of such proceeds being a realisation or conversion of capital. The Court considered that the case was governed by that of the Coltness Iron Company.

We have always held the view that as a matter of justice annuities should only be taxed on the portion which can be fairly called income after allowing a provision to replace the capital, but it has seemed to us difficult to deal with this administrativel.y. The opinion of the Chairman of the Committee which sat in 1904 (Mr. Ritchie), of Sir Henry

Edinburgh Cemetery Co. v. Cominis= sioners of Inland Revenue.

Part proceeds of sales of land disallowed.

Tax on annuity.

Principle discussed. 
Primrose, and of Mr. Buxton seemed to be that it is fair to tax the whole annuity, though the Chairman considered there was justice in a claim for wasting of capital.

'They apparently support this by suggesting :-

Tax on

annuity.

Principle

discussed.
Iron ore mine.

Allowance for driving levels. (a) That a person buying an annuity does so in order to convert it into income.

(b) That a person so doing escapes estate duty, as he leaves nothing.

(c) That transactions having been entered into on the present basis a change would be an absolute gift to annuitants at the expense of other taxparers.

Sir Henry Primrose made a strong point to his case when he brought out that as to leasehold interests the interest is a continuing one, though passing from A. to B., and that that transfer should not affect the State.

Mr. E. E. Price, in his paper reported in The Accountant, I8th. January I890, states that he has had an allowance by Local Commissioners, from the profits of an iron ore mine, for the expense of driving underground levels to win ore, where the expense was charged against the profits of the year in which it was incurred, and where a considerable part, if not the whole of the ore was realised in the same year. He also cites another case of a quarry, where continual expense was incurred for laying bare the mineral, and this outlay was made in advance of raising and realising the mineral, and then charged off by a tonnage rate on the mineral as it was raised. The work of raising and realising the ore followed pretty 
closely on the outlay for laying it bare, but a considerable sum was sometimes carried forward in the Balance Sheet representing the outlay on baring not yet written off against profits. In this case, after appeal to the Special Commissioners, an arrangement was made to allow a deduction from the profits of each year of the actual expenditure on baring taking place in that year, instead of the tonnage rate.

The case of Morant (Surveyor of Taxes) v. The Wheal Grenville Mining Company (Queen's Bench Division, 2and November 1894) raised a question as to the assessment of a "Cost Book" mine. Such a mine is, in effect, a common law partnership, the shareholders participating in profits and losses, and each shareholder being liable for the whole debts of the concern. There is not any Capital Account kept. If the expenditure exceeds the receipts, so that there is a loss on the working, a call is made to meet it. On the other hand, if the current receipts exceed the expenditure so that there is a profit, it is distributed in dividend. It had been resolved to erect an additional engine, and to sink a new shaft. A call of $\mathcal{E}^{2}$ ros. per share was made to meet the estimated cost, $\mathcal{E}^{15}$,000. The old shaft was worked as before. It was sought by the company to charge against their profit for income tax purposes so much of the call as had been expended, on the ground that the outlay was a necessary expense incurred in working the mine. The Surveyor contended that it was mainly an outlay of capital, and therefore could not be deducted. The Commissioners had allowed the deduction, being of opinion that in Cost Book mines there 
was not any such thing as capital, and that there could not be any profit on the working until every expense had been met. The Surveyor appealed.

The Court gave judgment for the Crown. They said that the fact of the mine being on the Cost Book plan did not make any difference. Under the Act the assessment was to be on an average of five years' profits, and there could not be any deduction for capital expenditure incurred in former years. This had been held in the Coltness case, and in Addie's case the same rule had been applied to expenditure in the current year. The question was whether this was an expenditure of capital or working expenditure. The question was one of fact, and it was asserted that the expenditure was necessary for, and conduced to, the earning of the profits during the period of assessment. That being asserted, the case might go back to be re-stated on that point, and as to whether the sinking of a shaft in this mine was working expenditure or expenditure of capital.

The Surveyor's appeal was therefore allowed, with leave to get the case re-stated on the matter of fact suggested, but the case never came back to the Court.

Dead rents.

An interesting question arises as to preparing returns for colliery proprietors who have to pay a dead rent merging in a royalty, and who have not raised sufficient mineral to work off the dead rent. As before mentioned (p. 319), income tax would be deducted by the colliery proprietors on paying the dead rent, and they would account for it to the Crown by not deducting the dead rent in returning their profits for assess- 
ment-or, in case they did not make a profit equal to the dead rent, they would be assessed upon the amount of the dead rent (see also p. I69). In the course of a few years they begin to work off the overpaid royalties, and though they charge, say, $£^{2}, 000$ against the profit for royalty, they have

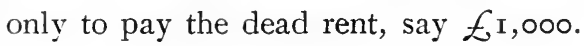

One might be inclined to make up the return as follows :Gross profit for the year 1880 after deducting

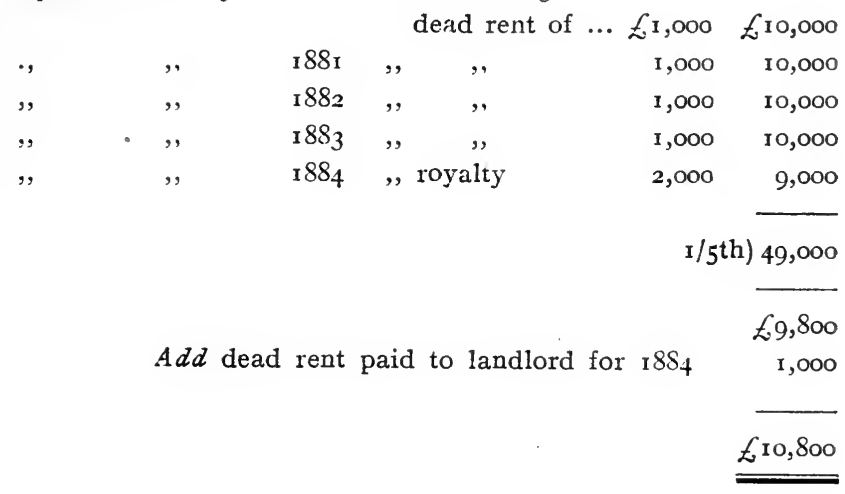

The return, however, is required to be :-

Gross profit for year 1880 without deduction of royalty or

\begin{tabular}{|c|c|c|c|c|c|c|}
\hline & & & & \multicolumn{3}{|c|}{ dead rent $\ldots £_{\text {II }, 000}$} \\
\hline ", & $"$ & I $88 \mathrm{I}$ & $:$, & ", & & 11,000 \\
\hline ", & ", & 1882 & , & , & ," & II 1,000 \\
\hline ", & ," & 1883 & , & ", & ", & 11,000 \\
\hline " & ", & I 884 & ", & , & , & II 1000 \\
\hline & & & & & & I/ $\left./ 5^{\text {th }}\right) 55,000$ \\
\hline & & & & & & $f_{111,000}$ \\
\hline
\end{tabular}


Broughton

The rule governing such cases has been laid down by the Queen's Bench Division in Broughton and Plas Power Company v. Kirkpatrick ( 17 th December 1884 ). The facts of this case were as follows :-The company had a lease for 42 years from the $25^{\text {th }}$ March 1874 . The dead rent was fixed at $\mathcal{E}^{\mathrm{1}, 000}$ a year for the first three years, '£2, the next seven years, and $£ 3,000$ a year for the residue of the term, merging in a royalty of $6 \mathrm{~d}$. per ton. They were to be allowed to recover the overpaid royalty in the first sixteen years. The mines were first worked in October 1880 . From October 1880 to March $188 \mathrm{I}$ the royalty exceeded the dead rent by $\mathcal{E} \mathbf{1}, 477$. In each year up to 1880 the company had paid the lessor the dead rent, less tax, and the tax had been paid over to the Revenue in due course. For the year I 88I -2 the Commissioners made an assessment upon them for $£ 5,843$, the figure being arrived at as follows :-

Balance of profit per Profit and Loss Account $£^{2,556}$ Add Royalties

$\begin{array}{rrr}\ldots & \ldots & 3,477 \\ \ldots & \ldots & 1,000 \\ \ldots & \ldots & 90 \\ \ldots & \ldots & 37 \mathrm{I} \\ \ldots & \ldots & 50 \\ & & £ 7,544\end{array}$

Less Depreciation ‥ $£ \mathrm{r}, 400$

Bank Interest

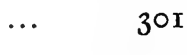


The company claimed that the whole sum of $£ 3,477$ should

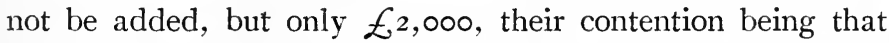
Broughton
and Plas
Power Co, Power Co, v. tax had already been paid on the $\mathcal{E}^{\mathrm{x}}, 477$ in past payments of dead rent. It was held that though the $£$ r,477 had already borne tax, it had been paid not by the company, but by the lessor, and that the company must now pay upon it as a part of the profit of their undertaking.

Though tax was paid upon some portion of the dead rent it really only illustrates the same effect as is produced in any concern, viz., that after a period (usually three years) past losses cannot be set off against present profits.

The following is another case in practice, mentioned in The Accountant, 2 ist February i89r.

A company owned houses, the rents of which constituted its sole income. The assessment under Schedule A exceeded the gross rents. Some of the leases which fell in were renewed at

a premium, and the premium was distributed among the shareholders by way of bonus. The question was raised, incidentally, whether such premiums were liable to tax, but the Inland Revenue did not make any claim. It seems only natural that, as the person paying the premium is not allowed to deduct any part of it from his profits before returning them for assessment, so the person receiving it should not be required to pay tax upon it. It must be considered as a payment and receipt on Capital Account so far as the respective persons are concerned. 
Mr. E. E. Price, in The Accountant, 7th March 1891, gives an illustration of the method to be adopted in order to arrive at the amount to return for assessment in the case of a company in receipt of an income from rents, and also making a profit from sales of property. It is as follows :-

Income from rents (taxed under Schedule A) $\ldots £ 5,000$

Deduct ground rents, insurance, and repairs ... 600

Net income from rents

Income from other sources ...

$$
\text { ... } £ 4,400
$$$$
\text { … I, }, 000
$$

$£ 5,400$

Assume the general expenses, exclusive of above expenses, agent's commission, \&c., to be $£ 400$. This should be divided proportionately between the two classes of income. The proportion chargeable against the untaxed income would be-

$$
\frac{1}{5} \frac{000}{40} \text { of } £ 400 \text {, or } £ 74 \text { is. } 6 \mathrm{~d} \text {. }
$$

and the income to return for assessment would be-

Profit as above ...

Less Expenses ...

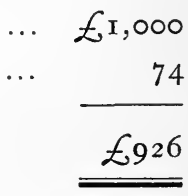

This system, Mr. Price states, was adopted on the advice of one of the City Surveyors, and it seems equitable, for though, as will be seen, it does not allow any expenses to be charged in respect of collection of rents, \&c., the company is only put on the same footing as a private individual would be, 
if the property were so owned-and, moreover, there is now an allowance of one-sixth for repairs, \&c.

As to directors' fees in case of a property company, \&c., see ante p. I 6 .

In the case of a trade carried on by two or more persons jointly, the assessment is to be made upon them jointly In case of partnership, assessment to (if either of them claims exemption, \&c., they can be treated separately though the assessment is in one amount, see Chapter VIII.), and distinct from any other duty chargeable on them or any of them, and the return is to be made by the precedent acting partner, or, in case none of the partners reside in the United Kingdom, by their agent in the United Kingdom ( $18+2$, sec. Ioo, Schedule D, third rule, applying to Cases I. and II.).

In the erent of a change taking place in the partnership, either by death or dissolution, or by admission of a new partner, or in the erent of any person succeeding to a trade, profession, \&c., the profit is, notwithstanding such change, to be ascertained as if the change had not taken place, unless it is proved to the satisfaction of the Commissioners that the profits have fallen short, or will fall short, from some specific cause, since the change took place, or by reason of it (1842, sec. Ioo, Schedule D, fourth rule, applying to Cases I. and II.). This rule is as follows :-

"If amongst any persons engaged in any trade, manufacture, adventure, or concern, or in any profession, in partnership together, any change shall take place in any such partnership, either by death or dissolution of partnership, as to all or any of the partners, or by admitting any other 
Ryhope Co. $v$. Foyer.

Purchase by company is a "succession." partner therein before the time of making the assessment, or within the period for which the assessment ought to be made under this Act, or if any person shall have succeeded to any trade, manufacture, adventure, or concern, or any profession within such respective periods as aforesaid, the duty payable in respect of such partnership, or any of such partners, or any person succeeding to such profession, trade, manufacture, adventure, or concern, shall be computed and ascertained according to the profits and gains of such business derived during the respective periods herein mentioned, notwithstanding such change therein or succession to such business as aforesaid, unless such partners or such person succeeding to such business as aforesaid shall prove, to the satisfaction of the respective Commissioners, that the profits and gains of such business have fallen short or will fall short from some specific cause to be alleged to them, since such change or succession took place, or by reason thereof."

In the case of Ryhope Coal Company, Lim. v. Foyer (Queen's Bench Division, Igth March I88I) it was held that the incorporation of a partnership creates a "succession" within the meaning of the above rule; also, that a diminution of profits caused by extraordinary depression of trade is a falling short of the profits from a " specific cause" within the exception. The facts of the case and the judgment are as follows :-

A partnership, after working certain coal mines for more than five years, was, on the 2 ist December ${ }_{1875}$, incorporated as a limited company, and sold to the company the assets, subject to the liabilities, of a partnership. The partners became holders of all the shares in the limited company according to their interests. After the 3 rd of August 1876 changes took place in the shareholders. The company, being assessed by the Income Tax Commissioners to income tax 
under Schedule D, for the year ending $5^{\text {th }}$ of April 1877 , on an average of the five preceding years, appealed, and contended that they were only liable to pay on a computation for Ryhope Co. v. Foyer. one year on the average of the profits from the 2 rst of December 1875 , the date of the incorporation. The Commissioners stated a case, in which they found that

" the profits and gains of the appellants' business had fallen short since the 21st December 1875 , from the following specific cause, viz., the extraordinary depression in the iron and coal trades, whereby the appellants were unable to sell either so large a quantity of their coals as they had formerly been enabled to do, or to obtain anything like so good a price for such coals."

Figures showing that the annual profits had fallen short by one-half were set out.

It was held that Schedule A, No. IV., Rule 6-which prescribes that if it shall appear that the account required by the rules

"cannot be made out by reason of the possession or interest of the party to be charged thereon having commenced within the time for which the account is directed to be made out, the profits for one year shall be estimated in proportion to the profits received within the time elapsed since the commencement of such possession or interest,"

did not apply.

That the business was a "trade . . . adventure or concern," within Schedule D, Rule I, of the rules for ascertaining the duties to be charged in respect thereof, and was not within the terms of the proviso "set up and commenced" within the period of three years; 
Depression of trade is a "specific cause" of falling off.
Highland Railway $v$. Special Com missioners.

Portion of andertaking discontinued. Profit or loss of that

portion still to be taken into ayerage.
That the company was a new association carrying on an old concern, and had "succeeded" to it within the fourth Rule of Schedule D, applying to the first and second cases; but that, since such succession, the profits had fallen short from a "specific cause" within the exception in that clause; and that the rule of the sixth case (i.e., in respect of profits not falling under any other case) in Schedule D applied, and under it the computation should be made " on the amount of the full value of the profits and gains received annually "i.e., for the current year.

In this connection the case of Highland Railway Company v. Special Commissioners of Income Tax, heard before the Court of Session, Scotland, Ioth and I 2 th November I885, is of interest. The headnote to the report of the case is as follows :-

"Income tax.-Basis of assessment.-Discontinuance of portion of an undertaking.-A railway company discontinues certain steamships which it had been running at a loss. In the following year the assessment on the company must be based on the net profits of the whole undertaking in the year preceding the year of assessment."

The company made a return of $£ 158,644$ for the year $1883^{-4}$, based on the profit of the year preceding the year of assessment (viz., to 28 th February I 883 ). The loss on working, and depreciation, of certain steamers in the half-year to August 1882, viz., $£ \mathrm{I}, \mathrm{I} 67$ and $£ 440$, were deducted in arriving at this sum. The steamers were discontinued during the year ended 28 th February 1883 , and the company entered into a traffic agreement with a steamship owner. The Special 
Commissioners disallowed these deductions, but stated a case for the opinion of the Court. The Court inclined to the opinion that, having entered into such agreement, the company had not abandoned the steamer traffic, but they decided that the assessment should be on the profits of the preceding year, whether any part of the business of that year had been discontinued in the subsequent year or not.

Lord Shand thought the decision turned on whether the company had really abandoned the steamer traffic, or were carrying it on in another form.

Putting this aside, however, the Lord President proceeded to discuss the question on the supposition that that portion of the business had been discontinued, and he came to the conclusion that it was still the same undertaking, and, as such, was to be assessed as if no change had taken place. He said :

"If a portion of the company's business becomes unprofitable, and is dropped, either permanently or for a time, the effect of that is not to make the undertaking of the company something different from what it was . . . the undertaking of the company remains exactly what it was."

He said this was not the same as the case of a business trading company voluntarily giving up a portion of their business, and resolving for the future to continue only in one line of trade.

"That, no doubt, would change the nature of the undertaking. But we have nothing of the lind here. The company exists for the purpose of exercising, as far as they think fit, all the powers conferred by their special Acts." 
He concluded :

"I think, therefore, that the preceding year to the year of assessment having been taken as that upon the profit of which the assessment is to be made, the Commissioners were bound to take the profits of that year just as they actually stood in point of fact, whether any part of the business of that year had been discontinued in the subsequent year or not."

We find a great difficulty in seeing the distinction to which the Lord President alludes. To our mind, the two cases seem to be on exactly the same lines. The only way in which one can see the distinction is by looking at it as one of degree. What relation does the part of the business discontinued bear to the whole business? Is it trivial in comparison, or is it such as to change the nature of the business? But the most important point to observe is that the Court were of opinion that the company had not discontinued any portion of its undertaking, and, that being the case, it will remain to be decided what the decision will be if other facts are found in some future case.

Ferguson $v$. Aikin.

Question as to "succession."
On $14^{\text {th }}$ December 1898 Messrs. Ferguson \& Co., Lim., appealed to the Court of Session under the following circumstances :--The company was formed in May I 896 to take over and derelop the business of Ferguson \& Co., who had, in March 1896 , taken a lease of a distillery, but had not commenced to work it. The distillery had been standing idle for some years. The Surveyor based the assessment for $1897-8$ upon the results shown by the accounts for the period from I6th May I896 to 3oth June 1897 , and the Commissioners upheld the assessment. The company contended that they were "successors" of the old firm, and that the assessment 
should have been made on the arerage profits for the three preceding years.

Ferguson v. Aikin.

Question as to "succession."

The Court held (Ferguson v. Aikin) that the case stated was one of fact as to the identity of the limited company and the old firm; and that the facts set forth would not justify them in coming to the conclusion that the Commissioners had arrived at a wrong legal result.

They therefore gave judgment for the Crown.

It has been held by the Court of Session, Scotland (Watson Bros. v. Lothian, I $3^{\text {th }}$ May I902), that the purchaser of a tramp ship (S.S. "Craigerne") does not acquire a business or concern, but acquires machinery or plant to carry on a business or concern, and that consequently on the transfer of the ship there is not a "succession." The profits were therefore to be assessed on the assumption that the business carried on was a new concern, and the assessment was to be made on the average profit earned since i899, when the purchaser acquired it. In this case there were not any book debts transferred, nor was there any introduction to customers.

Another case is that of Bell $\because$. The National Provincial Bank of England, Lim. (Court of Appeal, roth December 1903). In 1899 the National Provincial Bank (having I99 branches) acquired, as from 3 Ist December 1898 , the business of the County of Stafford Bank, Lim., which carried on business at Wolverhampton only. For 1899-1900, \&c., the Crown sought to assess the National Provincial Bank on a

Watson $v$. Lothian.

Purchaser of S.S. does not succeed to a business.
Bellv. National Provincial Bank of England, Lim.

Business acquired. 
Bell v.

National

Provincial

Bank of

England, Lim.

In yiew of

Commis-

sioners and

Queen's Bench

not $a$

succession,

figure arrived at by adding together the arerage past profits of the National Provincial Bank and of the County of Stafford Bank. The National Provincial Bank claimed to be assessed on the basis of their own arerage past profits without any such addition.

The Commissioners adopted the riew of the company that this was not a " succession " by the National Provincial Bank to the business of the Stafford Bank within the meaning of the rule (p. 327). The Queen's Bench Division took the same riew. They said that a man succeeds to an estate which derolves upon him, although he was previously the owner of other and larger estates, but the rule was not meant to apply to such a case-it was only meant to refer to cases where the concern was the same, but there had been a change of the partners carrying it on, $\mathbb{E}^{\circ} \mathrm{c}$. Ther thought it was impossible to say (assuming the business of the Stafford Bank still survived) that in the hands of the National Provincial Bank it was the same as before the change. In a former case (Ferguson v. Aikin) it had been said, ". . . There may " be cases where a new concern carrying on a large business " absorbs a small concern, and cannot in any legitimate sense " be regarded as their successors," and Ridley, J., thought this was a case in point.

The Crown appealed, and the appeal was allowed. The Master of the Rolls (Collins, L.J.) pointed out that if a new company had been formed to take orer the County of Stafford Bank the case would have come directly within the rule 
(p. 327), and the company would clearly have "succeeded" to the business. What difference could it make that the company was already in existence and carrying on business? The company none the less succeeded to the business because they already had another business. This was not the case of a person buying an existing business for the purpose of annihilating it, because he desired to get rid of the competition and carry on his own business more successfully. There was nothing of that kind here; the former business was now carried on pretty much as before, except that the profits were merged. It was not like the case of an old bank opening a new branch; this was the acquisition of an existing business.

Just about the time that decision was given another case in practice was brought to our notice. It is, indeed, the reverse Assessment of proflt where branch sold, of the National Bank case. A. carried on a business at X, with branches at $\mathrm{Y}$ and $\mathrm{Z}$. The accounts of the head office and the branches were all kept quite distinct. By agreement it was provided that each of the branch managers was, on the death of $\mathrm{A}$., to have the option of purchasing the branch on certain specified terms. They duly exercised the option (say) 3ist March 1902, and the question of the assessment for I 902-3 arose. The assessment had previously been made upon A. in one sum. The Surveyor contended that the assessment should be upon the average profits of the whole concern made in 1900, I901, and 1902. The representatives of A. contended that, as only the one business was now being carried on by them, the assessment should be on the average profits made in that one business during the three past years. The 
CHAP. VI.

Assessment of profit where branch sold, \&c.

Stockham $v$. Wallasey U.D.C.

Person cannot succeed to part of an undertaking.
Commissioners decided in favour of the Surveyor, and the representatives of A. appealed. Everything went on in preparation for the hearing, but at the last moment the authorities intimated that they had come to the conclusion that the view of the representatives of $\mathrm{A}$. was the correct one, and the assessment would be amended accordingly.

Of course, the branch businesses would be assessed separately on those who acquired them.

In Stockham v. Wallasey Urban District Council (King's Bench Division, roth and 18th December 1906) the facts were as follows :-

The Wallasey Tramways Company was incorporated by special Act in 1878 . The total length of the tramway was to be about six miles. It was a single line horse tramway, and was only authorised to carry passengers and small parcels. Only four miles were constructed.

In 1885 the Seacombe and New Brighton Omnibus Company, Lim., was incorporated.

In 1888 the two concerns were bought up by the Wallasey United Tranways and Omnibus Company, Lim. The actual transfer was completed in $\mathrm{I} 8 \mathrm{~g} \mathrm{I}$.

By the Wallasey Tramways Act I 886 certain of the tramways authorised were abandoned.

By the Wallasey Tramways and Improvements Act I 899 the Wallasey Urban District Council acquired powers to construct about eight miles of tramways, \&c. 
After litigation it was decided by the House of Lords that the Tramways Act 1870 , and the above Act of $18 ; 8$, gave the Council power to purchase the first-named tramway in $\mathbf{I} 900$. This was accordingly done in I90I, and the price was Stockham v. Wallasey U.D.C. $f_{20,500 .}$

The company then sold the remainder of its assets-viz., stables, horses, omnibuses, \&c.- to a new company called the Seacombe and New Brighton Omnibus Company, Lim.

The Council, immediately on the completion of its purchase, converted the horse tramway into an electric tramway and constructed about six miles more. During the period of construction (3Ist March I90I to $x 7$ th March, I902) the Council ran horse tramways so far as possible. On the I 7 th March I902 the Council had completed its new system of ten miles, and commenced to run twenty cars thereon (as against nine cars when it was a horse tramway).

Up to and including r900-or the old company had always paid on its profits an arerage as one business, and the directors' report and the accounts, \&c., treated it as one business.

The profits of the tramway portion of the old company were agreed at $\mathcal{E 3}_{3}, 268$ for the year ended 3 Ist March I9oo and $\mathcal{E} 4,902$ for the following year. The Council made an actual profit of $\mathcal{E}^{2,162}$ from 3 Ist March 1901 to 17 th March I902, of $£ 479$ from I 7 th March 1902 to 3 Ist March 1902 , and for the year ended 3 Ist March $1903 \mathcal{E I}_{2}, 49^{2}$. The agreed amount of wear and tear was $£ 6,040$. The interest payable for the year ended 3 ist March I903 was $£ 3,772$. 
Stockham $v$. Wallasey U.D.C.

Person cannot succeed to part of an undertaking.

For the year $1902-3$ the Council made up their return as follows :-

$$
\begin{aligned}
& \text { Profit } 1899-00 \quad \ldots \quad \ldots \quad \ldots £ 3,268 \\
& \begin{array}{lllll}
\text { I } 900-\text { OI } & \ldots & \ldots & \ldots & 4,902
\end{array} \\
& \text { I } 901-02 \quad \ldots \quad \ldots \quad \ldots \quad 2,64 \text { I } \\
& \text { 3) IO, } 8 \text { I I } \\
& 3,604 \\
& \text { Depreciation ... } 6,040 \\
& \text { Loss ... } \underline{\underline{£^{2,436}}}
\end{aligned}
$$

or alternatively they showed a loss of $\mathcal{E}_{3}, 399$ on the basis of the first year's working, I901-02. They claimed $(a)$ that their tramway from March I901 to March 1903 was one and the same business, irrespective of the fact that it had been run partly by horse and partly by electric traction; $(b)$ that it was the same tramway as that carried on by the old company; (c) that they were successors to the old company.

The Surveyor contended (a) that the business carried on during the year 1902-3 was a new business commenced I 7 th March I902; (b) that it was therefore to be assessed on the profit actually made ( $\mathrm{I}_{\mathbf{2}}, 492$, less depreciation); (c) that it was not the same tramway either as that carried on by the old company or as that carried on by the Council previously ; $(d)$ that it was not a succession; $(e)$ that the tramway was not sufficiently identical with the old tramway; (f) that any other estimate than that which he contended for would not be a "fair and just" estimate. 
The Commissioners decided in favour of the company, and the Crown appealed.

Stockham $v$. Wallasey U.D.C.

Person cannot succeed to

The Court (Bray, J.) said the Crown had argued that this part of an undertaking. had been both a tramway and an omnibus company, and that a person could not succeed to part of an undertaking; to that he agreed, but he thought that if a person were carrying on two separate businesses a purchaser could succeed to one of them. It thus became a question of fact whether there were two businesses. In view of the fact that the tramway was a separate undertaking created by Act of Parliament (and that the profits were distinguishable) he thought the Council might become "successors." Then, as to the question whether this was the same business or a new one, he thought a fair examination of the Act showed that the undertaking of the Council was the same business, though much larger. Of the $\mathcal{E}^{84,000}$ spent, only $\mathcal{E}^{20,000}$ was the cost of the original undertaking, but that did not cause him to alter his views.

In Merchiston S.S. Co., Lim: v. Turner (King's Bench Division, 4th March I910) the facts were as follows. The company was formed in I90 I as a single-ship company to acquire the S.S. "Merchiston." On Ist April 1906 the ship was lost at sea. Out of the proceeds of the insurance moneys the S.S. "Veraston" was built, and she commenced her first voyage on the 17 th October 1906 .

For 1906-7 the company were not assessed in respect of the "Merchiston." They were assessed in respect of the "Veraston" as follows :-

Merchiston S.S. Co., Lim. v. Turner.

New ship for old one. 
S.S. Co.,

Lim. $v$.

Turner.

New ship for old one.
Merchiston

\section{Profit of first voyage, I 7 th October 1906 to 7 th May}

$$
\begin{aligned}
& \text { r907 (203 days) } \quad \ldots \quad \ldots \quad \ldots \quad \ldots \quad \ldots \quad \ldots \text { E9r6 } \\
& \text { Proportion to } 5^{\text {th }} \text { April } 1907 \text {... } \quad \ldots £ 77 \text { I }
\end{aligned}
$$

For 1907-8 the assessment was based upon the above figure of $\mathcal{9 r 6} 6$ (subject to certain adjustments) at $£^{2,045}$ for the year (as a new business).

The company contended for an assessment upon the average profits of the past three years; and that the other mode would only be correct in the case of a steamer divided into 64 shares.

The Surveyor contended that the company was formed for carrying on "adventures" one at a time; that the adventure carried on in respect of the "Merchiston" ceased on her loss ; that no adventure was carried on from the ist April to the x6th October, and that a new one commenced on the 17 th October with the "Veraston" ; and finally that, in any case, as no business was carried on for six months, the assessment should be on $2 / 5^{\text {ths }}$ (12/30ths) of the total profit and not on $\mathrm{x} / 3$ rd only.

It was held that this was one business and was assessable on past results.

Distinct businesses-
A correspondent writing to The Accountant, $3^{\text {rd }}$ June 1893 , mentioned a case which had arisen under the following circumstances. A trader carried on the "A" business, making profits, and the " $\mathrm{B}$ " business, making losses. The latter business was discontinued in June 1892 , but in the return 
for the year 1893-4 he claimed to bring the losses into the three years' average. The Surveyor objected, on the ground that as the business was not being carried on there could not be any profit or loss for the year. The contention of the Surveyor seems reasonable. The trader is to estimate his profit for the year on an average of previous years, and it is not natural to bring into that arerage past results relating to a business which cannot possibly affect the year's profit or loss. Moreorer, the section (IOI) refers to a person "carrying on" two or more trades, and thus seems to contemplate only the case where the two businesses are being carried on during the year for which the return is being made.

The Highland Railway (p. 330) case can scarcely be considered an authority on this question, as in that case there was only one business.

The question has been raised whether, where a licence has been extended from six to seven days, it is the same business. On principle we think such a change should be regarded only as an extension of an existing business, and the concern should be assessed on the basis of past profits, just as is the case where the proprietors of a business open a new department.

Where a person who has been an employee becomes a partner, the amount of the salary paid to him should, in our opinion, be added to the profits of the respective years during which it was paid-before the arerage is taken. Thus, in the 
Employee made partner.

His salary to be added to profits for income tax purposes?
Effect of principle of axerage in case of "succession."

expenses" include salary paid $\mathrm{X}$. at $£ 300, £ 35 \circ$, and $£ 400$ for the respective years, and $\mathrm{X}$. is admitted a partner as from December 1910, the profits of the firm for the years of average must be taken as $£_{2}, 600, £_{3}, 260$, and $£_{3}, 640$, giving a total of $£, 9,500$, and an arerage of $£ .3,166$ i3s. 4d.

Many Surveyors, howerer, do not so adjust the old figures, but leave the profit as ascertained-an advantage to the taxpayer, but, apparently, wrong in principle, though approved by the authorities-see also post.

Now, this rule of averaging in the case of a succession is, by some, considered a hardship, but let us see what are the reasons for it, and how it really operates. In the first place, at the commencement of the year we want to estimate the profit for the current year. What better estimate can be made than one based on the profits in past years? The Inland Revenue evidently consider it inadvisable to wait till the end of the year, otherwise, no doubt, all trades, \&c., might be assessed on the year's profits. It is true that in the case of a person commencing a business the authorities will frequently allow him to wait until the end of the year and assess him on his actual profits, but this is because there is absolutely not any basis on which to compute what his profits are likely to be. In the case of a sale or succession, however, an estimate can be made from the profits of the person originally carrying on the business, and it does not seem a very violent supposition to think that the new business will make as much, on the average, as the old one did. The case of a profession, such as accountancy, is, of course, rather different from that of a 
trade; but then we have the exception as to a falling short from a "specific cause" to fall back upon, and seeing the liberal construction placed upon it in the $R y$ hope case, are we not justified in looking for an equally fair construction in the case of a profession? Surely, if it were shown, for example, that certain audits, \&c., would not be given to the purchaser of an accountancy practice, that would be a falling short from a "specific cause." and would be ground for not taking an average of past years.

In the case of a firm dissolving partnership and the partners going into business separately, there is not any "succession" ; but each of the new concerns will be assessed as a new business.

Where A. and B. are in partnership as A., B. \& Co., and A. buys the goodwill, and B. starts a new business of the same nature, not being prohibited by the agreement of sale, it would appear to be a "succession" by $\mathrm{A}$. to the business, and he would be assessed on the average of the entire profits made in the past, subject to his right to claim a reduction of the assessment on the ground of a falling off from a " specific cause" (ante).

In the case of an amalgamation of four concerns, A., B., C., and D., if the past profits are ascertainable, the profits

Amalgamation of firms or companies. would be assessed-

For the first year of the new company,

On the average three years' past profits of the old concerns. 
If accounts

obtainable, return to be on past profits.

If accounts not obtainable, return to amalgamated concern.

Mine purchased.

New business commenced.
For the second year,

On the average of two years' past profits of the old concerns, and of the one year's profit of the new concern.

and so on.

If, however, the past profits or any of them were for any reason not obtainable, the new company would be assessable, For the first year,

On the profits shown by the first accounts. It is usual in such cases, and cases of entirely new concerns, to leare the assessment till the first making-up.

For the second year,

On the profit of the first year.

For the third year,

On the average profits of the first two years, and so on.

In the case of the owner of one mine taking orer another mine, the profit should be assessed by taking the average result of each mine for the past five years, not, as has been suggested, by adding the profit of the second mine for the one year to the arerage profit of the original one during the past five rears.

Where, however, a person commences an entirely new business (not an addition to an existing business), and wishes to set off a loss in it against a profit in the old business (or vice versâ), the return will be as follows:- 


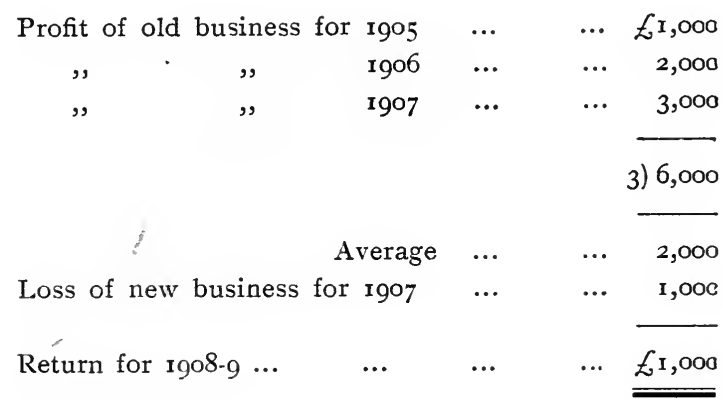

Not, as has been suggested,

Profit of old business for 1905

$£$ i,, 000

, , $\quad 1906$

2,000

,, $\quad$, $\quad 1907$

Loss of new business for 1907

$£ 3,000$

$\mathrm{I}, 000$

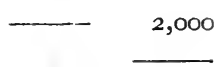

3) 5,000

Return for $1908-9$

f. 1,666

New business

commenced.

\section{(a)}

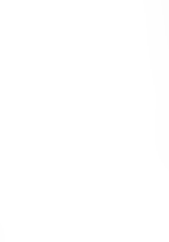


Specific cause and directors' fees.
"Specific cause" arises most frequently in the case of a partnership being converted into a company.

Assume a uniform profit of $\mathcal{E}_{\mathrm{I}, 000}$ drawn by two partners equally, and that, on incorporation, ther become entitled to salaries as dircctors of $£ 500$ each. The business is firstly assessed on the hasis of past results at $\mathcal{E}_{\mathrm{r}, 000}$ under Schedule $D$, and the directors are individually assessed on $£ 500$ each under Schedule E. It is therefore clear that, for the first year, there are assessments amounting to $\$, 2,000$ in respect of an anticipated profit of $E_{\mathrm{r}} \mathrm{r}, 000$. If the business improves and makes $£ 2.000$ before salaries ( $=£_{1} \mathrm{r}, 000$ net), there is no relief, and the company pays on $\mathcal{E}_{\mathrm{N}} \mathrm{I}, 000$ more than it would have done had it continued as a partnership. This is a new practice, which has only sprung up within the last year or two. Formerly, an original assessment would have been amended as a matter of course by adjusting the profit of each of the past years coming into arerage by the amount of fees for the current year which were coming into assessment under Schedule E.

Assume, again. that we have a private company with a fairly constant profit of $£, \mathrm{r}, 000$ per annum, and that previous to the $190 ;$ Act the (practically) sole shareholder, seeing that it then made no difference, did not hare any salary, and drew all the $E_{1} \mathrm{r} .000$ as dividend. Since 1907 he decides (and fulfilling the spirit of the Act, too, and not by way of evasion) to draw the $\mathcal{E}_{\mathrm{r}, 000}$ as salary, and pay on it at $9 \mathrm{~d}$. in the $\mathcal{E}$. As soon as this is known, an assessment under Schedule $E$ is made immediately, and he stands, for the time being, with the 
two assessments upon his profit. Other things being equal, the profit of the company will come out, after fees, at nil, and, the profit having fallen short from the "specific cause" of the fees, the assessment on the company will be discharged, and he will only bear a fair tax.

But, wrongly in our view, the same effect will not be accomplished if he had previously had a salary of $\mathcal{E}_{5}$ o0 and dividend $\mathcal{E}_{500}$, and then decided to take the whole $\mathcal{E}_{\mathrm{r}, \infty}, \infty 0$ as salary. We are told that an increase of salary is not a "specific cause," and profits being as follows :-

\begin{tabular}{|c|c|c|c|c|c|c|c|}
\hline Profit & Vear to 3 ist & March & 1904 & after & $£ 500$ & fees) & $£ 500$ \\
\hline , & , & , & 1905 & , & , & , & $5^{\circ 00}$ \\
\hline , & " & " & 1906 & ", & ", & " & 00 \\
\hline , & ", & , & 1907 & ffter & $6 x, 000$ & fees) & 1 \\
\hline , & , & , & 1908 & , & ," & , & il \\
\hline$\because$ & " & ", & 1909 & , & , & ," & \\
\hline ", & , & , & 1910 & , & ," & , & \\
\hline
\end{tabular}

Tax is assessed :--

Schedule D.

(on average)

\begin{tabular}{|c|c|c|c|c|}
\hline & & & $\begin{array}{l}\text { Schedule } \mathrm{D} \text {. } \\
\text { (on average) }\end{array}$ & $\begin{array}{c}\text { Schedule E } \\
\text { (actual) }\end{array}$ \\
\hline Year & $1906-7$ & $\ldots$ & $\ldots \quad £ .500$ & $f_{1}, 000$ \\
\hline , & $1907-8$ & $\ldots$ & $\begin{array}{ll}\ldots & 333\end{array}$ & I,OOO \\
\hline \multirow[t]{2}{*}{,. } & Igo\$-9 & $\ldots$ & $\ldots \quad 167$ & I,OOO \\
\hline & & & $£$ I,000 & $£ 3,000$ \\
\hline
\end{tabular}

Specific cause and directors' fees.

and the result is that tax is paid in three years on $\mathcal{E}_{4}, \infty 00$ instead of $£ 3, \infty 00$, and it is only from the following year onwards that the full benefit is obtained.

It may possibly be that sec. I 34 was really meant to apply only to a cessation of profit, in which case it is not available in the illustration given, and the original "succession" rule (p. 327) is clearly not applicable. The fact remains, however, 
that, possibly by concession, such adjustment used to be allowed, and has now been withdrawn. One sees the practical difficulty of allowing a dividend in a private company (which is really "earned ") to be regarded as such, but all representations in that direction were received sympathetically in the House, and the authorities, in this respect, are going out of their way to refuse the differential rate, where it might easily be granted without in any way straining the law.

Principle in

cases of

change or

"succession."
These cases of "change" and "succession" are frequently difficult to deal with, but the principles to be followed appear to be :-

(I) If the business is substantially the same business the profits are to be computed on the basis of past results, without any adjustment in respect of the change.

(2) If the business has been materially changed by the acquisition of some other business previously carried on, the past results of that business must be taken into account.

(3) If, on the other hand, the business has been materially changed by the sale or discontinuance of a portion of the business, the future basis of assessment is to be upon the past results of the portion remaining, an assessment being on a business carried on .

(4) If it is impossible to obtain the result of the business acquired, or the portion discontinued, we think the business might fairly be assessed as a new one. 
A person carrying on, either alone or in partnership, two or more distinct trades, \&c., chargeable under Schedule D, is entitled to set off a loss on one against a profit on another ( 1842 , sec. IOI), but it is only since 1890 that power has been given to set off a loss in trade against taxed interest or other income (see Part III. of this chapter, and also the case of Grimes v. Letham (post)).

In the somewhat exceptional case of a person being an employee in one business and owning, or being a partner in, another, he is not "carrying on two or more trades," and in the event of the business showing an arerage loss he cannot set this off against the salary under sec. Ior, but he can claim repayment under the Act of $1890(q . v$.

Where one company owns (practically) all the shares of another company, and thus controls it, the two companies are still, for the purpose of assessment, treated as quite distinct. As to setting off a loss in one company against a profit in the other under the Act of 1890 , see post (Part III. of this chapter).

The case is stronger where the one company does not hold all the shares of the other. In J. J. Farrell (Surveyor of Farrell $v$. Sunderland Taxes) v. The Sunderland Steamship Company, Lim. (King's Bench Division, I3th May rgo3) the facts were that the company owned only one ship, the "Brookside." In May I900 they purchased $59 / 64$ ths of the "Glendochart," and took over the management of her. Assessments for I90I-2 were made as follows :-

Person being both partner and employee.

One company owning another. 
Farrell v. Sunderland S.S. Co.

In respect of profits of the "Brookside" :-

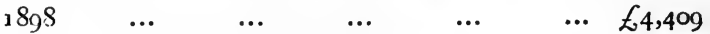

$$
\begin{aligned}
& \begin{array}{llllllll}
1899 & \ldots & \ldots & \ldots & \ldots & \ldots & 4,878
\end{array} \\
& \begin{array}{lllllll}
1900 & \ldots & \ldots & \ldots & \ldots & \ldots & 5,566
\end{array} \\
& \text { 3) } 14,853 \\
& \text { Assessment for } 1901-2 \quad \ldots \quad \ldots \ldots, \ldots, 951
\end{aligned}
$$

In respect of profits of the "Glendochart":-

$7^{\frac{1}{4}}$ months' profit to $3^{1 \text { st }}$ December 1900

$$
\cdots \frac{£_{1}, 874}{£_{3}, 101}
$$

(The accounts for previous years were not available, and it was agreed to deal with the ship on the basis of actual profits for the period.)

The company contended that the proper method was :-

$$
\begin{aligned}
& \text { "Brookside," } 1898 \quad \text {... } \quad \ldots \quad £ 4,409
\end{aligned}
$$

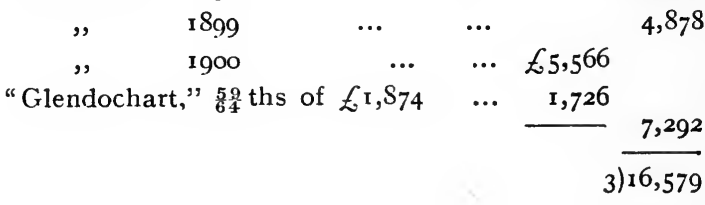

$$
\begin{aligned}
& \text { Assessment for 1901-2 } \quad \ldots \quad £ 5,526
\end{aligned}
$$

The Commissioners found that the acquisition of the "Glendochart" was a mere expansion of business.

The Surveyor contended that there were two separate concerns, with separate books, and that the third rule of Case I. and II. (see p. 327) applied. He relied on the case of Attorney-General v. Borrodaile, decided in $18 \mathrm{r} 4$.

Ridley, J., in giving judgment for the Crown, said that he had some doubt whether there might not be a distinction between the partner who merely owned some 64th shares and 
the partner who took an active share in the management, but that the case quoted was a case precisely in point, and doubt had never been thrown upon it; that case decided that under words exactly the same as the third rule the ship's husband, or owner, was held to be bound to make the return on behalf of all the other partners.

A claim by the Corporation of Birmingham to set off a loss on carrying on a trade so far as public baths, schools, sewage works, \&c., were concerned, against a profit on other concerns was disallowed by the Court ( $I n$ re Corporation of Birmingham, Court of Exchequer, 9th June 1875). It was held that the corporation could not be considered as carrying on two or more trades within sec. Ior (above).

A difficulty arising in the case of underwriters is that it is almost impossible for them to make up their accounts to show the profits for the three years immediately preceding the year of assessment. In I89 I an underwriter appealed against an assessment upon him for the year 1890 , and produced accounts for $1886,188^{\top}$, and 1888 , claiming to have the assessment reduced to the average of those years, and contending that it was impossible to show any accounts of a later date. The Surveror objected, but the Commissioners amended the assessment as desired. The Surveyor gave notice of appeal, but the Board of: Inland Revenue decided not to proceed with the appeal, and accepted the decision of the Commissioners. Underwriters.

In re CorBirmingham.

A corporation does not carry on two or more trades within the Act. 
Mode of assessment in case of municipal corporations.

The assessment of municipal corporations has been revolutionised by the decision of the House of Lords in the case of Attorney-General v. London County Council. The previous practice was given in the appendix to the Third Edition, including the case of London County Council v. Grove.

A..G. v. London C.C.

The facts in the London County Council case were as follows :-The amount paid by them as dividends and interest on loans in the year $1897-8$ was $£^{\mathrm{I}, \mathrm{I}_{42}, 884}$. The stock and the dividends thereon are, by virtue of the Metropolitan Board of Works (Loans) Act, r869, and subsequent Acts, made a charge upon the lands, rents, and property belonging to the London County Council and their predecessors (the Board of Works), and on the rates to be levied by the Council. The London County Council deduct tax on payment of dividends, and the question arose as to how much of such tax they were entitled to retain under sec. 24 of the Act of 1888 . The Attorney-General contended that by reason of this charge only a rateable proportion (if any) of the dividends could be regarded as payable out of profits or gains charged. $\mathrm{He}$ contended alternatively :-

Ist. That no part of the interest was payable out of profits.

2nd. Only such part was payable out of profits as was payable out of interest received by the London County Council from local authorities in respect of loans to them. 


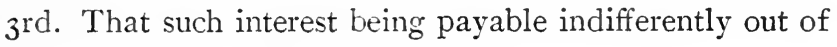

(a) Interest received; and

(b) the remainder of the Consolidated Loans Fund (both capital and income),

only a proportionate part was payable out of profits charged.'

Erentually the Crown abandoned the first alternative.

In the Queen's Bench Dirision, Ist June I899, Day and Lawrence, JJ., gare judgment for the Crown, holding that the third alternative was the correct method; also that Schedule $A$ and Schedule D were distinct, and that sec. 24 of the Act of r 888 had no reference at all to Schedule $A$.

The Council appealed, and the case came before the Court of Appeal, +th, 5th, and 2oth December I899, when the appeal was dismissed. Smith, Collins, and Vaughan Williams, Queen's Bench Division thought Schs. $A$ and $D$ were distinct. L.JJ., were unanimously of the same opinion as the lower Court as to Schedule $A$ and Schedule $D$ being distinct. Collins, L.J., thought the London County Council might have appropriated, and would have been justified in so appropriating their funds as to put themselves in a position to prove that they had actually applied certain specific sums of the Consolidated Loans Fund in a particular manner, and thus entitle them to retain tax on certain portions of the dividends paid-but they had not done so. Vaughan Williams, L.J., was of the same opinion; he, however, held that in applying the third alternative (above) regard was not to be had to any part of the fund which was capital, but only to such part as was income.

Court of Appeal confirmed decision of Queen's Bench Division. 
A.-G. v. . . .

\section{House of} Lords allowed appeal.
Act of 1888 . "Paid out of" profit.
Schs. A \& D not distinct. Income tax is one tax.

The County Council again appealed, and the case was heard in the House of Lords, $23^{\mathrm{rd}}, 24^{\text {th }}$, and 26 th July 1900 , before Lords Macnaghten, Darey, James of .Hereford, Brampton, Robertson, and Lindley. Judgment was given on the roth December 1900, when their Lordships unanimously allowed the appeal, and reversed the decision of the lower Courts.

Lord Macnaghten dismissed the idea of having regard to both the capital and income of the Loans Fund as "an ingenious but not very business-like suggestion," and " not open to argument." He called attention to the fact that in sec. 24 of the Act of 1888 the word "payable" was first used, and later the word "paid," and drew the conclusion that so far as interest was in fact paid out of profit (whether in law payable thereout or not) the person paying might deduct and retain the tax. He then proceeded:

"Income tax, if I may be pardoned for saying so, is a tax on income. It is one tax, not a collection of taxes essentially different. There is no difference in kind between the duties of income tax assessed under Schedule D and those assessed under Schedule A, or any of the other schedules of charge."

Again,

"But to read the enactment (the Act of 1888 ) as imposing a double duty would be contrary to the whole scope of income tax legislation, and whimsical in the highest degree, when you consider that the double burden would necessarily fall upon the fundholder, in whose case the collection of duty is certain, while a person chargeable under Schedule D would be expressly exempted from double duty."

Lord Davey, in the course of a like judgment, alluded to the view of Collins, L.J., that the London County Council 
might have made some appropriation of their funds; he $\underset{\text { London }}{\text { A.-G. }}$. . (Lord Davey) thought it difficult to see how any accountkeeping by the debtor could alter the rights of the Crown.

Tax paid under Schedule A on property occupied by the Council, and which, therefore, does not produce any rent, cannot be set off against tax deducted from interest paid (Attorney-General v. London County Council, House of Lords, 2 2nd and 25th June 1906 and 19th March 1907). The Council paid interest amounting to $\mathcal{E}, 371,000$. This was paid as to $£ 838$, 000 out of rents, \&c., and as to $£ 533,000$ out of rates. The Council were assessed to Schedule $A$, in respect of premises occupied by them, on $\mathcal{E}_{\mathrm{r}} \mathrm{8}$, 000. It was agreed that tax was rightly deducted and retained on $£ 838,000$, and the only point at issue was whether the Council should pay orer to the Crown tax on the whole of the remaining $£ .533,000$, or whether they were entitled to retain on $\mathcal{E}_{\mathrm{I}}$ 8,000, and were only liable to pay orer on $\mathcal{E}_{4 \mathrm{I} 5}, 000$. The Crown relied on the words "paid" in sec. 24 of the Act of I888. The King's Bench Division held that the substance of the matter should be looked at; that the Council in effect raised $\mathcal{E}_{\mathrm{I}} \mathrm{8} 8,000$ out of rates to pay for their occupation of the land, \&c., in question; that the land had no real value to them, being charged to its full value, and tax paid on it under Schedule A; that if they had to hand orer tax on the whole

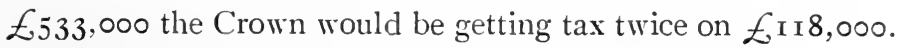

'They, therefore, held that the Council were entitled to the relief claimed. This was confirmed by the Court of Appeal, but the House of Lords unanimously decided to the contrary. 
A. $-G$. $v$. London C.C.

Tax paid on premises occupied cannot be set off against tax deducted from interest payable.
Loreburn, L.C., said that the only question was as to Err8,000.

"This," he continued, "is not paid out of profits and gains brought into charge. It is paid out of rates; and on the rates which the Council pays over to its creditors it is bound by the proviso at the end of sec. 102 of the Act of 1842 to deduct the tax and pay it over to the Crown. It is said that the effect of this conclusion will be to tax the same income twice over. I cannot see this. The County Council pays tax on $£$ r 8 ,ooo, the annual value of their own land, which they occupy. The holders of consolidated stock pay tax on $\oint_{11} 8,000$, the annual interest of the debt due to them from the County Council. It seems to me that the two incomes are different, and the persons who receive and enjoy them are different, and the persons who pay income tax on these two incomes respectively are also different."

Lord Macnaghten said the stock and dividends were charged "indifferently" on the whole of the lands, rents, and property, and on the rates.

"I cannot understand," he said, "what the property in the occupation of the Council has to do with the matter. It stands apart. It is quite true that this property is charged in favour of the holders of metropolitan stock, but the charge is not, and never can be, operative. It is superseded by the charge on the rates and vanishes altogether. The 'profits and gains' derived from the property in the occupation of the Council are charged at their source in the hands of the Council under Schedule A. The stream flows no further. . . . The Council are secure in the full and beneficial enjoyment of the property which they occupy. What possible claim can there be to relief or indemnity as regards income tax in respect of this property?"

He thought Channell, J., had misapprehended Lord Davey's observations as to the income of incumbered property being the income less interest on the incumbrance. That proceeded on the assumption of the interest being a real burden. 
If such interest was discharged by a person other than the owner the burden was nominal. In the present case the property never contributed, and was worth as much as if it were not charged. Collins, M.R., he said, had likewise accepted those remarks of Lord Davey. He himself agreed

A.-G. $v$. London C.C.

Tax paid on premises occupied cannot be set off against tax deducted from interest payabie. that the Crown could not ask for the tax twice, but here it only received it once. $\mathrm{By}$ the contention of the Council there might be taxable income, and the Crown might still receive no tax on it. For example, suppose the dividend on stock was $£ \mathrm{I} 00,000$; if there was no property in their occupation, and the dividend was raised entirely by rates, the Crown would receive tax on the whole; but if they acquired and occupied property, the amount would gradually diminish, and when the annual value reached $£$ I00,000 would vanish altogether. The property itself pays tax under Schedule A, whoever may be the owner and occupier, but they would lose tax on the dividends if, when collected, it went to recoup the Council for tax under Schedule A.

Lord James of Hereford entertained grave doubts as to the correctness of the judgments delivered, but his doubts were not strong enough to cause him to dissent.

Lords Robertson and Atkinson concurred.

The question of the right to set off tax on interest paid against profit on earning departments came before the Court in Leeds Corporation v. Sugden (King's Bench Division. I 4th February I9II).

\section{Leeds Corporation v. Sugden.




\section{Leeds} Corporation v. Sugden.

\section{Tax on} interest paid and taxed profit of productive departments.
The Corporation were assessed to Schedule $\mathrm{A}$ in respect of their waterworks, gasworks, tramways, markets, electric lighting undertaking, and annual value, in the sum of $£_{270,036 .}$ By their Act of 1901 , loans originally raised on various securities were charged indifferently on all the undertakings and on the rates; there was also to be established a Dividends Fund, out of which interest was to be paid. The total interest was $£^{285}, 446$, thus showing $£_{15}, 410$ in excess of tax-paid income. The position was as follows :-

$\begin{array}{lc}\text { Taxed } & \text { Dividends } \\ \text { Income. } & \text { Fund. }\end{array}$

Difference.

\begin{tabular}{|c|c|c|c|c|c|}
\hline Waterworks & $\ldots$ & $f^{88,498}$ & $£ 64,236$ & $E_{24,262}$ & \\
\hline Gasworks & $\because$. & 48,345 & 43,702 & 4,643 & \\
\hline Tramways & $\cdots$ & 25,320 & $x 9,092$ & 6,228 & \\
\hline Electricity & $\ldots$ & 8,748 & 19,258 & & $£_{10,5} 10$ \\
\hline City Fund & and Rate & 63,105 & 19,719 & $43,3^{86}$ & \\
\hline \multirow{2}{*}{\multicolumn{2}{|c|}{ Consd. Rate Fund... }} & 36,020 & I 19,439 & & 83,419 \\
\hline & & $£ 27$ & $f_{2} 8_{5}, 446$ & $£ 78,519$ & $£ 93,929$ \\
\hline
\end{tabular}

The Crown sought to tax the sum of $£ 93,929$ on the ground that to that extent the interest was not paid out of taxed profit. The Corporation tendered tax on the £15,410, contending that, except as to this sum, the interest was paid out of profits taxed.

The Court (Hamilton, J.) decided in farour of the Crown. $\mathrm{He}$ said it had been contended that the Corporation must resort to its income before resorting to rates, and that in contemplation of law that must be deemed to have been done which ought to have been done. He did not understand that to be contested, if it could be shown that on the provisions of all the Leeds Acts it could be established that the corporation 
could lawfully apply all and any of its incomings to the discharge of all and any parts of the interest upon the whole unified loans. But he did not think that was so. It was manifest that, if so, interest payable out of the consolidated rate (where there was differentiation) might have been applied out of the Borough Fund (where there was no differentiation). Lord Darey's expression (London County Council case) that it was enough " if the interest is charged upon or payable out of the taxable income," might seem to support the argument for the corporation, as it was (in certain remote contingencies) so charged; but this must be read in connection with the exposition of Lord Macnaghten in the subsequent case: "It is quite true that this property is charged in farour of the holders of the Metropolitan Stock, but the charge is not and nerer can be operative."

In the Court of Appeal, howerer, this judgment was reversed (2gth July I9II) (Kennedy, L.J., dissenting).

The Master of the Rolls said that in the Leeds Act of I9or some of the sections were inconsistent, and as to one section he had been unable to understand it at all. He had, however, come to the conclusion that the interest on the loans was no longer payable out of the net receipts of each separate undertaking.

Farwell, L.J., said the contention of the Crown amounted to a claim for the payment of tax twice over. 
Income tax a personal tax, and each partner should be charged with tax on interest and salary.
It should be remembered that the income tax is a personal tax, and in the case of a partnership care should be taken to deduct income tax on the partners' salaries and the interest on their capital before crediting them; otherwise, unless their capital is equal, the one gains a benefit at the expense of the other. For instance, suppose the result of the trading is as follows :-

Profit for income tax purposes ... ... \& 20,000 Less, A., one year's interest on $£ 200,000$ at 5 per cent. £io, $\quad$ ooo B., one year's interest on $£$ I00,000 at 5 per cent. 5,000

$-\frac{15,000}{£ 5,000}$

In the ordinary course the firm pay tax on $\mathcal{E}_{20,000 \text {, and }}$ it is charged against the profits, falling equally upon the partners. But as between the two of them,

A. should pay tax upon :-

Interest $\quad \ldots \quad \ldots \quad \ldots \quad \ldots \quad \mathcal{E}_{\mathrm{I} 0, \infty} \quad \ldots 0$

Half share of profit $\quad \ldots \quad \ldots \quad \quad 2,500$

And B should pay on :---

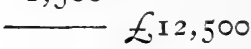

Interest $\ldots \quad \ldots \quad \ldots \quad \ldots, \quad \ldots, 000$

Half share of profit $\quad \ldots \quad \ldots \quad \quad \ldots, 500$ 
Taking tax at is. in the $\mathcal{E}$, the amount payable would $\begin{array}{llllllll}\text { be } & \ldots & \ldots & \ldots & \ldots & \ldots & \ldots & £ \mathrm{I}, \infty \circ \circ\end{array}$ of which

A. should bear (tax on $\mathcal{E} 2,500) \ldots \quad £ 625$

And B. should bear (tax on $£ 7,500) \quad 375$

Income tax

a personal

tax, and each

partner

should be

charged with

tax on

interest and

salary.

Crediting A. with interest £, 10,000

As a matter of bookkeeping, it is convenient to debit

"Interest Account" with the total interest on capital,

$$
£ \mathrm{I}_{5}, 000
$$

Less Income $\mathrm{Tax} 500$

, B. with interest $\overline{£ 5,000} 9,500$

Less Income Tax $25^{\circ}$

And crediting the Com-

$$
4,75^{\circ}
$$

missioners of Inland

Revenue with the tax...

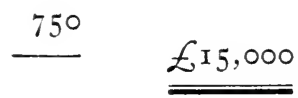

It is then necessary to credit the Commissioners and debit Profit and Loss Account with the tax upon the profit divisible ( $\left.2^{2} 5^{\circ}\right)$, and the Commissioners' Account is closed by a cash posting when the $\operatorname{tax}(\mathscr{I}, \mathbf{1}, \infty \circ)$ is paid.

It must be borne in mind that the accounts and figures are set out in the preceding pages to illustrate the method to be adopted in order to arrive at the proper amount to return for assessment-that is, the figure to be filled in on the second page of the Form No. II, furnished by the assessor. It is not absolutely necessary to render a copy of the accounts in the first instance, though this is usually asked for. 
The accounts set out on pages I 53 and I 54 would apply to almost any trading business; it has not, therefore, been considered needful to give more than the two forms. The principle is always the same. In case the books have been properly kept, it is a simple matter to prepare the accounts and arrive at the proper figure. Many persons, however, return as their income for assessment the amount they have drawn from their business. This is entirely wrong. The amount to be returned is the profit earned in the business, entirely apart from any question of drawings. In the same way, where the books have not been properly kept, regard must be had to the debts owing to and by the business, and to the stock on hand at the commencement and end of the period under review; not simply to the cash sales and payments for goods bought. 
CHAPTER V1.-(continued).

SCHEDULE D.-(continued).

PART III.-Appeals.

A PERSON so desiring may appeal against any assessment upon him by the Additional Commissioners, either to

Appeal to General or Special Commissioners. the General or Special Commissioners ( 1842 , secs. II 8 and I30). He must give ten dars' notice in writing to the Surveyor. A person claiming exemption on the ground that his income does not exceed $E_{1} 60$ per annum must, however, appeal to the General Commissioners ( $\mathrm{I}_{4} 42$, sec. ${ }_{1} 30$ ).

Very extensive powers are conferred on the Commissioners as to statements to be rendered and evidence to be sworn in connection with appeals. If it is contended that the decision of the General or Special Commissioners is erroneous in point of law they may be required to state a case for the opinion of the High Court, or, in Scotland, for the opinion of the Court of Session, and an appeal lies from the decision of the High Court to the Court of Appeal, and thence to the House of Lords, or, in Scotland, from the Court of Session to the 
Question of fact.

\section{Right of} solicitor, \&c., to appear.
House of Lords (1880, sec. 59). In the event of an appeal being heard before the Special Commissioners, they may be required to state a case upon any point for the opinion of the Commissioners of Inland Revenue, whose decision is conclusive $\left(I_{+2}\right.$, sec. I3I). There has not been any appeal to the Board under this section within the last thirty years, and in reply to an inquiry on the point some years ago they replied that "a mere question of fact, if submitted to them, "would seem to fall under their consideration as having the "general administration of the tax," and they suggested that the facts should be put in writing, and they would then state their views thereon. Further, there is only power to do this when the assessment has been made by the Special Commissioners, not if made by the General Commissioners. The decision of the General Commissioners on a question of fact is conclusive ( $18_{42}$, sec. 126 ).

By sec. 57, sub-sec. (9), of the Act of 1880 it was provided that :

"No barriser, solicitor, attorney, or any person practising the law shall be allowed to plead before the said (General) Commissioners on such appeal for the appellant or officers, either viz'â z'oce or by writing,"

but this is now repealed by sec. 16 of the Act of 1898 , which is as follows :-

"Section 57 (9) of the Taxes Management Act 1880 is hereby repealed, and it shall be lawful for the General Commissioners to permit any barrister or solicitor to plead before them on any appeal for the appellant or officers, either vivâ voce or by writing."

It will be noticed that the matter is wholly in the discretion of the Commissioners. 
But by the Revenue Act 1903 , sec. I3, if the General Commissioners refuse to permit a barrister or solicitor to plead solicitor, \&c., to appear. before them, or to hear any accountant, the appellant may appeal to the Special Commissioners, who are required to hear such barrister, \&c.

In the case of The Queen $\%$. Chew and others; ex parte Fletcher (Queen's Bench Division, 26th July 1894), Mr. Fletcher appealed against an assessment upon him and sent a schedule as required, and appeared before the Commissioners. who confirmed the assessment and refused to state a case, there being, in their opinion, no question of law. Mr. Queen v.
Chew.

Refusal to produce books.

Request to be put on oath refused. Fletcher applied for a mandamus to the Commissioners to state a case, stating in his affidarit that

"no objections were taken to my accounts and I offered to verify them on oath, but they proceeded to deal with the appeal, and, after asking me several questions as to my accounts, confirmed the assessment, quite ignoring the accounts."

In answer to this, two of the Commissioners made an affidarit stating that he was offered an opportunity of explaining the accounts he had sent in, and acknowledged that they had been prepared by Mr. J. J. Hitchings, managing director of the Rate and Tax Payers' Assessment Protection Association, from particulars sent by Mr. Fletcher's son, and that Mr. Hitchings had not had access to the books, \&c. Further, that Mr. Fletcher had been asked* to produce books, \&c., and he had refused to do so. " Under all the circumstances," they continued, "we considered we were not bound, and that it

*No one can be compelled to produce his books. 
Queen v.

Chew.

Refusal to produce books.

Request to be put on oath refused.

Rule for mandamus to Commissioners
discharged.

"was useless to put Mr. Fletcher on his oath with regard to " figures which he had not himself prepared, or to adjourn the " case for evidence which he declined to produce; and, having " regard to the fact that the evidence already given by him, "and the accounts, were unsatisfactory, we confirmed the " assessment." By sec. I 18 of the Act of 1842 power is given to any person to appeal against an assessment to the Commissioners for General Purposes (or by sec. I3 I to the Commissioners for Special Purposes), and they are to require the party to send a schedule respecting his profits (sec. I 20 ), and by sec. 122 they may gire notice to the party to appear before them to verify the statement on oath. By sec. I 23 the Commissioners may put any question, and demand an answer in writing, and by sec. 124 they may call upon him to rerify his answers on oath. By sec. I 25 they may examine upon oath any other person whom they think able to give evidence respecting the assessment. A rule nisi had been obtained for a mandamus. It was contended on the one hand that the Commissioners should be satisfied as to the truth of the accounts, and that, as they were not satisfied, and they were not bound to be so on a mere offer to rerify by the party's own oath, it was a mere matter of fact, and no question of law arose. On the other hand, it was urged that, as the Commissioners had not accepted Mr. Fletcher's offer to rerify the accounts by oath, and had not required any amendment of the schedule, they were bound to accept it, and were not entitled to ignore it.

The Court (Mathew and Kennedy, JJ.) being divided in opinion, the junior Judge withdrew his judgment, and the rule 
was discharged, with leare to appeal. Mr. Justice Mathew said that the contention of the appellant-that the Commissioners are conclusively bound by an affidarit as to the profits-was a startling one, and totally opposed to his view. From the conduct of the appellant the Commissioners were entitled to come to the conclusion which all reasonable men would come to, that the figures were not to be depended on.

The case was heard, on appeal, in the Court of Appeal (24th and 25th October 1894). It was contended for the appellants that the Commissioners had based their decision on the refusal of the appellant to produce his Pass Book and vouchers, but that they were not entitled to demand such production. That the sections referred to prorided that where the Commissioners were dissatisfied with the schedule presented, they might test its accuracy by calling upon the appellant to verify it upon oath, or by examining witnesses. That he should have been sworn as he had desired; and the Commissioners, by their conduct, had practically declined to hear his case. On the other hand, it was argued that the appellant was not entitled to require that he should be sworn, and his answers treated as conclusive. Further, that secs. I23, \&c., only applied where the Commissioners were not satisfied with the assessment or the schedule; and as, in this case, they were satisfied with the assessment, sec. I 22 applied. They were not, howerer, bound to require him to verify the statement on oath, and, after the appellant had stated that he had not himself prepared the schedule, they were justified in refusing to allow him to be sworn. They had examined 
Queen v. Chew.

Refusal to produce books.

Request to be put on oath refused

Rule for mandamus to Commissioners discharged.

\section{Conduct of} appeal.

Usually not necessary to appear before Commissioners.

the schedule, and were justified in coming to the conclusion that it could not be relied on.

The Court dismissed the appeal, and ruled that the case depended on sec. I22. The Commissioners could not be called upon to place a party on oath. If they thought that the schedule was not satisfactory, they were justified in deciding not to call for any verification on oath. If any point of law had been raised, it was a bad point. The decision of the Commissioners seemed a pure decision of fact, and, therefore, the application for a mandamus must fail.

Though appeals are actually settled by the Commissioners, yet, as a general rule, it is not necessary for the party to appear personally. In practice it is the custom when a person is dissatisfied as to any assessment made upon him to call upon the Surveyor, and explain the ground of his dissatisfaction, producing accounts in support of his case. If the Surveyor is satisfied with the accounts he will place them before the Commissioners, and the appeal, whether for adjustment or repayment, will be allowed. It is only when the taxpayer and the Surveyor cannot agree that it becomes necessary to actually appear before the Commissioners on an appeal.

Act of 1890.

Provided the return for assessment to Schedule $\mathrm{D}$ has been properly prepared on the average of the past three years, as explained in the preceding Part of this Chapter, the only relief granted to a trader on the ground of diminishing profits is under the Act of 1890 , which is dealt with later. 
In Re Calvert. (ex parte the Debtor) v. Walker (Queen's Bench Division, 4th May 1899) application was made in bankruptcy to expunge a proof by the collector of taxes on an assessment made on an estimated profit of $£$ ro, 000 . It was argued that the Court could go behind the assessment in the same way that it could go behind a judgment, and inquire whether or not there was a rebt; that if it were not so a man might, when on the eve of bankruptcy, return his profits at a fictitiously high sum, and thus, through spite, defeat his creditors.

The Court gave judgment for the Crown, holding that the assessment was not like a judgment; further, that if a man did as was suggested, possibly it could be dealt with as a fraudulent preference to the Crown.

Section 133 of the Act of 1842 and the Act of 1865 are repealed by the Act of 1907 in respect of the year $1907-8$, or any subsequent year $(1907,24$ (I)). Section 24 (2), however, contains the following important provision in respect of a new business :-

Where a person charged or chargeable with income tax in respect of any profession, trade, or vocation which has been set up or commenced within the period of three years upon the average of which the profits or gains are to be taken under the Income Tax Acts, or within the year of asséssment, proves at the end of the year of assessment to the satisfaction of the Commissioners by whom the assessment has been or can be made that the actual profits or gains arising from the profession, trade, or vocation in the year of assessment fall short of the profits or gains as computed in accordance with those Acts, he shall be entitled to be charged on the actual amount of the profits or gains so arising instead of on the amount of the profits or gains so computed, and, if he has paid the full amount of the tax on the profits or gains so computed, be entitled to repayment of the amount orerpaid.
Re Calvert.

Proof in

Bankruptcy.
Concern set up within three years. 
Re Calvert.

It will be noticed that this section is purely in farour of the taxpayer, giving him the right to appeal if his profits fall short, but not giving any corresponding porrer to the Crown if the reverse is the case.

Since the repeal of sec. I 33 the cases of the Cape Copper Mining Co., Lim. (The Qucen v. Commissioners for Special Purposes of Income Tax) and Russell v'. North of Scotland Bank, Lim., are obsolete.

Limitation

making

claims under

yarious Acts.
In "Dowell's Income Tax Laws" it is pointed out that in the Acts of 1842 and 1853 the time for claims is dealt with in six cases.

I. Act of $\mathrm{I} 84_{2}, \mathrm{sec}$. 6I. As to omission to claim allowances under Schedule A.

Here the Act grants relief "if at any time" it is found that certain allowances have not been claimed.

2. Act of 1842 , sec. $10_{5}$. As to exemption of charitable institutions.

3. Act of 1853 , sec. 54. As to abatements in respect of life assurance premiums.

In those two cases the Acts are silent.

4. Act of 1842 , sec. I34. As to abatement to be allowed where a person ceases to carry on a trade, or to receive a salary, or dies.

This claim is to be made within three months after the end of the year of assessment. 
5. Act of 1853 , sec. 18 . As to relief granted to landlords in Ireland, where the rent is lost by bankruptcy, \&c., of tenant.

This claim to be made within six months after the end of the year of assessment.

To these we might add :-

Act of 1842 , sec. I 7 I.-Double assessment. Here relief is granted "whenever" a person has been doubly assessed (see p. I5I).

Act of 1851 .-Appeal by farmer on ground of profits falling short of the assessment under Schedule B. This is to be within three months after the expiration of the year of assessment, but see Act of 1896 (ante, p. $3^{6}$ ).

Act of $18 ; 8$. - Wear and tear of machinery let. Here the claim must be made within twelve months after the expiration of the year of assessment.

Act of 1890.-Appeal in case of loss, with reference to aggregate amount of income. Here notice is to be given to the Surveyor in writing within six months after the expiration of the year of assessment.

Act of 1907.-Relief to "earned" incomes. Here the claim is to be made before 3 oth September in the year of assessment. 
Act of 1860 .

\section{Act of 1842 ,} sec. 134.

Abatement where business ceases.
Section 10 of the Act of 1860 (p. 30r) shortens the unlimited periods, but does not lengthen the limited ones.

Abatement is allowed when a person ceases to exercise any trade, or dies before the end of the year of assessment, and any overpayment by him may be repaid (I 842 , sec. I 34 ).

This section is as follows :--

In case any person charged to the said duties under Schedule D, whether the computation thereon shall have been made on the profits of one year or on an average as herein allowed, shall cease to exercise the profession, or to carry on the trade, employment, or rocation, in respect whereof such assessment was made, or shall die or become bankrupt or insolvent before the end of the year for making such assess. ment, or shall from any other specific cause be deprived of or lose the profits or gains on which the computation of duty charged in such assessment was made, it shall be lawful for such perscn, or his executors or administrators, to make application to the Commissioners for General Purposes of the district within three calendar months after the end of such year, and on due proof thereof to their satisfaction the said Commissioners shall cause the assessment to be amended, as the case may require, and give such relief to the party charged, or his executors or administrators, as shall be just; and in cases requiring the same the said Commissioners shall direct in manner before mentioned repayment to be made of such sum as shall have been overpaid on the assessment amended or vacated :

Provided always that where any person shall have succeeded to the trade or business of the party charged no such abatement shall be made, unless it shall be proved to the satisfaction of the said Commissioners that the profits and gains of such trade or business have fallen short from some specific cause, to be alleged to them and proved, since such change or succession took place, or by reason thereof, but such person succeeding to the same shall be liable to the payment of the full duties thereon without any new assessment. 
It will be noticed that the relief granted is that the Commissioners are to cause the assessment to be amended, "as the case may require," and to give such relief "as shall be just." The practice always was to decide such claims on the result of the trading (or as the case might be) for the portion of the year during which the trade, \&c., had been carried on, without reference to arerages; that is, of course. where diminution of the amount of the assessment was sought-not mere discharge of the assessment for the portion of the year during which the trade, \&c., had not been carried on. For example, a person is assessed for the year r $906-7$ ending $5^{\text {th }}$ April 1907 on $\mathcal{E}_{3.000}$. He discontinues business on the $5^{\text {th }}$ October 1906. He might claim on appeal under this section to have the assessment discharged (whatever the amount of his profits) as to one-half, and he would then only

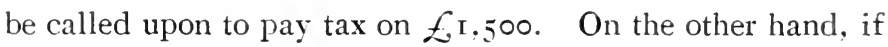
he found he had only made, say, $£_{\mathrm{I}, 000}$, he would claim to have the assessment reduced to the actual profits in the portion of the year of assessment during which the business had been carried ' $n$. The same remarks apply to the case of executors continuing the business of their testator for the purpose of winding-up.

This has now been placed on the Statute Book (Finance Act 1907 , sec. 24 (3)), with a further provision (ante p. 369) in lieu of the relief formerly given by sec. I 33 of the Act of I $84^{2}$. This sub-section is as follows :- 
Act of 1907 as to claims.

"Specific cause."
Where a profession, trade, or vocation is discontinued in any year, any person charged or chargeable with income tax in respect of that profession, trade, or vocation, shall be entitled to be charged on the actual amount of the profits or gains arising from the profession, trade, or vocation in that year, and shall also, if he proves to the satisfaction of the Commissioners, by whom the assessment has been or could have been made, that the total amount of the income tax paid during the three previous years in respect of that profession, trade, or rocation, exceeds the total amount which would have been paid if he had been assessed in each of those years on the actual amount of the profits or gains arising in respect of the profession, trade, or vocation, be entitled to repayment of the excess.

A liberal riew used to be taken of the "specific cause," and, as an illustration thereof, see the suggestion by $\mathrm{Mr}$. Gayler (late Chief Inspector of Taxes) to the Committee which sat in 1904 (Question $25 \%$ ) that a doctor relinquishing patients on account of his age would be entitled to the relief. It is difficult to define what does, and what does not, fall within the category of " any other specific cause," but there used to be every desire to meet necessities as far as practicable.

It is understood that Surveyors have recently (I9II) received instructions not to admit any important claim under sec. 134 without submitting it to Somerset House.

In this connection relief has been refused where a business was entirely stopped for some time by reason of a fire, though it was claimed and admitted that three-fourths of the reduction in profit was due to the fire. In this case Somerset House set up that a specific cause must involve a permanent stoppage of the business. 
Such a contention, if upheld, will render the section practically nugatory.

If the "specific cause" section means anything, it is to meet such a case as this, and it is to be hoped that where the Crown endeavours to put such a strained construction on the Act it will be resisted before the Commissioners.

An important concession is granted to the taxpayer by the Act of 1890. Customs and Inland Revenue Act 1890 , sec. 23, which permits of losses being set off against taxed profits. ${ }^{*}$ The section is as follows :-

"(I) Where any person shall sustain a loss in any trade, manufacture, adventure, or concern, or profession, employment, or vocation, carried on by him either solely or in partnership, or in the occupation of lands for the purpose of husbandry only, it shall be lawful for him, upon giving notice in writing to the Surveyor of Taxes for the district within six months after the year of assessment, to apply to the Commissioners for the general purposes (extended by the Act of 1907, sec. 27 , to the Special Commissioners) of the Acts relating to income tax for an adjustment of his liability by reference to the loss and to the aggregate amount of his income for that year estimated according to the several rules and directions of the said Acts.

"(2) The said Commissioners shall, on proof to their satisfaction of the amount of the loss, and of the payment of income tax upon the aggregate amount of income, give a certificate authorising repayment of so much of the sum paid for income tas as would represent the tax upon income equal to the amount of loss, and such certificate may extend to give exemption or relief by way of abatement in accordance with the provisions of the said Acts. Upon the receipt of the certificate, the Commissioners of Inland Revenue shall cause repayment to be made in conformity therewith.

Relief to trading or professional persons and farmers in case of losses. 
Act of 1890.

\section{Circular of} Board of Inland Reyenue.
"(3) If any person shall be guilty of any fraud or connivance in making any application under this section, or in obtaining any such adjustment or certificate as aforesaid, he shall forfeit the sum of fifty pounds, to be recoverable as a penalty imposed by virtue of the Taxes Management Act is 88 .

"(4) Where repayment has been made to a person in any year under the provisions of this section, he shall not be entitled to claim, or to be allowed, a deduction on the assessment for a subsequent year by reference to the amount of loss in respect whereof such repayment has been obtained."

A circular issued to Surveyors of Taxes by the Board of Inland Revenue says* :-

"In order to remove any doubts that may exist as to the exact interpretation to be put upon the section, and to secure uniformity of practice, the Board think it desirable to point out that the effect of the new enactment is, not to annul the provisions of the Act $5 \& 6$ Vict., cap. 35 (the Act of 1842 ), sec. 133, as amended by the Act 28 Vict., cap. 30 (the Act of 1865), sec. 6 , but to supplement the relief afforded by those provisions by an allowance in respect of an actual loss. The new section deals with the case of an actual loss incurred in the year of assessment and not with a case of a diminution of profits below the estimate upon which the assessment has proceeded. The latter case, which, where there is a loss, must, of course, be a diminution to the extent of the absence of all profit, is a case provided for by the previous law, and to be dealt with accordingly."

As illustrating the proper method of dealing with claims, the circular gives the following hypothetical case :-

*The circular is reproduced in extenso but should now be read in the light of the repeal of sec. 133 and the Act of 1865 . 
A. B. is assessed and has paid duty on $£ 6,900$ for the year I900-1, as under :-

Act of 1890 .

Method of

dealing with

claims.

(r) From rents and dividends $\ldots £ 2,200$ Schedules $A$ and $C$

(2) As a paper manufacturer ... 3,000 Schedule D

(3) As a solicitor $\quad \ldots \quad$... $\quad \ldots \quad$ 1,000 , , ,

(4) As clerk to Justices of the Peace $400 \quad,, \quad$ E

(5) As occupier of Lands for

'Husbandry only $\quad \ldots \quad$... $300 \quad, \quad$ B

On appeal at the end of the year, A. B. proves that he lost $£ 3$, ooo by the paper mills, and $£ 300$ by farming, and that his profits as a solicitor amounted to $£$;oo only. His liability, therefore, falls to be adjusted in the following manner:-

\begin{tabular}{|c|c|c|}
\hline Income assessed 1900-0r & $\begin{array}{l}\text { Aggregate Income for } \\
\text { I900-0I, estimated by the } \\
\text { Rules and Directions } \\
\text { of the Acts }\end{array}$ & $\begin{array}{c}\text { Repayment to be made } \\
\text { under } 5 \text { \& } 6 \text { Vic. c. } 35, \text { s. } 133 \\
28 \text { Vic. c. } 30, \text { s. } 6 ; 53 \& 54 \\
\text { Vic. c. } 8, \text { s. } 23 ; \\
59 \& 60 \text { Vic. c. } 28, \text { s. } 27\end{array}$ \\
\hline 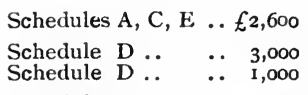 & $\left.\begin{array}{c}£ 2,600 \text { Schedules } A, C, E \\
* 2,000 \\
+700\end{array}\right\} \begin{array}{c}\text { Avge. for } 3 \text { year } \\
\text { including year } \\
\text { assessment. }\end{array}$ & $\begin{aligned} & \\
& £ \mathrm{r}, \mathrm{o00} \ldots \text { Schedule } \mathrm{D} \\
& 300 \ldots \text { Schedule } \mathrm{D}\end{aligned}$ \\
\hline Schedule B $\cdots \quad \cdots \frac{300}{£ 6,900}$ & $\frac{t \mathrm{Nil}}{£ 5,300} \quad \cdots \quad \cdots$ & $\frac{300}{£ 1,600} \ldots$ Schedule B. \\
\hline $\begin{array}{c}\text { Allow as a set-off the losses } \\
\text { in the year rgor } \\
\text { Duty to be paid on .. }\end{array}$ & $\frac{3,300}{£ 2,000}$ and repaid on & $\frac{3,300}{£ 4,900} \ldots$ Schedules B \& D \\
\hline
\end{tabular}

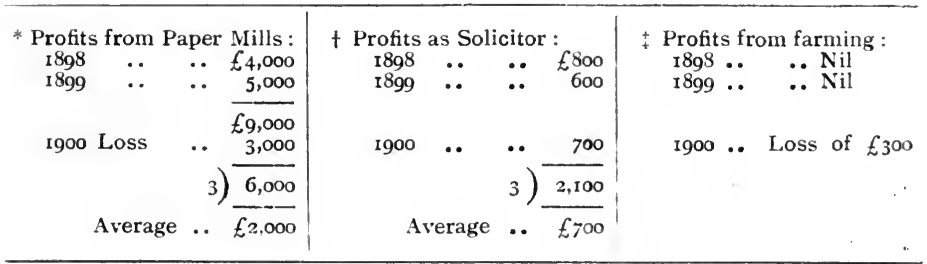


Act of 1890.

Effect of Act.

\section{Bruce v.} Burton.

The circular proceeds :-

"The Commissioners accordingly certify for repayment of duty on $£ 4,900$ under the Acts 5 \& 6 Vict., cap. 35 (the Act of I 842), sec. I 33 ; 28 Vict., cap. 30 (the Act of 1865 ), sec. 6 (Trades and Professions); $59 \& 60$ Vict., cap. 28, sec. 27 ; and $53 \& 54$ Vict., cap. 8 (the Act of 1890 ), sec. 23 (Relief in case of Loss); and retain in assessment the duty on $£ 2,000 . "$

The circular concludes by calling special attention to subsec. 4 of sec. 23 of the Act of 1890 .

In Bruce v. Burton (King's Bench Division, Ioth May I90I) the appellant claimed under this Act to set off a loss under Schedule B against other income. In the case stated the Commissioners found that in their view the alleged loss was caused by the appellant using the lands (inter alia) for the purpose of breeding cattle by way of recreation, and not as a matter of business or on ordinary commercial principles.

The case was not heard in this connection, however, as the Court held that an appeal under sec. 59 of the Taxes Management Act only lies where there has first been a determination of an appeal by the General Commissioners ; in this case there had been no such appeal; the assessment had been rightly made; he had made a claim for repayment.

This additional relief provided may not, in many cases, be of any further benefit, for any loss in a trade or business would come into average three times, which would amount to the same thing as an immediate repayment of tax on the amount of the loss. It would, however, be of advantage to the taxpayer in the case of a business where it was feared there might be a continuous loss for a number of years. 
Where the loss exceeds the tax-paid income the balance of Act of 1890 . such loss will be used in future average.

A point which might be looked upon as an objection in claiming the relief is that the person is to prove " the payment Objection to claiming under Act of 1890. of income tax upon the aggregate amount" of his income. Many persons would object to disclosing their total income. In practice, however, this is sometimes taken to mean on income equal to the amount of the loss, the Surveyor being satisfied that all income is tax-paid.

In the case of a club building company assessed under Schedule $\mathrm{A}$ and letting their premises to a political club, the accounts were :-

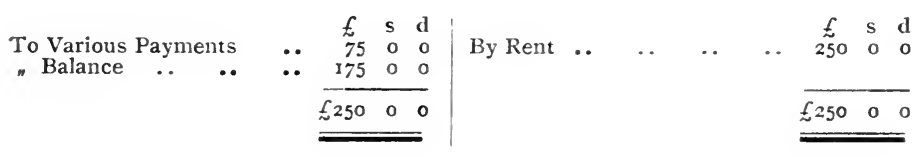

After writing back the Schedule $A$ assessment the result was a loss, and the company claimed under this Act. The claim was disallowed on the ground that the company did not " exercise any business in the nature of a trade."

An average loss is not sufficient. If the results were :-

\begin{tabular}{|c|c|c|c|c|c|c|}
\hline I9O4 & Profit & $\ldots$ & $f_{20,000}$ & & & \\
\hline 1905 & Loss & $\ldots$ & 20,000 & Loss & $\ldots$ & $£ 20,000$ \\
\hline 1906 & Profit & $\ldots$ & $9, \infty 00$ & Profit & $\ldots$ & 9,000 \\
\hline 1907 & & & & Profit & $\ldots$ & 2,000 \\
\hline & Total & $\cdots$ & £.9,000 & & & $\$ 9$,000 \\
\hline & Average & $\ldots$ & $£ 3,000$ & & & $f_{3}, 000$ \\
\hline
\end{tabular}


This would not establish a claim for 1907-8. There must be a loss in the year 1907 .

Assuming, then, an assessment of $£ 3,000$ for 1907-8, and a loss of $\mathcal{E}_{3}, 000$ in 1907 , the whole amount paid can be recorered. If this is done the year 1907 must be treated as nil for future arerages.

Had the assessment been nil, tax could have been recorered to the extent of any taxed income of the taxpayer or his wife (the income of the latter being his income for all purposes). Thus, assume there is such income to the extent of $\mathcal{E}^{\mathrm{I}, \infty 00 \text {, }}$ he would recorer on that, and the balance of loss $\left(£^{2, \infty}, \infty\right)$ could be used for future averages.

The Act naturally provides that a loss once so used cannot be used in average again. To give a person the right to use the loss again in average would give him tax upon it twiceviz., the whole at once and one-third in each of the subsequent three years.

Obviously, where it is known or expected that the tax will rise, it may be better not to clain if certain that future years will give arerage profits. On the other hand, when the tax is falling, it is better to claim in any case.

It is understood that, reading sec. 163 with this section, the Board hold that where we hare-

$\begin{array}{lllllllr}\text { Assessment } & 1907-8 & \ldots & \ldots & \ldots & \ldots & \ldots & £ \mathbf{r}, 500 \\ \text { Loss } & 1907 & \ldots & \ldots & \ldots & \ldots & \ldots & 500 \\ \text { Private Income } & 1907 & \ldots & \ldots & \ldots & \ldots & \ldots & \mathbf{1}, 000\end{array}$


the $£ \mathrm{r}, 500$ statutory income is to be taken into account in determining whether a claim for abatement arises when there is a claim under this Act, and we have a total income of Act of $\mathbf{1 8 9 0 .}$ $f^{2,000}\left(f_{1}, 500-f_{500}+f_{1,000}\right)$ and not a total income of only $£_{500}\left(£_{1}, 000-£ .500\right)$, and there is no claim for abatement.

It is open to argument whether this construction is correct, and whether the "aggregate amount of his income for that year, estimated according to the sereral rules and directions of the said Acts," is not $£ .500$.

In addition to the point as to rate of tax, cases may arise where a claim under the Act, depriving one, as it of course does, of the right to use the loss in future arerages, may affect an abatement or differentiation claim in the next three years.

On the other hand, there may be a benefit in getting the differentiation, \&c., in the year of loss.

As future profits are the chief factor, it is; perhaps, idle to discuss the matter at length, but one example may be useful.

Thus, assume a person makes a fairly regular profit of $£ 7,500$ (with a little taxed income), but makes a loss of $£ 3,001$ in 1909 , so that the results are :-

Year ended.

$\begin{array}{cccccccc}1905 & \ldots & \ldots & \ldots & \ldots & \ldots & \text { Profit } & £ 7,500 \\ 1906 & \ldots & \ldots & \ldots & \ldots & \ldots & ,, & 7,500 \\ 1907 & \ldots & \ldots & \ldots & \ldots & \ldots & ,, & 7,500 \\ 1908 & \ldots & \ldots & \ldots & \ldots & \ldots & \text {, } & 7,500 \\ \text { 1909 } & \ldots & \ldots & \ldots & \ldots & \ldots & \text { Loss } & 3,001 \\ \text { 1910 } & \ldots & \ldots & \ldots & \ldots & \ldots & \text { Profit } & 7,500 \\ 1911 & \ldots & \ldots & \ldots & \ldots & \ldots & , & 7,500 \\ 1912 & \ldots & \ldots & \ldots & \ldots & \ldots & ,, & 7,500\end{array}$


Act of 1890 .

\section{Claim in} relation to future returns.
(We assume a loss of $£ .3,001$ to distinguish the figure from the $£ 3,000$ in excess of which super-tax is payable.)

It must be remembered that under the I9ro Act the statutory income for $1908-9$ is taken to see whether super-tax is payable for I 909 -Io, and so on.

For 1908-9 he would have returned and paid on $£ 7,500$.

For 1909-10, if he made no claim, he would

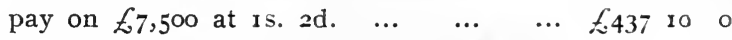

Also super-tax on $£_{4}, 500\left(£_{-7,500}\right.$ (Assess. ment r908-9) $-£ .3,000)$ at $6 \mathrm{~d} . \quad \ldots \quad \ldots \quad$ II2 10

$£ 55^{\circ} \quad \circ \quad \circ$

For 1909-10, if he made a clain, he would pay on $£_{7}, 500$ and recover on $£_{3}$, oor $=$ $£ 4,500$ at 1 s. 2d. $\quad \ldots \quad \ldots \quad \ldots \quad \ldots$

Also super-tax on $£_{4}, 500$ ( $E_{7}, 500$ (Assess. ment $1908-9)-f_{3},(\infty 0)$ at $6 \mathrm{~d}$. 
For 1911-12, if he made no claim, he would pay on $€ 4,000\left(\frac{7,500-3,001+7,500}{3}\right)$ at

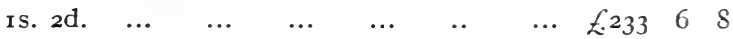

But no super-tax, the statutory income of rgro-r I being only $£_{4}$,ooo.

For Igri-I2, if he had made a claim in rgog-ro, he would pay on $£ 5$, 000 $\left(\frac{7,500+\mathrm{Nil}+7,500}{3}\right)$ at rs. $2 \mathrm{~d} . \quad \ldots \quad \ldots 29 \mathrm{I} \quad$ I3 4 Also super-tax on $£ 2,000(£ 5$,ooo assessed

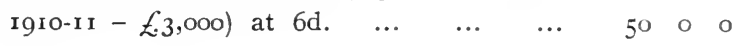
$£ 34$ I $13 \quad 4$

For 1912-13 (if no claim) he would pay on $£ 4,000\left(\frac{-3.001+7.500+7,500}{3}\right)$ at is. 2 d. $£^{233} 68$ (But again no super-tax.)

For 1912-I3 (if claim made) he would pay on $£ 5,000\left(\frac{\mathrm{Nil}+7,500+7,500}{3}\right)$ at is. 2 d...$\quad £^{29 \mathrm{I}}$ I3 4

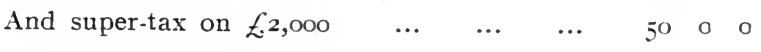
$£ 34$ I I $3 \quad 4$

For 1913-14 (if no claim) he would pay on $f_{7}, 500$ at 1 s. $2 \mathrm{~d}$.
(But no super-tax. .. $£ 437$ 1о о

For 1913-14 (if claim made) he would pay on $£ 7,500$ at is. 2d. $\quad \ldots . \quad \ldots \quad \ldots \quad £ 437$ ro o

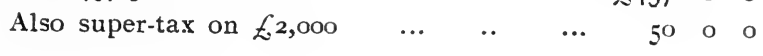
$£ 487$ 1о о 
Act of 1890 .

\section{Claim in}

relation to future returns.

So that the net result is-

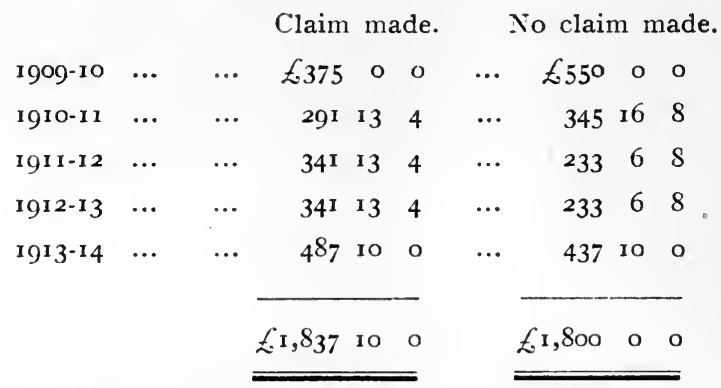

In the case of a new business the profits of the first year come in as follows:-

$\begin{array}{llrl}\text { Ist year } & \ldots & \text { Profit of Ist year } \\ \text { 2nd year } & \ldots & , & \text { Ist year } \\ \text { 3rd year } & \ldots & , & \frac{\text { Ist year }}{2}+\frac{2 \text { nd vear }}{2} \\ \text { 4th year } & \ldots & , & \frac{\text { Ist year }}{3}+\frac{2 n d \text { year }}{3}+\frac{3 \text { rd year }}{3}\end{array}$

It would therefore be desirable to claim for a loss in the first year (against taxed income, assuming the assessment had been held over pending results; against amount paid on if it had been assessed), since the loss would only be in average $\frac{1}{2}$ and $\frac{1}{3}=\frac{5}{6}$, there being nothing to pay on in the second year in either case.

A claim should also be made if there is a likelihood of the business being discontinued, as the result of a business discontinued cannot be brought into future arerages.

A somewhat anomalous position arises in the case of financial, insurance, and similar companies. 
For the purpose of a return for assessment, all taxed income is eliminated, the same account was applicable to a claim under the r $33^{\text {rd }}$ section before it was repealed, and it Act of $\mathbf{1 8 9 0 .}$ would seem natural to suppose that the same principle would operate for a claim under this Act (1890). Thus, assume the result of a given year to be a profit of $\mathcal{E}_{\mathrm{I}} 70,000$, after crediting income taxed at the source $\left(£_{200,000)}\right.$ one might naturally suppose it could be said that this was a statutory loss, for income tax purposes, of $£ 30,000$, and that consequently there was a claim for repayment on the $\mathcal{E}_{3} 0,000$. But the Revenue claim that there is not a loss. There is a profit of EI 70,000, and there cannot be any claim. This is especially hard on trust companies, who (probably) have most of their income taxed at the source, and are thus deprived of any chance of setting off a great part of their office expenses, salaries, \&c.

The position taken up seems inconsistent. Surely an account is not to be drawn one way for one purpose and another way for another?

The point came before the Court in Rex $v$. Commissioners of Income Tax for the City of London; ex parte Commissioners of Inland Revenue, where a claim under this Act Rex v. Com: missioners of Income Tax. (I890) had been submitted by The Exploration Company,

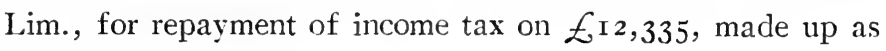
follows :- 
Act of 1890.

Rex v. Com-

missioners of

Income Tax.

Profit not

equal to

taxed interest.

Dr. PROFIT AND LOSS ACCOUNT, Year Igo2. $C r$,

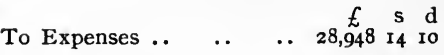
"Balance Profit .. $\quad . .69,560$ I 9

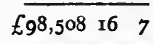

By Dividends $\cdots 39,270 \quad 7 \quad 4$ Less Tax .. 2,359 ○ 9

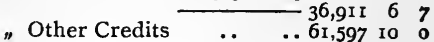

\section{$f \mathrm{~s} d$}

$£ 98,508 \div 6 \quad 7$

To Loss sustained on sale of shares in I902, but which had been provided for in the accounts of the com-

pany in previous years.. $\quad 44,983 \quad 9 \quad 4$

$\begin{array}{lllllll} & \text { "Balance } . . & . . & . . & 24,576 & \text { I2 } & 5\end{array}$

$£ 69,560 \times 9$

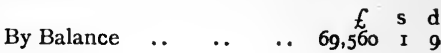

To amount written back, viz., $\quad £$ s d

Income taxed at source.. 36,9 I I 67

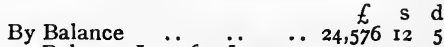

"Balance, Loss for Income $\begin{array}{llllll}\text { Tax purposes } & . . & \ldots & \text { I2,334 } & \text { I4 } & 2\end{array}$

\section{$£ 36,9$ I I 67}

The Surveyor contended that the result of the trading was

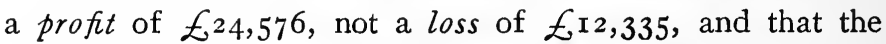
application was in respect of a loss on part only of a trade or business, and not within this Act.

[In arguing the case before the Commissioners, counsel had quoted a case of Carese (Surveyor of Taxes) v. Dunlop Pneumatic Tyre Co., Lim., in which the Crown had at first contended that such an amount as the $£ 44,983$ was not deductible, but had afterwards abandoned their appeal.]

The Exploration Company had in previous years made similar losses, and, as a matter of fact, had not been assessed to income tax, Schedule D, for 1902 . 
The Commissioners issued a certificate for repayment of tax on the $\mathcal{E}^{\mathrm{r} 2}, \dot{3} 35$, and the Crown claimed that the certificate was given without jurisdiction, there being no loss within the meaning of the section. A rule nisi had been granted for a writ of certiorari to bring up the certificate, and application Act of 1890. Rex v. Com missioners of Income Tax.

Commissioners allowed claim for repayment. was made for the rule to be discharged.

The Court discharged the rule (I 7 th May 1904). Lord Judgment of Alverstone, C.J., said the Commissioners had three things to consider : (r) the aggregate amount of income; (2) whether a loss had been sustained from one or more of the undertakings, \&c., carried on ; and (3) if so, what was the proper adjustment of the liability. Therefore the Commissioners had to consider not merely the question whether a loss had occurred in the course of a business which would give rise to a reduction on the amount on which Schedule D was payable, but "has " there been a loss which would render it right that a man " should not pay more than on the total income on which he " ought to pay, because he is allowed under this section to " have one set off against the other." He was satisfied that that was the question which the Commissioners had considered-if he had been satisfied otherwise, he would not have hesitated to make the rule absolute. Possibly, from the point of view of the Crown, they had answered that question improperly, either in law or in fact; but, even if that were the case, the Court could not interfere-if the Commissioners had been considering the right question, their decision was final. He was not, however, satisfied that they had gone wrong in any way in dealing with the matter. Wills and 
Act of 1890 .

Decision of Commissioners final.

Edinburgh Life Insurance Co. refused allowance.

Company owning ail shares of another.
Kennedy, JJ., gave judgment to the same effect, but both declined to express any opinion upon the actual decision of the Commissioners, as they considered the point did not arise.

The Commissioners of Inland Revenue have not accepted this ruling (except as to repayment in the particular case and for that particular year), and they oppose all such applications. It will be gathered from the judgment that the decision of General Commissioners in each case (whether for or against the Crown) is binding.

A similar application for relief was made by the Edinburgh Life Insurance Co. for the year 1903-4, but it was refused by the Commissioners.

The same point arises where one company, the whole of the shares in which are held by another company, makes a loss. Applying the principle enunciated above, it might be said that if it was the parent company which made the loss there was yet a profit on the whole, and if it was the subsidiary company, that it was a distinct entity, and there was not any taxed income against which to set the loss. It is, however, the practice to allow such set-off where the two companies are practically one. Unless, however, this is so, however overpowering the interest in the parent company may be, such set-off cannot be allowed. This will be understood when it is remembered that, after a claim under this Act, the loss cannot be used again in average, for to allow the parent company to use their share of the loss would prejudice the other shareholders in the subsidiary company. 
The effect of sub-sec. 4 is that, in taking an average for any subsequent year, the year in respect of which the tax has been recovered is to be regarded as having resulted neither in a profit nor a loss, thus :-

Act of 1890.

Method of computing profits in subsequent years after claim under the Act of 1890 .

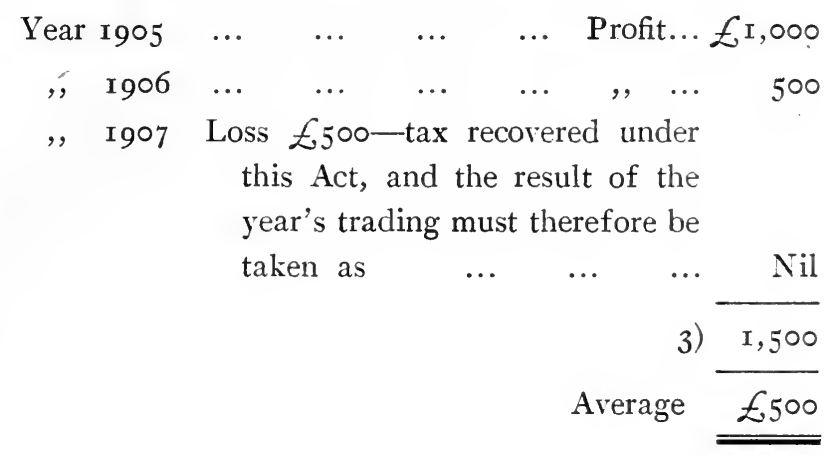

Some misapprehension prevails as to the proper treatment of depreciation in connection with claims under this Act, and some Surveyors have refused to allow depreciation to create or increase a loss. This, however, is incorrect. The proper method is to allow the depreciation in the claim, but for future averages to call the result of that year a profit equal to the depreciation so allowed, instead of nil. The following figures illustrate the application of the principle :-

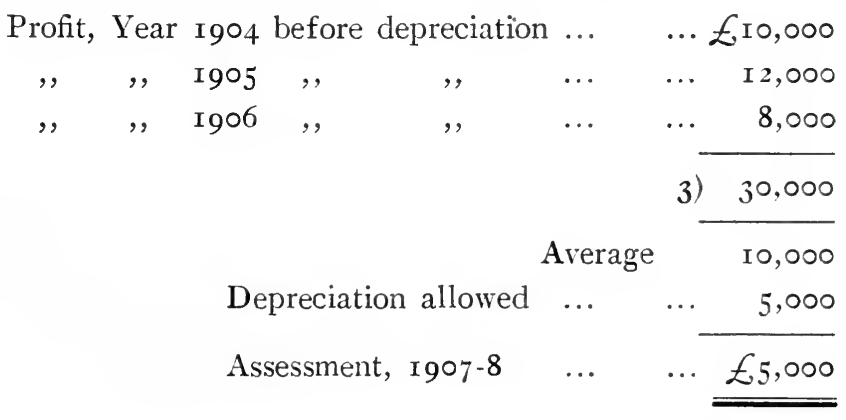

Treatment of wear and tear in connection with appeal under Act of 1890. 
Ict of 1890.

Treatment of wear and tear in connection with appeal under Ât of 1890.

Sch. A

assessment may be added to increase

loss.
The actual profit of 1907 before depreciation is found to

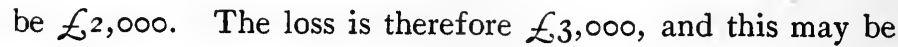
set-off against other taxed income.

For 1908-9, \&c., the result of the year 1907 must now be called a profit of $£ 5,000$ ( $\mathcal{8}^{8,000}$ less $£ 3,000$ on which tax has been repaid).

The reason is obvious. The practice for assessment being to deduct the allowance for depreciation after the average has been ascertained, the result of 1907 is only nil after deducting depreciation, and therefore that depreciation must be written back to bring all the years on to the same basis.

It is the practice in claims under this Act by an owneroccupier to allow the amount of the Schedule assessment to be added to increase the loss as if it were a rent.

In Grimes v. Letham (Queen's Bench Division, 28th April 1898) a commercial traveller claimed to deduct from his salary a loss incurred by him in connection with the production of a railway signal. The Surveyor contended that such a deduction was not allowable even under sec. 23 of the Act of 1890, as the loss was one of capital, since the appellant did not occupy any premises for manufacture, \&c., but appeared to be merely endeavouring to dispose of the patent invention, of which no sale had taken place.

The Court considered that there was nothing shown on the case upon which any relief could be claimed other than under the Act of 1890 , and notice of such claim had not been given 
within the prescribed time (six months) to bring it under that Act. Without so deciding, Wright, J., expressed the opinion Act of 1890. that, having regard to sec. 159 of the old Act (see p. 297), Grimes v. sec. 23 of the Act of 1890 possibly ought to be held to have the wide effect sought for, if properly inroked.

It is clear that the Act applies equally to " companies,", since by sec. 192 of the Act of 1842 " person" includes "bodies corporate."

It has been contended that after a claim under the 1890 Act the business is to be treated as a new one for the three following years. It is quite clear, however, that there is not anything in the Acts to justify this view, and that it is unsound. 


\section{CHAPTER VII.}

\section{RATE OF DEDUCTION OF TAX ON PAYMENT OF ANNUITIES,}

DIVIDENDS, INTEREST, ETC.

Doubt prevailing as to rate of deduction.

1853 , sec. 40.
S some doubt seems to prevail as to the rate at which tax
should be deducted from dividends, \&c., accruing over a period during which there has been a change in the rate of the tax, it may be well to point out the sections of the Acts governing such deduction.

By sec. 40 of the Act of 1853 (set out in full on p. 269) it was provided that every person liable to the payment of any rent, interest, annuity, \&c., either as a charge on any property, or as a personal debt by virtue of any contract, was entitled to deduct "the amount of the rate of duty which at the time when such payment becomes due shall be payable."

By the Customs and Inland Revenue Act 1864 , sec. I5, however, it is enacted that such person shall be entitled to deduct

"the amount of the rate, or a proportionate amount of the several rates of income tax which were chargeable by law upon or in respect of such rent, interest, annuity, or other annual payment, or the source thereof, during the period through which the same was accruing due." 
With respect, however, to dividends of the public funds, sc., and dividends payable out of any public rerenue and paid by the Bank of England, these are chargeable under Schertule C. In these cases the Bank is required ( 1842 , secs. 89 and 93 ) to retain "the amount of duty chargeable . . . at the rate before directed" (this is the rate in force'for the current year). A similar provision is contained in sec. 96 as to annuities, dividends, \&c., payable out of the public revenue of any Colony, \&c., and entrusted for payment to any person other than the Bank of England. The later Act of 1842 ( $5 \& 6$ Vict., cap. 80) extends the same rule to annuities, dividends, \&c., payable out of the revenue of any foreign State (chargeable under Schedule C). This was extented by sec. 10 of the Act of 1853 to the dividends of foreign companies (when it was provided that such dividends were to be charged under Schedule D, see p. 40), and by an Act of 186 I the rule was further extended to include the rlividends, \&c., in respect of the stocks and shares of Colonial companies, and by the Rerenue Act i 868 (3I \& 32 Vict., cap. 28), to annuities, \&c., payable out of any of the funcls of any institution in India.

The tax on interest on exchequer bills is chargeable at the rates in force during the period the bills run (Income Tax Act. 1854, I 7 \& 18 Vict., cap. 24).

Finally, the Customs and Inland Revenue Act 1888 pro1888 , sec. 24 . vides (p. 305) that on the payment of any interest, \&c., not payable out of profits brought into charge, the person paying

and foreign and colonial companies.
Dividends funds, \&c.

Dividends out of revenue of colonies,

\section{foreign states,}


1888, sec. 24. the same shall deduct the rate of income tax " in force at the time of such payment."

Circular of Board of Inland Rexenue.
The substance of a circular issued by the Board of Inland Revenue in May 1909 (the rate of tax having been changed from Is. for the year 1908-9 to Is. 2d. for the year 1909-10) is as follows :-

Memorandey as to Dedection of Ixcone Tax for the YEAR IgO9-IO.

Income tax is deductible at the rate of $\mathrm{Is}$. $2 \mathrm{~d}$. in the pound, in respect of-

(a) Dividends and interest from the public funds payable on or after April 6 rgog.

(b) Dividends and interest of foreign or Colonial Government securities, or of foreign or colonial companies entrusted to an agent in this country for payment here on or after April 6 Igog; also of like dividends or interest which, although not entrusted to an agent in this country for payment, are realised in the United Kingdom on or after that date through bankers, coupon dealers, or other persons.

(c) Interest and annuities paid by municipal corporations or other local authorities to creditors on rates.

(d) Interest and annuities not paid or not wholly paid out of profits and gains brought into charge to income tax.

But in respect of-

(a) Ground rents, \&c., secured on property charged with income tax.

(b) Interest or annuities wholly payable out of property profits or gains charged with income tax.

(c) Dividends paid out of the profits or gains of public companies in the United Kingdom,

the $\operatorname{tax}$ is deductible at the rate or rates in force during the period in which the same has or have been accruing-i.e., in respect of any portion which accrued in the year ended April 5 1909, at the rate of 1 s. in the pound, and in respect of any portion accruing subsequent to that date at the rate of $1 \mathrm{~s}$. $2 \mathrm{~d}$. in the pound.

Inland Revenue, Somerset House, London, May 1909.

(Such a circular is generally issued when there is a change in the rate of tax.) 
The Board of Inland Revenue, in reply to an inquiry some years ago, stated that a municipal corporation is not in the same position as a railway company; that in the case of a railway the charge of income tax is upon the profits and gains of the undertaking, without any allowance on account of annual interest payable out of such profits or gains, and there is not any separate charge and assessment of income tax on that interest; but that the company, who would have to pay the tax at the rate of $6 \mathrm{~d}$. for the first quarter of the year, and $7 \mathrm{~d}$. for the second quarter, would deduct, on payment of the interest, a combination of those rates, or (say). $6 \frac{1}{2} \mathrm{~d}$., by virtue of sec. 15 of the Act of 1864 ; that in the case of the payment of interest by a municipal corporation to creditors on rates, the interest is itself the subject of a charge and assessment, as rates are not chargeable as profits; and the charge is at "the rate of income tax in force at the time of such payment," according to the clear and express provision contained in sub-sec. 3 of sec. 24 of the Customs and Inland Revenue Act I888. The Board further stated that there is not any provision in the Income Tax Acts which authorises the corporation to reimburse themselves where deduction has been for a less amount than should have been made.

It may then be said that-

Interest, \&c., under Schedule C (i.e., payable out of the Summary. revenue of the United Kingdom or any Colony or foreign State) is liable to deduction of tax at the rate in force when the dividend is paid. 
summary.

Interest, \&c., under Schedule D is liable in the same manner if not paid out of profits brought into charge, but to an apportioned rate if paid out of profits, e.g., the interest, \&c., due from a foreign company is liable to deduction at the rate in force when the dividend is paid, such interest being payable out of profits not brought into charge; but dividends and interest, \&c., payable by British companies, whether chargeable under Case I. or Case IV., are liable to deduction at an apportioned rate.

In reply to a recent inquiry, the Board of Inland Revenue stated that the Grand Trunk Railway Company of Canada was considered as a Colonial company (Act of $\mathrm{r} 86 \mathrm{r}$ ), and that $\operatorname{tax}$ on their dividends should therefore be deducted at the rate in force when the payment was made.

Rey. Act 1911, sec. 14.
Sec. I4 of the Rerenue Act I9I I deals with the question of the recovery of tax which could not be deducted at the time of payment, viz. :-

(1) Where in any income tax year any half-yearly or quarterly payments have been made on account of any dividend, interest, or other annual profits or gains, previously to the passing of the Act imposing the tax for that year, and income tax has not been charged thereon or deducted therefrom, or has not been charged thereon or deducted therefrom at the rate ultimately charged for the said year, the amount not so charged or deducted shall be charged under Schedule D in respect of those payments as profits or gains not charged by virtue of any other schedule, in accordance with the provisions contained in the sixth case of Schedule D in section roo of the Income Tax Act 1842 , and the agents entrusted with the payment of the dividends, interest, or other annual profits or gains shall furnish a list containing the names and addresses of the persons 
to whom payments have been made, and the amount of those payments, to the Commissioners of Inland Revenue, upon a Rey. Act. 1911, requisition made by the Commissioners in that behalf.

(2) Any person liable to pay any rent, interest, or annuity, or to make any other annual payment, shall be authorised to make any deduction on account of income tax for any income tax year which he has failed to make previously to the passing of the Act imposing the tax for that year, or to make up any deficiency in any such deduction which has been so made on the óccasion of the next payment of the rent, interest, or annuity, or making of the other annual payment after the passing of the Act so imposing the tax, in addition to any other deduction which he may be by law authorised to make, and shall also be entitled, if there is no future payment from which the deduction may be made, to recover the sum which might have been deducted as if it were a debt due from the person as against whom the deduction could originally have been made if the Act imposing income tax for the year had been in force.

(3) In this section the expression "income tax year" means the year beginning the 6th day of April. 


\section{CHAPTER VIII.}

\section{EXEMPTIONS AND ABATEMENTS.}

\section{PART I.-General.}

Claim may be made for three years.

Act of 1842, sec. 163.
CLAIMS for repayment of tax on the ground that the person is entitled to exemption or abatement may be * made for three years past.

The sections of the Acts relating to exemptions and abatements are as follows :-

Act of 1842 , sec. $163-$

". . . Any person charged or chargeable to the duties granted by this Act, either by assessment, or by way of deduction from any rent, annuity, interest, or other annual payment to which he may be entitled, who shall prove before the Commissioners for General Purposes, in the manner hereinafter mentioned, that the aggregate annual amount of his income, estimated according to the several rules and directions of this Act, is less than *one hundred and fifty pounds, shall be exempted from the said duties, and shall be entitled to be repaid the amount of all deductions or payments on account thereof, in the manner hereinafter directed, except so much of such duties as the person claiming such exemption shall, or may be entitled to, charge against any other person, or to

*This exemption was limited by sec. 28 of the Act of 1853 to incomes less than $£$ Ioo, but was restored to $£ 150$ in 1876 . Now, however, see the Act of 1998 . 
deduct or retain from, or out of any payment to which such claimant may be or become liable; and such exemption shall be claimed and proved, and the proceedings thereupon shall be had before the Commissioners for General Purposes in the district where the claimant shall reside, pursuant to and under the powers and provisions by which the duties in Schedule D are herein directed to be ascertained and charged, but, nevertheless, subject to the rules and directions hereinafter contained."

Act of ${ }_{1} 876$, sec. 8 -

"The exemption granted by the Act of the fifth and sixth Act of 1876, years of Her Majesty's reign, chapter thirty-five, to persons whose respective incomes are less than one hundred and fifty pounds a year, is hereby restored, and in lieu of the relief granted by sec. 12 of 'The Customs and Inland Revenue Act 1872,' to a person whose income, although amounting to one hundred pounds or upwards, is less than three hundred pounds, the following relief or abatement shall be given or made to a person whose income is less than four hundred pounds-that is to say, any person who shall be assessed or charged to any of the duties of income tax granted by this Act, or who shall have paid the same either by deduction or otherwise, and who shall claim and prove in the manner prescribed by the Acts relating to income tax that his total income from all sources, although amounting to one hundred and fifty pounds or upwards, is less than four hundred pounds, shall be entitled to be relieved from so much of the said duties assessed upon or paid by him as an assessment or charge of the said duties upon one hundred and twenty pounds of his income would amount unto, and the relief shall be given either by reduction or abatement of the assessment upon such person, or by the repayment to him of so much of the excess as he shall have paid, or by both of those means, as the case may require."

Act of 1894, sec. 34 (I) (now obsolete), but which raised Act of 1894, sec. 34. the exemption limit to $\mathcal{E}_{\mathrm{r} 60}$ and granted an abatement to incomes not exceeding $£ 500$

Sub-section (2), relating to married women, is quoted later on in this chapter. 
Act of 1898,

sec. 8.
Fraudulent claims for exemption, \&c.
Act of 1898 , sec. 8

"(I) Any individual who having been assessed or charged to income tax or having paid income tax either by deduction or otherwise claims and proves in manner prescribed by the Income Tax Acts that his total income from all sources, although exceeding one hundred and sixty pounds, does not exceed seven hundred pounds, shall be entitled to relief from income $\operatorname{tax}$ equal-

"(a) If his total income does not exceed four hundred pounds, to the amount of the income tax upon one hundred and sixty pounds; and

"(b) If his total income exceeds four hundred pounds and does not exceed five hundred pounds, to the amount of the income tax upon one hundred and fifty pounds; and

"(c) If his total income exceeds five hundred pounds and does not exceed six hundred pounds to the amount of the income tax upon one hundred and twenty pounds; and

"(d) If his total income exceeds six hundred pounds and does not exceed seven hundred pounds, to the amount of the income tax upon seventy pounds;

and such relief shall be given either by reduction of the assessment or by repayment of the excess which has been paid, or by both of those means, as the case may require."

Sec. 166 of the Act of 1842 provides that :-

"If any person shall be guilty of any fraud or connirance in making any such claim, or in obtaining any such exemption or any such certificate as aforesaid, or shall fraudulently conceal or untruly declare any income or amount of income, or any sum which he may have charged, or been entitled under the authority of this Act to charge against any other person, or which he may have deducted or retained, or have been or be entitled as aforesaid to deduct or retain, from or out of any payment to which such person claiming exemption as aforesaid nay be or become liable, or if any such person shall fraudulently make a second claim for the same cause, every such person so offending in any of the cases aforesaid shall

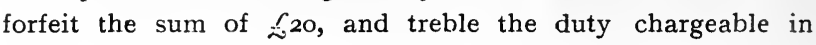


respect of all the sources of his income, and as if such claim had not been allowed; and if any person shall knowingly and wilfully aid, abet, or assist any such person in committing any such fraud as aforesaid, the person so aiding, abetting, or assisting shall forfeit the sum of $£ 50 . "$

By sec. 28 of the Act of 1853 this section is extended to apply to false claims for abatement.

In the case of Lord Advocate v. McLaren (Court of Session, Scotland, 7 th March and 18th July 1905) action was taken Advocate v. McLaren. under this section against McLaren for making such a false claim. His income arose partly from business and partly from interest, \&c., taxed at the source, and it was sought to charge $£_{20}$ and treble the duty on the whole income.

In the Court of first instance the Lord Ordinary pointed out that the section spoke of " fraudulently" concealing but only " untruly" declaring, and it was not therefore necessary to decide whether the conduct of McLaren was morally culpable or not, as he had in any event incurred the penalty by (at least) inexcusable carelessness. He further considered that sec. 178 , which struck not only at falsehood and fraud but also against " wilful neglect," helped to the interpretation of the general policy of the statute.

As to the amount of the penalty, $\mathcal{E}^{20}$ for each offence (two claims) was clearly due, but the treble duty could not be on Amount o penalty. all the sources of income, because income which had paid duty already could not be " chargeable." He considered that the section clearly meant treble duty on the income on which duty was still chargeable. This view also, he stated, was 
supported by sec. I 78 , that in case of fraudulent concealment, \&c. :-

"Every person shall, on proof thereof . . . be charged and assessed treble the amount of the charge which ought to have been made on such person if no such charge shall have been made; and if any such charge shall have been made which shall be less than the charge which ought to have been made on such person, then such person shall be assessed and charged, over and above such former charge, treble the amount of the difference between the sum with which such person shall have been charged and the sum with which he ought to have been charged, to be added to such assessment. . . ."

On appeal, however, it was held (Lord Adam, Lord Kinnear, and the Lord President) that the penalty extended to treble duty on the whole income. The fact of the declaration not having been acted upon did not exonerate-the penalty was for the untrue declaration, irrespective of result. The Lord Ordinary had considered it competent to the Court to modify the penalty (if exigible) under sec. 23 of the 6th of Queen Anne, c. 53, but they did not think that Act referred to penalties such as this at all. This penalty was absolutely fixed by statute, and the Court had no power to alter it.

It was during the year $1876-7$ that, for the first time, facilities were given to persons desirous of claiming exemption or abatement, by providing a form of claim in the form of return itself, instead of leaving persons to apply specially to the Assessor or Surveyor for a form, after making the return of income, as had been the previous practice. 
It will be seen from the sections quoted above that a person whose total income from all sources does not exceed $\mathcal{E}_{1} 60$ entitled to exemption or per annum is exempt from tax, and if he has paid tax by way of deduction, or otherwise, on the whole or any part of it, he is entitled to have it repaid to him.

Also where the total income of a person

Abatements.

Exceeds $\mathcal{E}^{\mathrm{I} 60}$ but does not exceed $\mathcal{E}_{400}$, he is entitled to an abatement of $£ \mathrm{r} 60$.

Exceeds $\mathcal{E}_{400}$ but does not exceed $\mathcal{E}_{500}$, he is entitled to an abatement of $£$ I 50 .

Exceeds $£ 500$ but does not exceed $\mathcal{E} 600$, he is entitled to an abatement of $£$ r 20 .

Exceeds $£ 600$ but does not exceed $£ 700$, he is entitled to an abatement of $\mathcal{E} 70$.

In order to claim the exemption or abatements, and avoid paying tax and then claiming it back (in cases where the income has to be returned for assessment and is not taxed at the source), the declaration in the Form (No. 9 or $\mathrm{Ir}$ ) must be filled up and signed. In the case of a partnership, the partners may claim to be treated separately for the Partners ma be treated separately. purpose of claiming such exemption or abatement ( $\mathrm{r}_{907}$, sec. 20, also 1842 , sec. I68). In such case the Form of Return No. I I should be filled up precisely as in other cases, and Filling up the form of return, \&c. each person claiming abatement or exemption should fill up and sign Form No. $3^{8}$ (see Chapter IX.), and these should accompany the Form of Return. 
Previous to 1907 , partners claiming abatement, \&c., were assessed separately. Since 1907 this is not so. They are "treated" separately (sec. 20, 1907), thus producing the same result in respect thereof, but the assessment is made on the firm. This seems to introduce needless complications. The claims are examined, and each is " treated" separately, and they are then lumped together and an assessment is made on the firm. If we are correctly informed, this arose because of certain difficulty in collecting the tax from individual partners. If this be so, we would suggest that a simpler method would be to assess separately and provide that tax should none the less be recoverable (if necessary) from the firm.

The following is the simplest illustration of the incidence of the tax as between partners :-

Assessable profit of A. and B. (say average profits of 1907, I908, and 1909), £.906, after adding back £ 100 for salary for Mr. A.

For income tax purposes for I9I0-II :-

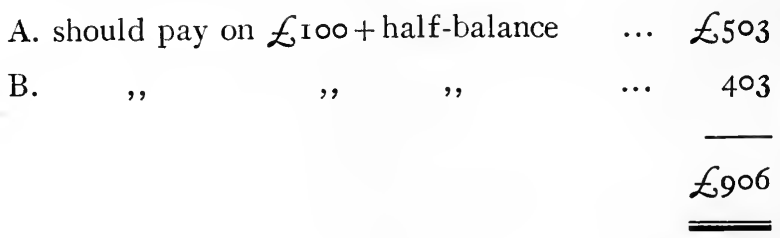

A being entitled to an abatement of $\mathcal{E I} 20$ and $\mathrm{B}$. of $\mathcal{I}^{\mathrm{I}} \mathrm{5}^{\circ}$. 
In connection with relief to earned incomes (see Part III. of this chapter) the Finance Act, 1907 , sec. 20 , provides :-

"Where an individual carrying on or exercising any profession, trade, or vocation in partnership with any other person makes any claim for exemption, relief, or abatement under the Income Tax Acts, the income of the individual from the partnership for the year to which the claim relates may be treated separately for the purpose of any such exemption, relief, or abatement, and if so treated shall be deemed to be the share to which he is entitled during the said year in the partnership profits, such profits being estimated according to the several rules and directions of those Acts."

It has been suggested that this is new, but it appears to us that it is simply placing on the statute book a practice which has been in existence as long as we can remember. Assume a case where the profit has been divided equally up to 3 ist March igio, but becomes A. $\frac{2}{3}$ rds, B. $\frac{1}{3}$ rd as from that date. The income for the year of assessment is to be divided on the basis of $\frac{2}{3} \mathrm{rds}$ and $\frac{1}{3} \mathrm{rd}$, though the amount of it is arrived at on the basis of three years when the shares were different. This principle we have invariably applied in practice.

In the case before us the net result is :-

A. B.

$\begin{array}{lrllll}\text { Salary } & \ldots & \ldots & \ldots & \ldots & £ \text { 100 } \\ \text { Net profit }(£ 806) & \ldots & \ldots & 537 & £ 269 \\ & & & & £ 637 & £ 269 \\ & & & \end{array}$

and $\mathrm{A}$. is only entitled to an abatement of $£ 70$ and $\mathrm{B}$. to one of $E_{1} 60$. 
ncidence of ax as between artners here

artnership terest has aried.

lling up the rm of turn, \&c.

Now let us assume profits as follows :-

Year ended 3 Ist March.

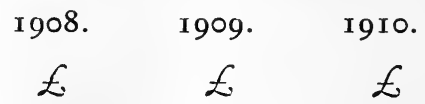

Net profit $\ldots \quad \ldots \quad$ I0,000 II, $000 \quad$ I 2,000
A.'s interest
... $\mathrm{I}, \mathrm{I} 00$
$\mathrm{I}, 200$
I, 300
B.'s
‥ 1,300
1,500
I, 400

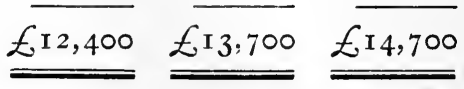
(Average, fiz.600.)

and that $\mathrm{A}$. has $\frac{1}{4}$ th share and B. $\frac{3}{4}$ ths. The shares in our opinion are :--
A.
B.

Interest for the year (using the last interest as near as possible) ... £ $£ \mathbf{r}, 300 \quad £ \mathbf{r}, 400$

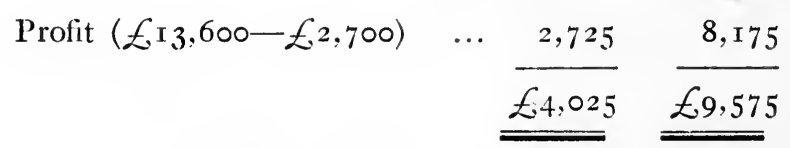

The point, of course, is how to deal with the interest, riz., whether to take it on the arerage, on the previous year, or on the current year. We farour the last alternative, and we use the interest on capital as standing at 3 Ist March r 9 ro as the best estimate possible for the current year-on the same principle as we use the machinery figure for depreciation purposes. We feel no doubt that this method is the proper way of arriving at a share of profits for the purpose of Section 20 of the Act of 1907 -though conscious that this would involve an adjustment every year, but where there was 
no material difference no notice would be taken. Again, no difficulty would usually arise if any of the three methods were Filling up the form of return, \&c. consistently followed, but looking at it from the point of view of an interpretation of the legally correct method, and taking an exaggerated case, suppose it were known that the business had permitted B. to withdraw all his capital on Ist April rgro, then the division should be :-

A. B.

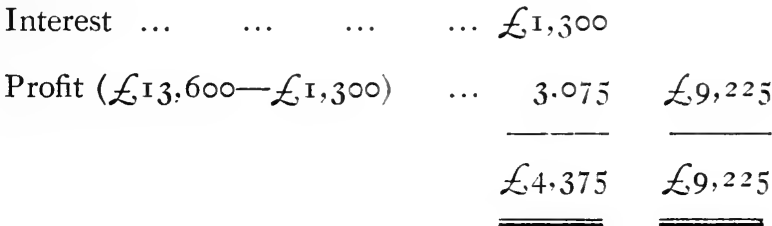

This abatement, \&c., does not apply in the case of a limited company, which is assessable. howerer small its profit, the No abatement, a company. remedy being for the individual shareholders to claim repayment-if entitled to it.

The point was before the Courts in two cases. In the Court of Session, Scotland, in Curtis v. Old Monkland Conservative Curtis v. Old Monkland C nservative Association (22nd Norember 1904), the club sought exemption from income tax, Schedule $A$, on the ground that its total income from all sources did not exceed $\mathcal{E}_{\mathrm{i}} 60$. Reliance was placed on sec. 40 of the Act of 1842 , viz., that-

"All bodies politic, corporate, or collegiate, companies, fraternities, fellowships, or societies of persons, whether corporate or not corporate, shall be chargeable with such and the like duties as any person will under and by virtue of this Act be chargeable with." 
Curtis v.

And also on sec. 192, providing that-

"Wherever in this Act, with reference to any person, matter, or thing, any word or words is or are used importing the singular number, or the masculine gender only, yet such word or words shall be understood to include several persons as well as one person, females as well as males, bodies politic or corporate as well as individuals, and several matters or things as well as one matter or thing, unless it be otherwise specially provided, or there be something in the subject or context repugnant to such construction."

Also on the Interpretation Act, 1889 , sec. r9, that-

"In this Act, and in every Act passed after the commencement of this Act, the expression 'person' shall, unless the contrary interpretation appears, include any bodies of persons, corporate or incorporate."

On behalf of the Crown it was urged that the wording of sec. $6_{3}$ (p. 398) was repugnant to such a construction, and that the association was not a "body politic or corporate."

The Court of Session allowed the exemption.

The case was then carried to the House of Lords, I Ith and I9th December 1905, where the decision was overruled and judgment given for the Crown.

In Mylam v. The Market Harborough Advertiser Co., Lim. (King's Bench Division, Igth January r905), the company similarly sought exemption from assessment to Schedules A and $\mathrm{D}$, on the ground that their total income did not exceed Ex6o. The argument was substantially the same as in the Old Monkland case; but the Crown further argued that, in any event, sec. ${ }^{6} 63$ excepts from exemption so much of the tax as the company should or might be entitled to deduct or retain from dividends. 
Phillimore, J.; held that the company was not entitled to the exemption claimed. He did not rely on the interpretation to be put upon the word " person," and did not desire to express any opinion as to whether the company was a "person," but assuming that it was a "person," it was not entitled to exemption because it was bound (sic) to deduct income tax from its dividends.

By the Finance Act 1904 , sec. 8 , it is provided that-

"Whereas doubts have arisen whether unregistered friendly societies are entitled to the exemption from income tax given under the Acts relating to income tax to persons whose income does not exceed $£_{\mathrm{i}} 6 \mathrm{o}$, be it enacted that an unregistered friendly society whose income does not exceed $£_{\mathrm{I}} 60$ is entitled to that exemption."

It is frequently overlooked that in all cases regard is to be had to the share of income payable to each person parRegard to be had to interest of ticipating in it, and not to the gross amount of that income.

Take the case of a large trust estate, where the income may be some thousands a year. It frequently happens that some, if not all, of the beneficiaries receive less than $£_{400}$ or $£_{5} 00$, \&c., per annum, some, possibly, receiving less than $£$ r6o. Probably the whole of the income is taxed at its source, so the only remedy is to recover the tax. In such cases each person must claim separately, and must give an account of his total income from all sources.

Previous to the Act of 1894 the income of a married woman residing with her husband was deemed to be his income for

Unregistered Friendly Societies.

\section{Case of} trust estate. 
income tax purposes ( 1842 , sec. 45), and any claim for exemption or abatement in respect thereof had to be made by him.

By the Finance Act 1897 (repealing a similar section of the Act of 1894 ) it is provided :-

"Sec. 5.-(I) Where the total joint income of a husband and wife charged to income tax by way either of assessment or deduction does not exceed $£_{500}$, and upon a claim for exemption, relief, or abatement, under the Acts relating to the income tax, the Commissioners for the general purposes of those Acts are satisfied that such total income includes profits of the wife from any business carried on or exercised by means of her own personal labour, and that the rest of the total income, or any part thereof, arises or accrues from profits of a business carried on or exercised by means of the husband's own personal labour, and unconnected with the business of the wife, they shall deal with such claim as if it were a claim in respect of the said profits of the wife, and a separate claim on the part of the husband in respect of the rest of the total income, but they shall deal with any income of the husband arising or accruing from the business of his wife, or from any source connected therewith, as if it were part of the income of the wife.

“(2) In this section 'business' means any profession, trade, employment, or vocation, or any office or employment of profit, and the 'profits of a business' mean any profits, gains, or remuneration arising or accruing from the business, and chargeable under Schedule D or Schedule $\mathrm{E}$ in the Income Tax Act i $853 . "$

The exact effect of these sections is further dealt with later on in the Chapter.

A few illustrations of cases where exemption or abatement may be claimed may be useful, e.g. :- 
A. is a salesman in a warehouse, his salary being as follows :-

Year ending 3ist Dec. $1904 \quad £^{150}$ !)

$\left.\begin{array}{cc}1905 & 180 \\ 1906 & 210 \\ 1907 & 240 \\ 1908 & 270 \\ 1909 & 300 \\ 1910 & 330\end{array}\right\}\left\{\begin{array}{ccc}£ 330 \text { Average } £ \text { I65 } \\ 540 & , " & 180 \\ 630 & , " & 210 \\ 720 & , & 240 \\ 810 & , & 270 \\ 900 & , " & 300\end{array}\right.$

His income for income tax purposes will be computed on an average of past years ( 1853 , sec. 48$)$ :-

For the Income Tax

year ending $\left.5^{\text {th April }}\right\} 1906$ based on salary for the year $1904 \quad \ell^{1} 50$ I907 based on average salary for $1904 \& 1905 \quad 165$

\begin{tabular}{|c|c|c|c|}
\hline 1908, & ," & " & $1904-05-06$ \\
\hline 1909, & " & " & $1905-06-07$ \\
\hline I9ro , & , & ", & I906-07-08 \\
\hline II & , & , & $1907 \cdot 08-09$ \\
\hline I9I2 & ,. & ,. & 1908-09. 10 \\
\hline
\end{tabular}

Thus, for the income tax year ended 5th April 1906 he would have been entitled to exemption, his income not having

Amount of abatements that may be claimed. exceeded $£$ i6o. In each subsequent year he was entitled to an abatement of $\mathcal{I}^{\mathrm{I} 60}$ off the respective averages of $\mathcal{E}^{\mathrm{I}} 6_{5}$, $£ \mathrm{I} 80$, \&c. If, in any subsequent year, his income (arrived at in like manner) exceeds $£ .400$, but does not exceed $£ .500$, he will be entitled to an abatement of $£_{\mathrm{I}} 5^{\circ}$, instead of $£_{\mathrm{I} 60}$, and so on.

In all these cases he will have a form of return sent to him to fill up. He should fill in the figure on page 2 , and also complete the "Notice and Declaration" on page 3, and 
Employer to return names of assistants and their salaries.
Income not deriyed wholly from salary.
Amount to return for assessment.

he will not have any difficulty in obtaining the abatement or exemption, as the case may be. There is, however, one question which might be raised in connection with his return. An employer is bound by sec. 21 of the Finance Act 1907 to make a return of all persons in his employment, and the salaries paid to them, except such as are not liable to the payment of income tax (see ante p. 45). His name will probably be furnished to the Surveyor as soon as he commences to receive $£ \mathrm{I} 60$ per annum. though his average salary for the past three years does not amount to that sum. In the absence of a return from him (on the Form No. II, which will have been forwarded to him) he will be assessed on such a sum as the Commissioners consider will probably represent his income, and he will be left to appeal if he is over-assessed. It is, therefore, important in his own interest that he should make a proper return. and be able to show (if called upon) the basis on which he has marle it up.

Let us now take the case of another salesman, B., who receives the same salary, but who has other income, e.g.,

Income from railway stock $\quad \ldots \quad$ Ei 10 per annum

Net annual value of house property, whether he occupies it himself $\begin{array}{llllll}\text { or not } & \ldots & \ldots & \ldots & 2+\end{array}$, ,

His statutory income for the year ending 5 th April 1908 is$\begin{array}{llllllll}\text { Salary } & \ldots & \ldots & \ldots & \ldots & \ldots & £ \text { ¿ } 80\end{array}$

Income from railway stock ... $\quad \ldots \quad \ldots \quad$ ro

Net annual value of house property $\quad \ldots \quad 24$

Total $\quad \cdots \quad £ 214$


He is thus liable to pay tax on $£ 2$ I4 less $£$ I6o, but he has already paid tax on the Ero by way of deduction and on the $£_{24}$ under Schedule $A$. He should, therefore, have filled in the figure $\mathcal{E}_{\mathrm{I}} 80$ on page 2 of the return, and completed the "Notice and Declaration" on p. 3, and he would have been assessed on $\mathcal{E}_{\mathrm{r}} 80$ less $\mathcal{E}_{\mathrm{i}} 60$ (i.e., on $£_{20}$ ).

Had his average salary been $£$ roo his income for t'ie year would have been-

$\begin{array}{lllllll}\text { Salary } & \ldots & \ldots & \ldots & \ldots & \ldots & £ \text { roo }\end{array}$

Income from railway stock $\quad \ldots \quad \ldots \quad$ Io

Net annual value of house property $\quad \ldots \quad 24$

$$
\text { Total } \quad \cdots \quad \underline{\underline{\text { E. } 34}}
$$

And he would have been exempt from tax, his income not having exceeded $£ \mathrm{r} 60$. He would also be entitled to recover the tax paid by way of deduction on the $E_{\mathrm{I}} \mathrm{O}$, and, under Schedule $\mathrm{A}$, on the $\AA_{24}$.

If the income exceeds $£ 400$ but does not exceed $\mathcal{E}_{500}$ he is only entitled to an abatement of $\mathcal{E}_{5}$ o, say,

$\begin{array}{lllllll}\text { Salary } & \ldots & \ldots & \ldots & \ldots & \ldots & £ 440\end{array}$

Income from railway stock $\quad \ldots \quad \ldots \quad 40$

Net annual value of house property $\quad \ldots \quad 20$

The total is ... $\overline{£ 500}$

And he would be assessed on $£ 290$. 
Gross and net income.
Estimate of income under Schedule B for exemption, \&c.

Tax deducted from mortgage interest, \&c.

In cases where the gross income is above $£ 700$, but, after the deduction of the one-sixth under Schedule A, it falls below that figure, there is a particular point to be noticed.

To take a case,

$$
\begin{aligned}
& \begin{array}{lllll}
\text { Salary } & \ldots & \ldots & \ldots & £ 640
\end{array} \\
& \text { Income from railway stock } 40 \\
& \text { Gross annual value of house } \\
& \begin{array}{llll}
\text { property } & \ldots & \ldots & £^{24}
\end{array} \\
& \text { Less one-sixth } \quad \cdots \quad 4 \quad 4 \quad 20 \\
& £ 700 \text { net, or } £ 704 \text { gross. }
\end{aligned}
$$

The income for income tax purposes is $£ 700$ (not $£ 704$ ), and the person is entitled to the abatement of $£ 70$ as his income does not exceed $£ 700$.

As to claims for exemption, \&c., under Schedule B see ante (p. 36).

To go a step further, suppose the income to be $\begin{array}{llllllll}\text { Salary } & \ldots & \ldots & \ldots & \ldots & \ldots & \ldots & £ 150\end{array}$

Net annual value of house property $\ldots \quad \ldots \quad$ r...

$$
\text { Total ... } \overline{£ 165}
$$

Less Interest payable on $£ 200$ loan at 4 per

$$
\begin{array}{cccccccc}
\text { cent. } & \cdots & \cdots & \cdots & \cdots & \cdots & \cdots & 8 \\
& & & & \text { Net income } & \cdots & & £ 157
\end{array}
$$

Then the income for income tax purposes is not $£$ r 65 but $£^{1} 57$, and he is entitled to exemption. It must, however, be observed that he cannot recover the whole of the tax on $£$ r 5 
paid under Schedule A, for he has deducted, or ought to have deducted, tax on $\AA^{8}$ on payment of the interest. This has Tax deducted from mortgage been done by him on behalf of the Revenue, and carrying out the principle of taxing income at its source. The amount he may recover will be tax on $£^{1} 5$ less $£^{8}$ (i.e., on $£ 7$ ), and for a subsequent year he may have the assessment discharged except as to the mortgage interest, or at least might where there was no reasonable doubt of his title to exemption continuing. Let us glance at the net result. The person to whom he has paid the $£^{8}$ has borne tax on it by way of deduction. He himself has paid tax under Schedule A on $E^{15}$. On the other hand, he has received tax on the $\mathcal{E}^{8}$, so that he is really only out of pocket to the extent of tax on $\mathcal{E}_{7}$, and this he recovers on proving that he is entitled to exemption. If he gets the assessment discharged except as to the $£^{8}$ the result is the same.

In most cases, where the individual receives a salary, he is able to obtain the exemption or abatement without paying the tax at all, but in many instances a person's whole income is derived from

Government Stocks,

Investments in Public Companies,

Foreign Stocks,

Interest on Mortgage,

Chief Rent,

House Property, 
Filling up claim for repayment.

or some of them. Except in the case of the house property, the income tax will be deducted before the interest, \&c., comes to the hands of the recipient, and it thus becomes necessary to make a claim and obtain repayment of it.

It should be borne in mind that any time before the $5^{\text {th }}$ April in any year a claim for exemption on abatement may be made for three years up to the previous 5 th April, i.e., any time before the $5^{\text {th }}$ April rgr 2 a claim may be made for the three income tax years ended 5th April 1907-08-09. After a claim has once been made and allowed, a form is forwarded by the authorities with each order for repayment of tax for the person to claim for the following year.

Dividend for one year paid during next year.

In reply to an inquiry the Board of Inland Revenue stated that a dividend paid in May 1899 for the half-year ended $3^{\text {Ist }}$ December 1898 should be regarded as income for the year $1898-99$ (not $1899-1900$ ), " that being the year in which " the company's profit would have been earned and assessed " to income tax." The practice is not, however, uniform, and the principle laid down might, in many cases, be difficult of application.

Eirst claim to be forwarded to Suryeyor.

\section{Subsequent}

claims to

Somerset

House, \&c.
The first claim, or claims, must be forwarded to the Surveyor for the district. Subsequent claims are to be forwarded, in the case of English claims, direct to Somerset House, and in the case of Scotch or Irish claims to the Comptroller, Inland Revenue, Edinburgh or Dublin respectively. 
We gave in the Appendix to the fourth edition a letter issued by the Comptroller at Edinburgh at the time when the repayments of income tax in Scotland were transferred from London to Edinburgh.

First claim to be forwarded to Suryeyor.

Subsequent

claims to

Somerset

House, \&c.

The following forms, with the certificates, will, it is hoped, be of material assistance to any person desirous of making such a claim :- 
NO. 40.

In writing about this claim quoteRegister No.

Repayment by

The following particulars must be furnished by the claimant :-

Full name of claimant

Mary Aluce Hodson,

If a widow, whether

Widow or Spinster.

Occupation (if none, state "none.")

Widow,

None.

Residence

135 New Road, Chorlton-on-Medlock, Manchester.

Money Order Office at which repayment is desired.

Spring Gardens, Manchester.

Whether repayment of Income Tax has ever been claimed before

No. If so, when?

The Declaration on page 3 must be signed.

When filled in, this form is to be sent to the Surveyor of Taxes for the District in which the claimant resides, to whom also application may be made for advice and assistance in filling up the form.

The Name and Address of the Surveyor may be obtained from the Local Collector of Taxes.

NOTE.-if Repayment is to be made to any other person than the claimant, a written authority must be furnished, by letter or otherwise, under the claimant's own hand.

Full instructions for completing the claim are given on page 2 .
The spaces below must not be written on by the claimant.

\section{Class}

Period Years to 191

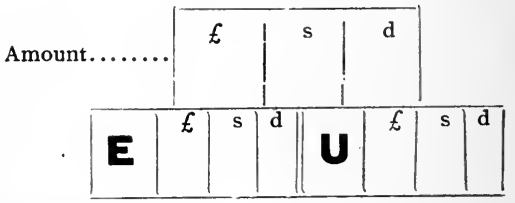

Examined by

Date 19I.

Countersigned

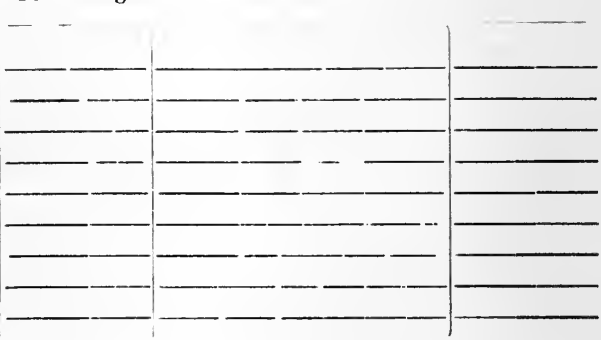




\section{INSTRUCTIONS.}

1.-The Income Tax year ends on the 5th April. No claim for repayment of Income Tax can be dmitted unless it be made within three years of the close of the tax year to which it relates.

2.-This form is for the use of a person resident in the United Kingdom. In the absence of special ircumstances, temporary residence in the United Kingdom does not confer any title to relief from ncome Tax.

3.- The income of a Married Woman living with her husband is deemed by the Income Tax Acts to his income, and particulars thereof must be included in any statement of income rendered by him for he purposes of a claim to Exemption or Abatement. The only exception to this rule is where a wife arns an income independently of her husband by the exercise of her own personal labour, and the oint income of husband and wife does not exceed $£ 500$. In such a case the profit so earned by the wife nay be treated as a separate income and a separate claim of Exemption or Abatement may be made in espect thereof.

4.- In filling in the particulars of income on page 3, the Claimant must conform to the following structions:-

If the income be derived-

(a) From Lands. or Houses.-State the precise situation of each property, with the name of occupier, and the amount of the annual rent or value, and who bears the cost of repairs. If the Claimant resides in his own house, the annual value thereof must be entered in the statement of income.

(b) From the Occupation of Land.-Reckon the income from this source at one-third of the full amount of rent and tithe.

(c) From Trade, Profession, or Employment.-State the nature thereof, where carried on, and the particulars of the Assessment, if any.

N.B.-The Collector's receipts for duties paid on income from above sources should be attached to the claim wherever practicable.

(d) From Dixidends on Stocks inscribed in the books of the Bank of England, Government Annuities and payments received through the Supreme Court Pay Office.-Certificates showing the Amount of Dividends, Annuities, \&c., are not required, but claimants must include the income from these sources in the general statement of income on page 3 of this form, and must, in addition, furnish further particulars as follows :-

Name or Description of Stock or Annuity, and whether the

Dividends are paid by post or through Bankers
Name or Names (in due order) in which the Stock or Annuity stands. If the funds are in Court the correct Title of the Cause or Matter must be given, and the title of the account (if any) in the Supreme Court Pay Office books.

John Henry Hodson, deceased-. Mary Alice Hodson executrix

Ditto
Amount of Stock, and if part of larger Sum state also larger Sum

$\begin{array}{ccc}£ & \mathrm{~s} & \mathrm{~d} \\ 400 & 0 & 0\end{array}$

200
Month and Year when Dividend or Annuity due, from which deduction made

5 July, 5 Oct. 1908

5 Jan. 5 A pr. 1909

1 May 1908

1 Nov. 1908

(e) From Dixidends or Interest arising from Money Inxested in any Stock, Shares, or otherwise (except in the Stock of the Bank of England, and those mentioned in the preceding clause).-Attach Certificates showing the amount of Dividends or Interest applicable to the period for which the claim is made.

(f) From Annuities, Interest of Money, Remittances from Abroad, or other property not coming under any of the foregoing heads. - State fully the particulars, including the name and address of the person by whom paid, and, if taxed before receipt, attach Certificates of deduction of tax, signed by the person who made such deduction.

N.B.-When the Certificates referred to in $(e)$ and $(f)$ are not in the name of the claimant state whether the person or persons in whose name or names the Certificates are given are Trustees or otherwise.

5.-Particulars must be given in space No. 2 of all deductions from the income, such as ground rent, interest on mortgage or loan (whether secured on property, life insurance policy, reyersion or otherwise), interest on unsecured loans, annuities, patent royalties, or other annual payments. If there be none, state "none."

6.-A claim may be made as soon as the whole of the Income of the Tax year (ending 5th Aprii) has been received.

7.-Penalties.-By Sec. 166 of 5 and 6 Vict., cap. 35, the Penalty for a fraudulent claim or untrue declaration is $f 20$ and treble the duty chargeable. By Sec. 94 of the Finance (1909-10) Act, I9Io, it is provided that "if any person for the purpose of obtaining any allowance, reduction, rebate, or repayment "in respect of any duty under this Act either for himself or for any other person, or in any return made " with reference to any duty under this Act, knowingly makes any false statement or false representation, "he shall be liable on summary conviction to imprisonment for a term not exceeding six months with "hard labour." 


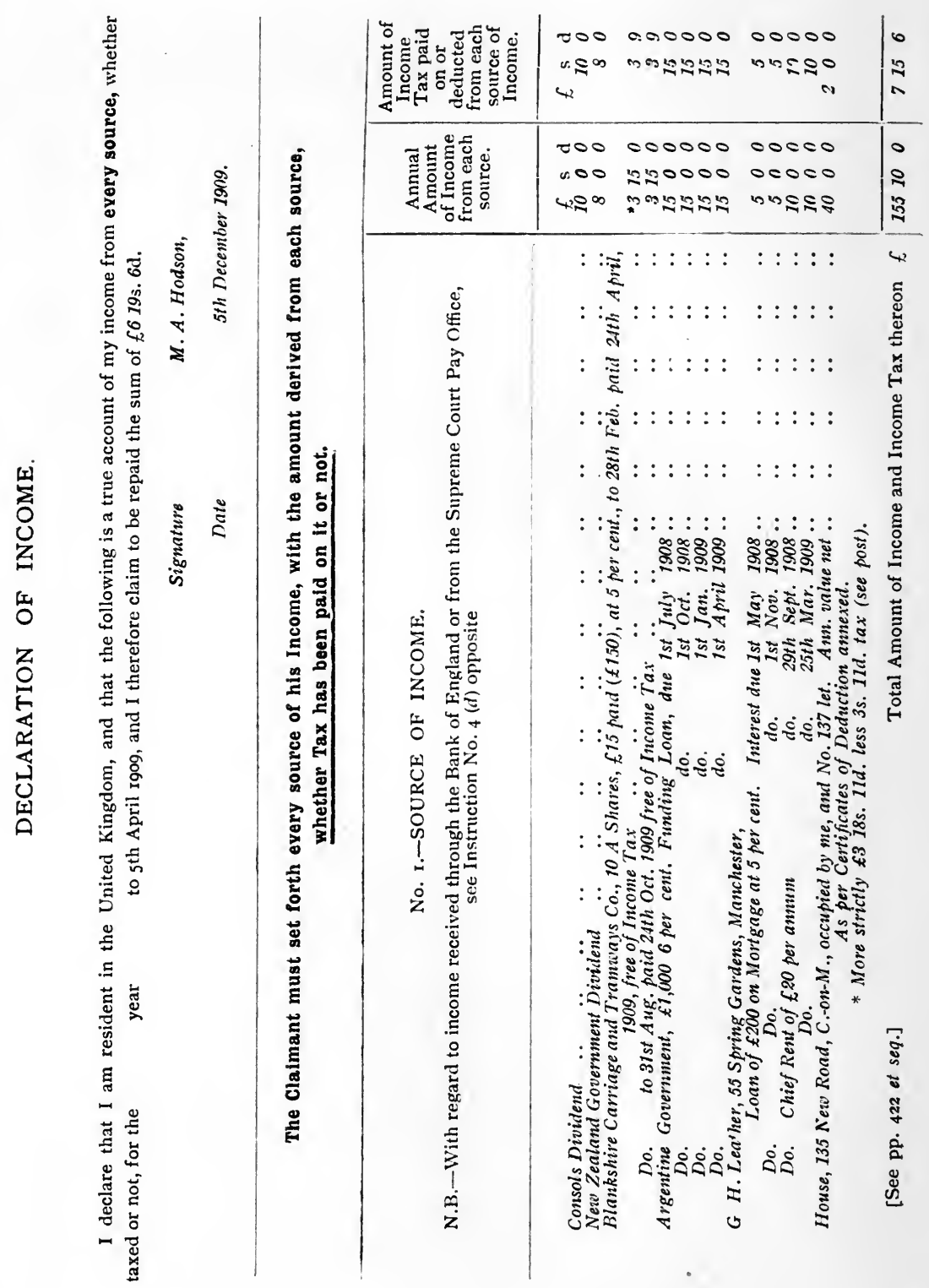


part I. Exfmptioss, \&C.-Clain where Tax Dedccted

AT SOLRCE.

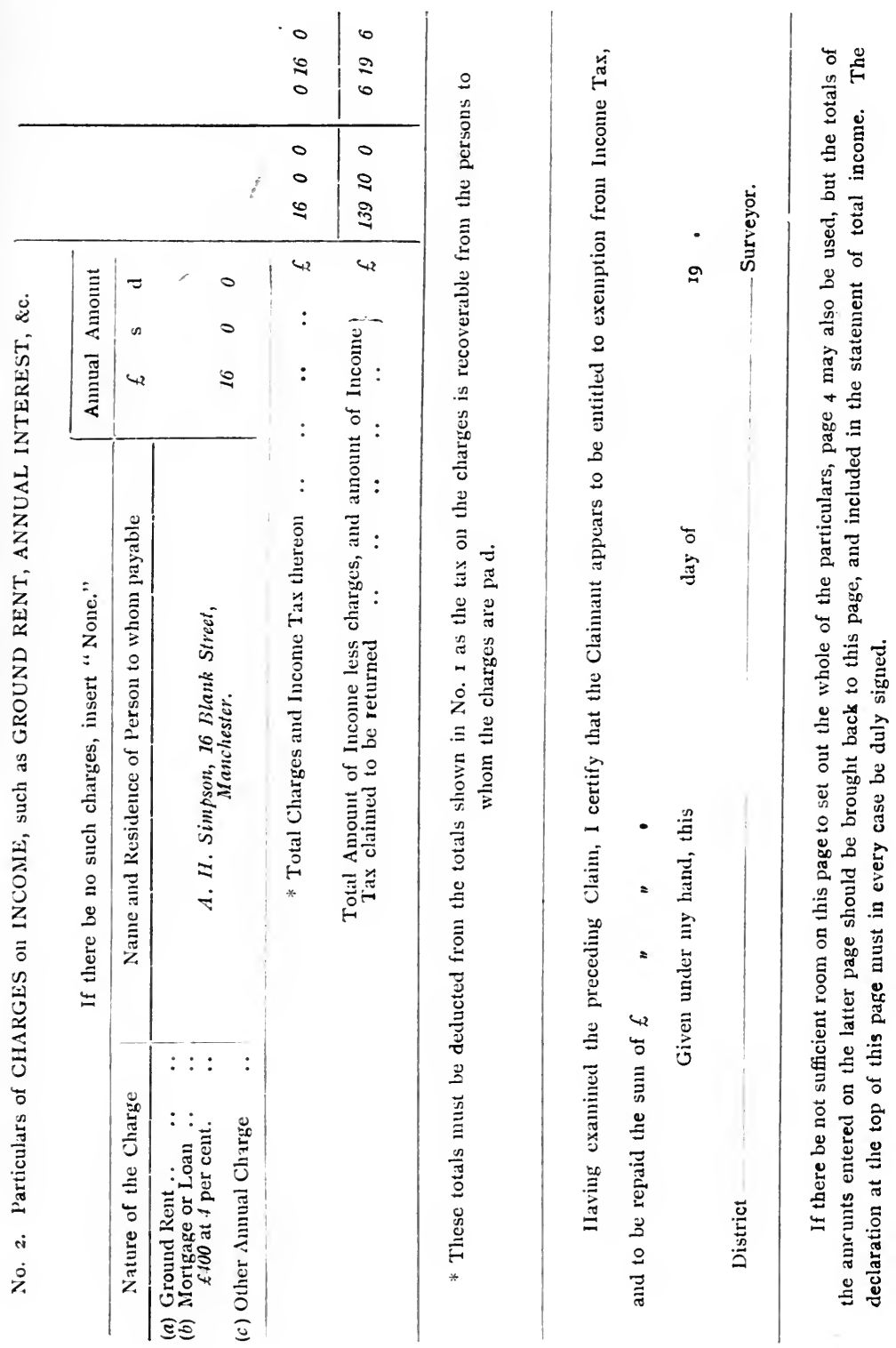


The Blankshire Carriage and Tramways Company.

Dividend for half-year ended February 28 th 1908.

57 Piccadilly, Blanktown,

April 24 th 1908.

To Extx. J. H. Hodson.

MADAM,

Herewith I beg to hand you cheque for $£_{3}$ I5s. od., being Dividend for the half-year ended February 28th 1908, upon the shares (as per particulars below) held by you in this Company, made payable at The Consolidated Bank, Lim., King Street, Blanktown.

Yours obediently,

T. Manser, Secretary.

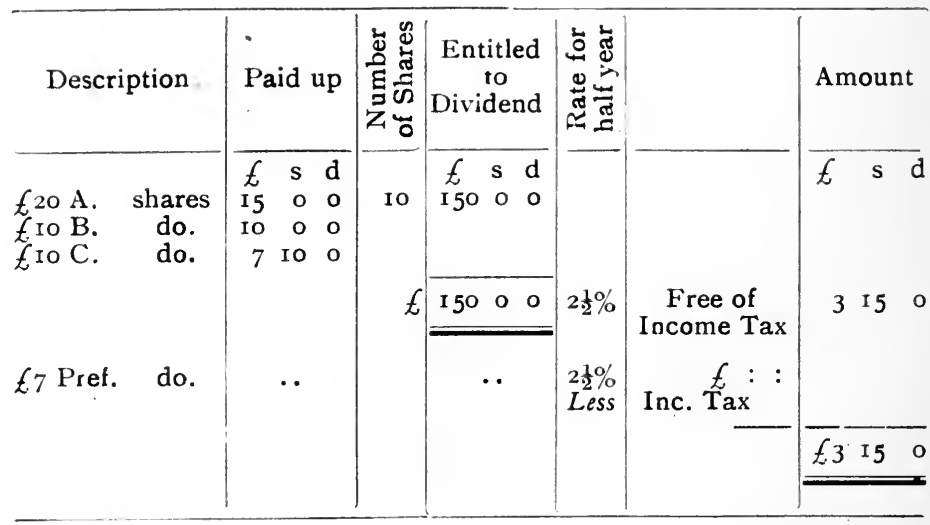

(This fortion to be retained by the shareholder.) 
No. $185 \mathrm{~A}$

\section{INCOME TAX.}

I hereby certify that Income Tax has been assessed on and paid to the Revenue by the Blankshire Carriage and Tramways Co., in respect of its Profits, and Gains, and that the sum of $£ 3$ 15s. od., being the Dividend payable for the Half-year ending on the 28th day of February roo8 to Extx. JNo. Hy. Hodson, on 10 A Shares, ŁI5 paid, is a portion of such Profits and Gains, in respect of which Income Tax has been assessed and paid as aforesaid.

Signature (1)

Quality.

Address

Date. 
No. I89A.

\author{
INCOME TAX. \\ Foreign and Colonial Securities. \\ Certificate for Repayment.
}

(To be used only by Bankers in the United Kingdom.)

We hereby certify that Coupons of the Argentine Government, as specified at the back hereof, which became due Ist July 1908 were forwarded by us to (1)

of

on behalf of Extx. Jxo. Hy. Hodsox, and that we received payment or were credited with the proceeds thereof LESS Income Tax as follows:-

$$
\begin{aligned}
& £ \mathrm{~s} d \\
& 15 \circ 0 \text { Gross amount. } \\
& \text { I5 O Tax deducted. } \\
& £ 1450 \text { Net amount. }
\end{aligned}
$$

Signature of Banker ?

or Bank Agent

Residence

Date

N.B.-The declaration on the other side to be signed by the Claimant. 


\section{SCHEDULE OF COLPONS.}

The number of Coupons to be entered in consecutive order

Aggregate amount of Coupons

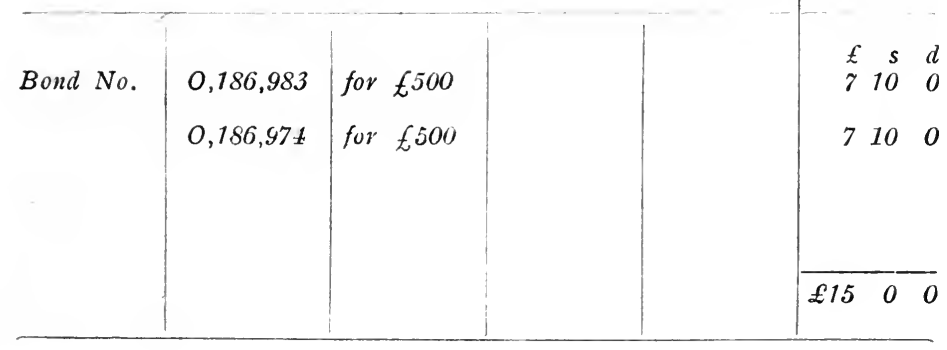

TO BE SIGNED BI CLAIMAXT.

I hereby declare that the coupons above-mentioned relate to Bonds which are my own property and are in the possession of myself.

Signature Mary Alice Hodson.

Date 5th Dec. 1909 .

N.B.--The Bonds in support of any Claim to be produced when required. 
No. 185 .

INCOME TAX.

I HEREBY CERTIFy, that on paying to Extx. Jno. Hy. Hodson, per Mrs. Hodson, of 135 New Road, C.-on-M., Manchester, the Sum mentioned in the second Column of the subjoined Statement, I deducted for Income Tax the amount set forth in the third Column of the said Statement, and I further certify that the amount of the Tax so deducted has been paid by me to the proper Officer for the receipt of Taxes.

\section{Signature}

Residence

Date 190.

\begin{tabular}{|c|c|c|c|}
\hline $\begin{array}{l}\text { Description of the Property,* or } \\
\text { Office, out of which the Rent, } \\
\text { Annuity, Salary, Pension, or } \\
\text { Interest is payable }\end{array}$ & $\begin{array}{l}\text { Amount of } \\
\text { Rent, Annuity, } \\
\text { Interest, \&c., } \\
\text { from which I } \\
\text { have deducted } \\
\text { the Tax }\end{array}$ & $\begin{array}{l}\text { Amount of } \\
\text { Income Tax } \\
\text { deducted } \\
\text { by me }\end{array}$ & $\begin{array}{c}\text { Period to which } \\
\text { the Rent, } \\
\text { Annuity, Salary, } \\
\text { Pension, or } \\
\text { Interest was } \\
\text { due }\end{array}$ \\
\hline 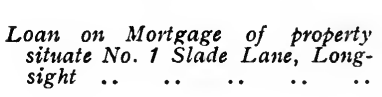 & $\begin{array}{lll}£ & \mathrm{~s} & \mathrm{~d} \\
10 & 0 & 0\end{array}$ & $\begin{array}{lll}£ & \mathrm{~s} & \mathrm{~d} \\
0 & 10 & 0\end{array}$ & $\begin{array}{c}\text { Date } \\
\text { Year ended } \\
\text { 1st Nov. } 1908\end{array}$ \\
\hline
\end{tabular}

*N.B.-In the case of Property, its situation, including Parish, County, and names of Occupiers must be distinctly stated.

This Form is supplied for the purpose of being filled up by the party deducting the Tax from the Income of the Claimant, and when filled up it must be attached to the Form on which the Claim is made for the return of the Tax. 
No. 185 .

\section{INCOME TAX.}

I HEREBY CERTIFY, that on paying to Extx. Jno. Hy. Hodson, per Mrs. Hodson, of 135 New Road, C.-on-M., Manchester, the Sum mentioned in the second Column of the subjoined Statement, I deducted for Income Tax the amount set forth in the third Column of the said Statement, and I further certify that the amount of the Tax so deducted has been paid by me to the proper Officer for the receipt of Taxes.

Signature

Residence

Date I9o.

\begin{tabular}{|c|c|c|c|}
\hline $\begin{array}{l}\text { Description of the Property,* or } \\
\text { Office, out of which the Rent, } \\
\text { Annuity, Salary, Pension, or } \\
\text { Interest is Payable }\end{array}$ & $\begin{array}{c}\text { Amount of } \\
\text { Rent, Annuity, } \\
\text { Interest, \&c., } \\
\text { from which I } \\
\text { have deducted } \\
\text { the Tax }\end{array}$ & $\begin{array}{l}\text { Amount of } \\
\text { Income Tax } \\
\text { deducted } \\
\text { by me }\end{array}$ & $\begin{array}{c}\text { Period to which } \\
\text { the Rent, } \\
\text { Annuity, Salary, } \\
\text { Pension, or } \\
\text { Interest was } \\
\text { due }\end{array}$ \\
\hline $\begin{array}{l}\text { Chief Rent arising out of property } \\
\text { situate No. } 5 \text { Bury New Koad, } \\
\text { Higher Broughton.. } \quad . . \quad . .\end{array}$ & $\begin{array}{lll}£ & \mathrm{~s} & \mathrm{~d} \\
20 & 0 & 0\end{array}$ & $£ \quad s \quad d$ & $\begin{array}{l}\text { Date } \\
\text { Year ended } \\
\text { 25th Mar. } 1909\end{array}$ \\
\hline
\end{tabular}

*N.B.-In the case of Property, its situation, including Parish, County, and names of Occupiers must be distinctly stated.

This Form is supplied for the purpose of being filled up by the party deducting the Tax from the Income of the Claimant, and when filled up it must be attached to the Form on which the Claim is made for a return of the Tax. 
Certificates of deduction required.

There is not any certificate of deduction required in the case of income derived from dividends on stocks inscribed in the books of the Bank of England, \&c. With respect to dividends and interest payable by public companies, these are usually issued with a counterfoil such as that of the Blankshire Carriage Company. These counterfoils must accompany the claim. In some cases, e.g., The London and North Western Railway Company, the counterfoils are to be sent to the company to be verified before the claim is sent up. If, however, the dividend, \&c., has been paid without any counterfoil being issued, or if the counterfoil has been lost, a certificate must be obtained on the form No. 185 or $185 \mathrm{~A}$, whicherer may be appropriate. Form No. I85A has been filled in to illustrate the manner in which it should be done. The tax on interest on Foreign Government loans, \&c., is deducted by the bankers, and here the certificate No. $189 \mathrm{~A}$ is required. In the case of mortgage interest and chief rent. the Form No. 185 is required. These forms should be filled up to the extent shown, and forwarded to the respective parties for completion. In the case of the house property, the collector's receipt must be attached to the claim.

bividend lescribed as Free of ncome Tax." sxpression hould not be ised

Particular attention is directed to the case of the Blankshire Carriage Company dividend, described as payable "Free of Income Tax." The expression is misleading, and should not be used. As a matter fact, it should be "The company pay the tax on the dividend." The dividend is really the balance of an amount from which tax has been deducted, and thus each shareholder has indirectly suffered 
deduction of tax, and is entitled to hare it repaid to him if his income is within the limit. Suppose tax to be at Is., and a person's total, income to be £. I40, consisting solely of a dividend on $£ 2.800$ at 5 per cent. described as payable "free of income tax." Such a one would be entitled to recover $E_{7}$ 7s. 4 d. ; in other words, $\mathcal{I}_{4} 40$ is the dividend after deduction of $\mathrm{rs}$. in the $£$ (or $\frac{19}{2} \frac{\mathrm{t}}{\mathrm{t}}$ ths of $i$ ), and that the

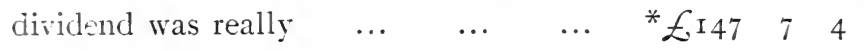

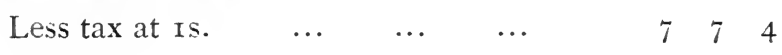

EI40 O

The actual amount of the dividend is easily obtained by a Formula. simple proportion sum, thus-

$£$ I less the current rate of $\operatorname{tax}: \mathcal{I}_{\mathrm{I}}:$ : the actual amount of dividend received: the amount of such dividend before deduction of tax;

or, taking the example given above--

I9s: 20s. : $£$ I 40 : the sum required.

That is, $\frac{1}{2} \%$ ths of the gross dividend is $\mathcal{E I}_{4} \mathrm{O}$, and the gross dividend is $\frac{£ 140 \times 20}{19}$

$$
\text { or } £ \text { i } 47 \text { 7s. } 4 \text { d. }
$$

IIith $\operatorname{tax}$ at Is. the following is an easier mode of calculation :-

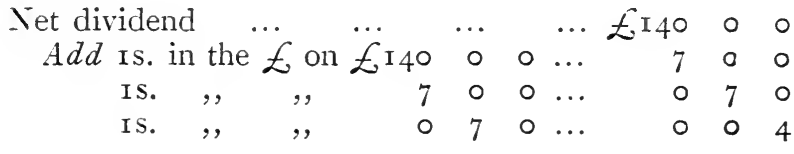

$$
\text { Gross dividend ... } \overline{£ \mathrm{I} 47 \quad \overline{7}}
$$

*In the case of Attorney-General v. The Asinton Gas Co. it has been held by the House of Lords (2ist November 1905) that where the dividend of a gas company was by their Act limited to ro per cent., they were not entitled to pay such dividend without deduction of income tax. 
Claims in case where dividends are so declared and paid.

The importance of this is more apparent when we come to the case of a person whose income has nearly approached $£ 400$ or $£ 500$, \&c., and it consists partly of a dividend declared " free of income tax," e.g., say

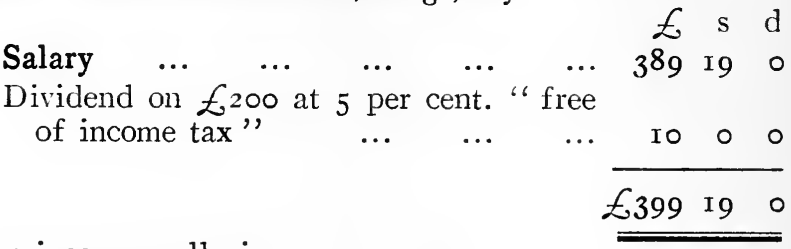

The income really is-

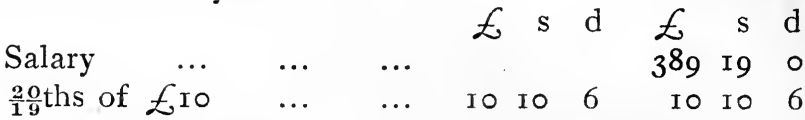

$$
\begin{aligned}
& \text { Less Tax at is. } \quad \ldots \quad \text { o } 10 \quad 6 \\
& \text { ro } 00
\end{aligned}
$$

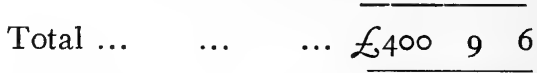

$\mathrm{He}$ is thus not entitled to an abatement of $\mathcal{E}^{\mathrm{x} 60}$, but only of $£^{1} 5^{\circ}$. It may readily be seen that where his income under similar circumstances appears to be not quite $£ 700$ he may not be entitled to any abatement-the actual income exceeding $£ 700$.

The payment of a dividend "free of income tax" differs slightly from that of interest. In the former case, as the shareholder is entitled to all the profit he clearly bears the tax and is entitled to recover. In the latter case, the borrower either :-

(I) Makes a present to the lender of the amount of the $\operatorname{tax}$; or

(2) Pays such a rate of interest as yields 5 per cent. (or as the case may be) after deduction thereof. 
The practice, until recently, was that where the interest was paid in accordance with the terms of an agreement or of a public announcement (as is the case with interest on loans to cotton mills, \&c., in Lancashire) it was regarded as increased interest and tax was repaid; but in other cases repayment was refused.

The authorities have recently taken a different view, and are now rejecting all such claims. The legality of this new position is in dispute.

In the case of a person who is entitled to claim exemption and whose income, or any part thereof, is derived from dividends of stocks inscribed in the books of the Bank of England, it is possible to have the dividends remitted in full without deduction of tax. The proper course to pursue is to make a claim at the end of any year for repayment of tax deducted, and to forward with the claim a request to have the dividends remitted in full in the future, when the dividends will, as a rule, be remitted in full as desired.

The two following claims would be appropriate in the case of a person who had paid tax on his salary without being Forms where abatement had not been aware of his being entitled to have the assessment made on an average of past years, or from any other cause.

The first case is one where the amount has been arrived at properly, but there has not been any claim made for the abatement. The second is a case of the proper amount not having been ascertained at all, e.g., where, having neglected to make a return, he has been assessed by the Surveyor, and paid without claiming the abatement or appealing against the assessment. 


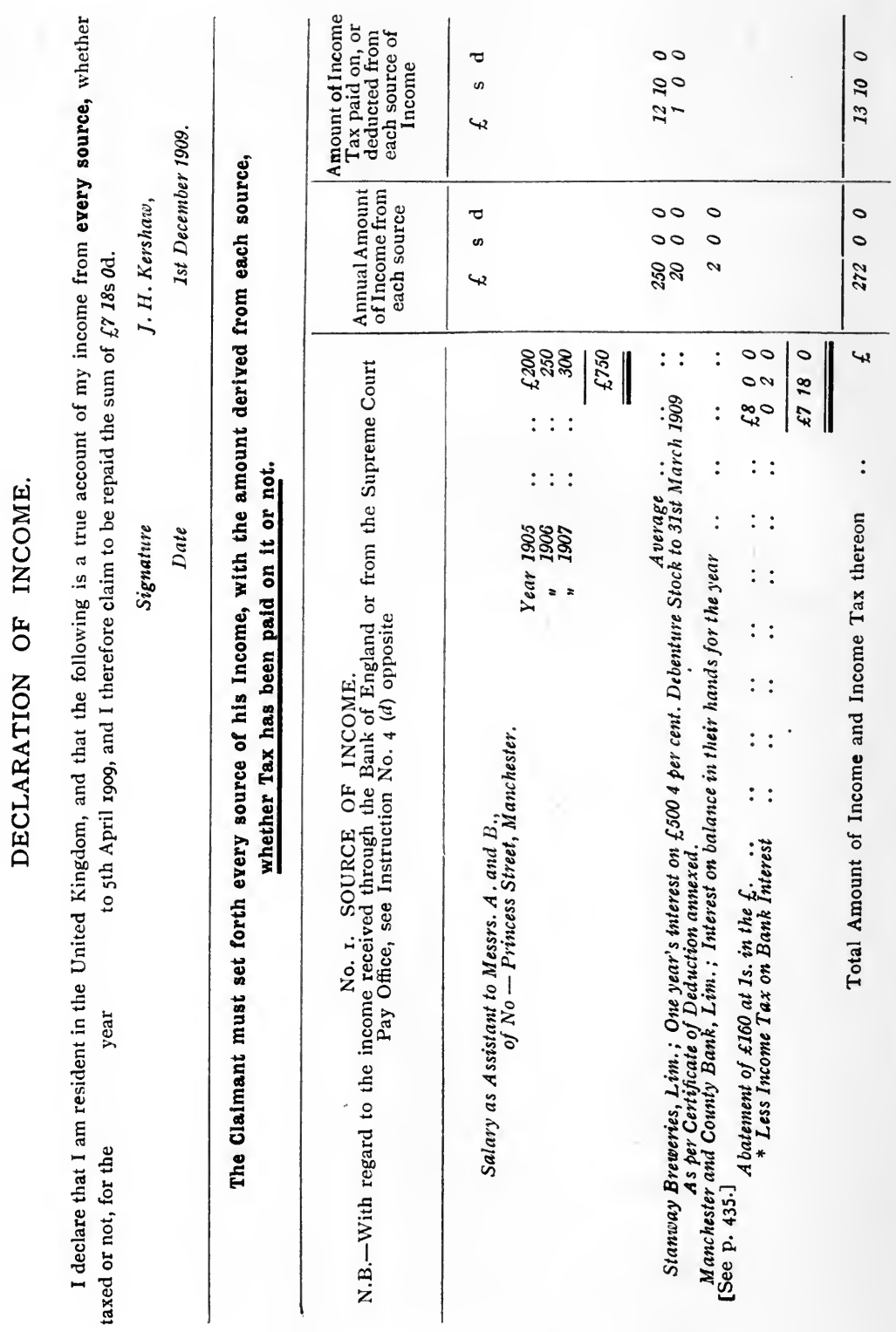




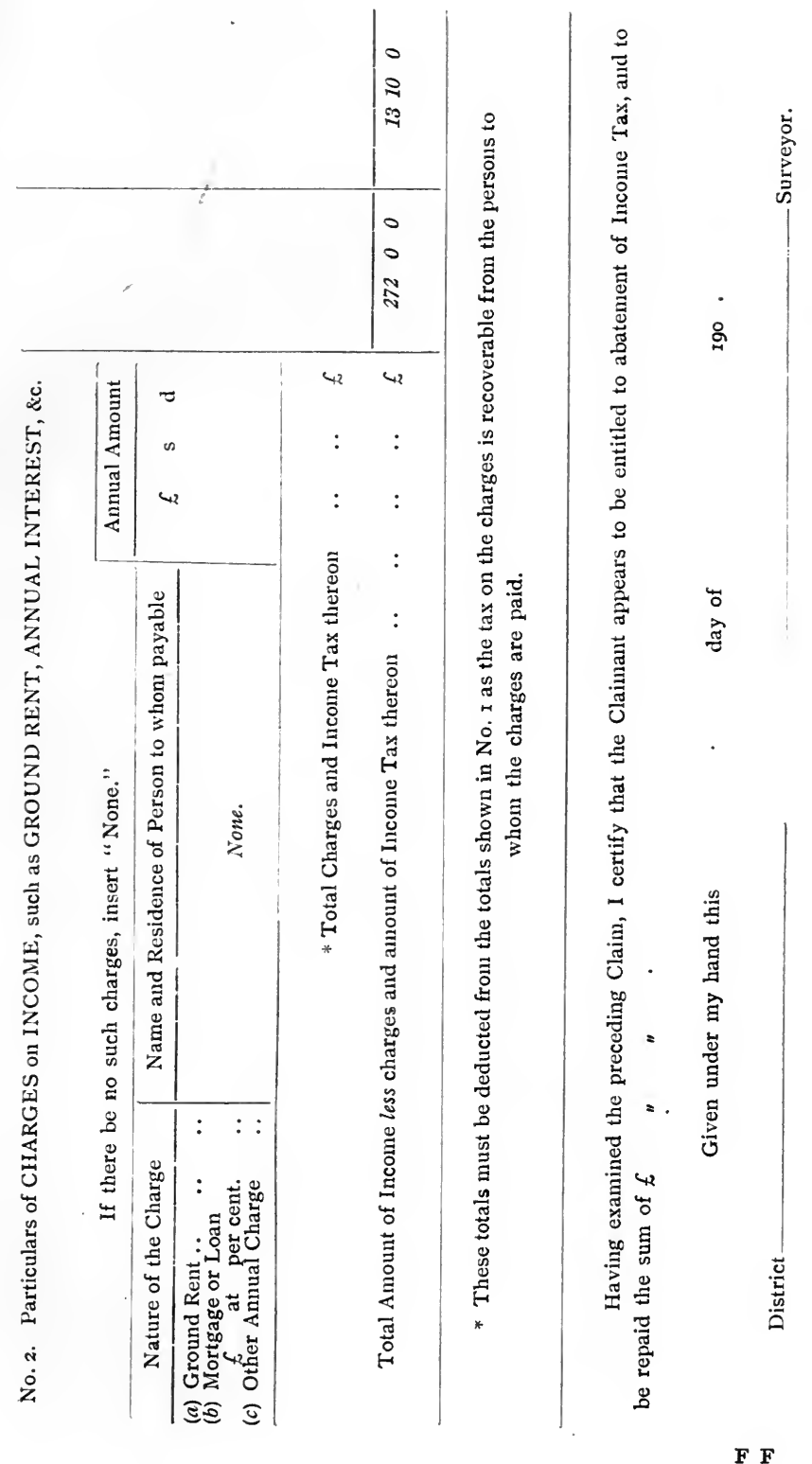




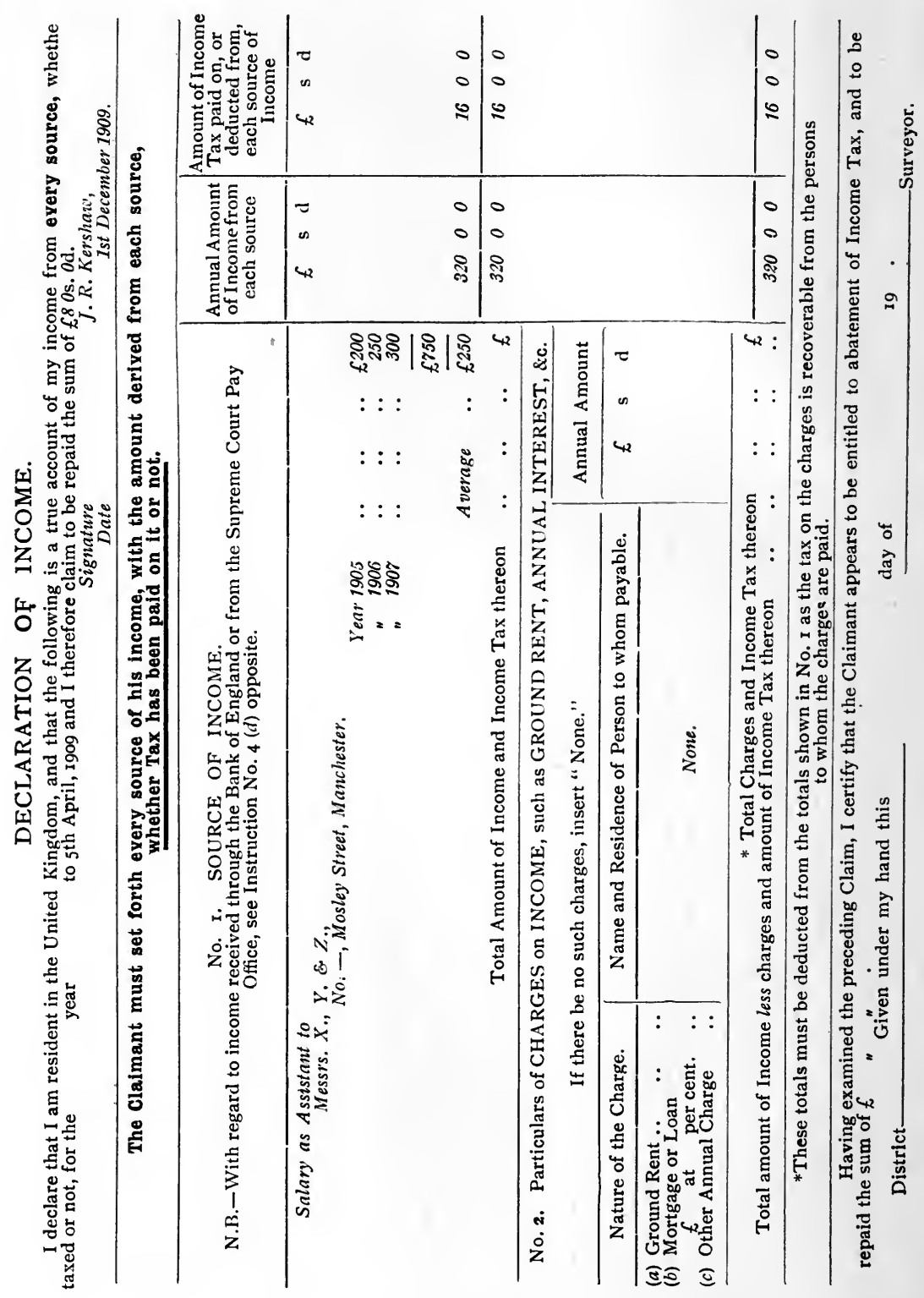


STANWAY BREWERIES, LIMITED.

No...... Stanway Brewery (Established r600), Stanway, 3ist March rgog.

Interest on 4 Per cent. Debenture Stock.

Annexed is a warrant for the Interest on the Debenture Stock standing in your name as per statement below.

I hereby certify that the income tax on the amount of this Warrant will be paid by the Company. Proprietors claiming exemption from Income Tax are informed that the Inland Revenue Department will receive this statement as a voucher.

T. Leverson,

Secretary.

Debenture Stock.

Half-year's Interest to 3 I Mar. 1909 on $£ 500$ $£ \quad \mathrm{~s} \quad \mathrm{~d}$

Less Income $\mathrm{Tax}$ at is. in the $\mathcal{E}$ Iо 0 o $\begin{array}{ccc}0 & 10 & 0 \\ £ 9 & 10 & 0\end{array}$

J. H. Kershaw, Esq.

This Statement to be retained by the Proprietor. 
Oyerpayment of Tax.

It may be noticed in this second case that when he has obtained repayment of the $£ 8$ os. od. the claimant will have paid $£^{8}$ os. od. for tax on a total income of $£ 25^{\circ}$. He ought really to have paid only $£_{3} 7$ s. 6 d., being 9 d. in the $£$ on $£_{90}\left(£^{250}\right.$, less $£_{160}$ ). The difference arises by reason of his having neglected to appeal and having paid on $£ 320$ in the first place, instead of $£^{2} 5^{\circ}$.

In both these cases it must be assumed the person has omitted to claim the relief to "earned" incomes (see post), and consequently he has to pay at Is. in the $£$. $\mathrm{Had}$ he claimed such relief he would ipso facto have had the abatement before paying.

Case of trust estate.

Claims by different persons.
We will now deal with the one case, above all others, in which tax is paid in full by persons who are really entitled to exemption or abatement.

Suppose a testator dies leaving property bringing in an income of $E_{\mathrm{r}, 000}$ per annum, and which he directs to be applied as follows : Annuities of $£ 35^{\circ}$ and $£ 50$ to his widow and brother respectively, and the balance-five-twelfths to each of his two daughters, and two-twelfths to his niece. The whole of the income would be taxed at its source, say :- 


\section{(20)}

$+$

(

London and North Western

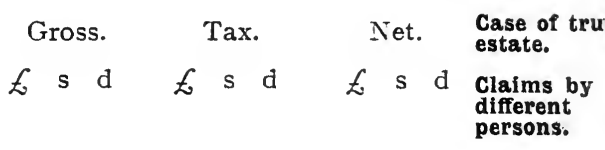

Railway Company, interest

on $£$ I2,500 4 per cent.

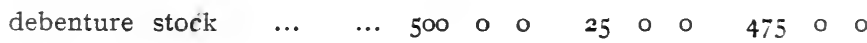

(Tax would be deducted by

the Company on payment.)

Lancashire and Yorkshire

Railway Company, interest

on $f_{5}, 0004$ per cent. deben-

ture stock $\quad \ldots \quad \ldots \quad \ldots$

2000001000000

(Tax would be deducted by

the Company on payment.)

Turkish Government, interest

on firo,ooo converted stock

at I per cent. ... ...

$\begin{array}{llllllllll}100 & 0 & 0 & 5 & 0 & 0 & 95 & 0 & 0\end{array}$

(Tax would be deducted by

the Bank on collection of

coupons.)

Freehold property, situate

$\begin{array}{llllllllllllll}\text { at } \mathrm{D} & \ldots & \ldots & \ldots & \ldots & 250 & 0 & 0 & 12 & 10 & 0 & 237 & 10 & 0\end{array}$

(Tax would be paid by the

Executors under Schedule A.)

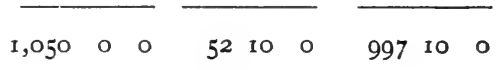

Less interest on mortgage,

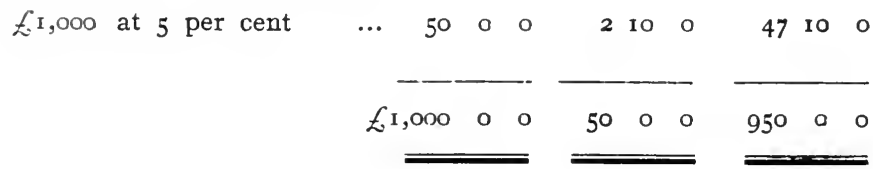


Case of trust estate.

Claims by different persons.

The income would be distributed as follows :-

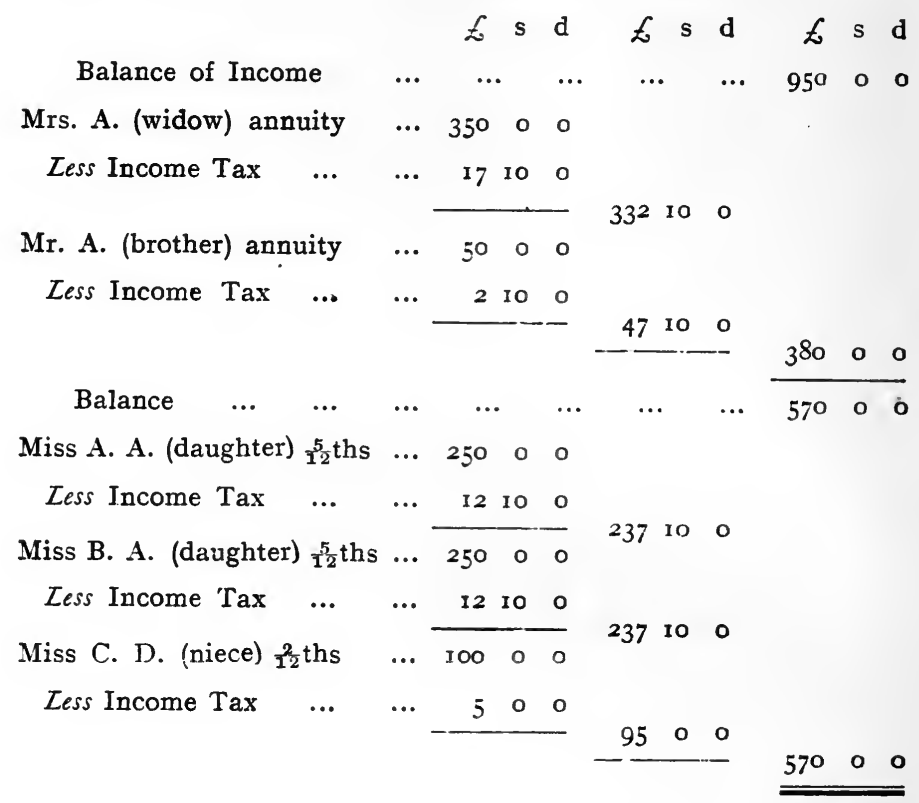

Mrs. A., Miss A. A., and Miss B. A. are all entitled to abatement of $£ \mathrm{I} 60$, as they have no other income, and they can recover tax thereon for three years back.

Mr. A. and Miss C. D. are entitled to exemption, as they have no other income, and they can likewise recover the tax on their annuity and share of income respectively.

Mrs. A.'s claim would be as follows (and Mr. A.'s would be precisely the same, except that the Exemption Form (No. 40) would have to be used instead of the Abatement Form No. 40 A) :- 
PART I.

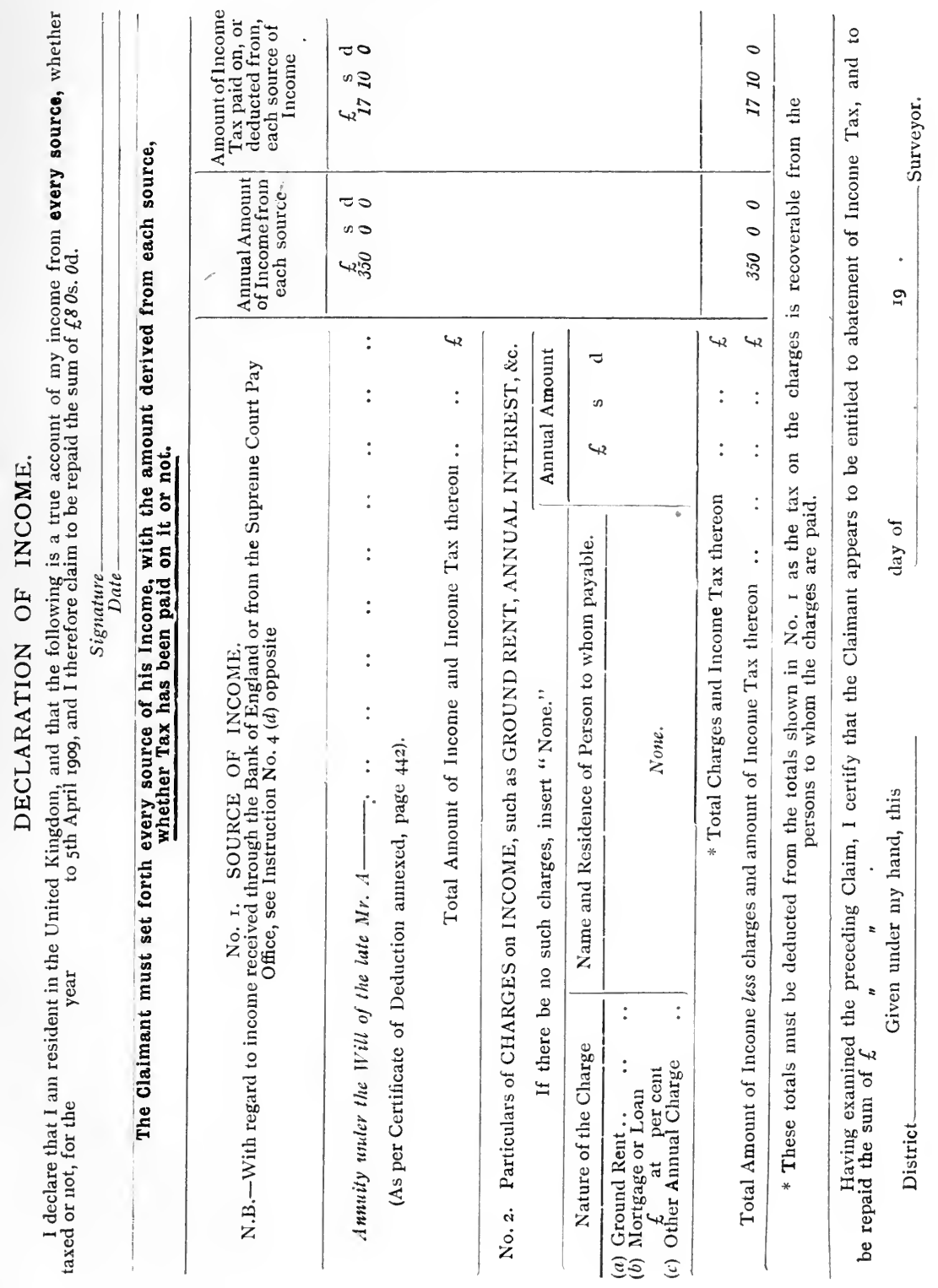


The claims of Miss A. A. and Miss B. A. would be (Miss C. D.'s being the same except for using Form 40 instead of Form 40A) :- 


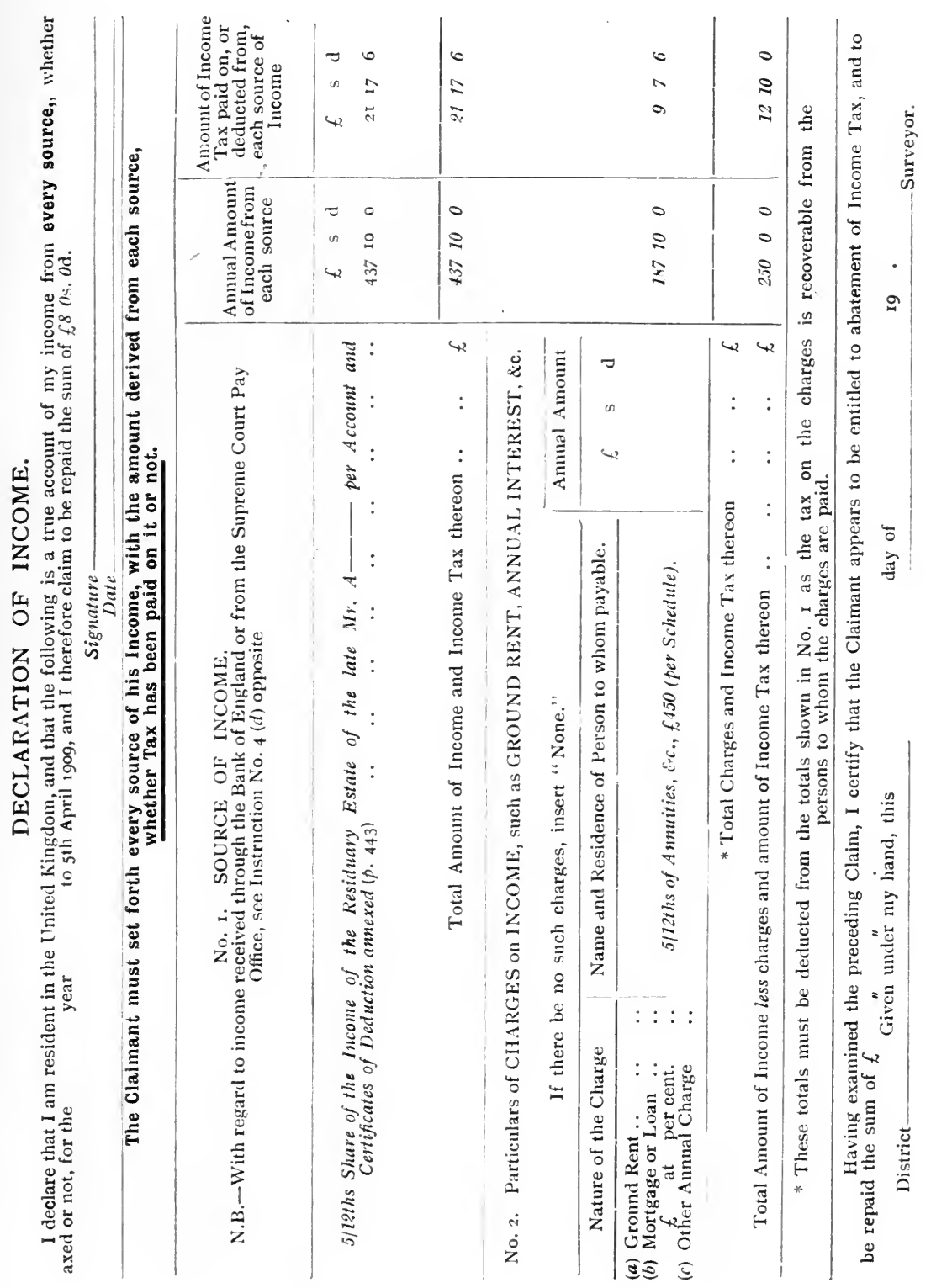


No. 185 .

INCOME TAX.

I HEREBY CERTIFY, that on paying to Mrs. A.

of. the Sum mentioned in the second Column of the subjoined Statement, I deducted for Income Tax the amount set forth in the third Column of the said Statement, and I further certify that the amount of the Tax so deducted has been paid by me to the proper Officer for the receipt of Taxes.

Signature

Trustee under the will of the late $\mathrm{Mr} . \mathrm{A}$.

Residence

Date 190

\begin{tabular}{|c|c|c|c|}
\hline $\begin{array}{l}\text { Description of the Property,* or } \\
\text { Office, out of which the Rent, } \\
\text { Annuity, Salary, Pension, or } \\
\text { Interest is payable }\end{array}$ & $\begin{array}{c}\text { Amount of } \\
\text { Rent, Annuity, } \\
\text { Interest, \&c. } \\
\text { from which I } \\
\text { have deducted } \\
\text { the Tax }\end{array}$ & $\begin{array}{l}\text { Amount of } \\
\text { Income Tax } \\
\text { deducted by } \\
\text { me }\end{array}$ & $\begin{array}{c}\text { Period to which } \\
\text { the Rent, } \\
\text { Annutty, Salary, } \\
\text { Pension, or } \\
\text { Interest was } \\
\text { due }\end{array}$ \\
\hline $\begin{array}{c}\text { Income of the Residuary Estate of } \\
\text { the late Mr. A. } \quad \cdots \\
\end{array}$ & $\begin{array}{ccc}£ & \mathrm{~s} & \mathrm{~d} \\
350 & 0 & 0\end{array}$ & $\begin{array}{lrr}£ & \mathrm{~s} & \mathrm{~d} \\
17 & 10 & 0\end{array}$ & Date \\
\hline
\end{tabular}

${ }^{*}$ N.B.-In the case of Property, its situation, including Parish, County, and Names of Occupier, must be distinctly stated.

This Form is supplied for the purpose of being filled up by the party deducting the Tax from the Income of the Claimant, and when filled up it must be attached to the Form on which the Claim is made or a return of the Tax. 
Estate of the late Mr. A.

An Account of the Income of the Residuary Estate for the Year ended 3ist December I 908.

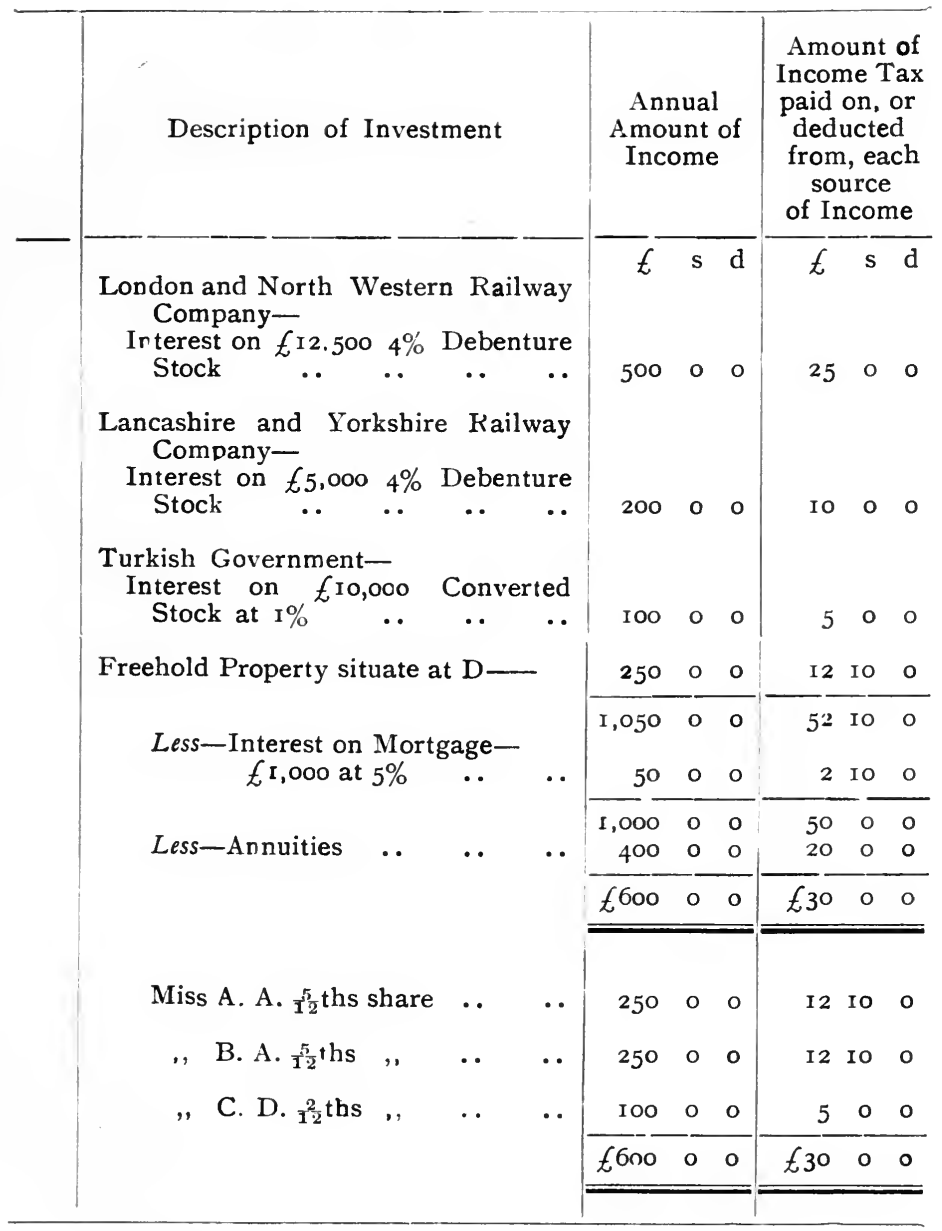


Case of trust estate.

Counterfoils would have been despatched by the railway companies with the dividends. The certificates as to the Turkish Government interest should be filled up and signed by the Bank (Form No. I89A). The collector's receipt for Income Tax Schedule A should also accompany the claim. There would, of course, be only one set of certificates. These should be attached to one claim, and the other claims could read, "As per certificates of deduction attached to the claim of Miss A. A., dated _-. If the parties lived in different districts it would be necessary to give such particulars as would enable the claim to which the certificates, \&c., had been attached to be traced.

If the claims were all being made at the same time, however, all the forms should be sent to the Surveyor in the district where the original claim is made, accompanied by a request that he will send the other claims forward to the proper quarter. It is very desirable to adopt this mode of making claims where possible, as it is great saving of labour to all parties concerned.

Sometimes

may haye

assessment adjusted

Suppose that in this case the income, instead of accruing from investments, is derived from a business left by the testator, the claims could be made in a similar manner on the same forms. In such a case, however, the form of return, when sent to the Surveyor, should be accompanied by claims 
on Form No. $3^{8}$ (see Chapter X.), and the assessment would be made on ...

$£ \mathrm{r}, \infty \circ \circ$

Less Allowances in respect of Mr. A. and Miss C. D. (two exemptions) $\cdots \quad £ 15^{\circ}$

Allowances in respect of $\mathrm{Mr}$. A., Miss A. A., and Miss B. A., (three abatements at $£$ I60) $\quad \ldots \quad 480$

$$
\text { Net assessment } \ldots . \frac{630}{£ 370}
$$

Tax on which would be borne as follows :-

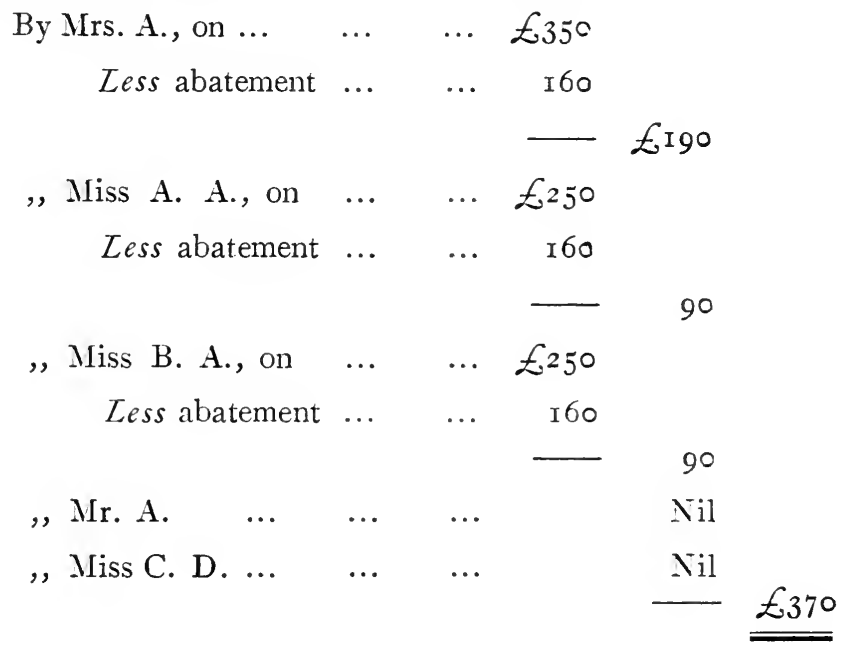

This obviates the necessity of paying the tax and then applying for repayment.

As to the position where the income is wholly or in part derived from an annuity purchased from an insurance company, see ante p. 208. 
An interesting case in income tax practice is mentioned in The Accountant, igth August 1893. A business was owned by two partners, who shared profits equally and were assessed separately for the purpose of claiming abatement. By the articles, on the death of either partner, the survivor was to retain the business, but had to pay the executors of his deceased partner, for three years, an annuity equivalent to what his share would have been had he survived. As there is not any deduction allowed " on account of any annuity or annual payment out of profits " ( $18_{42}$, sec. Ioo, Schedule D, first case, $4^{\text {th }}$ rule), it appeared as though the surviving partner would be obliged to return his income at the total profit (say $£^{6} 5^{\circ}$ ), and deduct the tax upon $£ 325$ when paying it to the executors. It was, however, represented to the Surveyor that this would cause needless complications, as both parties were entitled to abatement. The Surveyor, upon hearing the facts, granted separate assessments to the executors and the surviving partner.

It might well be contended that such payments are capital invested by the surviving partner in the purchase of the goodwill, and, that being so, under like circumstances a person would usually be held liable for tax on the whole profits without any abatement. A liberal view was taken in the case in question.

The same forms (Nos. 40 or $40 \mathrm{~A}$ ) are appropriate in the case of a partnership where the partners, being entitled to exemption or abatement, have omitted to claim it, and have paid tax on the whole of their profits. 
To revert to the question of husband and wife, the following is an illustration of the effect of the Act of 1897 Husband and wife.

p. 410$):-$

Act of 1897.

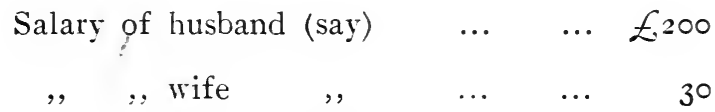

Ińcome from wife's investments $\quad \ldots \quad 20$

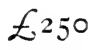

Prior to the Acts of 1894 and 1897 the husband would have

- been liable for tax on the whole $\mathcal{E}_{25} 5^{\circ}$ (1842, sec. 45), less abatement. Tax would have been paid on the $\mathcal{2}_{2}$ o by way of deduction, and it would have been necessary for him to make a return of $\mathcal{E}^{2} 3^{\circ}$ and to pay upon it, less abatement. Now. however, there will be two distinct claims.

The husband's income is deemed to be $£^{200}+\mathcal{E}^{20}=$ Effect of Act. $£^{220}$, and he is entitled to abatement, and the wife's income is $£ 3^{\circ}$, and she is entitled to exemption.

A construction of the Act once suggested by a Surveyor was that where the husband is employed as director and secrewife employed in same tary and the wife as bookkeeper to the same company, the husband's employment was not " unconnected with the business of the wife," and they could not be assessed separately. This is very strained, and, we submit, would not have been supported by the Commissioners. 
It should be observed that the section only applies where the total joint income does not exceed $£ 500$, and where each carries on a business, \&c. The Act of 1898 does not extend the principle to incomes between $£ 500$ and $£ 700$.

Forms are issued to meet all necessary cases.

In the case of an infant the claim is to be made by the infant's trustee, but in the case of the infant's interest being only a contingent one, repayment will only be allowed of tax on so much income as has been expended in education and maintenance. Where, however, the interest is absolute, the claim should be in respect of the whole of the income, irrespective of whether it is applied for education and maintenance or not.

Up to I9I I the official rule as to contingent interests was as follows :--

"Where income is allowed to accumulate during the period of minority, in the case of a minor who has merely a contingent interest in the property, exemption or abatement is not to be allowed; but, in such a case, the minor, on coming into possession, may claim repayment of the duty extending over the whole period of minority, provided he or she were entitled to exemption or abatemient for such time."

In cases where a portion of the income had been applied for maintenance, and a claim had been made in respect of that portion of the income, a claim could be made, when the minor came into possession, in respect of the balance. 
The reason of the rule is, of course, because, in the case of a contingent, interest, if the infant dies before attaining majority, the unexpended income becomes income of some other person-possibly not entitled to abatement. If the interest is rested, the claim must be made within the three years, as the Department (naturally) will not entertain a claim fór any further period.

At the early part of the present year (I9II) the Board commenced to repudiate such claims, intimating that such accumulations reached beneficiaries as capital ; further, claims in respect of sums expended in maintenance were disallowed except for three years. They set up this suggestion on the ground that the matter had had very careful consideration in connection with the super-tax, and that in cases where minors had only a contingent interest and the income was accumulated until attainment of majority, such income could not be regarded as income--and intimated that "the concession" could not be continued. The difference between the two cases was pointed out, and eventually the Board gave way, in view of a statement that the claims had been deferred " in reliance upon the previous practice."

Replying to a representation from the Income Tax Reform League, the Chancellor of the Exchequer wrote as follows :- 


\section{Treasury Chambers,}

WhitehaLL, S.W., 28th April 1911.

DEAR SIR,

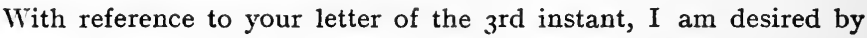
the Chancellor of the Exchequer to inform you that the Board of Inland Revenue are advised that where in the case of a contingent gift a minor is not absolutely entitled to the whole income thereof, but to maintenance only, only the amount of income expended on his maintenance and education should be treated as his income for the purpose of a claim to exemption or abatement. The surplus income which became accumulated and capitalised during the minority was not the income of the minor in the past years, and is ultimately received as capital. The Board have felt it necessary to alter their previous practice to conform with this opinion, and to refuse to admit claims in respect of the accumulations of surplus income that may be received by the minor on attaining his majority.

The claims must in future be made within the usual period of three years. Where, however, a complete claim in respect of the whole income could not under the old practice have been made within the three years' time limit, and the allowance of a partial claim in respect of the sums spent on education and maintenance has been postponed under that practice until the attainment of majority, the deferred claim in respect of such sums will be admitted for the whole time.

Yours faithfully,

(Signed) John Rowland.

G. O. Parsons, Esq.,

Secretary, Income Tax Reform League.

Sec. 134 of the Act of 1842 .
If a person claiming under the $134^{\text {th }}$ section of the Act of 1842 (see p. 372 et seq.) proves his total income not to exceed Ei6o or $\mathcal{E}_{400,}$ \&c., as the case may be, he is entitled to exemption or abatement ( 1853 , sec. 30 ). See also subsec. (2) of sec. 23 of the Act of 1890 (p. 375). 
Any claim for repayment on the ground of exemption, \&c.,

must be made within three years of the end of the year to which the claim relates (Act of 1860, 23 \& 24 Vict., cap. 14, sec. I0); that for relief to "earned" incomes must be made by the 3 oth September in the year of assessment.

Another point which is rery frequently overlooked is that a person whose income is derived from land and houses (taxed under Schedule A), or partly from land and houses and partly from other sources, is entitled to the same exemption or abatement, as the case may be. Possibly one reason why this is overlooked arises from the fact that income tax, Schedule A, is frequently called "property tax," and it is not realised that it is, in fact, "income tax" just as much as the tax payable under Schedule D.

In such cases, if the person entitled to the rents, \&c., being entitled to exemption, fills up Form No. $3^{8}$ (which may be had from any Surveyor or Assessor) and sends it to the Surveyor, there will not usually be any difficulty in getting the assessment on the property discharged, and thus saving the trouble of paying tax and then recovering it.

As the result of correspondence, it was decided in 1890 by Wesleyan ministers. the Board of Inland Revenue that Wesleyan ministers should not be required to enter the annual value of the furnished houses, provided for them free of expense, in their returns of income for the purpose of assessment to income tax. In many cases this will mean total exemption. (As to the assessment of the houses to Schedule A, see ante p. $3^{8}$.) 
Tennant $v$. Smith.

Exemption claim by executors.

Apportionment.

\section{Married} women.

Apportionment up to date of marriage.

Bowers $v$. Harding.

Schoolmaster may not deduct wages of servant.
Langston $v$. Glasson.

Salary of bursar liabie to direct assessment.
This is in accordance with the subsequent decision of the House of Lords in the case of Tennant v. Smith (p. 453).

Where a person having (say) £r,200 per annum dies (say)

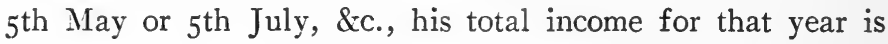
$£ 100$ or $£ 300$ (the amount received for the portion of the year), and he is entitled to exemption or abatement respectively, and his representative may recover accordingly.

Similarly, where a lady having a like income marries, she might make a claim for herself apportioned up to the date of her marriage, and the remainder of her income would fall in with her husband's.

In Bowers (Surveyor of Taxes) v. Harding, decided by the Queen's Bench Division, 5th February r89r, a national schoolmaster and his wife claimed exemption on the ground that, though their joint income was £ 68 per annum, they should be entitled to deduct $£ 30$ for the board and wages of a servant, as a necessary expense to enable them to perform their duties. It was held that the salary was derived from a public employment, and was taxable under Schedule E, and that the expense of keeping a servant was not incurred "wholly, exclusively, and necessarily" in the performance of their duties (1853, sec. $5 \mathrm{I}$ ).

In Langston (Surveyor of Taxes) v. Glasson, Mr. Glasson appealed against an assessment of $£ 45^{\circ}$, the amount of his stipend as principal bursar of St. John's College, made upon him under Schedule E. By sec. 40 of the Act of 1842 all 
bodies collegiate are liable to be assessed in respect of their corporate property. By sec. 54 their officer is to deliver an account of the profits before any dividend shall have been Langston $v$. Glasson.

Salary of bursar liable to direct made to any person having any share in such profits, but it is not necessary to include the salary of any officer otherwise chargeable under the Act. No. 260 of the "General Instructions to Surveyors of Taxes, I 886,' issued by the Board of Inland Revenue, states that members of a collegiate body are not liable to direct assessment in respect of sums which they are, as members, legally entitled to receive out of the taxed income of the corporation, but salaries paid to persons, not members, are chargeable by direct assessment unless they are, by statute or otherwise, a charge on the revenue of the corporation. Mr. Glasson claimed that, though not actually a member, his salary was, "by statute," a charge on the revenue of the corporation, and was, therefore, exempt from direct taxation. The Surveyor contended that the office of bursar in this case, not being held by a Fellow or any person on the foundation of the college, was an "office" held under a society corporate, and fell under Rule 3 of Schedule E. The Queen's Bench Division held (6th February r89 1 ) that the salary was, by sec. 54, liable to direct assessment under Schedule E.

A most important judgment was delivered by the House of Lords on the I4th March 1892 in the case of Tennant $v$. Smith. The appellant was a bank agent, and was bound, as part of his duty, to occlipy the bank-house. He was liable

Tennant $v$.
Smith.

In order to be taxable a benefit must be capable of being turned into money. 
Tennant $v$. Smith.

In order to be taxable a benefit must be capable of being turned into money.

to removal at any time, but was not entitled to vacate the house without leave of the directors, or to sub-let any part of the premises, and in case he desired to occupy other premises there was not any addition to be made to his income in respect of any house-rent which he might have to pay. His income, exclusive of any estimate of the value of the part of the bank occupied as residence, was under $£ 400$; but, if the annual value of the house was added, it was more than that sum. It was held that the appellant was entitled to the abatement (then in force) of $£ \mathrm{r} 20$, and that the value of the house was not to be taken into account.

The Lord Chancellor said :

"This is an Income Tax Act, and what is intended to be taxed is income. . . I am of opinion, in the words of Lord Young, that the thing sought to be taxed is not income unless it can be turned into money."

The view was further expressed that nothing was to be brought into account except what was chargeable for assessment.

M'Dougall $v$. Sutherland, following Tennant $v$. Smith.
The decision was followed in M'Dougall (Surveyor of Taxes) v. Sutherland (Court of Session, Scotland, 6th, 7th, and 2oth March 1894), where the facts were very similar, the house in this case being the Free Church Manse of Rothesay, which is rested in trustees for behoof of the Free Church congregation of Rothesay. 
The case of Curke v. Fry (Court of Session, Scotland. 9th Narch 1895) was distinguished from the above on the ground that, in this case, the appellant, the Rev. S. C. Fry, a minister of the Established Church of Scotland, could have let his manse, whereas the occupants in the other cases had not any such power. Accordingly, it was held that the value of the manse must be taken into account in computing the amount of his income for the purpose of ascertaining whether he was entitled to abatement.

If the salary of an official is $£ 700$, and the company pay the tax upon it, the person is not entitled to an abatement. Tax on salary of employee paid by If the extra benefit is capable of being turned into money, it is clear that under the decision in Tennant $v$. Smith (p. 453) it must be added. Though the tax is paid by the company, the assessment is upon the individual, and he receives a monetary benefit, just as if the company paid any other private account for him.

A very interesting point in this connection arose in $R e$ James Walker (Court of Session, Scotland, I ith January I go6).

\section{company.}


The Court reversed the determination of the Commissioners, on grounds explained by Lord Stormonth-Darling, who gave the opinion of the Court, and found the appellant entitled to expenses.

Lord Stormonth-Darling said that the case arose on a claim by the appellant for abatement of income tax which the Commissioners had refused to allow. The ciaim was made on the ground that the appellant's total income from all sources for the year of assessment, though exceeding $£ \mathrm{i} 60$, did not exceed $\mathcal{E} 600$, and he was therefore entitled to relief equal to the income tax upon $\mathcal{E}^{\mathrm{r}} 2 \mathrm{o}$. His precise income he stated at $\mathcal{E 5}^{61}$, made up of $\mathcal{E}^{3} \mathrm{r}$ of salary (the immediate subject of assessment) and $\mathcal{E}^{245}$ which had already borne tax. It was conceded by the Crown that that sum of $£ 5^{6} \mathrm{I}$ was all the income of which he had the actual enjoyment, but they contended that his income from all sources amounted to $£_{2,000}$ a year, if account were taken, not only of io per cent. of the profits of the business of R. \& J. Dick paid to him in cash, but of the balance of those profits credited to his account in the books of R. \& J. Dick in accordance with a certain deed of arrangement granted by the late Mr. James Dick on $4^{\text {th }}$ March 1902. The question for decision was whether that balance of profits was part of the appellant's income for the year of assessment, and that depended on the just construction of the deed of arrangement. The late Mr. Dick, who was the grantor of it, was the sole proprietor of a large and lucrative business in Glasgow as a boot, shoe, and 
belt manufacturer, and he seemed to have conceived the idea that the best means of achiering the double purpose of getting payment of his large capital out of the business after Re James Walker. his death, and the same time benefiting the heads of the various departments of his business, was to give them a prospective interest in the profits, and power ultimately to acquire the business itself. Accordingly by the first article of the deed he named fifteen emplorees (of whom the appellant was one), and he allocated to each of them a number of shares, varying in number from ten to two, and making in all one hundred shares, with a declaration that the provisions of the deed in their farour should not become rested interests until the whole of his capital and interest had been paid out, and that it should not be competent for them on any ground whatever to dispose of their interest in the profits or in the business itself. Ten per cent. of the profits of the business were to be paid orer to these employees in cash, and the remaining profits were to be credited to their respective accounts in the books of R. \& J. Dick until the whole of Mr. Dick's capital and interest was paid out. As if to emphasise that the interest of the employees in their profits was to be contingent on Mr. Dick's own capital being paid out, there was a declaration that the "said remaining profits allotted to the employees " as aforesaid shall be accumulated without adding interest, " and form a fund arailable for the paring out of my capital "from the business." Although the employees were to carry on the business Mr. Dick's trustees were placed in a position of absolute control, until the whole of Mr. Dick's capital and 
interest had been fully paid to them. At the date of $\mathrm{Mr}$. Dick's death, on 7 th March 1902 , his capital in the business amounted to $£ 35 x, 550$. At the same time the firm of $R$.

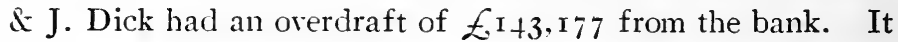
was arranged between the trustees and the employees that the overdraft should be liquidated by the employees before they began to pay out Mr. Dick's capital, and by 3 Ist December I903 so prosperous had the business been that the overdraft had been reduced by $£ .93,209$; accordingly at 3 ist December r 903 the debt to the bank stood at $£ \cdot 49,968$; the debt to Mr. Dick's trustees stood at its original figure of $£ 35^{1}, 55^{\circ}$; and the accumulated 90 per cent. of the profits of the business credited to the employees in the books of the firm amounted to $E_{72,076}$ I 7 s. Id. The assessable profits of the business for the year ending $5^{\text {th }}$ April 1905 were $£ .43,44$ I, for which an assessment had been made on R. \& J. Dick, and paid. What was the effect of the deed of arrangment on the legal position of these employees until the time arrived for $\mathrm{Mr}$. Dick's trustees making a conveyance of the business in their farour? Were they still only employees with a right to salary and immediate payment of a small percentage on profits, together with a prospective and contingent interest in the business itself? Or were they a purchasing partnership, with immediate entry to the business, but with a postponement of the obligation to pay the price, and only such limitations on their right of property as were necessary to give the seller security for the price? His Lordship had no hesitation in adopting the first of these alternatives and rejecting the 
second. The entire deed seemed to him redolent of the granter's desire to keep the business under the control of his trustees until the whole of his capital and interest had been Re James Profits not paid to person participating. paid out. Till then the employees were not to touch a shilling of the profits except the small percentage, which was much more appropriate to active management by a servant than to the position of a principal. In short, the business was to be in law and in fact the property of the trustees until the conditions were fulfilled for their conveying it to the employees. If so, it was impossible to predicate of the appellant that his share of the 90 per cent. of profits was a part of his income for the year of assessment. It was no doubt carried to his credit as a book entry, but it was primarily to form a fund available for the paying out of Mr. Dick's capital, and it might never be the property of the appellant at all. The King had had his tax upon it in the hands of R. \& J. Dick, and when the Crown demanded that the appellant's presumptive share of their profits should be reckoned as part of his individual income, the Crown must show that the share was not presumptively or contingently, but actually and indefeasibly his. In that the Crown had failed.

The other Judges concurred.

By sec. $7 \mathrm{x}$ of the igro Act there is not to be any abatement to a person not resident in the United Kingdom after the year 1908-9, except to :-

Act of 1910, sec. 71 .

Person abroad.

A person who is, or has been, in the service of the Crown, d.c.; or, who is employed in the service of a Missionary 
Act of 1910, sec. 71.

Person abroad.

Society abroad; or, who is resident in the Isle of Man or Channel Islands; or, who is resident abroad for the sake of his health.

But in such case all his income must be taken into account whether taxable here or not.

Also, non-residents are not to be charged with tax on interest of any security of a foreign State, or British possession payable in the United Kingdom.

Relief is to be claimed within six months of the end of the year.

The section is as follows :-

(I) No exemption, abatement, or relief under the Income Tax Acts which depends wholly or partially on the total income of an individual from all sources shall be given to any person, unless the person claiming the exemption, abatement, or relief is resident in the United Kingdom:

Provided that any person who is or has been employed in the service of the Crown or who is employed in the service of any missionary society abroad or in the service of any of the native States under the protectorate of the British Crown, and any person resident in the Isle of Man or Channel Islands and any person resident abroad who satisfies the Commissioners that he is so resident for the sake of health, shall be entitled to any relief, exemption, or abatement to which he would be entitled if he were resident in the United Kingdorn, and if his total income from all sources were calculated as including any income in respect of which income tax may not be chargeable as well as income in respect of which income tax is chargeable.

(2) Income tax shall not be payable in respect of the interest or dividends of any securities of a foreign State or a British possession which are payable in the United Kingdom, where it is proved to the satisfaction of the Commissioners that the person owning the securities and entitled to 
the interest or dividends is not resident in the United Kingdom; but, save as provided by this or any other Act, no allowance shall be given or repayment made in respect of the Act of 1910, sec. 71. income tax on the interest or dividends on the securities of any foreign State or any British possession which are payable in the United Kingdom.

Relief from income tax under this subsection may be given by the Commissioners either by way of allowance or repayment on a claim being made to them for the purpose within six months of the end of the year for which the income tax is charged.

The section is modified by the Revenue Act I9II as Rex. Act, 1911, sec. 12. follows :-

Sec. 12.-The proviso to subsection ( 1 ) of section 71 of the principal Act (which gives the right to persons resident abroad to claim relief, exemption, or abatement from income tax in certain cases) shall apply to a widow who is in receipt of a pension chargeable with income tax and granted to her in consideration of the employment of her late husband in the service of the Crown as it applies to the persons described in the proviso.

Sec. 13.-When the securities of a foreign State or British Possession are held under any trust, and the person who is the beneficiary in possession under the trust is the sole beneficiary in possession and can, by means either of the revocation of the trust or of the exercise of any powers under the trust, call upon the trustees at any time to transfer the securities to him absolutely free from any trust, that person shall be deemed to be the person owning the securities for the purpose of subsection (2) of section $7 \mathrm{I}$ of the principal Act (which exempts from income tax under certain circumstances the interest and dividends of the securities of a foreign State or British Possession). 
Ict of 1910, sec. 68.

Abatement in respect of children.
By sec. 68 of the I9ro Act, where the total income from all sources does not exceed $£ 500$, an abatement of tax on $£$ ro is allowed in respect of each child living and under r6 years of age at the commencement of the income tax year. This includes step-children, but not illegitimate children (unless the parents have married each other).

This relief (like abatement, \&c.) comes off the 9 d. part of the income (see post).

The section is as follows:-

(I) If any individual who has been assessed or charged to income tax, or has paid income tax either by deduction or otherwise, claims and proves, in manner prescribed by the Income Tax Acts, that his total income from all sources, although exceeding one hundred and sixty pounds, does not exceed five hundred pounds, and that he has a child or children living and under the age of sixteen years at the commencement of the year for which the income tax is charged, he shall be entitled, in respect of every such child, to relief from income tax equal to the amount of the income tax upon ten pounds.

The expression "child" and the expression "children" in this provision includes stepchild or stepchildren, but does not include illegitimate child or illegitimate children: Provided that where the parents of any illegitimate child or children shall, after the birth of such child or children, have married each other, such illegitimate child or children shall be included in the expression "child" and "children."

(2) Any relief under this section shall be given either by reduction of the assessment, or repayment of the excess which has been paid, or by both those means, as the case may require.

(3) Subsections (2) and (3) of section 19 of the Finance Act 1907 shall be construed as if this section were mentioned therein as well as section 8 of the Finance Act 1898 and sec. 
tion 54 of the Income Tax Act $18_{53}$, and the provisions of the Income Tax Acts, which relate to claims for exemption, relief, or abatement, or the proof to be given with respect to those claims shall apply to claims for relief under this section, and the proof to be given with respect to those claims.

The following are illustrations of the effect of sec. 54 of the Act of 1853 , as to deduction of life insurance premiums (see p. 259 et seq.) :-

(I) A.'s income (ascertained in accordance with the rules already laid down) is $\quad \ldots \quad £ 850$ per annum He pays premiums on policies on the life of himself and his wife to the extent of ... 50 ,"

$\mathrm{He}$ is therefore only called on to pay tax on

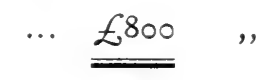

(2) B.'s income is ... ... £600 , And he pays premiums to the extent $\begin{array}{lllll} & \ldots & \ldots & \ldots & \text { I }\end{array}$

$\mathrm{He}$ is liable to pay tax (less abatement) on $\ldots \quad \ldots \quad £ 500 \quad$,

It must be observed, however, that his income is $£ 600$ per annum (not $\mathcal{E}_{500}$ ), and he is only entitled to the abatement of $£$ r 20 , not $£$ r5o.

(3)

D.'s income is $\ldots \quad \ldots \quad £^{600}$ per annum And he pays premiums ‥ $120 \quad$,

Leaving $\cdots \quad \longdiv { £ 4 8 0 }$ 
Deduction

limited to one-sixth of income.

$\mathrm{He}$ is only allowed to deduct premiums to the extent of one-sixth of his income, and he is liable for tax (less abatement) on

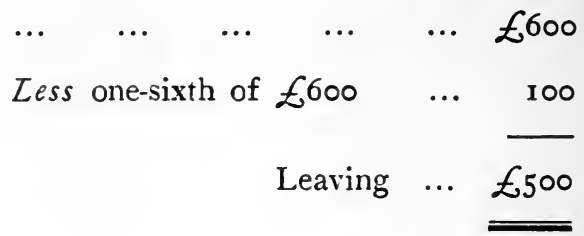

Any person who was entitled to claim this allowance and neglected to do so may make a claim any time within three years of the end of the year to which the claim relates (Act of 1860 , sec. 10). 


\section{CHAPTER VIII.-(continued).}

\section{EXEMPTIONS AND ABATEMENTS--(continued).}

\section{PART II.-Charities and Public Buildings.}

\begin{abstract}
CHARITIES are exempt from taxation under any schedule on due proof that the rents or interest which would otherwise be chargeable are bonâ fide applied to charitable purposes (1842, sec. 6I, Schedule A, No. VI.; sec. 88, Schedule C; sec. ro5, Schedule D).
\end{abstract}

Any college or hall in any of the Universities is also exempt from taxation under Schedule A, as are also hospitals, public schools, and almshouses; and any building belonging to a literary or scientific institution used solely for the purpose of such institution where there is not any payment demanded for instruction (1842, sec. 6r, Schedule A, No. VI.).

There is not any express provision in the Acts as to the Churches, \&c. exemption of churches from assessment to Schedule A, but many years ago the Board of Inland Revenue issued instructions to exempt all places of worship from assessment, as in the case of hospitals, \&c., except as regards ground rent and mortgage interest.
Charities exempt.

Colleges in Universities.

Public

schools, \&c. 
Under Schedule $\mathrm{C}$ the stock belonging to friendly societies is exempt, provided that the sum assured to any person under the rules does not exceed $£ 200$, or the annuity payable to any person does not exceed $£ 3^{\circ}$ per annum, as the case may be (1842, sec. 88), and where such societies are owners of lands, \&c., or receive interest or profits or gains, they are exempt from assessment in respect of them under Schedules $A$ or D (1853, sec. $49 ;$ I889, sec. I2).

By the Industrial and Provident Societies Act 1893 a registered society is not chargeable under Schedules $C$ and D unless it sells to persons not members thereof, and the number of shares of the society is limited either by its rules or its practice.

By the Trade Union (Provident Funds) Act 1893 (56 \& 57 Vict., cap. 2) exemption from income tax chargeable under Schedules A, C, and D is granted to any trade union duly registered under the Trade Union Acts 1871 and 1876 , subject to the $£^{200}$, or $£ 30$ per annum, limit as in the case of friendly societies above.

The income of the funds of savings banks is also exempt, so far as it is applied in the payment or credit to any depositor of interest not exceeding the sum of $£ 5$ in the year for which exemption is claimed (and see ante, p. II 2 ), (1842, sec. 88, Schedule C ; 1894, sec. 36). 
Section 70 of the 1910 Act provides additional exemption as

The exemption from income tax granted by the Income Tax Acts to a friendly society, and by the Trade Union (Provident Funds) Act 1893 , to a registered trade union, by the rules of which it appears that the sums assured to any person by the society or union do not exceed if by way of gross sum two hundred pounds, or if, by way of an annuity thirty pounds a year, shall extend to any registered friendly society and to any registered trade union, if the society or union are restricted either by virtue of any Act of Parliament or by their rules from assuring to any person any sum exceeding three hundred pounds by way of gross sum or fifty-two pounds a year by way of annuity.

Most of these allowances, \&c., are granted on proof of the necessary facts before the Commissioners for Special Purposes (г842, secs. 6r, 88, s.8, and ro5).

An important case is that of Coomber v. Justices of Berks, heard in the House of Lords, I $3^{\text {th }}$, I $4^{\text {th, }}$ and $5_{5}$ th November, and 3 rd December 1883. The justices of the county, under Coomber $v$.
Justices of Berks.

Assize Courts exempt. statutory power, erected a building containing Assize Courts, the necessary rooms and offices, and a police station. Parts of the building were occasionally used for committee meetings and other purposes not connected with the police or the administration of justice, but there was not any profit ever received from the use of any part of the building. The Surveyor sought to assess the justices under Schedule A for the annual value of the building. He contended that the question was, not whether the building produced profit, but whether it was capable of profitable occupation. The justices were 
Coomber v. Justices of Berks.

Assize Courts exempt.
Blake $v$. Mayor, de., Public school. the occupiers, and could let it for profit if they chose. The contention on the other hand was that the Crown was the occupier of the buildings, and they. were therefore not assessable to income tax. Further, that income tax is not payable where there is not any annual profit legally possible. By statute the justices could not use the buildings for any other than for public purposes, therefore there could not be any profit made. The House of Lords gave judgment in favour of the justices, and overruled Clerk v. Dumfries Commissioners of Supply, heard before the Court of Session, Scotland, in I880. They considered that the buildings were "public buildings," and Lord Blackburn quoted an old judgment (viz., of Lord Kenyon in The King $v$. Cook), to the effect that the Crown was exempt "by virtue of its prerogative, in the " same manner as it is virtually exempted under every Act " imposing a duty or tax on the subjects."

The Court of Appeal held (2 Ist and 23rd May 1887) in Blake (Surveyor of Taxes) v. Mayor and Citizens of the City of London, that a school carried on by a public body, not for purposes of profit, but for the benefit of a large portion of the public, and maintained partly by charity, is a "public school" within the meaning of the Act, notwithstanding the fact that the school is partly supported by fees charged for instruction; and as such it is entitled to exemption from tax under Schedule A. 
In The Baird Trustees v. The Tord Advocate it was decided by the Court of Session, Scotland (9th February and Ist June r888), that the term "charitable purposes" was to be interpreted in its ordinary and familiar sense, according to which the relief of poverty is signified; and that the words do not have the wide interpretation given to them by the Court of Chancery in England in interpreting the Statute of Charitable Uses, and the Statutes of Mortmain; and that the income of the trust, being applied towards providing the means of meeting or mitigating spiritual destitution among the population of Scotland, was not exempt from taxation-but see Commissioners of Income Tax v. Pemsel (post).

In Needham v. Bozeers (Survcyor of Taxes) it was held by the Queen's Bench Division (4th July I888) that an institution founded by charitable donations and supported wholly out of payments by the patients, of whom some paid more, and some less, than the cost of their maintenance, was not exempt from tax under Schedule $A$ as a "hospital." The exemption was restricted to a hospital maintained wholly or in part by charity.

The case of St. Andrew's Hospital, Northampton v. Shearsmith (Surveyor of Taxes) (Queen's Bench Division, and July I887) was decided similarly on the like grounds.

\section{Needham $v$.} Bowers.

Hospital.

In Bray v. The Justices of Lancashire the Court of Appeal held (3Ist January I889) that such parts of a county lunatic asylum as were occupied by officers having an income of

St. Andrew's Hospital $v$. Shearsmith. Hospital.
Bray. v. Justices of Lancashire. 
Justices of Edinburgh v. Surveyor.

Burgh Court exempt.
Profits from baths, \&c., assessable.

Queen v. Special Com missioners. Yorkshire Penny Bank. more than $\mathcal{E}^{\mathrm{r} 5}$ o per annum (1842, sec. 6r, No. VI.) were not in the occupation of the Crown, or the persons using them, exclusively in and for the service of the Crown, and were therefore not exempt from assessment under Schedule A.

Municipal buildings (e.g., town halls), so far as occupied for civic purposes, have been held liable to tax under Schedule A, but those parts used for the sittings of the Burgh Court are exempt, being part of the (King's) establishment for the administration of justice (The Justices of Edinbugh $v$. The Surveyor of Taxes, Court of Session, Scotland, I $5^{\text {th }}$ November 1889, sub. nom. Adam v. Maughan).

In the same case it was held that the revenues derived from public baths, markets, and slaughter-houses were assessable, the Court stating that this appeared perfectly plain.

An interesting point was raised in The Queen $v$. Special Commissioners of Income Tax (In re Yorkshire Penny Bank). The bank receives deposits in any amount from one penny upwards. There is not any restriction in the amount which may be received from individual depositors, and large deposits are in fact received. For many years the bank had obtained repayment from the Special Commissioners of the duty deducted from interest on investments, but attention having been drawn to the fact that the operations of the bank were no longer confined to the receipt of small deposits, the Special Commissioners, when a claim was presented in respect of the year ended $5^{\text {th }}$ April 1888 , declined to repay any larger sum 
than the duty on so much of the interest received as had been paid or credited to depositors whose annual interest did not amount to $£ 3$. The proposal of the Commissioners was contained in a letter dated the I 7 th May I 888 to the following effect :-

"The Board are, họwever, unwilling to withdraw entirely the relief hitherto conceded, and accordingly they have considered how far relief might be granted consistently with a due regard to the interests of the Revenue. The result is that they have consented to grant to the Yorkshire Penny Bank the same measure of relief which they have recently accorded to a very similar institution-namely, to entertain a claim for repayment of income tax in respect of the interest paid to those depositors whose annual interest in any year does not amount to $£ 3$."

On the case coming before the Court (29th and 3oth Arrangement October 1889) a settlement was arranged on the basis of the letter.

In a case where the profits derived from publishing a book of Psalms and Hymns were distributed among widows and orphans of Baptist missionaries, it was sought (The Trustees of the Baptist Psalms and Hymns v. Whitwell) to claim exemption. 'The Queen's Bench Division held (I6th December 1890) that the exemption applies only to "any yearly interest or other annual payment" (1842, sec. I05), and not to "profits or gains," and that profits are liable to assessment, no matter how applied.

In Cawse (Surveyor of Taxes) v. Committee of Lunatic Hospital, Nottingham, it was sought to exclude the asylumoriginally built out of charitable funds, and a portion of the

Cawse v.

Committee o Lunatic Hospital.

Hospital. 
Canse v. Commitice of Lunatic Hospital.

Hospital.

income of which was derived from interest on the endowment fund-from the benefit of exemption from income tax (Schedule A), and inhabited house duty, on the ground that, owing to the receipts for the care of patients who paid at a higher than the ordinary rate, the asylum was self-supporting.

The committee contended that the word "profits" in the Income Tax Acts means what remains after deducting the value of the occupation of the premises where the profit is made, and, if this were done, there would be a loss instead of a profit. Further, that the mere fact that in a single year the asylum had been self-supporting did not disentitle them to exemption; the whole of the income was, by the trust deeds, to be applied to charitable purposes only.

The Queen's Bench Division held (5th and 6th February I89I) that the committee were entitled to the exemption claimed.

Commis. sioners of Income Tax v. Pemsel.

"Charitable purposes."
In Commissioners of Income Tax v. Pemsel (the Moravian case), it was held that freehold estates, vested in trustees upon trust to apply the income in certain proportions for the maintenance of missionary establishments among the heathen, in connection with a particular religious body, and for the education and support of poor members of the body, were held "for charitable purposes," and were exempt from income tax under Schedule A (House of Lords, 2oth July 189r). This decision appears to overrule that of The Baird Trustees $v$. The Lord Advocate (ante, p. 469). 
It was held by the Court of Session, Scotland (I 9 th March 1892), in Sulley v. The Royal College of Surgeons in Edinburgh that the college was not exempt (under Schedule A) as a "scientific institution," as its main objects were professional, namely, the providing instruction for students, and the granting of licences to practise anatomy, \&c.

In Maughan $v$. Free Church of Scotland the facts were as follows :-The Free Church Assembly $\mathrm{Hall}$ was held in trust for the Free Church. It was the place of meeting for the General Assembly and Commissioners of Assembly of the Church, and was also sometimes used for other purposes, principally of a religious or semi-religious nature, and for charitable and temperance purposes. There were not any rents or profits made from the hall. It was held by the Court of Session, Scotland, 3oth May 1893, that the trustees were rightly assessed under Schedule $A$ on the annual value of the hall, and were not entitled to exemption under No. VI. of sec. 6I, as the allowance only applied where rents and profits received by trustees were applied by them to charitable pur-

The Corporation of Bristcl claimed (1892) to be entitled to the allowance under Schedule $A$ in respect of the ownership of three free libraries, on the ground that in respect of such ownership they were a "literary or scientific institution." The Queen's Bench Division held (23rd June 1892, Andrews v. Mayor, \&c., of Bristol) that the corporation did not come within the exemption, which applied rather to collegiate institutions, public schools, and alms. houses. This decision was, however, overruled in Mayor of Manchester v. McAdam (post).

Maughan v. Free Church.

\section{Hall not} exempt.
Sulley v. Surgeons.

College not exempt. 
Maughan v. Free Church.

\section{Hall not} exempt.

Commissloners of Income Tax v. Pemsel distinguished.

Mayor, \&c., of Manchester v. McAdam.

Free llbraries exempt.

Bain $v$.

Pree Church. poses. The Court pointed out that No. VI. of Schedule A was divided into four heads, viz., allowances in respect of-

Colleges and halls of universities,

Hospitals, public schools, and almshouses,

Buildings, the property of a literary or scientific institution, and

Rents and profits applied to charitable purposes.

The hall, they said, certainly could not fall under any of the first three heads, and as there were not any rents received from it, it could not fall under the fourth head, which related to rents and profits of lands, \&c., as distinguished from the lands, \&c., themselves. The case of Commissioners of Income Tax v. Pemsel (p. 472) was not in point, as in that case income was received and applied for charitable purposes.

The case of Andrews v. Mayor and Corporation of Bristol was followed by the Queen's Bench Division, 2Ist November I894, in the Mayor and Corporation of Manchester $v$. McAdam, where the corporation (unsuccessfully) sought to claim exemption from assessment in respect of the free libraries belonging to the city. The decision was confirmed by the Court of Appeal (8th March 1895), but orerruled by the House of Lords (3ist July 1896), Halsbury, L.C., dissenting.

In Bain v. Free Church of Scotland it was sought to establish that the Free Church College, Edinburgh, a divinity hall, was a public school within the exemption in 
No. VI., Schedule A, sec. 61 of the 1842 Act. The building is intended for the training of candidates for the ministry after they have completed their undergraduate course at one or other of the national universities, although other students are admitted. The case was heard in the Court of Session, Scotland, I 3 th January 1897 , and judgment was given on the $4^{\text {th }}$ February in farour of the Crown.

In Musgrave v. Magistrates and Toren Council of Dundee (Court of Session, Scotland, Ist and r6th June I897) a building belonging to the council, and used mainly as a free library, but in one room of which accommodation was provided for a subscription library, was held to be assessable under Schedule A. The case was distinguished from the Manchester case, as the building was not used wholly as a free library.

In Jno. Brown v. Jno. Smith (Court of Session, Scotland, I 7 th and $25^{\text {th }}$ October I90I) it was held that parts of premises occupied for municipal purposes and as private offices were liable to assessment under Schedule $\mathrm{A}$, and that the occasional use of a County Hall as a Court of Justice gave no title to relief.

In Trustees of the Mary Clark Home v. Anderson (Surveyor of Taxes), King's Bench Division, 3oth June 1904, the facts were as follows:- The home was founded in I 900 for ladies in reduced circumstances, and the building is the property of the trustees. The material rules of the home are that

\section{Brown v.
Smith.}

Municipal building used occasionally as Court of Justice.

Musgrave v. Dundee Tow Council.

Free library not exempt unless used solely as a free library. $\underset{\text { Mome }}{\text { Mary. }}$ Clark Anderson. 
Mary Clark Home $v$. Anderson.

University College of North Wales.

Essex Hall case. a person, to be an inmate, must be $(a) 50$ years of age or upwards, and $(b)$ in receipt of an income of not less than $\mathcal{E 2}^{2}$ and not more than $\mathcal{E 5 5}$. (This regulation $(b)$ was open to variation by the Board of Management, but had not been varied by them). Exemption was claimed on the ground that the home was an " almshouse," and the Court approved this view, and granted exemption from income tax, Schedule $A$, accordingly.

In The King v. Special Commissioners of Income Tax; ex parte University College of North Wales (C.A., 26th February r909), the college. the funds of which were applied "for the advancement of education," was granted exemption under Schedules A. C, and D.

In The King v. Spccial Commissioners of Income Tax; ex parte Essex Hall it was held (Court of Appeal, I8th May I9I I) (approving Maughan v. Free Church of Scotland) that the exemption in sec. $6 \mathrm{I}$ applied only to rents received, and that Essex Hall, which was in the occupation of the trustees who let out portions, was not exempt. 
CHAPTER VIII.-(continued).

EXEMPtIONS AND ABATEMENTS-(continued).

PART III.-Relief to "Earned" Incomes.

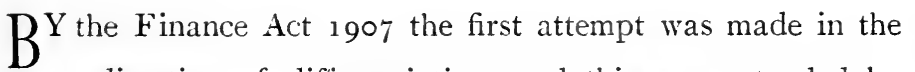
direction of differentiation, and this was extended by the Finance (I909-10) Act rgro.

In effect these provisions are that where the total income does not exceed $£ 3,000$, such part of it as is "earned" bears a lower rate of tax than the remainder.

The provisions are as follows :-

Finance Act 1907, sec. I9:-

(I) Any individual who claims and proves, in manner proAct of 1907. vided by this section, that his total income from all sources does not exceed two thousand pounds, and that any part of that income is earned income, shall be entitled, subject to the provisions of this section, to such relief from income tax as will reduce the amount payable on the earned income to the amount which would be payable if the tax were charged on that income at the rate of nine pence. 
(2) The relief given by this section shall be in addition to and not in derogation of any exemption or other relief or abatement under the Income Tax Acts, except that where an individual is entitled to relief from income tax under sec. 8 of the Finance Act 1898 (p. 400 ), or in respect of the payment of premiums, under sec. 54 of the Income Tax Act 1853 (p. 264) (as extended by any subsequent enactment), relief shall be given under this section only in respect of such earned income (if any) as remains after deducting therefrom the amount on which he is relieved of income tax under the said secs. 8 and 54 .

(3) Where relief is given under sec. 8 of the Finance Act 1898 , or sec. 54 of the Income Tax Act 1853 , by way of repayment of the tax after relief has been given under this section, the amount repaid shall be adjusted so that the total amount of the relief given under this section and under the said secs. 8 and 54 does not exceed the amount which would have been given if the whole relief had been claimed simultaneously.

(4) An individual who desires relief under this section must, in cases where he is required to make a return for the purpose of the assessment of income tax, claim that relief at the time the return is made and must, in any case, claim that relief before the thirtieth day of September in the year for which the $\operatorname{tax}$ is charged.

For the purpose of making a claim for relief under this section with respect to income tax charged under this Act for the current year, any individual may, before the thirtieth day of September nineteen hundred and seven substitute a fresh return for any return previously made by him.

(5) An individual shall not be entitled to relief under this section in respect of any income the tax on which he is entitled to charge against any other person, or to deduct, retain, or satisfy out of any payment which he is liable to make to any other person.

(6) Subject to the provisions of this section, all the provisions of the Income Tax Acts which relate to claims for exemption, relief, or abatement, or the proof to be given with respect to those claims, shall apply to claims for relief under this section and the proof to be given with respect to those claims. 
(7) For the purposes of this section the expression "income" means income as estinuated according to the several rules and directions of the Income Tax Acts; and the expression "earned income" means-

(a) any income arising in respect of any remuneration from any office or employment of profit held by the individual, or in respect of any pension, superannuation, or other allowance, deferred pay, or compensation for loss of office given in respect of the past services of the individual or of the husband or parent of the individual in any office or employment of profit, whether the individual or husband or parent of the individual shall have contributed to such pension, superannuation allowance, or deferred pay or not; and

(b) any income from any property which is attached to or forms part of the emoluments of any office or employment of profit held by the individual; and

(c) any income which is charged under Schedules B or D in the Income Tax Act 1853 , or the rules prescribed by Schedule $D$ in the Income Tax Act 1842 , and is immediately derived by the individual from the carrying on or exercise by him of his profession, trade, or vocation either as an individual, or, in the case of a partnership, as a partner personally acting therein.

In cases where a wife's profits are deemed to be profits of the husband, any reference in this provision to the individual includes either the husband or the wife.

(8) Sec. 34 of the Finance Act 1894 (p. 399) shall cease to have effect so far as it gives relief or abatement to persons who are entitled to relief under sec. 8 of the Finance Act 1898 .

Finance Act roro, sec. 67 :-

Act of 1910,

Section 19 of the Finance Act 1907 shall apply to any indisec. 67 . vidual who claims and proves, in manner provided by that section, that his total income from all sources exceeds two thousand pounds and does not exceed three thousand pounds, as if one shilling were substituted for ninepence, and as if, as respects any such individual, the thirty-first day of July nineteen hundred and ten were substituted for the thirtieth day of September nineteen hundred and seven.

Every point must be carefully noticed. 
Income not to be oyer $£ 3,000$.

The relief dres not operate unless the total income does not exceed $\mathcal{E} 3,000$.

No relief to "unearned" incomes.
Claim to be made before 30th Sept.
Where a person has both "earned" and "unearned" income the allowances for abatement and life insurance are to be allowed off the earned part, leaving the unearned to pay at the higher rate.

The claim must be made before the 3 oth September in each year. 'There is no provision in the Act for any concession in this respect, whatever the circumstances may be, though, for the year 1907-8, claims were admitted by persons who had been prevented from claiming by reason of prolonged illness, or absence abroad.

The income for the year is, of course, the statutory income-that is, the amount of profit is to be arrived at on the three years' arerage (or as the case may be), whether the actual amount in the year may be more or less. To this must be added the investment income for the year. There would not appear to be any provision for the case of a person who has, say, £I,000 of "earned" income, and who, having a large interest in a concern which has usually yielded him much more than $£_{2,000}$ per annum, deems it unnecessary to put in a claim, but finds, after 3 oth September, that his total income will be less than $£ 3,000$.

It would therefore be advisable for any person who, by any conceivable chance, might find his income to fall under 
£3,000, to put in a pro formâ claim which would preserve his rights.

A form (No. $38 \mathrm{H})$ is provided for the purpose.

Clause (5) is necessary, in view of the fact that tax on interest is deductible at the higher rate by the person paying the interest. Since, as a rule, interest is usually paid on loans secured in some shape, there will not be any great difficulty under this clause, as the source out of which the interest is paid will usually have borne tax at the higher rate. Where, however (say), a professional man has been able to borrow without security, he will deduct tax at the higher rate, and will have to account for it similarly. Having arrived at the figure for his return in the ordinary way, viz. :-

$\begin{array}{rccccc}\text { Profit after Interest of } & \mathcal{E} \text { 100 } & \ldots & \ldots & £ 705 \\ \text { A.dd Interest } & \ldots & \ldots & \ldots & \ldots & 100 \\ & & & & & \\ & & & & & \\ & & & & & \end{array}$

his demand note will not be tax on $£ 805$ at 9d., but will be

$$
\begin{aligned}
& \text { Tax on Net Profit ... } \quad \ldots \quad \ldots \quad £ 705 \text { at } 9 d . \\
& , \quad \text { Interest } \quad \ldots \quad \ldots \quad \ldots \quad \text { 100 , I } / 2
\end{aligned}
$$

It may be further noticed that the view of the authorities is that where a partnership paying (unsecured) interest makes a loss, and therefore has to pay upon interest, they cannot set that off against interest on the partners' private investments. 
Pension to bear lower rate.

One-man company.
It will be observed that Clause 7 provides that a pension is to bear the lower rate, whether contributed to by the pensioner or not.

The distribution of profits of a "family" limited company are held to be assessable as dividends, and therefore are not "earned," and it is difficult to see how they can be treated otherwise. No doubt where there is a genuine provision under articles for profit to be paid to directors as bonus, \&c., regard will be had to such provision, and this may become easier now that the Companies Act permits a "two-man " company, but there is little doubt that any claim based on any such arrangement not absolutely genuine will be resisted by the Crown. In this connection see p. 346 et seq.
Under Clause $7(e)$ "earned" income is defined to be income immediately derived by the individual from the carrying on or exercise by him of his trade, \&c., either as an individual or as a partner personally acting. This is held (rightly apparently) to exclude shares of profit of a business carried on by trustees and due to any beneficiaries not engaged in the business. 


\section{CHAPTER IX.}

THE SUPER TAX.

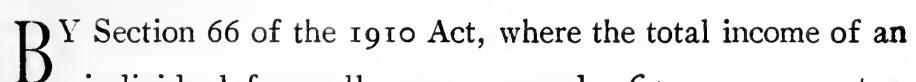
individual from all sources exceeds $£ 5,000$, a supertax of $6 \mathrm{~d}$. in the $\mathcal{E}$ is to be charged on all income over $\mathcal{E} 3,000$.

The "total" income is to be "the total income of that individual from all sources for the previous year, estimated in the same manner as the total income from all sources is estimated for the purposes of exemption or abatement" (but see below), thus :-

In respect of rents, the income is the Schedule A assessment (pp. 420-2I).

In the case of profits, it is the Schedule D assessment, irrespective of the actual profit (p. I25 (5)).

The income of the wife is to be aggregated (p. I29 (13)).

In the case of dividends receivable, or annual sums payable, the amount is to be used as applying to the year in which the sum is actually receivable or payable, as the case may be, irrespective of whether it accrued in whole or in part before that year.

Act of 1910,

sec. 66 , super-

$\operatorname{tax}$ on

incomes oyer $£ 5,000$. 
Act of 1910, sec. 66, super$\operatorname{tax}$ on incomes oyer $£ 5,000$.
There is one important exception to ascertaining the income as for the purpose of abatement, Esc., viz., life insurance premiums (up to one-sixth of the income) may be deducted.

(1) In addition to the income tax charged at the rate of one shilling and twopence under this Act, there shall be charged, levied, and paid for the year beginning on the sixth day of April nineteen hundred and nine, in respect of the income of any individual, the total of which from all sources exceeds five thousand pounds, an additional duty of income tax (in this Act referred to as a super-tax) at the rate of sixpence for every pound of the amount by which the total income exceeds three thousand pounds.

(2) For the purposes of the super-tax, the total income of any individual from all sources shall be taken to be the total income of that individual from all sources for the previous year, estimated in the same manner as the total income from all sources is estimated for the purposes of exemptions or abatements under the Income Tax Acts; but, in estimating the income of the previous year for the purpose of super-tax:-

(a) there shall be deducted in respect of any land on which income tax is charged upon the annual value estimated otherwise than in relation to profits (in addition to any other deduction) any sum by which the assessment is reduced for the purposes of collection under section 35 of the Finance Act 1894, or on which duty has been repaid under the provisions of this Act relating to the repayment of duty in respect of the cost of maintenance, repairs, insurance, and management; and

(b) there shall be deducted the amount of any premiums in respect of which relief from income tax may be - allowed under section 54 of the Income Tax Act 1853 (as extended by any subsequent enactment); and 
(c) there shall be deducted in the case of a person in the service of the Crown abroad, any such sum as the Treasury may allow for expenses which in their opinion are necessarily incidental to the discharge of incomes oyer the functions of his office and for which an allowance has not already been made;

(d) Any income which is chargeable with income tax by way of deduction shall be deemed to be income of the year in which it is receivable, and any deductions allowable on account of any annual sums paid out of the property or profits of the individual shall be allowed as deductions in respect of the year in which they are payable, notwithstanding that the income or the annual sums, as the case may be, accrued in whole or in part before that year.

The special provisions as to the assessment of the super-tax

(I) The super-tax shall be assessed and charged by the Commissioners for the special purposes of the Acts relating to income tax (in this Act referred to as the Special Commissioners).

(2) Every person upon whom notice is served in manner prescribed by regulations under this section by the Special Commissioners requiring him to make a return of his total income from all sources, or, in the case of a notice served upon any person who is chargeable with or liable to be assessed to income tax under section $4^{\mathrm{I}}$ of the Income Tax Act 1842, or section 24 of the Customs and Inland Revenue Act 1890, as representing an incapacitated, non-resident, or deceased person, of the total income from all sources of the incapacitated, non-resident, or deceased person, shall, whether he is or is not chargeable with the super-tax, make such a return in the form and within the time required by the notice. 
Act of 1910, sec. 72 , super$\operatorname{tax}$ on incomes oyer $£ 8,000$.
(3) It shall be the duty of every person chargeable with the super-tax to give notice that he is chargeable to the Special Commissioners before the thirtieth day of September in the year for which the super-tax is chargeable: Provided that for the purpose of this provision the thirty-first day of July nineteen hundred and ten shall, as respects the year beginning on the sixth day of April nineteen hundred and nine, be substituted for the thirtieth day of September of that year.

(4) If any person without reasonable excuse fails to make any return or to give any notice required by this section, he shall be liable to a penalty not exceeding fifty pounds, and after judgment has been given for that penalty to a further penalty of the like amount for every day during which the failure continues.

Any penalty under this provision shall be recoverable in the High Court, or in Scotland in the Court of Session.

(5) If any person fails to make a return under this section, or if the Special Commissioners are not satisfied with any return made under this section, the Special Commissioners may make an assessment of the super-tax according to the best of their judgment.

(6) All provisions of the Income Tax Acts relating to persons who are to be chargeable with duty, assessments, and appeals against those assessments, and to the collection and recovery of duty, and to cases to be stated for the opinion of the High Court shall, so far as they are applicable, apply to the charge, assessment, collection, and recovery of duty under this section, and the Special Commissioners shall, for the purpose of assessment, have any powers of an Inspector or Surveyor of Taxes, and for the purpose of the representation of the Crown on any appeal before the Special Commissioners, any person nominated in that behalf by the Commissioners of Inland Revenue shall have the same powers at and upon the determination of the appeal as a Surveyor of Taxes has at and upon the determination of any appeal under the Income Tax Acts. 
(7) The Special Commissioners may amend any assessment made by them under this section, or make an assessment or an additional assessment, during any time within the year of assessment, or within three years after the expiration thereof.

(8) The Commissioners may make regulations for the purpose of carrying this section into effect.

It will be observed that the information in respect to supertax differs essentially from that required in respect to abatement, \&c., claims, since, in the latter case, taxed income need not be stated with absolute accuracy, as the abatement or "relief" is the same for all

$$
\begin{gathered}
\text { Incomes between } £_{400} \text { and } £_{500} \\
\therefore, 500 \text { and } £_{600,8 c .}
\end{gathered}
$$

But, so far as super-tax is concerned, every $\mathcal{E}_{\mathrm{I}}$ over $\mathcal{E}_{5}, 000$ makes a difference of $6 \mathrm{~d}$. one way or the other. It thus becomes of the greatest importance to ascertain the exact amount of the income, and especially so when near $£ 5,000$, as the difference of a few pounds of income may bring it within or without the limit.

The Act provides that the statutory "total income" for one year is to be the "total income" for the previous year, " estimated in the same manner as the total income from all "sources is estimated for the purpose of exemption or abate"ment under the Income Tax Acts" (with certain exceptions to be noted later). Therefore profits and salaries are based on the average for the three preceding years, except in the case of salaries payable by companies, \&c., which pay on the 
actual salary of the year. Thus, assuming the figures in four different cases to be :-

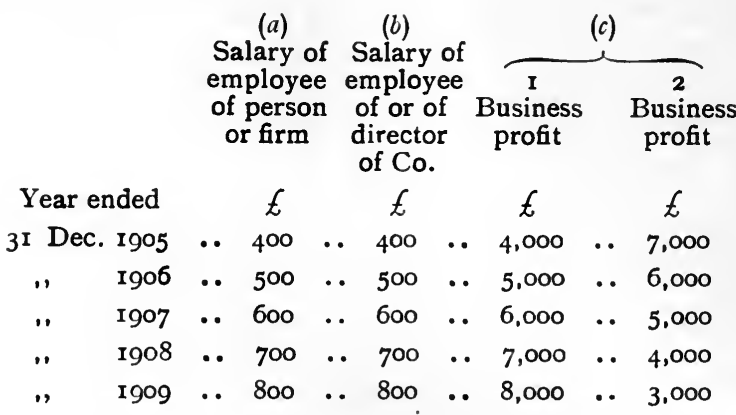

For 1908-9 in these separate cases the statutory incomes were as follow :-

In case (a) $£ 500-$ The average of $£ 400, £ 500$, and $£ 600$.

. (b) $£ 700-T h e$ actual income of the year.

, (c) (I) $£ 5,000$-The average of $£ 4,000, £ 5,000$. and $£ 6,000$.

, (c) (2) $£ 6,000$-The average of $£ 7,000, £ 6,000$, and $£ 5,000$.

So that, for super-tax purposes, for 1909-10 the income in case $(c)(\mathrm{I})$ is $£ 5,000$ (i.e., the statutory income of $1908-9$ ), though the actual profit is $£ 8,000$. Also in case $(c)(2)$ the income is $£^{6,000}$, although the actual profit is only $£ 3,000$. This produces, apparently, a glaring injustice; but the injustice is more apparent than real. It arises from, and illustrates the effect of, the three years' average, viz., (I) that the amount on which tax is payable has no relation to the profit of the year, (2) that over a series of years one pays on the total actual result, and (3) that one is frequently paying a heavy tax in bad years, which, however, is equalised by the payment of a lighter tax when profits are good, the assessment being based on the past (bad) results. 
For this purpose, then,

(I) Income Taxed at Source is to be the income of the year in which it is receivable, and annual sums paid (mortgage interest, \&c.) are to be deducted in respect of the year in which they are payable, without apportionment in respect of the period during which they accrued.

(2) Income Tax from Property is the net assessment under Schedule A (i.e., the rent, less one sixth, \&c.), without regard to the actual net receipts.

(3) Dividends "Free of Tax" must be increased by the amount of tax. Thus, a dividend of $£ 500$ purporting to be a dividend "free of tax" at ro per cent. on $£ 5,000$, must be considered to be $£ 530$ I9s. 6d., viz. :-

\begin{tabular}{|c|c|c|c|c|}
\hline Dividend $\quad \ldots$ & $\ldots$ & $\ldots$ & $£ 530 \mathrm{I}$ & 9 \\
\hline Tax at Is. $2 \mathrm{~d}$. & $\ldots$ & $\ldots$ & $30 \mathrm{I}$ & 9 \\
\hline & & & $£ 500$ & $\circ$ \\
\hline
\end{tabular}

The previous illustrations may be amplified. Assume that in cases $(c)(x)$ and $(c)(2)$ the persons have the following actual 
Information required to be exact.

$\begin{array}{lllllrrrr} & & & & \text { (c) (1) } & & \text { (c) (2) } \\ \text { Profit as above } \ldots & \ldots & \ldots & \ldots & £ 7,000 & \ldots & £ 4,000 \\ \text { Dividend "free of tax" } & \ldots & \ldots & \ldots & 500 & \ldots & 500 \\ \text { House property, say :- } & & & & & & \end{array}$

Rents

Repairs

$$
\begin{array}{rrrrrr}
\cdots & & \cdots & £ 1,000 & \\
\cdots & £ 300 & & & \\
\cdots & 100 & \ldots & 400 & \ldots
\end{array}
$$

Interest$$
600 \quad \ldots \quad 600
$$

Coupons due October I and April I, credited October 10 and April $10 \mathscr{E}^{120}$

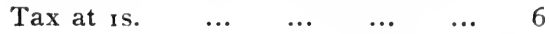

$$
\begin{array}{llrrrrr} 
& & & 114 & \ldots & 114 \\
& & 114 & \cdots & 114 \\
& & £ 8,328 & \cdots & £ 5,328 \\
\hline
\end{array}
$$

Their respective incomes for super-tax purposes for I909-10 are :-

Profit (assessment of $1908-9$ ) $\quad \ldots \quad \ldots \quad \ldots .5$, $000 \quad \ldots \quad £ 6,000$

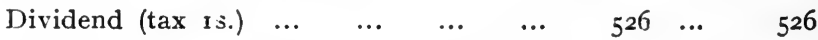

Income of house property, assessment of rgo8-9, viz., fir,ooo less 1 -6th (or a further $1-12$ th if proved in accordance with the Act)

$S_{33} \quad \cdots \quad 833$

Coupons (October and April) receivable in the year 1908-9, though not received till afterwards $\quad \ldots \quad \ldots \quad \ldots \quad \ldots$

Coupons (November and May)-November 1908 coupons only (as May form part of income of next year, not being receivable in the year) $\quad \ldots \quad \ldots \quad \quad \ldots$

$\begin{array}{llllllll}\text { Annual interest payable } & \ldots & \ldots & \ldots & \text { 100 } & \ldots & \text { 100 } \\ \text { Income for super-tax purposes } & \ldots & \ldots & £ 6,439 & \ldots & £ .7,439 \\ \end{array}$ 
A further very important point which must not be overlooked is the fact that life insurance premiums paid (up to one-sixth

of the income) may be deducted in computing the amount of the income; so that a person whose "total income" is $f 6, \infty 00$, and who pays $E_{1}, 000$ premiums, will just bring himself within the limit, and will be able to escape the tax. This is not so when considering "abatement," and a person with $£ 600$ per annum, paying $£$ I 00 premiums, only gets abatement in the $£ 600$ scale-not the $£ .500$ scale. It will be noticed that-

(1) Assessments are made by the Special Commissioners.

(2) Every person called upon to do so must make a return, whether chargeable or not.

(3) A duty is imposed upon every person who is chargeable to give notice thereof by September 30. (For I909-Io the notice had to be given by July 3 I I910, instead of September 30 i 909.)

(4) Failure (without reasonable excuse) to give such notice involves a penalty not exceeding $£ .50$, with $£ .50$ per day extra after judgment has been given.

(5) The Commissioners may assess, if not satisfied with the return made, or if no return is made, and may amend any assessment within three years. 
Interest payable.

Death.

By the Revenue Act, I9II, sec. II, it is provided :-

(1) Where a husband is required under subsection (2) of section 72 of the principal Act to make a return of his total income from all sources for the purpose of super-tax, and part of that total income is the income of his wife, the Special Commissioners may, if for any reason they consider that they are unable to obtain a satisfactory return of the wife's income from the husband, require the wife to make a return of her income, and in that case the wife shall be under the like obligation to make a return under the said section as if she were not married, and the husband shall be relieved from any obligation to make such a return as respects the income of the wife.

(2) Where super-tax is charged in a case where the wife has been required to make a return under the foregoing provision, such part of the total sum payable in respect of the super-tax as bears the same proportion to that total sum as the wife's income bears to the total income shall be assessed on and recoverable from the wife in lieu of the husband.

(3) This section shall have effect with respect to the supertax charged for the year beginning the sixth day of April nineteen hundred and nine and for any subsequent year as if it had been contained in the principal Act, and the provisions of that Act with regard to the assessment and collection of super-tax, and the penalties for failure to make a return, shall apply accordingly.

Replying to a question in the House of Commons, in October 1909, the Chancellor of the Exchequer stated that annual interest would be deductible in estimating the income, but not interest on short loans.

Presumably "annual interest" would include any bank interest on which the authorities will repay $\operatorname{tax}$ (p. 310), but not such interest as in the De Peyer case (p. 3ro).

Where a person, whose statutory income for I9I0-I I has been

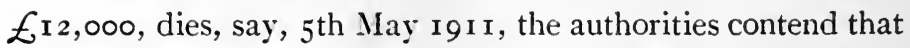
sec. 134 (p. 372) does not apply, and that his estate is liable to super-tax.

The point is going to the Courts on a case stated by the Commissioners. 


\section{CHAPTER $\mathrm{X}$.}

CONCLUSION.

HAVING now dealt with each Schedule in detail, it only remains to say a few words as to the forms issued by the Board of Inland Revenue in connection with returns, \&c.

The principal forms are as follows :-

No. 8. List to be delivered by persons employing others,

Form No. 8.

\&c., required by sec. 21 of the Act of 1907 . (See p. 45.) The full names and residences of the persons employed are to be set out, as also the salaries and emoluments payable to them.

(See also Form No. 46.)

No. 9. Statement to be returned by every occupier of a Form No. 9. messuage or tenement only. (See p. 36.) This contains spaces for specifying-

I. Name of owner.

2. Whether the house is used otherwise than as a dwelling-house.

3. Conditions of tenancy. 
4. Amount of rent.

5. Full annual value.

6. Amount of poor rate assessment.

7. Amount allowed to tenant by owner in respect of land tax.

8. Whether rates are paid by the tenant or the owner.

The form also contains a " Notice and Declaration of Claim of Exemption or Abatement," to be filled up in cases where the occupier is also the owner, and is entitled to exemption or abatement. This is similar to the Form No. $3^{8}$ (see p. 497 et seq. and Chapter VIII.).

Form No. 9d. No. 9D. Statement to be returned by owner of houses, \&c., under the annual value of $\mathcal{E}$ ro, for which the owner is therefore liable to be assessed (p. 23).

Form No. 9e. No. 9E. Return of rents received and paid, canals, docks, $\& c$.

Form No. 10. No. Io. Statement to be returned by every occupier of lands, tenements, and hereditaments (see p. 36). This contains :-

No. I. Space to be filled up by owner being also occupier, comprising details of acreage, annual value, tithe rent, deductions on account of land tax, drainage rates, repairing sea walls, \&c. 
No. 2. Space to be filled up by occupier not being owner, comprising details similar to those above, and to those contained in Form No. 9.

No. 3. Space to be filled up by persons receiving any payment in lieu of tithes.

No. 4. Space to be filled up by or on behalf of the lord of a manor.

No. 5. Space to be filled up by the receiver of any fine on renewal of leases, \&c.

No. 6. Space to be filled up by any person entitled to other profits arising from lands, \&c., not before stated.

This form also contains a "Notice and Declaration of Claim for Exemption or Abatement."

No. гов. Form of return-Railways.

No. IoD. Form of return-Farmer electing to be assessed

Form No. 10d. under Schedule D.

No. I I. Form of return for assessment under Schedule D. Form No. 11. This contains :-

Rules and regulations, the principal of these being quoted verbatim on p. I24 et seq. 
Declaration A. Where a return has already been made.

Declaration B. Where the person has not any income to declare.

Claim C. Claim in respect of life insurance.

Claim D. Abatement, \&c., claim.

Declaration E. Statement of interest payable.

Declaration F. Where a person is engaged in two or more trades.

Declaration G. Where profits have been included in profits of a firm.

Form No. 11b. No. IIB. Form of return for assessment of concerns described in No. III., Schedule A., of the Act of 1842 , viz., quarries, \&c., mines, \&c., and iron works, \&c. (see p. 146).

This is very similar to the Form No. Ir.

12.

13.

13a.

16.

No. $3^{8}$ or $3^{8 \mathrm{D}}$. 
Year 1911-12.

PAGE I.

Parish

Sch.

No. of Asst.

\section{INCOME TAX, IgII.I2.}

\section{CLAIM FOR EXEMPTION, ABATEMENT, OR THE RELIEF ALLOWED IN RESPECT OF EARNED INCOME.}

This form should be used by any person desiring to claim Exemption, Abatement, or the Relief allowed in respect of Earned Income.

In order to obtain the relief allowed to Earned Income a claim must be preferred at the time the Return for Assessment to Income Tax is made, and must in any case be preferred before 3oth September in the year for which the tax is charged.

Instructions as to the filling up of the form are given on page 2.

If an allowance is claimed in respect of Life Assurance Premiums, the space at the foot of this page should be filled up.

The Relief in Respect of Children, allowed to an individual whose total income does not exceed $£ 500$, may be claimed by completing the declaration on page 4 .

The form should be completed, signed by the claimant, and returned to the Surveyor of Taxes, or to the Assessor of Taxes for the Parish in which the claimant resides, within seven days from this date.

Dated

I9Ir.

To

CLAIM FOR ALLOIVANCE IN RESPECT OF LIFE ASSURANCE PREMIUMS OR PAYMENTS UNDER CONTRACTS FOR UEFERRED ANNUITIES.

The Allowance is authorised only in respect of Premiums paid on the Claimant's own life, or on that of his wfe; it is limited to an expenditure on Annual Premiums not exceeding one-sixth of the Claimant's Net Personal Income from all sources, and is not admissible as a deduction in arriving at the total income for the purpose of a claim for Exemption, Abatement, Allowance for Children, or relief in respect of "Earned Income." In order that the Allowance may be granted in respect of such Premiums, the undermentioned particulars should be stated, and the Receipts for the Premiums should, if required, be transmitted to the Surveyor of Taxes.

\begin{tabular}{c|c|c|c|c|c|}
\hline $\begin{array}{c}\text { Name of Person on whose Life } \\
\text { the Ascurance or Annuity } \\
\text { is effected }\end{array}$ & $\begin{array}{c}\text { Name of Assurance } \\
\text { Company or } \\
\text { Friendly Society }\end{array}$ & $\begin{array}{c}\text { Amount of Premiums claimed } \\
\text { as an Allowance from the } \\
\text { profits stated on page } 3\end{array}$ \\
\hline
\end{tabular}

I claim an Allowance for the foregoing amount of Life Assurance Premiums, and I hereby declare that $I$ have not deducted the amount of such premiums in arriving at the income entered on page 3 of this form.

Signature. 
INSTRUCTIONS FOR FILLING UP THIS FORM.

PAGE 2.

Total Exemption may be claimed when the Income from all sources does not exceed Ex6o per annum.

Abatement of $£_{1} 60$ may be claimed when the Income from all sources exceeds $£_{160}$ but does not exceed $£ 4$ oo.

Abatement of $£ 150$ may be claimed when the Income from all sources exceeds $£ 400$ but does not exceed $£ 500$.

Abatement of $£$ i 20 may be claimed when the Income from all sources exceeds $£ 500$ but does not exceed $£ 600$.

Abateme it of $£ 70$ may be claimed when the Income from all sources exceeds $£ 600$

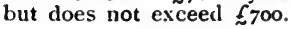

When the Income from all sources does not exceed $f 3,000$, and any part of that Income is Earnel Insome, a Claim may be made for reduction of the Income Tax on the Earned Income to the lower rate applicable thereto. In oriler to obtain this relief a Claim must be preferred at the time the Return is mode, ant must in any case be preferred before 30 th September in the year for which the tax is charged.

Note A.- Where Income is derived from Trade, Profession, Offica, Employment or Vocation, state the nature and particulars thereof, and where carried on.

Note B.-If the Income arises from the ownership of Land, Tenements, or Hereditaments. state the precise situation of each Pcoperty, with the name of the occupi-r, and the rent or annual value, including is the statement particulars of any House, Land, or other Property in the Claimant's own occupation, whether belonging to himself or his wife. If ground rent, mortgage interest, or other annual charge is payzble on any of the property, particulars thereof must be stated in No. 2 on page 3 .

Note C. - Pcofits from the occupation of Land are ts ba taken at one-third of the full annual value inclusive of Tithe.

Note D. - In the case of Income from Annuities, Interest of Money, or other sources not coming under any of the foregoing hearls, state fully the particulars. State also in regard to each item under this head whether it has been subjected to Income Tax before receipt. The amount to be entered is the kross amount, and not the net amount received after deduction of the tax.

Note E.-The Income of a married woman living with her husband is deemed by the Income Tax Acts to be his Income, and particulars thereof must be included in any statement of income rendered by him for the purposes of this claim. The only exception to this rule is where a wife earns an income independently of her husband by the exercise of her own personal labour, and the joint income of husband and wife does not exceed $f 500$. In such a case the profit so earmed by the wife may be treated as a separate income, and a separate claim may be made in respect thereof.

Note F.--Particulars must be given in space No. 2 of all deductions from the income, such as grount rent, interest on mortgage or loan (whether s.cured on property, life assurance policy, reversion or otherwise), annuities, patent royalties, or other annual payments.

If there be not sufficient room on page 3 to set out the income in full, particulars may be given on a separate sheet and the totals transferred to that page. The declaration at the foot of page 3 must in every' case be duly' signed.

The penalty for fraudulently concealing cr untruly declaring the Income is $f 20$ and treble the duty chargeable in respect of all the sources of Income -5 and 6 Vict., c. 35 , sec. 166

By the Finance (1909-10) Act, 1910, it is provided-" If any person for the purpose of obtaining any allowance, reduction, rebate or repayment, in respect of any duty under this Act, either for himself or for any other person, or in any return made witn reference to any duty under this Act, knowingly makes any false statement or false representation, he shall be liable on summary conviction to imprisonment for a term not exceeding six months with hard labour. 


\section{INCOME TAX, I9II-I2.}

PAGE 3.

\section{CLAIM for-}

(a) Exemption or Abatement, when the Income from all sources does not exceed $\underset{\sim}{f} 700$.

(b) The Relief allowed to Earnel Income, when the Income from all sources does not excsed $€ 3,000$.

NOTE.-The Claimant must set fort a every source of his Income, with the amount derived from each s surce, whether tax has been paid on it or not.

\section{See Note A.}

If you have no Income falling under heads $(a)$ to (e) write

"NONE"

in each space.

See Note B.

The precise situation of all property should be stated.

\section{No. I PARTICULARS OF INCOME}

(a) From Trade, Profession, Office, Employment or $\underset{\sim}{f} \mathrm{~s} d$ Vocation :-

(b) From Property (including the annual value of the property which I own and occupy):-

See Note C.

(c) From the Occupation of Land :-

See Note D.

State whether taxed before receipt, or not.

See Note E.

State whether included above, or, if none, write

"NÓNE." (d) From Bank and other Interest, Annuities, Dividends, or other Income not already entered :-

(e) Wife's Income (giving full particulatrs and stating whether taxed before receipt, or not) :- 
PAGE 3-(continued).

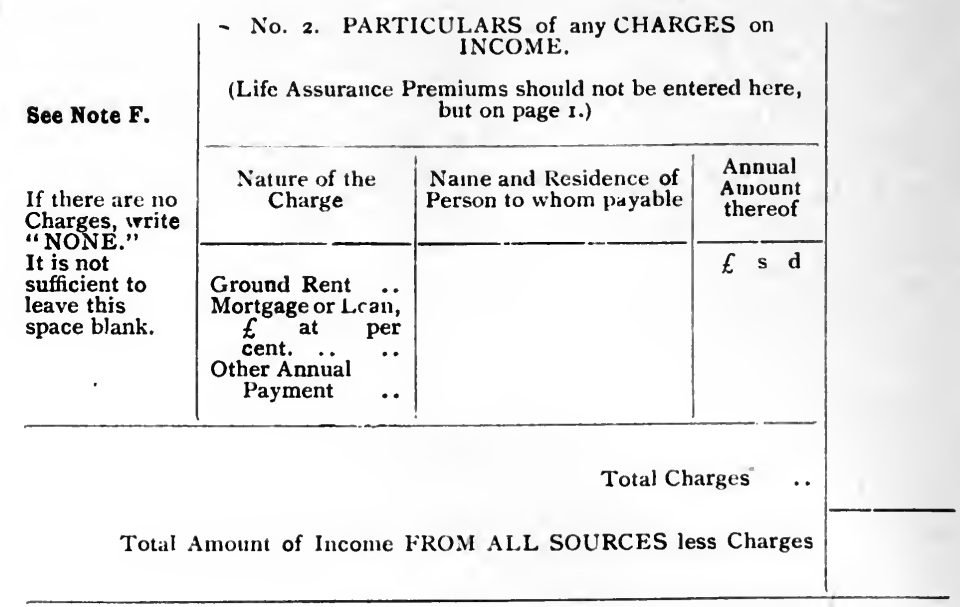

I declare that the above statement contains a full, just, and true account and return of the whole of my Income from every source "hatsoever, for the Year ending the 5th day of April 1912, and I therefore claim the relief $t \mathrm{~s}$ which I am entitled in respect of such Income.

Given under my hand, this

day of 191.

Signed-

Note.-A woman must state after her signature whether Married, Widow (Private) Resiclence or Spinster.

I hereby certify that the Claimant appears to be entitled to Exemption (or) an Abatement of $£$ , and to be charged at the rate of on $£$ of his Income.

Surveyor of Taxes.

District.

Date. 
PAGE +.

\section{CLAIM FOR RELIEF IN RESPECT OF A CHILD OR CHILDREN.}

Any individual who claims and proves that his total income from all sources, although exceeding $£$ r6o, does not exceed $£ 500$, and that he has a child or children living and under the ayse of sixteen years on the 6th April 1911, shall be entitled, in respect of every such child, to relief from Income Tax equal to the amount of income tax upon $£$ io.

No allowance can be made for the year $19 \mathrm{r}-\mathrm{1} 2$ in respect of children born on or before 6th April 1895 , or after 6th April $19 \mathrm{r}$.

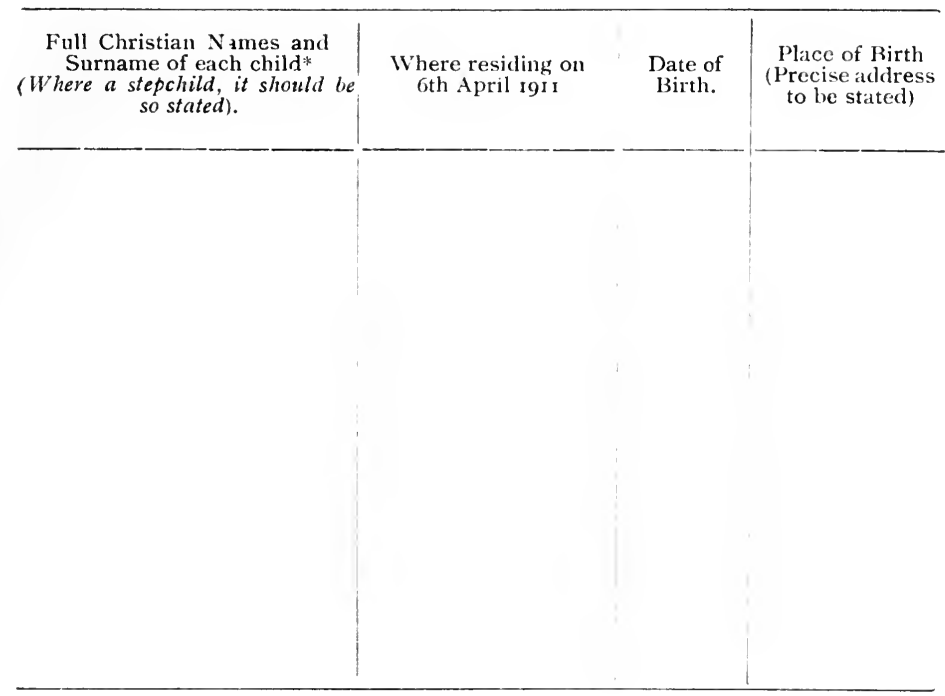

I declare that the above-named children + (

in number) are my children within the statutory definition at the foot of this form, + that they were living on the 6 th April 1911, and that the above particulars are true and correct in all respects.

-Signature.

* The full name of each child should be entered on a separate line.

+ If one child only, the certificate should be amended accordingly. If more than one, the number should be entered in words.

† The expressions " child" and "children" in this provision include stepclild or stepchildren, but not illegitimate child nor illegitimate children unless the parents shall, after the birth ot such illegitimate child or children, have married each other. 
Form No.

38a.

$38 \mathrm{~b}$.

39.

40.

40a.

44.

$44 a$.
No. 38A. Claims for exemption or abatement-Inland Revenue.

No. $3^{8 \mathrm{~B}}$. Claims for exemption or abatement-Inland Revenue (other than official income).

No. 39. Claim for repayment in respect of annual premiums on life insurance policies. This Form is so drawn that the authorities may see that the amount claimed does not exceed tax on one-sixth of the total income.

No. 40. Exemption clain.

'This is reproduced on p. $418,8 c$.

No. toA. Abatement claim.

This is similar to No. 40.

In Scotland a Form (No. 40) is used, which is applicable either to a clain for exemption or abatement.

No. 44. Exemption claim on behalf of minors, \&c.

No. 44A. Abatement claim on behalf of minors, \&c.

These Forms (Nos. $4+t$ and $44 \mathrm{~A}$ ) are substantially the same as Nos. 40 and $40 \mathrm{~A}$ respectively.

They are, however, drawn to meet cases where the person claims either for himself or on behalf of a minor, \&c., and they contain spaces for answers to the following questions :

Are both or is either of the parents of the child or children dearl?

Is the income expended for education or for maintenance?

Has the minor, or have the minors, a vested, or only a contingent, interest in the property? 
No. ${ }_{4} 6$. Notice to officers of corporations and limited companies for returns of salaries (see p. 45).

No. 64. Notice of charge and day of apjeal-Schedules D and E.

No. 65. Notice of charge by Special Commissioners.

No. 68. Exemption clajm-Dividends applied to charitable purposes.

This is somewhat similar to the other exemption claims.

No. 69. Friendly Societies' claim.

69.

$69 a$.

No. 69a. Trade Union (Provident Funds) claim.

No. 7o. Exemption claim-Rents, \&c., applied to

70. charitable purposes.

This contains spaces for full particulars of the rents, \&c.

No. 72. Ministerial expenses, claim of repayment.

72.

Nos. 79 and 79A. Precepts issued by the Commissioners requiring schedules of particulars on appeals.

$\left.\begin{array}{r}\text { Nos. } 185, \quad \text { I85A, } \\ \text { and } 189 \mathrm{~A}\end{array}\right\}$ ('ertificates of Deduction.

These are reproduced on p. 423, \&c.

No. 185B. Certificate of deduction-Building Society.

$185 b$.

Copies of any of these Forms may be obtained by any person when required, on application at the office of the Surveyor of Taxes for the district in which the person resides, and it has not therefore been thought needful to 
TABLE OF RATES OF INCOME TAX.

From First imposition to Present Time.

\begin{tabular}{|c|c|c|c|c|c|}
\hline \multirow{2}{*}{$\begin{array}{l}\text { Years ending } \\
5^{\text {th April }}\end{array}$} & \multicolumn{2}{|c|}{$\begin{array}{c}\text { Rate in the } £ \\
\text { of } \operatorname{Tax}\end{array}$} & \multirow{2}{*}{ 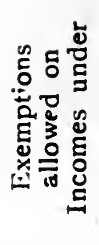 } & \multicolumn{2}{|c|}{$\begin{array}{l}\text { Abatements } \\
\text { allowed }\end{array}$} \\
\hline & 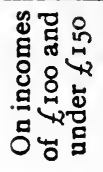 & 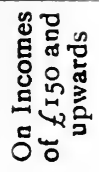 & & 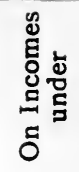 & 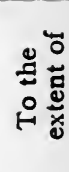 \\
\hline $\begin{array}{l}1843 \\
1844 \\
1845 \\
1846 \\
1847 \\
1848 \\
1849 \\
1850 \\
1851 \\
1852 \\
1853 \\
1854 \\
1855 \\
1856 \\
1857 \\
1858 \\
1859\end{array}$ & $\begin{array}{l}5 \mathrm{~d} . \\
\text { IOd. } \\
\text { I I } \frac{\mathrm{d}}{2} \mathrm{~d} . \\
\mathrm{I} \text { 就 } \mathrm{d} . \\
5 \mathrm{~d} . \\
5 \mathrm{~d} .\end{array}$ & $\begin{array}{c}\text { 7d. } \\
7 \mathrm{~d} . \\
7 \mathrm{~d} . \\
\text { 7d. } \\
\text { 7d. } \\
7 \mathrm{~d} . \\
\text { 7d. } \\
\text { 7d. } \\
7 \mathrm{~d} . \\
\text { 7d. } \\
\text { 7d. } \\
\text { 7d. } \\
\text { I4d. } \\
\text { I6d. } \\
\text { 16d. } \\
\text { 7d. } \\
\text { 5d. }\end{array}$ & $\begin{array}{r}£ 150 \\
150 \\
150 \\
150 \\
150 \\
150 \\
150 \\
150 \\
150 \\
150 \\
150 \\
100 \\
100 \\
100 \\
100 \\
100 \\
100\end{array}$ & & \\
\hline $\begin{array}{l}\text { Half-year ending } \\
\text { Ioth Oct. 1 } 859 \\
\text { 5th April } 1860\end{array}$ & $\begin{array}{l}8 d . \\
5 d .\end{array}$ & $\begin{array}{l}\text { r } 3 \mathrm{~d} . \\
5 \mathrm{~d} .\end{array}$ & $\begin{array}{l}\text { 100 } \\
100\end{array}$ & & \\
\hline $\begin{array}{c}\text { Years ending } 5^{\text {th }} \\
\text { April } \\
1861 \\
1862 \\
1863\end{array}$ & $\begin{array}{l}7 \mathrm{~d} . \\
6 \mathrm{~d} . \\
6 \mathrm{~d} .\end{array}$ & $\begin{array}{l}\text { Iod. } \\
\text { gd. } \\
\text { gd. }\end{array}$ & $\begin{array}{l}100 \\
100 \\
100\end{array}$ & & \\
\hline $\begin{array}{c}1864 \\
1865 \\
1866 \\
1867 \\
1868 \\
1869 \\
1870 \\
1871 \\
1872 \\
1873 \\
1874 \\
1875 \\
1876 \\
1877 \\
1878 \\
1879 \\
1880\end{array}$ & & & $\begin{array}{l}100 \\
100 \\
100 \\
100 \\
100 \\
100 \\
100 \\
100 \\
100 \\
100 \\
100 \\
100 \\
100 \\
150 \\
150 \\
150 \\
150\end{array}$ & $\begin{array}{l}f_{200} \\
200 \\
200 \\
200 \\
200 \\
200 \\
200 \\
200 \\
200 \\
300 \\
300 \\
300 \\
300 \\
400 \\
400 \\
400 \\
400\end{array}$ & $\begin{array}{r}E_{60} \\
60 \\
60 \\
60 \\
60 \\
60 \\
60 \\
60 \\
60 \\
80 \\
80 \\
80 \\
80 \\
120 \\
120 \\
120 \\
120\end{array}$ \\
\hline
\end{tabular}


Table of Rates of Income Tax-(continued).

\begin{tabular}{|c|c|c|c|c|}
\hline \multirow{2}{*}{. } & \multirow{2}{*}{ 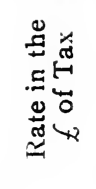 } & \multirow{2}{*}{ 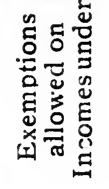 } & \multicolumn{2}{|c|}{ Abatements allowed } \\
\hline & & & 등ㄹ⿺ & 巳્さ \\
\hline $\begin{array}{c}\text { Half-Years ending } \\
5^{\text {th Oct. I } 8 \delta o} \\
5^{\text {th April }} \text { I } 88 \mathrm{I}\end{array}$ & $\begin{array}{l}5 \mathrm{~d} . \\
7 \mathrm{~d} .\end{array}$ & $\begin{array}{l}£_{150} \\
{ }_{150}\end{array}$ & $\begin{array}{r}£ 400 \\
400\end{array}$ & $\begin{array}{l}E_{\mathrm{r}}^{\mathrm{r} 20} \\
\mathrm{r} 20\end{array}$ \\
\hline $\begin{array}{l}\text { Year ending } \\
5 \text { th April } 1882\end{array}$ & $5 \mathrm{~d}$. & 150 & 400 & 120 \\
\hline $\begin{array}{c}\text { Half-Years ending } \\
\text { 5th Oct. I } 882 \\
\text { 5th April } 1883\end{array}$ & $\begin{array}{l}5 \mathrm{~d} . \\
8 \mathrm{~d} .\end{array}$ & $\begin{array}{l}\text { I5O } \\
\text { I5O }\end{array}$ & $\begin{array}{l}400 \\
400\end{array}$ & $\begin{array}{l}120 \\
\text { I } 20\end{array}$ \\
\hline $\begin{array}{c}\text { Year ending } \\
5^{\text {th }} \text { April } 1884\end{array}$ & $5 \mathrm{~d}$. & 150 & 400 & 120 \\
\hline $\begin{array}{c}\text { Half-Years ending } \\
\text { 5th Oct. I } 884 \\
\text { 5th April } 1885\end{array}$ & $\begin{array}{l}5 \mathrm{~d} \\
7 \mathrm{~d}\end{array}$ & $\begin{array}{l}\text { I50 } \\
150\end{array}$ & $\begin{array}{l}400 \\
400\end{array}$ & $\begin{array}{l}\text { I } 20 \\
\text { I } 20\end{array}$ \\
\hline $\begin{array}{l}\text { Years ending } \\
5^{\text {th April }}\end{array}$ & \multirow[b]{2}{*}{ Sd. } & \multirow[b]{2}{*}{ I 50} & \multirow[b]{2}{*}{400} & \multirow[b]{2}{*}{ I 20} \\
\hline I 886 & & & & \\
\hline I 887 & 8d. & I 50 & 400 & 120 \\
\hline I 888 & $7 \mathrm{~d}$. & ${ }^{1} 50$ & 400 & 120 \\
\hline I 889 & $6 \mathrm{~d}$. & I 50 & 400 & 120 \\
\hline I89o & 61. & I 50 & 400 & 120 \\
\hline 1891 & $6 \mathrm{~d}$. & 150 & 400 & I 20 \\
\hline I 892 & $6 \mathrm{~d}$. & 150 & 400 & I 20 \\
\hline I893 & 6d. & $\mathrm{I}_{50}$ & 400 & 120 \\
\hline I894 & $7 \mathrm{~d}$ & I 50 & 400 & I 20 \\
\hline I 895 & $8 \mathrm{~d}$. & I6o & $\left\{\begin{array}{l}400 \\
500\end{array}\right.$ & $\begin{array}{l}\text { I60 } \\
100\end{array}$ \\
\hline I 896 & 8d. & 160 & $\left\{\begin{array}{l}400 \\
500\end{array}\right.$ & $\begin{array}{l}\text { I6o } \\
\text { IOo }\end{array}$ \\
\hline I 897 & $8 \mathrm{~d}$. & I6o & $\left\{\begin{array}{l}400 \\
500\end{array}\right.$ & $\begin{array}{l}160 \\
100\end{array}$ \\
\hline I 898 & $8 \mathrm{~d}$. & 160 & $\begin{array}{l}400 \\
500\end{array}$ & $\begin{array}{l}160 \\
100\end{array}$ \\
\hline r 899 & 81. & \multicolumn{3}{|c|}{ For Exemptions, \&c., see p. 403} \\
\hline 1900 & $8 \mathrm{~d}$ & & ", & \\
\hline I9OI & Is. od. & & $\because$ & \\
\hline 1902 & Is. $2 \mathrm{~d}$. & & " & \\
\hline I903 & Is. $3 \mathrm{~d}$. & & ", & \\
\hline 1904 & I Id. & & , & \\
\hline 1905 & Is. od. & & , & \\
\hline I 906 & Is. od. & & " & \\
\hline $\begin{array}{l}1907 \\
1908\end{array}$ & $\begin{array}{l}\text { Is. od. } \\
\text { Is. od. }\end{array}$ & & , & " earned" \\
\hline roog & Is. od. & income & being ta & at 91 . if \\
\hline I9Io & Is. 2 d. & $\begin{array}{l}\text { total i } \\
£^{2} \text { ooo }\end{array}$ & ome doe & ot exceed \\
\hline I9I I & Is. $2 \mathrm{~d}$. & & $\because$ & " earned" \\
\hline I9I2 & Is. $2 \mathrm{~d}$. & $\begin{array}{l}\text { income } \\
f_{\text {Tax }}^{2.000} \\
\text { if total }\end{array}$ & $\begin{array}{l}\text { Is. if t } \\
\text { ut not } \ell^{3} \\
\text { n amoun } \\
\text { er } £ 5.000\end{array}$ & $\begin{array}{r}\text { exceeded } \\
\text { Super } \\
\text { ver } £ 3 \text {,000 }\end{array}$ \\
\hline
\end{tabular}




\section{N D E X}

Abatement, 56 I30. Chapter VIII., 398. See also Exemptions, Appeals, Deductions

as to application to company, 407

incomes not exceeding $£ 400, £ .500, \& c ., 403 \mathrm{et} \mathrm{seq}$.

facilities for claiming given in the year $18 ; 6-7,402$

forms fö claiming, Chapter X., 493

certificates of deduction and collectors' receipts to be attached to claims, 423, \&c.

claim for, before payment of tax, 403444

, ,, repayment of tax, 418

, in respect of income of infant, 114448

,,, , inarried woman, $409447 \quad 452$

,,$\quad$ joint interest, $409,43^{\circ}$ et seq.

, $\quad$, life insurance premiums. See I.ife insurance.

,, by partner in business. See l'artners.

, , person receiving salary, 4II 4 r2 431 et seq.

,, , beneficiaries under will of deceased person, $409436 \mathrm{et} \mathrm{seq.}$

to persons with certain number of children, $3 \quad 6 \quad 462$

where dividend received "free of income tax," ${ }_{42} \mathrm{~S}$ et seq.

under Schedule A-

on decrease in output, or failure of mine, 15

under Schedules $A$ and $B-$

for loss by flood or tempest, 37

under Schedule J3-

where profits have fallen short of assessment, $\begin{array}{llll}5 & 3^{6} & 3 \pi \mathrm{r}\end{array}$ under Schedule $\mathrm{D}$ -

claim $b_{y}$ successor to business on ground that profits have fallen short of average of past profits from a specific cause. See Succession

on cessation of trade, $3 \gamma^{\prime} \quad 3 \gamma^{2}$ ct $s e q$.

, death, 371372 et seq.

, ground of diminution of incolle in the year of assessment, 6

to person abroad, 6459

under Schedule F: 55 
Abroad. See also Residence, Foreigner.

company investing money abroad, how assessed. See Financial company.

person, dc., abroad carrying on business in United Kingdom may be charged personally or by agent here (if any), go et seq. 114.

, in United Kingdom, carrying on business abroad, liability to assessment in respect of profits, $67 \quad 75$ So et seq.

persons abroad, assessment of, 60

gasworks abroad, 17

abatement to, 6459

business abroad. See above.

deduction not allowed from profits received from abroad, 235

subsidiary company abroad, 8o et seq.

Absentee, temporary, 6o et seq.

Accident policy. See I.ife insvience.

\section{Accounts-}

preparation of, for returns, $15^{2}$

pro formâ accounts, 153154

not always required to be furnished in support of return, 361

required to be furnished on appeal, $3^{61} 3^{6}{ }_{3}$ et seq.

Action, 240, 247

Acts. See Table of Statutes at commencement.

Additional assessments, I $70-\mathbf{I}$.

, commissioners Sec Commissioners, additional.

, $\quad$ salary, charge of, vuder Schedule E, 45

Administrator. See Executors or Administrator.

Advertisements, deduction of ccsts from profits, 224

Aged and Infirm Ministers' Fund, 116

Agent of foreign principal may be charged in respect of profits of foreign principal, go $\mathrm{ct}$ seq.

Agreement, where rent fixed by, assessment of property under

Schedule A, ro

Agriculture. See Farmer.

Alimony, 284

Allowances. See Deductions under respective heads.

"All Taxes"-Exemption from, 21

Almshouses, exemption of, 465475

Alterations, Deductions for. See Improvements. 
Alum mines or works, assessment of, I6 $222 \quad \mathrm{I}_{4} 6$

,, $\quad$ appeals. Șee Appeals.

Amalgamation of railways, 259

", companies, Return in case of, 343. See also Succession

Annual value. See also Assessment, Return, Schedule $A$.

under Schedule A-

general rule for ascertaining, io

where landlord's rates paid by tenant or tenant's by landlord, $3^{6}$

deduction of, from profits, 126 i 50 et seq. 16 г et seq.

of tithes, dues, fines, \&c. See under respective heads.

,, mines of coal, tin, lead, copper, mundic, iron, \&c. See Mines.

„, ironworks, gasworks, salt springs or works, alum mines or works, waterworks, streams of water, canals, inland navigations, docks, drains and levels, fishings, rights of markets and fairs, tolls, railways and other ways, bridges, ferries, \&c. See Ironworks, \&c.

,, works, \&c., is a deduction from profits for assessment to Schedule D, i26 i 50 et seq. i6r et seq.

under Schedule B-

general rule for ascertaining, 34

Annual interest, difference between it and that which is not annual, 272 et seq.

Annuities. See also Interest.

payable "out of profits," 304

, under will, 290

deduction of duty from, by person paying same. See Interest.

," , , analogous to case of a mine, 319

payable at Bank of England, charged under Schedule C, 39

, by Commissioners for Reduction of National Debt, charged under Schedule C, 39

" out of public revenue, charged under Schedule C, 39

, by insurance company, $206 \mathrm{et} \mathrm{seq}$.

, to trustees, 290

small annuities, 1r2. See also Insurance companies. 


\section{Annuities (continued)}

deferred annuity. See Life insurance.

purchase-money converted into, 2;1 2;7 $314 \mathrm{ct}$ seq

terminable, taxation of, 319

What is an annuity? 279

A ppeals, Chapter VI., Part III., 363. See also Abatement, Exemptions. from decision of genera! commistioners on point of law, $36_{3}$

no appeal from general commissioners on question of fact, $3^{64}$.

But see $W^{\circ} \mathrm{e}$ ar and tear.

from decision of special commissioners on any point, $36_{3}$

to Board of Inland Revenue, 364

, High Court (King's Bench Division), or Court of Session, sculikind, $3^{\sqrt{3}} 3$

from High Court to Court of Appeal and House of Lords, 363 setting off loss under cne Sihedule against profit under another, or against taxed interest (Act of 1 Sgo), $5349 \quad 3^{6,8} \quad 371 \quad 375 \mathrm{et} \mathrm{seq}$. club lsuilding Co. Claim under Act of 1 \$go disallowed, 379. claim under Act of isgo, deduction of wear and tear. See Wear and tcar.

return of profits after appeal under Act of 1 Sgo See Return of profits.

limitation of time, $114 \quad 151 \quad 171 \quad 299 \quad 370 \quad 451 \quad 465$

on the ground of exemption to be to general commissioners, 363 .

in respect of assessment under Schedule A-

may be made by either landlord or tenant, 2329

usually to general commissioners, 38

in cases of mines, quarries, ironworks, \&c., may be to special commissioners, 38

in respect of assessment under Schedule B. See Farmer.

,, ,, tax deducted from interest under Schedule C. See lixemptions.

in respect of assessment under Schedule 1 -

to general commissioners, $3^{6} 3$

, special commissioners, $3^{6} \mathbf{3}$

against assessment by additional commissioners, 363

notice to be given to surveyor, $3^{6} 3$

actual procedure-not usually necessary to appear before commissioners, settlement may usually be arranged with surveyor, 368

evidence, $3^{6} 5$ 


\section{A ppeals (continued).}

accounts to be furnished in accordance with precept of commissioners, $3^{6} \mathbf{1} 3^{6} 3$ et seq.

from decision of general or special commissioners on point of law. See above.

, $\quad, \quad$ special commissioners on any point. See above. no appeal from decision of general commissioners on question of, fact. See above.

production of books, $3^{6} 5$

request to be put on oath, $36_{5}$

in case of cessation of trade or death, $370372 \mathrm{et} \mathrm{seq}$.

return for assessment after claim under Act of $1890, \quad 166 \quad 184 \quad 376$ $380 \quad 389$

in respect of assessment under Schedule E, 56

Application of profit and liability to tax, $64 \begin{array}{lllll}67 & 625 & 230 & 231 & 47\end{array}$

Appreciation. See Financial companies.

Assessment. See also Return.

of both property under Schedule $\mathrm{A}$ and interest under Schedule D. See Double Assessment.

,, assize courts, public buildings, charities, \&c. See under respective heads.

in case of discontinuance of portion of undertaking, $73 \quad 330 \quad 335$ two or more businesses-one discontinued, 340

under Schedule A. See also Schedule A.

by general commissioners, Chapter III., ro

of dwelling-houses of less annual value than f.io, 23

description of profits chargeable, Chapter III., Io

railways. See Railways.

where no return made, 37

notice of assessments to be given, 37

right of appeal. See Appeals.

made every five years, 38

adjustment of, in first four years, 38

deductions. See under respective heads.

of Cost Book mine, land, quarries, \&c. See under respective heads.

deduction of annual value under Schedule $\mathrm{A}$ from assessment under Schedule D, i 26 i 50 et seq. 16i et seq.

under Schedule B. See under Schedule A, above; also Farmer. by general commissioners, Chapter III., Io. 


\section{Assessment (continucd)}

general rules, 34 .

to be on basis of Schedule $\mathrm{A}$ assessment, 34

under Schedule C. See also Government securities.

by special commissioners, 39

of annuities payable by Bank of England, 39

$\begin{array}{cccc}, & \text { out of public revenue of United King- } \\ \text { dom, } 39\end{array}$

under Schedule $\mathrm{D}$ -

place of charge, 146

by general commissioners. See Commissioners, general

,, special commissioners. See Commissioners, special

under number or letter. See Number or letter.

of dividends of foreign and colonial companies, 39

,, interest. See Interest.

,, profits for discontinuance of business, 227

trades, \&c. See Trades, \&c.

of partners, to be assessed jointly. See Partners.

in case of change in a partnership. See Succession.

where no return made, I70-I

additional or supplementary, I 70-I

of new business. See New business.

", insurance companies, property companies, betting profits, coal dues, municipal corporations, railway companies, financial companies, woolbrokers, mines, \&c. See under respective heads.

„, company investing money abroad. See Abroad.

, bank officer occupying bank house, 453

double assessment. See Double assessment.

under Schedule E. See Schedule E.

Assessor to send out forms of return, 133

Assize Courts, Exemption of, 467

Assurance company. See Insurance companies.

Asylum. See Lunatic asylums.

Auditors of public companies, fees chargeable under Schedule E, 44 
Average. See also Assessment, Return.

return of salaries, \&c., to be on three years' average, $4^{12}$

profits of business to be on three years' average, 126

,, mines, quarries, ironworks, \&c. See under respective heads.

assessment of profits where any interest commenced within period prescribed for taking average, 22. And see New business.

director of company may not bring past losses into average against salary under Schedule E, $4^{8}$

in case of change in, or succession to, a business. See Succession. years to be brought into, 125159

where there is a loss in one year, 164 . Sce also Return of profits.

, , $\quad$ an average annual loss, 169

effect in case of succession, $34^{2}$

\section{Bad Debts-}

deduction of, 126247 et seq.

Bank manager occupying bank house, liability to assessment, 453

Bank house occupied by-manager, deduction of annual value of premises from profits of bank for purpose of assessment, 249

\section{Bank of England--}

gorernors and directors are commissioners for assessing dividends,

\&.c., payable at bank, 39

,, , , , , to deduct tax on payment of annuities, sc., 39

in case person exempt, dividends may be paid without deduction, $43 \mathrm{I}$

Bank, foreign, 64

Bank interest, $\mathrm{I}_{5} 2 \mathbf{\gamma}_{2} 306$ et seq.

\section{Banker-}

interest on short loans by, deduction of tax, 272

to deduct tax on payment of foreign coupons, 40,64

Bankrupt business partially carried on, 73

,, $\quad$,, proof for tax, 284369

Barrister, right to appear on appeal, $36_{5}$

Baths belonging to corporation. See Municipal corporation.

Beneficiaries. See Joint tenants.

Benevolent Fund. See Railways.

Betting profits liable to tax, 67 
Birmingham principle. See Municipal corporation.

Board of Inland Revenue. See Commissioners of Inland Revenue.

Bonds, repayment of. Deduction from profits under Schedule D, 224

\section{Bonus-}

paid by proprietary life office is liable to tax. See Life insurance companies.

payable by borrowers of money is not a deduction, 233

paid to members of staff, $48 \quad 160$

\section{Books-}

production of. See Appeals.

cost of, 246

Branch, foreign, of English bank, profits taxable, $\delta_{4}$

, sold, assessment, 335

Breeder. See Cattle dealer.

\section{Brewer-}

deduction of premiums paid for leases-of public-houses, 224

, money paid for call of licences, 238

, damages paid for injury to guest, 240

bad debts, 247 et seq.

repairs to tied houses, 250

depreciation in value of leases, 133226

payment for call of licences, 238

extension of licence, 341

Licensing Act, $2725 \mathrm{I}$

Bridges, assessment of, $1622 \quad 146$

, appeals. See Appeals.

British possessions. See Colonial possessions.

Brokerage, deduction of, from profits, 234

Building societies, 284 et seq.

\section{Buildings-}

when occupied for purposes of trade, annual value under Schedule $A$ is a deduction from profits for Schedule D, 126 150 et seq. i6r et seq.

public buildings, exemption of, from assessment, Chapter VIII., Part II., 465

loss on sale of. See Financial companies.

depreciation of, 133

allowance to be made for buildings unoccupied, 37 
Burgh court, exemption of, 470

Burial board, profits of. See Cemetery.

Bursar, assessment of salary of, $45^{2}$.

Business. See alśo Trade, \&c.

business abroad. See Abroad.

return of profit to be on three years' average. See Average.

new business. See New business.

"Call of licences," 238

Canals, assessment of, 1622146

, appeals. See Appeals.

\section{Capital-}

interest on, 127360

deduction of capital paid, 127226245

loss of, 133

exhaustion of, 314 et seq.

productive, 13

"Carried on," as contrasted with "Controlled," $8_{5}$

Case I, 2, 3, \&c. See First case, Second case, \&c.

\section{Case-}

stating case for opinion of Board of Inland Revenue, 363

$$
\text { ,, , , Court, } 363
$$

Cases in the Courts. See Table of cases, $x i$.

Cash Account contrasted with Profit and Loss Account, 157

Casual profit not assessable, 7 I 7475 I I5

$$
\begin{aligned}
& , \quad \text { on sale of patent rights, I I } 5 \\
& ,, \quad \text {, change of investment, I I } 5
\end{aligned}
$$

Casualty of superior, 33

Cattle dealer, assessment of profits of, I13

\section{Cemetery or burial board-}

proceeds of sale of land assessable, 319

amount received for upkeep of lair is assessable, 73

if owned by municipal corporation. See Municipal corporation.

Certificates of deduction in case of claim for exemption, \&c., 435, \&c., 503

Chalk quarries. See Quarries.

Change in partnership. See Succession.

, of investment. See Casual profit. 
Chapel, exemption of, $46_{5}$

Charge, place of, 146

Charging income at source, 2 2\%o

Charitable subscriptions, 160

Charities, \&c., Chapter VIII., Part II., $46_{5}$

Exemption of, 370

\section{Chief Rent-}

deduction of tax from, 297

$$
\text { ,, from profit, } 159
$$

Children, allowance to person with certain number, $36{ }_{462}$

Church, dues in right of, annual value, 13

, exemption of, $4^{6}{ }_{5}$

Claims. See also Abatement, Exemptions, Appeals.

time within which to be made. See Limitation of time.

\section{Clergyman-}

may deduct necessary expenses, 49

, ,,$\quad$ travelling expenses, $5^{\mathrm{r}}$

,, not deduct payments to another to perform his duty, 49, 54

," , annual value of study, 5 1268

exemption of houses occupied by Wesleyan ministers under

Schedule A, $3^{8}, 45^{1}$

voluntary contribution by parishioners is chargeable, 49

various deductions, 54

allowance from Aged and Infirm Ministers' Fund, ir6

, , Queen Victoria Clergy Sustentation Fund is chargeable, $5 \mathrm{I}$

, , Curates' Augmentation Fund is not chargeable, 50

, , Ministers" Stipend Augmentation Fund is chargeable, 53

Easter offerings are chargeable, 5354

Clerk. See Salary.

Club. See Mutual concern.

, Building Company and Act of r8go. See Appeals.

Coal dues, liability to assessment, 62

,, mines. See Mines.

,, Owners', \&c., Association, subscription to, 237242 


\section{Collector's receipt-}

to be given up by tenant on his claiming duty from landlord, 23

, attached to claim for exemption, \&c., 444

College of Surgeons in Edinburgh not exempt, 473

Colleges, exemption of, $46_{5} 473476$

Colliery. See Mine.

Colonial companies. See Foreign companies.

, possessions. See Foreign possessions.

, revenues. See Schedule C.

,$\quad$ securities. See Foreign securities.

Colportage, loss on, $7 \mathrm{I}$

Commission for placing shares, deduction of, from profits, 234

, $\quad$ paid to employee, $48{ }_{16} 60$

\section{Commissioners, additional-}

to assess duties under Schedule D, I 70

\section{Commissioners, general-}

assessnents under Schedules $A$ and B by, Chapter III., to

appeals under Schedules $\mathrm{A}$ and $\mathrm{B}$ to, 38

assessments under Schedule D by, 129 I47

may require overseers to produce Rate Books, 37

appeal to. See Appeals.

,, from decision of. See Appeals.

to hear claims for exemption. See Appeals.

\section{Commissioners of Inland Revenue-}

appeal to. See Appeals.

stating case for opinion of, $3^{6} 3$ et seq.

decision final, $3^{6} 3$ et seq.

\section{Commissioners for Reduction of National Debt-}

to assess certain duties, 39 .

\section{Commissioners, special-}

to assess railways. See Railways.

person may require himself to be assessed by, 129148

appeal to. See Appeal.

, from decision of. See Appeal.

to hear claims in respect of charities, \&c., 467

make all assessments in Ireland, 147

- Common, tenants in. See Joint tenants.

, errors in making returns, $3^{62}$

Commutation of salary, deduction of amount from profits, 236

, , , annual payment of upkeep of lair, 73 


\section{Company or corporation-}

same as " person," 39r (see also Person)

residence of. See Residence.

business abroad, profits chargeable. See Abroad.

profits of office held under a company are chargeable under

Schedule E. Chap. V., 44 .

one owned by another, assessment, 349.

Construction of Taxing Acts, 677

Constructive remittance, 186193 ig6 et seq.

Contract for payment of rent or annual interest, \&c., without deduction of tax, 2930

"Controlled," as contrasted with " Carried on," $s_{5}$

Co-operative societies, assessment of, 117

Copper mines. See Mines.

Corporation. See Company.

,, Municipal. See Municipal corporation.

Copyrights. Assessment, 2 10

Cost Book mine, assessment of, 321

Coupons, banker to deduct tax on páyment of, 4064

Curates' Augmentation Fund, contribution from, not assessable, 50

Dairyman, 113

Damages, 240247

Dead rent, 322

Dealer in cattle, 113

, milk, i 3

,, stocks and shares, I $_{5}$

Death, abatement. See Abatement.

,, of partner. See Partners.

Debentures issued for interest, 185

commission on issue of, 234

interest and lessee, 170

, where security not equal to loan, deduction of tax, 291 292

premium for insurance of, 234

Debts, bad or doubtful, 126247 et seq.

, treatment of, in accounts, $15^{6-7} \quad 362$

Deceased persons, 114372

Decisions in the Courts. See Table of Cases at commencement.

Deduction of tax. See also Rent, Interest.

rate of, Chapter VII., 392

by railway companies from officials. See Railways.

from Government salaries, 44 
Deductions from profits or annual value-Chapter III., 10

under Schedule A, 370

of tithes and land $\operatorname{tax}, 3^{2}$

,, casualty of superiority disallowed, 33

,, cost of repairing sea-walls, 33

,, ,, embankment for improvement of land, 33

, , collection of manorial rates, 34

,, expenses of collecting tithe, 32

,, insurance premium, 19

on account of repairs, 5 io

in case of concerns assessed under Schedule $\mathrm{A}$ according to rules of Schedule D. See under respective heads. under Schedule B. None.

,, , C. None.

under Schedule D, 126

action, costs of, advertisements, \&c. \&c. See under respective heads.

annual value under Schedule A of works (or rent), 126 I 50 et seq. 16r et seq.

interest not to be a deduction, 127 r $5923 \mathrm{r} 296 \mathrm{et}$ seq.

, not to be a deduction though person paying did not deduct tax, 226

, payable by corporation. See Municipal corporation.

,, $\quad, \quad$ to foreigner, 296305 et seq.

, , " "out of profits." See Interest, Deduction of tax on.

, petition of right where tax paid both on profit and interest, 299

under Schedule E. (See also under Schedule D)-

in case of clergymen. See Clergyman.

contribution under Poor Law Officers' Superannuation Act, 55 263

expense of keeping horse, \&c., 45

, travelling. See Travelling.

payment to another to perform duty. See Clergyman.

annual value of study. See Clergyman.

schoolmaster, wages of servant, $45^{2}$

of life insurance premiums. See Life insurance.

Deduction of tax on payment of rent, interest, \&c. See Rent, Interest.

Defalcation, 246

Deferred annuity. See Life insurance. 
Depreciation. See Wear and tear, Leases, Railways.

, in value of investments. See Financial company.

Development company. See Land development company.

Differentiation, 477

Diminution of income. See Appeals.

Diocesan Fund. See Clergyman.

Directors, assessment of, 4445 II 5 327. See also Specific cause-and Succession.

Discontinuance, 330 370 372 . See also Succession and Abatement. of portion of undertaking, 73330335

,, business, profit for, 227

,, one of two or more businesses, $34^{\circ}$

Discount on payment of tax in advance, 170

Dissolution of partnership, 343

Distraint for tax, 30

Dividends paid "free of income tax," +28

Docks, assessment of, 1622146

,, appeals. See Appeals.

Domestic expenses, deduction of, 127

\section{Double Assessment-}

relief on ground of, 150299371

assessment of both profit and interest on mortgage payablepetition of right, 299

Doubtful debts. See Debts.

Drains and levels, assessment of, 161722146

$$
\text { , , appeals. See Appeals. }
$$

Drawings from business no relation to profit, 362

Driving levels, 320

Dues, ecclesiastical, assessment of, 13

" payable to corporation. See Municipal corporation.

Duty on coal, assessment of, 62

, variation in rate of, and deduction of tax, Chapter VII., 392

\section{Dwelling:houses-}

if used for trade, deduction of value of, 126248

if of less annual value than $£ 10$, assessment of, 23

whether hotel is a dwelling-house, 249

Earned incomes, 63444 1 30 160 371. Chapter VIII., Part III., 477 
Easter offerings. See Clergyman.

Ecclesiastical dues, assessment of. See Dues.

Electric works, depreciation of, 222

Embankment for improvement of land, deduction of cost, 33

Embezzlement, loss by deduction of, from profit, 246

Emoluments. Seé Schedule E.

Employees, employer to return list of, $454^{12}$

,, admitted partners, $34^{1}$

,, also carrying on business, 349

, abroad, assessment of, 60

, $\quad$ tax paid for him, 1604.55

Employment. See Trade, \&c.

Empty buildings, 37

Errors, common, in making returns, 362

Exchequer securities. See (iovernment securities.

\section{Executors or administrator-}

to return profits of deceased, $\mathrm{dc}, \mathrm{11}+3 \pi^{2}$

Exemptions, 456 i 3 o. Chapter VIII., 398. See also Abatements, Appeals.

as to application to company, 407

limit of exemption fir6o, 403 et seq.

facilities for claiming given in the year $18 ; 6-7,402$

from " all taxes," 2I

claims for, before payment of tax, 403, 444

,, ,, repayment of tax, $4 \mathrm{I} S$

, usually to be heard by general commissioners. See Appeals.

, to be heard by special commissioners in case of charities, \&c., 467

, in respect of Assize Courts, almshouses, Burgh Court, \&c. See under respective heads.

, by partners. See Partners.

, person abroad, 6459

, $\quad$ executors, 372

,, person receiving salary, 4II 43 I et seq.

,, beneficiaries under will of deceased person, $409436 \mathrm{et} \mathrm{seq.}$

forms for claiming. Chap. X. 493

certificates of deduction and collector's receipts to be attached to claims, 423 \&c.

dividend "free of income tax," 29428 


\section{Exemptions (continued)}

where stocks registered at Bank of England, 431

" profits" not exempt though applied to charitable purposes, 471

to person abroad, 6459

Exhaustion of capital, 314 et seq.

Expenses, 127224251

Expert valuer-refusal to hear, 28

Extension of lines. See Railways.

Failure of mine. See Mines.

, to make return. See Penalties.

Fairs, rights of, assessment of, 1622146

False return. See Penalties.

,, claim. See Penalties.

Family, maintenance of, 127

Farmer, 5353637 i, and see Schedule B.

Fees. See Schedule E.

Ferries, assessment of, 1622146

, appeals. See Appeals.

Fifth case of Schedule D, see also Financial company, 597981 I07 II

$$
128186 \text { et seq. } 235
$$

,, ,, ,, difficulties of, 107200

\section{Financial company-}

return of profits in respect of, $179186 \mathrm{et}$ seq.

shares as profit, $74 \quad 116$

claim under Act of 1890,385

fluctuation in value of securities, 192

profit or loss on sale of investments, I 15 I91

$$
\text { , , , buildings, } 115
$$

constructive remittance, I86 193196 et seq.

Fines. See Leases.

Fire Insurance Companies. See also Insurance companies.

deductions on account of unearned premiums, 191203 et seq. deduction of premiums paid, 133

\section{Fire-}

loss of mill by, 246

,, stock by, 246

First case of Schedule D, see also Financial company, $5^{8} 788_{1}$ I 20 I68 188 et seq. 
Fishings, assessment of, $1622{ }^{2} 46$

, appeals. See Appeals.

Fleet of steamers, \&c. See Ships.

Flood or tempest, loss by, 37

Fluctuation in value of securities. See Financial company.

Foreign companies, dividends of foreign and colonial companies chargeable under Schedule D. See Assessment.

\section{Foreign Bank-}

branch in United Kingdom entrusted with payments of dividends, liability to tax, 64

Foreign branch of English bank, profits taxable, 84

,, worked by subsidiary company, assessment of company, so et seq.

business. See Abroad.

firms doing business in United Kingdom. See Abroad.

insurance company, premiums paid to. See Life insurance.

possessions. See Fifth case.

securities. See Fourth case.

,, memorial as to, ios

States. See Schedule C.

telegraph company, 84

estate expenses here, 235

Foreigner. See also Residence, Abroad.

may be charged personally or by agent. See Abroad.

liability for tax on profit on orders obtained by agents in United Kingdom, 90 et seq. I I 4 .

interest payable to, may not be deducted from profits, 296

Forms to be used, Chapter X., 493

Fourth case of Schedule D, see also Financial company, 59 I13 128 186 et seq.

Fraudulent claim. See Penalties.

Free libraries, exemption of, 473474

"Free of all deductions," in will, \&c., usually does not include deduction of income tax, 29

"Free of income tax"-

expression should not be used, $42 S$

claim for exemption or abatement in case of dividend so paid, $42 S$ et seq. 


\section{Friendly Societies-}

exemption of, $409,466,46_{7}$

premiums paid to, 266

Funds. See Government securities.

\section{Gas: works-}

assessment of, $1622 \quad 146$

belonging to municipal corporation. See Municipal corporation. depreciation of, 221

abroad, 17

appeals. See Appeals.

General commissioners. See Commissioners, general.

Gift of money to clergyman. See Clergyman.

Gifts not generally income, 112

Goodwill, 246

Government officials. Tax on salary is payable under Schedule E, 44

Government securities. See Schedule C.

small dividends or annuities charged under Schedule D, 112 interest on savings bank deposits charged under Schedule D, I 2

Ground rent. See Chief rent.

Guaranteed dividend, 239 .

Halls, exemption of, 465473475

High Court. See Appeals.

Hire-purchase, 289

History of Income tax. Chap. I., I, and see Income tax.

Hop girdens, assessment of, 34

Horses, expenses of keeping, 45

,, depreciation of, 214

Hospitals, exemption of, 465469471

Hotel, owner residing on premises, 249

House of Lords. See Appeals.

Household expenses, I 27

Houses. See I,ands, \&c.

Husband chargeable for wife. See Married women.

Husbandry. See Farmer.

Improvement of line of railway. See Railways.

, land, deduction of cost of embankment for, 33

Improvements, deduction of cost of, 127229230 


\section{Income-}

benefit must be capable of being turned into money or is not income, $45^{1} 453$ et seq.

for abatement purposes "totål" income includes income not assessable in U. K., 460

Income tax, origin and history of, Chapter I., I

ceased in 1816,3

deductión of, from interest, \&c. See Interest, Deduction of tax on payment of.

discount cn payment of, izo

reimposed in 1842,3

not to be deducted from profits for assessment to Schedule D, $\begin{array}{lll}127 & 133 \quad 159\end{array}$

is a personal $\operatorname{tax}, 360$

when payable, 170

rates of, 5 I 4

paid for employees, 160455

Incorporation of partnership creates a succession. See Succession.

Increases of salary of schoolmaster, 265

Indian officers, pensions of, 107

Industrial society, 466

Infant, $114,44^{\mathrm{s}}$

Inland navigations, assessment of, 1622 I46

, , , appeals. See Appeals.

,, Revenue. See Commissioners of Inland Revenue.

Innkeeper. See Brewer.

Insolvency, liquidator's liability for tax, I49

,$\quad$ tax deducted is payable in full, $2 S_{4}$

Instalment of lcan, deduction of, 224

\section{Institutions-}

Literary. See Literary institutions.

Public. See Public buildings.

Scientific. See Literary institutions.

Insurance Companies. See also Financial company-Life insurance. assessment of interest received by, $18_{4}$, and see Fourth case.

,, ,, proprietary company, 98

., , , mutual company, 102

,, ,, after claim under Act of 1890,184380

,. $\quad$,, profits of, 98 i $86 \mathrm{et} \mathrm{seq.}$

,, in respect of annuities payable, 206 


\section{Insurance companies (continued)}

fire company and unearned premiuns, 191 203 et seq. interest paid to company by borrower. See Bank interest. application of decisions in practice, $200 \mathrm{et} \mathrm{seq}$.

Insurance, Life. See Life Insurance.

, Marine. See Underwriter.

, premiun paid to insure debentures, 234

,,$\quad$ as deduction from Schedule A assessment, 19

Interest (and Annuity)-

annuity paid in full, liability of trustees, $2 \$_{4}$

assessment of debentures or shares issued in lieu of interest, $18_{5}$ commissioners for assessing interest under Schedule C. See Schedule C.

deduction of, $127159206 \mathrm{ct}$ seq.

interest appropriated to Sinking Fund, 225230231

payable out of public revenue chargeable under Schedule C. See

Schedule C.

tax to be deducted on payment. See Schedule C.

of money, ${ }_{1} 8_{4}$

on foreign securities. See Foreign sccurities.

payable by foreign or colonial company. See Foreign companies.

,$\quad$ corporation. See IIunicipal corporation.

annual, meaning of, $272 \mathrm{et}$ seq.

distinction between annual interest and that which is not annual, 272 et :eq.

profit not equal to interest, interest to be taxed, ;o 169

treatment of, in accounts of a financial company. See Financial

company.

chargeable as a distinct head of income, $18_{4}$

received abroad by British company. See Financial company.

on partner's capital. See Capital.

received by insurance company. See Foreign securities.

deduction of tax on payment of interest or annuity, 269 et seq.

\begin{tabular}{|c|c|c|}
\hline & ,' & ", interest as damages, 291 \\
\hline & ," & on taking over railway 294 \\
\hline & ", & ", alimony, 284 \\
\hline & "' & , arrears of annuity, $28_{4}$ \\
\hline & ", & " interest payable in a lump sum, 275 \\
\hline , & ", & $\begin{array}{l}\text { „, fixed percentage of receipts, } 293 \\
\end{array}$ \\
\hline
\end{tabular}




\section{Interest (continued)}

deduction of tax where interest paid in goods, 296

$$
\text { , , } \quad \text { security not equal to loan, } 291292
$$

contract for payment without deduction void, 29

, not void if tax still falls on recipient, 30

free of all deductions, 29

where payable out of profits, 207276302304306

,, not payable out of profits or not wholly, 305 et seq.

if tax not deducted on payment, cannot afterwards be deducted or recovered, 273

on short loans by bankers, 272

,, ," ,, corporation, 29I ; and see Municipal corporations.

,, instalment of composition, 275

,, ,, ,, purchase-money, 271277 et seq.

received by railway company on purchase by Government, 294

payable to foreigners, 299308

on bill of exchange, 273

included in wagon instalments, 289

buildings societies, 284 et seq.

person paying may deduct tax if interest annual, 269 et $s e_{\%}$.

bank interest. See Bank interest.

on Exchequer 13ills, 42

,, partners' capital. See Capital.

Investment, casual profit or loss on change of. See Casual profit.

, profit or loss in case of financial company. See Financial company.

, trusts. See Financial company.

Ireland, extension of income tax to, 4

, all assessments under special commissioners, I47

Iron mines. See Mines.

Ironworks, gas works, salt springs or works, alum mines or works, water works, streams of water, canals, inland navigations, docks, drains and levels, fishings, rights of markets and fairs, tolls, railways and other ways, bridges, ferries, \&c.

assessed under Schedule A, 1622146

assessment to be according to rules of Schedule D, 21

, where interest commenced within period prescribed for taking average, 22

appeals. See Appeals. 
Joint tenants, claiming exemption or abatement, $409436 \mathrm{el}$ seq.

Lairs, upkeep of, 73

Land, houses, \&c. See also Landlord.

charged under Schedule $A$, ro

depreciation of, 133

poor rate valuation is basis for assessment, 2328

assessment to be on rack rent, 10

, where rent fixed by agreement, ro

,, usually on occupier, 23

if let for less than one year, assessment to be on landlord, 23 part proceeds of sale of, 105319

\section{Landowner or Landlord-}

relief to, in case of loss by flood, dec., 37

appeal by, 2329

tenant usually charged for tax under Schedule $A$, but may deduct

tax on rent from landlord, 23

tenant must usually appeal, 28

formerly tenant had to deduct tax from next payment of rent, 24

now tenant in certain case may deduct tax from any future payment of rent, 24, 30

assessment if his taxes paid by tenant, $3^{6}$

deduction of tax by tenant where assessment exceeds rent payable, 23 et seq.

relief to landlord in Ireland in case of loss by bankruptcy of tenant, $37 \mathrm{r}$

Land sales, profit on, 105,310

, tax, deduction of, from schedule 1,32

,, development company, assessment of, ro7

Law costs, 240, 247

Lead Mines. See Mines.

Leased lines. See Railways.

\section{I.eases-}

depreciation in value of, 133226 . See also Brewer.

fines applied as productive capital, 13

, on renewal assessed under Schedule A, r3

premium paid for, cannot be deducted from profit, but purchaser

may charge annual value of property against trading, 26

premiums received on renewal of, 325

purchase money of, paid by instalments, deduction of tax, $28_{3}$

debenture interest and Schedule A assessment, I 7 ,

Letter or number, $129, \mathbf{r}_{4} \mathrm{~S}$ 


\section{Levels-}

assessment of, 16 I7 22 I46

appeals. See Appeals.

expense of driving, 320

Libraries, free. See Free libraries.

Licences. See Brewer.

Licensing Act levy, $2725 \mathrm{I}$

\section{Life Insurance or deferred annuity-}

allowance for premiums paid up to one-sixth of income, 4 127 I30

$$
259 \text { et seq. } 455463
$$

,, $\quad, \quad$ includes accident policies, 267

, , , , does not include single premium policy 268

$, \quad, \quad, \quad$ paid to friendly society, 266

thrift fund, 26r et seq.

allowance for premiums not to entitle to greater abatement if income brought within limit thereby, 259463

limitation of time for making claim, 370464

Life insurance companies. See Insurance companies.

Lighting public streets, deduction of cost of, 233

Limestone quarries. See Quarries.

\section{Limitation of time-}

for claims for repayment, I $5^{1}$, $29937045^{1} 46_{5}$

,, by surveyor, 114 I 7 I

, for penalties. See Penalties.

Liquidator's liability for tax, I49

List of Forms. See Forms.

, employees. See Employees.

Literary institutions, exemption of, $46_{5} 473474475$

Loan, deduction of instalment on repayment, 224

Loss. See Profits.

not connected with business, deduction of, $12722424025 \mathrm{I}$

by fire, 246

claim for loss in year. See Appeals.

Lunatic asylums, exemption of, 469

Machinery, wear and tear of. See iVear and tear.

, let, wear and tear of. See Wear and tear.

, loss by removal of, 229

, what is "Plant," 219

Mandamus, 365 


\section{Manors-}

profits of, charged under Schedule A, I3

rates, deduction of cost of collection of, under Schedule A, 34

Marufacturers' Association, 237242

Marine insurance. See Underwriters.

Markets, rights of, assessment of, i6 22 146. See also Municipal corporation.

appeals. See Appeals.

\section{Married women-}

her income deemed to be her husband's, 5 I $2940944745^{2}$

claim of, for exemption or abatement, $40944745^{2}$

Milk, dealer in, how charged, 113

Mill, loss of, by fire, 246

Mines. See also Iron works.

of coal, tin, lead, copper, mundic, iron, \&.c., assessed under Schedule A, 15 II

assessment to be according to rules of Schedule D, 2 I

, where interest commenced within period prescribed for taking average, 22, and see New business.

, , mine owner acquires another mine, 344

decrease in yield or output, or failure of, relief, 15

where slate obtained by underground workings, concern is a

quarry, 16

expense of driving levels, 320

appeal. See Appeals.

pit-sinking and exhaustion of capital, $3: 4$ et seq.

analogy between assessment of mines and of annuities, 319

deductions from profits, 237

Cost Book mine, principle of assessment, $32 \mathrm{I}$

nitrate company, $3^{18}$

royalties, dead rents, or minimum rents, $3^{1} 322$

, omission to deduct tax from, 3 I

subsidence, 246

subscription to Coal Owners' Association, 237242

Minimum rents, 322

Minister. See Clergyman.

Ministers' Stipend Augmentation Fund, 53 
Minors, parents chargeable for, II4

claim for exemption or abatement, 448

absolute interest, 448

contingent interest, 448

Mortgage companies. See Financial companies.

, debenture. See Debenture.

, interest on. See Interest.

Mundic mines. S€e Mines.

\section{Municipal corporation-}

creditors on rates, how charged, 303

mode of assessment, $688730335^{2} \mathrm{et} \mathrm{seq}$.

proportional system, $35^{2}$

baths belonging to, 68470

markets belonging to, 68

slaughter-house belonging to, 6869

water-works belonging to, $\sigma_{3} 6_{9} 8889$

gas-works belonging to, $6_{3}$

tolls receivable by, $6 \delta$

cemetery belonging to, 67232

town hall, 475

set off of interest paid against profit of earning departments, 357

dues payable to, 68

interest payable by, 392, and see Mode of assessment (above).

free libraries belonging to, 473474

Mutual life office. See I,ife Insurance companies.

, concerns cannot make "profit," 105

National Debt certificates, 39

Navigations, inland, assessment of, 1622146

New books for company, deduction of cost of, 246

·, business, $22 \quad 167$ et seq. 344369

Nitrate company, $3^{1} \delta$

Non-residents. See Residence.

Notice of Appeals. See Appeals.

Number or letter assessments, $12914 \mathrm{~S}$

Nursery gardens, assessment of, 35

Oath, request to be put on, $36_{5}$

Obsolescence, 175

Occupation of land charged under Schedule B, 34 


\section{Occupier of land or houses-}

charged under Schedule A, but may deduct tax from owner, 23

Offices under companies charged under Schedule E, 44

Omission by occupier to deduct tax from rent, 2430

Omnibus company, depreciation of horses, 214

One-man company, 346482

Opposition to new scheme, deduction of expense in case of railways, 259

Origin of Income 'Iax. Chapter I., I

Output of mine, decrease in, relief, 15

Over-payment of duty. See Abatements, Exemptions, Appeals.

Overseers to produce Rate Books, 37

Owner, occupier generally chargeable for, 23

Owner-occupier and deduction of annual value, 126 i5o et seq. 161 et seq.

Paper profits. See Financial company.

Parliamentary expenses, deduction of, in cases of railways, $25^{8}$

Participating policy-holders. See Life insurance companies

\section{Partners-}

usually charged jointly, 327

incidence of tax as between, $34^{5} 403$ et seq.

may require to be charged separately in order to claim exemption or abatement, $3^{27} 403$ et seq. $44 \overline{6} 477$ et seq.

return of profits, where employee admitted partner, 341

death of partner or change in firm, how return to be prepared. See

Succession.

dissolution of partnership, how return to be prepared, 343

in foreign house. See Abroad.

claiming "relief." See Earned incomes.

interest on capital not to be deducted, 127

, , $\quad$ tax should be deducted before crediting partner, 360

salaries not to be deducted, 127 133 $34^{\mathrm{I}}$

, $\quad$ tax should be deducted before crediting partner, 360

return after claim under Act of 1890,166

Patent rights, deduction of, 246

, , , royalties, 149293

, , $\quad$ sale of, $1 \mathbf{I}_{5}$

Payment of tax, time for, 170

Peel, Sir R., re-imposition of income tax, 3 
Penalties, 45133134 et sequ. I 7 I 400 et seq.

Pensions of Indian officers, 107

Percentage of receipts, 293

Period. See Time.

Personal tax, inconie tax is a personal tax, 360

Persons chargeable, Chapter VI., Part I., 57

\section{Persons residing out of United Kingdom-}

agent may be charged. See Agent.

Petition of right, 299

Philanthropic institution, profit of restaurant, 73

Pit-sinking, deduction of, $3^{14}$ et seq.

Place of charge, 146

, residence. See Residence.

, worship. See Church.

Placing shares, commission for, deduction of, 234

Plant. See Machinery, Wear and tear.

Police stations, exemption of, 467

Poor Law Officers' Superannuation Act, 55263

\section{Poor rate-}

as to basis of assessment for Schedule A, 2328

overseers to produce Rate Books, 37

Portion of undertaking, discontinuance of, 73330335

Possessions abroad. See Foreign possessions.

Precept of commissioners requiring accounts in support of appeal, $36 \mathrm{r}$

$3^{6} 3$ et seq.

Preliminary expenses of formation of company, deduction of, 246

Premises occupied, profit or loss on sale of. See Financial company.

\section{Premium-}

allowance for life insurance premiums. See Life insurance.

deduction of unearned premiums in case of fire insurahce com-

$$
\text { pany, 191 } 203 \text { et seq. }
$$

, , , amount paid for insurance of debenture, 234

paid for leases, deduction of, 224

on shares issued, 112

received on renewal of leases, 325

Production of document by Crown, 155156

Productive capital, I $_{3}$

Profession. See Trade, \&c. 


\section{Profits-}

profits chargeable, Chapter VI., Part I., 57

on single transaction, 717475115

chargeable irrespective of application, 6667225230231471

casual, ${ }^{7}$ r $74 \quad 75 \quad 115$

Cash Account not equal to Profit and Loss Account, ${ } 57$

annuities, whether paid out of profits or not, 304

, payable under will, 290

interest, whether paid out of profits or not: See Interest, deduction of tax on.

of foreign companies. See Foreign companies.

, branch of foreign company in United Kingdom, 64

, company registered here but carrying on business abroad, 67 i5

So et seq.

losses in one trade may be set off against profits in another, $7 \mathbf{r}$ $34935^{\mathrm{I}}$

,, , , company owned by another, 321349

employee having also business of his own cannot set off, 349

if not equal to interest, assessment to be on interest, 70169

ascertainment of, where books kept by single entry, 157

if trading is a loss, person may yet be assessed, 169

on sale of securities. See securities.

drawings no relation to profits, 362

debts and stock to be taken into account, $156-73^{62}$

profit under one schedule and loss under another. See Appeals.

not free from taxation though applied to charitable purposes, 471

share of, paid as royalty, 293

put to credit but not paid, 455

on change of investment. See Casual profit, Financial company.

, sale of buildings. See Financial company.

where there is a loss in one year, 164

distributed in shares. See Financial company.

" profits tax," deduction of, 242

promotion, profits of, 115

Property companies, assessment of, 325

, chargeable, Chapter VI., Part I., 57

,, $\quad \operatorname{tax}$ (so-called) is income tax, $4,5 \mathrm{I}$

Proportional system in case of municipal corporation, $35^{2}$

Proprietary life office. See Life insurance companies.

Provident society, 466 
Public buildings, exemption of, $46_{5}$ et seq.

, institutions, Chapter VIII., Part II., $46_{5}$

, houses. See Brewer.

, offices assessed under Schedule E, 44

, revenue, 39 et seq.

,, schools, exemption of, 463468474

, streets, deduction of cost of lighting, 233

Purchase-money of business, deduction of, 226

\section{Quarries-}

assessed under Schedule A, 15146

assessment to be according to rules of Schedule D, 2 I

allowance for laying mineral bare, 320

where slate is obtained by underground workings, concern is a quarry, not a mine, 16

assessment where interest commenced within period prescribed for taking average, 22 ; and see New business.

appeals. See Appeals.

Queen Victoria Clergy Fund, 5I

Quinquennial valuation', 20

Rack rent, io

\section{Railways-}

assessed under Schedule A, 1622146

assessment to be according to rules of Schedule D, 2I

, of interest received on purchase by Government, 294

date when tax is payable, 170

assessed by special commissioners, $2 \mathrm{I}$

officers of, assessed by special commissioners under Schedule E, and company may deduct tax, 2r 49

engine drivers assessed by special commissioners under Schedule D, 49

deductions, claims for-

expenses of opposition to new railway schemes, 258

, extension or amalgamation of lines, 259

contribution to Benevolent and Servants' Insurance Fund, 259

leased lines, expenses, 259

wear and tear of rolling stock, 2 I I

improvements, 230

Rate of deduction of tax, Chap. VII., 392

Rates of tax, 504 


\section{Rates and taxes-}

paymeint of, by landlord or tenant, 36

deduction of, from profits under Schedule D, 133

Rates, creditors on, how charged. See Municipal corporations.

Realisation of securities, profit or loss on. See Securities.

Reasonable time. See Appeals.

Receipt, collector's, 23

,, in United Kingdom. See Financial company.

Reduction of assessment. See Exemptions, Abatement, Appeals,

Double assessment.

Relief. See Exemptions, Abatement, Appeals, Double assessment.

Remittance, constructive. See Financial company.

,$\quad$ to wife from abroad, 60

Removal of machinery, loss by reason of, 229

, expense of, 239

Renewals, not to be charged as well as wear and tear, 211

\section{Rent-}

tenant to pay tax on, but may deduct from landlord, 23

contract for payment without deduction of tax, $3^{\mathbf{I}}$

deduction of, 126

, $\quad$ need not always be from next payment, $243^{\circ}$

Repairs, 5 10 126250

Repayment. See Appeals

Residence. See also Abroad, Foreigner.

of person, 6r et seq.

,, limited company, 8o et seq.

- ,, foreigner in United Kingdom, temporarily, 6o et seq.

,, British subject out of United Kingdom, temporarily, 6r et seq.

foreign branch of English bank, assessment of. See Bank; English.

Restaurant carried on by Y.M.C.A., 73

Return of duty. See Appeals.

Return of profits, Chapter VI., Part II., 119. See also Profits.

forms sent out by assessor, 133

when to be returned, 133

penalty for irregular return. See Penalties.

where to be returned, 146

arriving at amount to return, $x_{52}$

filling up the form, $133 \quad 164$ 


\section{Return of profits (continued)}

where no return made, I70-I

account in support of, 15215315436 I

of railway companies, financial companies, insurance companies, property companies, betting profits, coal dues, municipal corporations, woolbrokers, mines. See under respective heads.

where employee admitted a partner, $34^{\mathrm{I}}$

where several concerns are amalgamated, 343

deductions allowed. See under respective heads

after claim under Act of 1890,166379 et seq.

if person entitled to exemption or abatement. See Exemptions, Abatement.

where accounts show an average loss, 169

Rights of markets and fairs. See Markets.

River conservators, exemption of, 2 I

Rolling stock. See Railways.

Royalties, mining. See Mines.

, patent rights, 149293

Rubber company, deductions in case of, 245

Rule. See First case, Second case, \&c.

Sailing vessels. See Ships.

\section{Salary-}

commutation of, deduction of amount from profits, 236

partners, 127 I33 34 I

, income tax on, 360

payable "without any deduction," 29

of bursar, $45^{2}$

, schoolmaster, $45^{2}$

increase of, $26_{5}$

when person receiving salary is entitled to exemption, \&c., 4 II

431 et seq.

return to be on three years' average, 412

,, of, by employer, $454^{12}$

assessment of, under Schedule E. See Schedule E.

income tax paid for employee, I6o 455

bonus or commission paid to employee, $4^{8}{ }_{1} 60$

employee cannot set-off past losses, $4^{8}$

Sale of securities. See Securities.

") undertaking, profit on, 75

Salt springs or works, assessment of, $16 \quad 22 \quad 146$

', appeals. See Ap
Savings banks, exemption of, I I 2466470

Schedule, production of, 365 
Schedule A, Chapter III., io

schedule of charge, 8

general rule for assessment, ro

deduction of amount from assessment under Schedule D, 126

150 et seq. I6r et seq.

rule where landlord's rates paid by tenant or tenant's by landlord, 36

allowance for loss by flood or tempest, 37

,, ,, repairs, 5 10 250

,, ,, empties, 37

lands, assessinent of, 10

tithes, fines, \&c., assessment of. See under respective heads. mines, \&c., quarries, \&c., ironworks, \&c., to be assessed under

Schedule $A$ according to rules of Schedule D, 21 tax falls on landlord, though usually collected from tenant, 23 deductions. See under respective heads.

appeals. See Appeals.

exemption or abatement. See Exemptions, Abatement.

„, of charities, public buildings, \&c. See under respective heads.

Schedule B, Chapter III., ro. See also Schedule A.

schedule of charge, 8

amount of income for abatement, \&c., $3^{6} 4^{14}$

general rule for assessment, 34

hop gardens, assessment of, 34

rule where landlord's rates paid by tenant, or tenant's by land-

lord, $3^{6}$

tax falls on uccupier, 35

appeal if profits less than assessment, $3^{6}$

farmer may elect to be assessed under Schedule D, 35

allowance for loss by flood or tempest, 37

shooting rights assessable, 35

Schedule C, Chapter IV., 39. See also Government securities.

schedule of charge, 8

includes interest payable out of any public revenue, 39, \&c.

, , on coupons attached to National Debt certificates, 39

who are commissioners for assessing duties, 39

tax deducted on payment of interest, 39

exemption or abatement. See Exemptions, Abatement.

charities. See under respective heads. 
Schedule D, Chapter: VI., 57

schedule of charge, 857

residence. See Residence.

appeals. See Appeals.

accounts. See Accounts.

common errors, $3^{62}$

charities, $37046_{5}$

discontinuance of portion of undertaking. See Discontinuance.

exemption or abatement. See Exemptions, Abatement.

partnership. See Partners.

two or more businesses. See Profits and Discontinuance.

persons and profits chargeable, Part I. of Chapter VI., 57

agent, in respect of profits of principal, go et seq.

bank, foreign, 64

,, English, with foreign branch, 84

betting profits, 67

cattle dealer, is 3

corporation, mode of assessment. See Municipal corporation.

deceased persons, 114372

duty on coal, 62

foreign bank, 84

, securities. See Fourth case.

, possessions. See Fifth case.

, telegraph company, 84

foreigner exercising trade in United Kingdom. See Foreigner. gas works, abroad, $x z$

,, belonging to corporation. See Municipal corporation. Indian officer, pension of, Io7

infants, I 14448

interest payable where profit not equal to interest, ;o 169

investments, profit on change of, 115

niutual life insurance company. See Life insurance company.

preniums on shares, 112

profits assessable irrespective of application, 666722523023147 I

,, of business abroad, liability to assessment. See Abroad.

proprietary life insurance company. See Life insurance companies.

"residence" of a company, so et seq.

small dividends charged upon Schedule D, I 12

sweeping clause, 59 115 


\section{Schedule D (continucd)}

water works department of corporation. See Municipal corporation.

Return of profits, Part II. of Chapter VI., I I9. See also Return of profits, Assessment.

average, where a loss, 164 i6y

case 1, 2, 3, \&c. See First case, Second case, \&c.

company borrowing money abroad. See Financial company.

deductions. See under respective heads.

of municipal corporations, insurance companies, woolbrokers,

financial company, mines, property company, betting profits, coal dues. See under respective heads.

account for, preparation of, I 52 I 53 I 54

form of return, 120

interest received and paid, treatment of. See Financial company. loss on one trade set off against profit on another, 7 I $34935^{1}$

partnership. See Partnérs.

particulars of income, 120

premiums received for renewals of leases, 325

stock, treatment of, I $^{6-7} 3^{6 / 2}$

wear and tear. See Wear and tear.

where to be made, 146

when to be made, 147

,, no return made, 1;o-1

Schedule E, Chapter V., 44

inconvenience of schedule, 47

schedule of charge, 9

who are ccmmissioners for charging duties, Chapter V., 44

include salaries of Government officials and officers of public companies, auditors' fees, \&c., 44

deduction of travelling expenses, \&c. See under respective heads. directors, assessment of salaries of, 4445 I15 327

additional salary charged by supplementary assessment, 45

assessment to be on salary of year, 45

clerks, \&c., may average, 48

abatement. See Abatement.

railway officials assessed by special commissioners. See Railways. appeals. See Appeals.

deduction of duty on payment of salaries of Government officials, 44 past losses cannot be set off against salary, 48 
Schedules of charge, 48

Schools, public, exemption of, 463468474

Schoolmaster, assessment of salary of, $45^{2}$ increase of salary, $26_{5}$

Scientific institutions, exemption of. See Literary institution

Sea-walls, deduction of cost of repairs of, 33

Second case of Schedule D, 5878 i 20

Secrecy in Government departments, 155156

Securities. See also Foreign securities.

sale of, profit or loss on, 291 292. See Financial company.

fluctuation in value of. See Financial company.

Government securities. See Schedule C.

Seller of milk, assessment of profits of, II 3

Separate assessment of partners. See Partners.

Sewer, assessment of, 16 I 722 I46

Shares, premium on, II 2

, issued for interest, $18_{5}$

, distributed as profits. See Financial company.

,, of foreign company held by company in United Kingdom. See Abroad, Controlled.

Sheep dealer, II 3

Ships, wear and tear of, 214 et seq.

, purchaser of, does not " succeed" to a "business," 333

,, single-ship or steam-ship company acquiring other ships, 339345

Shooting rights, 35

Short loans, 272

Sickness policy, 268

Single entry bookkeeping, ascertainment of profit, 157

,, premium life policy, 268

,, transaction, profit on, 7 1 7475 115

, ship company. See Ships.

Sinking Fund, profit appropriated to, 66225230231

Sixth case of Schedule D, 59 II4 126227

Slate obtained by underground working, question whether the concern is a quarry or a mine, 16

„, quarries. See Quarries.

Slaughter-houses. See Municipal corporation.

Small annuities, I I 2

Solicitor, \&c., may now plead before general commissioners, $36_{5}$ 
Source, charging tax at, introduction of principle, 2 illustration of principle, 270

Special commissioners. See Commissioners, special.

Specific cause, $330 \quad 346374$. See also Succession.

Speculation, 115

Speculative builder. Interest on advances. See l3ank interest.

Statutes. See Table of Statutes at commencement.

Steamships. See Ships.

\section{Stock-}

exemption of various stocks. See Exemptions.

treatment of, in accounts for Schedule D, $156-\mathrm{T}$

loss of, by fire, 246

dealer in stocks and shares, 115

casual profit, \&c., on change of investment. See Casual profit.

Stone quarries. See Quarrics.

Streams of water, assessment of, 1622146

, ", appeals. Siee Appeals.

Structural alterations, 229

Study, deduction of annual value of, 51268

Subscriptions, charitable, deduction of, 159

Subsidence, 246

to Coal Owners' Association, 2.37242

Subsidiary company, foreign trade carricd on by means of. See Abroad.

advance to, is not a bad $\mathrm{d} \epsilon \mathrm{bt}, 248$

Succession. See also Amalgamation.

change in partnership by death, \&c., or succession, 327 et seq.

to business, assessment to be on average as if no change, 327

et seq. unless profits falling short from specific cause, 327 et seq. incorporation of partnership creates a succession, 327 et scq.

depression of trade is specific cause, $33^{\circ}$

advantage of rule to successor, $34^{2}$

appeal. See Appeals.

purchase of tramway by local authority, $33^{6}$

Super tax, $63^{82}$. Chapter IX., 481

Supplementary assessment, 170-1

Surgeons, Royal College of, in Edinburgh, not exempt, 473 


\section{Surveyor-}

notice of appeal to be given to. See Appeals.

settlement may be usually arranged with, 368

Sweeping clause. See Sixth case.

Syndicate, profit of, 74

Tax. See Income tax.

Taxing Acts, construction of, 677

Tempest or flood, loss by, 37

Tenant. See Landlord.

Tenants in common. See Joint tenants.

Tenements. See Lands, \&c.

Third case of Schedule D, $5^{8}$ 120

Thrift Fund, 26r et seq.

Tied houses. See Brewer.

Time. See also Iimitation of time.

if a concern set up within time prescribed for taking average, 22 ; and see New business.

when tax becomes payable, r 70

in case of railways, 170

Tin mines. See Mines.

\section{Tithes-}

assessment of, 13

deduction of, under Schedule A, 32

$$
, \quad \text { cost of collecting, } 32
$$

Tolls, assessment of, 162268 I46

, appeals. See Appeals.

, received by corporation. See Municipal corporation.

Total income in case of person abroad, 6459

Town hall, 475

\section{Trade, profession, employment, or vocation-}

profits of, 124

carried on by two or more persons, how return of profits should be made. See Partners.

loss on one may be set off against profit on another, 7 I $34935^{1}$

succession to. See Succession. 
Trade expenses, deduction of, 159

, union, 466

Tramways, depreciation of horses, 214

, , , , plant, 212222

, appeals. See Appeals.

, purchase by local authority, 336

Traveller, assessment of, 146

Travelling expenses, deduction of, 45 51 228229

Trust company. See Financial company.

, estate, claims for abatement or exemption. See Abatement, Exemptions

\section{Trustee-}

claims on behalf of infants, 448

Two or more trades, loss on one and profit on another, $7^{1} 34935^{1}$

, , $\quad$ discontinuance of one, $33^{\circ} 37037^{2}$

Underground workings, slate obtained by means of, the concern is a quarry, not a mine, 16

Underwriters, assessment of profits, $35^{\mathrm{I}}$

,

to deliver list of persons receiving profit, 134

Unearned premiums, 191203 et seq.

Universities. See Colleges.

Valuer, refusal to hear, 28

Variation in rate of duty, 392

Vocation. See Trade, \&c.

Voluntary contribution by parishioners is chargeable, 49

, subscriptions, deduction of, 159

,gifts, 112

Wages. See Salary.

Wagons, 289

Warehouse, tax on, sometimes collected direct from landlord, 29

\section{Water works-}

assessment of, 1622146

appeals. See Appeals.

belonging to corporation. See Municipal corporation.

Ways, assessment of, 1622146

„ appeals. See Appeals. 


\section{Wear and tear-}

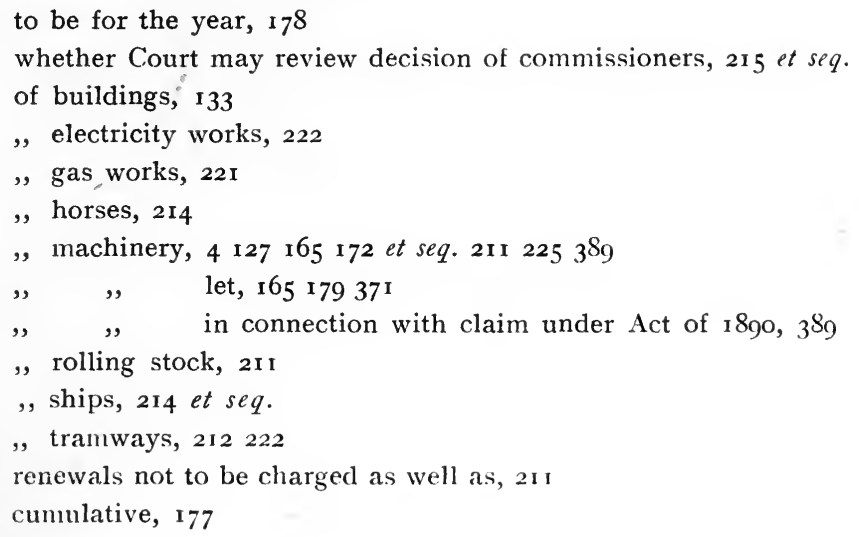

Wesleyan minister. See Clergyman.

Wife receiving remittances from abroad, 6o

Witnesses, power for commissioners to examine, 366

Woolbroking business, assessment of. See Financial company.

Works, deduction of annual value of, 126 I 50 et seq. I61 et seq.

Worship, place of. See Church.

Yacht, residence on, 57

Y.M.C.A., assessment of profit of restaurant carried on by, 73 



\section{OPINIONS OF THE PRESS.}

\section{Manchoster Guardian:-}

"The very comprehensive title almost forestalls any description of the book which might otherwise have been expected. All that seems left for us to say is that the promises set forth seem to be fully and faithfully performed. . . . The chapters towards the end on 'Exemptions and Abatements' contain much that is of general interest. . . . The book is furnished with an admirable index, and is arranged throughout in the clearest style, with every advantage of type and paper. . . .'

\section{Economic Journal:--}

"This work should be especially useful to business men and others needing guidance in the preparation of income tax returns and accounts for appeal. The greater portion of the work is devoted to Schedule D, which embraces the incomes derived from every kind of business and most of the professions. The complex regulations under which these are charged with the tax are accurately and clearly stated. Guidance is also given by means of specimen returns, accounts, and claims, and reference is facilitated by a good and copious index.-G. H. BLUNDEN."

\section{Macclesfield Courier :-}

". . . The authors are to be congratulated on their successful compilation. . . To the general reader the book is certainly well worth careful perusal. . . . The book is well 'got up,' and is printed and published by Gee \& Co., of London, at a price within the reach of all. We most certainly recommend those of our readers who are interested in this matter (and there are very few who are not in one way or other) to procure this excellent handbook, which will certainly repay them and help them to grapple with much that has been a matter of considerable difficulty in the past." 


\section{Financial Times:--}

"The book is replete with matters of interest and importance to taxpayers. . . ."

\section{The Accountant:-}

"There are few matters of practice upon which the want of a really practical treatise was more urgently felt than upon the difficult subject of income tax assessment, and the authors of the work now before us are, therefore, to be congratulated upon the selection of a subject at once untrodden and important. The most casual reader of Messrs. Murray \& Carter's book will, however, not be long in arriving at the conclusion that this is, perhaps, the least important claim that they have to the congratulations of the profession. Their manual is the result of a mature experience treated in a most masterly style, and the result is a work that will stand comparison with the best; indeed, there are very few books of reference that have attained the standard of excellence occupied by the one now before us. The subject-matter of the work is non-contentious, and thus the two points that naturally claim the attention of the reviewer are completeness and method of arrangement. In both respects Messrs. Murray \& Carter's work will be found excellent, and we have no hesitation in saying that it supplies a demand that has long been experienced, and will be appreciated by the profession accordingly."

\section{Manchester Courier:-}

"The authors of this useful and well-arranged manual, who are Chartered Accountants in this city, have chosen a subject which is of interest to most of us, while the minority hope to be concerned with it scme day. The method adopted is a sound one. Whilst avoiding controversial points such as fall within the purview of the politician rather than the writer of text-books, the authors have dealt fully with all the points which are likely to arise under the law as it stands. . . What can the taxpayer-for whom the book is primarily intended-want more?"

\section{Law Notes:-}

"As far as we are able to test the work, it appears to be accurate and exhaustive. It treats the subject in a somewhat different manner to Mr. Dowell's celebrated book, and there is, in our opinion, ample scope for both books." 


\section{The Scotsman :-}

". . . . Every case bearing on the interpretation of the law has been cited, while a complete index renders the information as to the state of the law readily available. There can be little doubt that the book supplies a distinct want, and that it should be of very considerable value to all taxpayers. It has been carefully compiled, the matter that it contains is admirably arranged, and it appears to be as complete as could well be desired."

\section{The Investor's Review:-}

"This is a good book, carefully compiled and brought up to date. . . . The book will be of especial value to men of business in making up their returns for the assessor, but it may be consulted with advantage by everyone who has the tax to pay or receive."

\section{Glasgow Herald:-}

"The book seems excellently adapted to carry out the authors' aim of presenting a digest of income tax law and practice for the use of taxpayers, dealing with the law as it stands rather than criticising it . . The best test of such a book as this is usefulness in practice, but so far as we have been able to examine its law it is clearly and simply expressed-no small merit in dealing with a difficult subject. . . . Scotch cases are freely used. . . .,

\section{Yorkshire Post:-}

". . . It is clear and well arranged, well indexed, and easy of reference."

\section{Stockport Advertiser:-}

". . . . After a most careful perusal of the $25^{\circ}$ pages, we must admit that a more complete explanation of a most difficult and complicated subject than the book under notice could scarcely be written. . . . Altogether the book is as full of information as an egg is full of meat, and whilst being of great service to those engaged in income tax practice, it will prove of immense benefit to that large section of the public who are called upon to pay income tax." 


\section{The Accountant:-}

"It is not long since, in reviewing a book on the death duties, that we expressed gratitude to those who endeavour to simplify an abstruse branch of statutory law. What was then stated in relation to death duties may with equal force be applied to the income tax statutes. The authors of the book now before us have attempted a task of an almost herculean nature, for they have tried to simplify the law and so make it to be 'understanded of the people.' And in this herculean task they have gone nearer to success than we should have thought possible. The book is well known, and it is not requisite to state what it contains. Suffice it to say that this is no mere compilation of cases and extracts from the statutes. The problems to be solved have been resolutely faced and dealt with in the light of reason and of the practical experience which the authors are well qualified to bring to bear on them. Amongst new matter we find the memorial to Sir Michael Hicks-Beach relative to allowances for depreciation of machinery, and his reply to it. The authors' remarks on this reply are, we think, warranted by its terms. We are not quite satisfied with the want of references to the reports where the law cases mentioned can be found; in future editions the table of cases might have these stated more fully. This is but a small matter, and does not interfere with the opinion we have formed of the book. As we stated when the first edition appeared, so we state now-there are few books of reference that have attained the standard of excellence of the one now before us."

\section{Scotsman :-}

"Messrs. Gee \& Co. have published a second edition of the 'Guide to Income Tax Practice,' written by Mr. Adam Murray and Mr. Roger N. Carter. This is a well-informed and clear digest of the income tax statutes and cases, written less, apparently, for the instruc. tion of lawyers than for the use of taxpayers, who wish either to make proper returns or to support claims for exemption or repayment. This edition gives it with its text brought down to date by notices of recent judicial decisions and with many other improvements."

\section{Stockport Advertiser:-}

"The second edition of 'A Guide to Income Tax Practice,' by Mr. Adam Murray and Mr. Roger N. Carter, two well-known accountants, ros.-The first edition was issued some four years ago, and was well received. This induced the authors to prepare the second 
Edition, which contains much additional matter, the work being brought entirely up to date, and now includes many important cases decided during the last four years. When we reviewed the first edition we said: 'After a most careful perusal of the $25^{\circ}$ pages, we must admit that a more complete explanation of a most difficult and complicated subject than the book under notice could scarcely be written. The book is as full of information as an egg is full of meat, and whilst being of great seryice to those engaged in income tax practice, it will prove of immense benefit to that large section of the public who are called upon to pay the income tax.' Read 400 pages instead of 250 , and our remarks hold good of this second edition, which is printed in good type. The authors have been to considerable pains in making explicit marginal references, whilst the index has the merit of being most complete. Briefly speaking, the book contains a summary of the various enactments relating to income tax; instructions as to the preparation of returns for assessments and accounts in support of appeals on the ground of over-assessment; also for claiming exemption; and a concise popular digest of the principal legal decisions on the construction of the Acts."

\section{Manchester Guardian:--}

"Messrs. Gee \& Co. have published a second edition of the exhaustive 'Guide to Income Practice' (8vo, pp. xxiv., 372, ros.), by Adam Murray and Roger N. Carter, Chartered Accountants, of this city. A number of important cases have been decided during the four years which have elapsed since the book was first issued, and the work has been revised and brought up to date for the purposes of the new edition."

\section{Saturday Review :--.}

This is the second edition of a most useful and practical book for professional men, such as solicitors and accountants, or officers of great undertakings, like railway companies, and institutions, such as municipal corporations. The subject is really much too technical and complicated to be understood by the ordinary man, though the book is offered for the use of taxpayers in general. Even lawyers, except in comparatively rare cases, are unacquainted with income tax practice. There is little of legal principle connected with it, and the decisions all turn on the construction of the dozen or so Acts which have been passed 
since ${ }_{1} 8_{42}$. These decisions are very numerous, and they are exhaustively considered by the authors, who also deal in a practical manner by specimen returns with every species of property and income which is affected oy the tax. They point out that it is an error to suppose that the surveyors or any other officials derive any advantage from the rise or fall of the assessments in their districts. They take, on the whole, a most charitable view of the officials, and they show by examples that the authorities do not, as they are suspected of doing, always choose the construction of the Act most favourable to themselves. Income tax payers are themselves very audacious at times; for example, the betting men who sought, unsuccessfully, however, to escape by claim. ing that their gains were illegal, and could not be recovered by law, and that the Legislature did not contemplate a trade like theirs."

\section{Liverpool Mercury:-}

"The contents of this useful publication are so fully described above that it is unnecessary to do more than call attention to the issue of a second edition, and to remark that a copious index adds much to its popular value."

\section{Manchester City Nezws:-}

"A second edition of 'A Guide to Income Tax Practice,' by Adam Murray and Roger $N$. Carter (London: Gee \& Co.), has been called for, a fact which is itself an evidence of the trustworthiness of the work. The authors are well-known in the accountancy world of Manchester. Since the issue of the first edition in 1 \$95 many complex cases have come before the Courts, in which the Inland Revenue Commissicners have sought to obtain legal decisions in regard to many schedules, clauses, and sections of the numerous Acts relating to income tax and the proper assessment of profits. Messrs. Murray \& Carter's volume contains a clear summary of some five hundred cases, and these seem to include every ground of dispute that can possibly or conceivably arise between the alert conımissioners and taxpayers who think they are unfairly assessed. The present edition contains about one hundred pages more than its predecessor, together with a copious index for reference, and tables of statutes, and a list of cases."

\section{Economist :-}

". . . Any income tax problem which is not governed by some one of the precedents here supplied must be complex indeed.". 


\section{Law Notes:-}

"It . . . . is intended for the use of taxpayers, who cannot fail to be pleased with the information the book affords and the way in which it is given."

\section{Glasgow Herald:-}

“. . . . The work as a clearly written and well informed treatise deserves the widest circulation among the taxpaying community."

\section{Scotsman:-}

“. . . . It keeps well abreast of its reputation as a book which all students have already learned to value highly."

\section{Liverpool Mercury:-}

“. . . . The fact that it has been found necessary to issue a third edition of this work affords conclusive proof of its reliability and usefulness." 


\section{OPINIONS OF SURVEYORS, OFFICIALS,}

AND OTHERS.

"A gentleman called on me the other day in reference to a proposed claim, and kindly lent me your bcok for reference.

"May I congratulate you on the manner in which you have dealt with the whole question of income tax as affecting the public. . . . I naturally welcome any book that will smooth the way for an understanding of a difficult subject, and shall recommend yours to the assistant surveyors as an invaluable help towards obtaining their commissions as surveyors."

"A model of clearness."

"It is no part of a surveyor's duty to seek to obtain more than is properly due from the taxpayer, and I hope those who did so have been weeded out of the service."

"The arrangement is admirable."

"I am convinced that if taxpayers will study carefully and act upon the advice which it contains, the administration of the income tax will be rendered much less irksome on both sides."

"I consider it the most lucid, comprehensive, and practical treatise of its kind that has ever fallen into my hands."

"I hope it may run into many more editions, for it is so easy of reference to the various points involved in the solution of problems that are constantly turning up, and in which the lay mind is no less grateful than the official mind for the valuable assistance to be derived therefrom."

"We have found this work of great use to us," 
"I can congratulate you on the production of a work which cannot fail to be of great assistance to taxpayers generally."

"It is a valuable résumé both of law and practice, and may be consulted both by the executive and the taxpayer."

"I have often recommended the book privately, and am glad to congratulate you on the issue of a new edition as indicating a large and continuing demand' for it."

"I look on it as a most valuable and interesting work for an official, as it aids to pull one out of the grooves into which there is always a tendency for officials to settle down."

"The first edition was exceedingly good, and, of course, this will be better, as it brings the tax cases up to date."

"I have already advised several firms to get it, for it will prove to be useful to us, if taxpayers would consult it and act upon it."

"You will quite ruin me if you bring out so many editions of 'Murray and Carter,' for I would not be without the latest.'(SURVEYoR.) 


\section{CATALOGUE OF}

\section{ACCOUNTANCY \\ PUBLICATIONS.}

\section{2.}

[FOURTEENTH EDITION.]

\section{LONDON :}

Gee \& Co. (Publishers) Ltd.

34 Moorgate Street, E.C. 
7C-7 TDE IATAS

DOA 


\section{CATALOGUE OF ACCOUNTANCY PUBLICATIONS.}

ACCOUNTANT, THE (Est. I874). A weekly newspaper issued in time for Friday evening's mail. The Accountant is the recognised organ of Chartered Accountants and Accountancy throughout the world. It contains Leading Articles, Contributed Articles, Weekly Notes, Correspondence and Enquiries, Current Law, Reviews, Reports of Meetings of Societies of Accountants and Students' Societies, Scottish Notes, Lectures and Debates on Accountancy, Bookkeeping (with specimens of Accounts), Auditing, Liquidations, Bankruptcies, Receiverships, Company Law, Income Tax, \&c., \&c., as well as Law Reports of all Decisions of interest to Accountants as to Administration Cases, Arbitrations, Winding-up of Joint Stock Companies, Liquidations, Bankruptcies, Mercantile Law, and Partnerships; and is generally a complete record of all matters of interest to the Profession. New Volumes commence in January and July each year.

Single copies $\mathbf{6 d}$. net, post free U.K. $\mathbf{6} \frac{1}{2} \mathbf{d}$. ; Abroad, $\mathbf{7 d}$.

Subscriptions : Yearly, post free U.K. 24/- ; post free, Abroad, 26/-; Half-yearly, U.K. 13/-; Abroad, 14/-.

Binding Covers issued tor each half-yearly volume, half calf, goldlettered, 2/6 net, post free U.K. 2/9; Abroad, 2/10.

Filing Cases for filing the weekly issues until volume is completed. 3/6 net, post free U.K. 3/11 (postage Abroad prohibitive).

Volumes, bound half calf, gold-lettered. Vol. X, 24/-; XI, \&1 10s.; XII, XIII, 15/-each; XIV, 20/-; XV-XVIII, 15/ each; XIX-XXI, 14/- each; XXII, 26/-; XXIII-XXIV, 14/. each: XXV, 30/-; XXVI, 40/-; XXVII, 50/:; XXVIII, $28 /-;$ XXIX, 20/-; XXX-XLVI, 14/- each, net, post free U.K. (Prices of Vols. I-X on application.)

ACCOUNTANTS' JOURNAL, THE (Est. I883). A monthly newspaper, issued about the I $5^{\text {th }}$ of the month.

The general contents of the paper are designed more especially to meet the requirements of Accountant Students, though the practitioner is by no means overlooked. A concise summary is given of the effect of all the Important Legal Decisions of the preceding month, Articles, Notes, Correspondence, Reviews and Prize Competitions appear in each issue together with Lectures delivered to the various Students' Societies, and the reports of their meetings. The new Volume commences in May each year.

Single copies $9 \mathrm{~d}$. net, post free, $10 \mathrm{~d}$.

Subscriptions : Yearly, post free U.K. 7/6; post free Abroad, 8/6.

Binding Covers issued for each Yearly Volume, half calf, goldlettered, 2/6 net, post free U.K. 2/9; Abroad, 2/10.

Filing Cases for keeping unbound copies until the completion of the volume. 1/- net, post free U.K. 1/4 (postage abroad prohibitive).

Volumes, bound half calf, gold-lettered I-XII 7/6 each, (except Vols. III and VI, 10/- each), XIII to XXIX, 8/6 each (post free U.K.).

GEE \& Co. (Publishers) Ltd., 34 Moorgate Street, London, E.C. 


\section{ACCOUNTANTS' LIBRARY, THE.}

Consists of a series of $5 \mathrm{I}$ handbooks, each separate volume of which deals with a complete system of Bookkeeping suitable for the particular business described, together with a complete set of pro forma Accounts. The books are published at a uniform price of $3 / 6$ net, with the exception of a few "Double" and "Triple" Numbers, for which the price is $5 /-$ and 10/6 respectively. To Subscribers these are published at the special rate of $2 / 6$ per volume (3/9 per "Double" and $5 /-$ per "Triple" volume). Subscriptions can still be received at this reduced rate for Vols. I to XX, XXI to LI, or the whole of the volumes of the Series. A list of the Volumes will be found on pp. $44-48$ of this Catalogue.

\section{ACCOUNTANT'S \& BOOKKEEPER'S VADE-MECUM.} (See Vade-Mecum, p. 42.)

\section{ACCOUNTANTS' ASSISTANT.}

(I 40 pp. 8vo.) By Thomas Beckett. A Bibliography of Accountancy: being an Index to the Accountancy Lectures and Leading Articles printed in The Accountant, The Accountants' Journal, The Transactions of the various Students' Societies, and other periodicals, during the last thirty years of the Nineteenth Century, to which is added a List of the principal Treatises now in use on each of the $I_{1} 7$ subjects affecting Accountancy.

\section{ACCOUNTANTS' CODE.}

Net price (post free U.K.) 6/- ; Abroad 6/6

A short, but sufficiently complete Telegraphic Code to be used by principals and clerks when desiring to communicate with each other by telegraph. Arranged to be affixed inside the Audit Note Book.

Net price (post free U.K.) 5/- per dozen; Abroad, 5/3 per dozen.

\section{ACCOUNTANT'S COMPENDIUM.}

(4th Ed., 749 pp., 4to.) By S. S. Dawson, M.Com., F.C.A. A complete Lexicon for Accountants, containing some I,500 articles upon subjects of general interest not only to the professional Accountant, but also to Chief Clerks, Secretaries, and others holding responsible positions in mercantile concerns. It is estimated that about 20,000 distinct points which are constantly arising in the practice of an Accountant have been dealt with in this Edition, and all references and authorities are quoted in the text. The following subjects dealt with will give some idea of the scope of this work:-Accountancy (generally). Actuarial Matters. Administration of Assets. Administrators. Agency. Apportionment. Arbitrations and Awards. Arithmetical Questions. Arrangements with Creditors. Auditing. Banking. Bankruptcy. Bills of Exchange. Bills of Sale. Bookkeeping. Branch Accounts. Building Societies. Capital and Income Questions. Carriage. Cheques. Company Law and Practice (Formation, Management, and Winding-up). Contracts (generally). Contributory. Death Duties. Debentures. Deeds of Arrangement. Departmental Accounts. Depreciation. Directors. Economic Questions. Equation of Payments. Executorship Accounts. Executorship Law. Factors. Foreign Exchanges. Goodwill. Guarantee. Hire-Purchase Agreements. Income Tax. Infant. Insurance. Interest (Questions involving). Investigations. Land Taxes. Lien. Limitation of Actions. Liquidators. Manufacturers' Accounts. Mercantile Law (generally). Municipal Finance. Official Receivers. Partnership. Pledge. Profit. Profit and Loss Account. Profits Available for Dividend. Promissory Notes. Receivers. Reserves and Reserve Funds. Sale of Goods. Savings Banks. Secretarial Matters. Self-Balancing Ledgers. Shipping. Single and Double Account. Single and Double Entry. Sinking Funds. Slip Bookkeeping. Stock Exchange Terms. Stock-inTrade (Questions affecting). Trustees. Trustees in Bankruptcy. Wills. Net price (post free U.K.) 25/-; Abroad, 26/6. 


\section{ACCOUNTANTS' DIARIES, THE.}

Eight Editions Annually. All editions (except No. 3) contain a Complete Directory of Accountants throughout the world, together with special information for Accountants, including extracts from Statutes and Rules relating to Building Societies, Companies, Trustees in Bankruptcy and under Deeds of Arrangement, and the Audit of Accounts of various bodies, \&c. (in so far as they affect accountants), and other usefưl information.

No. I. One day on each page, Foolscap folio, Free U.K.) Abroad.

with all information. bound in cloth. 8/- Too heavy.

No. 2c.

Two days on each page, with all information.

Foolscap folio,

bound in cloth.

$5 /-$

$6 / 2$

No. 2.

Two days on each page, with all information.

Foo!scap folio,

No. 3 .

Three days on each page, without Directory or information.

No. 3a. Three days on each page, Foolscap folio, with all information. bound in boards.

No. 4.

One day on each page, with all information.

No. 4 f.

One day on each page, with all information (ruled feint for hours

bound in boards. Foolscap folio, bound in boards.

$3 / 6$

$4 / 8$

$1 / 6$

$2 / 4$
Medium 8 vo,

bound in cloth.

Medium 8vo,

bound in cloth.

$\begin{array}{ll}2 /- & 2 / 10 \\ 5 /- & 5 / 8 \\ 5 /- & 5 / 8\end{array}$

Medium 8vo,

bound in cloth.
$2 / 6$

$3 /-$

Nos. $1,2 c, 2,3$, and $3 a$, are specially ruled for accountants with columns headed "Estate and Hour of Appointment," "Posting Folio," "Particulars," and " Hours Engaged." Copies can be obtained interleaved with blotting paper at an extra cost of $\mathbf{2}$ /- each for No. $\mathbf{r}$; 1/6 each for Nos. 2, 2c, 4 , and $4 \mathrm{f}$; and 1/- each for Nos. $3,3 \mathrm{a}$, and 5 . A Ledger Index is included in No. I Edition and can be supplied in the other Editions at an extra cost of $\mathbf{6 d}$.

\section{ACCOUNTANTS' MANUAL.}

A most valuable fund of information concerning various points of Practice and Law relating to the Profession is contained in the Questions and Answers of the Institute Examinations. The eleven Volumes already issued under the above title comprise the back parts of the Questions and Answers, with copious and carefully prepared Indices. By this means an extremely valuable mass of information is available to the Student for Examination purposes, and to the practitioner. The Examination Questions and Answers included in the Volumes cover the following periods:-

Vol. I. Dec. 1884 to June $1887 \mid$ Vol. VII. Dec. r898 to June Igoo "II. ," I887 to ", r890 ", VIII. ," I900 to ", 1902 ", III. ", I890 to ", 1892 ", IX. ", 1902 to ", 1904 "IV. ", I892 to ", I894 ", X. " I904 to ", I906 " V. ", I894 to ", 1896 ", XI. " , 1906 to ", 1908 ", VI. ", r896 to ", 1898 ", XII. ", r908 to ", I9ro

Vol. XIII. Dec. I9Io to May I9I2
The Questions and Answers published after the last date mentioned will form the succeeding Volumes, which it is proposed to issue every other year.

Thirteen Volumes have already been issued, net price (post free, U.K.) 7/6 each; Abroad, 8/2 each, or the set of thirteen Volumes 78/post free, U.K. ; 84/6 post free, Abroad.

Also issued in parts every June and December, net price 1/6 each, post free, U.K. or Abroad, 1/7. To those who have purchased the parts as and when issued the Indices can be supplied separately, price 1/- each.

Subscriptions, post free, U.K. or Abroad, 3/- per annum. This subscription includes 2 parts and the index issued biennially. 


\section{ACCOUNTANTS' TIME BOOK AND CLIENTS' LEDGER, COMBINED.}

(Large post folio.) Designed by H. W. Hazlehurst, A.C.A. The Author believes the above meets a distinct want in Accountants' offices, obviating the use of Ledger Accounts, both for time spent on clients' behalf and for the resulting charges. One line (only) devoted to each Stocktaking. "Fees by Scale" are set beside "Actual Fees," with space for record of sending in the bill, and of payment received. (Specimen entries showa.)

40 pp., 3/6 net. Post Free U.K. 3/9; Abroad, 3/10.

roo pp., 6/6 net post free U.K. ; 7/. r.et post free-Abroad.

\section{ACCOUNTANCY PROBLEMS,}

with Solutions by L. Greendlinger. (330 pp., 8vo.) Contains Problems on the Adjustment of Partnership Accounts, Practical Accountancy, Theory of Accounts, Auditing, Commercial Law, with Solutions and Notes, and Questions set at the C.P.A. Examinations. $21 / 6$ net. Post free U.K. 21/10; Abroad 22/4.

\section{ADVANCED ACCOUNTING.}

(4th Ed., 520 pp., 4to.) By Lawrence R. Dicksee, M.Com., F.C.A. This work will be found of the greatest value to Candidates for the Final Examination of the Institute, and to all serious Students of Accounts. In addition to an exhaustive treatment of the subject from an Accountant's point of view, an Appendix is included, which has been written by J. E. G. DE Montmorency, B.A., LL.B. (Cantab), of the Middle Temple, Barrister-at-Law, dealing with the Taw relating to Accounts, and the requirements of the Courts and of lawyers in connection therewith. The following matters dealt with (to each of which a chapter is devoted) will give some idea of the scope of the work :-Introduction-Capital and Revenue-Organisation of Accounts -Methods of Balancing-Branch Accounts, \&c.-Tabular Bookkeeping - Stock Accounts and Store Accounts-Partnership Accounts-Company Accounts-Vendors' Accounts-Executors' Accounts-The DoubleAccount System-Income-Tax-Bankruptcy and Insolvency AccountsLiquidation Accounts-Reconstructions and Amalgamations-Falsified Accounts-Bookkeeping without Books-Cost Accounts-Depreciation, Reserves, Reserve Funds and Sinking Funds-Payments by Instalments and Interest-The Form of Published Accounts-The Criticism of Accounts-Miscellaneous Problems in Accounts-Periodical ReturnsAccounts for Litigation.-The Law Relating to Accounts-Miscellaneous Questions on Accounts.

Net price (post free U.K.) 21/-; Abroad, $22 / 4$.

\section{AGRICULTURAL ACCOUNTS.}

(Vol. IV of "The Accodntants' Library" Series, q.v.) (2nd Ed., I 26 pp., 8vo.) By T. W. Meats (Incorporated Accountant). This work contains a complete system of Bookkeeping and Forms of Account, arranged specially to suit the requirements of Agriculture; and also a Specimen Set of Entries covering the transactions for One Complete Year. The application of Cost Accounts to the transactions is also dealt with, and provides for Departmental Profit and Loss Accounts. A separate section of the work deals with Income-Tax as relating to Agriculture. 5/- net. Post free U.K. 5/4; Abroad, 5/5. 
ANTE AUDIT.

(44 pp., $6 \frac{1}{2}$ in. by 4 in.) A concise Booklet of Rules and Instructions intended to be given by the Auditor to the Bookkeeper in order to facilitate the Auditing of the Books. Arranged in alphabetical order.

$\begin{array}{lccc} & \text { Net price. } & \text { Post free U.K. } & \text { Abroad. } \\ \text { Per copy } & 1 / 0 & 1 / 1 & 1 / 1 \\ \text { Per half doz. } & \mathbf{5} / \mathbf{6} & 5 / 6 & \mathbf{5} / \mathbf{1 0} \\ \text { Per doz. } & 10 / 0 & 10 / 0 & 10 / 6\end{array}$

\section{AUCTIONEERS' ACCOUNTS.}

(Vol. II of "The Accodntants' Library" Series, q.v.) (2nd Ed., 90 pp., 8vo.) By L. R. Dicksee, M.Com., F.C.A. Describes fully a System of Accounts suitable for Auctioneers, Valuers, and Estate Agents. Divided into Three Parts:-(I) General description of Books required and the method of keeping them. (2) Full Set of pro formâ Accounts. (3) Miscellaneous information as to Licences, Scales of Charges, Conditions of Sale, \&c.

3/6 net. Post free U.K. 3/9; Abroad, 3/10.

\section{AUDITING.}

(9th Ed., ro26 pp., 8vo.) A Practical Manual for Auditors. By Lawrence R. Dicksee, M.Com., F.C.A. This well-known textbook (of which upwards of ${ }_{15}, 000$ copies have been sold during the past 20 years) has been carefully revised and brought $u p$ to date. It is thoroughly comprehensive and reliable. As before, it contains copious extracts from all Acts of Parliament affecting the subject, and detailed reports of all the leading Legal Decisions to date. In addition to being indispensable to Practitioners and Accountant Students, the work is invaluable to Directors, Shareholders, and all Business men. The present edition has been issued at half the price of the preceding edition, to meet the views of those desirous of securing a work of admitted authority at a popular price.

The following is a summary of the contents:-Introductory: Auditing up to the Trial Balance (pp. I-40)-Methods of Account suggested in the course of Audit (pp. 4I-69)-Special Considerations in Different Classes of Audits (pp. 70-189)-From Trial Balance to Balance Sheet (pp. I90-248)-Forms of Accounts and Balance Sheets (pp. 250-285)-What are Profits? (pp. 286-303)-The Attitude of the Auditor (pp. 304-334)-The Liabilities of Auditors (pp. 335-370)Investigations (pp. 371-393)-Income-Tax (pp. 394-406)-Appendix A (Extracts from Statutes, \&c.) (pp. 4I7-678)-Appendix B (Legal Decisions) (pp. 679-992)-Appendix C, Extract from "Tretyce off Husbandry" (pp. 996-998)-Appendix D, Depreciation Tables (pp. 999-1002)-Index (pp. I003-1016).

10/6 net. Post free U.K. 11/- ; Abroad, 11/10.

\section{AUDIT MEMORANDA.}

(12 pp., 8vo.) By Andrew Binnie, C.A., F.C.A. This booklet, which is of the nature of an "Aid to Memory." is intended to be complementary to the ordinary detailed Audit Programme. It indicates the leading points to which the Auditor should direct his attention. when, with the Balance Sheet before him, he is finally completing an Audit. Space is left for the insertion of such further points as may arise in special matters. The Memoranda are divided into two parts, viz. :-I. Preliminaries to commencing detail work of a Company Audit; or, as far as is applicable, the Audit of a Statutory Report. 2. Points to be looked into when completing an Audit. 1/- net. Yost free U.K. and Abroad, 1/1. 
AUDIT NOTE BOOKS.

No. 1 ( 26 pp., 8 in. by 4 in.). Sixth Edition. Suitable for a Monthly Audit.

No. 2 ( 26 pp., 8 in. by 4 in.). Sixth Edition. Suitable for a Quarterly or Half-yearly Audit.

(Name and address printed free on covers on orders of Ioo copies.)

Net price. Post free U.K. Abroad.

$\begin{array}{lrrr}\text { Single copies } & -/ 6 & -17 & -17 \\ \text { Per dozen } & 5 /- & 5 /- & \mathbf{5} / 7 \\ \text { Per Ioo } & \mathbf{4 0} /- & \mathbf{4 0} /- & \mathbf{4 4 / 6}\end{array}$

No. 3 (I50 pp., I $2 \frac{1}{2}$ in. by 4 in.). For Important Audits.

(Name and address printed free on covers on orders of 50 copies.)

$\begin{array}{lccr} & \text { Net price. } & \text { Post free U.K. } & \text { Abroad } \\ \text { Per copy } & 2 /- & 2 / 3 & 2 / 3 \\ \text { Per dozen } & 20 /- & 20 /- & 22 / 6 \\ \text { Per 50 } & 70 /- & 70 /- & 85 /- \\ \text { Per I00 } & 110 /- & 110 /- & 130 /-\end{array}$

\section{AUDITORS, SUMMARY OF LEGAL DECISIONS AFFECTING.}

(40 pp., 8vo.) By H. G. Cocke, A.C.A. A pamphlet, summarising the leading cases affecting Auditors.

AUDITS.

1/- net. Post free U.K. and Abroad, 1/2.

(2nd Ed., 200 pp., 8vo.) By Arthur E. Cutforth, A.C.A. This work describes, within the limits of a book of moderate size, the main duties of Auditors, and the principles affecting their work. Regard has also been had to the needs and requirements of Students for Examinations, in the choice and treatment of the subjects dealt with. The following is a summary of the contents:-Preface-Auditor's Duty with regard to various items of Profit and Loss, \&c.-Auditor's Duty with regard to various Balance Sheet items-Programmes of Audits of various kinds-Specimens of Accounts of Various Concerns-Forms of Auditor's Certificate under Different Acts-Provisions of the Companies Acts relating to Auditors-Legal Decisions affecting AuditorsMiscellaneous Representative Examination Questions Answered and Discussed, \&c. \&c. $\quad$ Net price (post free U.K.) 6/6 ; Abroad, 7/-

\section{AUSTRALIAN MINING COMPANIES' ACCOUNTS.}

(Vol. XVI of "The Accodntants' Library" Series, q.v.) (86 pp., 8 vo.) By D. Godden, F.F.I.A., Aust. and Wm. N. Robertson, F.F.I.A., Aust. This volume deals very fully with all classes of Mining Companies' Accounts, as usually kept in Australia, and contains a complete description of the Laws of the various States relating to the subject. $3 / 6$ net. Post free U.K. 3/9; Abroad, 3/10.

\section{BAKERS' ACCOUNTS.}

(Vol. L of "The Accoontants' Library" Series, q.v.) (I 20 pp., 8vo.) By F. Meggison, Chartered Accountant. A complete System of Bookkeeping for Bakers, with additional Chapters on Income Tax, Branch Shops, and Bakehouse Accounts. Synopsis: Introduction-Opening the Books-The Baker and his Creditors-The Baker and his Customers-The Baker and his Cash-The JournalImpersonal and Private Ledgers-Balancing the Books-Trading and Profit and Loss Accounts, and Balance Sheet-Wages-The Treatment of Sacks-Depreciation-Bookkeeping for Small Bakeries-The Baker as Taxpayer-The Accounts of Branch Shops-A System of Bakehouse Accounts-Additional Books required by a Limited Company-An alternative ruling for the Customers' Ledger.

5/- net. Post free U.K. 5/4 ; Abroad, 5/5. 


\section{BALANCE SHEET OF A COMMERCIAL CONCERN, HOW TO READ THE.}

(3rd Ed., 64 pp., Demy 8vo.) By F. W. Pixley, F.C.A., Barristerat-Law. This book has been written to show Shareholders, Financial Experts, and others, how to understand this complicated subject, and deals with "Working Capital," "Fixed Capital," and the Gauging of the Position of a Company from its certified Balance Sheet. While the most inexperienced will derive some benefit from the perusal of its pages, it has not been written solely for them, but is also intended for those who possess some knowledge of Bookkeeping and Accounts, and it is hoped that such will find some useful hints which will better enable them to criticise a strange Balance Sheet, whether they may receive it in their capacity as shareholder, intending investor, or even for the purpose of writing an article thereon in the financial columns of a newspaper.

1/6 net. Post free U.K. and Abroad, 1/9.

\section{BANK BOOKKEEPING AND ACCOUNTS.}

(Vol. I of "The Accodntants' Library" Series, q.v.) (2nd Ed., r67 pp. 8vo.) By John A. Meelboom, Chartered Accountant, and Chas. F. Hannaford. A concise Treatise, showing the application of the principles of Bookkeeping to the record of Banking transactions. With about 40 Forms, indexed fully, and complete even to posting folios, enabling the reader to instantly trace the history of any transaction through the entire system of Accounts. The examples given are not special to any one Bank, but the facts have been gathered from many different sources, so as to give the greatest possible information. A Glossary of Banking and Commercial Terms is appended, legal definitions being given as frequently as possible.

5/- net. Post free U.K. 5/4; Abroad, 5/6.

\section{BANKRUPTCY.}

(2nd Ed., 286 pp., 8vo.) By the late T. M. Stevens, D.C.L., Barrister-at-Law. Second Edition revised by F. N. KeEN, Barristerat-Law. A work designed more especially for the use of those acting as Trustees in Bankruptcy, or otherwise engaged in the practical work of administration in bankruptcy matters. The author's aim has been to produce a book which, though not attempting the exhaustiveness or minuteness of the leading authorities (Williams' Bankruptcy Practice and Robson on Bankruptcy), should yet follow on their lines, and be an accurate and reliable text-book of the law, far removed from the popular handbook class of literature.

Net price (post free U.K.) 7/6 ; Abroad; 8/-

\section{BANKRUPTCY AND COMPANY TIME TABLES.}

(r6 pp., 8vo.) Useful Time Tables of some of the principal matters in connection with Bankruptcy and Deeds of Arrangement, and of the steps in a Company Liquidation. In pamphlet form : 6d. net. Post free U.K. and Abroad, $7 \mathrm{~d}$.

The Company Liquidation and Bankruptcy Time Tables are also published in map form, 6d. net. Post free U.K. and Abroad, 7 d. each.

\section{BANKRUPTCY, LEXICON FOR TRUSTEES IN.}

(See Lexicon, p. 30.)

34 MOORGATE STREET, LONDON, E.C. 


\section{BANKRUPTCY TRUSTEE'S ESTATE BOOK, THE.}

(2nd Ed., 84 pp.) Compiled by L. R. Dicksee, M.Com., F.C.A. This book contains the whole of the information likely to be required by Trustees in Bankruptcy in such a form that in conjunction with the "Record Book" it provides a complete statement of all the facts relating to any particular estate, entirely doing away with the necessity for memoranda and loose sheets, which are so frequently lost.

Net price. Post free U.K.

Abroad.

Each

4/-

$4 / 4$

$4 / 5$

Per doz.

$40 /-$

$40 /-$

$45 /-$

\section{BOOKKEEPING AND ACCOUNTS.}

(2nd Ed., 900 pp., Crown 8vo.) By L. Cuthbert Cropper, F.C.A. This work covers the whole field of practical Bookkeeping, Accounting, and Banking. It includes a very large number of Test Questions, with answers prepared by the Author, and many pages of Examination Papers set by all the important educational bodies examining in this subject. The book as a whole is the outcome of the Author's experience as an Examiner, Lecturer, and Accountant in large practice. It fully explains the NEw Assurance ACT, 1910. The chapter dealing with Assurance Accounts extends to 43 pages, and will be found to convey an accurate and lucid explanation of the system of Bookkeeping employed in Assurance Offices, the way the annual accounts are compiled, and the new form in which they must be presented. There is also a chapter dealing with INCOME TAX; a chapter of 26 pages on BANK. Accounts; and one of 62 pages dealing with the FORM OF PUBLISHED Accounts. The examples selected cover a wide field, including the Accounts of Water and Gas Undertakings, and to each set of accounts explanatory and critical notes are appended. Special advice and instructions from an Examiner's point of view are given throughout the book. There is a most complete index, extending to 20 pages. The style of writing is particularly simple and lucid.

$3 / 6$ net. Post free U.K. 3/10; Abroad, 4/1.

BOOKKEEPING, ELEMENTARY.

(48 pp., 8vo.) By W. G. Day, Chartered Accountant. A suitable Elementary Text Book for Students.

1/- net. Post free U.K. and Abroad, 1/2.

\section{BOOKKEEPING, ELEMENTS OF.}

(7o pp. and 9 diagrams, 8vo.) By T. E. Streeter. For use in Schools.

$1 / 6$ ne.t. Post free U.K. and Abroad, 1/9.

\section{BOOKKEEPING EXERCISES.}

(3rd Ed., 96 pp., 8vo.) By L. R. Dicksee, M.Com., F.C.A. This book consists of a series of roo Exercises, with skeleton Answers, specially compiled to form a graduated and comprehensive course of instruction for the Bookkeeping Examinations of the Institute of Chartered Accountants.

$3 / 6$ net. Post free U.K. 3/9; Abroad, 3/11. 


\section{BOOKKEEPING FOR ACCOUNTANT STUDENTS.}

(6th Ed., 300 pp., 8vo.) By Lawrence R. Dicksee, M.Com., F.C.A. The standard work on the subject. A complete treatise on the Science of Bookkeeping for the use of Accountant Students. Summary of Contents :--

Part I.-Simple Ledger Accounts-Closing the Ledger-Transactions of Henry Jackson-The " Continental " System-Closing the Ledger on the "Continental " System-Exercises.

Part 2.-Commercial Terms-Accounts of Traders-Transactions of Fox \& Crane (Opening the Ledger, the Subsidiary Accounts)-Adjustment Accounts and Self-Balancing Ledgers-Examination Papers.

Part 3.-Accounts of Manufacturers-Transactions of a Manufacturing Company (General and Trade Ledgers, Cost Accounts, \&c.)-Forms of Accounts and Account Books (Double-Account System, SingleAccount System, Ledgers, Journals, Cash Books) - Miscellaneous Questions of Account. Net price (post free U.K.) 10/6; Abroad, 11/2.

\section{BOOKKEEPING FOR BEGINNERS.}

(45 pp., 8vo.) By G. W. Wheeler, A.K.C., Incorporated Accountant. A new text-book equally suitable for self-instruction or for use in Schools. The principles of "Double-entry". are explained, with Illustrations and Exercises, but without the confusing effect of subsidiary books until considerable progress is made.

1/6 net. Post free U.K. and Abroad, 1/8.

\section{BOOKKEEPING FOR COMPANY SECRETARIES.}

(4th Ed., I92 pp., 8vo.) By L. R. Dicksee, M.Com., F.C.A. The subject of Bookkeeping in relation to Joint Stock undertakings is very fully dealt with. A certain amount of preliminary knowledge of the Elements of Bookkeeping is assumed. The following matters, amongst others, are fully dealt with :-Accounts of Companies -Adjustment Accounts-Accounts of Branches-Tabular Bookkeeping -Organisation of Accounts-Balancing Accounts-Applications, Allotments, \&c.-Reserve Funds, Depreciation, \&c.-Profits, Dividends. Income Tax, \&c.-The Companies Acts.

The Appendices comprise Examination Questions and Answers, and the Institute of Secretaries' Examination Papers.

5/- net. Post free U.K. 5/4; Abroad, 5/5.

\section{BOOKKEEPING FOR EXECUTORS AND TRUSTEES.}

(82 pp., 8vo.) By T. Whittem Hawkins, Chartered Accountant. The purpose of this handbook is to set forth the simplest system of Bookkeeping for Executors, Trustees, and Administrators, compatible with a clear and accurate presentment of their transactions. With a complete set of pro formâ Accounts.

3/6 net. Post free U.K. 3/9; Abroad, 3/11. (For other books on this subject see under Executorship Accounts.)

BOOKKEEPING FOR RETAIL TRADERS.

(76 pp., 8vo.) By James Findlay, Chartered Accountant. A simple system of Bookkeeping, illustrated by a complete set of pro formâ Accounts.

3/- net. Post free U.K. and Abroad, 3/3. 


\section{BOOKKEEPING FOR TECHNICAL CLASSES AND SCHOOLS.}

(r ro pp., 8vo.) By Geo. F. Clarke, A.S.A.A. A Practical Elementary Treatise on Double Entry Bookkeeping.

$2 / 6$ net. Post free U.K. 2/9; Abroad, 2/10.

\section{BOOKKEEPING, MODERN. THE PRINCIPLES OF}

(152 pp. 8vo.) By W. R. Hamilton, F.C.A. This book does not profess to deal exhaustively with the subject of Boolkeeping as an art, attention being concentrated on its spirit, rather than on its form. All systematic bookkeeping is based on a principle, but on one which modern abbreviations necessarily tend to obscure. The book is an attempt to set forth this principle, and to show that, however obscured it may be, yet it exists, and must be thoroughly g. asped by anyone who would become proficient in the art. Such forms as are employed are used only to illustrate the text-they are not given as dogmatic instarces of how any particular bookkeeping problem should be solved. The principle is explained and insisted upon, and it is left to the reader, or his teacher, to apply this principle in any desired direction. Synopsis:-PART I-The principle of Double-Entry as applied to ordinary Bookkeeping. Introductory-Books in everyday use briefly described: Day Book, Invoice Book, Cash Book, Ledger-The Principle of the Journal Entry-The Application of the Journal Entry to a Series of Transactions-Some Disadvantages of the old style of DoubleEntry: How it has been Simplified-The place of the Journal in Modern Bcokkeeping-Some Special Pcssible Abbreviations-Real and Nominal.' Accounts-The Trial Balance-The Balance Sheet: Preliminary Work-The Balance Sheet (continued): The Closing of the Books-The Balance Sheet (concluded): Fcrmal Accounts, Capital Accounts, \&c. PART II : The Application of the Principle in Special Cases-Columnar Books: What Books constitute a Set ?Petty Cash Book: What Items go into the Invoice Book?-Branch Accounts: Foreign Currency-Sectional Balancing, Company and Partnership Bookkeeping, I epartmental Accounts, Cost Accounts, Suspense Accounts, Stock Accounts-Conclusion.

3/6 net. Post free U.K. 3/10 ; Abroad, 4/-

\section{BOOKKEEPING, THE PRINCIPLES OF.}

(I16 pp., Svo.) By J. A. Carlill, F.C.A. A short treatise on the subject.

$3 / 6$ net. Post free U.K. $3 / 9$; Abroad, 3/10.

\section{BOOKKEEPING.}

(2nd Ed., 460 pp., 8vo). By Gerard van de Linde, F.C.A. Being a reprint of the seven following works by this author:-I.-Bookkeeping, in four Parts. II.-A Merchant's Office. III.-A Merchant's Accounts. IV.-Company Work. V.-Collieries. VI.-Secretarial. VII.-The Audit of Banks and Mercantile Firms, together with a Glossary of the principal Mercantile Terms in general use. A practical treatise of universal utility to everyone connected with the Accounts of Banks, Mercantile Firms, Joint Stock Companies, and other important Financial Institutions.

Net price (post free U.K.) 7/6 ; Abroad, 8/2. 


\section{BOOT AND SHOE COSTINGS.}

(6o pp., 8vo.) By Lawrance C. Headly, Chartered Accountant. Deals fully with the Cost Accounts of a Boot and Shoe Factory and with the Periodical, Manufacturing, Trading, and Financial Statements. The first part describes a simple and practical system for checking costs in detail, and ascertaining the results of manufacturing, the profits and losses in connection with the working up and consumption of materials and in connection with wages-the items of prime cost. The second part deals with Trading, and the expenses of carrying on the business, and gives examples of periodical statements by means of which full information on every detail can be obtained.

2/6 net. Post free U.K. and Abroad, $2 / 9$.

\section{BRANCH ACCOUNTS.}

(See Multiple Shop Accounts, p. 32.)

\section{BREWERS' AND BOTTLERS' ACCOUNTS.}

(Vol. XLIV of "The Accountants' Library" Series, q.v.) (200 pp., 8vo.) By H. Lanham, Chartered Accountant, with a chapter on the Licensing Act, 1934, by W. C. NoRTHCOTT, Chartered Accountant. Synopsis:-Purchases, Goods-in, Order and Stock Books, and Bought Ledger-Sales, Goods-out, Cellar, and Delivery Books, and Sales Ledgers-Customers' Cask Ledgers and Cask Registers-Bottled Beer Accounts-Cash, Petty Cash, Bills Receivable, Bills Payable, and Wages Books-Journal and Rents Receivable Book-Subsidiary and Statistical Books-Impersonal and Private Ledger Accounts and Balance Sheet-Stocktaking-Audit-The Licensing Act, 1904, with the text of the Act. Net price (post free U.K.) 10/6 ; Abroad, 11/-

\section{BRICKMAKERS' ACCOUNTS.}

(Vol. XXXIV of "The Accodntants' Library" Series, q.v.) (100 pp., 8vo.) By W. H. Fox. A complete handbook on the subject. Summary of Contents: Introduccion-Descriptive Sketch of the Industry - Varieties in Manufacture - Two complete Sets of Accounts, including Balance Sheets, Profit and Loss Accounts, Percentage of Cost, List of Plant, Stock, \&c.-Set of Specimen Books of Account, Contract Notes, Labour Sheets, \&c.-Co.xclusion and Index.

$3 / 6$ net. Post free U.K. 3/9; Abroad, 3/11.

\section{BUILDERS' ACCOUNTS.}

(Vol. III of "The Accountants' Library" Series, q.v.) (2nd Ed., 96 pp., 8vo.) By John A. Walbank, Chartered Accountant. This work explains in a clear and lucid way the methods of keeping the books of a Builder and Contractor. It is so arranged as to meet the requirements of both the large and small builder. With a minimum of clerical labour, and in a simple form, the cost of each job, \&c., can be readily ascertained. The records are so arranged as to allow of periodical Balance Sheets and Profit and Loss Accounts being quickly prepared, showing the cost of, and profit or loss on, each contract or speculative building.

3/6 net. Post free U.K. 3/9; Abroad, 3/10. 


\section{BUILDING SOCIETIES' ACCOUNTS.}

(Vol. XXV of "The Accountants' LibRaRy" Series, q.v.) (II6Ipp., 8vo.) By W. Colin Grant-Smith, LL.B., Chartered Accountant. For Permanent or Terminating Building Societies, but more especially adapted for Permanent Societies. Amongst the special features of this work are included:-Subscription Shares Table-Advanced Shares Table (four alternate)-Specimen Clauses of all matter that must be inserted in the Rules of a Society-Extracts from the Building Societies Acts relating to Accounts, Audit, \&c.-Specimen Forms of Pass Book, Register of Members, Application for Shares, \&c. \&c.-Copies of all Memoranda and Forms (now in use) issued from time to time by the Registrar. The System here recommended is so concise that the position of the Society at any time may be ascertained in a few minutes. This is especially valuable where it is desired to present to the Board of Directors Monthly, Fortnightly, or even Weekly Statements. 3/6 net. Post free U.K. 3/9 ; Abroad, 3/10.

\section{BUILDING SOCIETY TABLE AND LOAN CALCULA-} TIONS.

(I 8 pp., 8vo.) By George Johnson, F.S.S., F.C.I.S. A pamphlet. 1/- net. Post free U.K. and Abroad, $1 / 1$.

\section{CHARTERED ACCOUNTANTS' CHARGES AND THE LAW RELATING THERETO.}

(3rd Ed., 256 pp., 8vo.) By F. W. Pixley, F.C.A., Barrister-at-Law. The Author states what his experience leads him to consider are the usual Charges amongst Chartered Accountants with regard to Auditing, Investigations, Liquidations, Receiverships, Administrations, Trusteeships in Bankruptcy and under Deeds of Assignment, Trusteeships for Debenture-holders, Arbitrations, together with Tables for calculating Charges from one hour to one hundred days. The Law relating to the subject is dealt with, and a number of decided cases have been added. Net price (post free U.K.) 10/6 ; Abroad, 11/3.

\section{CHECK FIGURE SYSTEMS, ELEMENTARY TREATISE ON.}

(24 pp., 8vo.) By G. H. Hay, C.A. A pamphlet.

6d. net. Post free U.K. and Abroad, 7d.

\section{CHECK FIGURE SYSTEMS, PRINCIPLES OF.}

(I65 pp., 8vo.) By G. H. Hay, C.A. A complete treatise on the subject for Accountants and Bookkeepers, with numerous devices for quickly obtaining the Check-figure of Pounds, Shillings, and Pence, or Decimal Coinage from five selected base numbers, and special hints for discovering errors.

Net price (post free U.K.) 7/6; Abroad, 7/10.

\section{COLLIERY ACCOUNTS.}

(Vol. LI of "The Accountants' Library" Series, q.v.) (I30 pp., 8vo.) By John Mann, Junr., M.A., C.A., and Harold G. Judd, C.A. This book is intended to assist in the modernisation and improvement of existing systems of Colliery Accounting as well as in the institution of a system from the beginning. The work describes first the bookkeeping necessary to record the mining and disposal of the coal; the next sections treat of Purchases, Stores, and Costs, with special reference to Depreciation; and a later chapter deals with several matters which are incidental, though not essential, to almost every Colliery businesssuch as the ownership of Depôts and Washers, Railway Wagons and Sidings, and Workmen's Houses. Special attention has been directed to the question of Depreciation, and to modern methods of recording and tabulating Mining Costs.

5/- net. Post free U.K. 5/4; Abroad, 5/5. 


\section{COMPANIES ACT, 1907.}

(40 pp., 8vo.) By F. W. Le Blount Lean, F.C.A. A Classified Abridgment of the principal provisions affecting Directors, Secretaries, and Auditors.

1/- net. Post free U.K. and Abroad, 1/1.

\section{COMPANIES ACTS. THE DUTIES OF AUDITORS} UNDER THE.

(66 pp., 8vo.) A Series of Articles reprinted from The Accountant.

$1 /$ - net. Post free U.K. and Abroad, 1/2.

\section{COMPANIES (CONSOLIDATION) ACT, 1908, A PRACTICAL INDEX TO THE.}

(6o pp., 4to.) By A. Binnie, F.C.A., C.A. This very complete Index is a Key to the contents of the 296 Sections into which the I908 Act is divided. The details given as to the Statutory Duties cast upon Auditors, Directors, Liquidators, Receivers, Secretaries, and others; the Penalties incurred by neglect of same; the Rights of Creditors and Members; the Liabilities of Contributories; the requirements as to Prospectuses; and the many Returns to be filed with the Registrar, illustrate the practical nature of the contents. $3 / 6$ net. Post free U.K. and Abroad, 3/8. Also issued bound up with a King's Printers' copy of the Act.

5/-net. Post free U.K. 5/4; Abroad, 5/5.

COMPANY LAW.

(76 pp., 8vo.) By W. R. Willson, Barrister-at-Law. 'Deals with the Acts of 1900 and 1907 in a systematic manner.

1/6 net. Post free U.K. and Abroad, 1/8.

${ }^{*} *$ New Edition in the Press.

COMPANY (PRIVATE LIMITED).

(See Promotion and Accounts of a Private Limited Company, p. 35.)

\section{COMPANY (PUBLIC LIMITED).}

(See Promotion and Accounts of a Public Limited Company, p. 35.)

\section{COMPANY SECRETARIES' BOOKKEEPING.}

(See Bookkeeping for Company Secretaries, p. Ir.)

\section{COMPANY SECRETARY, THE.}

(6th Ed., 468 pp., foolscap folio.) By W. H. Fox. Completely re-written and revised under the Companies (Consolidation) Act, I908. This important Work contains a full description of the Duties of a Company Secretary, together with an Appendix of 350 pages of Forms and Precedents used from the Formation of a Company to its Winding-up. Each Form is filled in as it would be in actual use, and the result is a compendium of valuable information that entitles the book to rank as the Standard Work on Company procedure. The duties of the Company Secretary are fully explained in the letterpress portion, as also the use of the Forms in the Appendix. Every Form that can possibly be required finds a place. This Edition contains various Forms, \&c., required in the Winding-up of Companies and also in connection with the Companies (Consolidation) Act, 1908.

Net price (post free U.K.) 25/-; Abroad, $26 / 6$. 


\section{COMPANY WINDING-UP TIME TABLES.}

(See Bankruptcy and Company Time Tables, p. 9.)

\section{COMPENDIUM, ACCOUNTANT'S.}

(See Accountant's Compendium, p. 4.)

\section{COMPENSATION FOR MAN AND MAID.}

(Ir5 pp., 8vo.) By Oscar M. Wihl, B.A., LL.B. A full explanation of the Workmen's Compensation Act, 1906, with Tables and special chapters on Industrial Diseases, Seamen, and Domestic Service, together with the text of the Act briefly annotated.

2/- net. Post free U.K. 2/3; Abroad, $2 / 4$.

\section{CONTRACT, CHART OF THE LAW OF.}

Compiled by Robert W. Holland, M.Sc., LL.B., and R. C. Reynolds, A.C.I.S. 6d. net. Post free U.K. and Abroad, 7d.

\section{CO-OPERATIVE SOCIETIES' ACCOUNTS.}

(Vol. VI of "The Accodntants' Library" Series, q.v.) (126 pp., 8vo.) By F. H. Sugden. Synopsis:-Distributive Societies.' Accoonrs - Shares, \&c.-Small Savings (Penny Bank) Accounts - Cash Account-Trade Account-Producrive Societies' Accounrs -Shares, \&c.-Manufacturing Department - The AסDIT - General Considerations-Auditing-Systems of Check. (The Book, Eccles, Climax, and Leakage Systems are succinctly treated, the various forms being given, as far as possible, in extenso.)

5/- net. Post free U.K. 5/3 ; Abroad, 5/4.

\section{COST ACCOUNTS.}

(2nd Ed., r28 pp., 8vo.) By L. Whittem Hawkins, Chartered Accountant. An explanation of Principles and a Guide to Practice. Deals in a general way with the subject of Manufacturers' Cost Accounts. Summary of Contents:-Introduction-Direct Wages in the Cost Accounts-Wages in the General. Accounts-Materials in the Cost Accounts-Materials in the General Accounts-Chargeable ExpensesThe relationship between the Cost Accounts and the General Accounts - Indirect Charges and Oncost-How to Charge Oncost-Credits to Job Accounts-Completed Contracts and Sales in the General AccountsFinished Stock in the Cost Accounts-The relationship between the Cost Accounts and the General Accounts further considered-Diagram illustrating the Double-entry Principle of the Cost Accounts and their relationship to the corresponding portions of the Gereral AccountsClosing the Cost Ledger-Comparing the Cost Accounts and the General Accounts-Stores Accounts-Further consideration of MaterialsFurther consideration of Oncost-Patterns, Designs, Moulds, \&c.Some Special Features-The Cost Ledger and Journal (some details)Forms and Appendix.

5/- net. Post free U.K. 5/4; Abroad, 5/5.

COST ACCOUNTS FOR SMALL MANUFACTURERS. (56 pp., 8vo.) By M. Webster Jenkinson, Chartered Accountant. A useful treatise containing numerous pro forma Accounts.

1/- net. Post free U.K. and Abroad, 1/2. 


\section{COST ACCOUNTS, WITH SPECIAL REFERENCE TO THOSE OF AN ENGINEER AND IRONFOUNDER.}

(2nd Ed., I25 pp., 8vo.) By J. W. Best, F.C.A. The title denotes "specialisation," rather than " generalisation," but as similar principles have to be applied to all "Cost " Accounts, whatever the nature of the business, the book will be found useful not only to those associated with Engineering and Ironfounding, but also to Practitioners, Students, and all who are interested in, or who may be called upon to design or carry out a system of Cost Accounts in connection with any other business. Since the Ist Edition was written, Loose-Leaf Ledgers and Card Systems have proved to be useful in certain cases, and a special chapter bas been added on the Card System generally and as applied to Engineering and Foundry Costs.

5/- net. Post free U,K. 5/4; Abroad 5/5.

\section{COST ACCOUNTS, MULTIPLE.}

(Vol. XLII of "The Accodntants' Library" Series, q.v.) (I04 pp., 8vo.) By H. Stanley Garry, Chartered Accountant. This work illustrated with numerous pro forma Accounts and Charts, deals with the special Cost Accounts applicable to undertakings where a number of Products are involved bearing little or no apparent relation to each other in cost or selling price-such as Engineering specialities, Cycles, Hosiery, Boots, Furniture, Agricultural Implements-in which standardisation in parts is carried to a high degree of specialisation in manufacturing. Synopsis : Introductory-Organisation-Manufacturing Account-Purchases - Wages - Indirect Expenses-Stock - Departmental Units-Periodical Returns-Sale Units-Factory Units-Conclusion-Diagrams.

3/6 net. Post free U.K. 3/9; Abroad, 3/10.

\section{COST ACCOUNTS, PROCESS.}

(Vol. XLIX of "The Accodntants' Library" Series, q.v.) (I7o pp., 8vo.) By H. Stanley Garry, Chartered Accountant. The System of Costing described is applicable to Chemical Industries, Food Products, \&c., in which conversion of material takes place, and there are principal and by-products, such as Farmers, Fellmongers, \&c., and embodies an explanation and résumé of technical data which cannot fail to be of invaluable service to the Student of Process Accounting. Summary of Contents:-Division I. Technical and Process Data : Technical Data-Raw Material-Measurement of Solids-LiquidsGases-Liquid Processes-Useful Tables. Division II. Cost Grouping. Division III. Economics of Cost: Transportation of Material-Standard of Output-Stocks and Stocktaking-Steam-Power and Coal-Depreciation of Plant in Chemical Industries-Diagrams and Charts-Periodical and Statistical Returns-Index.

5/- net Post free U.K. 5/4;Abroad, $5 / 5$. 


\section{COST ACCOUNTS, SINGLE.}

(Vol. XLVII of "The Accotntants' Library" Series, q.v.) (150 pp., 8vo.) By G. A. Mitchell, Incorporated Accountant. This volume deals with undertakings possessing a natural unit of cost and measurement, such as Maltings, Breweries, Collieries, \&c. The work, written on unconventional and up-to-date lines, consists of Six Sections, and includes many useful pro forma Balance Sheets, Manufacturing Accounts (showing " volume" of Output), Trading Accounts, Cost Sheets, Estimates, \&c. I. Malting Accounts and Season's Estimates or forecast fully worked out and reconciled; Stock Checks, \&c.-II. Engineering Business with a Standardised Output.-III. Brewing Accounts and Costings agreed with Consumption and Production records. - IV. Colliery Working Accounts and Weekly Cost Sheets adjusted.-V. Stocktaking; Principles underlying the Correct Survey and Valuation of Stocks.-VI. Card and Loose-leaf Records compared with book-recorded data. The systems outlined, whilst retaining thoroughness and efficiency in all essentials, are practical and inexpensive in their introduction and day-to-day working.

5/- net. Post free U.K. 5/4; Abroad 5/5.

\section{COST ACCOUNTS, TERMINAL.}

(Vol. XLVI of "The Acccontants' LibraRy" Series, q.v.) (66 pp., 8vo.) By A. G. Nisbet, Chartered Accountant. This volume deals with a system of Costing suitable for undertakings where definite Contracts are entered into in which the Costing is definite and terminating, such as Constructional Engineers, Builders, Contractors, Bridge Builders, Shipbuilders, \&c. Synopsis: Introduction-Procedure on Receipt of Orders-Method of Charging-up Labour-Shop Expenses and Establishment Charges-Cost Sheets and their relation to the Manufacturing Account-The Premium System of Remuneration to Workmen-Index. $3 / 6$ net. Post free U.K. 3/9; Abroad, 3/10.

\section{COST OF PRODUCTION.}

(98 pp., 8vo.) By John A. Wild. An Explanation of Principles, and a Guide to Practice, for the Printing and Allied Trades, with an Appendix of Thirty-eight Forms. Summary of Contents:Introduction-The Basic Factor-Departmentalisation Essential Stocks and Stocktaking-Ascertaining Production-The Analysis of Wages-Consumption of Stores-Ascertaining Departmental Cost The Analysis of Expenses-Recovering Working Expenses - Ascertaining Job Cost-Management from Cost Records-The Selling Price -Conclusion-Appendix.

Net price (post free U.K.) 10/6 ; Abroad, 10/10.

COSTINGS, BOOT AND SHOE.

(See Boot and Shoe Costings, p. r3.) 


\section{COSTS, FACTORY ORGANISATION AND.}

(II in. by $8 \frac{1}{2}$ in., 420 pp.) By J. Lee Nicholson, C.P.A. A complete treatise on the subject, written not only from a standpoint of theory, but also from practical experience. Synopsis :-Organisation and Cost Finding-Wage Systems-Analysis of Cost Accounting-Distribution of Indirect Expenses-General Introduction to Forms and Systems -General Introduction to Designs and Explanations-Purchase Requisitions - Purchase Orders - Report of Material Received-Stock Record: Raw Material-Production Order-Material RequisitionTime Tickets-Pay Roll and Distribution Sheets-Production Reports - Stock Records: Finished Product-Cost Records-Defective Work Report-Statement of Factory Expenditures - Operating LedgerBilling System : Sales : Credit Certificate-Register of Sales and Costs -Accounts Payable Vouchers-Register of Accounts Payable-Check Voucher-Cash Systems-General Forms-Drawing, Pattern, and Equipment Records-Inventory of Material Forms-Sales Report and Analysis-Monthly Report relative to Financial Status and EarningsEstimated Cost System-Departmental Cost System-Special Order System-Product System. Mechanical Office Appliances (Calculating and Computing Machines-Adding and Listing Machines--Multigraph and Mimeograph-Addressing Machines-Time Clocks-Time Stamps -Wage Tables, Check Stamps, Phonograph, Counting MachinesFiling and Loose-Leaf Devices).

Net price (post free U.K.) 25/- ; Abroad, $26 / 8$.

\section{COTTON SPINNERS' ACCOUNTS.}

(Vol. XXXIX of "The Accountants' LibraRY" Series, q.v.) (I50 pp., 8vo.) By Wm. Moss, F.C.A. This book describes a complete system of Accounts for a Cotton Mill. It gives a list of the whole of the books, and separately describes the use of each. The statutory books of a Limited Company, the principal and subsidiary books of account, the books relating to internal management, and those relating to the Directors' supervision, are all dealt with. A complete set of pro formâ Accounts is given, fully written up, with specimen entries.

5/- net. Post free U.K., 5/4; Abroad, 5/5.

\section{CURRENCY (FLUCTUATING), TREATMENT OF, IN ACCOUNTS.}

(See Treatment of Fluctuating Currency in Accounts, p. 39.)

\section{DAIRY ACCOUNTS.}

(Vol. XXXIII of "The Accountants' Library" Series, q.v.) (I20 pp., 8vo.) By F. Rowland, A.C.A. The Complete System of Accounting is clearly and fully described, and facsimiles of all the Books and Forms recommended are given. Synopsis:-Introduction-The various Books of Accounts-Stock Books-Order Book-Cash Books-Ledgers, \&c.-The Accounts as applied to a Firm with Retail Shops and Branches, or to a Limited CompanyThe Books and Accounts for Small Dairymen possessing one Establishment only-Statutory Enactments relating to Dairies-Index.

3/6 net. Post free U.K. 3/9; Abroad, 3/10. 


\section{DEEDS OF ARRANGEMENT.}

(220 pp., 8vo.) By D. P. Davies, F.S.A.A. A Practical Manual for the use of Trustees. The fact that no other book exists dealing with Deeds of Assignment from an administrative point of view has led the Author to embody here the results of nearly twenty years' active insolvency experience. Special attention has been given to the requirements of Trustees, and all points, legal and otherwise, likely to arise in the administration of an estate are dealt with. Where cases are reported in The Accountant Law Reports, special reference is made thereto, for the convenience of Accountanis. The following matters are dealt with :-Deeds of Arrangement Generally-The Contents of a Deed of Assignment-Deeds of Composition-Deeds of Inspectorship and Letters of Licence-Registration-Assents-The Trustee-Acts of Bankruptcy-Preferential Creditors-The Avoidance of Deeds-Private Arrangements-The Realisation and Distribution of Assets-The Administration of Partnership Estates in Bankruptcy-Investigations and Meetings of Creditors-with an Appendix of Acts and Forms.

Net price (post free U.K.) 8/- ; Abroad, 8/6.

DEPRECIATION, RESERVES, AND RESERVE FUNDS. (Vol. XXVI of “The Accountants' Library"' Series, q.v.) (3rd Ed., 90 pp., 8vo.) By L. R. Dicksee, M.Com., F.C.A. Deals fully with the following matters:-The Importance of DepreciationMethods of Providing for Depreciation-Depreciation of FreeholdsDepreciation of Leaseholds-Depreciation of Plant and MachineryDepreciation of Loose Tools, \&c.-Depreciation of Patents, Copyrights, and Goodwill-Reserves, Secret Reserves-Reserve FundsSinking Funds-The Double-Account System-Local Authorities and Depreciation. It has been carefully revised, and is the most complete work of $i_{\text {is }}$ kind.

3/6 net. Post free U.K. 3/9; A.broad, 3/10.

\section{DEPRECIATION TABLES.}

(2nd Ed., 34 pp., 8io.) By L. R. Dicksee, M.Com., F.C.A. The tables are worked out (a) on the original cost, and (B) on the reducing balances to the close of the $25^{\text {th }}$ year. The unit adopted has been $f, \mathrm{I}, 000$, and the calculations are worked to the nearest penny at the following rates per cent. $1,2,2 \frac{1}{2}, 3,5,6,7 \frac{1}{2}, 10,12 \frac{1}{2}, 15,17 \frac{1}{2}, 20$, $25,30,33 \frac{1}{3}$.

1/. net. Post free U.K. and Abroad, 1/2.

\section{DIARIES, ACCOUNTANTS'.}

(See Accountants' Diaries, p. 5.)

\section{DRAPERS,' DRESSMAKERS,' AND MILLINERS' ACCOUNTS.}

(Vol. XXXI of "'The Accountants' Library" Series, q.v.) (and Ed., I 40 pp., 8vo.) By G. H. Richardson, Incorporated Accountant. This important and successful work, dealing fully with the different methods applicable to Drapery Accounts, has been thoroughly revised and partly re-written so as to include the latest developments in Counting House organisation; it comprises a detailed description of the use of Cash Registers, Pneumatic Tube and Carrier Systems, Slip Systems, Itemised Monthly Account System, Card and LooseLeaf Ledgers, Departmental Accounts, Workroom Accounts including Cost Card System, and last, but not least, a valuable chapter on Statistical Returns with numerous rulings. The book deals fully with the following matters, to each of which a chapter is devoted:General Principles-The Acquisition of a Business-Opening Entries -Cash Sales-Credit Sales-Returns, Appro., and Despatch-Sales Ledgers-Purchases-Expense Accounts-Cash and pro formâ Set of Accounts-Postal or Mail Order Work-Dressmakers,' \&c., Workroom Accounts-Wholesale System-Statistical Returns.

5/-net. Post free U.K. 5/4; Abroad, 5/6. 


\section{EARLY STAGES OF PREPARATION FOR THE ACCOUNTANCY PAPERS OF THE INTER- MEDIATE EXAMINATION.}

(roo pp., 8vo.) By A. E. Cutforth, A.C.A. The subjects dealt with in this book are those on which questions have been most frequently set in past Examinations. Each subject has been explained as clearly as possible by the aid of the working out of simple Examples. At the end of each chapter are given Questions which have been set in the past, the Answers to which are covered by the information given in the chapter. The following is a summary of the contents :The Cash Book-Self-Balancing Ledgers-Opening Entries of Joint Stock Companies' Books-Depreciation-Some Points in Partnership Accounts-Executorship Accounts-Goods on Sale or Return-Consignment Accounts-Bills of Exchange-The Double-Account SystemStatements of Affairs and Deficiency Accounts - Minimum Rent Accounts-Cost Accounts-Some Notes on Goodwill-Some Notes on Stock-in-Trade-The Companies Act, I900, re Auditors-Some Notes on Income-Tax-Forms of Books-Hints on "Tackling " Examination Papers. $\quad 2 / 6$ net. Post free U.K. and Abroad, 2/9.

\section{ELECTRIC LIGHTING ACCOUNTS.}

(Vol. XXIX of "The Accodntants' Library" Series, q.v.) (I40 pp., 8vo.) By G. Johnson, F.S.S., F.C.I.S. This work deals fully with the Accounts of Electric Lighting Companies. Synopsis:Introduction-Income and Expenditure-Costs and Charges-Purchase, Storage, and Record of Stores and Materials - Invoices - Inwards Account Book-Allocation of Stores and Materials Issued-Stocktaking - Wages - Salaries - Other Books of Account - Statements for Board-Depreciation and Renewals-Complete Set of pro formá Transactions-Accounts set out in Board of Trade form-Company Books-Insurances-Factory and Workshops Act, Igor.

5/-net. Post free U.K. 5/4; Abroad, 5/5.

** New Edition in the Press.

\section{ENGINEERS' AND SHIPBUILDERS' ACCOUNTS.}

(Vol. XIV of "The Accountants' Library" Series, q.v.) (2nd Ed., I20 pp., 8vo.) By F. G. Burton, Incorporated Accountant. Describes the System of Bookkeeping adapted for Engineering Factories and Shipyards. Synopsis:-Introductory - The Special requirements and difficulties of such Accounts-Materials and StoresPurchases and Stores Received and Issued Books and Ledger-Stores Credit Accounts-Salaries and Wages--Wages Book for Day Wages and Piece Work-Allocation of Wages-Manufactured Goods and Contracts-Large Contracts-Fixed Price Sales-Machinery for Stock purposes-Day and Warehouse Books-Credits to Customers-Cash Book, Depreciation, Establishment Charges, and Sundry Nominal Accounts-Ledger, Trade Account, Balance Sheet, and AuditExamples of various Accounts employed - Cost Accounts - Consideration of different Methods of keeping Costs, and Examples of the threefold form recommended.

3/6 net. Post free U.K. 3/9 ; Abroad, 3/10. 


\section{ERRORS IN BALANCING.}

(3rd Ed., 32 pp., 8vo.) A concise handbook dealing with the more usual causes of differences in Trial Balances and the methods of their detection. Summary of contents :-Preliminary - Importance of Subject to Accountants-Systems for Localising Errors-Causes of Specific Errors-Figures Badly Placed-Indistinct Figures-Errors in Copying Figures-Classes of Errors-Complex Errors-Errors of Advancement-List of First Series of Errors of Advancement-List second do.-List third do.-List fourth do.-Errors of TranspositionErrors $\ell_{100}$ and upwards-Errors $\ell^{1,000}$ and upwards-Transposi. tions of Three Figures-Conclusion. (Reprinted from articles that have appeared in The Accountant).

1/- net. Post free U.K, and Abroad, 1/2.

\section{EXAMINATION GUIDES.}

Intermediate Guide (I96 pp., 8vo); Final Guide (327 pp., 8vo) By John G. Nixon, Junr., A.C.A. These books are compilations of the Questions (only) set at the Intermediate and Final Examinations of the Institute of Chartered Accountants, from December 1893 to June 1903, inclusive. The Questions are arranged, according to subject, in alphabetical order. The Intermediate Guide contains a total of 776 Questions, and the Final Guide 1,157 Questions.

Intermediate Guide, 3/6 net. Post free U.K. 3/9; Abroad, 4/Final Guide, 5/- net. Post free U.K. 5/4; Abrcad, 5/7.

\section{EXAMINATION QUESTIONS AND ANSWERS}

to the Examinations of the Institute of Chartered Accountants. (About I 70 pp., 8vo.) Issued in June and December each year. First issued in 1884. These Answers are designed to give the fullest and most reliable information on each question asked, and are compiled with a view to lasting reference. Each part contains the answers to the Intermediate and Final Examinations. Back parts dating from December 1884 can be obtained. They can also be had bound up in volumes of four parts with index, under the title of "The Accountants' Manual" (q.v.) 1/6 net. Post free U.K. or Abroad,1/7.

Subscription, per annum, post free $\mathbf{3} / \mathbf{-}$

(The subscription includes two parts and the index issued biennially.)

\section{EXAMINATIONS, CHARTERED ACCOUNTANTS', HOW TO PREPARE FOR}

(3rd Ed., 24 pp., 8vo.) By J. A. Carlill, A.C.A. A Pamphlet.

1/6 net. Post free U.K. and Abroad, 1/7.

\section{EXAMINATIONS, PREPARATION FOR.}

(See Early Stages of Preparation, \&c., p. 21.)

\section{EXAMINATIONS, THE MONTH BEFORE THE.}

( 40 pp., 8 in. by $3 \frac{1}{\text { in.) }}$ By A. E. Cutforth, A.C.A. A collection in convenient pocket-book form of those portions of each subject which are most difficult to retain in the memory. Synopsis:Arbitrations and Awards-Bankruptcy-Company Law-Executorship Law-Mercantile Law (including Agency, Bailments, Contracts, Lien, Shipping, Negotiable Instruments, Sale of Goods, Suretyship and Guarantees)-Partnership Law.

1/6 net. Post free U.K. and Abroad, 1/7. 


\section{EXAMINATIONS, THE INSTITUTE, AND HINTS TO ACCOUNTANCY EXAMINEES.}

(8o pp. Demy 8vo, limp cloth.) By Roger N. Carter, M.Com., F.C.A. Revised Reprints of Papers read by the Author before various Chartered Accountants Students' Societies in IgIo and IgrI. In response to numerous requests, these lectures have been revised and enlarged for general circulation. It is hoped that they will be of assistance to examination candidates in reaching obscure points and in investing their reading with more interest. Synopsis: The Institute Examinations-Introduction-Bookkeeping-Auditing-Partnership-Executorship-Bankruptcy-Deeds of Arrangement-Com: panies-Receivers-Mercantile Law-Agency-Bills of Exchange-Guarantees-Gaming Contracts-Restraint of Trade-Sale of GoodsGeneral Contracts-Hints to Accountancy Examinees.

Price 2/-. Post free, U.K. and Abroad, 2/2.

\section{EXAM. ROOM PROBLEMS.}

(30 pp., $8 \frac{1}{2}$ in. by $4 \frac{1}{1}$ in.), with suggestions for their solution. In this pamphlet the following points have been selected for full treatment :-Introduction-Exam. Room Equipment-Order of Working out Answers-Style of Written Answers on Lengthy Topics-Detailed Bookkeeping Answers-Tackling a Trial Balance-Profit and Loss Account Preparation-Balance Sheet Preparation-Answers to Legal Questions-The "Shortness of Time" Complaint-Revision of Work. 1/- net. Post free U.K. and Abroad, $1 / 1$.

EXECUTORS, BOOKKEEPING FOR.

(See Bookkeeping for Executors, p. II.)

\section{EXECUTORS', ADMINISTRATORS', AND TRUSTEES' RECORD.}

(67 pp., foolscap.) By Chas. Jarvis Collier, Chartered Accountant. This volume, which is strongly bound in half calf, is designed to assist trustees to keep a record of their transactions. For small and medium-sized estates it provides all that is necessary to enable a readily intelligible and permanent record to be kept.

Net price (post free U.K.) 10/6 ; Abroad, 11/-

\section{EXECUTORSHIP ACCOUNTS.}

(3rd Ed., 82 pp., 8vo.) By O. H. Caldicott, F.C.A. Contains a complete set of Trust Accounts, with Explanatory Text.

$3 / 6$ net. Post free U.K. and Abroad, 3/9.

EXECUTORSHIP ACCOUNTS, STUDENTS' GUIDE TO. (2nd Ed., 240 pp., 8vo.) By R. N. Carter, M.Com., F.C.A. A complete Guide to Executorship Accounts, with a Summary of the principal points of the Law and numerous pro forma Accounts. Synopsis:Definition of Terms-Summary of the Law relating to Wills, Executors, and Administrators (comprising the Office of an Executor, Probate, Administrations, The Getting in and Distribution of the Estate, Legacies, Realty and Personalty, Apportionment, Investments, The Rule in Howe v. Lord Dartmouth, Carrying on the Testator's Business, The Distribution of the Estate of an Intestate, Responsibilities of Trustees)-Payment of Probate or Estate DutyPayment of Legacy or Succession Duty-Specimen Questions and Answers-The Audit of Trust Accounts-Capital and Income, amplified reprint of articles written for The Accountant-Example of an Intestacy -Example of a Legacy in Trust-Acts and Rules-Pro forma Accounts. Net price (post free U.K.) 6/-; Abroad, 6/5. 


\section{EXPENSES BOOK, FOR SOLICITORS, AUCTIONEERS, ACCOUNTANTS, \&C.}

(Foolscap folio, 120 openings.) (Copyright-Registered No. 593,82r.) By Edward J.Tubbs, Chartered Accountant. This book will prove useful to all professional men, whatever the size of their practice. A special feature of the Book is the introduction of the Invoice Column; by this means all the expenses of the business, whether paid by cheque or in cash, can not only be readily classified in the one book, but also a proper check is had upon all the accounts owing by the business. A great advantage, too, is that the payments on behalf of clients, whether paid by cheque or in cash, being debited up through the medium of the Clients' Expenses Ledger Column one can make up at any time a client's bill and have all the payments before one without fear of any item being missed, which may easily happen where they are simply ticked off from a rough Petty Cash Book. This book is a combination of the Expenses Journal and Petty Cash Book, which, of course, in the case of a large firm can be easily separated if desired, but the present book is very useful for any average-sized firm.

Price $8 / 6$ net post free U.K.; 9/6 post free Abroad.

\section{FACTORY ACCOUNTS.}

(6th Ed., 300 pp., 8vo.) By E. Garcke and J. M. Fells. A Handbook for Accountants and Manufacturers, with Appendices on the Nomenclature of Machine details; The Income Tax Acts; The Rating of Factories; Fire and Boiler Insurance, \&c., including also a Glossary of Terms and a large number of specimen rulings. In view of the continuous demand for this work, the authors have taken the opportunity presented by a further edition of adding to and re-arranging the chapters it previously contained, whereby it more adequately reflects the great progress which has been made in Cost Accounting methods since, in 1887 , they made the first attempt to place before English readers a systematized statement of the principles relating to Factory Accounts. The changes that have taken place in methods of production, the continuously increasing use of machinery, and the larger proportion of the cost due to its use, have rendered it desirable to deal in greater detail than hitherto with the apportionment of machinery charges. Additional chapters are therefore now devoted to consideration of this matter. Synopsis:- Chapter I, IntroductoryChapter 2, Labour-Chapter 3, Stores-Chapter 4, Prime Cost and the Cost Ledger-Chapter 5, Indirect or Incidental Expenses and their Allocation-Chapter 6, Fixed Capital and DepreciationChapter 7, Machinery Use-Chapter 8, Stock-Chapter 9, SurveysChapter Io, Subsidiary Books-Chapter I I, Methods of Remunerating Labour-Appendices-Glossary-Index-Table of 57 Specimen Rulings-Diagram $\mathrm{r}$, The Assimilation of Wages and Commercial Books-Diagram 2, Assimilation of Stores and Commercial BooksDiagrams 3 and 4 , The Assimilation of Cost and Commercial BooksDiagram 5, The Assimilation of Stock and Commercial Books.

$$
\text { 6/- net. Post free U.K., 6/4; Abroad, 6/9. }
$$

\section{FACTORY ORGANISATION AND COST ACCOUNTS.}

(See Cost Accounts, pp. I6-I9.) 


\section{FISHING INDUSTRY ACCOUNTS.}

(Vol. XX of "The Accountants' Library" Series, q.v.) (8o pp., 8 vo.) By Charles Williamson, M.A., C.A. This Volume deals at length with the Accounts of Steam Fishing Boats, Fish Salesmen, Fish Merchants, and Fish Curers, and describes the various necessary books. The system advocated is illustrated by full tro formâ rulings, and will be found complete in every way.

3/6 net. Post free U.K. 3/9; Abroad, 3/10.

\section{FORMS OF ACCOUNT BOOKS.}

(Ioo pp., 8vo.) By J. G. Johnston, C.A. Synopsis:-Part I.Forms of Books for Manufacturing Businesses. Part II.-Forms of Books for Retail Businesses. Part III.-Forms of Books for the use of Solicitors and Law Agents. Part IV.-Forms of Books for the use of Stockbrokers. Part V.-Forms of Housekeeping Books. Part VI.- Form of Investment Register and Calendar of Income.

2/6 net. Post free U.K. 2/9; Abroad, 2/10.

\section{FRAUD IN ACCOUNTS.}

(Vol. XXX of "The Accodntants' Library" Series, q.v.) (2nd Ed., Ioo pp., 8vo.) Deals with the Methods of circumventing Frauds on the part of both Employees and Directors, and shows how they may be detected at an early date-The Functions and Limitations of an Audit-Systems of Internal Check-Motives and Methods of Fraud -Specific Instances of Fraud: Misappropriations of Money-Specific Instances of Fraud not involving the Misappropriation of MoneySpecific Instances of Fraud: Falsifications of Directors and Proprietors -Appendix.

$3 / 6$ net. Post free U.K. 3/9;Abroad, 3/10.

\section{FRIENDLY SOCIETIES' ACCOUNTS AND STATISTICS.}

(48 pp., 8vo.) By V. Marr, F.F.A., F.I.A. A Pamphlet. Synopsis :-Classes of Friendly Societies-Regulations as to AccountsAudits-Public Auditors-Statistical Tables-Annual Return-Card Register-Sickness Aliment-Tabulation of Statistics-Funeral Benefits -Contributions-Management Expenses-Investments-Use of Cards - Journal Entries-Appendix.

1/- net. Post free U.K. and Abroad, 1/1.

\section{FRIENDLY SOCIETIES' AND TRADES UNIONS' ACCOUNTS.}

(Vol. XXVIII of "The Accountants' Library" Series, q.v. (I6o pp., 8vo.) By E. Furnival Jones, A.S.A.A. A concise and practical system of Account-keeping-sufficiently comprehensive for the needs of a large centralised Association, and at the same time easily adjustable to the limited operations of the smallest Branch. Starting with the method of recording the receipt of Contributions from Members, the reader is taken step by step through the modes of paying Benefits and dealing with Investments, to the completion of the Quarterly or Yearly Accounts and Balance Sheet, and the Filing of Returns with the Chief Registrar. Many practical hints to the Auditor and Accountant are thrown out in the course of the work; valuable suggestions are given for keeping proper Statistical Records, and the nature and importance of the Actuarial Valuation are touched upon and explained. The following may be noted, among other special features of the book : Extracts from the Acts of Parliament relative to Accounts and Audit; Specimen Forms of Account Books and Registers, specially suited to the needs of Friendly Societies; Copies of Forms required to be filed with the Chief Registrar of Friendly Societies from time to time. $5 /$ - net. Post free U.K. 5/4;Abroad, 5/6. 


\section{GAS ACCOUNTS.}

(Vol. VII of "The Accodntants' Library" Series, q.v.) (2nd Ed., r30 pp., 8vo.) This work deals fully with the accounts of all classes of Gas undertakings. Synopsis: Introduction, dealing with the constitution of Gas Companies, \&c.-Sale of Gas and Collection of Gas Rates-Fittings Accounts, and Prime Cost Accounts incidental thereto-Sale of Residual Products-General Ledger and full set of pro forma Accounts for one year-Statutory Form of Annual Accounts-Shares, Stock, and .Debentures-Cost Accounts with pro forma Statement-Capital and Revenue Expenditure-Local Authorities as Owners of Gasworks-Index. 5/-net. Post free U.K. 5/4 ; Abroad, 5/5.

\section{GAS COMPANIES' BOOKKEEPING.}

(240 pp., 4to.) By J. H. Brearley and B. Taylor. A practical treatise. A full description is given, with illustrations, of all the Books and Forms. The Frontispiece, a concise Chart, shows at a glance the linking together of the respective books. A complete set of transactions is worked out, and from these a Model Balance Sheet and Statement of Accounts is compiled.

Net price (post free U.K.) 12/6 ; Abroad, $13 / 6$.

\section{GOODWILL.}

(3rd Ed., I76 pp., 8vo.) By L. R. Dicksee, M.Com., F.C.A., and F. Tillyard, M.A., Barrister-at-Law. The subject of Goodwill, its treatment in Accounts and the Law relating thereto, is fully dealt with. Synopsis:-The Connection between Goodwill and Trade Names and Trade Marks-The Nature of Trade Names and their Protection-Trade Marks and their Protection-The Nature of Goodwill-The Assignment of Goodwill-Partnership and GoodwillGoodwill and Accounts-The Valuation of Goodwill-The Fluctuations of Goodwill-The Purchase of Goodwill-Goodwill in Partnership Accounts-Goodwill in Companies' Accounts-Text of the Trade Marks Act, I905-Common Form Clauses relating to Good will.

Net price (post free U.K.) 5/6 ; Abroad, 5/10.

\section{GRAIN, FLOUR, HAY, AND SEED MERCHANTS' ACCOUNTS.}

(Vol. X of "The Accountants' Library" Series, q.v.) (II2 pp., 8vo.) By G. Johnson, F.S.S., F.C.I.S. Describes a complete system of Bookkteping for Grain, Flour, Hay, and Seed Merchants, with numerous Forms and a set of pro forma Accounts, with Specimen Entries and a Glossary of Trade Terms and Abbreviations. $3 / 6$ net. Post free U.K. $3 / 9$; Abroad, 3/10.

\section{GROCERS' BOOKKEEPING.}

(48 pp., 8vo.) By M. Webster Jenkinson, Chartered Accountant. A System of Bookkeeping suitable for Grocers and other Retail Tradesmen, with specimen Forms of Accounts.

1/- net. Post free U.K. and Abroad, 1/2.

\section{HIRE PURCHASE ACCOUNTS.}

(48 pp., 8vo.) By G. Johnson, F.S.S., F.C.I.S. A short treatise on the Bookkeeping, Accounts, and Calculations relating to the HirePurchase Wagon Trade and Colliery Royalties, and Wayleaves.

$1 / 6$ net. Post free U.K. and Abroad, $1 / 8$. 


\section{HOTEL ACCOUNTS.}

(Vol. XXXVII of "The Accodntants' Library " Series, q.v.) (2nd Ed., 80 pp., 8vo.) By L. R. Dicksee, M.Com., F.C.A. A complete system of Bookkeeping for Hotels of all sizes is described. Synopsis: Introduction-Preliminary Records-Office-Nominal Ledger-Cellar and Bar-General Ledger-Kitchen and Stores-Internal Check and Audit-The "Simplex System"-Railway Hotels and Restaurants. There are 27 Forms, including forms of Interim Trading Account and Daily Cost Sheet. $\quad 3 / 6$ net. Post free U.K. 3/9;Abroad, 3/10.

\section{INCOME-TAX, Return for Assessment, schedule D.}

(8 pp. 4to) A Reprint of the Official Form (No. II), with the "Notes, Explanations and Instructions." The Form is printed on good quality account book paper, and will be of use to Accountants and others, enabling them to keep complete copies of Returns made.

Per Copy, 3d. net. Post free U.K. and abroad, $3 \frac{1}{2} \mathbf{d}$.

Per dozen, 2/-net. Post free U.K. and abroad, $2 / 3$.

\section{INCOME-TAX ON EARNINGS.}

(4th Ed., 20 pp., 8vo.) By C. E. Isaacs. This is a simple Exposition of the Finance Act, I907, so far as it relates to Incometax on earned Income, together with the proposals for the year Igog affecting the subject. A Summary of all the important Incometax provisions of the above-mentioned Act is include?, together with Hints, Instructions, and Warnings to Taxpayers, which should be eminently useful to all who wish to avoid being overcharged.

6d. net. Post free U.K. 7d. ; Abroad, 8d.

\section{INCOME-TAX PRACTICE, MURRAY AND CARTER'S GUIDE TO.}

(6th Ed., 590 pp., 8vo.) By the late A. Murray and R. N. Carter, Chartered Accountants. This standard work contains a Summary of the principal Enactments relating to Income-Tax, with notes of every reported case; Instructions as to the preparation of Returns for Assessment and Accounts in support of Appeals on the ground of over-assessment; also for claiming Exemption and Abatement; and a Concise Popular Digest of the Principal Legal Decisions on the Construction of the Acts for the use of Taxpayers. Synopsis : Table of Cases-Table of Statutes-History of the Income-Tax and Epitome of the principal Acts relating thereto-The Schedules under which Income-Tax is Charged - Schedules A, B, C, and E - Schedule D (Persons and Property Chargeable-Returns for Assessment-Appeals)-Rate of Reduction of Tax on Payment of Dividends, \&c.-Exemptions and Abatements (General-Charities and Public Buildings-Relief to "Earned" Incomes)-Conclusion -Index. Net price (post free U.K.) 15/-; Abroad, 15/10.

\section{INCOME-TAX, SIMPLEX GUIDE TO.}

(2nd Ed., 90 pp., 8vo.) By R. N. Carter, M.Com., F.C.A. A Handbook for business men. Synopsis: Taxation at the Source-The Schedules under which Income-Tax is Charged-What are Profits for Income-Tax Purposes-Cash Accounts and Profit and Loss AccountsThe Application of the Principle of Taxation at the Source-Preparing the Return-Change in a Business and the "Succession "Rule-The General and Special Commissioners-Exemptions and AbatementsClaims for Repayment where the Income is derived from Investments - Claims for Repayment in respect of a Loss-New Businesses and Businesses Discontinued-Relief to "Earned" Incomes.

2/6 net. Post free U.K. and Abroad, 2/9. 


\section{INSTITUTE OF CHARTERED ACCOUNTANTS EXAMINATION QUESTIONS AND ANSWERS.}

(See Examination Questions and Answers, p. 22.)

\section{INSTITUTE OF CHARTERED ACCOUNTANTS-LIST OF MEMBERS.}

(Issued yearly.)

2/- net. Post free U.K. $2 / 3$; Abroad, $2 / 6$.

\section{INSURANCE AGENTS' ACCOUNTS.}

(45 pp. 8vo.) By A. H. Maclean, Chartered Accountant. Every Insurance Agent should possess a copy of this work. It is indispensable to the Agent who wants to keep a grip of his business. The book is divided into Two Parts-the First Part dealing with the recording of policies, etc. ; the Second Part dealing with the recording of monetary transactions. The whole system is quite simple and can easily be grasped and put into operation even by those having but little knowledge of bookkeeping. The number of books and the entries in them have been kept down to the smallest possible limits. The system is peculiarly suitable for solicitors, accountants, estate agents, etc., as it can be adopted irrespective of the method of bookkeeping used for the other branches of the business, and will record many or few transactions equally well. The simplicity of the method renders information easy of access to anybody, even though they are unacquainted with the whole system.-Particularly useful in an Expanding Business.

2/6 net. Post free U.K. and Abroad, $2 / 9$.

\section{INSURANCE COMPANIES' ACCOUNTS.}

(Vol. XXXVI of "The Accountants' Library" Series, q.v.) (200 pp., 8vo.) By E. A. Tyler, Incorporated Accountant. This work is the only book dealing exclusively with the subject of the Accounts of Insurance Companies as a whole. It discusses exbaustively the general principles underlying insurance accounts of every description, and treats in considerable detail of such important divisions of the business as: Life, Sickness, Fire, Accident, Burglary and Plate Glass, Employers' Liability. It shows amongst other things the proper treatment of Half-yearly and Quarterly Premiums, and outlines more than one system of dealing effectively with the many complications arising in connection with the payment of Overriding Commission. The general plan of the work is easy to follow; the arrangement of detail is particularly clear; and a very large number of forms, with specimen entries and a full index, make the volume by far the most complete work of reference obtainable on the subject of which it treats.

Net price (post free U.K) 10/6 ; Abroad, 11/.

\section{INTEREST TABLE.}

(2 pp., foolscap.) By C. Roberts. A Table for calculating interest on current accounts. Its especial usefulness lies in the fact that it is all contained in a single opening, and that much turning over of pages will be saved by its users. Mounted on stiff cloth boards, or on linen.

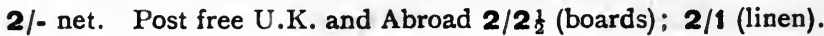


INVESTMENT AND LOAN SOCIETIES' ACCOUNTS.

(ro8 pp., 8vo.) By D. J. A. Brown and E. Thomas. Indicates clearly the guiding principles relating to the Formation and Management and to the Compilation and Audit of the Accounts. Contains chapters on the Objects and the Formation and Management of a Society, Income and Expenditure, the Books of Account, the Branch Accounts, the Secretarial and Statistical Books, the Audit Rules, and a fully worked set of Accounts.

5/- net. Post free U.K. and Abroad, 5/4.

\section{JEWELLERS' ACCOUNTS.}

(Vol. XXIII of "The Accountants' LibraRy" Series, q.v.) (I80 pp., 8vo.) By Allen Edwards, F.C.A. Describing a complete System of Bookkeeping for Manufacturing, Retail, and Wholesale Jewellers, Diamond Merchants, Silversmiths, Electro Platers, Gilders, Watch Manufacturers, \&c. A leading feature of the work is the showing how Gold, Silver, and Precious Stones can be checked and accounted for, in the various processes of manufacture, together with systems for checking Stocks. The prevention of Fraud, Embezzlement, and other avoidable loss is dealt with, and chapters upon Crossed Cheques, the giving of Credit, the Renewals of Customers' Bills, Bad Debts, Appro., Income Tax, and the Conversion of Private Businesses into Limited Companies, are also included. In addition, the ordinary books usually kept in a Trader's Office are clearly and concisely explained, the whole book being illustrated by upwards of fifty Forms, specially drawn up for the work.

5/-net. Post free U.K. 5/4: Abroad, 5/6.

\section{JOINT TRANSACTIONS OF THE UNION OF CHARTERED ACCOUNTANT STUDENTS' SOCIETIES.}

(See Union, \&c., p. 4r.)

\section{LAUNDRY ACCOUNTS.}

(Vol. XXXVIII of "The Accountants' Library" Series, q.v.) (124 pp., 8vo.) By F. J. Livesey, F.C.A. A complete System of Bookkeeping for Laundries. Summary of Contents : Introduction - Subsidiary Books - Shorts - Hotel Work - Receiving Shops Nominal and Private Ledgers-Weekly Return-Branch Accounts. There are fifty-one Forms, including Profit and Loss Account and Balance Sheets, and Weekly Return Sheet.

3/6 net. Post free U.K. 3/9; Abroad, 3/10.

\section{LEGAL TERMS, SOME.}

(50 pp., $7^{\prime \prime} \times 44^{\prime \prime}$.) By A Barrister. Introductory Lectures on Law for Accountant Students. Synopsis:- "Law" and "Equity" - "Common Law" and "Statute Law," "Codes" and "Codification "-- "Property" and "Possession "-_ "Privity of Contract " and "Privity of Estate "- "Tort," "Crime," "Felony," "Misdemeanour," "Action," "Prosecution "- " The Courts of Law" -The Criminal Courts-The Civil Courts.

1/- net. Post free U.K. and Abroad. 1/1. 


\section{LEXICON FOR TRUSTEES IN BANKRUPTCY, \&C.}

(422 pp., 8vo.) By S. S. Dawson, M.Com., F.C.A. A Lexicon for the use of Trustees in Bankruptcy and under Deeds of Arrangement, and Liquidators of Companies. This work forms a ready and reliable book of reference for practitioners. The numerous Statutes and the Schedules thereto, the accumulation of Rules, Board of Trade Regulations, Orders, Directions, and the countless Decisions of the Courts have necessarily formed the basis of the work, and these varied sources are referred to throughout the text.

3/6 net. Post free U.K. 3/9; Abroad, 4/-

\section{LIMITED PARTNERSHIPS ACT, 1907.}

(70 pp., 8vo.) By D. P. Davles, F.S.A.A. Deals fully with the Limited Partnerships Act, I907; some Continental and other Provisions relating to Limited Partnerships; the Relation between the Partnership Act, 1890, and the Limited Partnerships Act, 1907. It contains the Rules, Forms, full text of the Limited Partnerships Act, 1907, and of the Partnership Act, 1890, with an Index.

1/6 net. Post free U.K. and Abroad, 1/71

\section{LIQUIDATORS.}

(See Trustees, Liquidators, and Receivers, p. 40.)

\section{LOCAL AUTHORITIES' ACCOUNTS, ORGANISATION AND AUDIT OF.}

(488 pp., 8vo.) By A. Collins, A.S.A.A. The only complete treatise on this important subject, incorporating the recommendations of the Departmental Committee on Municipal Accounts ; an exposition of up.to-date methods of financial control, collated from the most efficient systems in use in the leading local authorities of the Kingdom; the whole of the present day systems of Audit reviewed, analysed, and compared. Summary of Contents:-Review of Local Authorities' Accounts and their Audit -Extent of Local Authorities' Operations-Local Authorities' Powers, Duties, and Obligations-The Position of the Chief Financial OfficerThe Accounting Systems in vogue-The Internal Check in vogueSpecial Considerations in: (a) County Council Accounts; (b) County Borough Council Accounts; (c) Non-County Borough Council Accounts: (d) Metropolitan Borough Council Accounts; (e) Urban District Council Accounts, \&c.-Accounts Audited by the Local Government Board-Statutory Regulations-The Board's Control of Accounts and Audit-The Audit by the District Auditor-The Elective Audit-Minor Audit Provisions-The Professional. Audit of Local Authorities' Accounts-Preparation for Audit-The Cash Transactions - The Revenue Transactions-The Capital Transactions-The Arithmetical Accuracy of the Books-Questions of Principle involved in the Financial Statements - Compliance with Statutory RegulationsMiscellaneous Considerations arising out of Audit-Auditors' Certificate and Report - Appendix - Standardised Forms of Published Accounts-Index. Net price (post free U.K.) 12/6 ; Abroad, 13/4. 


\section{LOCAL AUTHORITIES' ACCOUNTS, THE DIAGRAM- MATIC PRESENTMENT OF.}

(6o pp. and 19 diagrams, 4to.) By Sidney E. Allen, A.S.A.A. By the use of diagrams the author presents the principal financial and statistical facts of one of our largest cities in a clear, concise, and intelligible form. In less than 20 diagrams he gives the "condensed essence " of over 200 pages of published accounts, and mucl additional information. The practical value of the novel idea at once appeals to the reader. He sees that the diagrams show at a glance what only a laborious examination of figures would otherwise give him. The book, being written in a popular style, is easy and pleasant to read. Summary of Contents:-Preface; I-Rates; II-Assets and Debts; III-Local "National" Expenditure; IV-Trading Undertakings: (r) Waterworks, (2) Tramways, (3) Electric Supply, (4) Markets, (5) Trading undertakings compared with each other; V-Education; VI-General Statistics: (I) Police, (2) Fire Brigade, (3) Streets and Sewers, (4) Street Lighting, (5) Parks and Recreation Grounds, (6) Population, Births and Deaths, (7) Salaries and Wages; VII-Conclusion: I.ist of Diagrams: Index.

Net price (post free U.K.) $\mathbf{7} / \mathbf{6} ;$ Abroad, $8 /$.

MANUAL, ACCOUNTANTS'.

(See Accountants' Manual, p. 5.)

\section{MEDICAL PRACTITIONERS' ACCOUNTS.}

(Vol. XVIII of "THE Accodntants' Library" Series, q.v.) (85 pp., 8vo.) By J. H. May, A.S.A.A. The system of Bookkeeping described in this volume is designed to combine simplicity with economy of labour, yet enabling the medical man to summarise his total income and expenditure on any balancing date, and therefrom to have regular Profit and Loss Accounts and Balance Sheets prepared. Full pro forma Accounts in illustration of the forms of Account Books are given in each case. Chapters are subsequently devoted to subjects which accountants find it necessary, at one time or another, to apply themselves-such as "Medical Men's Income Tax," "The Assessment of Practice Values," "Notes on the Collection of Debts Outstanding," \&c.

3/6 net. Post free U.K. 3/9; Abroad, 3/10.

METRIC SYSTEM, THE.

(40 pp., 8vo.) By The Rev. G. T.P.Streeter, B.A. A Pamphlet. 1/- net. Post free U.K. and Abroad, 1/1.

\section{MINERAL WATER MANUFACTURERS' ACCOUNTS.}

(Vol. VIII of "The Accountants' Library" Series, q.v.) (75 pp.. 8 vo.) By J. Lund, A.S.A.A. and G. H. Richardson, F.S.S. The system of Bookkeeping described can be safely taken as a model upon which a set of Books and Accounts should be constructed. The work describes and explains the following: Purchases Day BookPurchases Ledger-Sales Book-Sales Ledger-Cartmen's Delivery Book-Cash Sales Book-Bottles and Boxes-General Cash BookPetty Cash Book-Nominal Ledger-Wages-Commission-Private Ledger-Balance Sheet-Trading Account-Bottle Exchange-Stock Book-Mineral Water Associations and their Officers. Numerous pro forma $\Lambda$ ccounts with specimen entries are given.

$\mathbf{3 / 6}$ net. Post free U.K. $\mathbf{3} / \mathbf{9} ;$ Abroad, $\mathbf{3} / \mathbf{1 0}$.

MINING ACCOUNTS, COAL.

(See Colliery Accounts, p I 4 .) 


\section{MINING COMPANIES' ACCOUNTS.}

(See Australian Mining Companies' Accounts (p. 8) and West African Gold Mining Accounts (p. 42).)

\section{MONEY MARKET, AN OUTLINE OF THE.}

(56 pp, 8vo.) By E. E. Spicer, F.C.A. This book deals with the growth of the Money Market from the earliest times, and shows fully and clearly the working of the complex machine which our present civilisation has evolved. Banking, the Bank of England, the Bank Rate, the Foreign Exchange, and the vital question of the Gold Reserves, are dealt with in a lucid and interesting manner.

2/- net. Post free U.K. and Abroad, $2 / 2$.

\section{MOTOR CAB COMPANY, THE ACCOUNTS OF A}

(46 pp., 8vo.) Reprinted from The Accountant. This work describes in detail a system of accounting of the most up-to-date description suitable for a Motor Cab Company of ordinary dimensions. Special attention is directed to the practical aspects of the matter, e.g., Stores Records, Trial Performances, Drivers' Records, Working Costs, and the like; while the application to these purposes of the Card System gives a wider interest to the book. The system described, which has been found to work smoothly in actual practice, can easily be adapted to suit the requirements of all garages where motor cars are let out on hire.

2/- net. Post free U.K. and Abroad, 2/17.

\section{MULTIPLE COST ACCOUNTS.}

(See Cost Accounts, p. 17.)

\section{MULTIPLE SHOP ACCOUNTS.}

(Vol. XXIV of "The Accountants' Library" Series, q.v.) (I20 pp., 8vo.) By J. Hazelip, F.C.I.S. A work describing the best method of keeping the Accounts of Multiple Shop Companies having a number of branches, and dealing in Boots and Shoes, Bread, Butter, Clothing, Drapery, Drugs, Fancy Articles, Fish, Game and Poultry, Furniture, Hats and Caps, Hosiery, Jewellery, Meat, Milk, Provisions, Tea, Tobacco. The reader is guided through the different departments of a theoretical business step by step till the final results of the year's trading are ascertained. The chapters on Organisation, Stockkeeping, and Stocktaking are of great practical value, and the following matters are also dealt with, viz. :Contracts and Agreements; Leases; Assessment of Rates; Appeals against Assessments; Fire and Plate Glass Insurance; Fidelity Guarantees; Income Tax Returns; Credit Accounts; Collection of Bad Accounts; Banking, \&c. Summary of Contents :-Organisation -Shops: their Functions and Methods of Receiving Supplies-Central Warebouse: Purchase of Goods and Distribution to Branches-Head Office: How the Accounts are gathered together and finally dealt with - Stockkeeping and Stocktaking: Adjustment and ReconciliationCapital and Revenue Expenditure : Renewals and Repairs-Organisation into Districts, Differences in Books and Accounts explainedHints on Matters of Importance.

3/6 net. Post free U.K. 3/10; Abroad, 3/11. 


\section{MUNICIPAL ACCOUNTS.}

(Vol. XXI of "The Accountants' Library" Series, q.v.) (200 pp., 8vo.) By John Allcock, F.S.A.A. This work is based on the methods adopted by some of the leading Municipalities in England. The entire system of Bookkeeping and Checking of Municipal Accounts is dealt with, and facsimiles of all Books and Forms recommended are given. Synopsis: Introduction-Ordering Goods and Preliminary Measures relating to Accounts-Checking AccountsPresentation of Accounts-Schedule of Cheques, \&c.-Income and Expenditure Ledger-Works Accounts-Estimate and ExpenditureRates-Electricity Accounts-Corporation Stock-Registration of Stock -Private Improvement Works Accounts - Exchequer Contribution Account-Town Hall Lettings-Police Pension Fund Account-Petty Cash, \&c. \&c.-Insurance of Workmen-Audit.

Net price (post free U.K.) 10/6; Abroad, 11/-

\section{MUNICIPAL ACCOUNTS.}

(See also Local Authorities' Accounts (p. 30), The Diagrammatic Presentment of Local Authorities' Accounts (p. 3I), and Urban District Councils' Accounts (p. 4I).)

\section{MUNICIPAL FINANCE.}

(44 pp., 8vo.) By R. F. Miller, F.C.A. A pamphlet dealing with some aspects of Municipal Finance and Accounts from the standpoint of a Professional Auditor. 6d. net. Post free U.K. and Abroad, 7 d.

\section{MUNICIPAL FINANCE FOR STUDENTS.}

(7o pp., 8vo.) A short work, written by an eminent Municipal Accountant, on the most important features in Local Government Finance for Students. 2/6 net. Post free U.K. and Abroad, 2/9.

\section{MUNICIPAL INTERNAL AUDIT, A.}

(I 40 pp., 8vo.) By A. Collins, F.S.A.A. Not only is the Audit of the Collection of Rates and other peculiarlv Municipal Revenues lucidly set out in this work, but the trade undertakings (such as Gas Works, Electricity Works, Waterworks, Tramways, Markets, \&c.) receive special attention.

3/6 net. Post free U.K. 3/9; Abroaj, 3/11.

MUNICIPAL RATING.

(iro pp., 8vo.) By A. James Pearce, A.C.A. A complete practical guide for Municipal Rating, showing, step by step, the duties which are necessary for the collection of Rates. The Comparative Charts, the specially compiled Returns from other Boroughs, the Assessment Tables, and, in particular, many of the Forms which are included in the book, have never appeared before in any similar work, and have all been tested in actual practice.

5/- net. Post free U.K. 5/4; Abrcad, 5/5.

\section{NEWSPAPER ACCOUNTS.}

(238 pp., 8vo.) By B. J. Norton, F.C.A., and G. T. Feasey, A.C.A. Synopsis: Introductory-Booksrelating to Sales-Books relating to Advertisements-Books relating to Contributions-Books relating to Purchases and Expenses-Books relating to Cash-Private Books -Departmental Checks upon the Bookkeeping-Adaptation of the System to Papers of Small Circulation-Adaptation of the System to Evening Papers-Adaptation of the System to Weekly PapersSpecimen set of Books containing Entries representing Transactions for one half-year-Special Rulings of Books for Papers of Small Circulation-Special Rulings of Books for Evening Papers-Special Rulings of Books for Weekly Papers-Index.

Net price (post free U.K.) 10/- ; Abroad, 10/6. 


\section{PAWNBROKERS' ACCOUNTS.}

(Vol. XIII of "The Accodntants' Library" Series, q.v.) (90 pp., 8vo.) By Fred Thornton and J. Henry May, A.S.A.A. This work embodies a complete System of Accounts for this peculiar and (to the outsider) complicated trade. The system has been perfected by many years of experience in Pawnbroking circles, and is placed before Accountants as the best, not only by reason of its meeting the recognised requirements of modern accountancy, but above all because it is already in operation in a large number of Single-shop Pawnbroking Establishments, as well as in the Offices of up-to-date Companies with Branches.

$3 / 6$ net. Post free U.K. 3/9; Abroad, 3/10.

\section{PERSONAL AND DOMESTIC ACCOUNTS.}

(56 pp., 8vo.) By J. G. P. Ibotson, A.C.A. A useful handbook, showing how to keep Personal Accounts on a proper footing. Synopsis :-Introductory-Records of Payment-Records of Receipt-The Cash Book-Classification-The Ledger-Receipts and Payments Account and Balance Sheet-Income and Expenditure Account-Capital Accounts-Comparative Statements - VouchersIncome Tax-Trust Accounts-Appendix-Trustee Investments.

1/- net. Post free U.K. and Abroad, $1 / 2$.

\section{POLYTECHNIC ACCOUNTS.}

(Vol. XI of "The Accountants' Library" Series, q.v.) (86 pp., 8vo.) By H. Calder Marshall, F.C.A. A complete set of Bookkeeping and Accounts for Polytechnic Institutions. Synopsis: Introductory-System of Finance-List of Books-Organisation of Staff -Chief Books of Account-Departmental Books-Subsidiary Statistical Books - The Final Accounts - Capital Accounts - Establishment Charges-Resolutions passed at Conference of Polytechnic Auditors -Grants-Audit-Appendix.

3/6 net. Post free U.K. 3/9; Abroad, 3/10.

\section{PRINTERS' ACCOUNTS.}

(Vol. XVII of "The Accountants' Libriary" Series, q.v.) (80 pp., 8vo.) By H. Lakin-Smith, Chartered Accountant. A thoroughly reliable handbook on Bookkeeping for Printers. Summary of Contents : Introduction-Estimating Purchases-Cash Books-Wages-SalesCost Accounts-Private Ledger, \&c.-Balance Sheet-DepreciationDepartmental Accounts-Index.

3/6 net. Post free U.K. 3/9; Abroad, 3/10.

\section{PROCESS COST ACCOUNTS.}

(See Cost Accounts, p. I7.)

\section{PROFESSIONAL ACCOUNTANTS.}

(I28 pp., 8vo.) By B. Worthington. An Historical Sketch. This book gives an historical survey of the Profession in this country from its early inception to the present time. It embraces, amongst other chapters, one entitled "An Accountant's Report, about I72I," which is reprinted in full in an appendix, and which should prove of undoubted interest to all Accountants. Other subjects dealt with are: The Early Progress of the Profession; The Railway Mania and its sequel; Auditors, past and present; \&c. \&c. Throughout the book there is much didactic information bearing on the subject of Accountancy in a lucid manner.

2/6 net. Post free U.K. 2/9 ; Abroad, 2/10. 


\section{PROMOTION AND ACCOUNTS OF A PRIVATE LIMITED COMPANY, THE.}

(88 pp, 8vo.) By M. Webster Jenkinson, F.C.A. A Paper read before the members of various Chartered Accountants Students' Societies in January I9II. Revised and Reprinted with an Index. Synopsis: Advantages and Disadvantages on the Conversion of a Business into a Private Limited Company-Definition of "Private Company "-Procedure-Memorandum of Association-Articles of Association-Copies of Memorandum and Articles-Sale AgreementFees Payable upon Incorporation-Incorporation of the CompanyPreliminary Expenses-First Directors' Meeting-Statistical Books to be kept and Returns to be made to the Registrar-Allotment of Shares - Statutory General Meeting-Statutory Requirements-Penalties for Non-compliance with Statutory Requirements-Entries in Financial Books-Adjustments in Vendor's Accounts-Profits prior to Incorporation-Share Capital Accounts-Forfeiture of Shares-DebenturesFinal Accounts and Audit-Income Tax-Conclusion.

Boards, 2/. net. Post free U.K. and Abroad, 2/3. Cloth, 2/6 ",, , 2/9; , 2/10.

\section{PROMOTION AND ACCOUNTS OF A PUBLIC LIMITED COMPANY.}

(I84 pp., 8vo.) By M. Webster Jenkinson, F.C.A. A Revised and Enlarged Reprint of a Lecture read before various Students' Societies in rgr2. Synopsis: Procedure-Constitution and Memorandum of Association-Name-Registered Office-Objects-Alteration of Memorandum of Association-Articles of Association-Inspection of Memorandum and Articles-Capital and Shares-Application and Allotment of Shares-Share Certificates-Transfer of Shares-Debentures-Registration-Use of Name-Underwriting-Promoter and Prospectus-Advertising-Payment of Interest out of Capital-Directors - Purchase Price-Preliminary Expenses-The Preliminary ContractCommencement of Business-Profits prior to Incorporation-Meetings and Proceedings-Statutory General Meetings-Extraordinary General Meetings-Other Meetings and Votes-Statutory RequirementsPenalties for Non-compliance with Statutory Requirements-Books to be Kept-Register of Members-Register of Mortgages-Annual List and Summary Book-Share Capital Accounts-Final Accounts and Audit-Conclusion.

Cloth bound. 5/. net. Post free U.K., 5/4; Abroad, 5/5.

\section{PUBLISHERS' ACCOUNTS.}

(I28 pp., 8vo.) By C. E. Allen. A complete system of Accounts for Publishers, illustrated with numerous pro forma Accounts, and a fully worked example of typical transactions Synopsis:-Nature of the Business-Method and Organisation of the Book Trade-BooksRoutine-Nature of the Ledger Accounts-Stocktaking-BalancingAnalysis of Subsidiary Books-Worked Example of Typical Transactions-Copyright-Definition of Literary Property-Peculiarities of its Nature-As a Monopoly - Circumstances which affect the Value of Copyright-Duration and Term-Copyright Act- Magazine Accounts, involving the Treatment of Printing Plant, Wages of Compositors, \&c.-Outline Forms of Agreement between Author and PublisherElectros, Stereos, List of Assets.

2/6 ret. Post Free U.K. 2/9; Abroad, 2/10. 


\section{QUARRY AND STONE MERCHANTS' ACCOUNTS.}

(Vol. XXVII of "The Accountants' Library" Series, q.v.) (II2 pp., 8vo.) By J. G. P. Ibotson, Chartered Accountant. A complete System of Accounts for Quarry Owners and Managers and Stone Merchants. Synopsis:-Introductory-Quarry Department-Works Department - Transport - Sales Department - Financial - Annual Accounts-Audit-Branch Accounts-Plant Accounts, \&c.-Granite Sett, Slate, and Marble Quarries-Appendices-Index.

$3 / 6$ net. Post free U.K. 3/9; Abroad, 3/10.

\section{RAILWAY ACCOUNTS, A DIGEST OF.}

(92 pp., 8vo.) By A. C. Anderson, Chartered Accountant. This work sets out briefly and concisely the sources from which the figures appearing in the published accounts of a Railway Company are compiled. Synopsis :-Traffic Department : Ccaching-GoodsMinerals. ExpENDITORE: Stores Departmert-Works and Ways Department-Lccomotive, Carriage, and Wagon Department. Traffic Secretary's Departikent : General Secretarial Duties-Accountancy in the Secretary's Office. Accountant's Department: Audit Offices (Coaching-Goods and Minerals-Mileage and Demurrage ReturnsGovernment Duty on Passenger Traffic)-Station Ledger Office-Bookkeepers' Office-List of Accounts-Appendix. THE Audit OF RAILWAY Companies: General Remarks on the Professional Audit-Forms of Account prescribed by the Regulation of Railways Act, 1868-Index.

$3 / 6$ net. Post free U.K. 3/9; Abroad, 3/10.

RATING, MUNICIPAL.

(See Municipal Rating, p. 33.)

\section{RECEIVER AND MANAGER IN POSSESSION, THE.}

(52 pp., 8vo.) By A. Binnie, F.r.A., C.A. This work describes the methods by which the Receiver and Manager carries out the practical duties devolving upon him after his appointment, deals with many of the difficulties which confront him, and contains useful Forms and directions relating to the Preparation and Vouching of the Receiver and Manager's Accounts. Carrying out of Contracts, Management of Routine Work, Preferential Claims, Borrowing, Realisation of Property, and Personal Liabilities incurred by Receivers and Managers, are among the points dealt with in the book, which should be of practical interest to the Student of Accountancy, and may, for purposes of reference, appeal to many practitioners. Synopsis: Appointment-Preliminaries to Appointment by the Ccurt-Power to Borrow immediately fur certain purposes-Acts after Appointment and on taking Possession-Management and Routine Work-Preferential Claims-Income Tax-Liquidation - Removing Property-Disputed Property-Realisation-Conditions of Sale-Delivery to PurchaserAuctioneers' and Valuers' Charges-Transfer of Debentures-Transfer of Shares-Paying Money into Court-The Receiver's AccountDischarge. $2 / 6$ net. Post free U.K. 2/8; Abroad, $2 / 9$.

\section{RECEIVERS, LAW OF.}

(See Law of Trustees, Liquidators, and Receivers, p. 40.)

\section{RESERVES AND RESERVE FUNDS.}

(See Depreciation, Reserves and Reserve Funds, p. 20.)

\section{SHIPBUILDERS' ACCOUNTS.}

(See Engineers' and Shipbuilders' Accounts, p. 2r.) 


\section{SHIPPING ACCOUNTS.}

(Vol. XL of "The Accountants' Library" Series, q.v.) (roo pp., 8vo.) By R. R. Daly, Chartered Accountant. This important work deals fully and explicitly with the Accounts of Shipping Companies. The text is amply explained by the many Forms of Account which are included. It deals with the following branches:- The Accounts of a Sailing Ship-The Accounts of a Single-Ship Company-The Accounts of a Company owning several Vessels-The Accounts of a Line of Steamers-Passenger Office Accounts.

3/6 net. Post free U.K. 3/9; Abroad, 3/10.

\section{SHOPKEEPERS' ACCOUNTS.}

(2nd Ed., 50 pp., 8vo.) By S. B. Quin, F.C.A. A System for a Grocery, Provision, or General Store, which can be adapted to the Accounts of a Shopkeeper engaged in any business. Synopsis: Introduction - Sales Ledger-Sales Ledger Analysis Book-Cash Book - Cash Book, Alternative Form - Invoice Book-General Ledger-Specimen Accounts-Gereral Remarks and ConclusionForms: Balance Sheet-Sales Ledger-Sales Ledger Analysis BookCash Book-Cash Book, Alternative Form-Invoice Book - General Ledger-together with Specimen Accounts and Entries.

2/6 net. Post free U.K. 2/9;Abroad, 2/10.

\section{SINGLE COST ACCOUNTS.}

(See Cost Accounts, p. 18.)

\section{SOLICITORS' ACCOUNTS.}

(Vol. XII of "The Accocntants' Library" Series q.v.). (2nd Ed., 92 pp., 8vo.) By L. R. Dicksee, M.Com., F.C.A. Designed to meet the requirements of either large or small practices, the system of Accounts advocated is clearly described, and numerous alternative methods, suitable under various circumstances, are fully dealt with. The work consists of Six Chapters, and contains a fully worked out set of pro forma Transactions illustrating the correct method of keeping each book described. Among other important matters the following are duly considered :- The Separation of Clients' Moneys, County Court Business, Agency Business, Draft Bills of Costs, \&c. Every effort has been made to formulate a system combining Simplicity with Completeness and Practical Efficiency.

$3 / 6$ net. Post free U.K. $3 / 9$; Abroad, 3/10.

\section{STOCKBROKERS' ACCOUNTS.}

(Vol. IX of "The Accountants' Library" Series, q.v.) (2nd Ed., I Io pp., 8vo.) By W. D. Callaway, Chartered Accountant. The unique system of Dealing and Accounting that obtains on the London Stock Exchange is fully explained in this book. Synopsis:-(I) The method of dealing; (2) The Settlement of Bargains; (3) Minor and Subjective Difficulties, Calls and Dividends, Rights, Options, Put and Call, Giver and Taker, Arbitrage, Settlement, Department or Clearing House; (4) Description of Books necessary for a Jobber; (5) Description of Books necessary for a Broker; (6) Trial Balance; (7) Specimen Accounts; (8) The-Audit; (9) Fraud in Stockbrokers' Accounts. A Glossary of Stock Exchange Words and Phrases and a comprehensive Index follow, the whole being supplemented by an Appendix divided as follows: (a) Share Calculation Table: (b) Stamp Duties; (c) Illustration of a Make-up; (d) Ccmmission usually Charged by Brokers; (e) Stock Exchange Rules relating to Official Quotations. $3 / 6$ net. Post free U.K. 3/9; Abroad, 3/10. 


\section{STUDENTS' GUIDE TO ACCOUNTANCY.}

(2nd Ed., rio pp., 8vo.) By L. R. Dicksee, M.Com., F.C.A. This work affords reliable information for those who contemplate entering the Accountancy Profession, and will be found of value to all Articled Clerks in helping them to acquire the necessary knowledge to enable them to pass their examinations. Synopsis :A Sketch of the Accountancy Profession-On being ArticledThe Preliminary Examination-The First Half of Articles-The Intermediate Examination-The Last Half of Articles-The Final Examination - Afterwards - Appendix A: Pro formá ArticlesAppendix B: Instructions to Candidates-Appendix C: Hints on Preparation for the Examinations.

2/6 net. Post free U.K. and Abroad, 2/9.

\section{SUPERTAX, THE, AND HOW TO AVOID OVER- CHARGES AND PENALTIES.}

(2o pp., 8vo.) By C. E. Isaacs. This new work will be of timely service to taxpayers, who, under the Finance Act, 1909, will be compelled to disclose their total incomes from every source-not to obtain alleviation of their income-tax burdens, but to reveal to the Inland Revenue authorities the extent to which they are liable to increased taxation, under the newly imposed "Supertax."

1/- net. Post free U.K. and Abroad, 1/1.

TABLE A. [Revised.]

(22 pp., 8vo.) Regulations for Management of a Company Limited by Shares.

6d. net. Post free U.K. and Abroad, 7d.

\section{TERMINAL COST ACCOUNTS.}

(Sce Cost Accounts, p. I8.)

\section{THEATRE ACCOUNTS.}

(Vol. V of "The Accountants' Library" Series, q.v.) (8I pp., 8vo.) By W. H. Chantrey, Chartered Accountant. This work sets out the system of Recording the Receipts of a Theatre, with a Complete Set of House Returns, and also details the method of Checking the House and other Receipts. It deals with the Treasury and other Expenditure, and includes a Form of Weekly Financial Statement and Treasury Sheet. Advance Booking, Library Accounts, Provincial Tours, and Authors'. Fees are also dealt with, together with the consideration of Cost of Production and Depreciation, with an explanation of the Depreciation Table. Notes concerning the Revenue Account and Balance Sheet, and the Audit are included, and the Appendix contains Forms of Lord Chamberlain's Licences, Agreements with Artistes, Authors, and Touring Company, a pro formâ Balance Sheet and Revenue Account, and a Depreciation and Sinking Fund Table for Ioo years, at 3 to 6 per cent.

3/6 net. Post free U.K. 3/9; Abroad, 3/10. 


\section{TIMBER MERCHANTS' ACCOUNTS.}

(Vol. XXXV of "The Accountants' Library" Series, q.v.) (100 pp., 8vo.) By E. E. Smith, Chartered Accountant. The Accounts of both the Wholesale and Retail Businesses are dealt with in this volume, and information is given as to the methods necessary to properly record the transactions of a firm having branches at various places. 3/6 net. Post free U.K. 3/9; Abroad, 3/10.

\section{TIME TABLES}

(See Bankruptcy and Company Time Tables, p. 9.)

\section{TRAMWAY BOOKKEEPING AND ACCOUNTS.}

(Vols. XV and XLVIII of "The Accountants' Library" Series, q.v.) (282 pp., 8vo.) By Donald McColl. This work is based upon the very thorough and up-to-date methods in operation in the Glasgow Corporation Tramways Department, and will be of considerable service to Tramway Officials and others interested in Tramways, both here and in America. The entire System of Accounting is clearly and fully described, and facsimiles of all the Books and Forms recommended are given. Synopsis : Introductory and General-Traffic-Wages-General Stores -Power Stations-Depôts-Works-Permanent Way and Electrical Equipment of Track-Weekly Revenue and Expenditure StatementGeneral Bookkeeping-Annual Balance-Sinking Fund, Depreciation, Renewal, and Reserve Funds-Insurances-Friendly Societies-Superannuation Fund-Valuation for Local Assessments, together with a Supplement dealing with the following:-Standardisation of Accounts -Disadvantages of Expenditure Ledger System-Numerical List of Accounts - Allocation of Wages - Allocation of Materials - Special Statistical Items suggested-List of Forms-Facsimiles of Books and Forms-Index. Net price (post free U.K.) 12/6; Abroad, 13/2.

The Supplement separately.

2/6 net. Post free U.K. and Abroad, 2/9.

\section{TRANSACTIONS OF THE UNION OF CHARTERED ACCOUNTANT STUDENT SOCIETIES.}

(See Union, \&c., p. 4I.)

\section{TREATMENT OF FLUCTUATING CURRENCY IN ACCOUNTS.}

(6o pp., 8vo.) By A. E. Cutforth, A.C.A. This book deals as shortly and concisely as possible with this particular branch of the subject of Foreign Exchange. Simple examples have been used throughout to illustrate the detailed explanations given. Among the matters discussed in relation to fluctuating currency are : Treatment of Revenue Receipts and Expenditure-Treatment of Capital Expenditure - Current Account between an English and a Foreign Office-Valuation of Floating Assets and Liabilities-Treatment of Stores AccountsDifferences in Exchange: how arising and how dealt with-Use of "Permutation" or "Conversions" Account.

2/6 net. Post free U.K. 2/9;Abroad, 2/10.

TRIAL BALANCE BOOK, THE HANDY.

7d. net. Post free U.K. and Abroad, per copy, 8d. Per doz., 6/- net. Abroad, 6/8. 


\section{TRUSTEES, LIQUIDATORS, AND RECEIVERS, A CHART OF THE RIGHTS AND DUTIES OF.}

By W. R. Willson, B.A., Barrister-at-Law. A Chart of the Liabilities, Duties, Powers, Rights, Appointment and Removal of Trustees in Bankruptcy, Compulsory, Voluntary, and Supervision Liquidations, Trustees under Deeds, and Receivers.

1/- net. Post free U.K. and Abroad, $1 / 3$.

\section{TRUSTEES, LIQUIDATORS, AND RECEIVERS, THE ACCOUNTS OF.}

(Vol. XLI of "The Accodntants' Library" Series, q.v.) (I35 pp., 8vo.) By S. S. Dawson, M.Com., F.C.A., and H. R. Graves, A.C.A. This Work deals fully with its subject, and will be found of the greatest use to all Accountancy Practitioners. It deals with the Accounts of Trustees in Bankruptcy, under Deeds of Arrangement; Liquidators in Compulsory Winding-up, in Voluntary Winding-up, and in Winding-up subject to the supervision of the Court ; "Pending" Liquidations and Accounts of Receivers. All necessary Forms and Examples are given, together with an exhaustive Index.

$3 / 6$ net. Post free U.K. 3/9; Abroad, 3/10.

\section{TRUSTEES, LIQUIDATORS, AND RECEIVERS, THE LAW OF.}

(3rd Ed., 278 pp., 8vo.) By W. R. Willson, B.A., Barristerat-Law. A succinct statement of the law, as established by the latest statutes and decisions, written analytically for students reading for the Examinations of the Institute of Chartered Accountants and the Society of Accountants and Auditors. The work deals with the Appointment and Removal, the Rights, Powers, Duties, and Liabilities of Trustees in Bankruptcy: Trustees under Schemes or Compositions and in Administrations of Deceased Insolvents: Special Managers in Bankruptcy: Trustees under Private Deeds of Arrangement : Liquidators in Compulsory Winding-up: Provisional Liquidators: Special Managers in Winding-up: Liquidators in Voluntary Winding-up: Liquidators in Winding-up under Supervision: Receivers appointed by the Court: Managers and Consignees: Receivers appointed by Parties, together with Abbreviations, Definitions, Index to Cases cited. Appendix of Forms, Time Table, and Chart.

Net price (post free U.K.) 10/6; Abroad, 11/(See also Receiver and Manager in Possession, p. 36.)

\section{UNDERWRITERS' ACCOUNTS.}

(Vol. XXII of "The Accountanrs' Library" Series, q.v.) zlid Ed., (Ioo pp., 8vo.) By E. E. Spicer, F.C.A., and E. C. Pegler, F.C.A. This work deals somewhat fully with the general principles underlying the business, in order that those not acquainted with Accounts of this nature may more readily grasp the system laid down; but the whole subject has necessarily been dealt with from the point of view of Accounts. Since the first edition of this book was published the system of Account-keeping at Lloyd's has materially altered in certain respects, necessitating a thorough revision of the text. The general adoption of what is known as "Syndicate Form," which involves considerable difficulties from an Accountancy point of view, rendered necessary the addition of a special chapter on this subject, which is amply illustrated by specimen forms and accounts.

5/- net. Post free U.K. 5/3 ; Abroad, 5/4. 


\section{UNION OF CHARTERED ACCOUNTANT STUDENT SOCIETIES' JOINT TRANSACTIONS.}

(8vo.) This publication, which is issued annually, contains selected and edited Lectures and Essays read before the various Chartered Accountant Students' Societies.

The issue for I9II (8vo., xvi. +424 pp.) contains the following Lectures :- The Promotion and Accounts of a Private Limited Company, by M. Webster Jenkinson, F.C.A. ; Reserves, Annuities, and Sinking Funds, by Ernest Evan Spicer, F.C.A. ; Balance Sheet Values and Reserve Funds, by W. R. Hamilton, J.P., F.C.A. ; The Verification of Assets: Essay, by Philip H. Blackwell; Contracts in Restraint of Trade, by Paul E. Sandlands, Barrister-at-Law; Some Notes on the Accounts and Records of Printers, by H. Lakin-Smith, F.C.A., F.S.S. ; Mnemonics, and other Aids to Preparation for the Institute Examinations, by Allan Welch, A.C.A.; How Values are Ascertained, by J. Keetley, A.C.A. ; An Audit of Trust Accounts under the Public Trustee Act, 1906, by Ernest C. Pegler, F.C.A.; The Administration of the Income Tax Acts, by C. E. Isaącs ; Hints to Accountancy Examinees, with Special Reference to the Accountancy Subjects, by Roger N. Carter, M.Com., F.C.A. ; Voluntary Liquidations, by W. H. Shaw, F.C.A. ; The Duties of Trustees and Official Receivers in Bankruptcy, by George A. Baker, Solicitor, Birmingham; Trust Accounts, by W. J. Birks; Remarks on Railway Records, by A. W. Air ; Investigations of Accounts for Purposes other than Flotations, by H. R. Morland, M.A., A.C.A. ; The Preparation and Audit of the Statutory Report, Section 65 of the Companies (Consolidation) Act, I908, and Matters Co-Incident thereto: Prize Essay, by R. E. Dawe; Some Duties of a Liquidator in a Winding-up by the Court, by Wilfrid Price, Barrister-at-Law; Debentures, by J. Sampson, Solicitor; Frauds, by Daniel Hill, F.C.A.

Price 4/-net. Post free U.K. 4/4; Abroad, 4/6.

${ }_{*}^{*}$ The issues for 1909 and 1910 can still be obtained.

\section{URBAN DISTRICT COUNCILS' ACCOUNTS.}

(Vol. XLV of "The Accountants' Library" Series, q.v.) (r4o pp., 8vo.) By F. S. Eckersley. This work provides a complete practical manual illustrative of the method of keeping the Accounts of Local Authorities on the basis of Income and Expenditure, for the use of Clerks and Accountants to Urban District Councils. The book will also be found useful to Clerks to Rural District Councils, Assistant Overseers, Rate Collectors, and other Financial Officers, to members of Local Authorities interested in financial matters affecting local government, and to students of municipal finance. Synopsis : Introduction-General District Revenue, Income-General District Revenue, ExpenditureIncome from Loans and Capital Outlay-Private Street Works Accounts -Income from and Expenditure in connection with Reproductive Undertakings-Education Accounts-Audit and General-Financial Administraticn, tcgether with 56 Forms, Appendix and Index.

5/- net. Post free U.K. 5/4;Abroad, 5/5. 


\section{VADE MECUM, ACCOUNTANT'S AND BOOK- KEEPER'S.}

(I68 pp., 8vo.) By G. E. Stuart Whatley, Chartered Accountant. This Work consists of a Series of practical Articles upon Capital and Revenue Expenditure, Revenue Accounts, Deficiency Accounts. Statements of Affairs, Depreciation, Reserve and Sinking Funds, Adjustment of Partnership Accounts, Joint Stock Companies' Accounts, Tabular Bookkeeping, Hotel and Theatre Accounts, and other matters not generally dealt with in existing works on Bookkeeping, together with useful Forms and Directions and numerous fro forma Accounts.

Net price (post free U.K.) 7/6; Abroad, 7/11. ** New Edition in the Press.

\section{WATER COMPANIES' ACCOUNTS.}

(Vol. XIX of "The Accodntants' Library" Series, q.v.) (80 pp., 8 vo.) By F. Key, Incorporated Accountant. The complete system of Bookkeeping advocated is illustrated by full pro forma Accounts. Synopsis: Introduction. Chapter I.-Meter and General Rent Ledgers and books subsidiary thereto. Chapter II.-The Collection of the Company's Rents and the internal check thereon. Chapter III.The Stores Department: Intake and Delivery. Chapter IV.-The Principal Financial Books; Capital and Revenue; Audit. Chapter V. - Miscellaneous Books; Conclusion. Appendices :-Accounts of the Hillside Water Company; Trial Balance; Revenue and Capital Accounts and Balance Sheet; Extracts from Acts of Parliament pertaining to Water Companies' Accounts. Index.

3/6 net. Post free U.K. 3/9; Abroad, 3/10.

\section{WEST AFRICAN GOLD MINING ACCOUNTS.}

(134 pp., 8vo.) By Fred J. Lock, A.S.A.A. This practical guide for the introduction and working of a system of accounts suitable for a gold mine in West Africa is the result of the many years' experience the Author had as Chief Accountant on some of the largest gold mines of that country. In carrying out the duties which devolve upon an Accountant on a mine, the need is often felt of a book of reference giving some concise and workable system of accounts, suitable for either large or small undertakings, and this book will, it is hoped, prove of value to mine managers and accountants, and those whose business brings them into contact with mining companies. The work is freely illustrated with Forms distributed throughout the text, and deals with the engagement of Workmen and Conditions of Service, \&c., Allocation Lists, Time-keeping, Stores, the General Bookkeeping and Final Accounts, Record Books, Returns, \&c., and the Head Office Books. The Forms have for the most part been put to the test by actual use on the West African Goldfields.

5/-net. Post free U.K. 5/3 ; Abroad 5/4. 
WINE AND SPIRIT MERCHANTS' ACCOUNTS.

(Vol. XXXII of "The Accodntants' Library" Series, q.v.) (Igo pp., 8vo.) By A. Sabin. This book describes a complete system of Accounts on a thoroughly practical basis, suitable for a small Country Business, or one with a large Town connection. The transactions of the "Universal Wine and Spirit Company" are followed in detail from the receipt of an Order to the appropriation of the Profits in the Partners' Balance Sheet. The system is a simple one, and the books self-balancing. The technical information given, with the Customs and Excise Regulations and Duties, and Licences payable in dealing with Wines and Spirits, will be found useful.

5/- net. Post free U.K. 5/4; Abroad, 5/6.

\section{WOOLLEN ACCOUNTS.}

(Vol. XLIII of "The Accountants' Library" Series, q.v.) (76 pp., 8vo.) By J. Mackie. A complete System of Bookkeeping for Woollen and other Warehousemen. Describes fully the necessary Books and Forms for the Warehouse and the Counting House, together with the Statistical Books.

3/6 net. Post free U.K. 3/9; Abroad, 3/10. 


\section{A LIST OF THE VOLUMES OF THE ACCOUNTANTS' LIBRARY.}

A SERIES of 5 I Handbooks, each separate volume of which deals with a system of Bookkeeping suitable for the particular business described, together with a complete set of pro formâ Accounts. Demy 8vo size, uniformly bound in cloth, gold lettered.

I.-BANK BOOKKEEPING AND ACCOUNTS.

2nd Ed. (Meelboom \& Hannaford.) Double Number. (See p. 9.) 5/-net. Post free U.K. 5/4; Abroad, 5/6.

II.-AUCTIONEERS' ACCOUNTS.

2nd Ed. (Dicksee.) (See p. 7.)

$\mathbf{3} / 6$ net. Post free U.K. 3/9: Abroad, 3/10.

III.-BUILDERS' ACCOUNTS.

2nd Ed. (Walbank.) (See p. I3.)

$3 / 6$ net. Post free U.K. $3 / 9$; Abroad, 3/10.

IV.-AGRICULTURAL ACCOUNTS AND INCOME TAX.

2nd Ed. (Meats.) Double Number. (See p. 6.)

5/-net. Post free U.K. 5/4; Abroad, 5/5.

V.-THEATRE ACCOUNTS.

(Chantrey.) (See p. 38.)

$3 / 6$ net. Post free U.K. 3/9; Abroad, 3/10.

VI.-CO-OPERATIVE SOCIETIES' ACCOUNTS.

(Sugden.) Double Number. (See p. I6.)

5/- net. Post free U.K. 5/3; Abroad, 5/4.

VII.-GAS ACCOUNTS.

2nd Ed. (The Editor.) Double Number. (See p. 26.)

5/- net. Post free U.K. 5/4; Abroad, 5/5.

VIII.-MINERAL WATER MANUFACTURERS' ACCOUNTS.

(Lund \& Richardson.) (See p. 3I.)

$3 / 6$ net. Post free U.K. 3/9 ; Abroad, 3/10.

IX.-STOCKBROKERS' ACCOUNTS.

2nd Ed. (Callaway.) (See p. 37.)

$3 / 6$ net. Post frę UU.K. 3/9; Abroad, 3/10. 
X.-GRAIN, FLOUR, HAY, AND SEED MERCHANTS' ACCOUNTS.

(Johnson.) (See p. 26.)

3/6 net. Post free U.K. $\mathbf{3} / \mathbf{9}$; Abroad, $\mathbf{3} / 10$

XI.-POLYTECHNIC ACCOUNTS.

(Marshall.) (See p. 34.)

3/6 net. Post free U.K. 3/9; Abroad, 3/10.

XII.-SOLICITORS' ACCOUNTS.

2nd Ed. (Dicksee.) (See p. 37.)

3/6 net. Pest free U.K. 3/9 ; Abroad, 3/10.

XIII.-PAWNBROKERS' ACCOUNTS.

(Thornton \& May.) (See p. 34.)

3/6 net. Post free U.K. 3/9; Abroad, 3/10.

XIV.-ENGINEERS' AND SHIPBUILDERS' ACCOUNTS.

2nd Ed. (Burton.) (See p. 2r.)

3/6 net. Post free U.K. 3/9; Abroad, 3/10.

XV.-TRAMWAY ACCOUNTS.

(McColl.) Triple Number. (See p. 39.)

Net price (post free) U.K. 10/6 ; Abroad, 11/-

XVI.-AUSTRALIAN MINING COMPANIES' ACCOUNTS.

(Godden \& Robertson.) (See p. 8.)

3/6 net. Post free U.K. 3/9; Abroad, 3/10.

XVII.-PRINTERS' ACCOUNTS.

(Lakin-Smith.) (See p. 34.)

3/6 net. Post free U.K. 3/9; Abroad, 3/10.

XVIII.-MEDICAL PRACTITIONERS' ACCOUNTS.

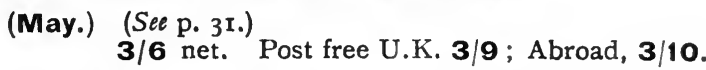

XIX.-WATER COMPANIES' ACCOUNTS.

(Key.) (See p. 42.)

3/6 net. Post free U.K. 3/9; Abroad, 3/10.

XX.-FISHING INDUSTRY ACCOUNTS.

(Williamson.) (See p. 25.)

3/6 net. Post free U.K. 3/9; Abroad, 3/10.

XXI.-MUNICIPAL ACCOUNTS.

(Allcock.) Triple Number. (See p. 33.)

Net price (post free) U.K. 10/6; Abroad, 11/.

XXII.-UNDERWRITERS' ACCOUNTS.

2nd Ed. (Spicer \& Pegler.) (See p. 40.)

5/- net. Post free U.K. 5/3; Abroad, 5/4. 
XLIX.-PROCESS COST ACCOUNTS.

(Garry.) Double Number. (See p. 17.)

5/- net. Post free U.K. 5/4; Abroad, 5/5.

L.-BAKERS' ACCOUNTS.

(Meggison.) Double Number. (See p. 8.)

5/- net. Post free U.K. 5/4; Abroad, 5/5.

LI.-COLLIERY ACCOUNTS.

(Mann.) Double Number. (See p. I4.)

5/- net. Post free U.K. 5/4; Abroad, 5/5.

To Subscribers to 20 or more volumes at a time these are published at the special subscription rate of $2 \mathrm{~s}$. $6 \mathrm{~d}$. per "Single" number, 3s. 9d. per "Double" number, and 5s. per "Triple" number. The subscription prices, CARRIAGE PAID, are as follows :-

ONITED KINGDOM. ABROAD.

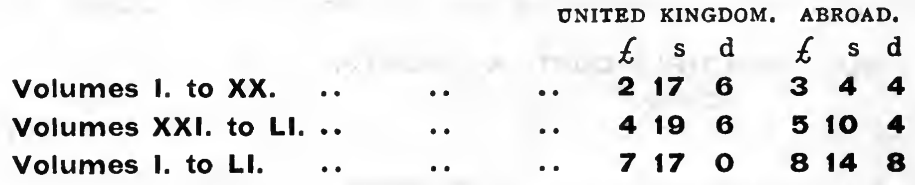

Single coples of any volume may be obtained at the ordinary rates, as detalled above. 
RETURN TO the circulation desk of any University of California Library

or to the

NORTHERN REGIONAL LIBRARY FACILITY

Bldg. 400, Richmond Field Station

University of California

Richmond, CA 94804-4698

ALL BOOKS MAY BE RECALLED AFTER 7 DAYS

- 2-month loans may be renewed by calling (510) 642-6753

-1-year loans may be recharged by bringing books to NRLF

- Renewals and recharges may be made 4 days prior to due date

\section{DUE AS STAMPED BELOW}

\section{OCT 082003}




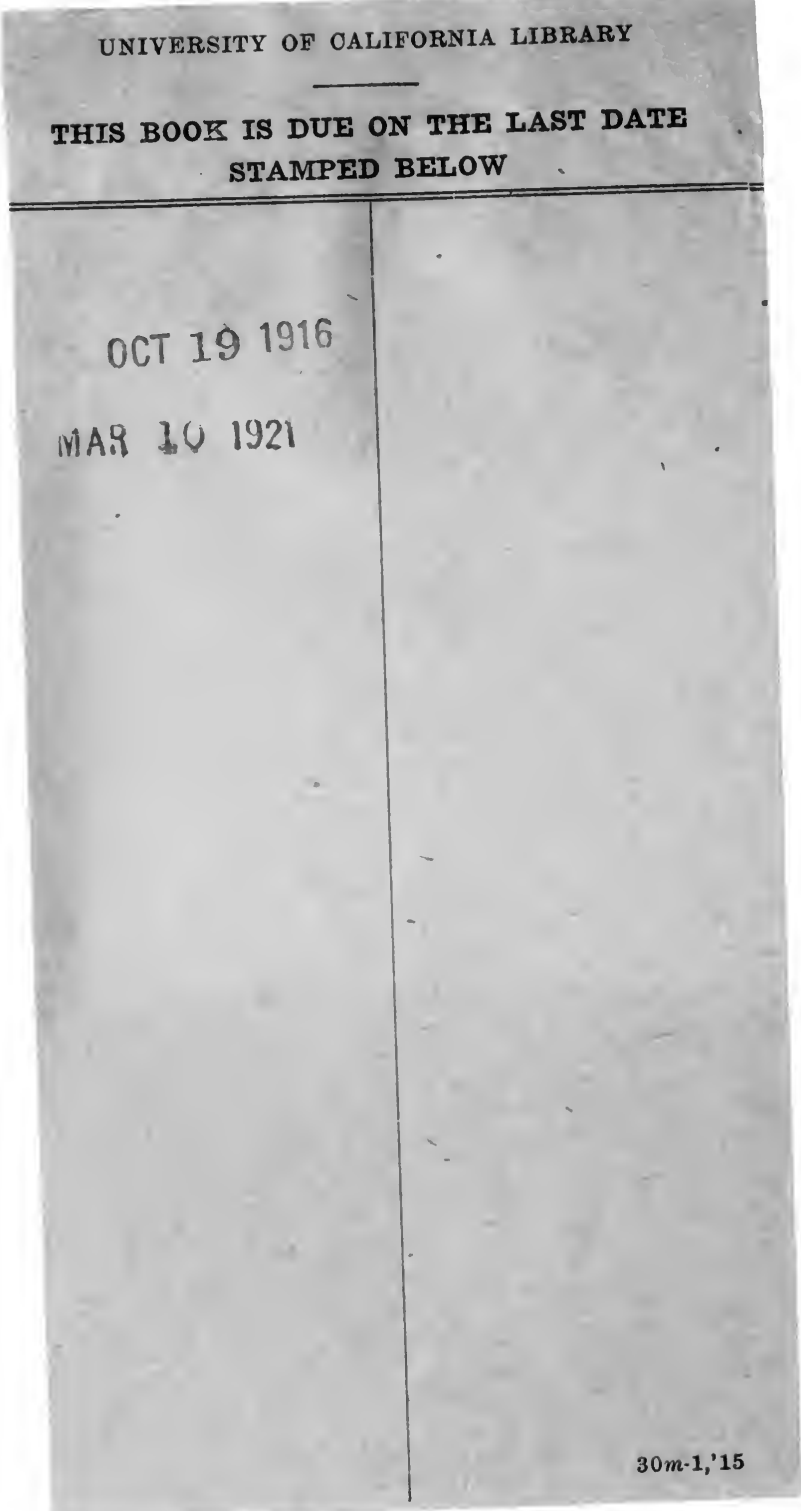




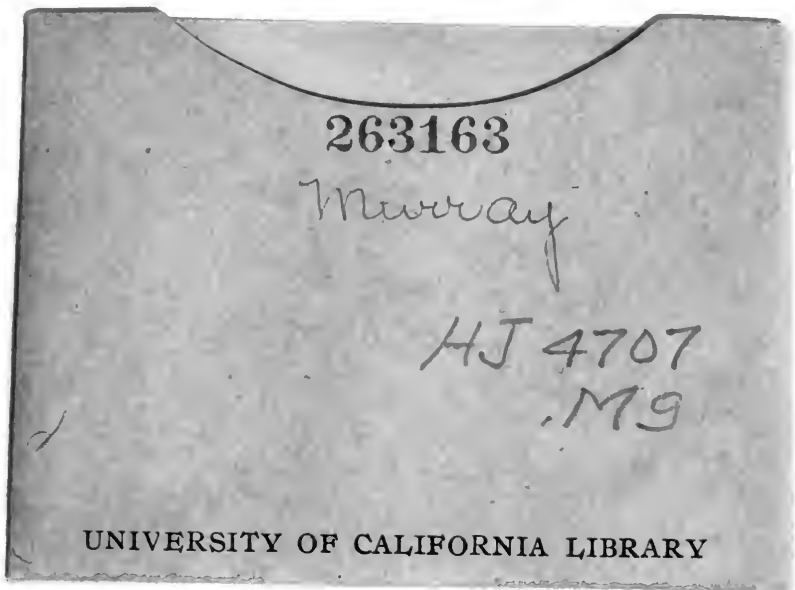


